\title{
LATE HOLOCENE PALEOCLIMATIC AND PALEOCEANOGRAPHIC RECORDS IN ANOXIC BASINS, SEYMOUR-BELIZE INLET COMPLEX, BRITISH COLUMBIA
}

By

\section{LAMIDI OLABODE BABALOLA}

B. Sc., University of Ilorin, Nigeria, 1985

M.Sc., Obafemi Awolowo University, Ile-Ife Nigeria, 1992

M.S, KFUPM, Saudi Arabia, 1999

A thesis submitted to

the Faculty of Graduate Studies and Research

in partial fulfillment of the

requirements for the degree of

Doctor of Philosophy

Ottawa-Carleton Institute for Geosciences

Department of Earth Sciences

Carleton University, Ottawa, Ontario

Canada

September 2009

CLamidi Olabode Babalola, 2009 


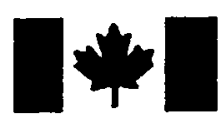

\author{
Library and Archives \\ Canada \\ Published Heritage \\ Branch
}

395 Wellington Street

Ottawa ON K1A ON4

Canada
Bibliothèque et

Archives Canada

Direction du

Patrimoine de l'édition

395 , rue Wellington

Ottawa ON K1A 0N4

Canada
Your file Votre référence
ISBN: 978-0-494-60099-3
Our file Notre référence
ISBN: 978-0-494-60099-3
NOTICE:

The author has granted a nonexclusive license allowing Library and Archives Canada to reproduce, publish, archive, preserve, conserve, communicate to the public by telecommunication or on the Internet, loan, distribute and sell theses worldwide, for commercial or noncommercial purposes, in microform, paper, electronic and/or any other formats.

The author retains copyright ownership and moral rights in this thesis. Neither the thesis nor substantial extracts from it may be printed or otherwise reproduced without the author's permission.
AVIS:

L'auteur a accordé une licence non exclusive permettant à la Bibliothèque et Archives Canada de reproduire, publier, archiver, sauvegarder, conserver, transmettre au public par télécommunication ou par l'Internet, prêter, distribuer et vendre des thèses partout dans le monde, à des fins commerciales ou autres, sur support microforme, papier, électronique et/ou autres formats.

L'auteur conserve la propriété du droit d'auteur et des droits moraux qui protège cette thèse. $\mathrm{Ni}$ la thèse ni des extraits substantiels de celle-ci ne doivent être imprimés ou autrement reproduits sans son autorisation.
In compliance with the Canadian Privacy Act some supporting forms may have been removed from this thesis.

While these forms may be included in the document page count, their removal does not represent any loss of content from the thesis.
Conformément à la loi canadienne sur la protection de la vie privée, quelques formulaires secondaires ont été enlevés de cette thèse.

Bien que ces formulaires aient inclus dans la pagination, il n'y aura aucun contenu manquant. 


\section{ABSTRACT}

Geochemical, foraminiferal and thecamoebian proxies archived in two piston and a freeze cores from glacier-carved fjords in the Seymour-Belize Inlet Complex (SBIC), British Columbia coast, were utilized to investigate fluctuations in the late Holocene regional paleoclimate and paleoceanography. The investigated piston cores from Frederick Sound (FS) and Alison (ALS) Sound are predominantly composed of organic-rich mud/silt sediments mainly deposited as annually laminated and massive intervals interspersed by occasional slump and graded sediments. The Mereworth Sound (MS) freeze core is characterized by monotonous mud/silt sediments with a substantial sand component occurring in the uppermost $68.5-0 \mathrm{~cm}(1248-2002$ cal AD) interval.

The overall high concentrations of redox-sensitive elements and preponderance of low oxygen-tolerant agglutinated foraminiferal species in the piston cores are interpreted as indication that the bottom waters in the SBIC were characterized by low oxygen levels during the late Holocene. Cluster analysis of the piston core samples discriminated three biofacies in the FS core and two in the ALS core. In addition, a total of four biofacies were recognized in the MS freeze core.

The distribution of $\delta^{13} \mathrm{C}$ and $\delta^{15} \mathrm{~N}$ stable isotopes, laminae thickness and foraminiferal species in the FS and ALS cores suggest the existence of periodic alternations between cool/wet and cooler/dry climate conditions in the SBIC. A dramatic shift to heavier $\delta^{13} \mathrm{C}$ and lighter $\delta^{15} \mathrm{~N}$ values at 3135 cal yr BP (FS core) and 2462 cal yr BP (ALS core), respectively, indicates a regime change to cooler/dry regional climate conditions which corresponds to the late Holocene Neoglacier advance in the Northeast Pacific.

A high enrichment of redox-sensitive elements and dearth of foraminiferal species within the 577-1248 cal AD interval in the MS indicates that the late Holocene bottom water anoxiasuboxia persisted until the mid of the $13^{\text {th }}$ century in the SBIC. Bottom water conditions during this interval were likely similar to those that existed during the Medieval Warm Period (MWP). A regime change to high oxic, cooler climate conditions corresponding to the Little Ice Age (LIA) events occurred from 1248-1386 cal AD. The overall regional LIA cool climate conditions in the SBIC were punctuated by a short warm episode during the late $14^{\text {th }}$ through early $16^{\text {th }}$ century (1386-1518 cal AD). The topmost 1518-2002 cal AD interval in the MS core was 
marked by cool climate conditions, suggesting that the LIA events in the SBIC region occurred in two stages. 


\section{ACKNOWLEDGEMENTS}

I would like to express my sincere appreciation to my thesis advisors - Drs. R. Timothy Patterson and Andreas Prokoph for their support and guidance throughout the duration of this research. Their various contributions, invaluable expertise advice and constructive criticism during the laboratory work, data analysis and preparation of this dissertation are thankfully acknowledged. All the members of my examination committee are also thanked for finding time out of their tight schedules to read through my dissertation and agreeing to conduct its oral defense.

The contributions of the crew members, led by Dr R.T. Patterson, on board the Vector CCG vessel during the fieldwork aspect of this research, are also thankfully acknowledged. The training and assistance rendered to me by Messer's Peter Jones and Lewis Ling on the use of the Scanning Electron Microscope at the Department of Earth Science's Electron Microprobe and SEM Laboratory are gratefully acknowledged. Paul Middlestead and Wendy Abdi of the Hatch Stable Isotope Laboratory at University of Ottawa are thanked for conducting the organic geochemical analysis aspect of this research.

The discussion and personal communication that I had with Drs. Richard E. Thomson and Audrey Dallimore of the Pacific Geoscience Centre at Sydney, British Columbia are indeed appreciated. The discussion I had with Dr. Paul Gammon was also helpful in improving the geochemical interpretation. I thank him for his assistance. The constructive criticism and assistance rendered by Dr. Elizabeth Anderson at the initial stage of preparing this dissertation tremendously helped me to improve the quality of its manuscripts. I thank her for her effort and valuable assistance. The exchange of research ideas and assistance from my fellow research colleagues such as Andrew Wigston, Jennifer Galloway, Natalia VázquezRiveiros, Bob Boudreau, Alice Chang, Hafida El-Bilal and Darvin Carter within the Patterson research group, are deeply appreciated.

The moral support and numerous forms of assistance rendered by the following family friends - AbdulKareem Adinoyi, AbdulKareem Melaiye, Khamis Salam-Alada, Ismail Kaka, Taofiq Ayinde, Qamardeen Abidogun, Mustapha Olajuwon, Sulaiman Olagoke, Akin Oshuntoye, Surajudeen Adewusi, Balarabe Yushau and Ruth Gbadeyan throughout the period 
of my studentship and particularly at the time of preparing this thesis, are unquantifiable and are duly appreciated.

This research was initially funded through the Canadian Foundation for Climate and Atmospheric Studies grant awarded to Dr. R.T. Patterson and subsequently the NSERC research grants of both Drs. R.T. Patterson and Andreas Prokoph. The domestic tuition waiver scholarship and various forms of departmental scholarships (e.g., the Alice Wilson award for paleontological research and the Gold Millennium scholarship) greatly helped me through this program. The bursary awards granted me by the Faculty of Graduate Studies and Research, are also kindly acknowledged. The American Association of Petroleum Geologists Grant-inAid award that I received in 2006 is also duly acknowledged.

The acknowledgement will not be complete without remembering my immediate and extended family members, especially my wife (Saadat), our lovely children - Ridwanallah, Habibullah, Saeed and baby Mariam; my aged parents (Chief Alimi and Mrs. Sidikat Babalola) and younger sister (Mrs. Hassana Aina) for their enduring moral support, prayers and patience throughout the duration of my studentship at Carleton University. I thank you all for your understanding and support. 


\section{TABLE OF CONTENT}

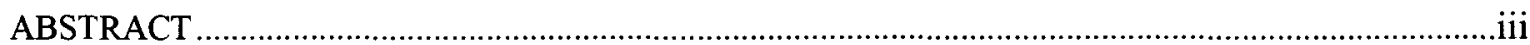

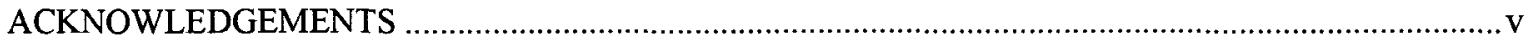

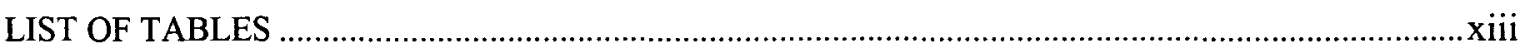

LIST OF FIGURES

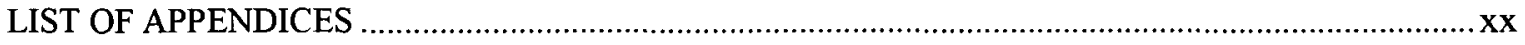

CHAPTER ONE

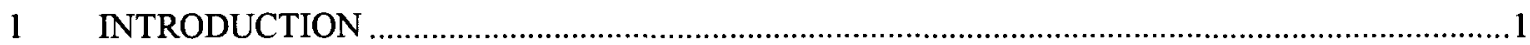

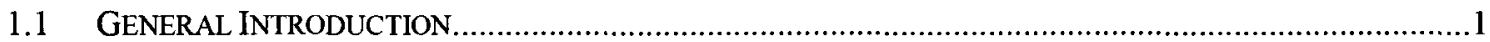

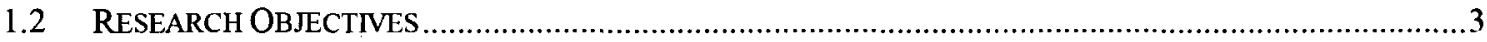

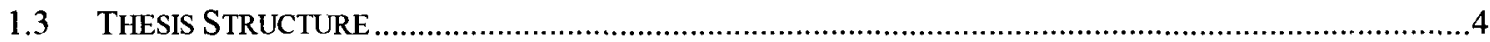

CHAPTER TWO

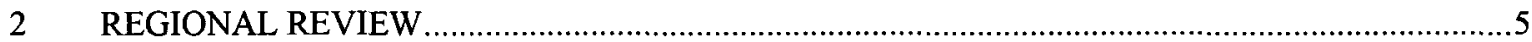

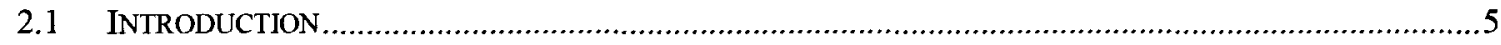

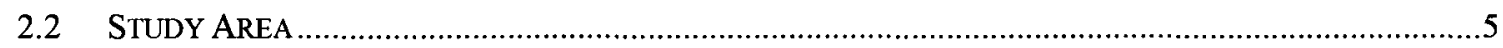

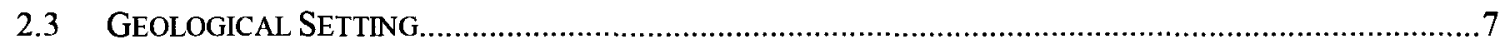

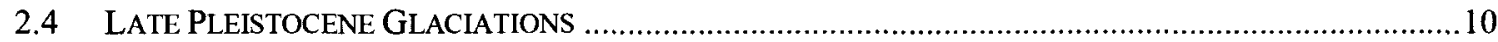

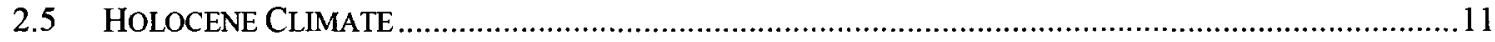

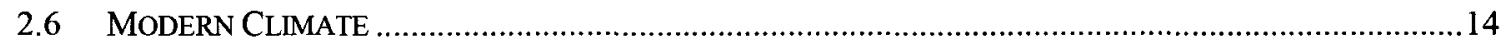

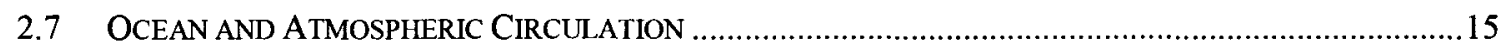

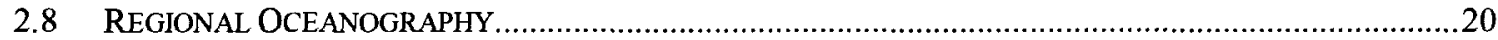

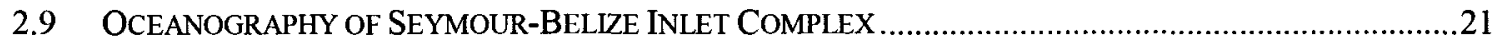

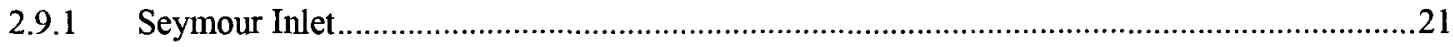

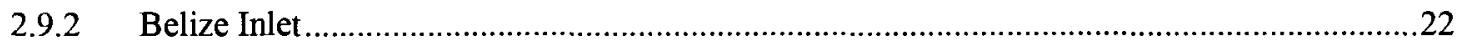

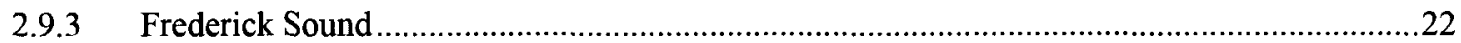




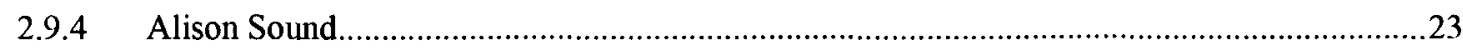

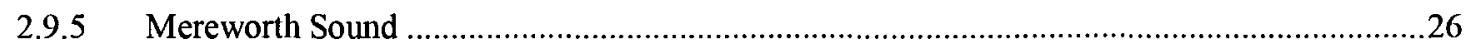

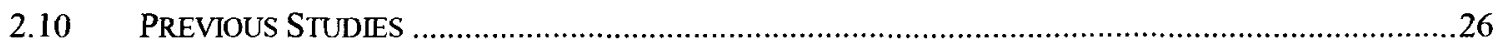

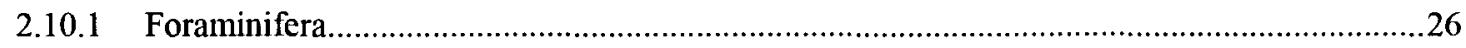

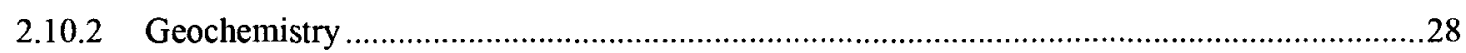

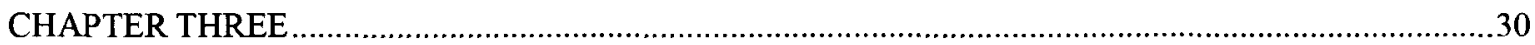

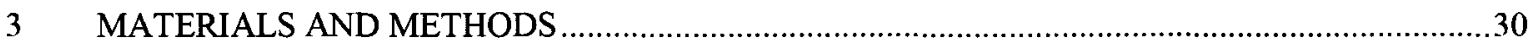

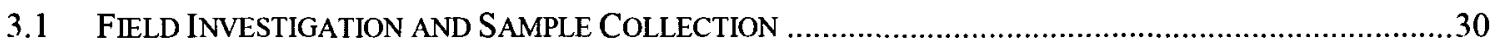

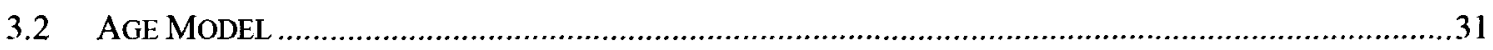

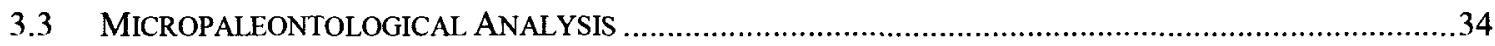

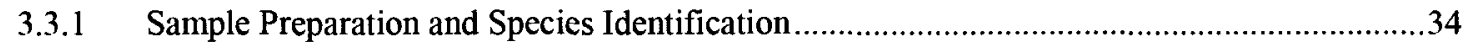

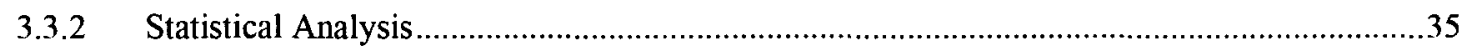

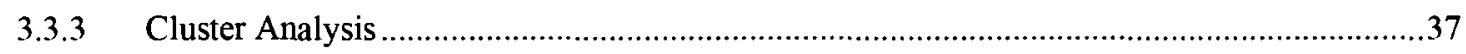

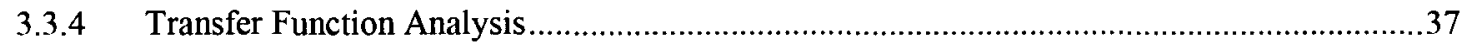

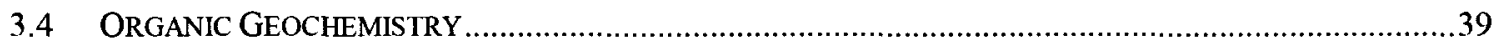

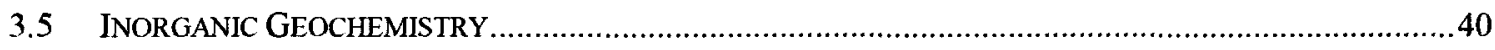

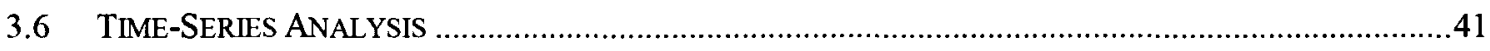

CHAPTER FOUR

4 FORAMINIFERAL DISTRIBUTION AND SEDIMENTOLOGY IN THE FREDERICK AND

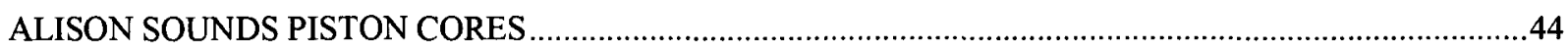

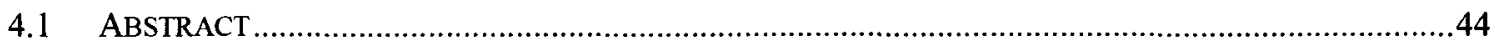

4.2 INTRODUCTION

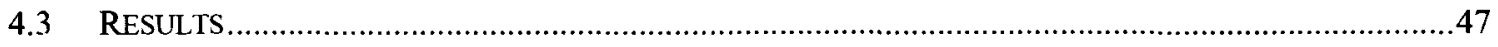

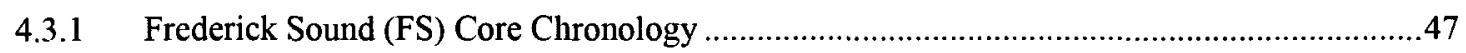

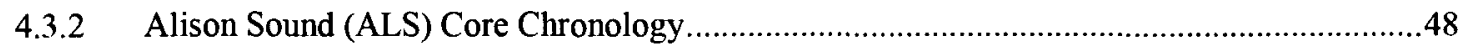

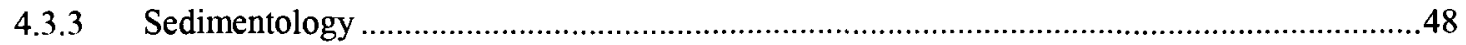

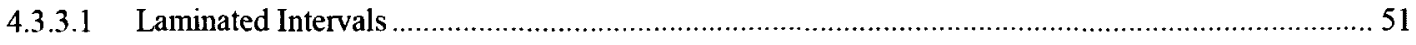




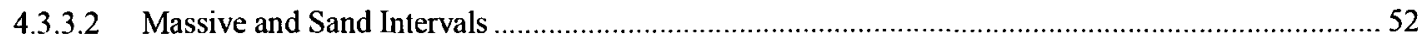

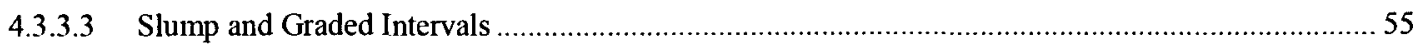

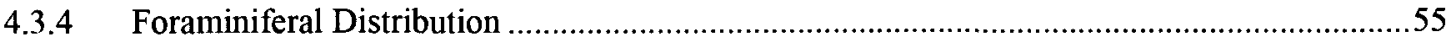

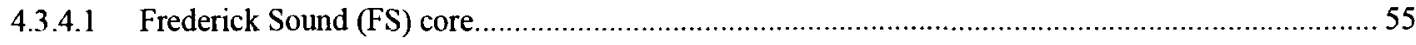

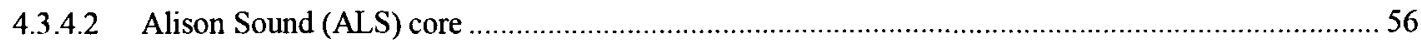

4.3.5 Foraminiferal and Thecamobian Biofacies in the Frederick Sound (FS) core ........................57

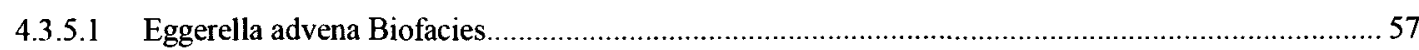

4.3.5.2 Eggerella advena-Spiroplectammina biformis Biofacies .............................................................. 58

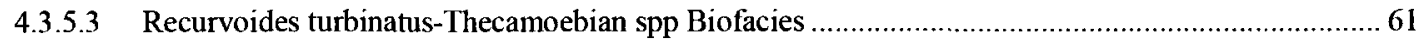

4.3.6 Foraminiferal and Thecamoebian Biofacies in the Alison Sound (ALS) core........................61

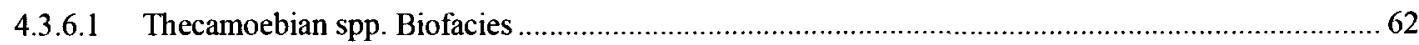

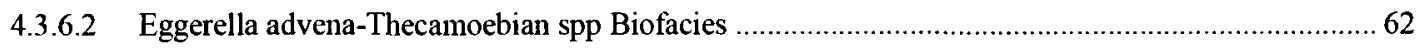

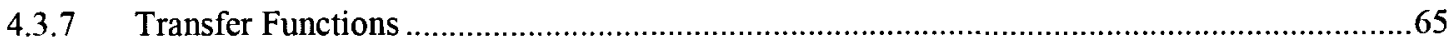

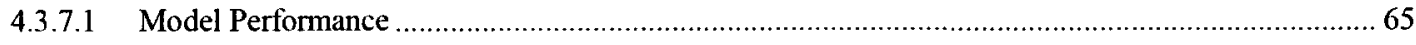

4.3.7.2 Reconstructed environmental variable in the Frederick Sound (FS) core ..........................................67

4.3.7.3 Factor Analysis of the reconstructed variables in the Frederick Sound (FS) core ...............................69

4.3.7.4 Reconstructed environmental variables in the Alison Sound (ALS) core ........................................... 73

4.3.7.5 Factor Analysis of the reconstructed variables in the Alison Sound (ALS) core …........................... 75

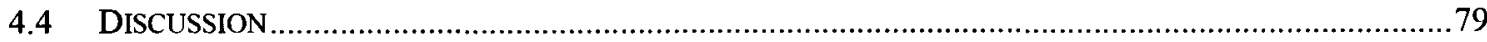

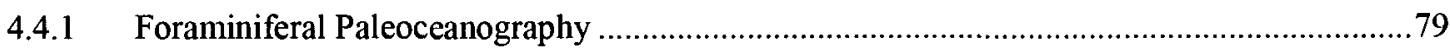

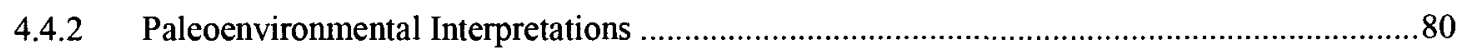

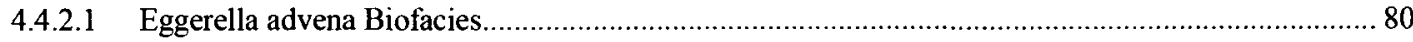

4.4.2.2 Eggerella advena-Spiroplectammina biformis Biofacies................................................................. 82

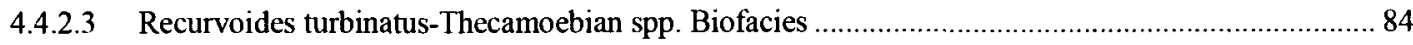

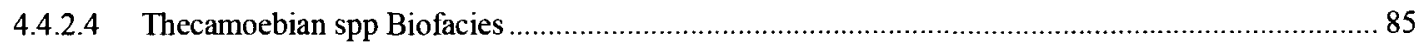

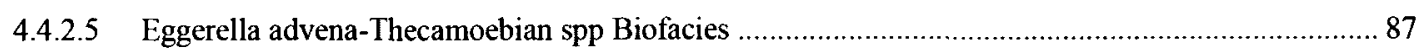

4.4.3 Paleoclimate

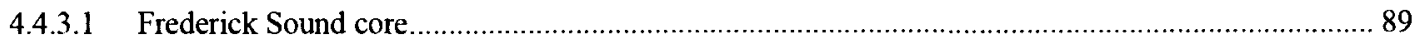

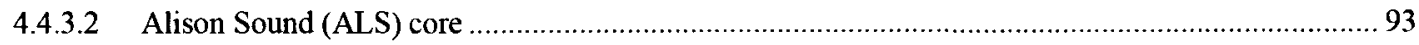

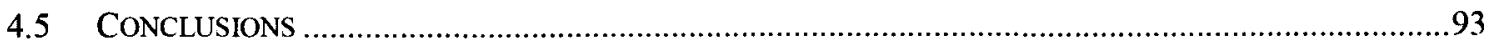


5 GEOCHEMICAL PROXIES IN THE FREDERICK AND ALISON SOUNDS PISTON CORES ....95

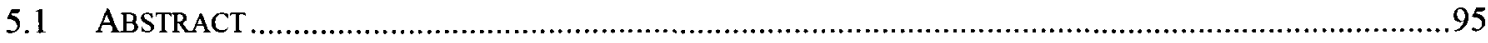

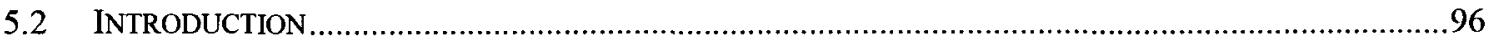

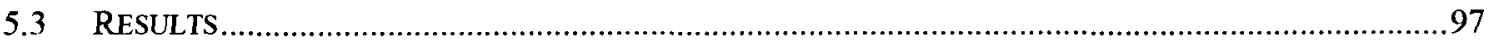

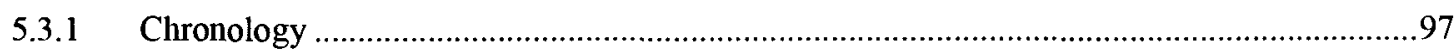

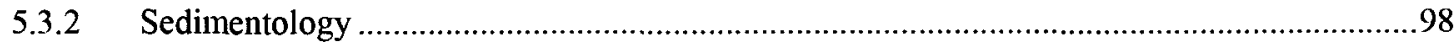

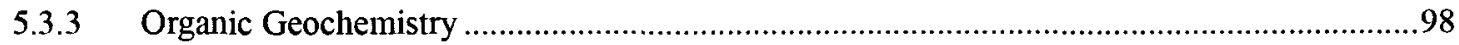

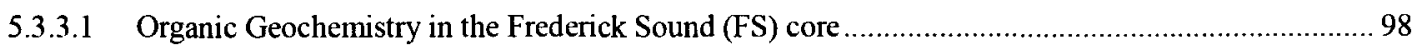

5.3.3.2 Organic Geochemistry in the Alison Sound (ALS) core ............................................................. 103

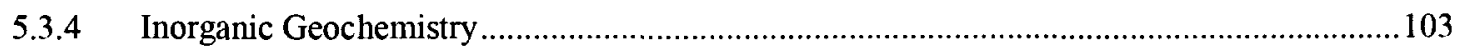

5.3.4.1 Inorganic Geochemistry in the Frederick Sound (FS) core........................................................ 106

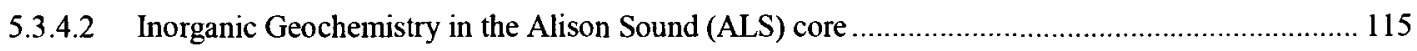

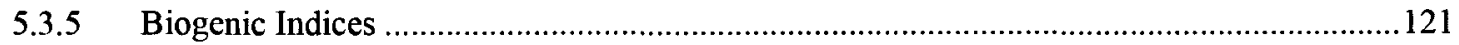

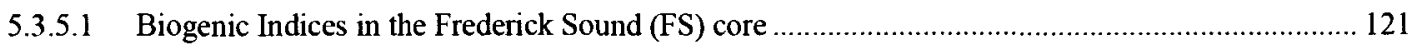

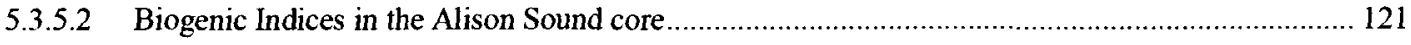

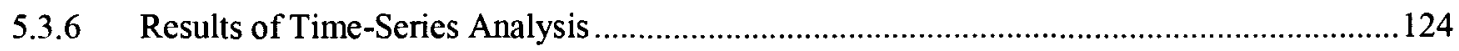

5.3.6.1 Time -Series Results in the Frederick Sound (FS) core ............................................................... 124

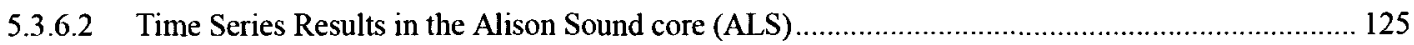

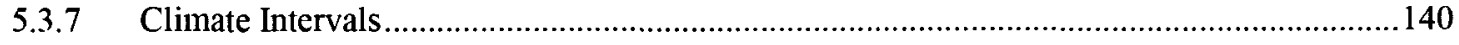

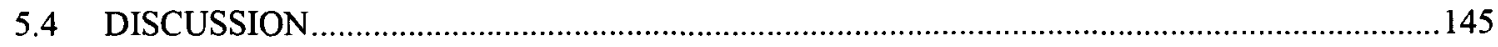

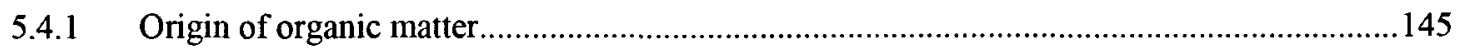

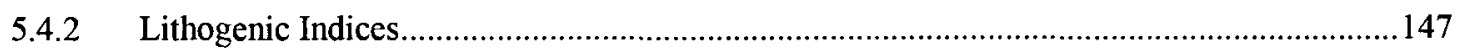

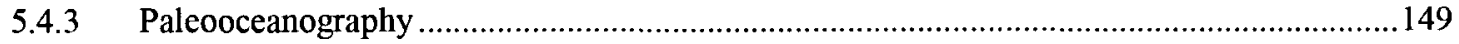

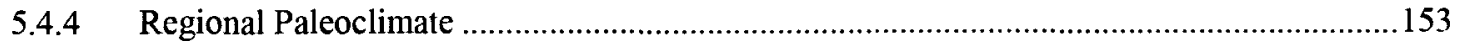

5.4.4.1 Climate Interval 1 (4200-3135cal yr (FS); 3500-2462 cal yr BP (ALS)) ……............................ 153

5.4.4.2 Climate Interval 2 (3135-1956 cal yr BP (FS); 2462-2238 cal yr BP (ALS) ................................ 156

5.4.4.3 Climate Interval 3 (1956-1464 cal yr BP (FS); 2238-1627 cal yr (ALS)) …………...................... 159

5.4.4.4 Climate Interval 4 (1464-1288 cal yr BP (FS); 1627-1405 cal yr BP (ALS)) ............................. 160 
5.4.4.5 Climate Interval 5 (1288-1100 cal yr BP (FS; 1405- 1000 cal yr BP (ALS)) .......................... 160

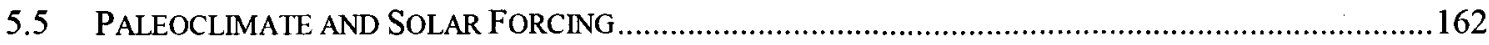

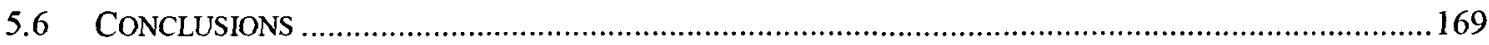

CHAPTER SIX

6 FORAMINIFERAL AND GEOCHEMICAL DISTRIBUTION IN THE MEREWORTH SOUND

FREEZE CORE

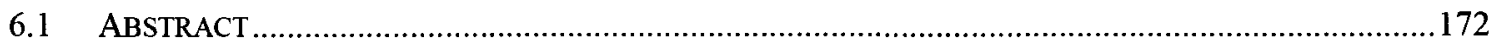

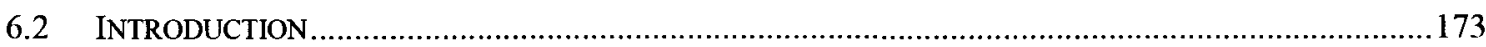

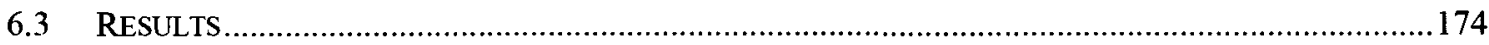

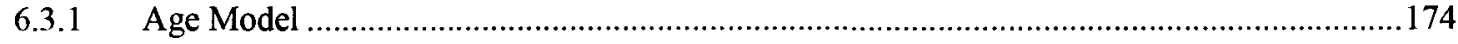

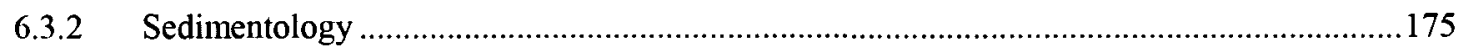

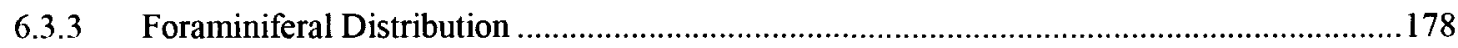

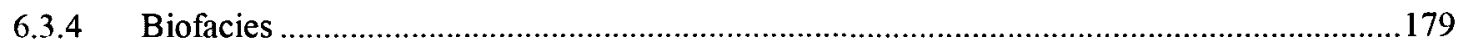

6.3.4.1 Haplophragmoides bradyi-Eggerella advena (HB-EA) Biofacies ……………........................... 179

6.3.4.2 Buccella frigida-Cribroelphidium excavatum (BF-CE) Biofacies ............................................... 180

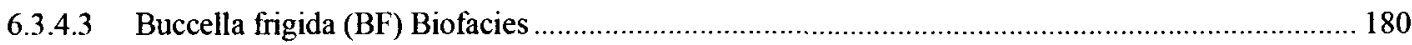

6.3.4.4 Haplophragmoides bradyi-Cribroelphidium excavatum (HB-CE) Biofacies................................... 180

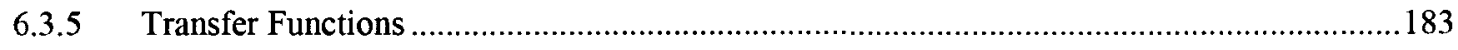

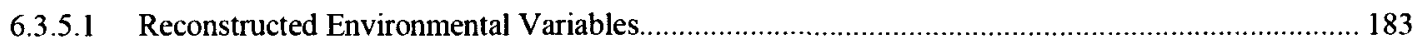

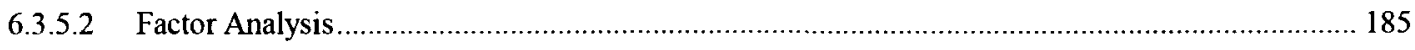

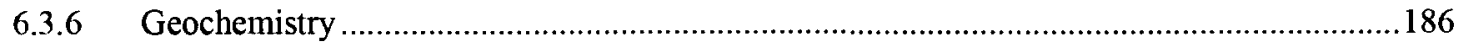

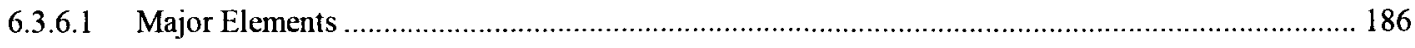

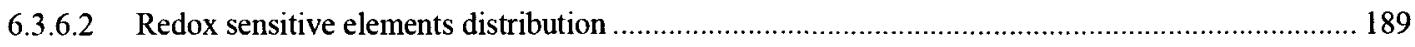

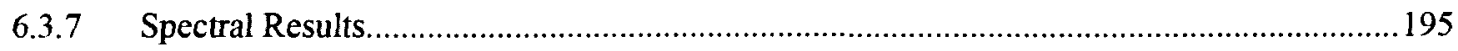

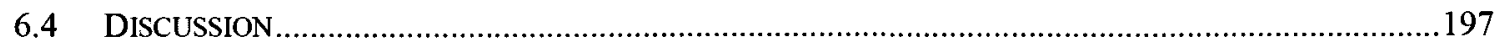

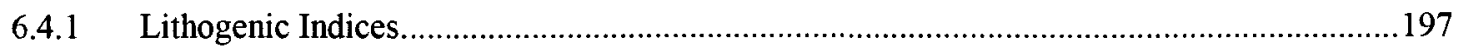

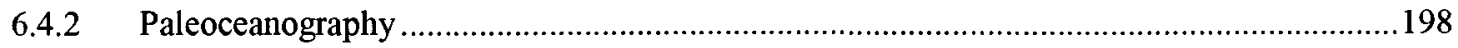

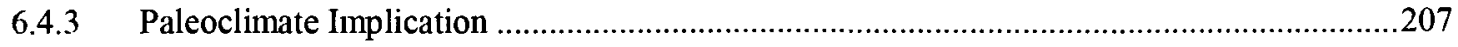




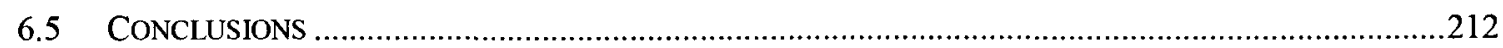

CHAPTER SEVEN

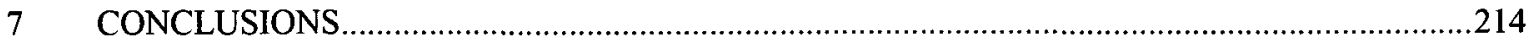

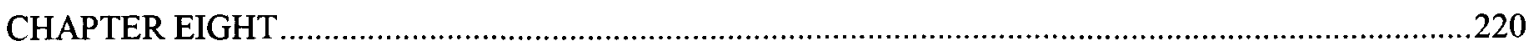

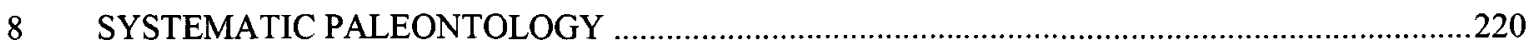

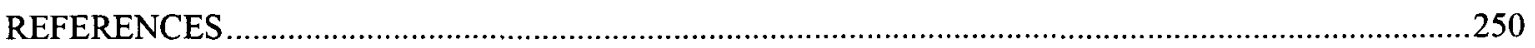

PLATES 1-14

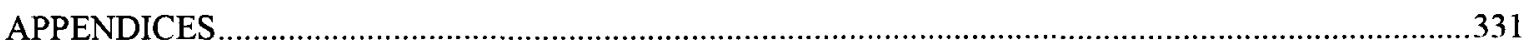




\section{LIST OF TABLES}

Table 3.1. Radiocarbon and Calendar ages from Frederick Sound core VEC02A04 ............ 32

Table 3.2. Radiocarbon and Calendar ages of Alison Sound core VEC02A07 .................. 32

Table 3.3. Radiocarbon and Calendar ages of Mereworth Sound. .................................. 33

Table 4.1. Sample weighted averaging (WA) and weighted averaging with tolerance (WATOL) deshrinking statistics summary for the inverse and downweighting models.........66

Table 4.2. Correlation matrix based on Pearson moment correlation coefficient for foraminiferal species, thecamoebians and environmental variables in the Fredrick Sound.

Table 4.3. Principal component (varimax rotated) R-mode factor analysis loading for foarminiferal species, thecamobians and reconstructed variables in the Fredrick Sound (FS) core.

Table 4.4. Correlation matrix based on Pearson product moment correlation coefficient for

foraminiferal species and environmental variables in the Alison Sound (ALS) core...... 76

Table 4.5. Principal component (varimax-rotated) factor loadings for foraminiferal species, thecamoebians species and reconstructed variables in Alison Sound (ALS) core. 78

Table 5.1. Summary of organic geochemical proxies in Frederick Sound and Alison Sound piston cores. 99

Table 5.2. Major elements in SBIC. Upper crust data (Taylor and McLennan, 1985), modified by McLennan (2001); Average shale data (Wedepohl, 1971; 1991). 107

Table 5.3. Trace elements and redox indices in SBIC. Upper crust data (Taylor and McLennan (1985), modified by McLennan (2001); Average shale data (Wedepohl, 1971; 1991). 108 
Table 5.4. Correlation matrix for elements in Frederick Sound (FS) core.

Table 5.5. Correlation matrix of major and trace elements in Alison Sound (ALS) core

Table 5.6. Results of the spectral analysis of geochemical proxies from the Frederick Sound core 126

Table 5.7. Wavelet results showing temporal distribution of cycles in Frederick Sound core.

Table 5.8. Results of the spectral analysis of geochemical proxies from the Alison Sound

(ALS) core.

Table 5.9. Wavelet Results showing temporal distribution of cycles in Alison Sound (ALS)

core

Table 5.10. Climate Intervals in the Frederick Sound (FS) core.

Table 5.11. Climate Intervals in the Alison Sound (ALS) core.

Table 6.1. Correlation coefficient of variable response and reconstructed environmental variable in Mereworth Sound freeze core.

Table 6.2. R-mode Principal Component (Varimax Rotated) Factor loadings for foraminiferal species and environmental variables in Mereworth Sound freeze core. 188

Table 6.3. Summary of concentrations of major elements in Mereworth Sound freeze core. Upper crust data (Taylor and McLennan, 1985, modified by Taylor and Mclennan, 1995; Mclennan, 2000); Average shale data (Wedepohl 1971; 1991). 190

Table 6.4. Summary of concentrations of trace elements in Mereworth Sound freeze core.Upper crust data (Taylor and McLennan, 1985, modified by Taylor and Mclennan, 1995; Mclennan, 2000); Average shale data (Wedepohl 1971; 1991). 191

Table 6.5. Spectral Results from Mereworth Sound core. 195 


\section{LIST OF FIGURES}

Figure 2.1. Location of the study area (SBIC). (A) Map of north America showing Vancouver Island, (B) Map of southwest British Columbia showing study area and (C) Map of Seymour-Belize Inlet Complex showing the locations of Frederick Sound, Alison Sound and Mereworth Sound, core sites and sills (after Galloway et al., in press)

Figure 2.2. Terrane map of western Canada and Alaska (modified after Wheeler et al., 1991; Greene et al., 2005) showing the distribution of the Wrangellia Terrane (WR) in British

Columbia, the Yukon and Alaska.

Figure 2.3.Geological map of Cape Caution showing the bedrocks in Seymour-Belize Inlet

Complex (After Pinsent, 1999).

Figure 2.4. Seasonal variations in Aleutian Low (AL) and North Pacific High (NPH) (after Thomson, 1981, modified by Patterson et al., 2004a). AL is intense in winter (January); NPH is intense in summer (July)

Figure 2.5. Coastal upwelling and downwelling in the Northeast Pacific (Favorite, et al., 1976, modified by Patterson et al., 2004a). 18

Figure 2.6. Fisheries production domains and general large-scale circulation in the Northeast Pacific Ocean (from Ware and McFarlane 1989; modified by Batchelder and Powell, 2002).

Figure 2.7. Oceanographic data from Frederick Sound (Thomson personal comm., 2003).

Figures 2.7a, b and c (April, 2002 data) ; Figures 2.7 c, d, e (October, 2002) 24

Figure 2.8. Oceanographic data for April 2002 in Alison Sound (Thomson personal comm., 2003) 
Figure 4.1. Linear regression age model for the Frederick Sound (FS) core. Calibrated calendar age (open square and solid trendline); radiocarbon age (filled circle and dash trendline).

Figure 4.2. Fourth order polynomial age model for the Alison Sound core (modified from Patterson et al., 2007). Radiocarbon dates (solid square) and calibrate calendar dates (open circle)

Figure 4.3. Stratigraphic column of the Frederick Sound core. 53

Figure 4.4. Stratigraphic column of the Alison Sound (ALS) core. 54

Figure 4.5. Q-mode versus R-mode cluster dendrogram for the Frederick Sound core samples. Range of abundances (\%) of foraminiferal species and thecamoebians are indicated by symbols. 59

Figure 4.6. Distribution of foraminiferal biofacies in the Frederick Sound core. 60

Figure 4.7. Q-mode versus R-mode cluster dendogram for the Alison Sound core samples. Ranges of abundances (\%) of foraminiferal species and thecamoebians are indicated by symbols. 63

Figure 4.8. Stratigraphic distribution of foraminiferal biofacies in the Alison Sound core. .... 64

Figure 4.9. Stratigraphic distribution of foraminiferal fractional abundances and the reconstructed environmental variables in the Frederick Sound core samples. 68

Figure 4.10. Comparison of foraminiferal and thecamoebian distribution with organic matter, biogenic silica and mean grain size in the Frederick Sound core. 71

Figure 4.11. Distribution of foraminiferal species and reconstructed ecological variables in the Alison Sound (ALS) core. 74 
Figure 4.12. Comparison of foraminiferal and thecamoebians fractional abundances to organic matter proxies in the Alison Sound (ALS) core. 77

Figure 4.13. Summary of the foraminiferal inferred depositional environments and paleoclimate events in the Fredrick Sound core

Figure 4.14. Summary of the foraminiferal inferred paleoclimate events in Alison Sound core.

92

Figure 5.1. Laminae thickness, mean grain size and organic matter proxies in the Frederick

Sound core. 101

Figure 5.2. Bivariate plots showing relationships between the organic matter proxies in Frederick Sound core. 102

Figure 5.3. Mean grain size and organic matter proxies in the Alison Sound core. 104

Figure 5.4. Bivariate plots of the organic matter proxies in the Alison Sound core. 105

Figure 5.5 Distribution of major elements in the Frederick Sound core. 110

Figure 5.6. Bivariate plots showing relationships between some elements in the Frederick

Sound core.

Figure 5.7. Distributionof trace elements in the Frederick Sound core.

Figure 5.8. Profiles of redox indices in the Fredrick Sound core.

Figure 5.9. Distribution of major elements in the Alison Sound core 116

Figure 5.10. Bivariate plots of some elements and oxides in the Alison Sound core. 117

Figure 5.11 Distribution of trace elements in the Alison Sound core. 118

Figure 5.12. Profiles of redox indices in the Alison Sound core. 120

Figure 5.13. Comparison of productivity indices in the Frederick Sound core to the Bond et al. (2001) ${ }^{14} \mathrm{C}$ production rate. Low productivity intervals are indicated by vertical lines.. 122 
Figure 5.14. Comparison of productivity indices in the Alison core to the Bond et al. (2001)

${ }^{14} \mathrm{C}$ production rate. Low productivity intervals are indicated by vertical lines. 123

Figure 5.15. Spectral analysis of organic matter proxies in the Frederick Sound core.

Figure 5.16. Spectral analysis of redox sensitive elements in Frederick Sound core and ${ }^{14} \mathrm{C}$ production rate. 128

Figure 5.17. Wavelet analysis of biogenic silica in the Frederic Sound core. 129

Figure 5.18. Wavelet analysis of $\delta^{13} \mathrm{C}$ in the Frederick Sound core. 130

Figure 5.19. Wavelet analysis of $\delta^{15} \mathrm{~N}$ in the Frederick Sound core.

Figure 5.20. Wavelet analysis of $\% \mathrm{C}_{\text {org }}$ in the Frederick Sound core.

Figure 5.21. Spectral analysis of organic matter proxies in the Alison Sound core and ${ }^{14} \mathrm{C}$ production rate.

Figure 5.22. Spectral analysis of some redox related elements in the Alison Sound core.... 136

Figure 5.23. Wavelet analysis of $\delta^{13} \mathrm{C}$ in the Alison Sound core.

Figure 5.24. Wavelet analysis of $\delta^{15} \mathrm{~N}$ in the Alison Sound core 138

Figure 5.25. Wavelet analysis of $\% \mathrm{C}_{\mathrm{org}}$ in the Alison Sound core.

Figure 5.26. Climate proxies in the Frederick Sound core. Distribution of the $\delta^{13} \mathrm{C}$ and $\delta^{15} \mathrm{~N}$ shows five climate intervals in Frederick Sound. 143

Figure 5.27. Climate proxies in the Alison sound core. Distribution of $\delta^{13} \mathrm{C}$ and $\delta^{15} \mathrm{~N}$ indicates five climate intervals in the Alison Sound. 144

Figure 5.28. Summary of climate events in SBIC: (A). Frederick Sound core and (B). Alison Sound core. 171

Figure 6.1. Age-Depth model of the Mereworth Sound freeze core. 176

Figure 6.2. Stratigraphic column of Mereworth freeze core. 177 
Figure 6.3 Q-mode and R-mode cluster dendrogram showing foraminiferal biofacies in Mereworth Sound. Haplphragmoides bradyi-Eggerella advena (HB-EA), Buccella frigida (BF), Buccella frigida-Cibroelphidum excavatum (BF-CE) and Haplphragmoides bradyi-Cibroelphidum excavatum Biofcaies (HB-CE). Range of abundances (\%) of species are indicated by symbols

Figure 6.4. Stratigraphic distribution of foraminiferal biofacies in Mereworth Sound freeze core

Figure 6.5. Reconstructed environmental variables and species fractional abundances in the Mereworth Sound core 184

Figure 6.6. Stratigraphic distribution of major elements in the Mereworth Sound core 192

Figure 6.7. Distribution of trace elements in the Mereworth Sound core.

Figure 6.8. Bivariate plots of some elements and ratios in the Mereworth Sound core. 194

Figure 6.9. Spectral times series of some elements in Mereworth Sound core. 196

Figure 7.1. Summary of climate events in the Frederick Sound core 216

Figure 7.2. Summary of climate events in the Alison Sound core.

Figure .7.3. Depositional environments and climate events in the Mereworth Sound freeze core 


\section{LIST OF APPENDICES}

Appendix A. AMS Radiocarbon $\left({ }^{14} \mathrm{C}\right)$ Dating Results 332

Appendix B. Fractional abundances and reconstructed variables in SBIC 347

Appendix B 1. Foraminiferal and thecamoebian fractional abundances in the Frederick Sound.

Appendix B 2. Foraminiferal fractional abundances in the Alison Sound core. 355

Appendix B 3. Foraminiferal fractional abundances in the Mereworth Sound core 357

Appendix B 4. Reconstructed paleoenvironmental proxies in the Frederick Sound core...... 359

Appendix B 5. Reconstructed environmental proxies in the Alison Sound core. 363

Appendix B 6. Reconstructed variables in Mereworth Sound.365

Appendix C. Geochemical Data . 366

Appendix C 1. Distribution of organic proxies in Frederick Sound core.

Appendix C 2. Distribution of organic proxies in the Alison Sound core.

Appendix C 3. 100-year (5-sample) averaging of organic matter proxies in the Frederick

Sound core. 376

Appendix C 4. 100-year (5-sample) averaging of organic matter proxies in the Alison Sound core 377

Appendix C 5. Distribution of major elements in the Frederick Sound core. 378

Appendix C 6. Distribution of oxides of major elements in the Frederick Sound core. 380

Appendix C 7. Distribution of trace elements in the Frederick Sound core. 382

Appendix C 8. Distribution of paleoredox indices in the Frederick Sound core 385

Appendix C 9. Distribution of major elements in the Alison Sound core. 387

Appendix C 10. Distribution of oxides of major elements in the Alison Sound core. 388

Appendix C 11. Distribution of trace elements in the Alison Sound core. 390 
Appendix C 12. Distribution of paleoredox indices in the Alison Sound core.

Appendix C 13. Distribution of major elements in the Mereworth Sound core 395

Appendix C 14. Distribution of oxides of major elements in the Mereworth Sound core..... 397

Appendix C 15. Distribution of trace elements in the Mereworth Sound core. 398

Appendix C 16. Stratigraphic distribution of trace elemnt ratio in the Frederick Sound core.

Appendix C 17. Stratigraphic distribution of trace elemnt ratio in the Alison Sound core... 401 Appendix C 18. Chemical conversion factors (Geoscience Laboratories, Mannual, 2003) .. 402 


\section{CHAPTER ONE}

\section{INTRODUCTION}

\subsection{General Introduction}

The climate of the Earth has varied greatly and changed significantly over time. Understanding past climate variability might allow researchers to understand possible future climate fluctuations. Research studies have mostly focused on the evidence of abrupt centennial and millennial-scale changes in Quaternary climate. Many of these changes are periodic or quasiperiodic at a global scale and are often linked to thermohaline circulation changes throughout the Pleistocene (Keigwin and Boyle., 2000).

The climate during the Holocene had been relatively more stable than the climate during any other interval for the last 100,000 years (Keigwin and Boyle., 2000). However, centennial to millennial-scale climate fluctuations have recently been detected in several Holocene proxy records. There is not a general agreement on the precise timing, amplitude and cause of such climatic fluctuations. Nevertheless, orbital or Milankovitch forcing is widely believed to be the driving mechanism influencing climate variability on the scale of 1,000 to 400,000 years (McDermott et al., 2001).

One of the goals of investigating climate fluctuations is to ascertain whether there are physical forcing mechanisms behind them, or if some long-term resonance in the climate 
systems exists. Understanding the causes of the fluctuations would enable the comprehension of the phasing of millennial events among geographic regions and different parts of the climate system. It is also important to establish whether human activity could worsen the effects of natural oscillations in the climate system, and/or even trigger independent events. All of these factors are important to government and other policy makers in formulating policies regarding climate change adaptation strategies and other climate related matters. Although Holocene climate events are relatively minor from a glacial/interglacial perspective, even small changes in the polar vortex and atmospheric storminess (O'Brien et al., 1995) could translate into widespread disruption of human society if they were to occur in the future.

This research is an integral part of a multidisciplinary research project mandated to understand Ultra High Resolution Holocene Paleoclimatic and Oceanographic records from anoxic basins along British Columbia Coast. This multidisciplinary project was initiated to document any paleoenvironmental trends and cycles recognizable in Holocene sedimentary and micropaleontological records from coastal inlets and lakes, as well as to investigate the impact of marine climate changes on fish production in the region.

Foraminiferal and thecamoebians distribution, stable isotopes, and trace element chemistry in piston cores from Alison Sound (ALS) and Frederick Sound (FS) and a freeze core from Mereworth Sound (MS) within the Seymour-Belize Inlet Complex (SBIC) are utilized to determine changes in regional late Holocene oceanography and climate conditions in the study area. In addition, this study provides an insight into the Holocene foraminiferal paleoecology of the region. Except for a recent analysis of marsh (Vázquez-Riveiros et al., 2007) and surface to near surface foraminifera (Vázquez-Riveiros, 2006), there had not been any previous foraminiferal-based research carried out in the SBIC. Previous studies 
conducted on inlets in this region did not utilize geochemical proxies. Therefore, this study also includes the application of geochemistry to assist in recognizing paleoceanographic and paleoclimate fluctuations in the region.

\subsection{Research Objectives}

Holocene paleoclimatic and paleoceanographic variability archived in sediments from three glacier-carved fjords; Frederick, Alison and Mereworth sounds found within the SBIC, British Columbia coast are investigated in this study. Reconstruction of paleoenvironments enhances the knowledge and understanding of the major drivers of climate and oceanographic fluctuations and their effects on biological systems (Hay et al., 2007). This research utilizes foraminiferal distribution, organic carbon and total nitrogen isotopes as well as major and trace element proxies preserved in piston and freeze core sediments to reconstruct regional climate cycles and oscillations in the area.

This study aims at achieving the following specific research objectives:

Identify high-resolution variation in biofacies in the core sediments.

Use modern foraminiferal distribution as a training set to develop a regression model to reconstruct paleoenvironmental conditions from core sediments.

* Use foraminiferal biofacies, trace element and stable isotope distribution to identify oceanographic and climate fluctuations throughout the Late Holocene.

* Conduct spectral and wavelet analysis to identify climate cycles in the stable isotope and elemental geochemical data.

Integrate all proxies to determine the climate driver in the region. 


\subsection{Thesis Structure}

On the basis of the research approaches used in this study, the thesis is divided into eight chapters. A general introduction to the thesis and purpose of the research are presented in chapter 1 . Relevant reviews of the physiographic setting, climate setting and oceanography of the study area as well as its adjacent areas are briefly discussed in chapter 2 . The materials and methods used in the research are presented in chapter 3 . The results and discussions of the faunal and geochemical data investigated in the inlets are presented in the remaining chapters of the thesis. These include a discussion of the foraminiferal and thecamoebians distribution and biofacies in Alison Sound and Frederick Sound piston cores, VEC02A07 and VEC02A04, respectively, and their implications to the interpretation of oceanography and regional climate in chapter 4. The results and interpretations of geochemical proxies in these cores are also presented in chapter 5. Chapter 6 discusses the faunal and geochemical data from Mereworth Sound freeze core VEC02A13. Microfaunal and geochemical data of this core were combined for a more robust and meaningful interpretation, because only a few of the analyzed samples have statistically significant number of microfossils. Integrated summary and conclusion are presented in chapter 7 while brief systematic descriptions of key foraminifera and thecamoebian species are presented in chapter 8 . 


\section{CHAPTER TWO}

\section{REGIONAL REVIEW}

\subsection{Introduction}

This chapter provides a geographic and geological overview of the Seymour-Belize Inlet Complex (SBIC), and adjacent regions. It highlights the physiographic setting and geological setting as well as the preglacial and postglacial climate history of the region. A general regional oceanographic setting and summary of the oceanographic properties of SBIC inlets and previous research on foraminifera and geochemistry in the adjacent regions are also reviewed.

\subsection{Study Area}

British Columbia coastal area is very mountainous with a total length of $29,500 \mathrm{~km}$, making it one of the most incised coasts in the world (Patterson et al., 2007). This coast is an example of a typical fjord coast, rocky and indented by many inlets (Pickard and Giovando, 1960). The inlets being studied; Frederick, Alison and Mereworth sounds are distributaries of SBIC. The SBIC is geographically positioned between latitudes $51^{\circ} 50.2^{\prime} \mathrm{N}$ and $51^{\circ} 10.6^{\prime} \mathrm{N}$ ) and longitudes $126^{\circ} 30.2^{\prime} \mathrm{W}$ and $127^{\circ} 40.5^{\prime} \mathrm{W}$ and $40 \mathrm{~km}$ northeast from Port Hardy on Vancouver Island (Figure 2.1). The SBIC consists of a series of deep, steep-sided glacial- 


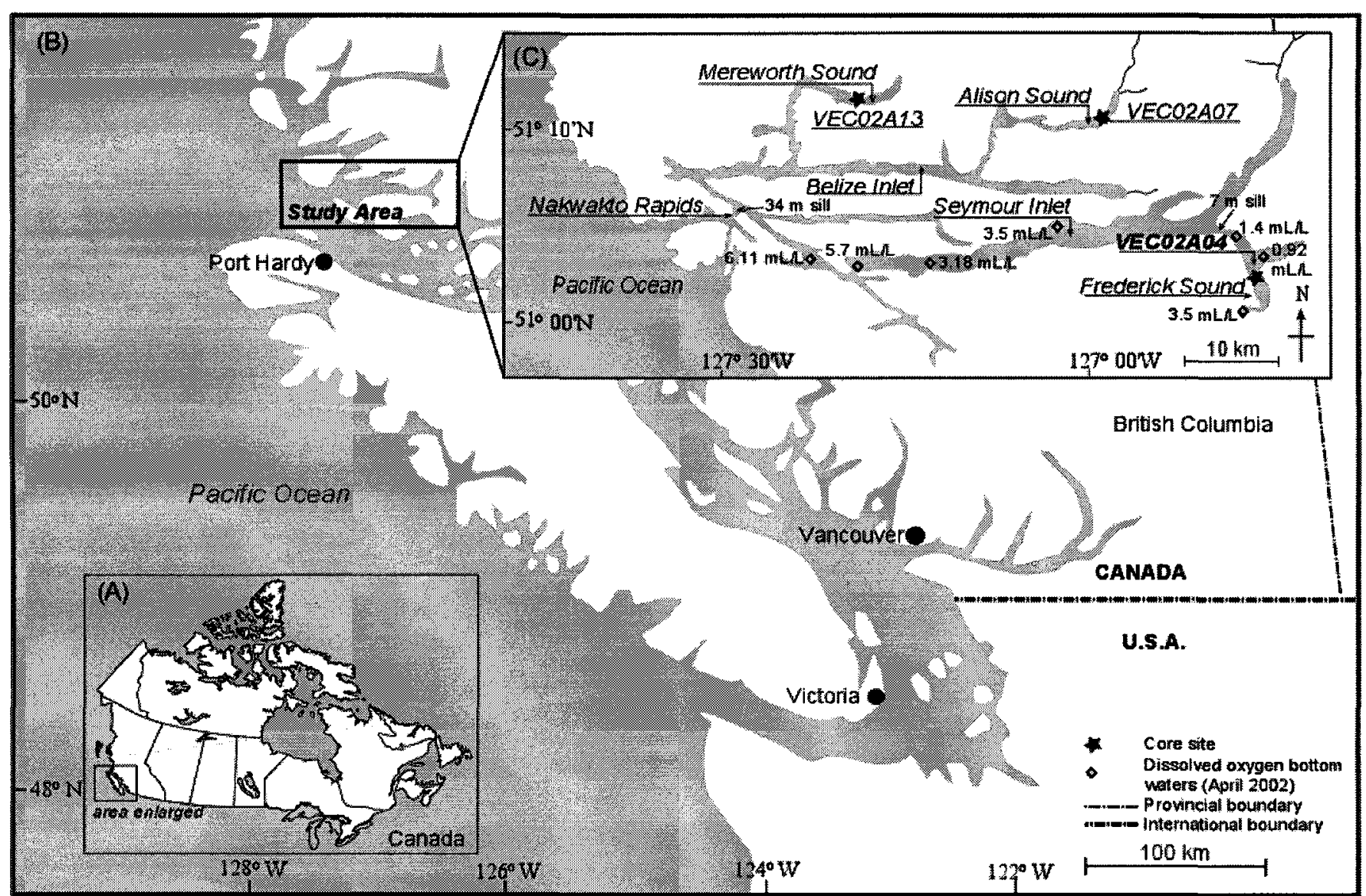

Figure 2.1. Location of the study area (SBIC). (A) Map of north America showing Vancouver Island, (B) Map of southwest British Columbia showing study area and (C) Map of Seymour-Belize Inlet Complex showing the locations of Frederick Sound, Alison Sound and Mereworth Sound, core sites and sills (after Galloway et al., in press) 
carved fjords, which indent the southern part of the mainland coast of British Columbia (Pickard, 1961, Vazquez-Rivieros et al., 2007).

\subsection{Geological Setting}

Vancouver Island is underlain by Paleozoic and Mesozoic rocks of the Wrangellia Terrane (Jones, et al., 1977; Coney et al., 1980; Nixon and Orr, 2007). In the northern part of Vancouver Island the Wrangellia Terrane rocks are intruded by granitoid rocks of the Coast Plutonic Complex, and on its western side fault-bounded by the Pacific Rim Terrain and the metamorphosed rocks of the Western Crystalline Complex (Wheeler and McFeely, 1991; Greene et al., 2005; Nixon and Orr, 2007). This terrane is characterized by the Karmusten flood basalt, the Quatsino limestone, and the Parson Bay mixed carbonate-clastic suite (Jones et al., 1977; Panteleyev et al., 1996; Nixon and Orr, 2007). The Jurassic volcanic granitoid and sedimentary beds of Parson Bay are comprised of a mixed carbonate-clastic sequence (Figure 2.2). Wrangellia amalgamated with the Alexander Terrane during the Carboniferous period (Yorath et al., 1985; Gardner et al., 1988; Yorath and Nasmith, 1995; Greene et al., 2005; Nixon and Orr, 2007) to form the Insular Belt. The terrane might have also merged with the Taku Terrane of south-eastern Alaska and Peninsular Terrane of southern Alaska by the Middle Jurassic to Early Cretaceous period (Greene et al., 2005; Jones and Silberling, 1979; Berg et al., 1978; Coney et al., 1980; Monger et al., 1982; Chamberlain and Lambert, 1985; van der Heyden 1992; Monger and Journeay, 1994). The final accretion of the Cordillera to the North America plate probably occurred in the Early Cretaceous (Tempelman-Kluit, 1979; Coney et al., 1980).

As shown in Figure 2.3, the SBIC is located within geological map sheets 092L and $092 \mathrm{M}$ of Cape Caution, and adjacent parts of Vancouver Island (Bellefontaine and Alldrick, 


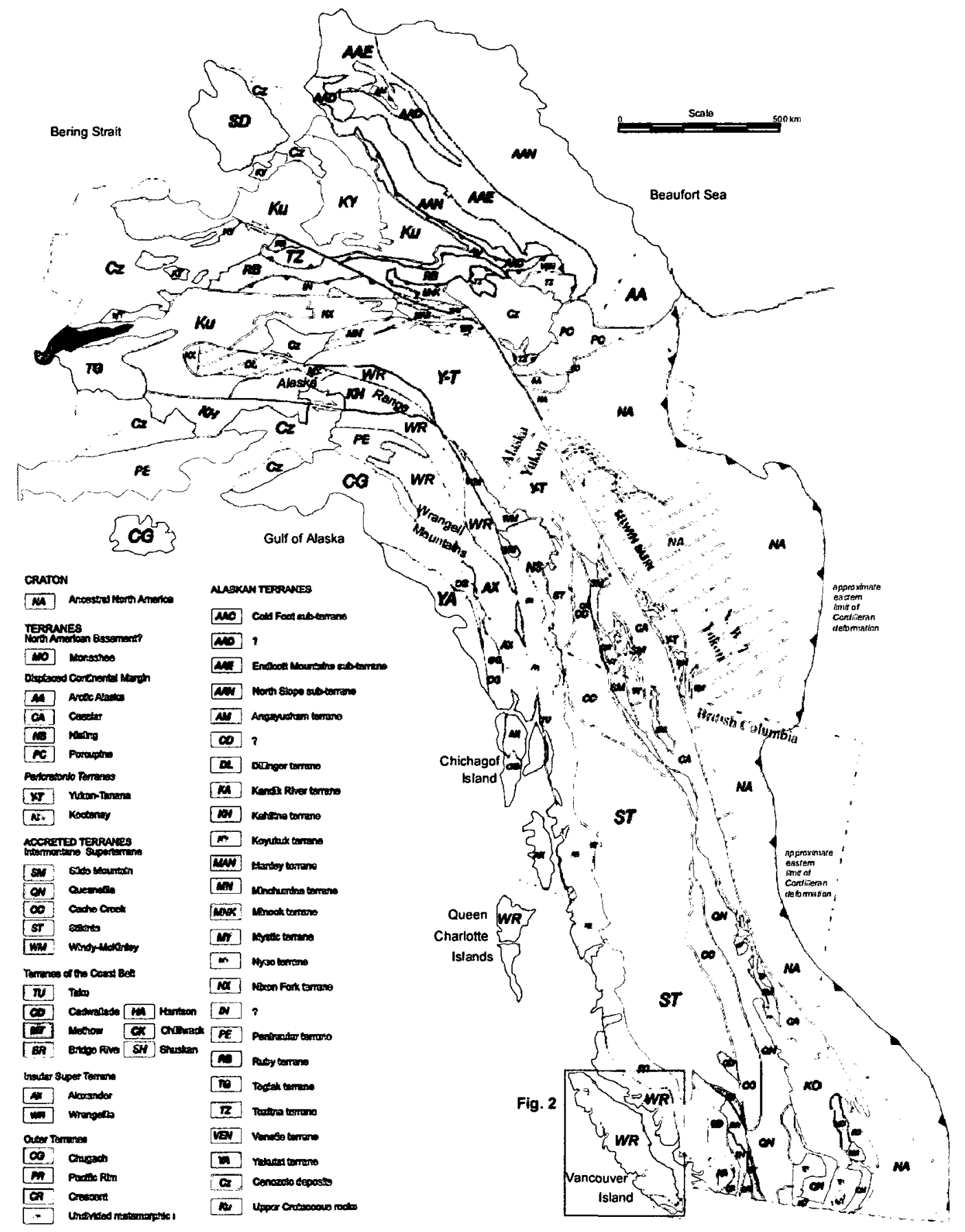

Figure 2.2. Terrane map of western Canada and Alaska (modified after Wheeler $e t$ al., 1991; Greene et al., 2005) showing the distribution of the Wrangellia Terrane (WR) in British Columbia, the Yukon and Alaska. 


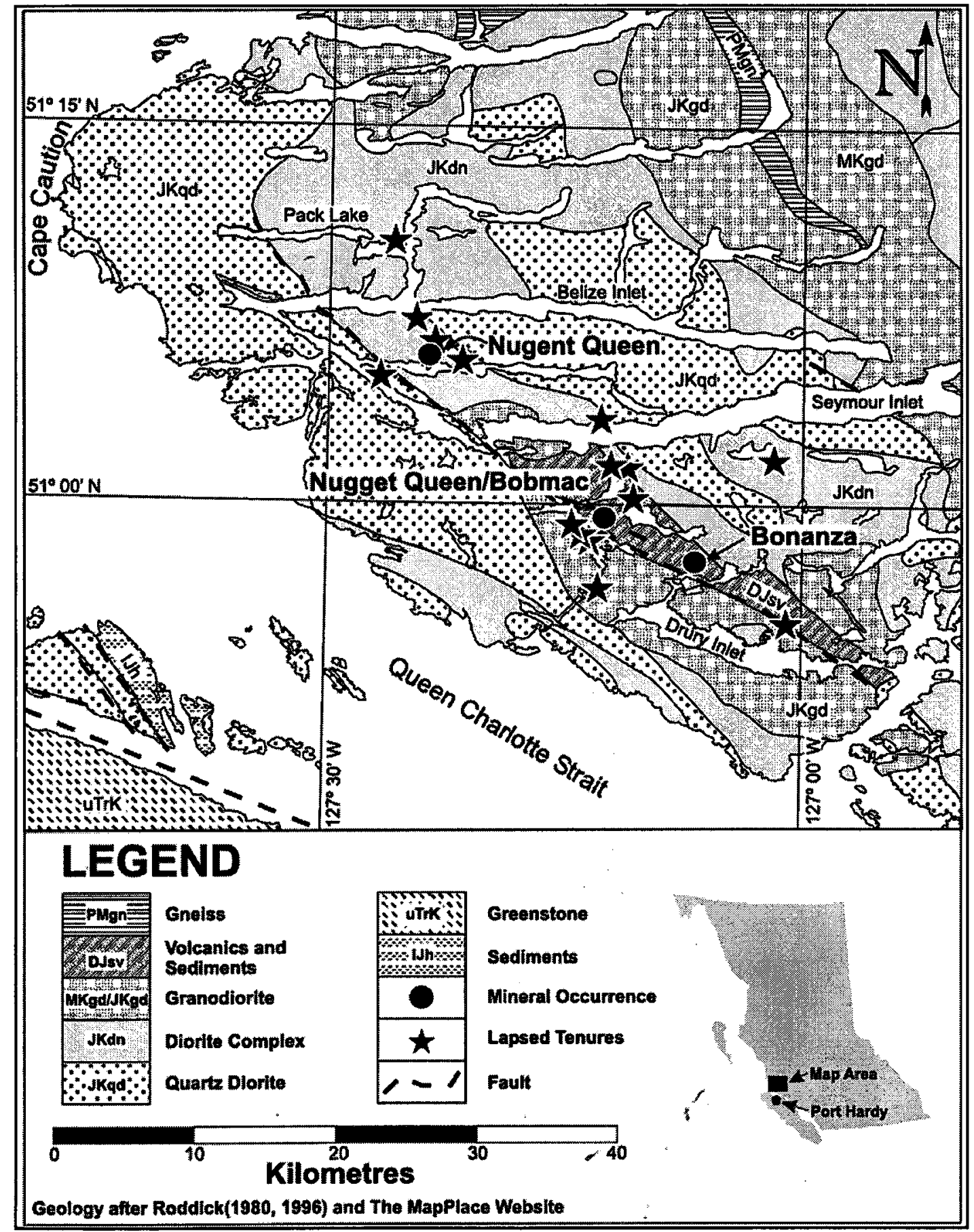

Figure 2.3.Geological map of Cape Caution showing the bedrocks in Seymour-Belize Inlet Complex (After Pinsent, 1999). 
1994). The area is characterized by subparallel, weakly to strongly metamorphosed volcanic and sedimentary strata, diorite complexes, and massive to foliated plutonic of Devonian to Cretaceous age (Pinsent, 1999). These metamorphosed rocks are overlain by agmatite, gneiss, and gabbroic to dioritic amphibolites (Bellefontaiane and Alldrick, 1994; Pinsent, 1999). These crystalline rocks are overlain by superficial sediments that are mainly composed of glacier mud and silts (Toombs, 1956).

\subsection{Late Pleistocene Glaciations}

The landscape of British Columbia and its continental shelf are a result of Late Pleistocene glaciations (Blais et al., 1990; Barrie and Conway, 1999; Clague and James, 2002; Chang, 2004). These glaciations are represented by the Wisconsin ice sheet (locally called Fraser Glaciations) and greatly influenced the atmospheric circulation and climate of the entire Western North America (Clague and James 2002). In this region, glaciations started to develop from 25,000 to $30,000{ }^{14} \mathrm{C}$ yr BP, and reached their peak between 21,000 and 15,000 ${ }^{14} \mathrm{C}$ yr BP (Clague 1977, 1981; Blais et al., 1990; Clague and James, 2002; Barrie and Conway, 2002).

In the Queen Charlotte Islands' area, glaciers developed independently of the Cordilleran ice sheet and occurred as ice caps within the network of valleys and piedmonts (Blais et al., 1990). In the western part of British Columbia, advancing glaciers flowed into valleys and extended to the Coastal Mountain areas where they carved out fjords and covered most parts of the continental shelf (Prest, 1970). In the southern Mountains and Vancouver Island regions, the glaciers coalesced to form piedmont lobes that flowed into the Puget Lowland area in Washington as well as to the Juan de Fuca Strait (Armstrong et al., 1965; Waitt and Thorson, 1983). The largest glacier reached up to $900 \mathrm{~km}$ wide and covered as 
much as $2000 \mathrm{~m}$ in elevation over most of the interior of British Columbia (Wilson et al., 1958), and up to $2000 \mathrm{~m}$ thick in major valleys (Clague et al., 1982; Barrie and Conway, 1999). Glaciers retreated at different times in different areas. Deglaciation in the offshore region of the Queen Charlotte basin started at about 16,000 to $15,000{ }^{14} \mathrm{C}$ yr BP when it retreated eastwards. Glaciers had retreated from the Strait of Georgia by ca $14,000{ }^{14} \mathrm{C}$ yr BP (Clague, 1981, 1994) and in the Lowland area at about $13,900{ }^{14} \mathrm{C}$ yr BP (Potter and Swanson, 1998). The tide water was ice free between 13,500 and $13,000{ }^{14} \mathrm{C}$ yr BP (Blais et al., 1990; Barrie and Conway, 2002). Postglacial radiocarbon dates from the interior of British Columbia suggests that the entire region was totally free of ice by $10,000{ }^{14} \mathrm{C}$ yr BP (Clague and James, 2002). The imprint of these glaciers across the region have produced distinctive landscapes including steep sided glacier carved valleys (fjords) which are indented along the coastal areas.

\subsection{Holocene Climate}

Knowledge of the variations in the Holocene climate in British Columbia is mainly based on numerous palynological studies (Mathewes and Heusser, 1981; Mathewes, 1985; Thompson et al., 1993; Pellatt and Mathewes, 1997; Hebda, 1995; Brown and Hebda, 2002, 2003; Clague et al., 2004). Fossil chronomids are also used to reconstruct climate oscillations in parts of British Columbia (Walker and Mathewes, 1987; Heinrichs et al., 1997; Smith, 1997; Smith et al., 1998; Palmer et al., 2002; Rosenberg et al., 2004).

Following the final glacial retreat, three climate intervals are identified through the Holocene in the Northwest Pacific region (Hebda, 1995; Pellatt and Mathewes, 1997). The postglacial early Holocene $(\sim 11,000-7,800$ cal yr BP) was warmer and drier than during any other part of the Holocene (Pellatt and Mathews, 1997; Brown and Hebda, 2002, 2003; Clague 
et al., 2004; Larcouse, 2005). Mathewes and Heusser (1981) informally termed this climate episode the "xerothermic period". During this interval, vegetation was open and lake levels were low (Mathewes and King, 1989); douglas fir, grass, bracken fern and Sellaginella wallace $i$ were the dominant plants. The temperatures were from $2^{\circ} \mathrm{C}$ to $4^{\circ} \mathrm{C}$ warmer than during the preceding time and any subsequent time including the present (Hebda, 1995; Brown and Hebda, 2003). Pellatt et al. (2001) established that this warm and dry period was predominantly characterized by an abundance of Pseudostuga menziensii, grass and bracken pollen. Between 8,300 and $7,040 \mathrm{cal}$ yr BP, a warm interval with milder conditions, is indicated by the high abundances of Quercus, high grass and bracken in Saanich Inlet. The appearance and proliferation of Abies, Picea, Tusga heterophylla, Pseudostuga menziensii and Alnus suggest that this warm and dry interval existed in the Vancouver Island region for the last 11,400-8,215 yr BP (Hebda, 1995; Brown and Hebda, 2003; Lacourse, 2005). In the Seymour-Belize Inlet Complex, early Holocene warm and dry climate conditions are suggested by the migration of Pseudostuga menziensii where it grew in association with Tsuga heterophylla and Alnus pollen in the last $10,200-8,000{ }^{14} \mathrm{C}$ yr BP or $12,300-9,200 \mathrm{cal}$ yr BP (Galloway, 2006; Galloway et al., 2007, 2008).

The middle Holocene $(7,800-4,500$ cal yr BP), informally termed "mesothermic period" (Hebda, 1995), was warm and moist. These warm and wet conditions are well defined in the interior of British Columbia, but are less well expressed along coastal British Columbia, northwest Washington and southeast Alaska (e.g., Mathewes, 1973, 1989; Hebda, 1983, 1995; Hebda and Mathewes, 1984; Pellatt, 1996; Pellatt and Mathewes, 1997). Cool and wet conditions probably occurred in SBIC earlier than in southern coastal British Columbia. The increase of Cupressaceae pollen, and decline of Picea, Abies and Alnus occurred by $8,000{ }^{14} \mathrm{C}$ 
yr BP $(9,200 \mathrm{cal}$ yr BP) in the SBIC (Galloway 2006; Galloway et al., 2007) whereas in the southern coastal region of British Columbia, the expansion of Cupressaceae pollen (Thuja plicata) occurred between 6,600 and $7,500{ }^{14} \mathrm{C}$ yr BP (e.g., Mathewes, 1973; Hebda and Mathewes, 1984; Barnosky, 1981; Hebda, 1995; Pellatt et al., 2002; Brown and Hebda, 2002). These cool and wet conditions also occurred in the study region (Galloway, 2006; Galloway et al., 2007, 2008) earlier than in the northern part of Vancouver Island and the Queen Charlotte Islands (Hebda, 1983; Warner, 1984; Fedje, 1993; Pellatt and Mathewes, 1994; Lacourse, 2005; Lacourse and Mathewes, 2005).

The Late Holocene is considered as relatively stable with moderate temperatures and precipitation (Mathewes and Rouse, 1975; Mathewes and Heusser, 1981). During this interval modern climate conditions became established (Hebda, 1995) although the interval is also punctuated by several intervals of Neoglaciation, which impacted climate in the northwest Pacific region. This period is generally considered to have experienced cool conditions and glacier advances following the dry and warm early Holocene interval (Porter and Denton, 1967; Clague et al., 2004). This interval of Neoglacial climate is time transgressive, beginning from ca 5,000 to $3,000{ }^{14} \mathrm{C}$ yr BP depending on location in the NW Pacific region (Heusser, 1985; Mathewes, 1985; Hebda, 1995). It commenced from about 5,000 yrs BP in western Canada (Luckman et al., 1993) and attained its maximal peak with the onset of the Little Ice Age glacial advance from $\sim 1,200 \mathrm{AD}$ through the late 19th century (Luckman, 2000).

The transition to cool and moist climate Neoglacial conditions was rapid in northwest Washington (Mathewes and Pellatt, 1997). It started in the northwest Washington and Puget Lowland region between $7,000{ }^{14} \mathrm{C}$ yr BP and $6,000{ }^{14} \mathrm{C}$ yr BP with several maximum glacier advances including the Tiedemann $\left(2,300{ }^{14} \mathrm{C}\right.$ yr BP), Gilbert (1,900 cal yr BP), Frank Mackie 
(maximum at 2,700 cal yr BP) and Berendon (maximum from 2,200-2,800 cal yr BP) occurring in the coastal Mountains region (Clague and Mathewes, 1996; Ryder and Thomson, 1986; Luckman et al., 1993). The Pyto and Robson glacier advances which occurred between 3,300 cal yr BP and 1,900 cal yr BP characterized the southern Canadian Rocky Mountains are additional examples of the onset of Neoglacial conditions (Ryder and Thomson, 1986; Luckman et al., 1993). In the northern Coastal Mountain region of British Columbia there was an additional major Neoglacial advances, which started between 2,800 and 3,000 cal yr BP with intervening smaller advances from 1,200 to 1,300 cal yr BP (Clague et al., 2004). According to Ryder $(1987,1989)$, there are also several records of glacier events in the last millennium $\left(100-900{ }^{14} \mathrm{C}\right.$ yr BP), particularly during the Little Ice Age.

\subsection{Modern Climate}

The modern climate of northern Vancouver Island and the central coast of British Columbia is wet-cool temperate (Patterson et al., 2000; Kumar and Patterson, 2002; Chang et al., 2003). The winter sea surface temperature reaches up to $8^{\circ} \mathrm{C}$ with a maximum of $18^{\circ} \mathrm{C}$ $20^{\circ} \mathrm{C}$ in spring and summer (Thomson, 1981). Coastal air temperatures vary from 1 to $5^{\circ} \mathrm{C}$ in winter with a maximum of $20^{\circ} \mathrm{C}$ in summer (Ryder, 1989; Chang and Patterson, 2005). Most precipitation occurs during the cool winter months and could reach up to $2500 \mathrm{~mm}$ annually (Ryder, 1989).

The SBIC lies within the Coastal Western Hemlock (CWH) biogeoclimatic zone (Research Branch, 1988), which occurs at elevations ranging from 0 to $900 \mathrm{~m}$ (Allen et al., 1999; Rollerson et al., 2001; Haggarty et al., 2003) and is the wettest and most productive forest zone in British Columbia (Rollerson et al., 2001). The CWH is usually characterized by cool summers and mild winters. Instrumental temperature records from Port Hardy's 
meteorological station (latitude $50^{\circ} 68 \mathrm{~N}$ and longitude $127^{\circ} 37^{\prime} \mathrm{W}$ ) located about $40 \mathrm{~km}$ from the SBIC indicates that the maximum mean summer monthly temperature is $\sim 17^{\circ} \mathrm{C}$ and the minimum winter temperature near $\sim 0.67^{\circ} \mathrm{C}$ (Environment Canada, 2007). Annual precipitation of $1,820 \mathrm{~mm}$ is typical of this locality with over $72 \%(1,313 \mathrm{~mm})$ falling during autumn and winter. Summer precipitation is usually very low, ranging from $73 \mathrm{~mm}$ in June to $56 \mathrm{~mm}$ in July.

\subsection{Ocean and Atmospheric Circulation}

Seasonal variations between the two main pressure systems in the Northeast Pacific the Aleutian Low (AL) and North Pacific High (NPH)-determine the nature of climate conditions that prevail in the region (Thomson, 1981; Kumar and Patterson, 2002)). In the winter, winds associated with the anticlockwise circulation of the AL cause the North Pacific Coastal current to flow northwest (Thomson, 1981; Thomson and Gower, 1998). In the summer, the current direction shifts southeast as the shelf current responds to winds associated with the clockwise circulation of the NPH (Thomson and Gower, 1998; Chang and Patterson, 2005). The AL attains its maximum intensity in January and shifts its center of action southeast from northern Bering Sea to the Gulf of Alaska (Figure 2.4). In the spring when the AL declines in intensity, the NPH builds up and attains maximum intensity in summer (Figure 2.4).

The AL generates warm and southerly winds in winter while in summer; the clockwise circulating NPH produces cold and dry northerly winds (Thomson, 1981; Ware and Thomson, 1991; Beamish, 1993). The intensified AL causes higher wind stress, warmer temperatures and higher sea levels along the coast (Emery and Hamilton, 1985; Ware, 1995) and is also responsible for winter storms in the northeast Pacific (Miller et al., 1994; Beamish et al., 1999; 
Chang and Patterson, 2005). Storms from the ocean move northeast towards the southern part of $\mathrm{BC}$ and north of Washington while those from the Gulf of Alaska move southeast from the northern Berring Sea to the Gulf of Alaska (Figure 2.4).

Along the west coast of the US and Vancouver Island, wind-driven upwelling is prevalent during the summer season from May to August. This type of upwelling extends seawards from the $200 \mathrm{~m}$ shelf break (Chang and Patterson, 2005) resulting in surface waters in coastal areas being very cold. It is usually caused by a seaward forced Ekman transport in the surface layer which coincides with the southeastward-flowing shelf break current (Figure 2.5) (Thomson, 1981; Chang and Patterson, 2005). This wind-induced upwelling is associated with the northwesterly wind of the NPH, which displaces warm water from the surface resulting in the subsequent development of offshore Ekman transport upwelling conditions. The well oxygenated, nutrient-rich, and cold upwelled waters move shorewards over the shelf where they initiate an increase in phytoplankton production along the coastline (Thomson, 1981; Thomson et al., 1989; Allen et al., 2001; Patterson et al., 2004a, b; Chang and Patterson, 2005). The enhanced phytoplankton productivity, in turn, influences other higher level members of the marine food chain (Thomson, 1981; Minobe, 1997; Francis and Hare, 1994; Francis et al., 1998).

Oceanographically, the SBIC is situated within the Coastal Transition Domain (CTD) just beyond the northern limit of the Coastal Upwelling Domain (CUD) (Ware and McFarlane, 1989). The Coastal Transitional Domain is characterized by conditions which are in between the ones of the Coastal Upwelling Domain to the south and those of the Coastal Downwelling Domain (CDD) to the north (the Gulf of Alaska region) (Figure 2.6) (Patterson et al., 2007). Since the SBIC is not directly connected to the Pacific Ocean but only opens to 

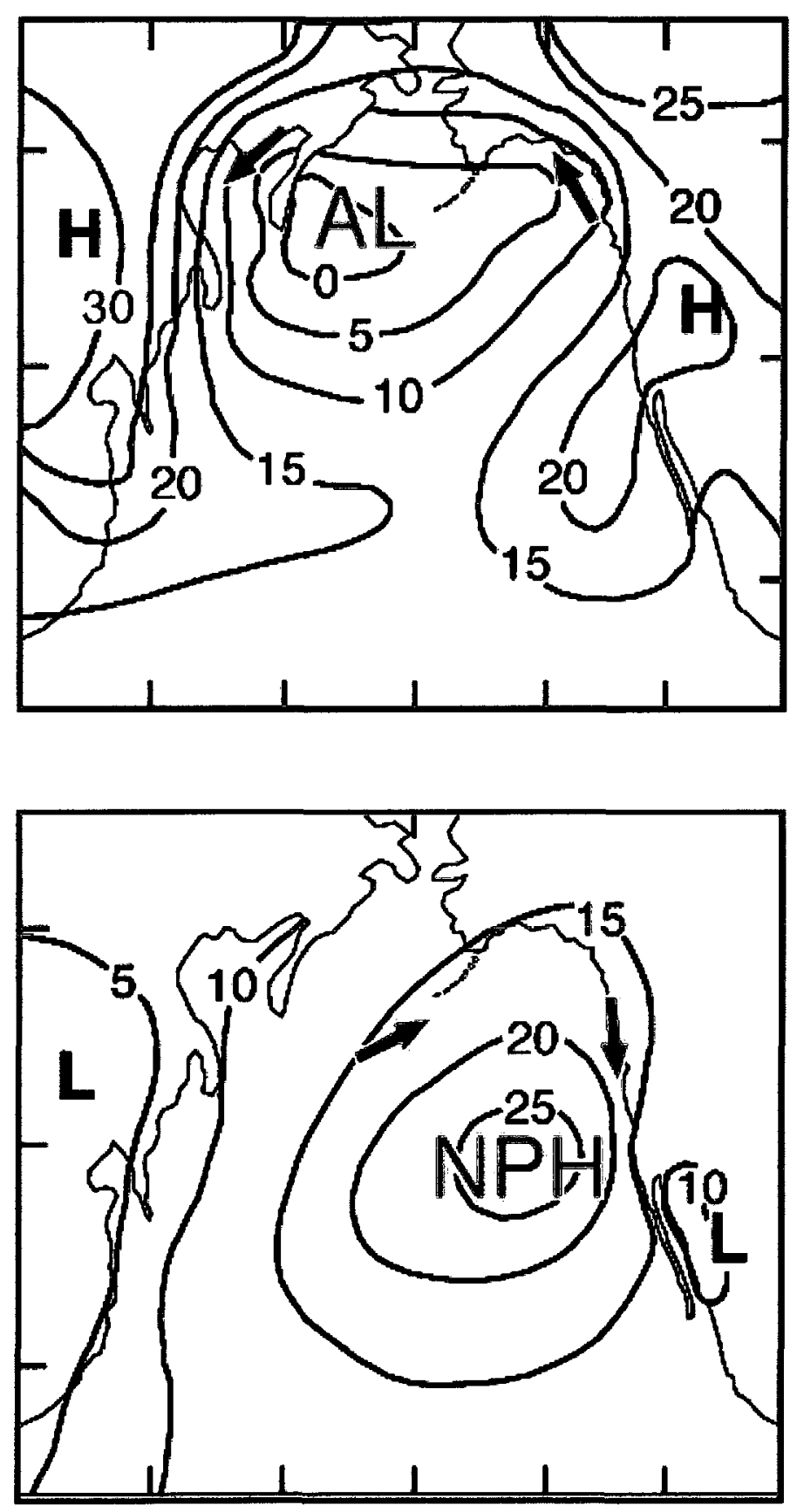

Figure 2.4. Seasonal variations in Aleutian Low (AL) and North Pacific High (NPH) (after Thomson, 1981, modified by Patterson et al., 2004a). AL is intense in winter (January); NPH is intense in summer (July). 

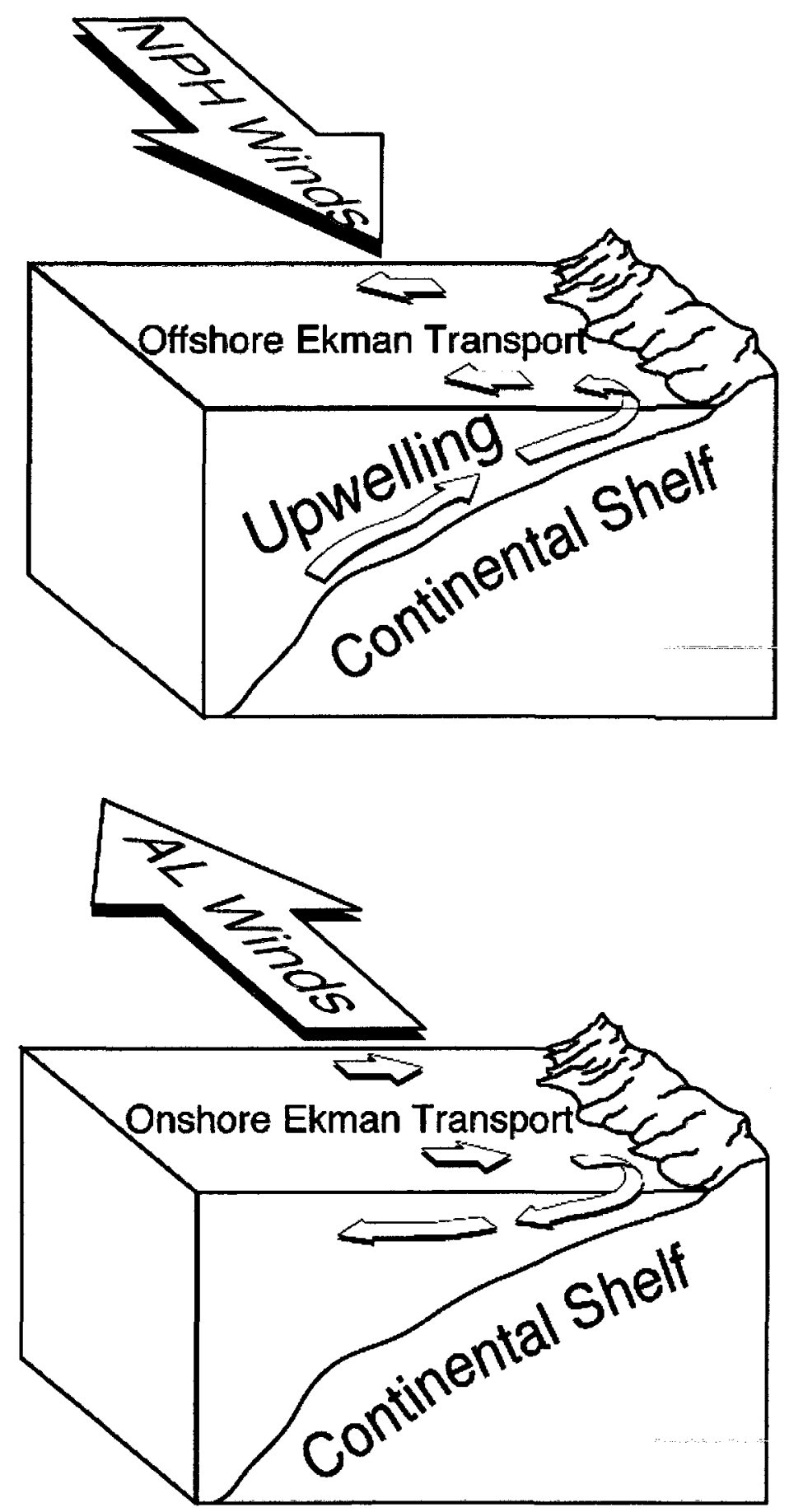

Figure 2.5. Coastal upwelling and downwelling in the Northeast Pacific (Favorite, et al., 1976, modified by Patterson et al., 2004a). 


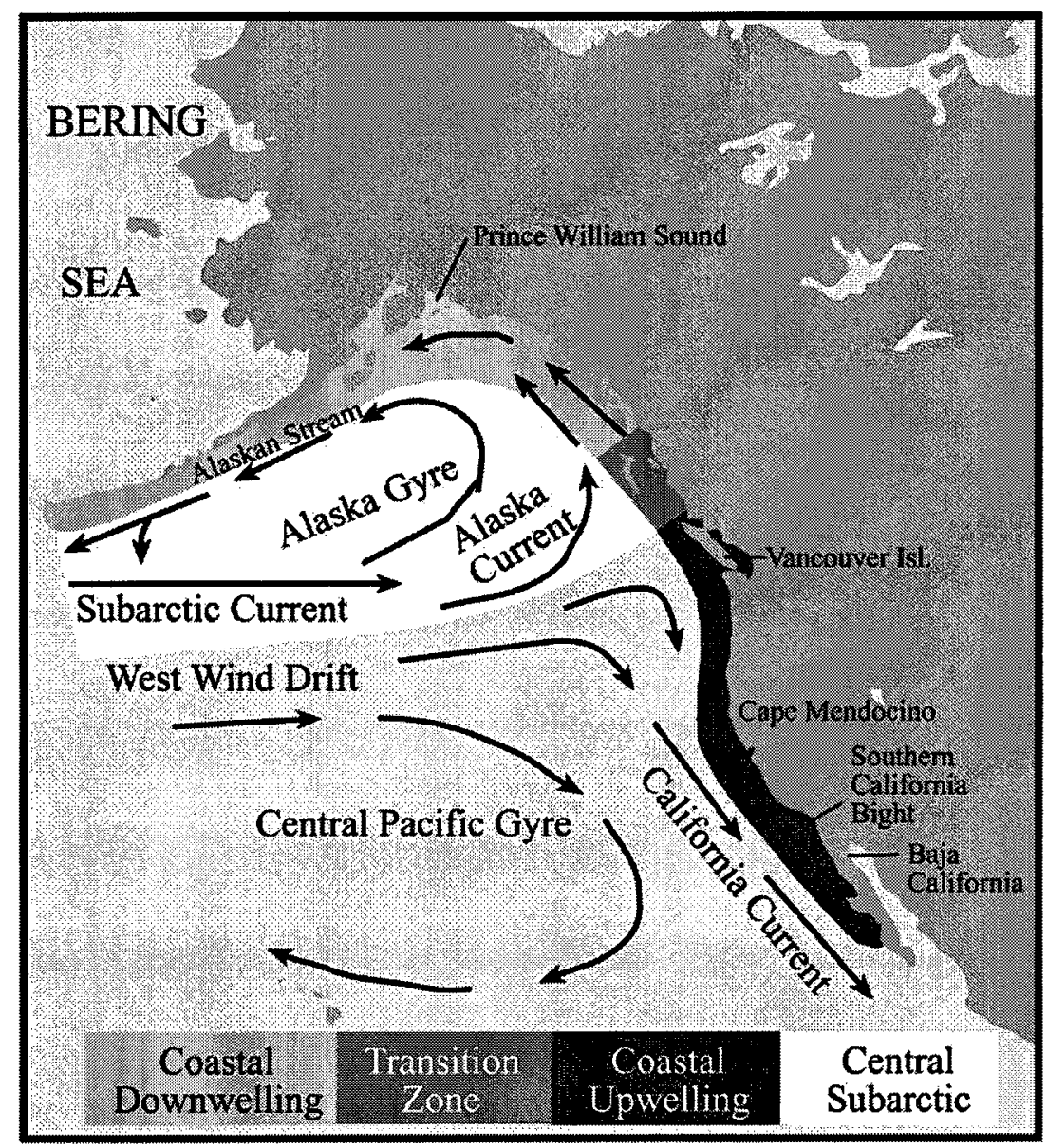

Figure 2.6. Fisheries production domains and general large-scale circulation in the Northeast Pacific Ocean (from Ware and McFarlane 1989; modified by Batchelder and Powell, 2002). 
Queen Charlotte Sound, this area experiences little or no upwelling compared to other regions such as Effingham Inlet on the west coast of Vancouver Island (e.g., Patterson et al., 2004 a, b; Patterson et al., 2007).

\subsection{Regional Oceanography}

The SBIC is quite large, comprised of more than $1600 \mathrm{~km}$ of steep-walled glaciercarved fjords. The SBIC opens to the southern end of Queen Charlotte Sound through Slingsby and Schooner channels, which merge to a single passage at the Nakwakto Rapids (Thomson 1981; Hemingway and Douglas, 1999). The Nakwakto Rapids, which are $34 \mathrm{~m}$ deep and $400 \mathrm{~m}$ wide form a narrow rocky passage located at about $11.26 \mathrm{~km}$ to the southeast of Cape Caution and $9.66 \mathrm{~km}$ to the east of the Slingsby channel (Bailey and Nyberg, 2006). The constriction formed by this channel makes the tides at the entrances of Seymour and Belize inlets one of the swiftest in the world, ranging from 8 to $10 \mathrm{~m} / \mathrm{s}(16-20 \mathrm{knots})$ on a spring ebb tide to $7 \mathrm{~m} / \mathrm{s}$ (14 knots) during the maximum flood current (Thomson, 1981; Hemingway and Douglas, 1999; Bailey and Nyberg, 2006). Despite the high currents within the Nakwakto Rapids, the narrowness of the channel prevents sea levels within the complex and Queen Charlotte Sound from equilibrating with each other across the turn of a tide. As a result, the tidal range fluctuations within the complex only rise and fall about $1.3 \mathrm{~m}$ in contrast to more than $3 \mathrm{~m}$ tides within Queen Charlotte Sound (Fisheries and Oceans, 2003).

The presence of these shallow topographic sills makes the water columns of most fjords highly stratified throughout most of the year with estuarine circulation due to freshwater discharge at the head (Haggarty et al., 2003). A balanced salt content in the inlet is maintained because dense saline water flowing into the inlet enters below the less dense out flowing freshwater (Pickard and Stanton, 1980). The resulting unidirectional flow is 
superimposed on the flood and ebb currents, thus decreasing the flood speed and increasing that of the ebb (Pickard, 1961; Pickard and Stanton, 1980). The restricted ocean water inflow and low-salinity wedge caused by the freshwater discharge at the head of the inlets reduce the net mixing between the surface and bottom waters, thus forming stratified water columns (Pickard and Stanton, 1980; Thomson, 1981; Patterson et al., 2007).

The stratification of the water column creates anoxic conditions suitable for formation and preservation of organic matter, and annual deposition of rhythmatically laminated sediments (varves). These varved sediments from glacier-formed fjords contain excellent proxy records which could be utilized to reconstruct paleoceanography (Baumgartner et al., 1985; Schimmelmann et al., 1990; Kemp, 1996, 2003).

\subsection{Oceanography of Seymour-Belize Inlet Complex}

A series of lagoons, sounds and numerous bays, found within the SBIC, are considered to have archived an almost complete paleoeceanographic and paleoclimate Holocene record. The features of some of these fjords are briefly highlighted in the following sections.

\subsubsection{Seymour Inlet}

Seymour Inlet is the main arm of the Seymour-Belize Inlet Complex located at $51^{\circ}$ $03 \mathrm{~N}$ latitude and $127^{\circ} 05^{\prime} \mathrm{W}$ longitude and is about $70 \mathrm{~km}$ in length away from the mouth of Seymour River (Figure 2.1) (Patterson et al., 2007). Seymour Inlet has a mean depth of $420 \mathrm{~m}$ with a maximum depth of over $600 \mathrm{~m}$ and an average width of $1.45 \mathrm{~km}$ (Pickard, 1961). Unlike other large inlets in the region such as Knight and Bute Inlets, Seymour inlet is not surrounded by high mountains, but none the less has a rugged physiography (Pickard, 1961). It is characterized by narrow waterways, tidal pools and lagoons. Smaller adjoining inlets to Seymour inlet include Frederick Sound which forms its southern arm. The Seymour Inlet, 
characterized by moderate runoff with little or no freshwater contributions from glacier or summer snow melt, has a $100 \mathrm{~m} / \mathrm{s}$ mean annual freshwater discharge. The main source of its freshwater is from the Seymour River. The surface salinity ranges from 1-11\% at the head to $15-29 \%$ at the mouth. Dissolved oxygen concentrations ranges from 2.92 to $6.11 \mathrm{~mL} / \mathrm{L}$.

\subsubsection{Belize Inlet}

Belize Inlet is a fjord with an average depth of $255 \mathrm{~m}$ (400 m maximum), length of about 45 to $50 \mathrm{~km}$ (Pickard, 1961; Patterson et al., 2007) and width of $0.9 \mathrm{~km}$. Some of the inlets in the Coastal Mainland region, such as Seymour and Belize Inlets, are not fed with runoff from stored glacier melts (Pickard, 1961). This group of inlets is normally characterized by low to moderate runoff, with an above average annual runoff in the spring and winter, and below average one from July through September (Pickard, 1961). Freshwater enters Belize inlet through its tributary inlet -Alison Sound- at its northern end (Pickard, 1961). The average annual freshwater discharge in the inlet is about $80 \mathrm{~m}^{3} / \mathrm{s}$ (Trites, 1955; Pickard, 1961). The surface salinity is low, (1-11\%o), and ranges from 15 to $29 \%$ at the bottom of the water column (Trites, 1955, Pickard, 1961). Watermass properties of this inlet measured in April, 2002 indicate that salinity ranges from $26 \%$ close to the head to $30 \%$ at the mouth of the inlet (Thomson personal communication. 2003; Vázquez-Riveiros, 2006). The dissolved oxygen within the inlet ranges from 3.7 to $4.95 \mathrm{~mL} / \mathrm{L}$.

\subsubsection{Frederick Sound}

Frederick Sound (FS) is about $10 \mathrm{~km}$ long, is $<0.5 \mathrm{~km}$ wide at its entrance into Seymour Inlet, and $>1.5 \mathrm{~km}$ wide at its opening to the adjoining Salmon Sound (Pickard, 1961; Bailey and Nyberg, 2006). Piston core VEC02A04 from FS was collected from $240 \mathrm{~m}$ water depth. In addition to the main sill-the Nakwakto Rapids, the presence of a $7 \mathrm{~m}$ deep sill 
at the entrance of FS to Seymour Inlet restricts water circulation. Subbottom water profiles obtained by the Pacific Geoscience Center in Sydney in 2002 show that FS has a welldeveloped estuarine circulation (Thomson, 1981; Patterson et al., 2007). As shown in Figures 2.7a, salinity measured in April 2002 increases from $\sim 15 \%$ at the head to about $27.6 \%$ towards the mouth and temperature decreases from $\sim 14^{\circ} \mathrm{C}$ at the surface to about $8.5^{\circ} \mathrm{C}$ with depth (Figures 2.7c). A thermocline occurs at about $50 \mathrm{~m}$ water depth. The dissolved oxygen content ranges from $\sim 8 \mathrm{~mL} / \mathrm{L}$ at the surface to a low $0.9 \mathrm{~mL} / \mathrm{L}$ at depth (Figures $2.7 \mathrm{~b}$ ). The October 2002 data show a similar pattern with oxygen ranging from $0.063 \mathrm{~mL} / \mathrm{L}$ at depth to $\sim 6 \mathrm{~mL} / \mathrm{L}$ at the surface (Figure 2.7e). Within the vicinity of the core VEC02A04 site, the water salinity varies between $20 \%$ at the surface and $27.5 \%$ at the bottom, and oxygen content at depth ranges between $0 \mathrm{~mL} / \mathrm{L}$ and $0.92 \mathrm{~mL} / \mathrm{L}$ (Figure 2.7).

\subsubsection{Alison Sound}

Alison Sound (ALS) which forms the north eastern arm of Belize Inlet is $17.7 \mathrm{~km}$ long, $0.8 \mathrm{~km}$ wide and $185 \mathrm{~m}$ deep (Pickard, 1961). The inlet attains $\sim 136 \mathrm{~m}$ depth of water at the site where piston core VEC02A07 was collected. Alison Sound, an anoxic fjord within the SBIC, contains basins with sediments that are annually laminated. ALS is permanently stratified because shallow sills at its mouth (17-31 m deep) and the Nakwakto Rapids at the mouth of the SBIC greatly restrict circulation. The dissolved oxygen reaches up to $4 \mathrm{~mL} / \mathrm{L}$ at the surface (Vázquez-Riveiros, 2006). Near the core site, the bottom oxygen level ranges from 0 to $0.06 \mathrm{~mL} / \mathrm{L}$ (Patterson et al., 2007). The salinities in the inlet range from $0-15 \%$ at the head and reaches up to $28 \%$ owards its mouth (Figure 2.8 ). 
(a)

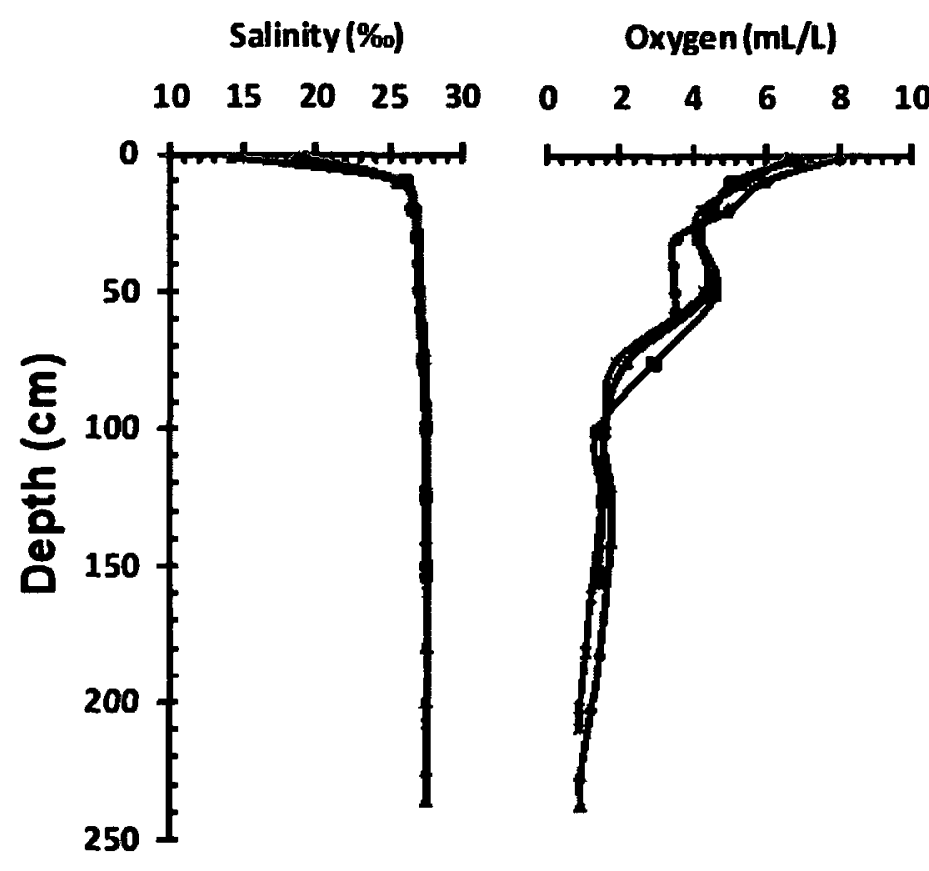

(c) Temperature $\left({ }^{\circ} \mathrm{C}\right)$

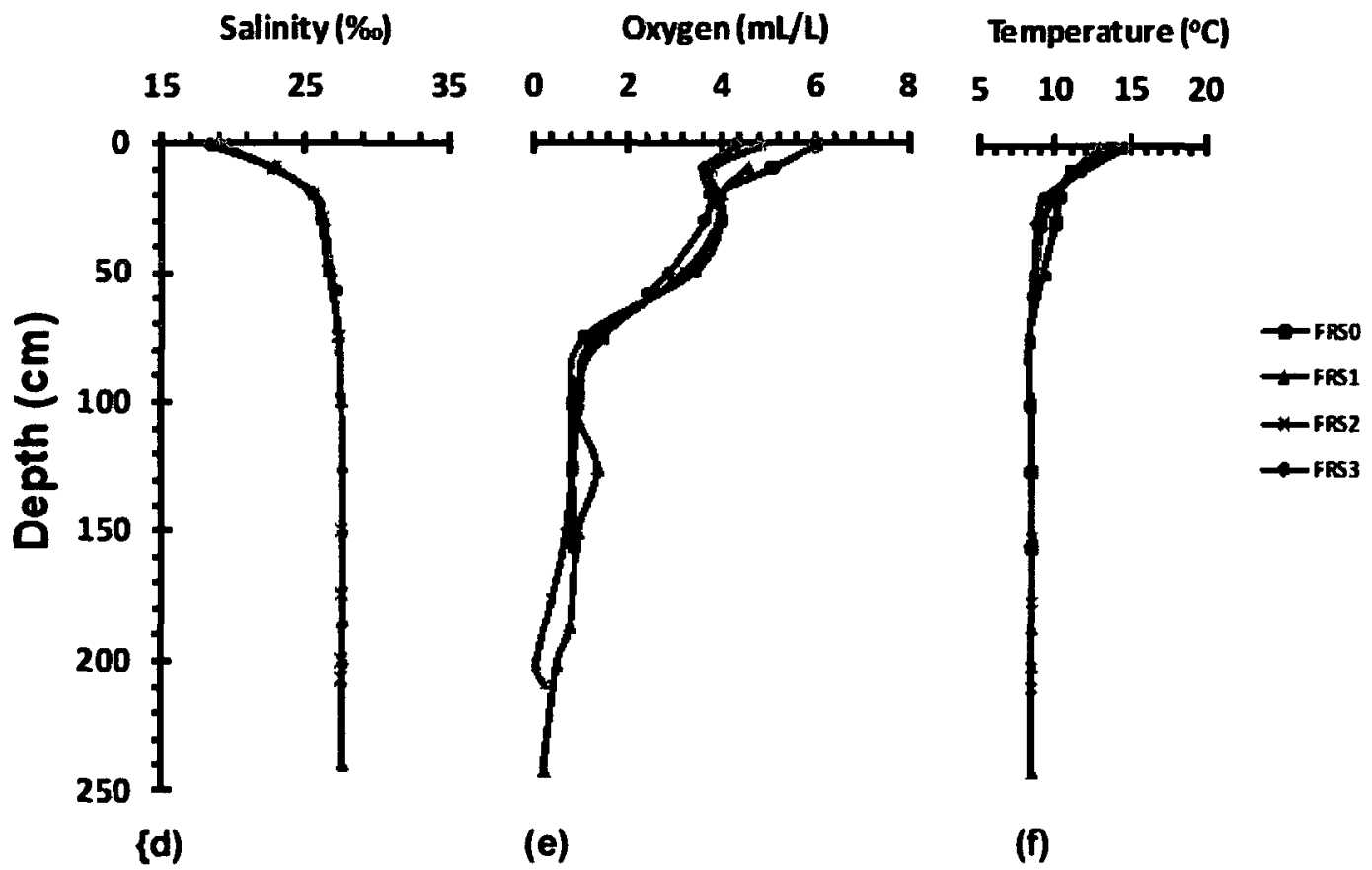

Figure 2.7. Oceanographic data from Frederick Sound (Thomson personal comm., 2003). Figures 2.7a, b and c (April, 2002 data); Figures 2.7 c, d, e (October, 2002). 


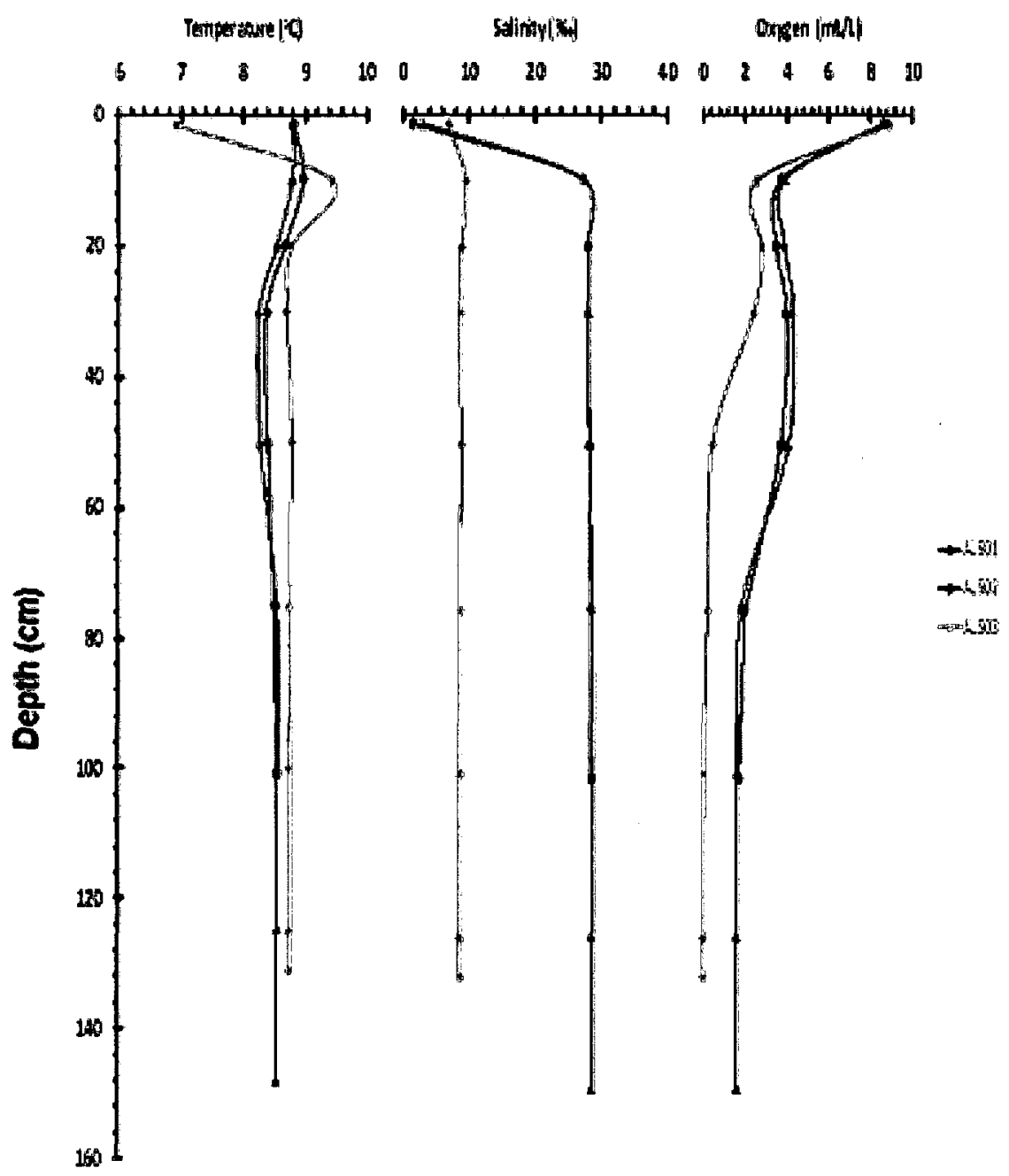

Figure 2.8. Oceanographic data for April 2002 in Alison Sound (Thomson personal comm., 2003). 


\subsubsection{Mereworth Sound}

Mereworth Sound (MS) a small northern distributary arm of the Belize Inlet, is located between latitude $51.017^{\circ} \mathrm{N}$ and longitude $127.42^{\circ} \mathrm{W}$. The MS is $\sim 16 \mathrm{~km}$ long, $\sim 0.8 \mathrm{~m}$ wide, and the water depth reaches up to $185 \mathrm{~m}$ in some parts of the inlet (Pickard, 1961). Bottom water properties were not collected from this inlet. Freeze core VEC02A13 was retrieved below $149 \mathrm{~m}$ water depth.

\subsection{Previous Studies}

\subsubsection{Foraminifera}

Foraminiferal paleoecology has been well investigated along many parts of the west coast of North America. However, only a few of these studies have been carried out on modern foraminifera found along the coast of mainland British Columbia (Vázquez-Riveiros, 2006). The earliest study in the region examined recent shallow water foraminifera from Queen Charlotte Sound and Virago Sound (Cushman, 1925). This was followed by a description of recent fauna from the coastal area of the State of Washington (Cushman and Todd, 1947). Cockbain (1963) studied the distribution of foramininfera in shallow waters in the Georgia Strait region. In her work on foraminiferal taxonomy in the Eastern Pacific, McCulloch (1977) described and illustrated foraminiferal species along Vancouver City Harbor. Foraminiferal distribution along the continental shelf and slope of Vancouver Island is also documented by Gallagher's study in 1979. Jones and Ross (1979) relate the seasonal distribution of foraminifera in Samish Bay, Washington to different ecological factors. Patterson et al. (1998) compiled an atlas illustrating and describing common foraminiferal species from coastal British Columbia. 
In many of the adjacent basins bordering the SBIC, a number of studies examined foraminifera in the adjacent basins bordering SBIC in the context of investigations of climate change (e.g., Blais et al., 1990; Patterson and Cameron, 1991; Patterson, 1991; Patterson1993; Guilbault et al., 1997; Huntley et al., 2001; Guilbault et al., 2003), earthquake events, and sea level fluctuations (Luternauer et al., 1989; Clague and Mathewes, 1996; Reinhardt et al., 1996).

The first micropaleontological research carried out on fjords along the Coastal Mainland was on Bute and Knight Inlets (Schafer et al., 1989). The authors studied the paleoenvironmental implications of foraminiferal and thecamoebian biofacies identified in the inlets. Patterson (1991, 1993), Mathewes et al. (1993), and Patterson et al. (1995) utilized peak abundances of the cold-water indicator Cassidulina reniforme and vegetation changes in the Northeast Pacific to identify an abrupt occurrence of a cold interval similar to the Younger Dryas of Europe and eastern North America. In Queen Charlotte Sound and southern Hecate Strait regions, Patterson (1993) examined foraminiferal biofacies in cores from Queen Charlotte Sound and southern Hecate Strait to assess the variability in Late Quaternary paleoceanography in the region. Likewise, Guibault et al. (1997) investigated paleoceanographic settings of the Dixon Entrance region in the northwestern part of British Columbia using the distribution of Late Quaternary foraminifera.

Blais-Stevens and Patterson (1998) used foraminiferal distribution and identified biofacies to assess paleoenvironmental conditions in Saanich Inlet. Patterson and Kumar (2002a) further established five distinct foraminiferal biofacies, which corresponded to differing paleoceanographic regimes in Saanich Inlet from late Pleistocene to Present. Foraminiferal distributions in low oxygen environments were used to assess the effects of 
climatic variability on fish production in Effingham Inlet (Patterson et al., 2000). Guilbault et al. (2003) used benthic foraminiferal, diatom and dinocyst assemblages to investigate the paleoenvironmental conditions in the Strait of Georgia during the last deglaciation.

The first major research conducted in the SBIC fjords, examined the sedimentary properties archived in piston core VEC02A07 from Alison Sound to identify changes in regional Late Holocene climate (Patterson et al., 2007). In Frederick Sound and lakes, pollen (Galloway, 2006, Galloway et al., 2007, 2008; Stolze et al., 2007) and diatoms (Wigston, 2005) were utilized to assess regional paleo-vegetation and paleo-climate variability. Doherty (2005) also examined changes in sea level using diatom distribution in marsh transects and lake sediments in the region.

Vázquez-Riveiros (2006) studied foraminiferal and thecamoebians distribution in a freeze core (FC04) and surface grab samples from the Alison sound and Belize Inlet to determine the paleoceanographic and climate variations in the region through the last 1100 years. In another study in the SBIC, foraminiferal and thecamoebians in two marsh transects near the heads of Alison and Frederick Sounds were examined to determine changes in sea level (Vázquez-Riveiros et al., 2007) .

\subsubsection{Geochemistry}

In determining variations in the past climatic and oceanographic conditions in adjacent regions to SBIC, especially during the late Pleistocene glacial and early Holocene, several geochemistry-based studies were conducted. Many of these studies took place in Saanich Inlet, which is situated southeast of the SBIC (Calvert and Pedersen, 1993; Calvert et al., 2001; Russell and Morford, 2001; Morford et al., 2001). Francois (1988) examined the factors influencing redox sensitive elements in Saanich Inlet. Calvert and Pedersen (1993) 
used data from Saanich Inlet to determine the processes that control deposition and recycling, and developing the criteria for the application of trace elements as proxies for oxic or anoxic bottom water. Calvert and Pedersen (2007) also included data from Saanich Inlet in their comprehensive review of the utilization of redox sensitive elements as proxies for interpreting the paleoclimatic and paleoceanographic conditions in marine depositional environments.

Timothy and Soon (2001) utilized organic matter and biogenic silica in bottom waters from Saanich Inlet, southern Vancouver Island Jarvis Inlet in mainland coastal region of British Columbia to quantify primary paleo-productivity and deep-water oxygenation. Hay (2005) examined deep-water renewal using the distribution of carbon and nitrogen isotopes, and elemental chemistry in box, freeze and piston cores sediments retrieved from Effingham Inlet. McKay et al. (2004) studied the organic, biogenic barium and opal content from piston core JT96-90 obtained from the continental shelf of Vancouver Island to determine variations in marine productivity during the last deglaciation. The effects of redox conditions on the accumulation of redox-sensitive trace metals are also investigated in other cores from the same area (McKay et al., 2007).

In other anoxic basins along continental margins such as the Black Sea and Cariaco Basin, redox sensitive elements were also used to assess bottom water oxygen circulation (Calvert 1990, Dean et al., 1999; Morford and Emerson, 1999). Russell and Morford (2001) recognized the same distributional trends and concentrations of redox sensitive elements in both the laminated and homogeneous sediments from a short core collected during the ODP Leg 169S expedition (Site 1033B) in Saanich Inlet as found in the SBIC fjords. 


\section{CHAPTER THREE}

\section{MATERIALS AND METHODS}

\subsection{Field Investigation and Sample Collection}

The coring and sampling of coastal marine fjords and lakes sediments from the Seymour-Belize Inlet Complex (SBIC) were conducted during research cruises of the CCGS Vector in April and October 2002. An initial reconnaissance survey of the SBIC was carried out using a $3.5 \mathrm{kHz}$ air gun to locate sites containing gas free sediments suitable for coring within the top few meters below the water-sediment interface. Gas free sediments tend to not come apart under pressure subsequent to core recovery and are therefore preferable to ensure coring without loss of core sections.

A total of eight piston cores including a $12.26 \mathrm{~m}$ long core (VEC02A04) from Frederick Sound (FS) and a $8.72 \mathrm{~m}$ long core (VEC02A07) from Alison Sound (ALS) were obtained during the fieldwork. In addition to the piston cores, nine freeze cores including a $129 \mathrm{~cm}$ long core (VEC02A13) from Mereworth Sound (MS) and eight surface grab samples were also obtained. The piston cores provided long sediment records. The freeze cores and surface samples yield information about the sediment-water interface, which piston cores often over penetrate and therefore not sampled. Piston cores were split upon return to the Pacific Geosciences Center in Sydney, British Columbia. One split of core VEC02A04 from FS was subdivided to 62 intervals measuring $20 \mathrm{~cm}$ long by $3 \mathrm{~cm}$ thick. The working split of 
core VEC02A07 from ALS was similarly subdivided into 46 short core intervals. Freeze core VEC02A13 from MS was also subdivided into 8 smaller subsections.

The short cores were brought to Carleton University where they were stored in a cool room at $4^{\circ} \mathrm{C}$. The freeze core subsections were also brought to Carleton University and stored in the cold room facility at $-4.5^{\circ} \mathrm{C}$. Core slabs were X-rayed to facilitate the recognition of internal structures and the sedimentology was logged. The other half of the core was subsampled to provide samples for various paleontologial and particle size analysis in April, 2006.

\subsection{Age Model}

Radiocarbon analysis was conducted using the Accelerator Mass Spectrometry (AMS) facility at the IsoTrace Laboratories at the University of Toronto, Ontario and Beta Analytic Incorporation, Florida. The materials submitted for radiocarbon dating of Frederick Sound core VEC02A04 consisted of six wood fragments, one pine-cone and a twig (Table 3.1 and Appendix A). Seven of the samples were dated; the remaining sample had insufficient carbon to be datable. A total of 9 samples comprising of wood fragments and a stick extracted from the sediments in the Alison Sound core VEC02A07 were used for dating the core (Table 3.2 and Appendix A). The dated materials in Mereworth Sound freeze core VEC02A13 include a bulk sediment sample, three wood fragments and a pine-cone (Table 3.3 and Appendix A).

The radiocarbon dates were calibrated using CALIB REV. 5.1 for Windows with reference to the Intcal04 data set (Reimer et al., 2004; Stuiver et al., 2005). The CALIB REV. 5.1 program converts radiocarbon age to calibrated calendar years (Stuiver et al., 2005). 

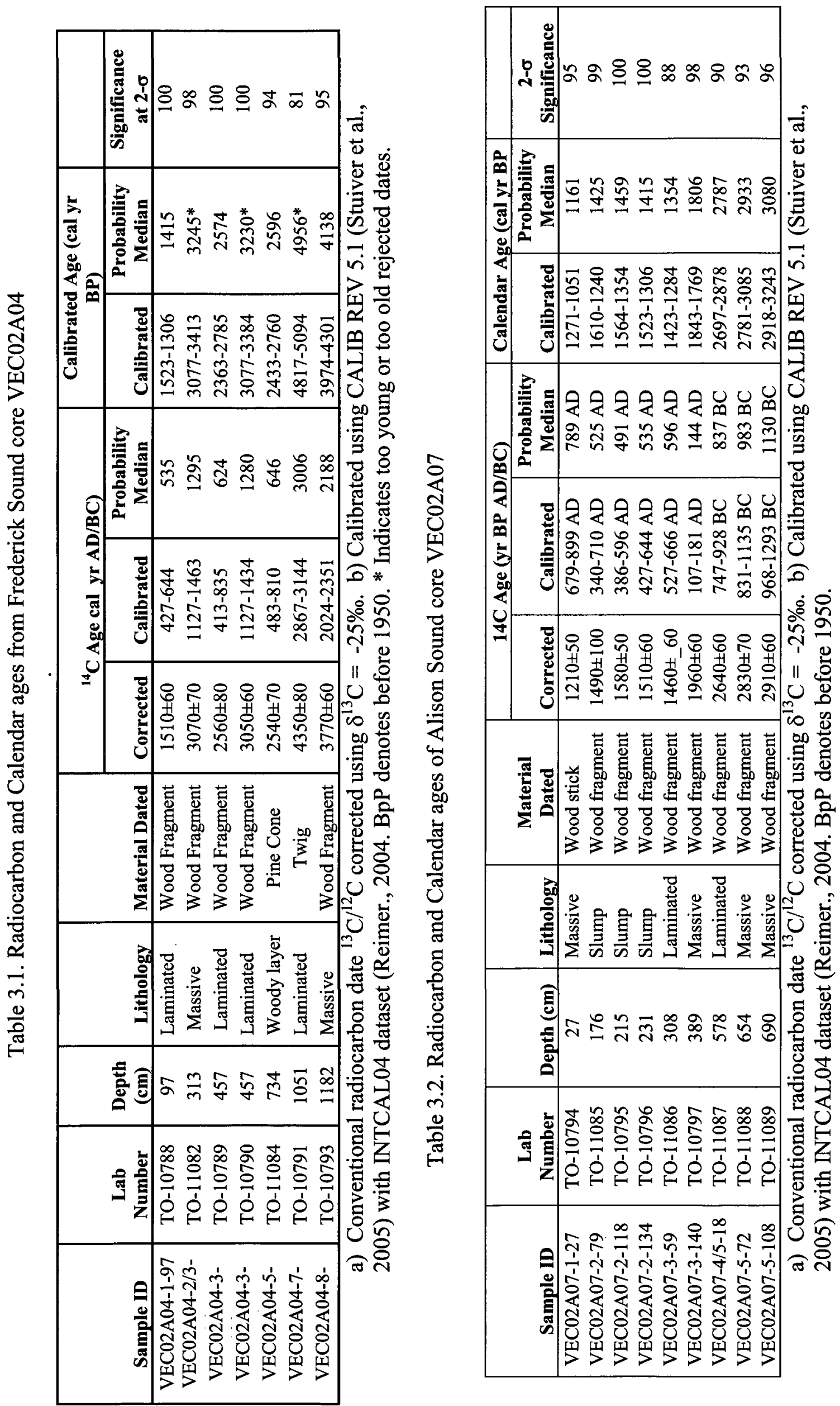


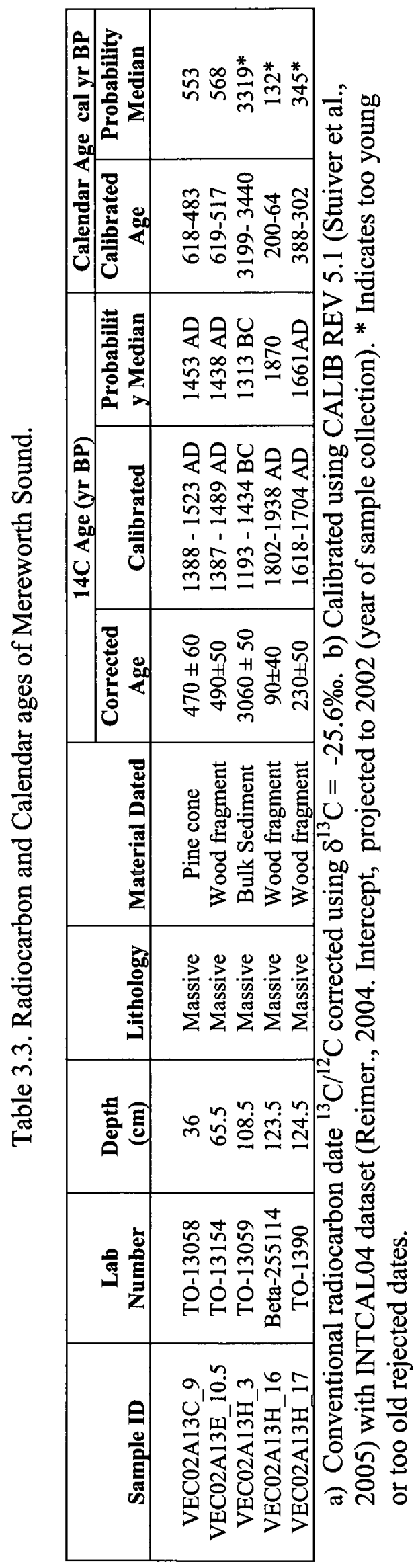




\subsection{Micropaleontological Analysis}

\subsubsection{Sample Preparation and Species Identification}

Samples processed for micropaleontological analysis consisted of 211 taken from piston core VEC02A04 in FS, 46 from VEC02A07 in ALS and 101 subsamples from freeze core VEC02A13 from MS. The VEC02A13 core was sampled at $1 \mathrm{~cm}$ intervals. However, the topmost $27 \mathrm{~cm}$ sand-rich interval was found to be completely dried out due to improper storage. It was therefore difficult to subsample this section at precisely $1 \mathrm{~cm}$ intervals. The uppermost $15 \mathrm{~cm}$ was treated as one sample while the $15-27 \mathrm{~cm}$ interval was sampled at $2 \mathrm{~cm}$ intervals. All subsamples from the three cores were wet sieved with a $63 \mu$-mesh and dried at $\sim 45^{\circ} \mathrm{C}$ in an oven. The $<63 \mu \mathrm{m}$ fraction from the MS freeze core was collected for subsequent geochemical analysis. The FS core subsamples were taken at a $5 \mathrm{~cm}$ sampling interval while those of the ALS core were subsampled at lower resolution $20 \mathrm{~cm}$ intervals.

Specimens of all foraminiferal and thecamoebian species were sorted into standard gridded and hollow-type micropaleontological slides for identification purposes. Identification and subsequent enumeration of the faunal contents of the samples were conducted with a SZH 10 Olympus stereoscopic microscope. Relevant reference materials including the Loeblich and Tappan (1987) classification schemes, the online Catalogue of Foraminifera and Atlas of common Quaternary benthic foraminifera of the British Columbia shelf (Patterson et al., 1998) were used in identifying the different foraminiferal species. Thecamoebian species were identified using the Holocene lacustrine Arcellacean identification schemes (Medioli and Scott, 1983; Kumar and Dalby, 1998). The well-preserved specimens were photographed with a Scanning Electron Microscope JEOL 6400 at Carleton University. 


\subsubsection{Statistical Analysis}

The relative fractional abundance $\left(F_{i}\right)$ of each species in the each sample was determined using the following equation:

$$
F_{i}=\frac{C_{i}}{N_{i}}
$$

where $\mathrm{C}_{\mathrm{i}}$ is the species count and $N_{i}$ is the total of all species counts in a given sample.

Applying the information provided by the calculated fractional abundance of each species, the standard error $\left(\mathrm{S}_{\mathrm{xi}}\right)$ at $95 \%$ confidence level (Patterson and Fishbein, 1989; Fishbein and Patterson, 1993) was determined using the following formula.

$$
S_{x i}=1.96 \sqrt{\frac{F_{i}\left(1-F_{i}\right)}{N_{i}}}
$$

The species with standard errors greater than their fractional abundances in all the samples were discarded in the next step of the multivariate statistical analysis.

In order to identify statistically significant samples, the probable error (pe) for total counts in each sample was calculated using the following equation.

$$
p e=1.96\left(\frac{S}{X_{i}}\right)
$$

where $\mathrm{S}$ is the standard deviation of the specimens population counts and $\mathrm{X}_{\mathrm{i}}$ is the number of specimen counts per sample. A sample is statistically significant if its total faunal count is greater than the probable error (Boudreau et al., 2005; Vázquez-Riveiros et al., 2007). 
A total population of at least 500 specimens is the most appropriate for paleoecological research (Patterson and Fishbein, 1989; Patterson et al., 2000). However, in a highly stressed environment, where low abundances are encountered, samples with at least 50 specimens are considered to be statistically significant if the most abundant species account for $50 \%$ or more of the total population (Patterson and Fishbein, 1989). The most abundant species Eggerella advena in the FS core, Thecamoebian spp and E. advena in the ALS core and Buccella frigida in the MS core, account for more than $50 \%$ of the total populations in most of the samples.

The proportion and species diversity of faunas in a sample measure the relative health of the depositional environments of the sediments in which they occur. Environmental stability is commonly assessed using the Shannon-Weaver Diversity Index (SDI) (Shannon and Weaver, 1949; Fishbein and Patterson, 1993). This index is calculated using the following equation:

$$
S D I=-\sum_{1}^{S}\left(\frac{F_{i}}{N_{i}}\right) \times \ln \left(\frac{F_{i}}{N_{i}}\right)
$$

where $S$ is the species richness of the sample, $F_{i}$ is the fractional abundance of each species and $N_{i}$ is the total abundance (counts) of the sample.

In healthy and stable environments where fauna abundances are over 500 specimens $/ \mathrm{cm}^{3}$ or higher (Patterson and Kumar 2002b), SDI commonly ranges from 2.5-3.5 (e.g., Sageman and Bina, 1997; Legendre and Legendre, 1998; Patterson and Kumar, 2002a). The value of this index ranges from 1.5-2.5 in transitional environments (Kumar and 
Patterson, 2002), and is generally between 0.1 and 1.5 in highly stressed environments such as in MS. Faunal abundances in stressed environments are commonly between 30 and 150 specimens $/ \mathrm{cm}^{3}$ and are usually dominated by one or two taxa with other associated species occurring rarely (Patterson and Kumar, 2002b).

\subsubsection{Cluster Analysis}

Cluster analysis organizes data hierarchically into components that have similar trends or characters (Parker and Arnold, 2002). Using the 'error weighted maximum likelihood' clustering method of Fishbein and Patterson (1993), Q-mode cluster analysis was carried out on a total of 101 samples from Frederick Sound, 28 samples from Alison Sound and 20 samples from Mereworth Sound, respectively. The cluster methodology employed was Ward's minimum variance method, which uses as a linkage the Squared Euclidean Distance between groups of samples. The results were displayed in hierarchical diagrams using SPSS version 15 for Windows. R-mode cluster analysis was performed using the same technique as in the Qmode analysis to determine the similarities between species and characterize the assemblages represented by the Q-mode sample groupings.

\subsubsection{Transfer Function Analysis}

Transfer functions as a methodology to assess the relationships between variables and microfossils pioneered by Imbrie and Kipp (1971) is widely used in paleoecological research (e.g., Birks et al., 1990; Jones and Juggins, 1995; Zong and Hortons, 1999; Telford and Birks, 2005, Hortons et al., 2005; Hortons and Edwards, 2006). The application of microfossils in paleoenvironmental reconstruction is based on the assumption that the modern relationship between indicator taxa and environmental variables of interest has not changed significantly through time (Imbrie and Webb, 1981; Edwards et al., 2004). Therefore, by quantifying the 
modern distribution of a paleoenvironmental indicator species relative to target variables, their past distributional records can be used as evidence for past environmental conditions, provided that fossil assemblages are present in modern analogues (Edwards et al., 2004).

The transfer function analysis used in this study was carried out in two stages. The first one involved performing regression analysis to model the relationship between the abundances of modern foraminifera and the environmental variable data in eight grab samples from AS and Belize Inlet (Table 3.4, Vázquez-Riveiros, 2006). This stage of the analysis yielded ecological response models that were used in calibrating the fossil data in the second stage of the analysis. Paleoecological conditions from the fossil foraminiferal assemblages were reconstructed through calibration of the response models. The software application (C2) used for the analysis cannot validate models built on fewer than 10 samples. Therefore, the models of this study were not validated and the error of the transfer function was not obtained.

The C2 program (Juggins, 2005), used to carry out the transfer function analysis applies weighted averaging (WA) and weighted averaging tolerance (WA TOL) to calculate the transfer function regression equation. These two techniques are considered suitable for species displaying unimodal response to environmental variables (Birks et al., 1990). Weighted averaging (WA) reconstruction usually results in shrinkage of the range of inferred values towards the mean (Birks et al., 1990). Hence, linear deshrinking with inverse regression is commonly used to correct the shrinkage (Birks et al., 1990; ter Braak and Juggins, 1993; Birks, 1995). The WA (TOL) utilizes a modification of the WA and involves assigning more weight to species with narrow ranges because such species have better indicator values (Vazquez-Riverios, 2006). 
The performance of the models was assessed with the regression parameters produced by $\mathrm{C} 2$. These are root-mean squared error of prediction (RMSE), coefficient of determination of the observed versus predicted values $\left(\mathrm{r}^{2}\right)$ and maximum bias. The RSME is the average squared difference between the observed and predicted values of the variable of interest.

Table 3.4. Environmental Variable Data from Alison Sound and Belize Inlet (adopted from (Vázquez-Riveiros, 2006).

\begin{tabular}{|l|c|c|c|c|c|c|c|}
\hline & $\begin{array}{c}\text { Depth } \\
(\mathbf{c m})\end{array}$ & $\begin{array}{c}\text { Temp } \\
(\mathbf{C} \mathbf{C})\end{array}$ & $\begin{array}{c}\text { Salinity } \\
(\% \mathbf{\%})\end{array}$ & $\begin{array}{c}\text { Oxygen } \\
(\mathbf{m L} / \mathbf{L})\end{array}$ & $\begin{array}{c}\text { Nitrate/Nitrite } \\
(\boldsymbol{\mu} \mathbf{m o l} / \mathbf{L})\end{array}$ & $\begin{array}{c}\text { Silicate } \\
(\boldsymbol{\mu} \mathbf{m o l} / \mathbf{L})\end{array}$ & $\begin{array}{c}\text { Phosphate } \\
(\boldsymbol{\mu m o l} / \mathbf{L})\end{array}$ \\
\hline BE1 & 221 & 7.84 & 30.05 & 4.95 & 20.9 & 44 & 2.2 \\
BE2 & 190 & 8.38 & 30.16 & 4.16 & 23 & 46.1 & 2.51 \\
BE3 & 290 & 8.57 & 30.23 & 3.7 & 22.5 & 51 & 2.43 \\
BE5 & 276 & 8.61 & 30.23 & 3.71 & 23 & 51.8 & 2.45 \\
BE7 & 215 & 8.52 & 30.21 & 3.74 & 33.3 & 46.7 & 2.52 \\
ALS1 & 152 & 8.55 & 28.83 & 1.67 & 23.3 & 61.9 & 3.23 \\
ALS2 & 136 & 8.56 & 28.8 & 1.72 & 23.6 & 61.2 & 3.24 \\
ALS3 & 136 & 8.76 & 26.52 & 0.06 & 23.6 & 61.2 & 3.24 \\
\hline
\end{tabular}

This parameter measures the predictive capability of a model (Wallach and Goffinet, 1989; Birks et al., 1990) and the systematic differences in prediction errors (Horton et al., 2006). The coefficient of determination $\left(\mathrm{r}^{2}\right)$ (Massey et al., 2006) is the square correlation between the observed and predicted variable values (Birks, 1995; Horton et al., 2006). Maximum bias is the largest difference between the mean observed and predicted values along the regression gradient (Birks, 1998, Massey et al., 2006).

\subsection{Organic Geochemistry}

A total of 235 samples taken at $5 \mathrm{~cm}$ intervals from the FS core VEC02A04 (Appendix B7) were initially analyzed at the Pacific Geosciences Center, North Saanich, British Columbia, for inorganic carbon, organic carbon, nitrogen and biogenic silica. Of these samples, a subset of 92 alternate samples at $10 \mathrm{~cm}$ sampling intervals were analyzed for 
carbon $\left(\delta^{13} \mathrm{C}\right)$ and nitrogen isotopes $\left(\delta^{15} \mathrm{~N}\right)$ at the Hatch Laboratories facilities at University of Ottawa. In the ALS core VEC02A07 (Appendix B8), a total of 83 samples were analyzed for organic carbon, total nitrogen and their isotopic compositions $\left(\delta^{13} \mathrm{C}\right.$ and $\left.\delta^{15} \mathrm{~N}\right)$.

The samples were pre-treated by acid digestion using $10 \%$ hydrochloric acid. This process is used to remove inorganic carbon content in the samples. The digested samples were dried, and pulverized using agate mortar and pestle. At the Hatch stable isotope Laboratories, University of Ottawa, the pulverized residues were weighed into tin capsules and loaded with standards into a Vario EL III elemental analyzer (EA) to determine their carbon and nitrogen compositions. Each sample was flash combusted with oxygen at about $1800^{\circ} \mathrm{C}$ and carried by helium through adsorption columns of reducing/oxidizing chemicals to separate $\mathrm{N}_{2}, \mathrm{CO}_{2}$, $\mathrm{H}_{2} \mathrm{O}$ and $\mathrm{SO}_{2}$ fractions by "purge and trap" using the thermal conductivity detector (TCD) to detect each gas separately. The routine analytical precision $(2 \sigma)$ for the elemental determination is $\pm 0.1 \%$ (Pella, 1990; VarioEL III Manual). The resulting gases from this process were carried via helium through the EA to purify and fractionate into $\mathrm{NO}_{2}$ and $\mathrm{CO}_{2}$ components. The gases were passed from the EA into an isotope ratio mass spectrometer (IRMS) for the isotope analysis via a Conflo interface. Data was normalized using internal standards previously calibrated with international standards IAEA-CH-6, IAEA-NBS22,

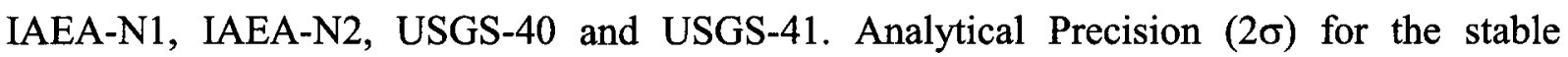
isotopes measurement is $\sim 0.2 \%$ (Pella, 1990; VarioEL III Manual).

\subsection{Inorganic Geochemistry}

The concentrations of major, trace and rare earth metals in 72 samples from the FS core VEC02A04 and 61 samples from the ALS core VEC02A07 were determined with Inductive Couple Plasma-Mass Spectroscopy (ICP-MS) at the Geoscience Laboratories (Geo 
Labs) in Sudbury, Ontario. The samples, selected mostly at $10 \mathrm{~cm}$ intervals, were pulverized and sieved with a $150 \mu \mathrm{m}$-mesh. The less than $150-\mu \mathrm{m}$ fraction of each sample was pre-treated using the solution-OT4 open vessel digestion method. This process involved the combination of hydrofluoric, hydrochloric, nitric, and perchloric acids to dissolve the silicate phases in the sediments (Geolabs Manual, 2003). The elemental analysis was conducted with a Perkin Elmer Elan 9000 ICP-MS instrument (Burnham and Schweyer, 2004). The concentrations of oxides of the major elements were determined using X-ray fluorescence (XRF). The concentrations of the individual elements in their respective oxides were calculated using the conversion factors provided by the Geoscience Laboratories, Sudbury, Ontario.

In FS core VEC02A04, 43 samples whose weights were not sufficient for X-Ray florescence (XRF) analysis were analyzed for major elements and trace elements using the Teledyne Leeman Laboratories Prodigy Inductive Couple Plasma-Atomic Emission Spectroscopy (ICP-AES) Radial-View instrument. Twelve additional samples from this core as well as 37 samples ( $63 \mu \mathrm{m}$ fraction) selected at $3 \mathrm{~cm}$ sampling interval from the MS freeze core VEC02A13 were also analyzed using ICP-AES. As in the case of ICP-MS, the samples analyzed with ICP-AES method were also digested using OT3 open vessel acid digestion process using hydrofluoric, hydrochloric, nitric, and perchloric acids (Geolabs Manual, 2003; Palmer, 2007).

\subsection{Time-Series Analysis}

Spectral analysis was conducted on both organic and inorganic geochemical data using the Redfit software (Schulz and Mudelsee, 2002). Due to the unevenly spaced nature of paleoclimate data, autoregression requires interpolation. This interpolation is often biased because the time domain alters the estimated spectrum by enhancing low frequency results at 
the expense of high frequency output (Schulz and Mudelsee, 2002), making the estimated spectrum too red when compared to the time series (Schulz and Stattegger, 1997).

Redfit uses the first order autoregression (AR1) to determine the spectra of unevenly spaced time series without interpolating with the Lomb-Scargle Fourier Transform (Lomb, 1976; Scargle 1982, 1989). The Welch-overlapped-segment averaging (WOSA) of Welch (1967) that was used in this analysis splits the time series into n50-segments overlapping by $50 \%$. The final time series spectrum was obtained by averaging the n50 periodograms. The red wire spectrum is overlaid on the estimated spectrum. The first order autoregression (AR1) was used as a null hypothesis to check whether the variability in the time series is consistent with a stochastic origin (Gilman et al., 1963) and is applicable in explaining climate data rednoise signatures (Hasselmann, 1976).

Red noise describes noise with relatively enhanced low frequency fluctuations arising from the interaction of white noise with slow response components of a system (Mann and Lees, 1996). The fact that the thermal inertia of the ocean provides memory that effectively integrates atmospheric weather forcing (Hasselmann, 1976) makes red noise an important descriptor of background conditions within climatic time series. Red noise models provide a reasonable description of the noise in spectra for climatic and hydrologic series including long-term climatic records (Kutzbach and Bryson, 1974), historical sea and air temperatures (Allen, 1992; Allen and Smith, 1994) and station precipitation data (Gilman et al., 1963). AR1 is the simpliest statistical model used for discrete finite red noise series (Mann and Lee 1996). Other models with high order autoregressive (AR1) (where $\mathrm{n}>1$ ) can provide a better fit for the overall spectrum but they often entail using parameterizing features which might be produced with signals (Mann and Lee, 1996). 
Wavelet analysis allows for automatic localization of periodic-cyclic attributes in time and frequency domains (Prokoph and Agterberg, 1999). In contrast to the Fourier Transform, which uses a single window for all frequencies (Rioul and Vetterli, 1991), wavelet transform analysis uses more than one window; narrow windows for high frequencies and wide windows for low frequencies (Prokoph and Barthelmes, 1996; Prokoph and Agterberg, 1999). Continuous wavelet analysis uses the Morlet mother wavelet, a sinusoidal function that is modulated by the Gaussian function (Morlet et al., 1982). A value of the analysis window length factor of 10 that has proven to be excellent in climate related records (Ware and Thomson, 2000; Gedalof and Smith, 2001; Patterson et al., 2007), is used in this study. 


\section{CHAPTER FOUR}

\section{FORAMINIFERAL DISTRIBUTION AND SEDIMENTOLOGY IN THE FREDERICK AND ALISON SOUNDS PISTON CORES}

\subsection{Abstract}

The distribution of agglutinated foraminifera and freshwater thecamoebians were utilized to investigate paleoceanographic and paleoclimate records in two glacier-carved fjords in the Seymour-Belize Inlet Complex (SBIC), British Columbia coast. The sediment records from these cores are characterized by unevenly distributed laminated and massive intervals intercalated by occasional slumps and turbidites.

The faunal assemblages in the Frederick Sound (FS) core VEC02A04 are overwhelmingly dominated by the foraminiferal species Eggerella advena while thecamoebians as a group are more abundant than any individual foraminiferal species in the Alison Sound (ALS) core VEC02A07. Cluster analysis identified the presence of five foraminiferal/thecamoebian biofacies in the cores; Eggerella advena Biofacies, Eggerella advena-Spiroplectammina biformis Biofacies and Recurvoides turbinatus-Thecamoebian spp. Biofacies. A Thecamoebian spp Biofacies and Eggerella-advena-Thecamoebian spp. 
Biofacies are recognized in the ALS core. In both cores, these biofacies are characterized by low Shannon-Weaver Diversity Index (SDI) (0.064-1.35) indicating that the microfaunal species lived in an unfavourable habitat under highly stressed, near anoxic conditions.

The distribution of the foraminiferal species and biofacies indicates that a major oceanographic shift occurred at $2,835 \mathrm{cal}$ yr BP in the FS core and 2,860 cal yr BP in the ALS core. This regime shift was marked by the increased abundances of the glaciomarine indicator species Spiroplectammina biformis, Recurvoides turbinatus, Portatrochammina bipolaris and Cribrostomoides jeffreysii in both inlets, and is coincident with a previously documented climatic shift marked by neoglacial advances throughout northeast Pacific region.

The weighted average regression models obtained from the transfer function analysis of modern foraminiferal distribution were used to obtain quantitative estimates of the environmental variables in the two cores. The analysis indicates that temperature $\left(8.6^{\circ} \mathrm{C}\right)$, oxygen $(0.85-1.68 \mathrm{~mL} / \mathrm{L})$, salinity $(27.8-28.5 \%)$ and nutrients predominantly control the faunal distribution. High organic matter content and the overall anoxic nature of the core sediments might have also contributed to the low faunal abundances and diversity. The presence of varying amounts of freshwater thecamoebians throughout the cores is a result of coastal soil erosion and subsequent reworking of nearshore sediments into deep water.

\subsection{Introduction}

The configuration of underwater topography and elevated primary production in coastal fjords can lead to the development of anoxic bottom water and subsequent preservation of varves. Paleonvironmental proxies from laminated sediments are excellent for investigating paleoceanographic and paleoclimatic conditions at high temporal resolution 
(Jennings and Weiner, 1996; Taylor et al., 2001; Chang et al., 2003; Jensen et al., 2004; Cockburn and Lamoureux, 2008).

Many foraminiferal species are known to possess survival mechanisms permitting them to function under low oxygen conditions (Bernhard, 1993; Alve and Bernhard, 1995; Bernhard and Alve, 1996). Species capable of surviving at the low end of the oxygen tolerance range and are not only tolerant of dysoxic conditions but can temporarily survive under anoxic conditions (e.g., Bernhard, 1989; Moodley, 1990; Moodley et al., 1997; Patterson et al., 2000). The foraminiferal species which live in anoxic environments usually are of small size (Phleger and Souter, 1973), and have thin and highly perforated walls, large pore size, and high pore density (Phleger and Souter, 1973; Moodley and Hess, 1992; Kaiho, 1994). In general, they survive low oxygen conditions by using encystment, reducing their metabolic activities and obtaining aeration through anaerobic pathways (Bernhard, 1993). Rhoads and Morse (1971), and subsequent researchers (e.g., Tait, 1981; Tyson and Pearson, 1991; Bernhard and Sen Gupta, 2002) have proposed classifications of microfaunal environments based on variations in dissolved oxygen content in oceans and marginal marine environments. Kaiho (1994) used benthonic foraminiferal tolerance to different levels of oxygenation in water columns to subdivide microfaunal environments to high oxic ( $>3 \mathrm{~mL} / \mathrm{L})$ and low oxic $(1.5-3 \mathrm{~mL} / \mathrm{L})$ conditions. The suboxic ranges from $0.3 \mathrm{~mL} / \mathrm{L}$ to $1.5 \mathrm{~mL} / \mathrm{L}$, dysoxic ranges between $0.1 \mathrm{~mL} / \mathrm{L}$ and $0.3 \mathrm{~mL} / \mathrm{L}$ ) and the anoxic from $0-0.1 \mathrm{~mL} / \mathrm{L}$.

In this chapter, foraminiferal and thecamoebian distribution patterns and biofacies of two piston cores from Frederick Sound (FS) (core VEC02A04) and Alison Sound (ALS) (core VEC02A07) are used to assess variations in late Holocene bottom water conditions in the SBIC. The distribution patterns of the biofacies are also correlated to paleoclimate conditions 
within the SBIC and regional climate patterns. Transfer function analysis using modern foraminifera as a training set were also applied to assess quantitatively the effects of environmental variables on the foraminiferal species distribution patterns in the cores. Foraminiferal distribution and biofacies are widely used to evaluate and differentiate oxygen depleted (anoxic) from oxygen-rich (oxic) environments. For instance, Alve $(1991,1995)$ studied the foraminiferal assemblages in Norwegian fjords to determine the effects of pollution superimposed on climate variability. Likewise, Blackwelder et al. (1996), and Sen Gupta et al. (1996) utilized foraminiferal distribution patterns to assess oxygen stress patterns in an inner shelf environment along the Gulf of Mexico.

Foraminiferal based studies have been conducted on many fjords and marginal seas with seasonal anoxia on the West coast of North America (Douglas et al., 1976, 1979; Bernhard et al., 1997; Patterson et al., 2000). Foraminiferal faunas in the Santa Barbara Basin, California, for example, were correlated to oxygen concentrations (Douglas et al., 1976, 1979; Bernhard et al., 1997). Patterson et al. (2000) studied the effects of variations in oxygen concentrations on biofacies distribution in sediment-water interface sediments from Effingham inlet, Vancouver Island area, British Columbia. Foraminiferal research has also been utilized to assess paleoenvironmental and paleoceanographic conditions in a seasonal anoxic Saanich Inlet, Vancouver Island adjacent to the present study area (Blais, 1995; BlaisSteven and Patterson, 1998; Patterson and Kumar, 2002a).

\subsection{Results}

\subsubsection{Frederick Sound (FS) Core Chronology}

The four youngest ${ }^{14} \mathrm{C}$ calibrated dates in stratigraphic order (Table 3.1) were utilized to construct an age model for FS core VEC02A04 (Figure 4.1). The remaining three dates 
were determined to be either too young or old and were rejected. A linear regression method was used to model the age of the entire core interval. Galloway (2006) used a similar approach in interpreting the same radiocarbon dates from this core. According to Telford et al. (2004), an age model based on samples from sediments deposited over a long time period of time always yields high $r^{2}$ values. In the FS core, a high $r^{2}$ of 0.93 was obtained for constructing a model using uncalibrated radiocarbon ages and $\mathrm{r}^{2}$ of 0.94 was obtained when the calibrated ages were used. Based on the sedimentation rate $(\sim 0.397 \mathrm{~cm} /$ year $)$ for the calibrated calendar dates, the core spans the 1124 to $4213 \mathrm{cal}$ yr BP $\left(1199-3865{ }^{14} \mathrm{C}\right.$ yr BP) interval (Figure 4.1).

\subsubsection{Alison Sound (ALS) Core Chronology}

The dates used for the ALS core's age/depth model, are presented in Table 3.2. For the current study a $4^{\text {th }}$ order polynomial-age model is utilized (Figure 4.2) as was previously adopted for piston core VEC02A07 (Patterson et al., 2007). The polynomial age model was used because of the presence of some reversals in both the calibrated and radiocarbon dates (Patterson et al., 2007). This model indicates that the ALS core was deposited from $\sim 3500$ to $\sim 1000$ cal yr BP under varying sedimentation rates. The core's sedimentation rate averaged $\sim 0.3 \mathrm{~cm} / \mathrm{yr}$, but ranged from $<0.8 \mathrm{~cm} / \mathrm{yr}$ through the upper $\sim 100-350 \mathrm{~cm}$ to $\sim 0.48 \mathrm{~cm} /$ year in the lowermost 650-872 cm section of the core (Patterson et al., 2007). An approximately 1.2 $\mathrm{m}$ of sediments, representing several hundred years was lost due to over penetration by the piston corer.

\subsubsection{Sedimentology}

Visual examination of the X-ray images and sample description from the entire 12.26 $\mathrm{m}$ long core from FS and an $8.72 \mathrm{~m}$ long core from ALS indicates that their sediments are generally composed of organic rich mud and silts with occasional sand intervals, which were 


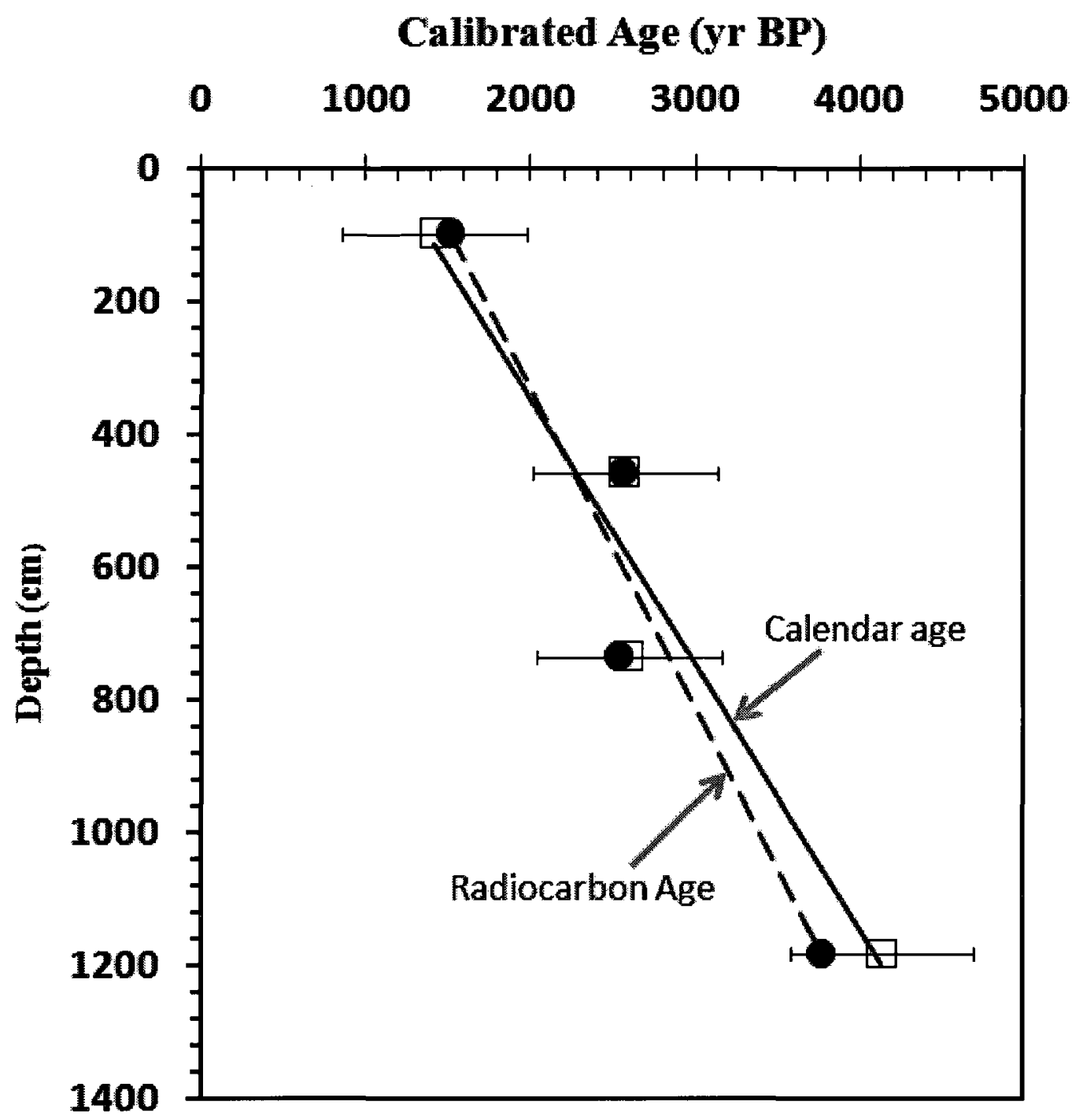

Figure 4.1. Linear regression age model for the Frederick Sound (FS) core. Calibrated calendar age (open square and solid trendline); radiocarbon age (filled circle and dash trendline). 


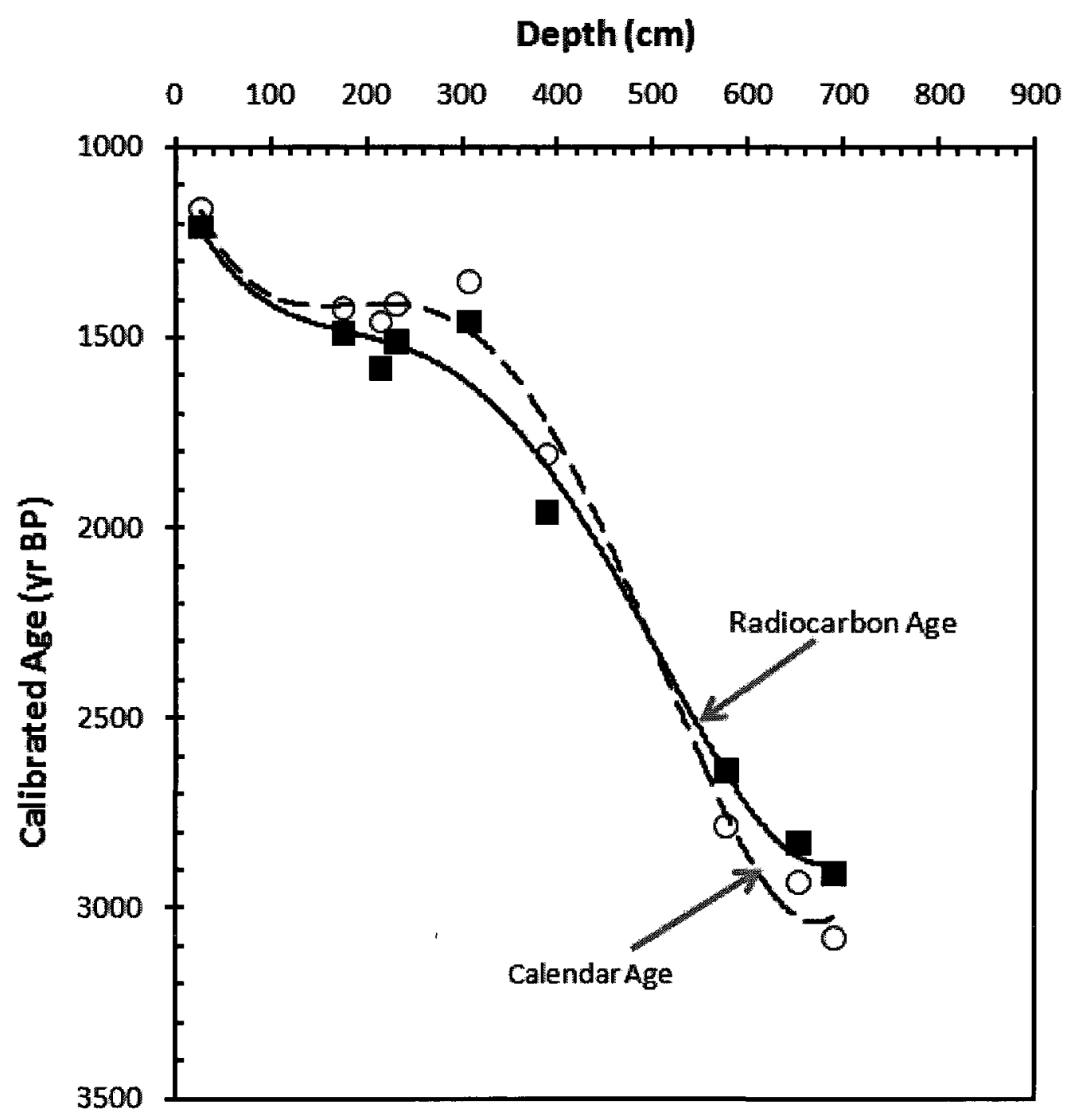

Figure 4.2. Fourth order polynomial age model for the Alison Sound core (modified from Patterson et al., 2007). Radiocarbon dates (solid square) and calibrate calendar dates (open circle). 
deposited as massive, annually laminated, slump or graded intervals. The entire core interval in FS is comprised of massive (44.19\%), laminated (41.22\%), graded (5\%) and slump (2.86\%) units (Figure 4.3). Approximately $6.73 \%$ of the core was not recovered during coring either due to caving or as a result of over penetration. The ALS core also contains intercalation of annually laminated (32.13\%) and homogenous intervals (52.85\%) with minor occurrences of graded intervals (2\%) and slumps (8.02\%) (Figure 4.4).

\subsubsection{Laminated Intervals}

The laminated intervals, comprising $41.22 \%$ in the FS and $32.13 \%$ in the ALS cores respectively, are unevenly distributed throughout the core intervals (Figures 4.3-4.4). The couplets are comprised of alternate olive to dark grey organic-rich clay and silt laminae representing winter through late autumn deposition. Light olive to yellow diatom-rich laminae represent spring and summer deposition. Dark terrigenous laminae record annual and seasonal variations in precipitation and runoff of spring meltwater whereas diatomaceous laminae indicate abundant diatom productivity in spring and summer (McQuiod and Hobson, 1997; Dallimore, 2001; Kemp, 2003).

The couplets have varied thickness ranging from $\leq 0.05 \mathrm{~mm}$ to $3 \mathrm{~mm}(\sim 0.2 \mathrm{~mm}$ mean) in the FS core and from $0.7 \mathrm{~mm}$ to $3 \mathrm{~mm}$ in the ALS core. They are generally thicker in the uppermost $2 \mathrm{~m}$ (average $2.1 \mathrm{~mm}$ ) of the ALS core. The laminae are concentrated within the 3$7 \mathrm{~m}$ interval of the (average $2.1 \mathrm{~mm}$ ) of the ALS core. The laminae are concentrated within the 3-7 $\mathrm{m}$ interval of the of the FS core while the uppermost $3 \mathrm{~m}$ are less laminated. Likewise, in the ALS core, the laminated intervals are less concentrated in the uppermost $0.8 \mathrm{~m}, 3 \mathrm{~m}$ and below $8.2 \mathrm{~m}$ core intervals. 
The laminations are generally horizontal; however, there are indications of gently inclined and disturbed laminations at certain intervals. Within some intervals, the laminations are highly distorted to the extent that only faint traces are recognizable. The laminated intervals are predominantly composed of mud faecal pellets with a small amount of silt-sized quartz grains. Mica flakes and organic matter debris vary from common to abundant in these intervals.

\subsubsection{Massive and Sand Intervals}

The massive intervals account for $44.19 \%$ of the FS core and $52.85 \%$ of the ALS core, respectively. The massive intervals unevenly alternate with the laminated sediments in the FS core, with the exception of the lowermost 8.03-12.26 m interval. In the ALS core, massive intervals are mostly concentrated in the bottommost $715-872 \mathrm{~m}$ interval. The thickness of these intervals ranges from a few millimeters to $22 \mathrm{~cm}$ in the FS core and reaches up to $\sim 32$ $\mathrm{cm}$ in the ALS core (Figures 4.3-4.4). These homogenous sediments mainly contain dark mud faecal pellets, fine silt and abundant organic matter as well as common to abundant wood fragments.

Approximately $1.2 \%$ of the massive sediments in FS core and $1.4 \%$ of the massive sediments in ALS core are composed of very fine-to fine-grained sands. The thickness of these sand beds ranges between 1 and $5 \mathrm{~cm}$ in the FS core and reaches up to $9 \mathrm{~cm}$ in the ALS core. The thickest sand bed occurs from $635-640 \mathrm{~cm}$ interval in the FS core and from the 399$408 \mathrm{~cm}$ interval in the ALS core. These sand beds are predominantly comprised of very fine to fine quartz grains, with clay, mica flakes and plant debris being common constituents. Minor amounts of accessory minerals are also present. There was not any evidence of bioturbation within the homogenous intervals of either the FS or ALS cores. 


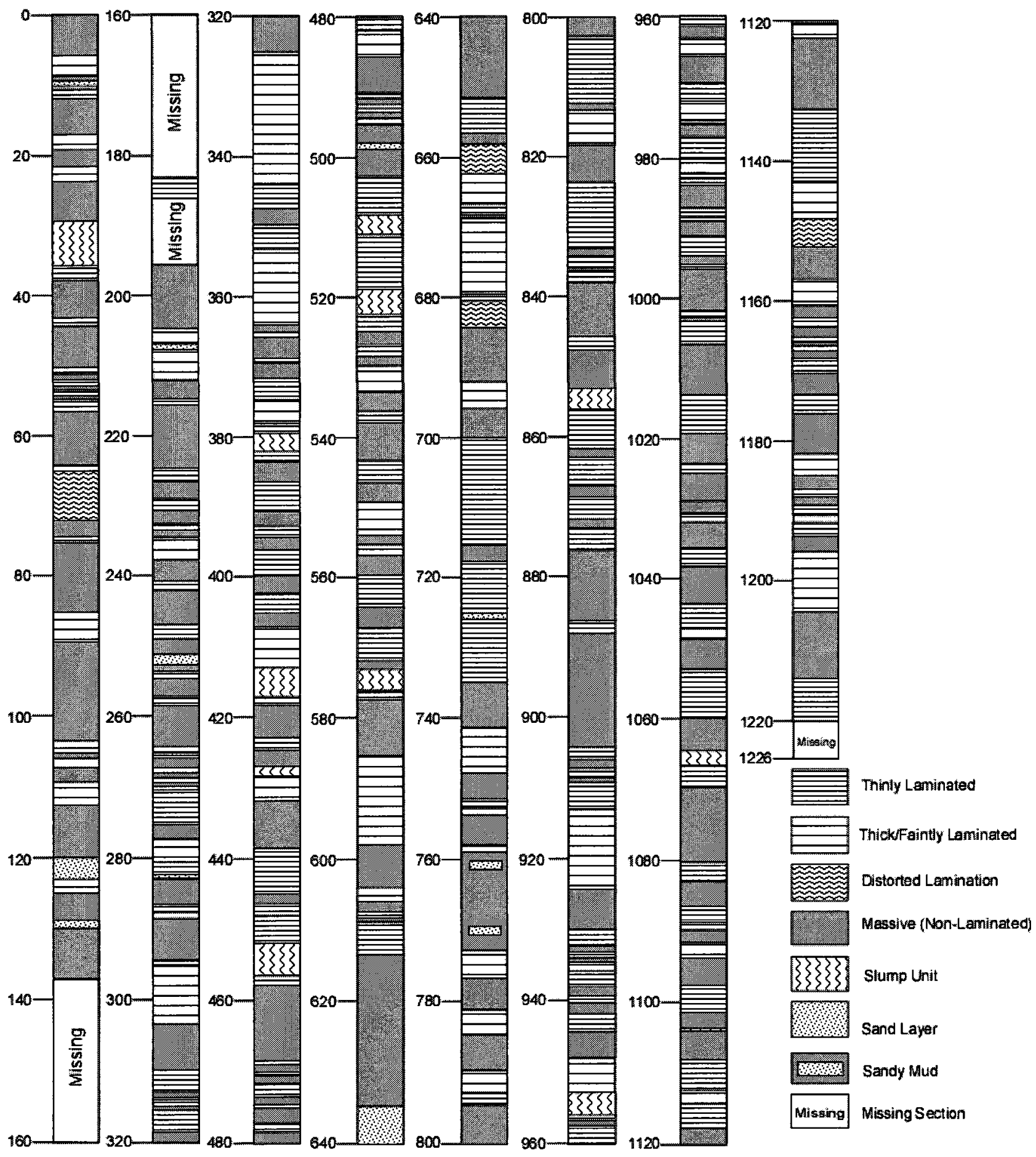

Figure 4.3. Stratigraphic column of the Frederick Sound core. 


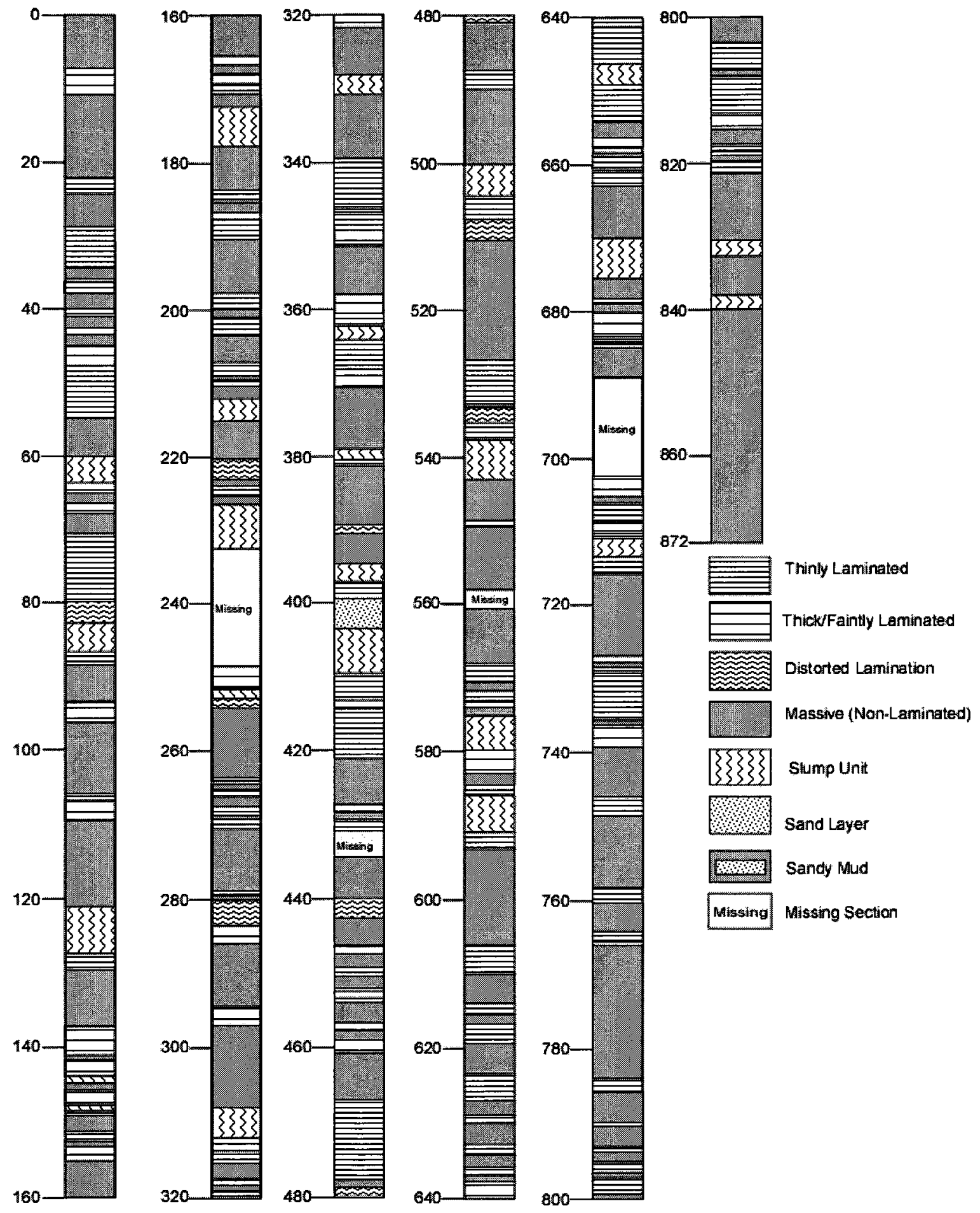

Figure 4.4. Stratigraphic column of the Alison Sound (ALS) core. 


\subsubsection{Slump and Graded Intervals}

Slump sediments which are concentrated between $380-540 \mathrm{~cm}$ interval of the FS core are comprised of $\sim 2.86 \%$ of the total core length (Figure 4.3). In the ALS core, these sediments account for $\sim 8.02 \%$ of the entire core interval and are mostly concentrated at 60 $140 \mathrm{~cm}, 200-312 \mathrm{~cm}$ and $500-591 \mathrm{~cm}$ intervals (Figure 4.4). The thickness of these slump sediments ranges from $2 \mathrm{~cm}$ to $7 \mathrm{~m}$ in both cores (Figures 4.3-4.4). The mineralogy of the slump units is mostly composed of mud faecal pellets with substantial amounts of fine grained quartz particles and wood fragments. The light grey to yellow color typical of these intervals is due to the high quartz content in the sediments.

Approximately $5 \%$ of the FS core and $2 \%$ of the ALS core intervals are comprised of graded units which contain a gradual fining upward sequence. The units usually commence with basal sand bodies which grade to dark hemipelagic mud and finish with diatom-rich layers.

\subsubsection{Foraminiferal Distribution}

\subsubsection{Frederick Sound (FS) core}

Out of the 211 samples processed for foraminiferal analysis from the FS core, 20 were completely barren leaving a total of 191 samples for formaniniferal enumeration and statistical analysis. The species diversity and abundances are low in this core. A total of 41 species including 29 foraminiferal and 13 thecamoebians species were identified in the 191 samples. Due to the observed low abundances relative to the probable errors of the samples, some adjacent samples were combined for multivariate Q- and R-mode cluster analyses. As a result of their low species fractional abundances, samples from the lowermost $22 \mathrm{~cm}(1204-1226$ $\mathrm{cm}$ ) interval were excluded from the cluster analyses. The species fractional abundances for a 
total of 101 samples are presented in Appendix B1. The entire core interval was dominated by agglutinated foraminiferal species, specifically Eggerella advena, which accounts for over $50 \%$ to $93 \%$ of the foraminiferal assemblages.

\subsubsection{Alison Sound (ALS) core}

Species diversity and abundances are also low in the ALS core. A total of 18 foraminiferal and 14 thecamoebians species were identified in 46 samples in this core. Due to the observed low abundances, 18 of these samples were found to be statistically insignificant and were, therefore, excluded from multivariate cluster analysis. The fractional abundances of the species in the samples are presented in Appendix B2. Thecamoebians with abundances over $50 \%$ to $90 \%$ abundances dominate the faunal assemblages from the ALS core. A similar dominance of thecamoebian species over foraminiferal species was observed in the Waump Marsh transect (WIR 16) located close to the head of the ALS core. However, foraminiferal species prevailed over thecamoebians in the Wawwat'l Marsh transect (WIR 12), which is situated at the northeastern end of FS had more foraminifera than thecamoebians (VázquezRiveiros et al., 2007). As in the FS core, Eggerella advena is the most important foraminiferal species in the ALS core.

Spiroplectammina biformis, Recurvoides turbinatus, Portatrochammina bipolaris, and a number of Trochammina and Cribrostomoides species are subordinate taxa in both the ALS and FS cores. Calcareous foraminiferal species are completely absent in these cores. A new Eggerella species informally named here Eggerella beliziensis (Eggerella sp of VázquezRiveiros, 2006) was also identified in both cores. However, due to its low species fractional abundances, it was combined with Eggerella advena as single taxa for the purposes of the 
statistical analyses. The freshwater thecamoebian species represented mainly by Centropyxis spp., Difflugia spp. and Cyclopyxis kahli are also treated as one species in the study.

\subsubsection{Foraminiferal and Thecamobian Biofacies in the Frederick Sound}

\section{(FS) core}

A Q-mode cluster analysis of 101 samples based on 10 foraminiferal and thecamoebian species from the FS core yielded three biofacies: Eggerella advena Biofacies, Recurvoides turbinatus-Spiroplectammina biformis Biofacies and Recurvoides turbinatusThecamoebian spp. Biofacies (Figure 4.5). The Eggerella advena Biofacies is predominant in the lower section (1204-689 cm), Eggerella advena-Spiroplectammina biformis Biofacies occurs mostly in the $679-325 \mathrm{~cm}$ interval while the Recurvoides turbinatus-Thecamoebian spp Biofacies is mainly restricted to the topmost $0-136 \mathrm{~cm}$ interval (Figure 4.6).

\subsubsection{Eggerella advena Biofacies}

The Eggerella advena Biofacies is comprised of 40 samples mainly from the lower section (1204-679 cm) of the FS core (Figure 4.6). A few other samples from the 502-532 cm, $420-462 \mathrm{~cm}, 360-390 \mathrm{~cm}$ and $120-130 \mathrm{~cm}$ in the upper section of the core also belong to this biofacies. The SDI values are very low (0.064-0.89) indicating that the microfaunal environment was highly stressed and unfavourable.

The faunal composition within this interval is overwhelmingly dominated by Eggerella advena (range: 71.9-93.3\%, mean: 83.1\%), Recurvoides turbinatus (range: 0-9.4\%, mean: 4\%), Spiroplectammina biformis (range: 0-8.3\%, mean: 3.4\%), and Zavodovskina nana (0-9.4\%). Lepidoparatrochammina charlottensis (range: 0-6.5\%, mean: $1.4 \%$,) and Portatrochammina bipolaris (range: 0-6\%, mean: 1.6\%) are the other important components of the biofacies. Less frequent species include; Cribrostomoides jeffreysii (range: 0-4.9\%, 
mean: 1\%), Cribrostomoides subglobosum (range: 0-3.1\%, mean: 0.2), Trochammina squamata (0-2.3\%) and Trochammina sp 3. (range: $0-3.3 \%$, mean: $0.3 \%$ ). Relative thecamoebian abundances range from $0-6.3 \%$ (mean: $1.3 \%$ ) in this biofacies. The biofacies recorded very low SDI values $(0.064-0.97)$.

\subsubsection{Eggerella advena-Spiroplectammina biformis Biofacies}

Forty five samples from the $679-325 \mathrm{~cm}$ interval in the FS core are dominated by this biofacies (Figure 4.6). The basal limit of the interval is at the top continuous occurrences of the Eggerella advena Biofacies at $679 \mathrm{~cm}$ depth. The absence of samples spanning the 325$136 \mathrm{~cm}$ interval did not allow the recognition of the biofacies at shallower depths. A number of samples of this biofacies (e.g., those from $1045-1020 \mathrm{~cm}$ and $797-757 \mathrm{~cm}$ intervals) are grouped with those from the Eggerella advena Biofacies and the overlying Recurvoides turbinatus-Thecamoebian spp Biofacies.

An increase in the distribution frequency and abundances of $R$. turbinatus (range: 020.1\%, mean: $7.8 \%$ ) and $S$. biformis (range: $0-20.9 \%$, mean: $7.3 \%$ ) as well as a moderate reduction of $E$. advena (range: $64.2-78.5 \%$; mean: $71.9 \%$ ) characterize this biofacies. There is also a relative increase of $C$. jeyffreyssii (range: $0-9.2 \%$, mean: $0.24 \%$ ). Portatrochammina bipolaris also has higher abundance (8.2\%) than in the Eggerella advena Biofacies. Lepidoparatrochammina charlottensis (range: $0-4.8 \%$, mean: $1.3 \%$ ) and $Z$. nana (range: $0-$ 6.1\%, mean: $0.4 \%$ ) are slightly reduced whereas C. subglobosum (range: 0-5.5\%, mean: 0.4\%), T. squamata (range: 0-4.8\%, mean: $0.4 \%$ ) and freshwater Thecamoebian spp (range: 0 13.3\%, mean: $3.9 \%$ ) are increased in the biofacies. The SDI for this biofacies ranges from 0.24-1.03. 


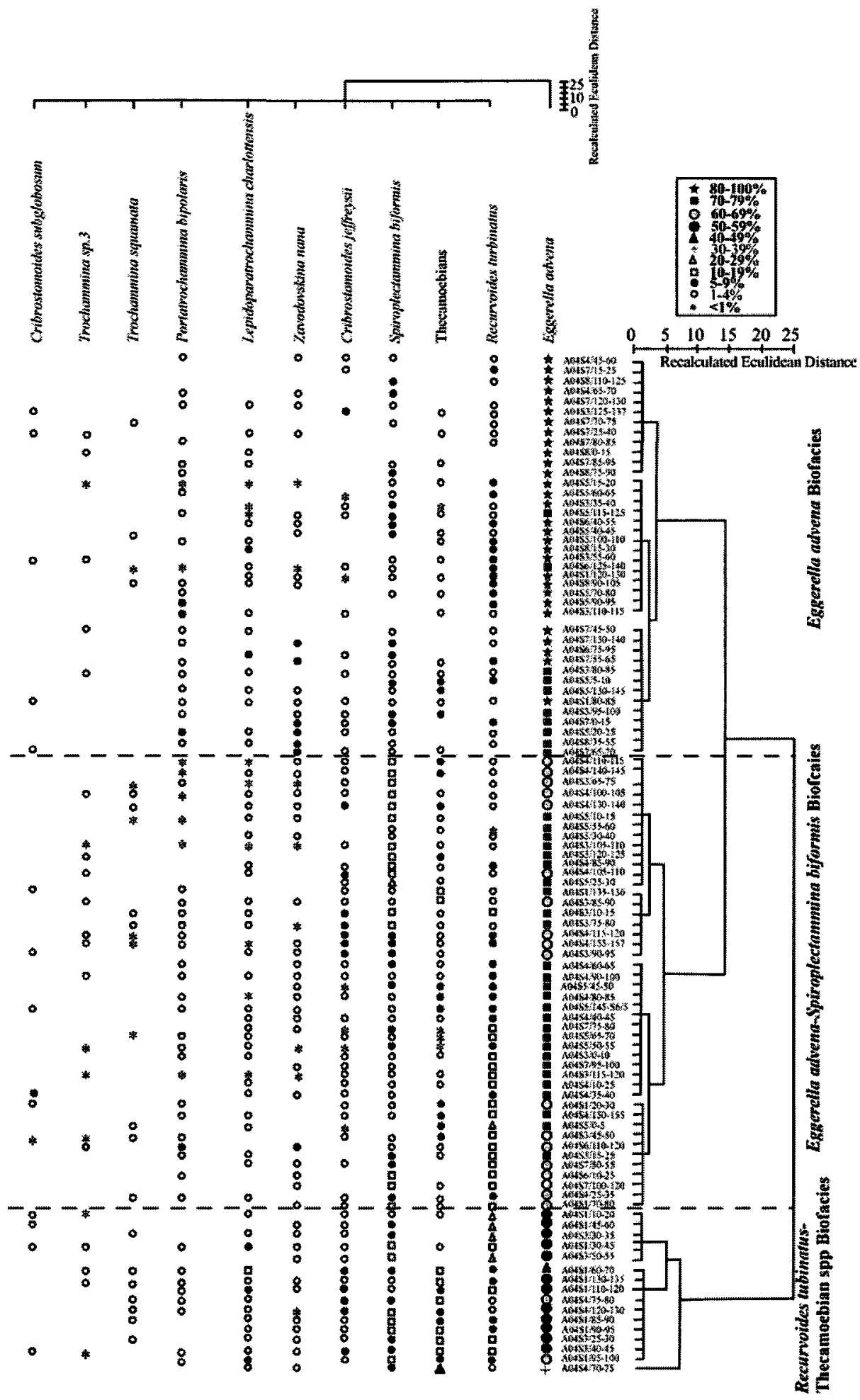

Figure 4.5. Q-mode versus R-mode cluster dendrogram for the Frederick Sound core samples. Range of abundances (\%) of foraminiferal species and thecamoebians are indicated by symbols. 


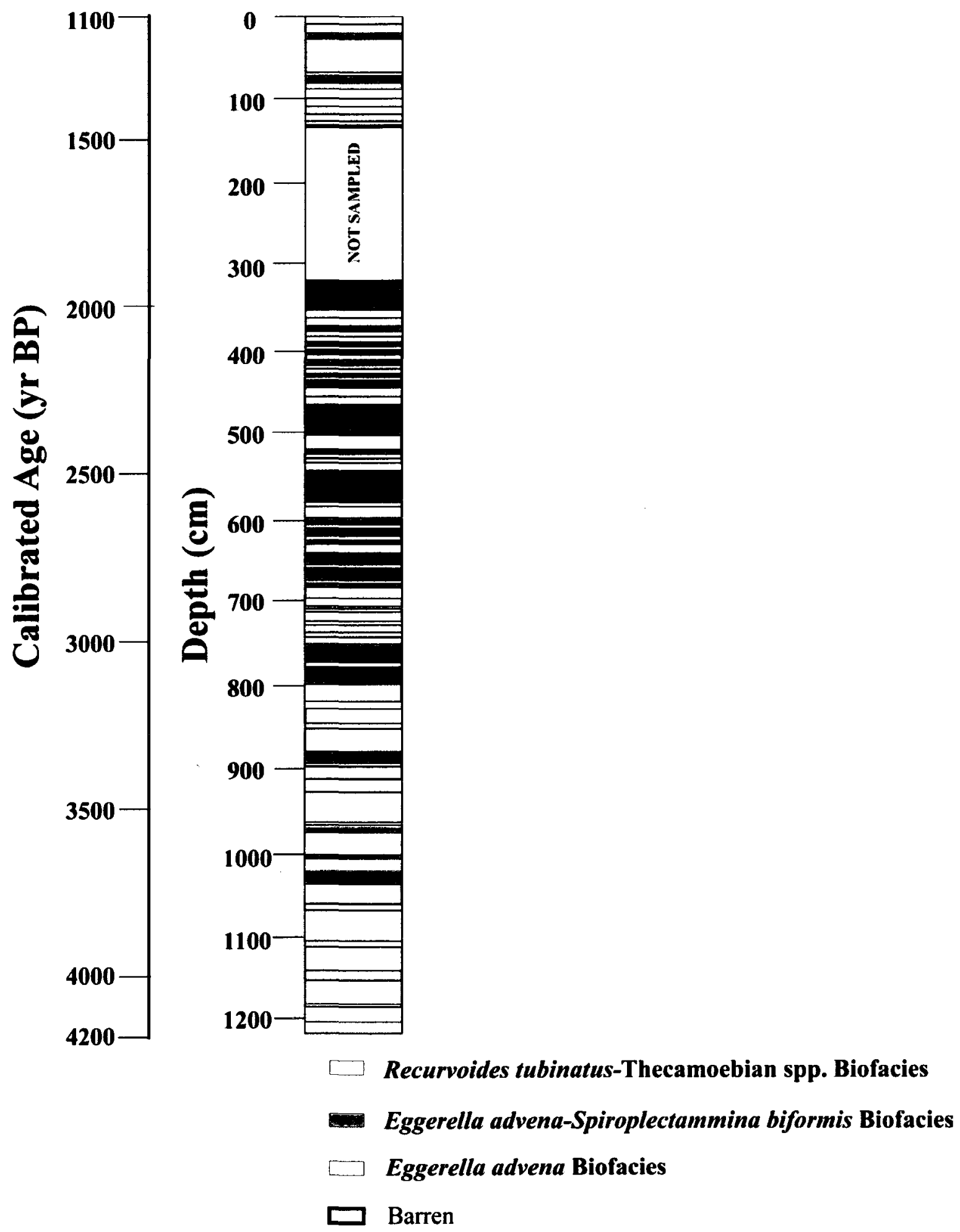

Figure 4.6. Distribution of foraminiferal biofacies in the Frederick Sound core. 


\subsubsection{Recurvoides turbinatus-Thecamoebian spp Biofacies}

A total of 16 samples predominantly from the upper $136 \mathrm{~cm}$ of the FS core (Figure 4.6), are represented by this biofacies. Five samples from the $350-360 \mathrm{~cm}, 375-380 \mathrm{~cm}, 532-$ $542 \mathrm{~cm}$ and $582-592 \mathrm{~cm}$ intervals are also represented in this biofacies. The observed SDI values of $\sim 0.66 \sim 1.35$ are slightly higher than those in the underlying biofacies.

Recurvoides turbinatus has both a much higher frequency and abundances in this biofacies than in the underlying Eggerella advena and Eggerella advena-Spiroplectammina biformis Biofacies. The mean of the fractional abundances is $12.7 \%$ and reaches $\sim 23.7 \%$ to $26.4 \%$ in at least four samples within this biofacies. Spiroplectammina biformis also has a higher average abundance $(9.1 \%)$ in this biofacies than in the underlying biofacies whereas $E$. advena is highly reduced (54.3\% mean). An increasing trend of thecamoebians in the Recurvoides turbinatus-Spiroplectammina biformis Biofacies also continues to this biofacies. These freshwater species with $10.3 \%$, mean abundance, have their highest abundance (45.7\%) within this zone. The average occurrences of $C$. jeffreysii (range: 0-9.1\%, mean: $4.1 \%$ ) and $L$. charlottensis (range: 0-6.4\%, mean: 3.6\%) are slightly increased whereas $P$. bipolaris (range: 0-2.9 \%, mean: $0.9 \%$ ) is noticeably reduced within this biofacies. Zavodovskina nana, $T$. squamata, and C. subglobosum account for a maximum of 3.2 to $4.5 \%$ of the total abundances within the biofacies.

\subsubsection{Foraminiferal and Thecamoebian Biofacies in the Alison Sound (ALS) core}

Two foraminiferal biofacies were identified in the ALS core using Q- and R-mode cluster analyses of 18 samples and 9 species (Figure 4.7). These biofacies, which are informally named the Eggerella advena-Thecamoebian spp and Thecamoebian Biofacies are unevenly distributed throughout the entire core intervals (Figures 4.8). 


\subsubsection{Thecamoebian spp. Biofacies}

This biofacies consists of 13 samples which are concentrated within the $0-182 \mathrm{~cm}$ and $607-872 \mathrm{~cm}$ intervals in the ALS core (Figure 4.8). Single occurrences of some samples belonging to this biofacies are present within the $0-60 \mathrm{~cm}, 217-222 \mathrm{~cm}, 249-254 \mathrm{~cm}$, and 349 $354 \mathrm{~cm}$ intervals. This biofacies is mainly comprised of thecamoebian spp (range: $64.9-92 \%$, average: $\sim 79.6 \%$ ) and moderate abundances of $E$. advena (range: $4-21.4 \%$, mean: $13.1 \%$ ). Cribrostomides crassimargo (range: $0-5.4 \%$, mean: 0.8\%), P. bipolaris (range: 0-5.1\%, mean: $1.4 \%$ ) and S. biformis (range: $0-4.3 \%$, mean: $1.3 \%$ ) are the other important faunal component of this biofacies. Recurvoides turbinatus $(0.8 \%$ mean) and $C$. jeffreysi $(0.4 \%)$ occur in the intervals of this biofacies. The SDI values are very low ranging from $0.24-0.73$.

\subsubsection{Eggerella advena-Thecamoebian spp Biofacies}

The Eggerella advena-Thecamoebian spp Biofacies is represented in 15 samples across the entire ALS core interval. It is predominantly located within the $182-607 \mathrm{~cm}$ core interval (Figure 4.8) and is characterized by moderately high abundances of Eggerella advena (range mostly from 24.3 to $65.6 \%$ with a mean of $48.6 \%$ ) and Thecamoebian spp. (range: 5.8 57.8\%, mean: $29.6 \%$ ). The sample from the $443-448 \mathrm{~cm}$ interval has the highest proportion of Eggerella advena (80.9\%). High abundance of Thecamoebian spp, and lower abundances of Recurvoides turbinatus (range: 0-16.1\%, mean: 4.1\% mean), Spiroplectammina biformis (range: 0-8.8\%, mean: 3.8\%), Portatrochammina bipolaris (range: 0-13.1\%, mean: 4\%) and Zavodovskina nana (range: $0-7 \%$, mean: $3 \%$ mean) differentiate this biofacies from the Recurvoides turbinatus-Thecamoebian spp Biofacies in the FS core. 


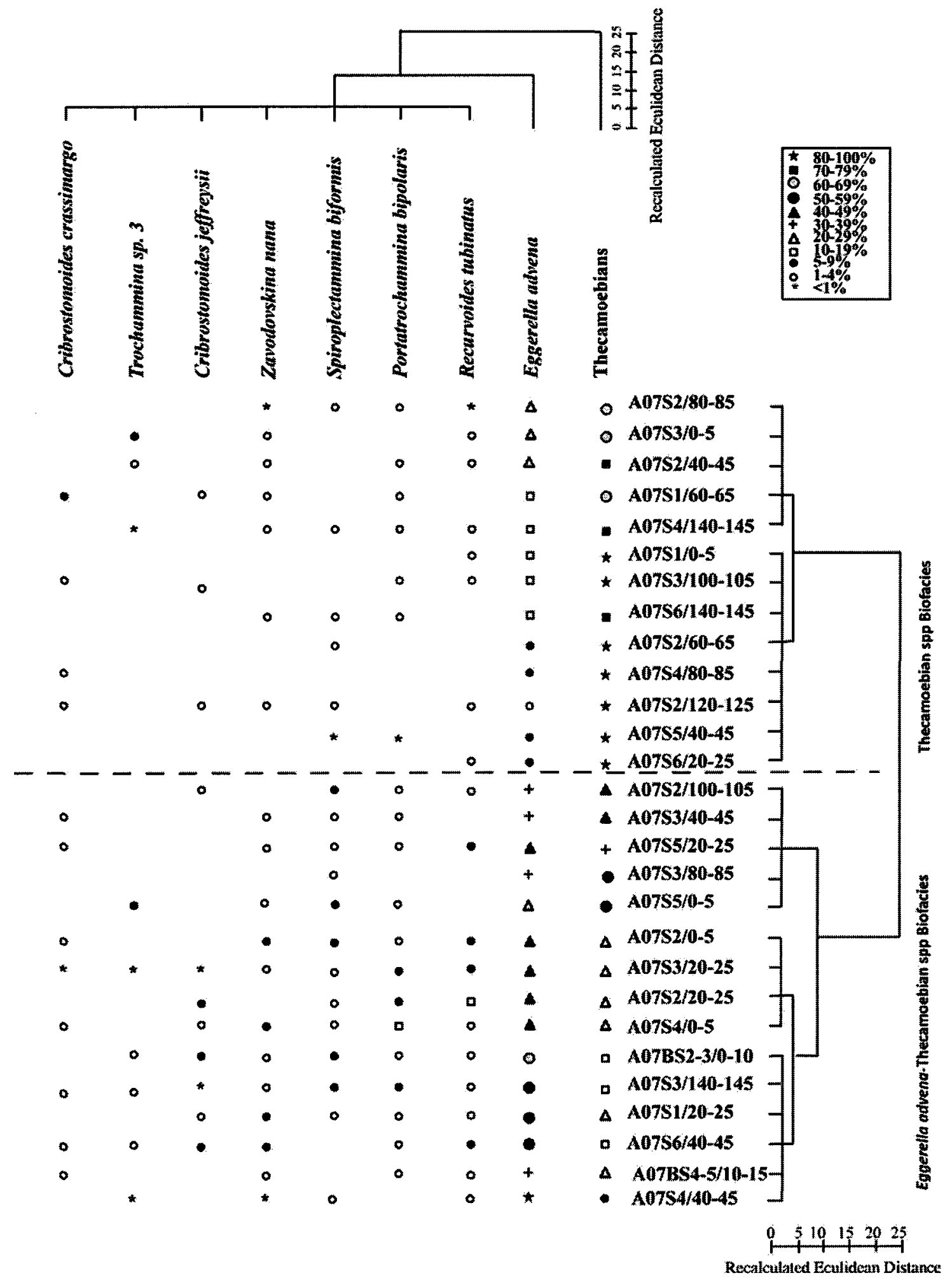

Figure 4.7. Q-mode versus R-mode cluster dendogram for the Alison Sound core samples. Ranges of abundances (\%) of foraminiferal species and thecamoebians are indicated by symbols. 


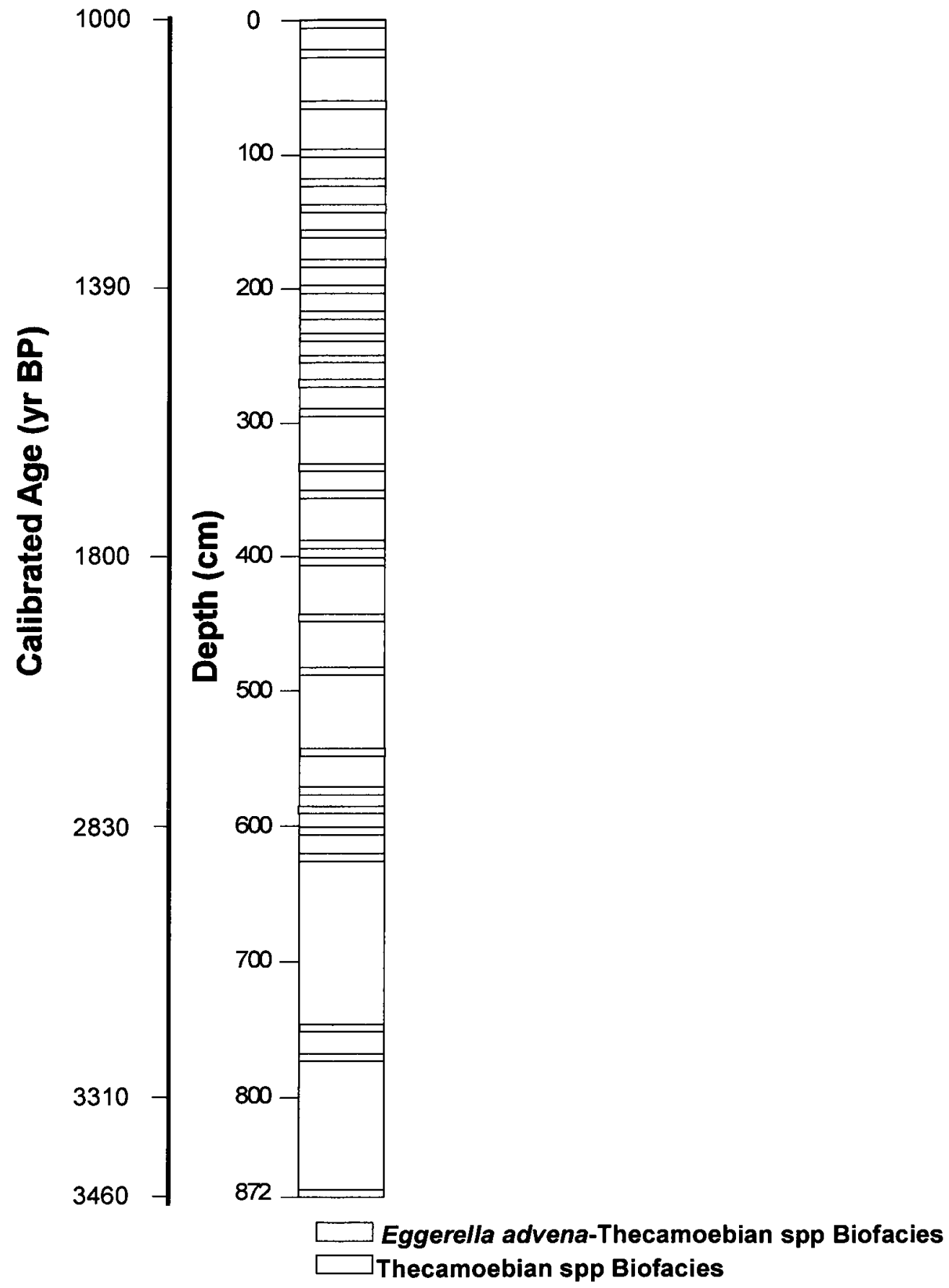

Figure 4.8. Stratigraphic distribution of foraminiferal biofacies in the Alison Sound core. 
Cribrostomoides crassimargo (range: $0-4.5 \%$, mean: 1.2\%), Cribrostomoides jeffreysii (range: $0-8 \%$, mean: $1.6 \%$ ) and Trochammina sp. 3 (range: $0-5.4 \%$, mean: $0.8 \%$ ) are also represented. The SDI values range from 0.12 to 1.35 , suggesting a stressed environment (Sageman and Bina 1997).

\subsubsection{Transfer Functions}

\subsubsection{Model Performance}

The performance of the inverse deshrinking models of "transfer function regression weighted average" (WA) and "weighted average tolerance" (WA-TOL) are evaluated by their statistical parameters: the RSME, $\mathrm{r}^{2}$ and maximum bias (Table 4.1). Both the WA and WATOL inverse deshrinking models show relatively low RSME and maximum bias values, an indication of their good predictive utility. A variable is better predicted by a model which has low RSME and max-bias, and high $\mathrm{r}^{2}$. Therefore in this study, the WA classical deshrinking method with low RSME and max bias as well as high $r^{2}$, better predicts temperature while oxygen, salinity, nitrate and phosphate are better predicted by the WA-Tolerance inverse deshrinking method. Except for nitrate and nitrite, the $\mathrm{r}^{2}$ values are very high, generally higher than 0.93 . These high $r^{2}$ values are an indication of a strong relationship between the measured and predicted values of all variables. The WA and WA-TOL deshrinking inverse models for silicate were not used in the interpretation because of their high RSME and max bias values (Table 4.1). This variable is better predicted by the WA-TOL inverse deshrinking method which has the lowest RSME and maximum bias values. 
Table 4.1. Sample weighted averaging (WA) and weighted averaging with tolerance (WA-TOL) deshrinking statistics summary for the inverse and downweighting models.

\begin{tabular}{|c|c|c|c|c|}
\hline \multicolumn{5}{|c|}{ Temperature } \\
\hline Model & Deshrinking method & RMSE & $\mathbf{r 2}$ & Max bias \\
\hline WA & Inverse & 0.04 & 0.98 & 0.07 \\
\hline WA & Classical & 0.04 & 0.98 & 0.06 \\
\hline WA-TOL & Inverse & 0.06 & 0.95 & 0.11 \\
\hline WA-TOL & Classical & 0.06 & 0.95 & 0.11 \\
\hline \multicolumn{5}{|c|}{ Oxygen } \\
\hline Model & Deshrinking method & RMSE & $\mathbf{r 2}$ & Max bias \\
\hline WA & Inverse & 0.38 & 0.94 & 0.59 \\
\hline WA & Classical & 0.39 & 0.94 & 0.76 \\
\hline WA-TOL & Inverse & 0.21 & 0.98 & 0.41 \\
\hline WA-TOL & Classical & 0.21 & 0.98 & 0.36 \\
\hline \multicolumn{5}{|c|}{ Salinity } \\
\hline Model & Deshrinking method & RMSE & $\mathbf{r 2}$ & Max bias \\
\hline WA & Inverse & 0.30 & 0.94 & 0.40 \\
\hline WA & Classical & 0.31 & 0.94 & 0.36 \\
\hline WA-TOL & Inverse & 0.18 & 0.98 & 0.26 \\
\hline WA-TOL & Classical & 0.18 & 0.98 & 0.27 \\
\hline \multicolumn{5}{|c|}{ Nitrate/Nitrite } \\
\hline Model & Deshrinking method & RMSE & $\mathbf{r 2}$ & Max bias \\
\hline WA & Inverse & 2.49 & 0.51 & 4.95 \\
\hline WA & Classical & 3.50 & 0.51 & 6.02 \\
\hline WA-TOL & Inverse & 1.26 & 0.87 & 2.27 \\
\hline WA-TOL & Classical & 1.34 & 0.87 & 3.06 \\
\hline \multicolumn{5}{|c|}{ Silicate } \\
\hline Model & Deshrinking method & RMSE & $\mathbf{r 2}$ & Max bias \\
\hline WA & Inverse & 1.65 & 0.94 & 2.76 \\
\hline WA & Classical & 1.70 & 0.94 & 3.46 \\
\hline WA-TOL & Inverse & 1.82 & 0.97 & 1.30 \\
\hline WA-TOL & Classical & 1.20 & 0.97 & 1.14 \\
\hline \multicolumn{5}{|c|}{ Phosphate } \\
\hline Model & Deshrinking method & RMSE & $\mathbf{r 2}$ & Max bias \\
\hline WA & Inverse & 0.11 & 0.93 & 0.14 \\
\hline WA & Classical & 0.11 & 0.93 & 0.20 \\
\hline WA-TOL & Inverse & 0.03 & 0.99 & 0.04 \\
\hline WA-TOL & Classical & 0.03 & 0.99 & 0.04 \\
\hline
\end{tabular}




\subsubsection{Reconstructed environmental variable in the Frederick Sound (FS) core}

The fractional abundances of the foraminiferal species and thecamoebians as well as reconstructed variables in the FS core are presented in Figure 4.9. The predicted temperatures are nearly constant $\left(8.6^{\circ} \mathrm{C}\right)$. Only subtle variations are discernible (Figure 4.9$)$. Relatively high values are predicted within the intervals where thecamoebians are common to abundant, whereas low values correspond to increased foraminiferal dominance. The highest value of $8.64^{\circ} \mathrm{C}$ was recorded within the $532-537 \mathrm{~cm}$ interval where the peak abundance $(>45 \%)$ of thecamoebians occurs.

The inferred salinity and oxygen values are inversely correlated to those of the temperature. Oxygen concentrations with a mean of $1.3 \mathrm{~mL} / \mathrm{L}(0.87-1.63 \mathrm{~mL} / \mathrm{L})$ are generally lower than the present day values. The salinity with an average of $28.3 \%$ ( range: 27.8 $28.5 \%$ ) is also low in this core. Nitrate/nitrite distribution is characterized by largely fluctuating pattern throughout the lower $1226-325 \mathrm{~cm}$ interval of the core while phosphate distribution follows the same distribution patterns as paleotemperature.

Correlation of the species with the reconstructed environmental variables in the FS core shows that E. advena is positively correlated with salinity, oxygen and nitrate and negatively related to temperature, silicate and phosphate (Table 4.2, Figure 4.9). Spiroplectammina biformis, $Z$. nana and Recurvoides turbinatus are positively correlated with silica, temperature and phosphate. Portatrochammina bipolaris and C. jeffreysii are positively correlated with temperature, salinity and oxygen. Thecamoebians are only positively correlated to temperature. Organic carbon is weakly correlated with $C$. jeffreysii, $R$. turbinatus and thecamoebians (Table 4.2; Figure 4.10). 


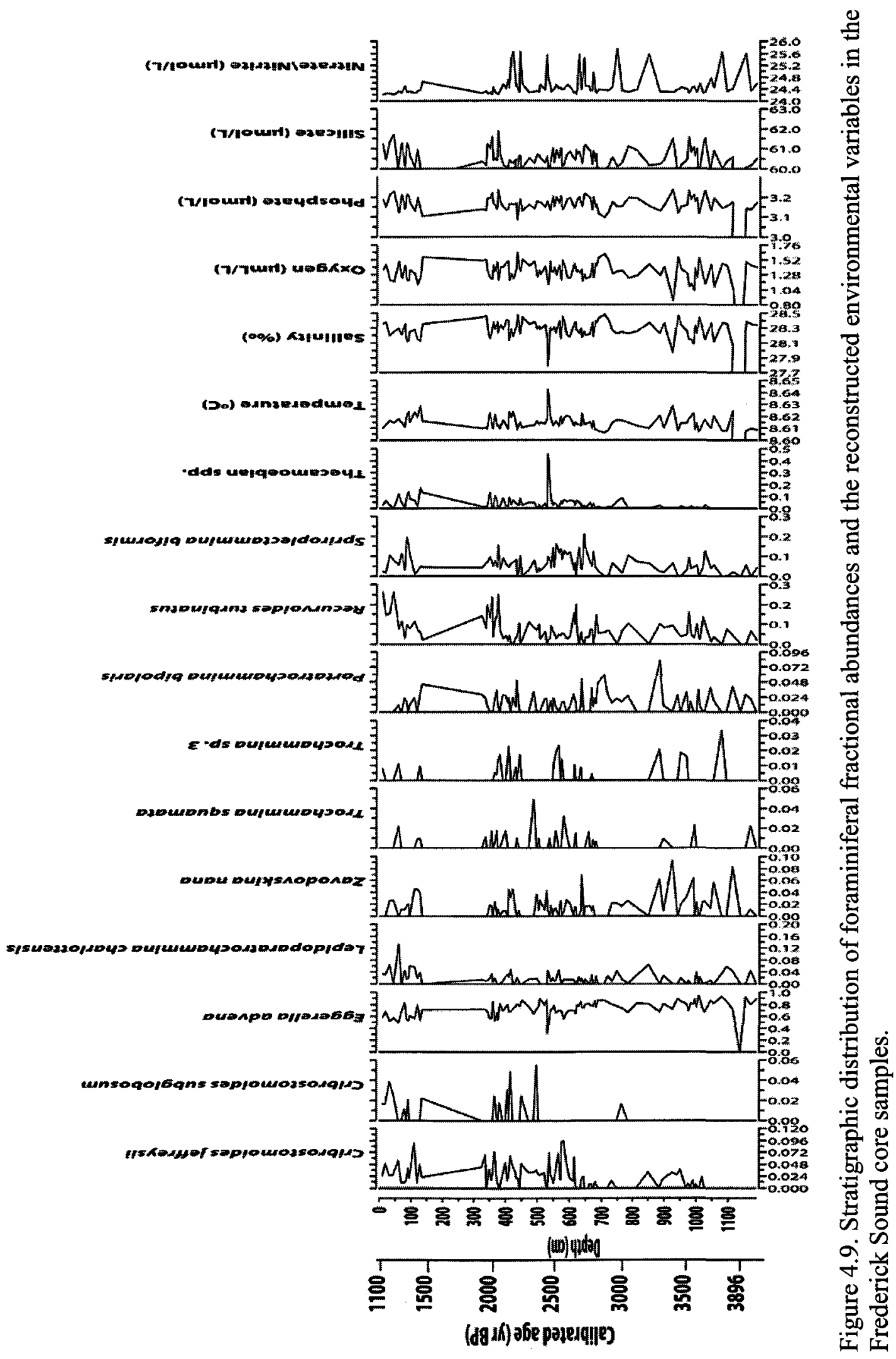




\subsubsection{Factor Analysis of the reconstructed variables in the Frederick Sound (FS) core}

R-mode principal component with varimax rotation factor analysis was used to investigate the influence of the environmental variables on the species' distribution in the FS core. A total of 7 factors extracted from the data set accounts for $\sim 77.98 \%$ total variance (Table 4.3).

Factor $1(23.93 \%$ variance $)$ is dominantly characterized by positive loadings for $E$. advena, oxygen and salinity. Zavodovskina nana, temperature, phosphate and silicate are inversely correlated in this factor. Factor 2 , which has a total variance of $15.01 \%$ is defined by positive loadings for $E$. advena, salinity and biogenic silica as well as strong negative loading for thecamoebians. Factor 3 with $11.34 \%$ of the variance is characterized by positive loading for R. turbinatus silica and organic carbon, and negative loadings for E. advena and Trochammina sp. 3

Factor 4 with a total variance of $9.14 \%$, is mainly characterized by positive loadings for P. bipolaris, total nitrogen, organic carbon and biogenic silica. This factor is additionally defined by negative loadings for $C$. jeffreysii, C. subglobosum and $L$. charlottensis. Factor 5 (7.43\% variance), is defined by positive loadings for $P$. bipolaris, E. advena, oxygen and salinity, and negative loadings for $S$. biformis, silicate and phosphate.

Cribrostomoides jeffrreyssii, Trochammina sp.3, C. subglobosum, total nitrogen and organic carbon are positively loaded in Factor 6 which has a total variance of 


\begin{tabular}{|c|c|}
\hline (wn') วZ!̣s u!̣:.8ิ ueə⿳亠 & $\stackrel{8}{8}$ \\
\hline 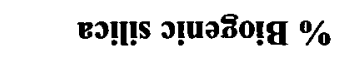 & $\stackrel{8}{-} \overline{0}$ \\
\hline${ }^{8 x 0} \mathrm{~J} \%$ & 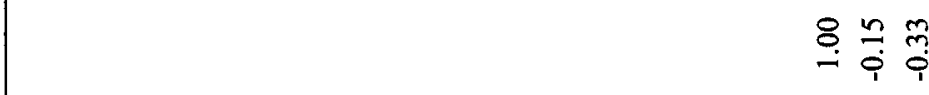 \\
\hline${ }^{[830]} \mathrm{N} \%$ & 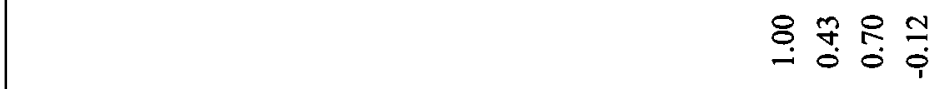 \\
\hline 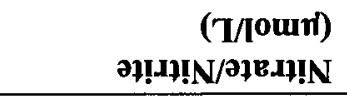 & 8 苍告 \\
\hline (T//ouni) วમยग!I!S & 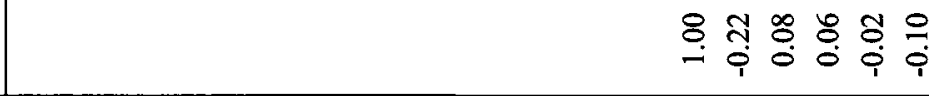 \\
\hline (T//Oun') әрвчdsOYd & 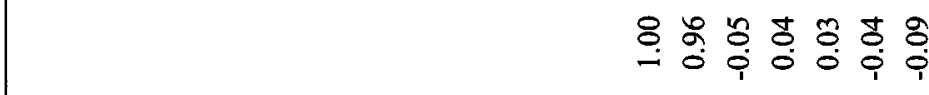 \\
\hline (T/Tس) บวริК & 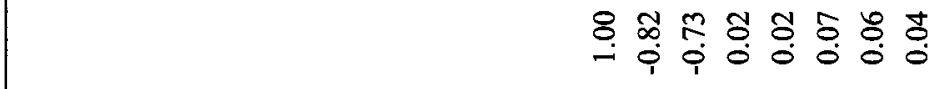 \\
\hline (\%\%) Al!u!!es & 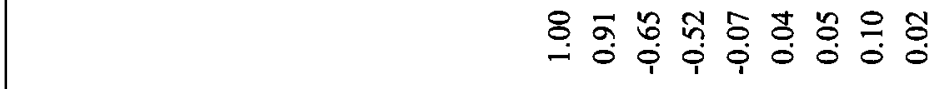 \\
\hline 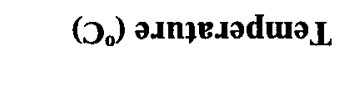 & 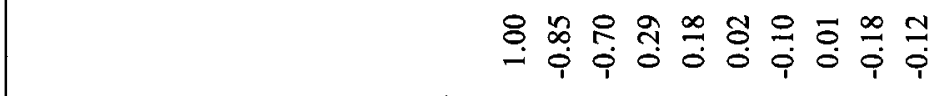 \\
\hline suห!̣әоนвәәч $\mathbf{L}$ & \& $\delta$ 我 \\
\hline s?uusof?q $\mathrm{S}$ & 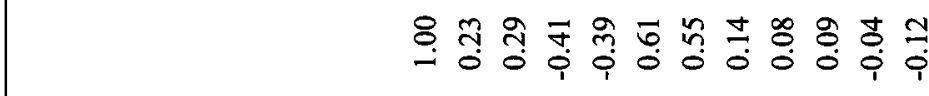 \\
\hline snנpu!qım! $\mathrm{d}$ & 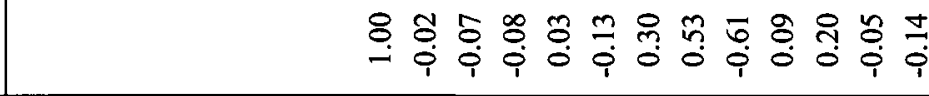 \\
\hline s!.uppod!q $\cdot \mathrm{d}$ & 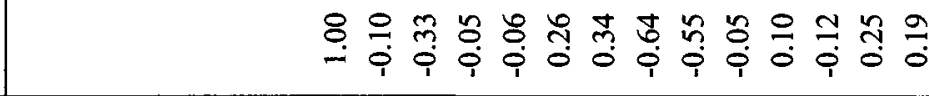 \\
\hline $\mathcal{E} \cdot d s$ рu! uиuрчроג $L$ & 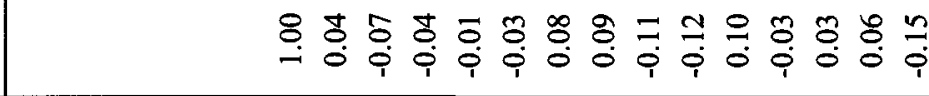 \\
\hline pдpumpnbs $: L$ & 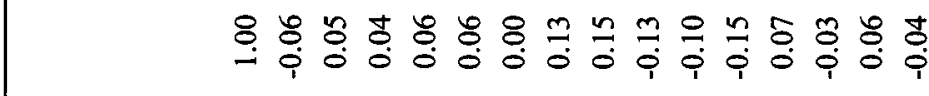 \\
\hline рupu $Z Z$ & 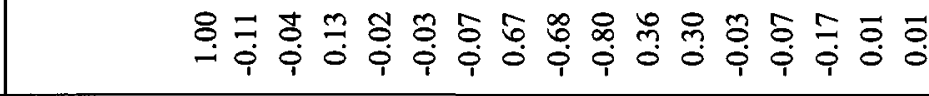 \\
\hline s!suano|Аvчว ${ }^{\circ} \mathrm{T}$ & 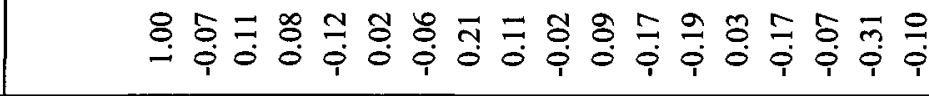 \\
\hline рuวхрр $: \exists$ & 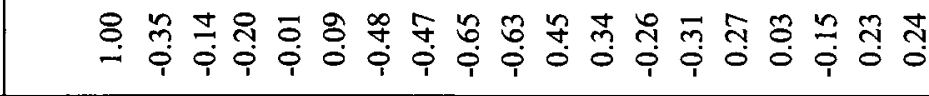 \\
\hline unsqoloqns ? & 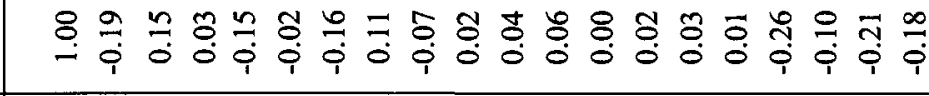 \\
\hline "nsíanffa! ว & 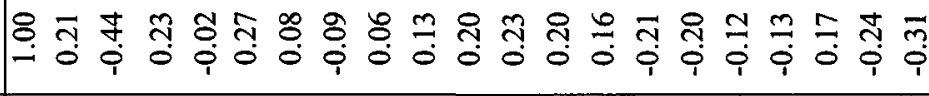 \\
\hline sәТqе!ле $\Lambda$ & 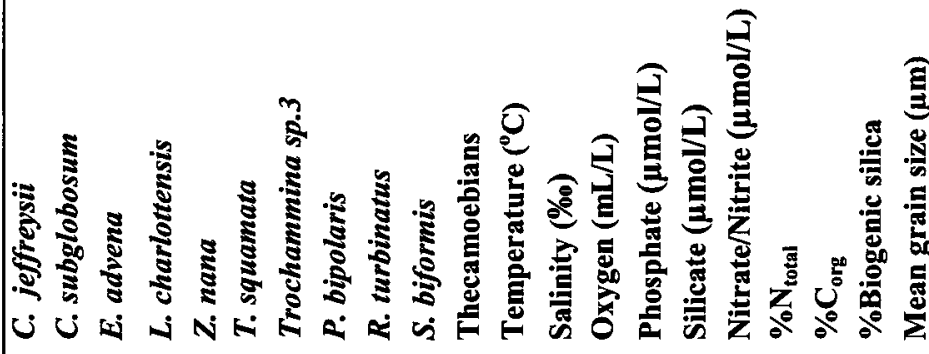 \\
\hline
\end{tabular}




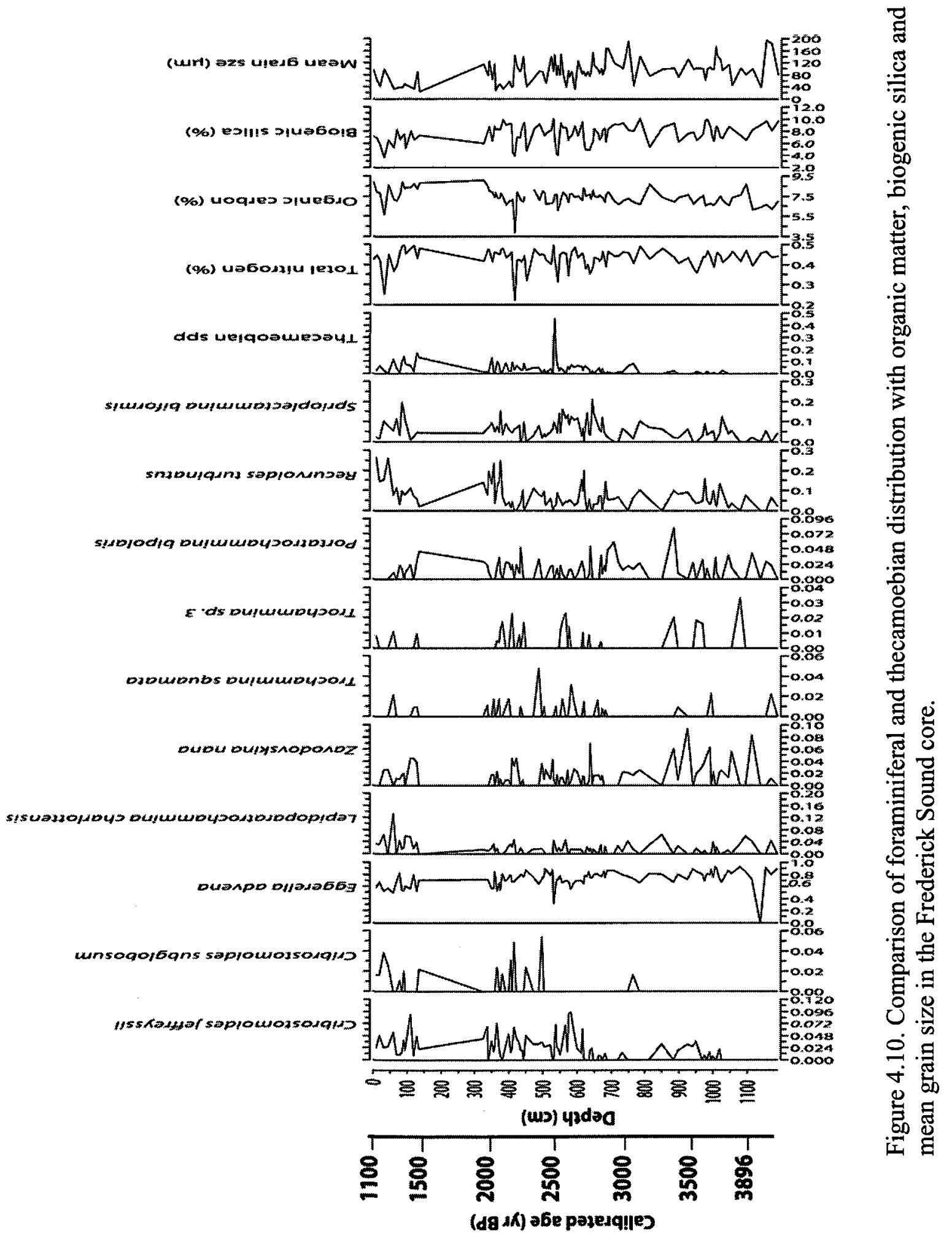


Table 4.3. Principal component (varimax rotated) R-mode factor analysis loading for foarminiferal species, thecamobians and reconstructed variables in the Fredrick Sound (FS) core.

\begin{tabular}{|l|r|r|r|r|r|r|r|}
\hline Variables & Factor 1 & Factor 2 & Factor 3 & Factor 4 & Factor 5 & Factor 6 & Factor 7 \\
\hline C. jeffreysii & 0.06 & -0.16 & 0.06 & -0.30 & 0.06 & 0.50 & 0.57 \\
C. subglobosum & -0.04 & 0.05 & 0.09 & -0.57 & -0.01 & 0.23 & -0.08 \\
E. advena & 0.21 & 0.68 & -0.39 & 0.16 & 0.25 & -0.16 & -0.35 \\
L. charlottensis & 0.08 & -0.26 & -0.03 & -0.45 & 0.07 & 0.10 & 0.27 \\
Z. nana & $\mathbf{- 0 . 9 7}$ & 0.05 & 0.03 & -0.01 & 0.04 & 0.02 & -0.04 \\
T. squamata & 0.11 & -0.05 & 0.10 & 0.15 & 0.02 & -0.08 & $\mathbf{0 . 8 2}$ \\
Trochammina sp.3 & -0.06 & 0.12 & -0.26 & -0.03 & 0.10 & 0.53 & 0.02 \\
P. bipolaris & -0.12 & 0.01 & 0.04 & 0.27 & $\mathbf{0 . 7 9}$ & -0.12 & 0.08 \\
R. turbinatus & 0.02 & 0.03 & $\mathbf{0 . 8 9}$ & -0.04 & -0.19 & 0.01 & 0.02 \\
S. biformis & -0.05 & -0.26 & -0.15 & 0.14 & -0.76 & 0.05 & 0.24 \\
Thecamoebians & -0.02 & $\mathbf{- 0 . 9 7}$ & -0.06 & -0.08 & 0.02 & 0.03 & 0.03 \\
Temperature $\left({ }^{\circ} \mathbf{C}\right)$ & -0.71 & -0.66 & -0.05 & -0.08 & -0.10 & 0.09 & 0.08 \\
Salinity $(\%)$ & 0.74 & 0.47 & 0.06 & -0.03 & 0.41 & 0.11 & 0.15 \\
Oxygen $(\mathrm{mL} / \mathrm{L})$ & $\mathbf{0 . 8 2}$ & 0.12 & -0.08 & -0.02 & 0.52 & 0.05 & 0.12 \\
Phosphate $(\mu \mathrm{mol} / \mathrm{L})$ & -0.40 & 0.07 & 0.16 & 0.05 & $\mathbf{- 0 . 8 9}$ & -0.06 & -0.13 \\
Silicate $(\mu \mathrm{mol} / \mathrm{L})$ & -0.34 & 0.14 & 0.38 & 0.07 & $\mathbf{- 0 . 8 3}$ & -0.07 & -0.10 \\
Nitrate/Nitrite $(\mu \mathrm{mol} / \mathrm{L})$ & 0.04 & -0.03 & $\mathbf{- 0 . 8 5}$ & 0.00 & -0.10 & -0.08 & -0.10 \\
\%N $\mathrm{N}_{\text {total }}$ & 0.10 & -0.04 & 0.11 & $\mathbf{0 . 8 5}$ & -0.05 & 0.27 & -0.04 \\
\%org & 0.29 & -0.27 & 0.26 & 0.26 & -0.13 & 0.54 & -0.27 \\
\%Biogenic silica & -0.07 & 0.22 & -0.07 & $\mathbf{0 . 7 9}$ & 0.12 & -0.02 & 0.09 \\
Mean grain size $(\mu \mathrm{m})^{\text {Eigenvalue }}$ & 0.01 & 0.08 & -0.22 & 0.07 & 0.12 & -0.75 & -0.04 \\
Variance $(\%)$ & $\mathbf{5 . 2 7}$ & $\mathbf{3 . 3 0}$ & $\mathbf{2 . 5 0}$ & $\mathbf{2 . 0 1}$ & $\mathbf{1 . 6 4}$ & $\mathbf{1 . 2 8}$ & $\mathbf{1 . 1 7}$ \\
& $\mathbf{2 3 . 9 3}$ & $\mathbf{1 5 . 0 1}$ & $\mathbf{1 1 . 3 5}$ & $\mathbf{9 . 1 4}$ & $\mathbf{7 . 4 3}$ & $\mathbf{5 . 8 1}$ & $\mathbf{5 . 3 1}$ \\
\hline
\end{tabular}


$5.81 \%$. Factor 7 (variance of $5.31 \%$ ) is mainly represented by strong positive loadings for $C$. jeffrreyssii and T. squamata and weak loadings for L. charlottensis and S. biformis.

\subsubsection{Reconstructed environmental variables in the Alison Sound (ALS) core}

The fractional abundances of the foraminiferal species and reconstructed variables are presented in Figure 4.11. The estimated paleotemperatures are generally constant with only very minor variability, averaging $8.7^{\circ} \mathrm{C}$. Subtle fluctuations in paleotemperatures correlate to the faunal distribution with slight peak excursions corresponding to variation in the allochthonous Thecamoebian spp. abundances (Figure 4.11). The inferred oxygen, salinity and phosphate values are similarly distributed (Figure 4.11). Both oxygen and salinity, characterized by a decrease at $217 \mathrm{~cm}$ core interval have peak excursions between 197 and $177 \mathrm{~cm}$. Phosphate has a positive excursion in the upper $117 \mathrm{~cm}$ of the core. The reconstructed nitrate/nitrite shows peak excursions through the $622-602 \mathrm{~cm}, 483-443,177-137$ and $97-0 \mathrm{~cm}$ core intervals.

The correlation between faunal fractional abundances and reconstructed environmental variables in the ALS core shows that thecamoebians are strongly correlated to inferred temperature and nitrate/nitrite levels (Table 4.4). In contrast Eggerella advena, Cribrostomoides jeffreysii, Zavodovskina nana, Portatrochammina bipolaris, Recurvoides turbinatus and Spiroplectammina biformis are inversely correlated to temperature and nitrate/nitrite. Portatrochammina bipolaris, E. advena, $R$. turbinatus and C. jeffreysii are correlated to oxygen and salinity. Both of these variables are inversely correlated to $Z$. nana 
(7/lowm) oxE4dsoydsoud

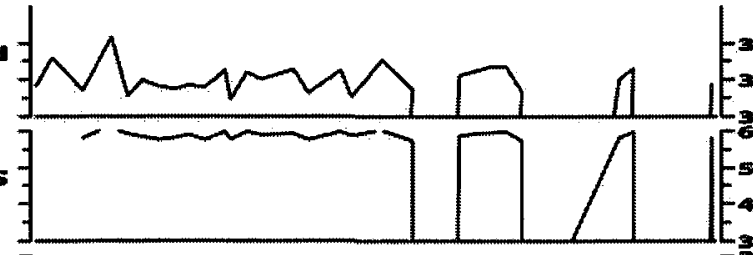

$-3.2$

3.1

(7/10um) oxesils

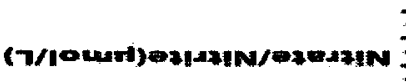

录 (106) xalunes

承

$\Lambda \Lambda N / N$



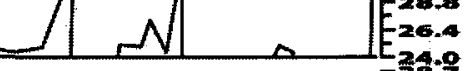

26:9

$-28.2$

27.7

주류

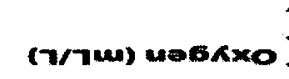

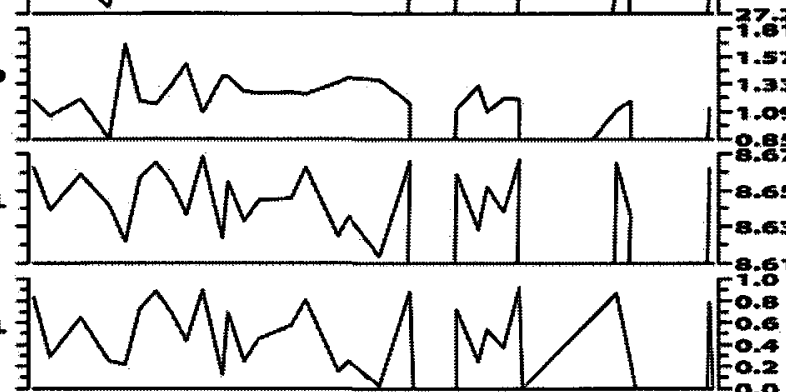

dis uegroemesent.

(Do) anmesedment

dds Heigoomesent.

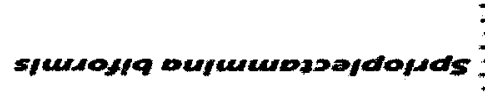

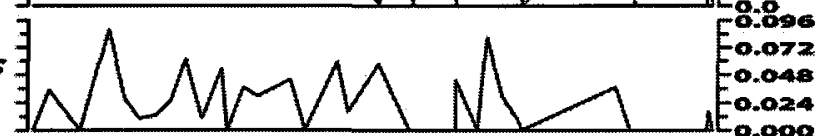

0.096

i.33

1.09

8.67

令

$\stackrel{0}{=}$

.$\Xi$

smunugand sopionunsed

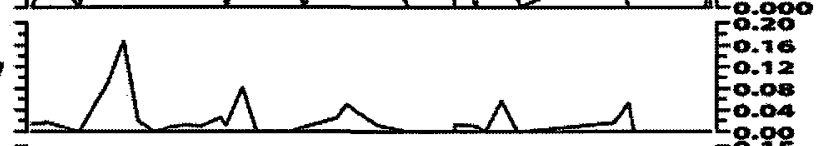

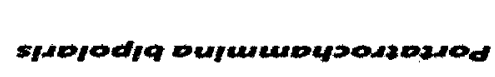
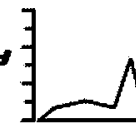

8:99

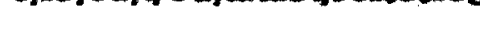

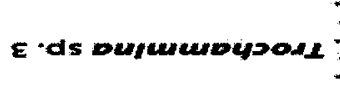

Dureu oujysnoponoz

Derougysnoponoz

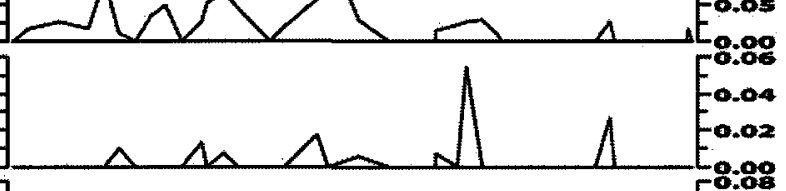

8.09

Duappo ofleces6g
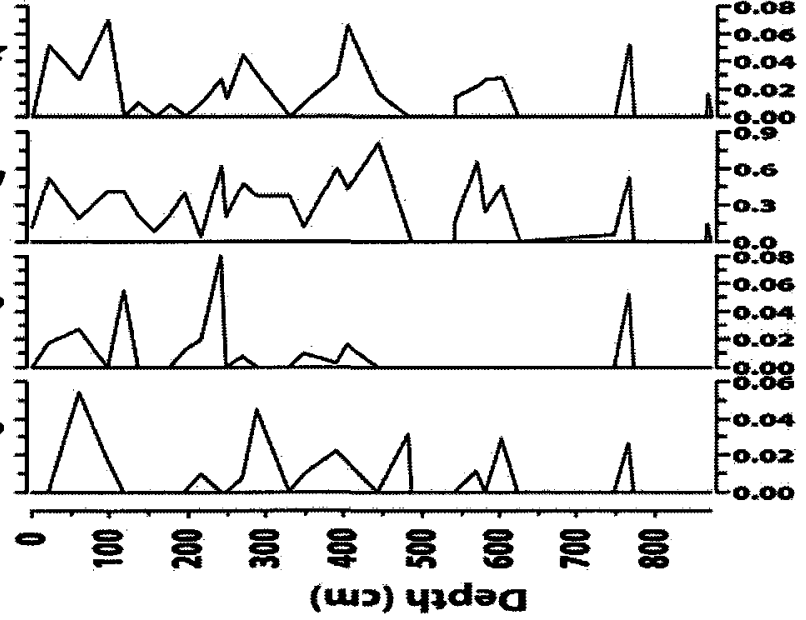

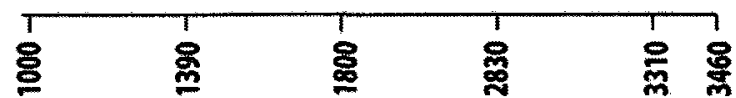

(da $\wedge_{K}$ ) ə6e posesq!ןes 
and thecamoebians. Eggerella advena, Z. nana, S. biformis, and Trochmmina sp 3. also have positive relationships with phosphate and silicate. In addition, $C$. jeffreysii is moderately correlated to silicate. Only S. biformis is positively correlated to organic carbon and total nitrogen while $P$. bipolaris correlates to mean grain size (Table 4.4; Figure 4.12).

\subsubsection{Factor Analysis of the reconstructed variables in the Alison Sound (ALS) core}

The influence of the inferred environmental variables on the down core foraminiferal distribution was investigated with principal component with varimax rotation R-mode factor analysis. The analysis groups together closely related species. A total of 5 factors with a total variance of $82.02 \%$ was extracted (Table 4.5 ).

Factor 1, which accounts for $38.74 \%$ variance, was characterized by strong positive loadings for E. advena, Z. nana, P. bipolaris, R. turbinatus, S. biformis and weak loadings for $C$. crassimargo and Trochammina sp. 3. Factor 2, with a $17.46 \%$ variance, is defined by positive loadings for $R$. turbinatus, C. jeffreysii, P. bipolaris, and negative loadings for C. crassimargo, Z. nana, and Trochammina sp3.. Oxygen and salinity are the only positively loaded environmental variables in the Factor 2.

Factor 3 is characterized by positive loadings for Spiroplectammina biformis, organic carbon, total nitrogen and phosphate. It accounts for $10.63 \%$ variance and also has negative loading for Trochammina sp3. Factor 4 which accounts for $9.3 \%$ variance is characterized by positive loadings for Portatrochammina bipolaris, $Z$. nana, R. turbinatus, oxygen and mean grain size. Cribrostomoides crassimargo and the nitrate/nitrite are positively loaded in Factor 5. This factor which accounts for $5.9 \%$ of the total variance is additionally defined by negative loadings for Trochammina sp.3 and S. biformis. 


\begin{tabular}{|c|c|c|}
\hline & $\begin{array}{r}\text { (um) } \\
\text { วZ!̣ u!̣dפ urəWW }\end{array}$ & 8 \\
\hline & ${ }^{[100} \mathbf{N} \%$ & 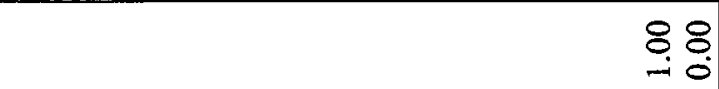 \\
\hline . & 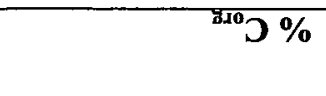 & 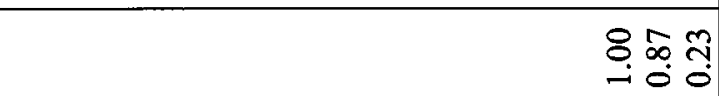 \\
\hline 急 & (\%) K!!U!!es & 8 웅웅ㅇㅇㅇ \\
\hline 总 & (T//ourn') әpвчdsoyd & 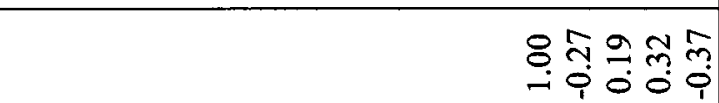 \\
\hline 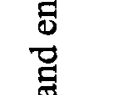 & (T//OUn) ว|вอ!!!S & 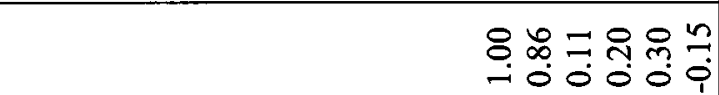 \\
\hline 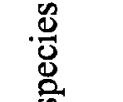 & 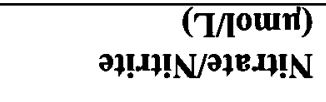 & \&: \\
\hline 氶 & 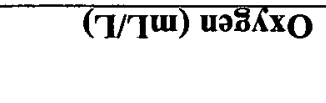 & 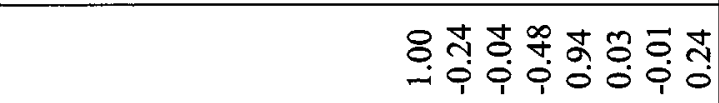 \\
\hline 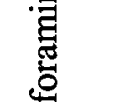 & 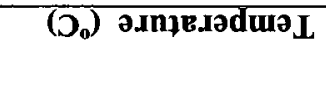 & ৪ ڤ̂ñ \\
\hline 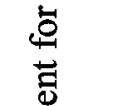 & Sиห!̣วошеวәч.L & 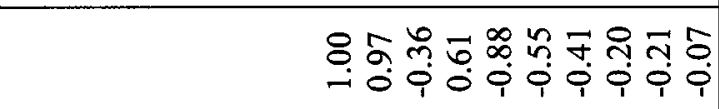 \\
\hline 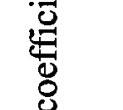 & s!mudf!q $\mathbf{S}$ & 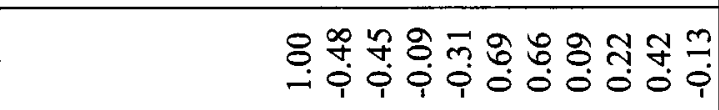 \\
\hline . & snypu!q,an! $\cdot \mathrm{d}$ & 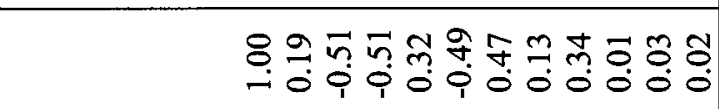 \\
\hline $\begin{array}{l}\overrightarrow{0} \\
\stackrel{0}{0}\end{array}$ & s!uplod!̣ $\cdot \mathrm{d}$ & 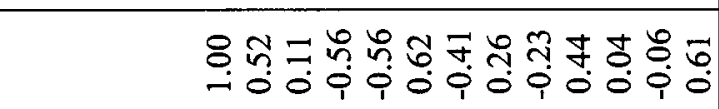 \\
\hline $\begin{array}{l}\text { : } \\
\text { : }\end{array}$ & Eds pu!̣uupyoo.L & 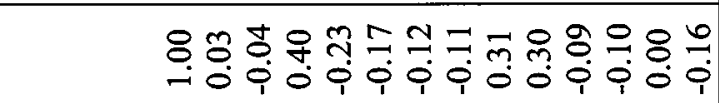 \\
\hline 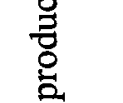 & рири $\cdot Z$ & 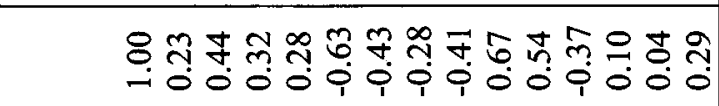 \\
\hline 居 & 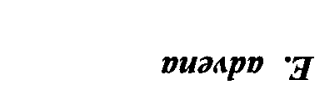 & 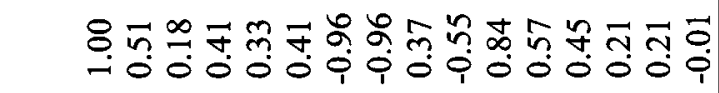 \\
\hline$\tilde{0}$ & 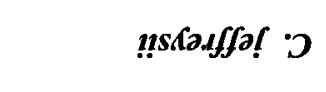 & 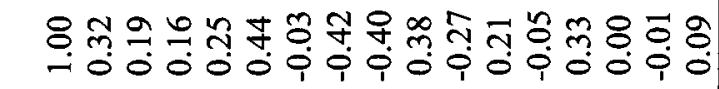 \\
\hline$\stackrel{\tilde{\Xi}}{x}$ & 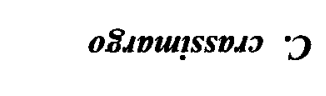 & \& \& \\
\hline 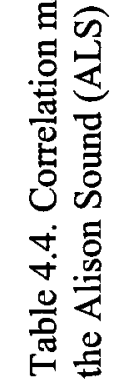 & səIqв!̣.de $_{\Lambda}$ & 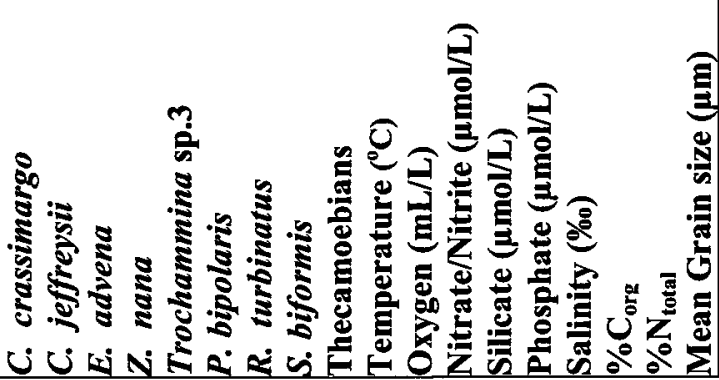 \\
\hline
\end{tabular}




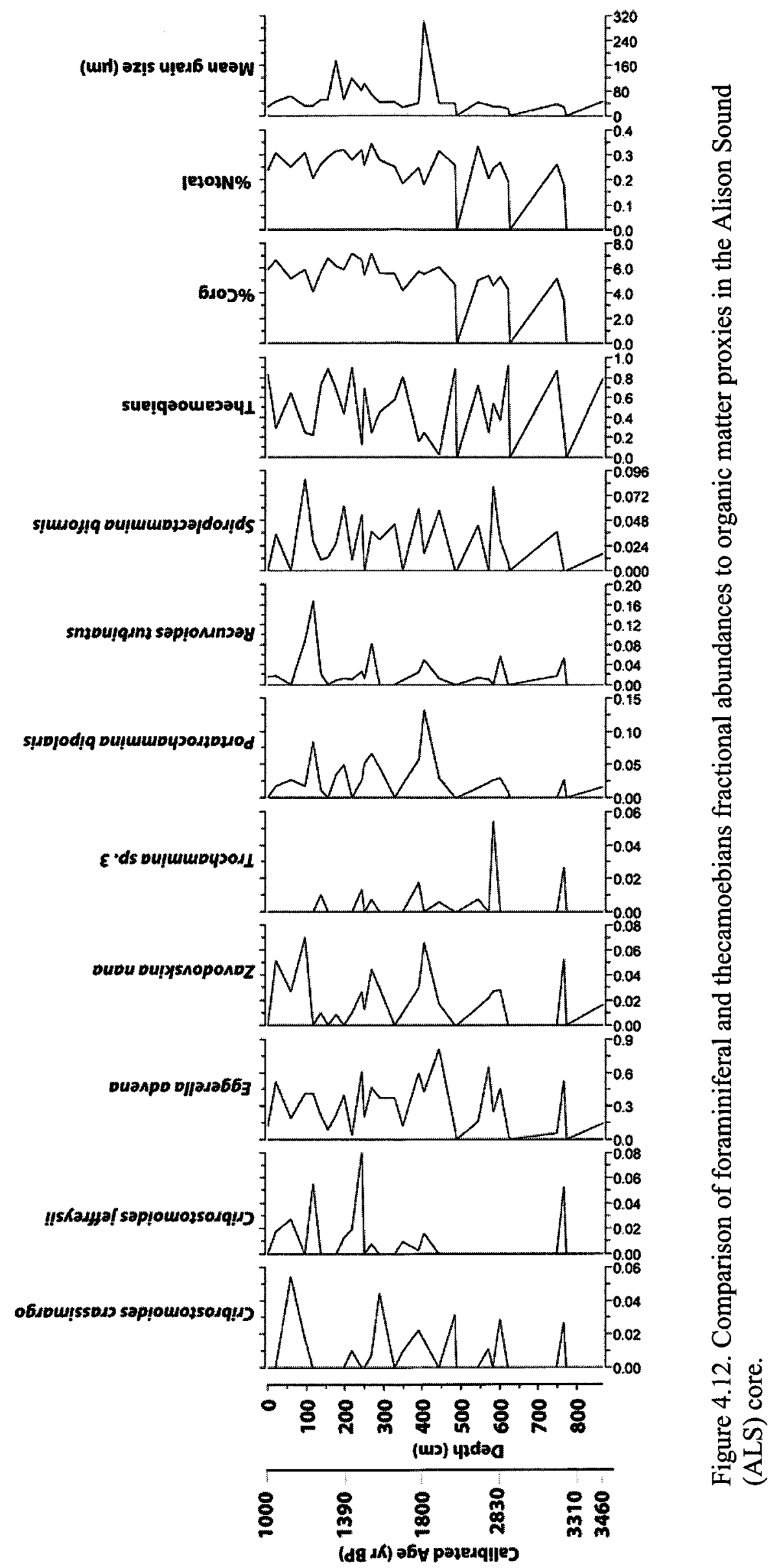


Table 4.5. Principal component (varimax-rotated) factor loadings for foraminiferal species, thecamoebians species and reconstructed variables in Alison Sound (ALS) core.

\begin{tabular}{|l|r|r|r|r|r|}
\hline Variable & Factor 1 & Factor 2 & Factor 3 & Factor 4 & \multicolumn{1}{|c|}{ Factor 5 } \\
\hline C. crassimargo & 0.21 & -0.32 & -0.10 & -0.01 & $\mathbf{0 . 7 8}$ \\
C. jeffreysii & 0.44 & 0.31 & -0.17 & 0.12 & 0.11 \\
E. advena & $\mathbf{0 . 9 2}$ & 0.12 & 0.14 & -0.06 & -0.02 \\
Z. nana & 0.66 & -0.62 & -0.03 & 0.38 & 0.09 \\
Trochammina sp. 3 & 0.25 & -0.24 & -0.24 & -0.06 & -0.56 \\
P. bipolaris & 0.50 & 0.28 & -0.11 & 0.74 & 0.05 \\
R. turbinatus & 0.57 & 0.22 & -0.09 & 0.21 & -0.02 \\
S. biformis & 0.47 & -0.19 & 0.28 & -0.14 & -0.61 \\
Thecamoebians & $\mathbf{- 0 . 9 8}$ & -0.07 & -0.09 & -0.09 & 0.04 \\
Temperature & $\mathbf{- 0 . 9 3}$ & -0.29 & -0.11 & -0.03 & 0.07 \\
Oxygen & 0.28 & $\mathbf{0 . 9 1}$ & -0.03 & 0.24 & 0.06 \\
Nitrate/Nitrite & -0.61 & -0.07 & -0.27 & -0.28 & 0.23 \\
Silicate & $\mathbf{0 . 9 1}$ & -0.25 & 0.16 & -0.13 & -0.23 \\
Phosphate & 0.60 & -0.55 & 0.23 & -0.42 & -0.26 \\
Salinity (\%o) & 0.34 & $\mathbf{0 . 9 2}$ & 0.07 & 0.00 & -0.08 \\
\%C org & 0.10 & 0.00 & $\mathbf{0 . 9 4}$ & 0.14 & 0.04 \\
\%N $N_{\text {total }}$ & 0.14 & -0.02 & $\mathbf{0 . 9 3}$ & -0.08 & -0.07 \\
Mean Grain size $(\boldsymbol{\mu m})^{\text {Eigenvalue }}$ & -0.04 & 0.01 & 0.13 & $\mathbf{0 . 9 3}$ & 0.06 \\
Variance (\%) & $\mathbf{7 . 3 6}$ & $\mathbf{3 . 3 2}$ & $\mathbf{2 . 0 2}$ & $\mathbf{1 . 7 7}$ & $\mathbf{1 . 1 2}$ \\
\hline
\end{tabular}




\subsection{Discussion}

\subsubsection{Foraminiferal Paleoceanography}

Foraminiferal assemblages and biofacies distribution are useful in interpreting paleoceanographic conditions of coastal marine sediments (Culver, 1993; Blais-Stevens and Patterson, 1998). Water mass properties and organic matter concentration are the main factors, which control foraminiferal distribution in high latitude fjords such as the SBIC inlets (Schafer and Cole, 1986; Osterman and Nelson, 1989; Hunt and Corliss, 1993; Jennings and Helgadottir, 1994; Rytter et al., 2002; Husum and Hald, 2004). The amount of nutrient and substrate type (Jennings and Helgadottir, 1994; Korsun and Hald, 1998; Husum and Hald, 2004), distance from glaciers (Vilks et al., 1989; Korsun and Hald, 1998) and duration of ice cover (Schröder-Adams et al., 1990a, b; Osterman et al., 1999) are the other ecological factors which control foraminiferal distribution in fjord environments.

The inferred oxygen concentrations in the examined SBIC piston core sediments range from 0.87 to $1.63 \mathrm{~mL} / \mathrm{L}$ in the $\mathrm{FS}$ core and 0.85 to $1.68 \mathrm{~mL} / \mathrm{L}$ in the ALS core, respectively, indicating that dysoxic to suboxic conditions prevailed during the deposition of the foraminifera bearing core intervals. The low abundances and diversity of agglutinated foraminifera and thecamoebians with low SDI (ranging from $0.064-1.35$ in the FS core and 0.12-1.34 in the ALS core) are consistent with the stressed low-oxygen conditions indicated by the estimated values of oxygen. Dysoxic estuarine environments in high latitude fjords, such as those in the SBIC, are typically characterized by low diversity of agglutinated benthic fauna which mainly consists of one or a few species (Alve, 1991a, b; Schafer et al., 1991; Scott et al., 2001; Sen Gupta, 2002). On the other hand, well ventilated, open, marine environments are dominated by highly diverse calcareous foraminiferal faunas. The absence of calcareous foraminiferal species in the sediments 
of the FS and ALS cores is therefore, likely due to the stress and unfavorable nature of the depositional environments in the inlets (Schafer et al., 1991).

According to Schafer et al. (1991), high organic matter contents and flux in sediments usually facilitate the development of bottom water anoxia, and consequently lead to high food supply, preservation of laminated sediments and faecal pellets. Therefore, the high abundance of mud faecal pellets and diatom valves in the SBIC core sediments translate into high productivity and by extension into high food supply for foraminifera such as $E$. advena, $C$. jeffreysii, $S$. biformis and $P$. bipolaris (enabling them to populate). An increase in diatom productivity most likely led to biochemical oxygen demand, quickly depleting the bottom water oxygen in the inlets and facilitating the development of anoxic conditions.

The estimated salinity levels in both the FS and ALS cores are low, ranging between 27.5 and $28.5 \%$. These values are consistent with the measured salinity values near the core sites and are also an indication of estuarine environment prevalence in both FS and ALS.

\subsubsection{Paleoenvironmental Interpretations}

\subsubsection{Eggerella advena Biofacies}

An Eggerella advena Biofacies in the basal 4200-2835 cal yr interval of the FS core is similar in composition and diversity to inner shelf biofacies identified along the coastal region of Washington State (Snyder et al., 1990) and the Strait of Georgia (Guilbault et al., 2003). Likewise FS, these assemblages are predominantly comprised of E. advena with low amounts of R. turbinatus and S. biformis. The Eggerella advena Biofacies found in the present study is also similar to Biofacies 1 encountered in contaminated shallow inner shelf brackish water in Saanich Inlet (Blais, 1995 and Blais-Stevens and Patterson, 1998). Saidova (2002) identified a similar 
assemblage dominated by $E$. advena in shallow water ( $50 \mathrm{~m}$ of depth) along the Hudson Bay coast.

Positive correlations of E. advena and P. bipolaris to the estimated low salinity (less than normal marine) and oxygen (Tables 4.2 and 4.3) are interpreted as an indication that these species thrive in oxygen-depleted, brackishwater environment in FS. Eggerella advena, a shallow water species (Vilks and Deomarine, 1988; Lloyd, 2006), mainly occurs in nearshore environments of the arctic-boreal and lagoon environments in Atlantic North America (Cushman, 1922a; Leslie, 1963; Vilks, 1967, 1969; Bartlett, 1972; Schafer, 1972; Vilks and Deomarine, 1988; Murray, 2006). It also lives in waters of varying temperatures including non-glaciomarine (Korsun and Hald, 2000), arctic (Loeblich and Tappan, 1953; Phleger, 1952; Vilks, 1969; Vilks et al., 1989) and cold regions along the east coast of North America as well as temperate regions such as the New Jersey continental shelf (Murray, 2006).

Eggerella advena is also an important pollution indicator (Watkins, 1961; Schafer, 1973; Schafer et al., 1975; Alve and Nagy, 1986) and survives in highly polluted, oxygen depleted, organic-rich environments close to sewage dump sites such as the ones found on the continental shelf of eastern Canada and the Pacific coast of North America (e.g., Watkins 1961; Clark, 1971; Schafer and Cole, 1974; Alve, 1993, 1995; Alve and Nagy, 1986, 1990; Blais-Stevens and Patterson, 1998). It is one of the pioneering species that recolonize recovering sewage dump sites (Schafer, 1972; Schafer and Cole, 1974; Schafer and Young, 1977; Schafer, 1982; Schafer et al., 1991). Low oxygen content and high organic matter richness in FS would have provided favourable conditions for the abundance of this species in the SBIC. However, the SBIC is located in a remote area lacking any settlements, industrial or agricultural activity. Therefore, the abundances of $E$. advena and other organic matter tolerant species in the region are not due to pollution from sewage but to natural accumulation of organic matter. 
A morphologically similar species, Eggerella scabra is also frequently found in low oxygen, shallow brackish water environments in fjords and shelves in Northern Europe (Alve and Nagy, 1986; Alve, 1990; Murray, 2006). The species survives in oxygen depleted $(0.5 \mathrm{~mL} / \mathrm{L}$, Olsson, 1989 personal comm. cited in Alve, 1995), brackish waters with salinities $>24 \%$ o (Murray, 2006).

Zavodovskina nana and $R$. turbinatus are common species in this biofacies and found in a wide range of water depths (Vilks, 1969; Lagoe, 1979a) ranging from shallow to deep waters. Zavodovskina nana is the most abundant species in waters warmer than $-1^{\circ} \mathrm{C}$ in fjords around Baffin Island (Schafer and Cole, 1988) and $0-1^{\circ} \mathrm{C}$ in McClure Strait, Canadian Arctic Archipelago (Iqbal, 1973). There are also reports of high abundances of $Z$. nana in warm bottom waters in the Amerasian Basin and adjacent continental shelf (Lagoe, 1979a). The moderate presence of $Z$. nana, and $E$. advena dominance in this section of the FS core, are suggestive of relatively warm bottom waters.

\subsubsection{Eggerella advena-Spiroplectammina biformis Biofacies}

The Eggerella advena-Spiroplectammina biformis Biofacies within the 2835-1943 cal yr BP interval of the FS core is differentiated from the Eggerella advena Biofacies by a slight decrease in E. advena abundance and an increase in the frequency, and abundance of $R$. turbinatus and $S$. biformis. Both $S$. biformis and $R$. turbinatus account for over $20 \%$ of the total fractional abundance in at least one sample. This biofacies is also characterized by increased proportions of $C$. jeffreysii, P. bipolaris, $C$. subglobosum, $T$. squamata and thecamoebians and likely represents a slightly deeper environment than the Eggerella advena Biofacies.

Blais (1995) and Blais-Stevens and Patterson (1998) interpreted a similar biofacies from Saanich Inlet as an indication of a deeper brackish water a (21-57 $\mathrm{m}$ deep) assemblage than 
indicated by their Biofacies 1 (Eggerella advena Biofacies). Snyder et al. (1990) found a similar biofacies that is characterized by reduced E. advena representation, and increased $S$. biformis and R. turbinatus in middle shelf environment along the Washington State coastal region. The Eggerella advena-Spiroplectammina biformis Biofacies of the present study also resembles the $S$. biformis and Textularia torquata Sub-biofacies encountered in shallow waters (17-45m deep) in the Amerasian Basin (Lagoe, 1979a) and an inner fjord assemblage dominated by S. biformis and Adercotryma glomerata in Lancaster Sound, Baffin Island (Schröder-Adams et al., 1990a). A similar assemblage dominated by S. biformis with supplementary amounts of $R$. tubiantus and $P$. bipolaris was also reported from 23-36 m water depths in Scoresby Sund, Greenland (Murray, 2006).

High abundances of $S$. biformis are often widely identified in shallow inshore environments of the Arctic (Vilks, 1964; Vilks, 1989; Madsen and Knudsen, 1994; Hald and Korsun, 1997; Korsun and Hald, 1998, 2000) and intermediate waters in fjords on Baffin Island (Schafer and Cole, 1988). Murray (2006) and Blais-Stevens and Patterson (1998) interpreted a close association of this species to $E$. advena as an indication of brackish water conditions. Spiroplectammina biformis, a typical species of glaciomarine environments (Elverhoi et al., 1980; Schafer and Cole, 1986; Madsen and Knudsen, 1994; Hald and Korsun, 1997; Korsun and Hald, 1998; Korsun and Hald, 2000; Llyod, 2006), is among first foraminiferal taxa to colonize proximal glaciomarine environments in Arctic regions (Korsun and Hald, 2000).

Recurvoides turbinatus and S. biformis dominate the faunal composition of cold waters in the Canadian Arctic (Lagoe, 1979a; Saidova, 2002). High abundance of this species in Disko Bugt, Greenland was attributed to prevalence of low salinity cold waters (Llyod, 2006). In the same relation, Schafer and Cole (1988) found high abundances of S. biformis and Reophax arctica confined to cold water environments. 
An inverse correlation of $S$. biformis to oxygen and salinity in the FS core is consistent with the species' known tolerance to low levels of oxygen and salinities. Spiroplectammina biformis, a good indicator of oxygen depleted environments (Scott et al., 2001), survives under brackish water conditions with severely depleted oxygen levels $(<0.5 \mathrm{ml} / \mathrm{L})$ (Sen Gupta and Machain-Castillo, 1993). Similar to Eggerella advena, S. biformis is abundant in semi-polluted environments in Eastern Canadian estuaries and embayment (Schafer et al., 1991).

Another important species from this biofacies, Portatrochammina bipolaris, is dominant in deeper waters of the Canadian Arctic (e.g., Vilks, 1989; Murray, 2006) and deeper polar water masses (29.6-35 m) in Scoresby Sund, Eastern Greenland (Madsen and Knudsen, 1994). Positive correlations between $P$. bipolaris and ecological variables such as oxygen, salinity and biogenic silica in the FS core suggest that its distribution was likely controlled by water mass (salinity and oxygen) and productivity. Madsen and Knudsen (1994) interpreted an assemblage dominated by P. bipolaris, S. biformis and $R$. turbinatus in Scoresby Sund, in Greenland as a transition to more stable polar water mass.

The increased abundance of these cool waters species (e.g., P. bipolaris, S. biformis and $R$. turbinatus) in intervals of the FS dominated by this biofacies indicates the development of cooler climate conditions than had characterized conditions during deposition of the Eggerella advena Biofacies.

\subsubsection{Recurvoides turbinatus-Thecamoebian spp. Biofacies}

The Recurvoides turbinatus-Thecamoebian spp. Biofacies is defined mainly by high frequencies and peak abundances of $R$. turbinatus and $S$. biformis in combination with moderate abundances of thecamoebians (10.3\% mean) and highly reduced $E$. advena in the 1467- 1100 cal yr BP interval of the FS core. This biofacies is interpreted as an indication of a deeper environment than those of the Eggerella advena biofacies and Eggerella advena- 
Spiroplectammina biformis Biofacies. Snyder et al. (1990) encountered a similar biofacies that is characterized by an increase in $R$. turbinatus, and decrease in $E$. advena and S. biformis in middle shelf environments along the continental shelf of Washington State.

Recurvoides turbinatus is abundant in a wide range of depths (Vilks, 1969; Lagoe 1979a). Snyder et al. (1990) reported the dominance of this species in waters as deep as $90 \mathrm{~m}$. Recurvoides turbinatus is found in cold waters in Greenland Port Barrow, Alaska (Loeblich and Tappan, 1953). Cribrostomoides jeffreysii, a typical Arctic water indicator species, is fairly well represented within this biofacies. It inhabits a wide range of water depths, ranging from 45-360 m in the Canadian Arctic (Vilks, 1969; Lagoe, 1979a). In Europe, this species lives in inner shelf (Lutze, 1965) and middle shelf environments (Murray, 1970). Vilks (1969) described Cribrostomoides jeffreysii, dominated assemblage as indicating shallow water environment in the Canadian Arctic. Cribrostomoides jeffreysii, a low oxygen indicator, tolerates near bottom water anoxia $(<0.1 \mathrm{ml} / \mathrm{L})$ conditions (Bernhard, 1989; Sen Gupta and Machain-Castillo, 1993) and thrives under a narrow range of salinity (Murray, 1968). Cribrostomoides jeffreysii is considered to be a cold water indicator and is found in association with Portatrochammina karica in cold waters in the Canadian Arctic (Saidova, 2002).

The moderate occurrence of thecamoebians suggests increased fresh water influx to the SBIC during deposition of this portion of the core. Thecamoebians are inversely correlated to salinity and oxygen. The inverse relationship between thecamoebians and salinity in the FS core is consistent with the freshwater origin of this group of protozoans.

\subsubsection{Thecamoebian spp Biofacies}

The basal $872-607 \mathrm{~cm}(3500-2860) \mathrm{cal}$ yr BP and topmost $182-0 \mathrm{~cm}(1385-1000 \mathrm{cal} \mathrm{yr}$ BP) intervals of the ALS core are dominated by Thecamoebian spp Biofacies. This biofacies is 
overall characterized by thecameobians (mean: $79.6 \%$ ) and moderate abundances of $E$. advena (13.1\% mean).

The dominance of thecamoebians together with Eggerella advena in this biofacies is suggestive of a shallow nearshore depositional environment with a high influx of freshwater. Schafer et al. (1989) interpreted the dominance of thecamoebians and subordinate amounts of $E$. advena in a similar assemblage in Knight and Bute fjords, Mainland British Columbia as an indication of transitional conditions between upper estuarine and marginal marine environments. Likewise, Schafer and Cole (1986) attributed high positive loadings for thecamoebians and high negative ones for agglutinated foraminifera in a multivariate factor analysis to nearshore conditions with a proximal freshwater source.

The high abundance of thecamoebians in these sections of the ALS core probably indicates high freshwater influx and well developed estuarine circulation. The distribution of these freshwater organisms in coastal marginal marine environments, such as those in the SBIC inlets, is likely enhanced by their transportation through freshwater discharge and runoff along with sediments (e.g., Guilbault et al., 1996; Patterson et al., 1985, 1996). Schafer et al. (1989; 1991) and Snyder et al. (1990) ascribed high abundances of thecamoebians in fjords to passive transport of sediments by mass flow processes, entailing mixing and re-deposition of cohesionless gravity flows (Schafer et al., 1989). The high frequency of slump and turbidite sediments in the SBIC provides strong evidence for a passive transportation of thecamoebians (along with sediments) into the inlet through slumping and turbidite sedimentation processes.

An increase in river discharge from the head of the inlet could also account for the high thecamoebian abundance in the SBIC fjords. For example, Schafer et al. (1991) attributed high abundances of thecamoebians in Saguenay fjord, Quebec to freshwater stagnation caused by increased late summer river discharge related to the release of stored water. An increase in river 
discharge usually leads to an expansion of warm, stratified, brackishwater environments that could support or enhance thecamoebian populations. In FS, stagnation of warm freshwater at the sill was likely enhanced by late summer precipitation.

Likewise in the FS core, the distribution of thecamoebians in the ALS core is inversely correlated to salinity and oxygen. This is consistent with their freshwater origin. Thecamoebians thrive under $<5 \%$ salinities (Scott et al., 2001). A similar inverse relationship between thecamoebians and salinity was interpreted as an indication of shallow to intermediate depths in fjords along Baffin Island (Schafer and Cole, 1988).

\subsubsection{Eggerella advena-Thecamoebian spp Biofacies}

The $607-182(2860-1385$ cal yr BP) interval in the ALS core is dominated by the $E$. advena- Thecamoebian spp Bofacies. This biofacies is characterized by a high abundance of $E$. advena (48.6\% average), and increased proportions of other foraminiferal species such as $R$. turbinatus, S. biformis, C. jeffreysii, C. crassimargo and P. bipolaris. The presence of low oxygen, shallow depositional environment is suggested by the foraminiferal assemblages in this biofacies.

As discussed previously, E. advena is found mainly in nearshore environments (e.g., Vilks, 1969; Vilks and Deomarine, 1988; Lylod, 2006, Murray, 2006). Likewise $E$ advena, $S$. biformis is also often encountered in shallow inshore environments in the Arctic (Vilks, 1964; Vilks, 1989; Madsen and Knudsen, 1994; Hald and Korsun, 1997; Korsun and Hald, 1998, 2000) and in intermediate waters in fjords in Baffin Island (Schafer and Cole, 1988). The association of this species with $E$. advena is suggestive of shallow brackish water conditions in fjords such as ALS (Blais-Stevens and Patterson, 1998; Murray; 2006). 
Cribrostomoides crassimargo, and $P$. bipolaris, also common species in this biofacies, are usually found in shallow waters (Madsen and Knudsen (1994). The association of $C$. crassimargo with Spiroplectammina earlandi, Ammotium cassis and $R$. tuninatus was also reported in inner-shelf environments in Advebtfjorden Fjord, Norway (Majewski and Zajaczkowski, 2007). Schröder-Adams et al. (1990a) identified S. biformis, Labrospira (Cribrostomoides) crassimargo and other substrate dependent species in the inner-fjord of Lancaster Sound in the Canadian Arctic.

In the ALS core, the Eggerella advena-Thecamoebian spp Biofcaies is represented by multivariate factors 1 and 2 (Table 4.5). Eggerella advena, S. biformis, $R$. tuibnatus, P. bipolaris, C. jeffreysii and $Z$. nana, important members of this biofacies, are positively loaded in these factors. The strong correlation of oxygen, salinity and phosphate in these factors is an indication that the distribution of these species and the biofacies they characterize are predominantly influenced by bottom water mass properties. The preponderance of these agglutinated foraminiferal species is consistent with inferred low oxygen $(0.85-1.68 \mathrm{~mL} / \mathrm{L})$ and salinities conditions (27.3-28.5\%) in the intervals of the biofacies.

The positive correlation between $S$. biformis and Trochammina sp.3 to organic carbon and total nitrogen in this core (Table 4.4) is consistent with their tolerance, especially S. biformis, to high substrate organic matter enrichment. Likewise Eggerella advena, S. biformis is abundant in low oxygen semi-polluted environments (Schafer et al., 1991). The correlations of $R$. turbinatus, $Z$. nana and $P$. bipolaris to mean grain size and oxygen suggest that the distribution of these species in the ALS core was most likely influenced by grain size. Recurvoides turbinatus is a dominant species in fine grained sediments but less abundant in silt sediments along the Washington State continental shelf (Snyder et al., 1990). 
Similar to what was identified in the FS core, almost all the foraminiferal species (e.g., $S$ biformis, $R$ turbinatus, $C$. jeffreysii and $P$. bipolaris) in this biofacies, are cold water indicators (e.g., Vilks, 1969; Lagoe, 1979a; Madsen and Knudsen, 1994; Lloyd, 2006; Saidova 2002; Murray, 2006). Østby and Nagy (1982) also found an assemblage dominated by Adercotryma glomeratum and C. crassmargo with common representations of Ammotium sp. and R. turbinatus in an extremely cold bottom water $\left(<1^{\circ} \mathrm{C}\right.$ temperature $)$ in the Barrents Sea. The presence of these cool water fauna in the intervals of the ALS core dominated by this biofacies, suggests that bottom waters were cooler than during the deposition of the Thecamoebian spp. Biofacies' intervals.

The abundance of thecamobians in the assemblage indicates that the freshwater influx of the underlying Thecamoebian spp. Biofacies continued during deposition of this biofacies. Their abundance also indicates that freshwater incursion was still prominent during the deposition of the intervals of the biofacies, and that the environment was most likely brackish nearshore with a proximal freshwater influence.

\subsubsection{Paleoclimate}

\subsubsection{Frederick Sound core}

Foraminiferal species and biofaciess distribution in the FS core indicate that the climate history of the SBIC commenced with relatively warm conditions from 4200-3387 cal yr BP. The common abundances of warm water indicator species - Zavodovskina nana (Lagoe, 1979a) and the predominance of Eggerella advena are an indication of the warm climate conditions in the inlet. Even though Eggerella advena is described as an eurythermal species (Guibault et al., 2003), it has been reported as a dominant species in waters in the Canadian Arctic (Saidova, 2002). The prevalence of warm bottom water conditions during deposition of this lowermost 
section of the core was frequently punctuated by short periods of cooler climate, particularly during the 3732-3694 cal yr BP interval (Figure 4.13). The occurrence of these cooler events corresponds to the periodic appearance of the Eggerella advena-Spiroplectammina biformis Biofacies.

The first continuous appearance of the Eggerella advena-Spiroplectammina biformis Biofacies, characterized by increased cool water species (such as S. biformis, C. jeffreysii, $R$. turbinatus and P. bipolaris) and decreased Eggerella advena and Z. nana within the 3387-3037 cal yr BP interval, marks a major episode during which cool bottom waters developed (Figures $4.9 ; 4.13)$. The overlying interval deposited from $3037-2835$ cal yr BP and dominated by the Eggerella advena Biofacies witnessed a return to relatively warm bottom water conditions in the inlet.

The dominance of Eggerella advena-Spiroplectammina biformis Biofacies through the 2835-1943 cal yr BP interval and Recurvoides turbinatus-Thecamoebian spp Biofacies within the $1467-1100$ cal yr BP interval in this inlet suggests the establishment of more stable, cool bottom water conditions. As in the underlying intervals 3732-3694 cal yr BP interval, the presence of cool climate conditions within this middle to upper section (2835-1943 cal yr BP) of the FS core are indicated by increase of cool water species and reduction of the warm water indicator $Z$. nana. Similar to the observed trend in the underlying warm interval, this cool climate period was also interrupted by the periodic recurrence of warmer bottom waters through the $2465-2402$ cal yr BP, 2288-2182 cal yr BP and 2097-2021 ca yr BP intervals. Due to the unavailability of samples from the 1943-1467 ca yr BP, climatic variability during this interval cannot be interpreted. 


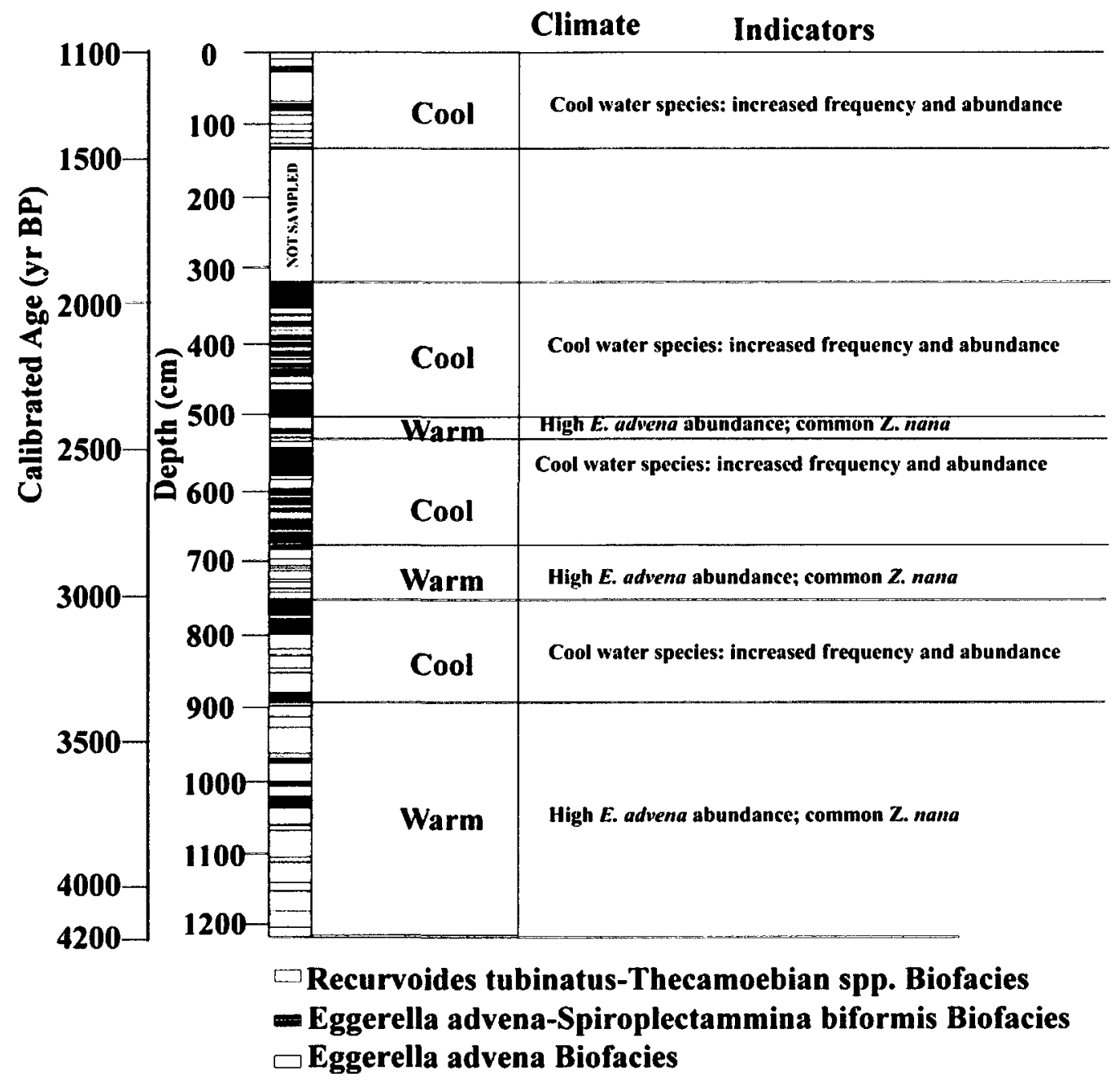

Figure 4.13. Summary of the foraminiferal inferred depositional environments and paleoclimate events in the Fredrick Sound core. 


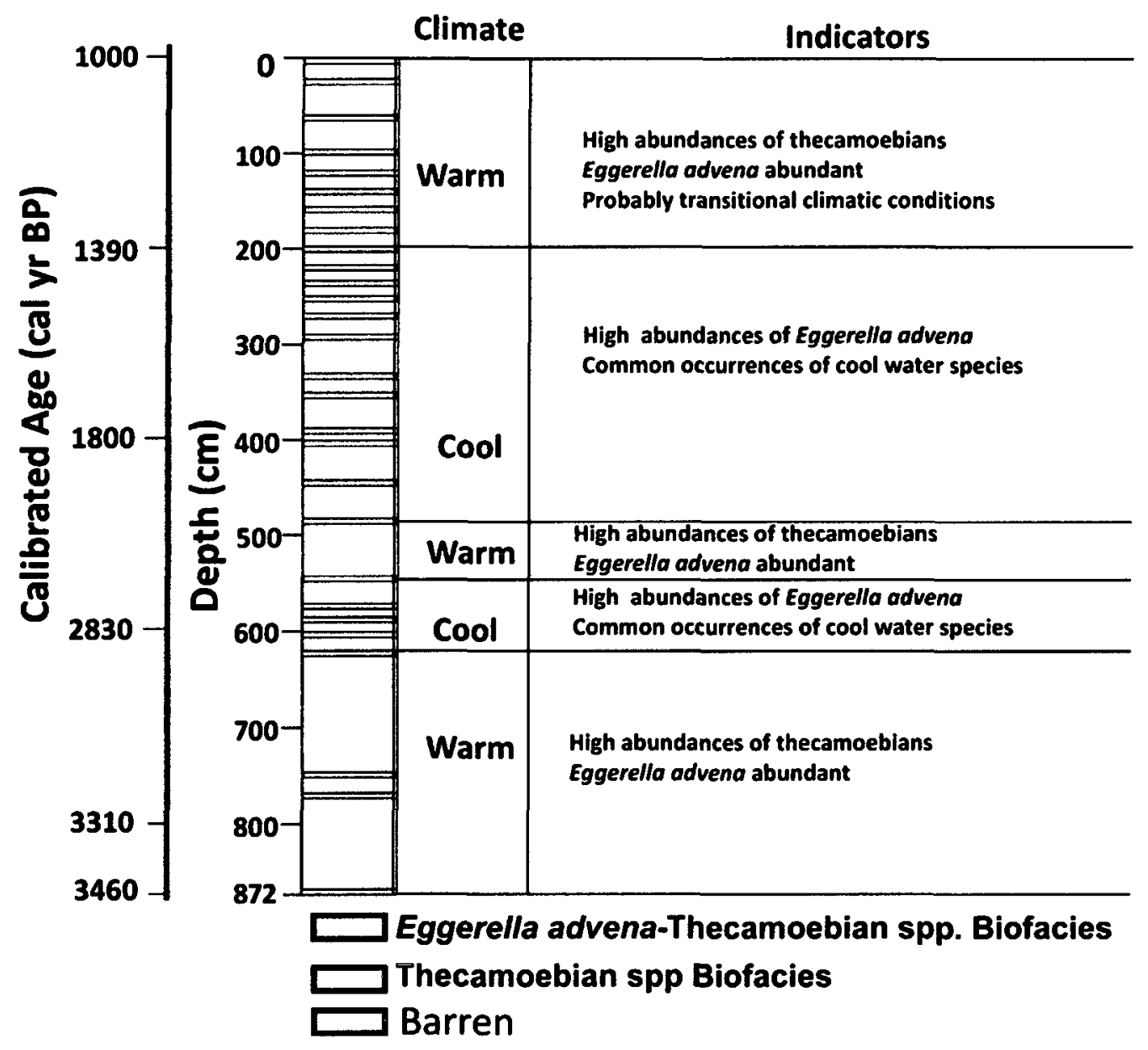

Figure 4.14. Summary of the foraminiferal inferred paleoclimate events in Alison Sound core. 


\subsubsection{Alison Sound (ALS) core}

The 3500-2860 cal yr BP and 1385- 1000 cal yr BP intervals in the ALS core were dominated by thecamoebian species (Figure 4.14). The predominance of thecamoebians in these intervals suggests a period characterized by high precipitation and well developed estuarine circulation, which would be required to deliver so many of these terrestrial organisms to the marine environment. The exchange between the cooler bottom water and warmer surface water at this time most likely facilitated the development of thick stratified warm bottom waters.

The dominance of foraminiferal species, mainly $E$. advena, in association with common occurrences of cool water species $R$. turbinatus, $S$. biformis, $C$. jeffreysii, $C$. crassimargo and $P$. bipolaris suggests a transition to cool climate conditions during deposition of the $2860-1385$ cal yr BP interval in the ALS core. A decrease of freshwater thecamoebians in this interval suggests a likely decrease in precipitation and, consequently, a reduction in freshwater influx.

\subsection{Conclusions}

This study has shown that the FS and ALS cores are mainly comprised of an uneven alternation of laminated and homogenous sediments, with the occasional occurrence of slump and degraded units. The foraminiferal and thecamoebian assemblages recovered from the cores were characterized by not only low abundances but also a lower diversity of species, which resulted in very low Shannon Diversity Index (SDI) values. The results also revealed that the faunal makeup of the two cores is exclusively comprised of cool water, low oxygen tolerant agglutinated foraminiferal species. Freshwater thecamoebian species are also common throughout intervals in both cores.

Cluster analysis resulted in discrimination of five biofacies including Eggerella advena, Eggerella advena-Spiroplectammina biformis, and Recurvoides tubinaus-Thecamoebian spp Biofacies in the FS core. Thecamoebian spp and Eggerella advena-Thecamoebian spp Biofacies 
are found in the ALS core. Increased frequency and abundances of cool water indicator foraminiferal species at $2835 \mathrm{cal}$ yr BP in the FS core and $2860 \mathrm{cal} \mathrm{yr} \mathrm{BP}$ in the ALS core suggest a transition to a cooler climate than had characterized the core during earlier phases of Late Holocene deposition in the investigated SBIC inlets.

Based on inferred oxygen and salinity concentrations in the examined samples, well developed low oxygen, estuarine environments are inferred for the SBIC inlets. Dysoxic conditions were prevalent during deposition of the fossiliferous intervals whereas the bottom waters were likely anoxic during the deposition of the barren intervals. Correlation and factor analyses of the faunal fractional abundances and quantitative estimates of ecological variables revealed that the foraminiferal distribution in the cores from SBIC was mainly controlled by mainly salinity and dissolved oxygen. The high concentration of organic matter contained in the sediments, and associated high nutrient supply might have also influenced the faunal distribution in the inlets. 


\section{CHAPTER FIVE}

\section{GEOCHEMICAL PROXIES IN THE FREDERICK AND ALISON SOUNDS PISTON CORES}

\subsection{Abstract}

Fluctuations in Late Holocene regional oceanographic and climatic records in the Seymour-Belize Inlet complex (SBIC), British Columbia were investigated. Stable isotope and trace element geochemical proxies archived in two piston cores VEC02A04 from Frederick Sound and VEC02A07 from Alison Sound were used in this study. Time series analysis was used to detect the trends and climate related cycles archived in the geochemical proxies.

The cores are mainly composed of organically-rich mud and silt sediments that were deposited as annually laminated intervals and punctuated by massive slump and turbidite sedimentation. The concentrations of organic carbon and redox sensitive elements are similar in the laminated and massive units. The distribution pattern of the proxies and absence of bioturbation suggest that the homogenous sediments were deposited under the same paleoceanographic conditions as the laminated intervals. The organic geochemical properties of these cores are characterized by high concentrations of organic carbon, $\mathrm{C}_{\mathrm{org}} / \mathrm{N}_{\text {total }}(12-50)$ and $\delta^{13} \mathrm{C}(-26.5$ to $-24.4 \%$ ) values which are typical of organic matter from terrestrial origin. The distribution patterns of the redox sensitive elements (e.g., $\mathrm{Cd}, \mathrm{Cr}, \mathrm{Cu}, \mathrm{Mo}, \mathrm{U}, \mathrm{V}$, and $\mathrm{Zn}$ ) and 
their ratios (e.g., $\mathrm{V} / \mathrm{Sc},(\mathrm{V} / \mathrm{V}+\mathrm{Ni})$, , $, \mathrm{U} / \mathrm{Th}, \mathrm{U}_{\text {authigenic }}$ and $\left.(\mathrm{Cu}+\mathrm{Zn}) / \mathrm{Zn}\right)$ strongly indicate the existence of anoxic to suboxic bottom water conditions throughout the entire depositional histories of these cores.

Five climate intervals characterized by alternating cool/wetter and cooler/drier conditions were identified based on the distribution trends of $\delta^{13} \mathrm{C}$ and $\delta^{15} \mathrm{~N}$ in the cores. Major changes in the regional climate are indicated by drastic shifts from lighter to heavier $\delta^{13} \mathrm{C}$ values at $3135 \mathrm{cal}$ yr BP in Frederick Sound (core VEC02A04) and 2462 cal yr BP in Alison Sound (core VEC02A07), respectively.

This regime shift which corresponds to the Late Holocene Neoglacial glacier advance records in NE Pacific was mainly controlled by a variation in the position and intensity of the regional Aleutian Low (AL) and the North Pacific High (NPH. The presence of the PDO (31-69year), Gleissberg (70-140-year) and Suess-like ( 150-250-year) solar cycles in the geochemical records indicate the influence of solar activities on the $\mathrm{AL}$ and ultimately on the regional climate.

\subsection{Introduction}

Marine depositional basins with high sedimentation rates, such as silled coastal glacial carved fjords are excellent depositional environments for the reconstruction of paleoclimate histories (Baumgartner et al., 1985; Syvitski and Shaw, 1995). The underwater topography and elevated primary production in coastal fjords facilitate the development of anoxic bottom water and the subsequent preservation of annually deposited laminated sediments (varves). These high resolution sedimentary records can be used to better understand and assess the history of regional climate change in coastal British Columbia (Nederbragt and Thurow, 2001; Chang et al., 2003; Patterson et al., 2004a, b; $2005 ; 2007)$. This is important since the instrumental weather records in the entire Northeast Pacific region are sparse, dating back only to the end of the 19th century (Ware 
and Thomson, 2000; Hsieh et al., 1995). As these sedimentary successions can often be precisely dated, they are particularly useful in tracking short time climate changes with an absolute time scale (Baumgartner et al., 1985; Blais-Stevens et al., 2001; Kemp, 2003). Some laminated sediments, such as those in the inlets of SBIC, are true varves, which preserve seasonal input signals and often record individual depositional events (Schimmelman and Lange, 1996; Pike and Kemp, 1997).

Frederick Sound (FS) and Alison Sound (ALS) are anoxic fjords within the SBIC, which contain basins where annually deposited laminated sediments accumulate. At the coring site ALS is completely stratified with anoxic bottom waters where the dissolved oxygen ranged from 0 to $0.06 \mathrm{~mL} / \mathrm{L}$. Within the vicinity of the FS VEC02A04 core site, the oxygen content at depth ranged between $0.00 \mathrm{~mL} / \mathrm{L}$ and $0.92 \mathrm{~mL} / \mathrm{L}$.

In this chapter, the isotopic geochemistry of organic carbon and nitrogen, and major and trace elements' geochemistry from the FS core VEC02A04 and ALS core VEC02A07 are examined to determine the magnitude of fluctuations in Late Holocene climate and bottom water oxygen circulation in the SBIC. The source of organic matter in the sediments is also determined. Results of time series analysis are also used to identify cycles and trends archived in the organic matter and elemental proxies. The impact of these cycles and trends on the regional atmospheric pressure systems, and specifically the AL and the NPH are also examined.

\subsection{Results}

\subsubsection{Chronology}

A detailed description of the age model used for each core (i.e. the FS core VEC02A04 and ALS core VEC02A07) is provided in chapter 4. The age/depth model of the FS core indicates 
that the entire core interval was deposited between 4200 and 1100 cal yr BP while the ALS core spanned from 3500 to $1000 \mathrm{cal}$ yr BP interval (Figures 4.1-4.2).

\subsubsection{Sedimentology}

The FS and ALS piston cores are mainly composed of dark to light olive organically rich unconsolidated mud and silt sediments with small amounts of sand. The sediments are comprised of an uneven alternation of annually laminated and massive units. Minor intervals of graded and slumped sediments are also present through intervals of the two cores (Figures 4.3-4.4). The characteristics of these different units are discussed in detail in Chapter 4.

\subsubsection{Organic Geochemistry}

Both FS core VEC02A04 and ALS core VEC02A07 are highly enriched in organic matter with an average organic carbon content of $7.42 \%$ in FS and $5.38 \%$ in ALS (Table 5.1). The distribution of the organic matter proxies $\left(\mathrm{C}_{\text {org }}, \mathrm{C}_{\text {org }} / \mathrm{N}_{\text {total }}, \mathrm{N}_{\text {total }}, \delta^{13} \mathrm{C}\right.$, and $\left.\delta^{15} \mathrm{~N}\right)$ examined in both cores does not show any difference between the laminated and massive sediments.

\subsubsection{Organic Geochemistry in the Frederick Sound (FS) core}

As shown in Figure 5.1, the organic matter proxies in FS are largely uniformly distributed throughout the core interval. The subtle shifts observed in their distribution patterns inversely correlate to the mean grain size distribution. Except for $\delta^{15} \mathrm{~N}$, almost all measured proxies are characterized by low values where grain size increases, especially in the topmost $500 \mathrm{~cm}$ of the core.

The organic carbon $\left(\mathrm{C}_{\text {org }}\right)$ contents $(3.25-10.27 \%)$ are high in the FS core sediments. The $20 \mathrm{~cm}(\sim 100$-year) sampling intervals for this proxy resulted in detection of low values at $410 \mathrm{~cm}$ and $210 \mathrm{~cm}$ depths. The organic carbon concentrations are poorly correlated to biogenic silica 


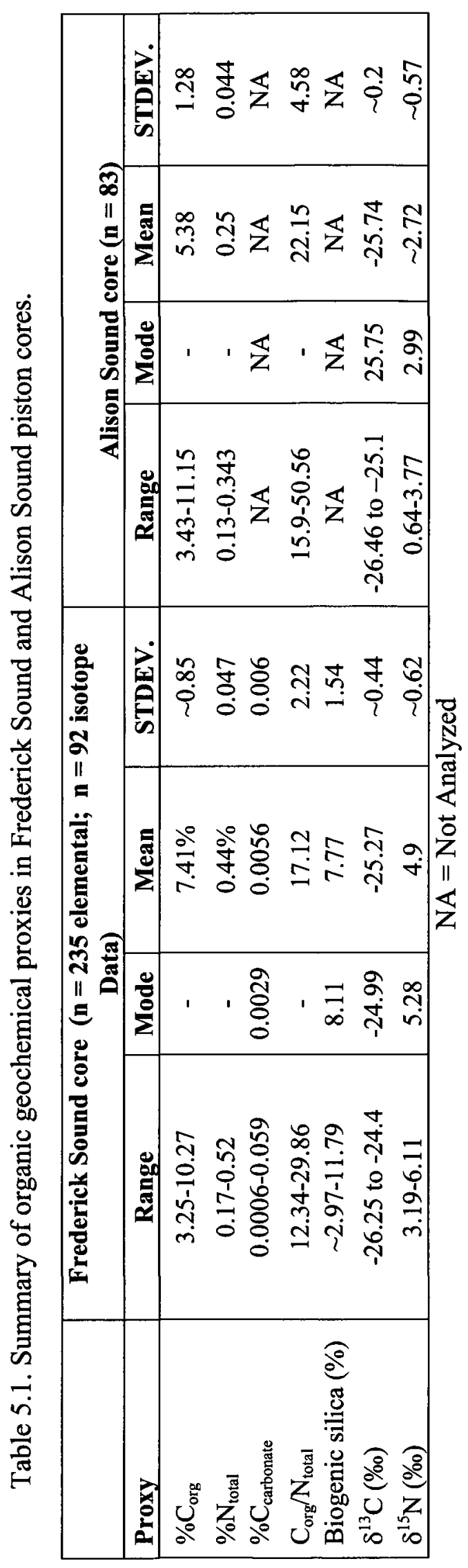


and total nitrogen $\left(\mathrm{N}_{\text {total }}\right)$ in the FS core. High concentrations of $\mathrm{C}_{\text {org }}$ are recorded within the intervals containing finer grained sediments (mud to silt) while low values are found within intervals comprised of coarser grained sediments (Figure 5.1). Table 5.1 shows that the concentrations of inorganic carbon in the sediments are very low in the FS core.

The concentrations of $\mathrm{N}_{\text {total }}$ are lower than those of $\mathrm{C}_{\text {org, }}$ (Table 5.1; Figures 5.1). The 100-year sample (5-sample) average analysis indicates the presence of minor variability within its data set (Appendix C). A bivariate plot of this proxy against the $\mathrm{C}_{\text {org }}$ shows a weak positive correlation and a non-zero intercept (Figure 5.2). In addition, $\mathrm{N}_{\text {total }}$ has a positive correlation to biogenic silica, and a negative correlation to the $\mathrm{C}_{\text {org }} / \mathrm{N}_{\text {total }}$ ratio (Figure 5.2). The organic carbon to total nitrogen ratio $\left(\mathrm{C}_{\text {org }} / \mathrm{N}_{\text {total }}\right)$ is high in the core sediments (Table 5.1; Figure 5.1). A bivariate plot of $\mathrm{C}_{\text {org }} / \mathrm{N}_{\text {total }}$ with $\delta^{13} \mathrm{C}$ demonstrates a non-zero intercept and insignificant correlation between the two proxies (Figure 5.2). $C_{\text {org }} / \mathrm{N}_{\text {total }}$ correlates weakly to $\mathrm{C}_{\text {org. }}$

The $\delta^{13} \mathrm{C}$ and $\delta^{15} \mathrm{~N}$ data only display subtle variations in the FS core (Figure 5.1). Sample averaging of the $\delta^{13} \mathrm{C}$ data reveals the presence of two main populations characterized by lighter values at the lowermost $1209-818 \mathrm{~cm}$ interval and slightly heavier ones from the 818-340 cm interval (Appendix C). The $\delta^{15} \mathrm{~N}$ concentrations, with an average of $4.9 \%$, are generally low in the core (Table 5.1; Figure 5.1); although there is considerable variability (Appendix C 3). This isotope is weakly correlated to $\delta^{13} \mathrm{C}, \mathrm{C}_{\text {org }} / \mathrm{N}_{\text {total }}, \mathrm{C}_{\text {org }}$ and $\mathrm{N}_{\text {total }}$ (Figure 5.2). 


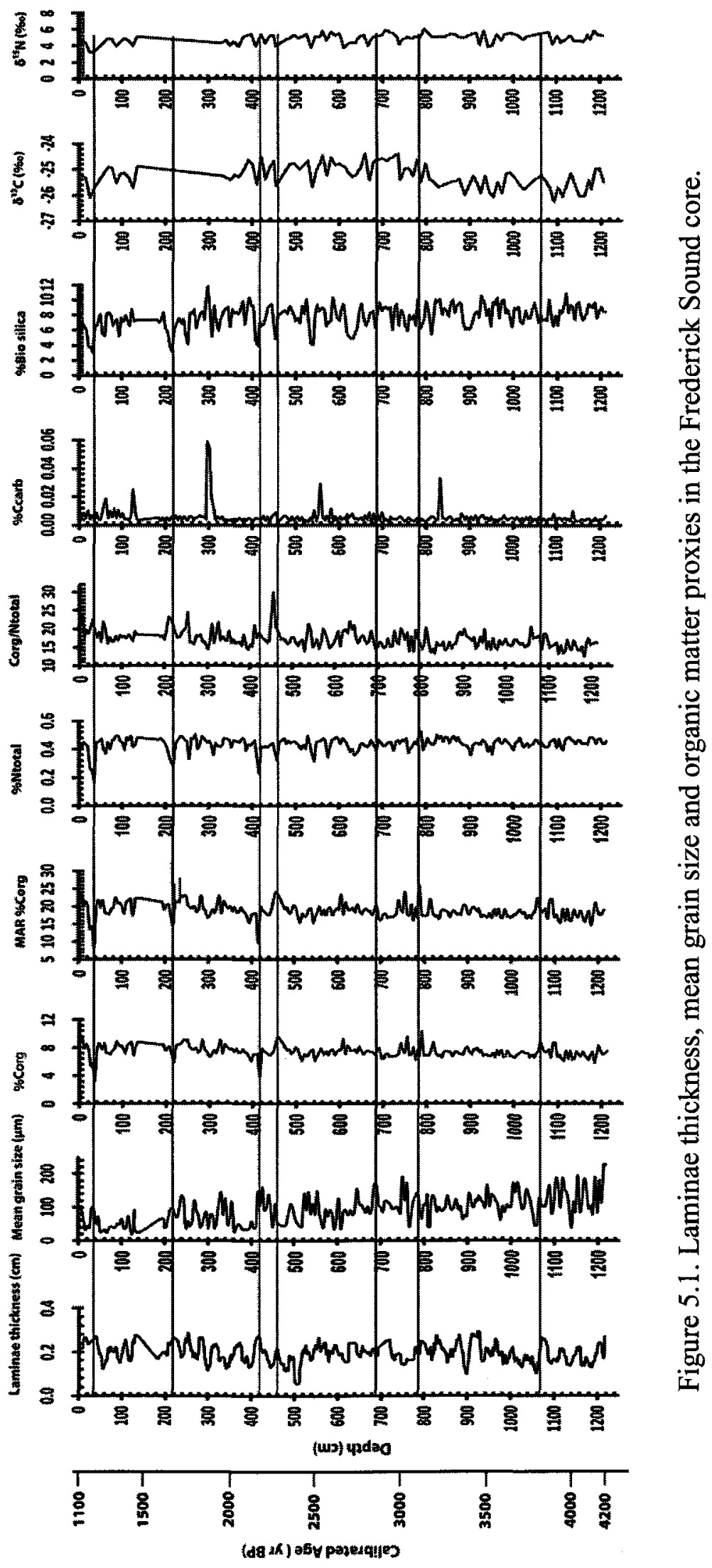



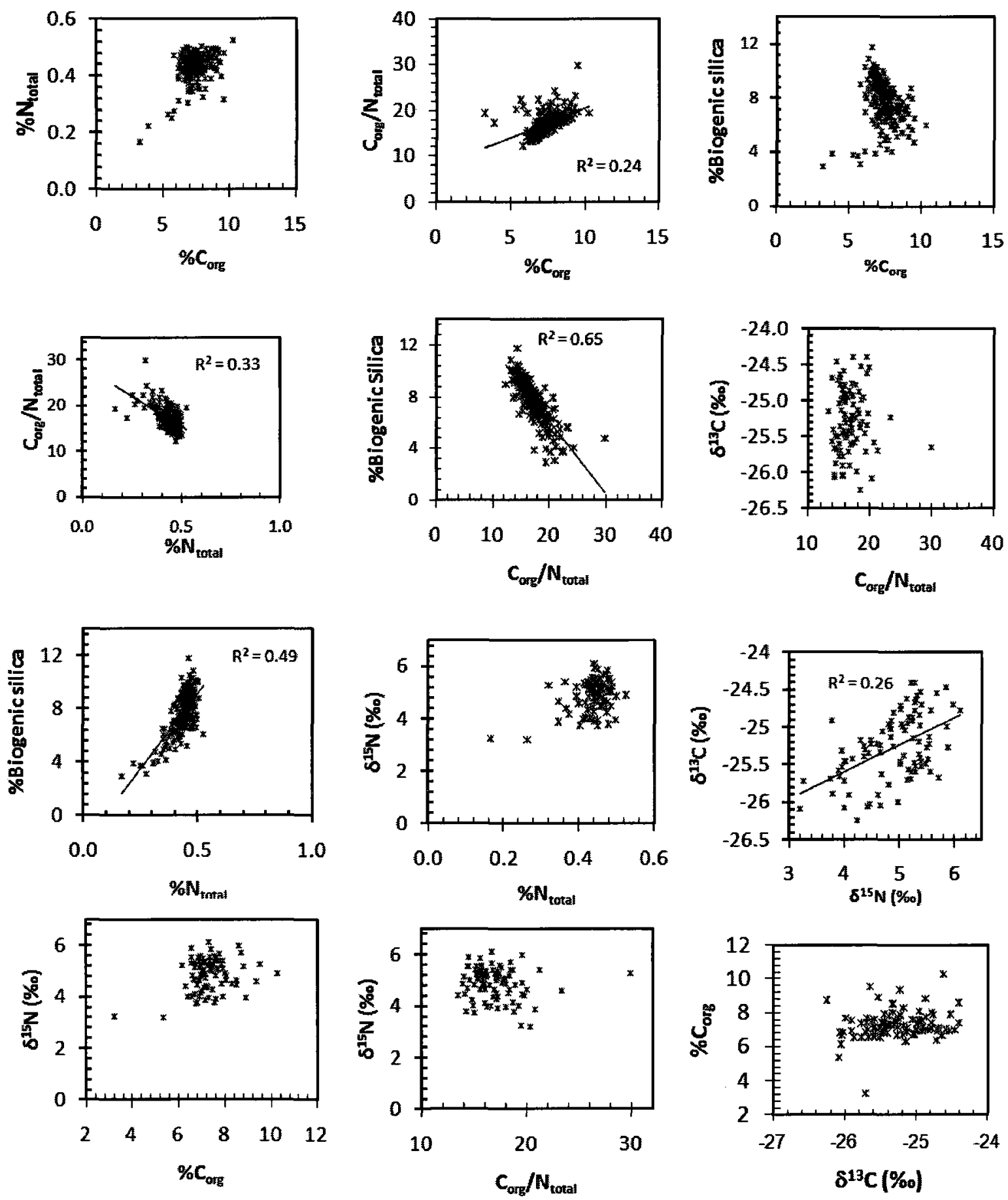

Figure 5.2. Bivariate plots showing relationships between the organic matter proxies in Frederick Sound core. 


\subsubsection{Organic Geochemistry in the Alison Sound (ALS) core}

The unevenly sampled organic matter proxies co-vary with the mean grain size distribution pattern in the ALS core (Figure 5.3). $\mathrm{N}_{\text {total }}$ and $\delta^{15} \mathrm{~N}$, characterized by decreasing trend where grain size increases, exhibit a more consistent correlation to grain size than $\mathrm{C}_{\mathrm{org}}$ and $\delta^{13} \mathrm{C}$. Organic carbon and $\delta^{13} \mathrm{C}$ are also characterized by decreasing trend with peak occurrences of mean grain size at most intervals. These proxies, however, show peak concentrations within the slump interval 232-237 cm (Figure 5.3).

The concentrations of $\mathrm{C}_{\text {org }}$ and $\mathrm{N}_{\text {total }}$ are lower in the ALS core than those of FS core (Table 5.1). $\quad C_{\text {org }}$ and $\mathrm{N}_{\text {total }}$ are moderately correlated $\left(\mathrm{r}^{2}=0.38\right)$ (Figure 5.4). The concentrations of $\mathrm{C}_{\mathrm{org}} / \mathrm{N}_{\text {total }}$ ratio are high throughout the entire core interval (Figure 5.3). This proxy positively correlates to $C_{o r g}\left(r^{2}=0.42\right)$, poorly to $N_{\text {total }}$ and negatively to $\delta^{15} \mathrm{~N}\left(r^{2}=0.33\right)$ (Figure 5.4).

The values of $\delta^{13} \mathrm{C}\left(-25.74 \%\right.$ mean) and $\delta^{15} \mathrm{~N}$ (2.71\%o mean) are low and poorly correlated to each other in this core. $\delta^{13} \mathrm{C}$ is additionally poorly correlated to $\mathrm{C}_{\text {org }} / \mathrm{N}_{\text {total }}$ and $\mathrm{C}_{\text {org }}$ and $\delta^{15} \mathrm{~N}$ is also poorly correlated to $\mathrm{N}_{\text {total }}$ and $\mathrm{C}_{\text {org }}$ (Figure 5.4). The 100-year (5-sample) sample averaging of all organic matter proxies in this core shows very weak variability (Appendix C 4).

\subsubsection{Inorganic Geochemistry}

The analytical results for major and redox related elements, and their ratios are briefly discussed in this section. In addition to the absolute concentrations of the redox related elements, paleoredox indices such as $\mathrm{U} / \mathrm{Th}, \mathrm{Th} / \mathrm{U}, \mathrm{Ni} / \mathrm{Co}, \mathrm{V} / \mathrm{Cr}, \mathrm{V} /(\mathrm{V}+\mathrm{Ni}), \mathrm{V} / \mathrm{Sc}, \mathrm{U}_{\text {authigenic }}$ and $(\mathrm{Cu}+\mathrm{Mo}) / \mathrm{Zn}$ are also examined. 

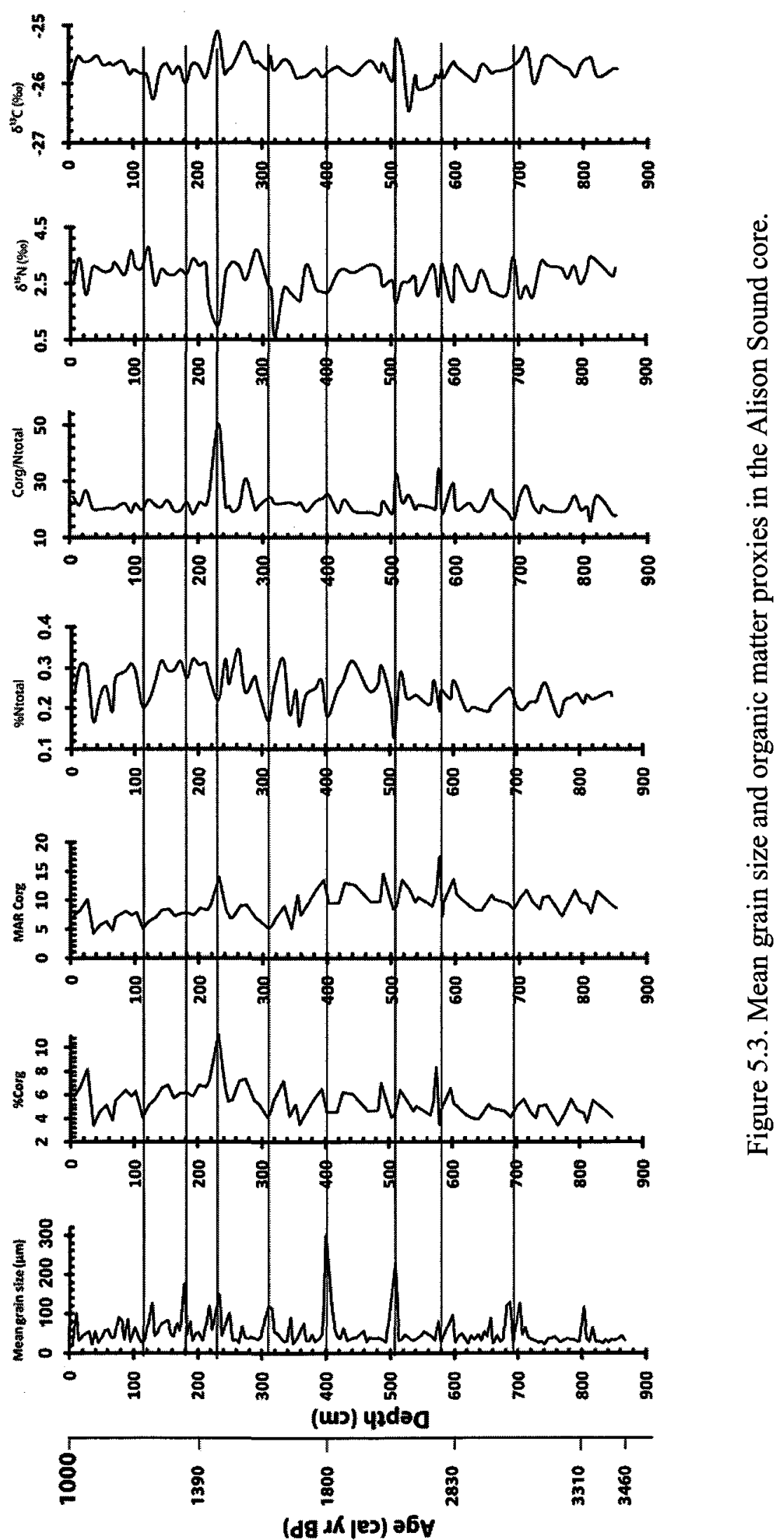

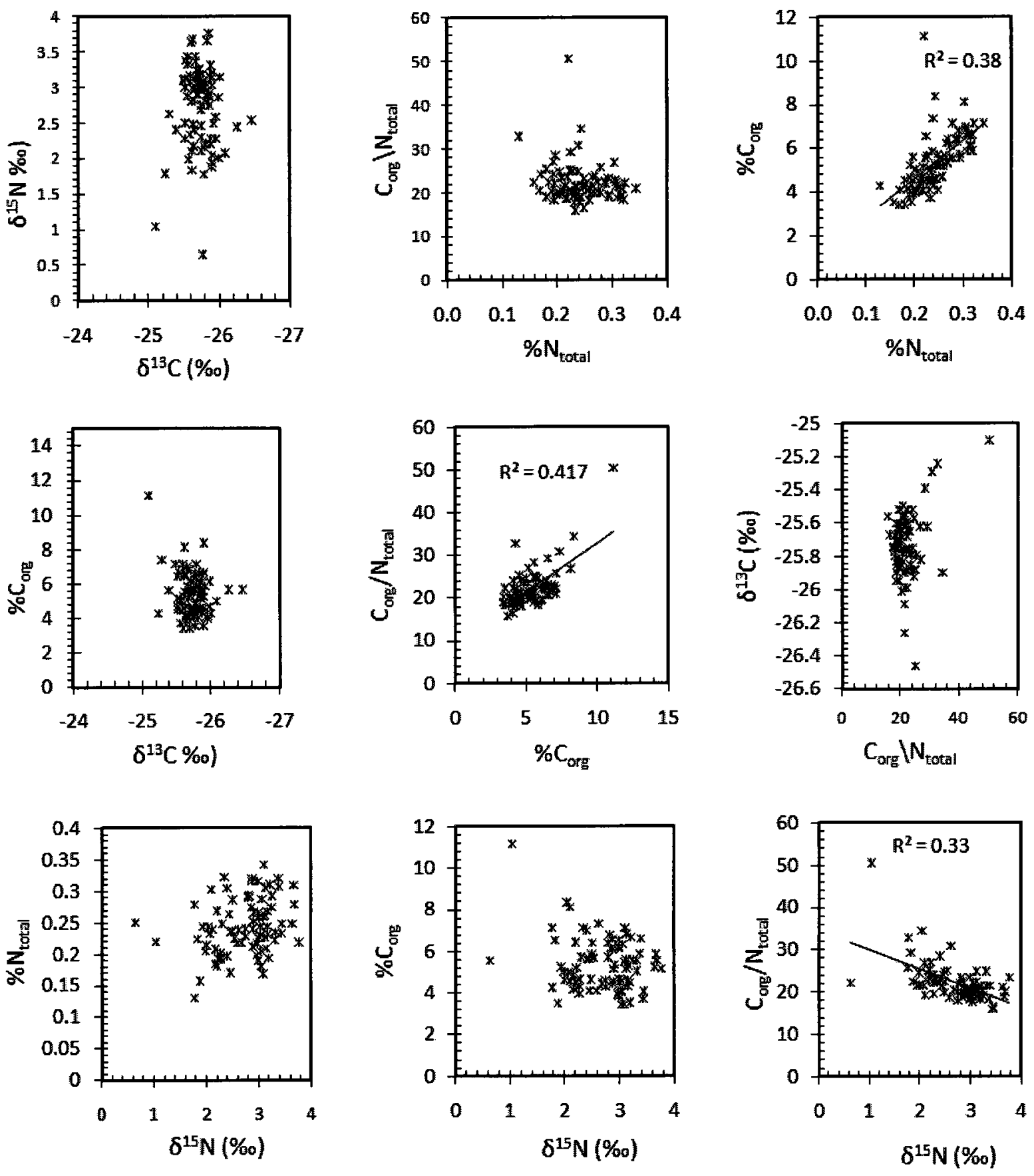

Figure 5.4. Bivariate plots of the organic matter proxies in the Alison Sound core. 
Wignall and Myers (1988) proposed using authigenic uranium values as an index of bottom water anoxia in sedimentary environments. Authigenic uranium is derived based on the assumption that the minimum value of $\mathrm{Th} / \mathrm{U}$ in an average mudstone is 3 and that ofthorium (Th) is totally detrital (Wignall and Myers, 1988). The value of Th that is associated with detrital uranium is estimated by dividing the measured concentration by 3 . Therefore, the authigenic uranium can be computed using the following equation:

$$
U_{\text {authigenic }}=U_{\text {total }}-\frac{T h_{\text {measured }}}{3}
$$

where both $U_{\text {total }}$ and $T h_{\text {measured }}$ are the measured concentrations of uranium and thorium, respectively, in a given sample.

The stratigraphic distribution of major and redox sensitive elements; and their ratios show high variability throughout the entire intervals of the FS and ALS cores. Likewise the organic matter proxies, the concentrations of the major and trace elements' concentrations are similar for both the laminated and homogenous sediments in the two cores. The ranges and mean concentrations of each element are compared to its crustal values in Tables 5.2-5.3. The absolute concentrations of the elements in each sample can be found in Appendices C5 and C6. The major elements' mean concentrations are higher in the ALS core than in the FS core (Table 5.2). In contrast, the concentrations of redox related elements (e.g. $\mathrm{Cd}, \mathrm{Cu}, \mathrm{Mo}, \mathrm{U}, \mathrm{V}$ and $\mathrm{Zn}$ ) are higher in the FS core than in the ALS (Table 5.3).

\subsubsection{Inorganic Geochemistry in the Frederick Sound (FS) core}

Almost all major elements have a similar distribution in the FS core (Figure 5.5). Aluminum is strongly correlated to $\mathrm{Ca}\left(\mathrm{r}^{2}=0.88\right), \mathrm{Mg}\left(\mathrm{r}^{2}=0.84\right), \mathrm{Mn}\left(\mathrm{r}^{2}=0.79\right), \mathrm{Ti}\left(\mathrm{r}^{2}=\right.$ 
Table 5.2. Major elements in SBIC. Upper crust data (Taylor and McLennan, 1985), modified by McLennan (2001); Average shale data (Wedepohl, 1971; 1991).

\begin{tabular}{|c|c|c|c|c|c|c|}
\hline \multirow[b]{2}{*}{ Element } & \multirow[b]{2}{*}{$\begin{array}{l}\text { Upper } \\
\text { Crust }\end{array}$} & \multirow[b]{2}{*}{ Average shale } & \multicolumn{2}{|c|}{$\begin{array}{l}\text { Frederick Sound (FS) core } \\
\qquad(n=80)\end{array}$} & \multicolumn{2}{|c|}{$\begin{array}{l}\text { Alison Sound (ALS) core } \\
(n=61)\end{array}$} \\
\hline & & & Range & Mean & Range & Mean \\
\hline $\mathrm{Al}(\%)$ & 8.04 & 8.84 & $3.04-6.94$ & 4.34 & $5.13-7.056$ & 6.228 \\
\hline $\mathrm{Ca}(\%)$ & 3 & 1.57 & $1.5-3.93$ & 2.23 & $2.27-3.64$ & 2.98 \\
\hline $\mathrm{Fe}(\%)$ & 3.5 & 4.83 & $3.26-4.99$ & 3.88 & $3.42-5.3$ & 4.62 \\
\hline K (\%) & 2.2 & 2.99 & $0.71-1.19$ & 0.87 & $0.54-1.51$ & 1.19 \\
\hline $\operatorname{Mg}(\%)$ & 1.33 & 1.57 & $1.23-2.21$ & 1.56 & $1.38-2.33$ & 1.91 \\
\hline $\operatorname{Mn}(\%)$ & 0.06 & 0.085 & $0.037-0.101$ & 0.06 & $0.069-0.1084$ & 0.096 \\
\hline $\mathrm{Na}(\%)$ & 2.89 & 1.27 & $0.31-3.98$ & 2.35 & $0.34-3.23$ & 0.72 \\
\hline $\mathrm{P}(\%)$ & 0.07 & 0.0698 & $0.053-0.96$ & 0.073 & $0.039-0.27$ & 0.113 \\
\hline Si (\%) & 30.8 & & NA & NA & $15.6-25.02$ & 19.11 \\
\hline $\mathrm{Ti}(\%)$ & 0.41 & 0.47 & $0.181-0.38$ & 0.26 & $0.26-0.47$ & 0.38 \\
\hline S (\%) & & & $1.53-3.44$ & 2.26 & $1.09-2.7$ & 2.03 \\
\hline $\mathrm{Al} / \mathrm{Ti}$ & & & $13.7-20.42$ & 16.8 & $14.33-27.36$ & 16.37 \\
\hline $\mathrm{Ca} / \mathrm{Al}$ & & & $0.395 \sim 0.6$ & 0.51 & $0.37-0.52$ & 0.48 \\
\hline $\mathrm{Fe} / \mathrm{Al}$ & & & $0.62-1.37$ & 0.92 & $0.48-0.9$ & 0.75 \\
\hline $\mathrm{K} / \mathrm{Al}$ & & & $0.11-0.26$ & 0.2 & $0.077-0.24$ & 0.19 \\
\hline $\mathrm{Mg} / \mathrm{Al}$ & & & $\sim 0.3-0.42$ & 0.36 & $0.19-0.35$ & 0.31 \\
\hline $\mathrm{Mn} / \mathrm{Al}$ & & & $\sim 0.012-0.018$ & 0.014 & $0.0125-0.0175$ & 0.015 \\
\hline $\mathrm{Na} / \mathrm{Al}$ & & & $0.065 \sim 0.12$ & 0.59 & $0.048-0.55$ & 0.12 \\
\hline $\mathrm{P} / \mathrm{Al}$ & & & $\sim 0.011-023$ & 0.017 & $0.0056-0.041$ & 0.018 \\
\hline $\mathrm{Si} / \mathrm{Al}$ & & & NA & NA & $2.41-3.55$ & 3.06 \\
\hline $\mathrm{Ti} / \mathrm{Al}$ & & & $0.049-0.073$ & $\sim 0.06$ & $0.037-0.07$ & 0.062 \\
\hline $\mathrm{Ca} / \mathrm{Sr}$ & & & $55.07-102.71$ & 86.74 & $75.26-100.21$ & 89.74 \\
\hline $\mathrm{Mn} / \mathrm{Fe}$ & & & $0.0089-0.025$ & 0.015 & $0.015-0.029$ & 0.21 \\
\hline $\mathrm{Al}_{2} \mathrm{O}_{3}(\%)$ & & 16.7 & $\sim 5.74-13.11$ & $\sim 8.21$ & $9.69-13.33$ & 11.75 \\
\hline $\mathrm{CaO}(\%)$ & & 2.2 & $2.1-5.5$ & 3.12 & $3.17-5.1$ & 4.17 \\
\hline $\mathrm{Fe}_{2} \mathrm{O}_{3}(\%)$ & & 6.9 & $\sim 4.66-7.13$ & 5.56 & $4.89-7.59$ & 6.61 \\
\hline $\mathrm{K}_{2} \mathrm{O}(\%)$ & & 3.6 & $0.85-1.43$ & 1.05 & $0.65-1.82$ & 1.44 \\
\hline $\mathrm{MgO}(\%)$ & & 2.6 & $2.04-3.67$ & 2.59 & $2.28-3.86$ & 3.16 \\
\hline $\mathrm{MnO}(\%)$ & & $\sim 0.11$ & $\sim 0.048-\sim 0.013$ & 0.077 & $0.089-0.14$ & 0.12 \\
\hline $\mathrm{Na}_{2} \mathrm{O}(\%)$ & & 1.6 & $\sim 0.42-5.36$ & 3.17 & $0.42-4.0$ & $\sim 0.9$ \\
\hline $\mathrm{P}_{2} \mathrm{O}_{5}(\%)$ & & 0.16 & $0.12-0.22$ & 0.17 & $0.09-0.61$ & 0.26 \\
\hline $\mathrm{TiO}_{2}(\%)$ & & 0.78 & $0.3-0.63$ & 0.43 & $0.43-0.79$ & 0.64 \\
\hline $\mathrm{SiO}_{2}(\%)$ & & 58.9 & NA & NA & $33.37-53.51$ & 40.88 \\
\hline $\mathrm{Fe}_{2} \mathrm{O}_{3} / \mathrm{Al}_{2} \mathrm{O}_{3}$ & & 0.41 & $0.47 \sim 1.04$ & 0.69 & $0.37-0.68$ & 0.57 \\
\hline
\end{tabular}


Table 5.3. Trace elements and redox indices in SBIC. Upper crust data (Taylor and McLennan (1985), modified by McLennan (2001); Average shale data (Wedepohl, 1971; 1991).

\begin{tabular}{|c|c|c|c|c|c|c|}
\hline \multirow[b]{2}{*}{ Element } & \multirow[b]{2}{*}{$\begin{array}{l}\text { Upper } \\
\text { Crust }\end{array}$} & \multirow[b]{2}{*}{$\begin{array}{c}\text { Average } \\
\text { Shale }\end{array}$} & \multicolumn{2}{|c|}{ Frederick Sound $(\mathrm{FS})$ core $n=85$ ) } & \multicolumn{2}{|c|}{ Alison Sound (ALS) core $(n=61)$} \\
\hline & & & Range & Mean & Range & Mean \\
\hline $\mathrm{Ba}(\mathrm{ppm})$ & 550 & 580 & $189.48-327.35$ & 246 & $283.32-507.06$ & 444.48 \\
\hline $\mathrm{Cd}(\mathrm{ppm})$ & 0.098 & 0.13 & $0.771-3.91$ & 2.37 & $1.03-2.68$ & 1.46 \\
\hline Co (ppm) & 17 & 19 & $9.9-17.41$ & 12.61 & $11.76-20.11$ & 17.43 \\
\hline $\mathrm{Cr}(\mathrm{ppm})$ & 83 & 90 & $23.07-76.1$ & 35.23 & $7.51-61.12$ & 32.32 \\
\hline $\mathrm{Cu}(\mathrm{ppm})$ & 25 & 45 & $32-1530$ & 171.25 & $53.5-253.5$ & 107.72 \\
\hline Mo (ppm) & 1.5 & 1 & 21.41-121.54 & 61.15 & $15.07-70.97$ & 48.83 \\
\hline $\mathrm{Ni}(\mathrm{ppm})$ & 44 & 68 & $13.12-32.41$ & 20.56 & $4.84-24.95$ & 17.33 \\
\hline $\mathrm{Pb}(\mathrm{ppm})$ & 17 & 22 & $5.15-76.89$ & 16.64 & $6.3-44.62$ & 12.72 \\
\hline $\mathrm{Rb}(\mathrm{ppm})$ & 112 & 140 & $17.05-35.58$ & 24.45 & $15.96-40.15$ & 31.84 \\
\hline Sr (ppm) & 350 & 300 & $181.95-389.93$ & 254.45 & $291.1-423.1$ & 332.32 \\
\hline Th (ppm) & 10.7 & & $1.39-3$ & 2.01 & $0.96-3.72$ & $\sim 2.75$ \\
\hline $\mathrm{U}(\mathrm{ppm})$ & 2.8 & 3.7 & $4.47-13.99$ & 10.28 & $2.26-10$ & 7.67 \\
\hline $\mathrm{V}(\mathrm{ppm})$ & 107 & 130 & $83.21-142.01$ & 105.12 & $79.17-147.68$ & 128.31 \\
\hline $\mathrm{Zn}(\mathrm{ppm})$ & 71 & 95 & $57.55-88.98$ & 71.22 & $61.22-129.92$ & 78.97 \\
\hline $\mathrm{Zr}(\mathrm{ppm})$ & 190 & 160 & $6.52-26.04$ & 9.12 & $5.62-14.54$ & 8.83 \\
\hline $\mathrm{Ba} / \mathrm{Al}$ & & 0.0066 & $0.0041-0.0069$ & 0.0057 & $0.004-0.0074$ & 0.0065 \\
\hline $\mathrm{Ba} / \mathrm{K}$ & & 0.019 & $0.021-0.038$ & 0.028 & $0.028-0.053$ & 0.034 \\
\hline $\mathrm{Cd} / \mathrm{Al}$ & & 0.0000015 & $0.00001-0.00013$ & 0.000058 & $0.000016-0.000044$ & 0.000024 \\
\hline $\mathrm{Co} / \mathrm{Al}$ & & 0.00021 & $0.00021-0.00037$ & 0.00029 & $0.00017-0.00038$ & 0.00028 \\
\hline $\mathrm{Cr} / \mathrm{Al}$ & & 0.00102 & $0.00039-0.0011$ & 0.00081 & $0.00011-0.00088$ & 0.00052 \\
\hline $\mathrm{Cu} / \mathrm{Al}$ & & 0.00051 & $0.00055-0.043$ & 0.0041 & $0.00088-0.0046$ & 0.0017 \\
\hline $\mathrm{Mo} / \mathrm{Al}$ & & 0.000015 & $0.00031 \sim 0.0035$ & 0.0015 & $0.00022-0.0013$ & 0.0008 \\
\hline $\mathrm{Ni} / \mathrm{Al}$ & & 0.00077 & $0.00021-0.00068$ & 0.00048 & $0.00007-0.00038$ & 0.00028 \\
\hline $\mathrm{Pb} / \mathrm{Al}$ & & 0.00025 & $0.000092-0.00145$ & 0.0004 & $0.000093-0.00084$ & 0.00021 \\
\hline $\mathrm{Rb} / \mathrm{Al}$ & & 0.0016 & $0.00026-0.00085$ & 0.00057 & $0.00023-0.00064$ & 0.00051 \\
\hline $\mathrm{Rb} / \mathrm{K}$ & & 0.0047 & $0.0022-0.0038$ & 0.0028 & $0.0022-0.0031$ & 0.0027 \\
\hline $\mathrm{Th} / \mathrm{Al}$ & & & $0.000023-0.000063$ & 0.000047 & $0.000014-0.00056$ & 0.000044 \\
\hline $\mathrm{Sr} / \mathrm{Al}$ & & 0.0034 & $0.0052-0.0072$ & 0.0059 & $0.0047-0.0063$ & 0.0054 \\
\hline $\mathrm{U} / \mathrm{Al}$ & & 0.000042 & $0.000065-0.00038$ & 0.00024 & $0.000032-0.00019$ & 0.00013 \\
\hline $\mathrm{V} / \mathrm{Al}$ & & 0.0015 & $0.0018-0.0033$ & $\sim 0.0025$ & $0.0011-0.00245$ & 0.0021 \\
\hline $\mathrm{Zn} / \mathrm{Al}$ & & 0.0011 & $0.00093-0.0021$ & 0.0017 & $0.00087-0.0019$ & 0.0013 \\
\hline $\mathrm{Zr} / \mathrm{Al}$ & & 0.0018 & $0.00016-0.00064$ & 0.00021 & $0.000084-0.00022$ & 0.00014 \\
\hline $\mathrm{Zr} / \mathrm{Rb}$ & & 1.143 & $\sim 0.22-1$ & 0.38 & $0.22-0.4$ & 0.28 \\
\hline$(\mathrm{Zr}+\mathrm{Rb}) / \mathrm{Sr}$ & & & $0.081-0.214$ & 0.133 & $0.052-0.16$ & 0.123 \\
\hline $\mathrm{Ni} / \mathrm{Co}$ & & 3.58 & $1-2.09$ & 1.63 & $0.41-1.3$ & 0.99 \\
\hline $\mathrm{V} / \mathrm{Cr}$ & & 1.44 & $1.64-5.02$ & $\sim 3.1$ & $2.19-10.55$ & 4.24 \\
\hline $\mathrm{V} / \mathrm{Sc}$ & & 0.66 & $7.89-15.59$ & 11.49 & $5.36-12.31$ & 9.88 \\
\hline $\mathrm{V} /(\mathrm{V}+\mathrm{Ni})$ & & 0.48 & $\sim 0.78-1$ & 0.84 & $\sim 0.84-0.94$ & 0.88 \\
\hline$(\mathrm{Cu}+\mathrm{Mo}) / \mathrm{Zn}$ & & & $0.48-21.11$ & 2.41 & $0.88-3.99$ & 1.99 \\
\hline $\mathrm{U} / \mathrm{Th}$ & & & $\sim 2.13-7.14$ & 5.18 & $1.51-4.76$ & 2.89 \\
\hline $\mathrm{Th} / \mathrm{U}$ & & & $0.14-0.47$ & 0.2 & $0.21-0.66$ & 0.37 \\
\hline $\mathrm{U}_{\text {authigenic }}$ & & & $3.77-13.26$ & 9.61 & $1.94-9.25$ & 6.76 \\
\hline
\end{tabular}


$0.77)$ and $\operatorname{Sr}\left(r^{2}=0.89\right)$ (Figure 5.6). Calcium is also strongly correlated to $\mathrm{Mg}\left(\mathrm{r}^{2}=0.77\right)$ and $\operatorname{Ti}\left(r^{2}=0.63\right)$ while $\mathrm{Mg}$ and $\mathrm{Mn}$ are also strongly correlated to each other $\left(r^{2}=0.7\right)$. The concentrations of $\mathrm{Fe}_{2} \mathrm{O}_{3} / \mathrm{Al}_{2} \mathrm{O}_{3}, \mathrm{MgO} / \mathrm{Al}_{2} \mathrm{O}_{3}$ and $\mathrm{TiO}_{2}$, are high (Figure 5.5). Phosphorous and sulphur are also highly concentrated in the core. Figure 5.6 shows that $\mathrm{Ca}$ and $\mathrm{Sr}$ are also strongly correlated $\left(\mathrm{r}^{2}=0.79\right)$ in the FS core.

The distribution of trace elements in the FS core follows a similar pattern to that displayed by the major elements (Figure 5.7). A decreasing trend is observed in the concentrations of $\mathrm{Ba}, \mathrm{Cd}, \mathrm{Co}, \mathrm{Cr}$ and $\mathrm{Ni}$ at $930 \mathrm{~cm}$ depth where a lone peak in the $\mathrm{Cu}$ concentrations occurs. Lead $(\mathrm{Pb})$ has maximum enrichment within the $1015-680 \mathrm{~cm}$ interval. The mean concentrations of redox related elements such as $\mathrm{Cd}, \mathrm{Cu}$, Mo and $\mathrm{U}$ are above their average upper crustal limits while those of $\mathrm{Zn}, \mathrm{Pb}$ and $\mathrm{V}$ are near or equal to their crustal limits (Table 5.3).

An examination of Table 5.4 reveals that $\mathrm{Cd}$, Mo and $\mathrm{U}$ are fairly correlated to each other. Cobalt, $\mathrm{Cr}, \mathrm{Ni}, \mathrm{Sc}, \mathrm{V}, \mathrm{Zr}$ are also strongly correlated in this core while $\mathrm{Zn}$ is correlated to $\mathrm{Cd}, \mathrm{Pb}, \mathrm{Ni}, \mathrm{U}, \mathrm{V}$ and $\mathrm{Co}$. Aluminum correlates positively to $\mathrm{Co}, \mathrm{Cr}$ and $\mathrm{V}$, and negatively to Cd, Mo and U (Table 5.4).

As shown in Figure 5.8, the redox indices $(\mathrm{U} / \mathrm{Th}, \mathrm{Th} / \mathrm{U}, \mathrm{Ni} / \mathrm{Co}, \mathrm{V} / \mathrm{Cr}, \mathrm{V} /(\mathrm{V}+\mathrm{Ni}), \mathrm{V} / \mathrm{Sc}$, $\mathrm{U}_{\text {authigenic }}$ and $\left.(\mathrm{Cu}+\mathrm{Mo}) / \mathrm{Zn}\right)$ examined in this study display similar distributional trends to the elements from which they are derived. The $\mathrm{V} / \mathrm{Sc}, \mathrm{U} / \mathrm{Th}, \mathrm{Ni} / \mathrm{Co},(\mathrm{Cu}+\mathrm{Mo}) / \mathrm{Zn}$ and $\mathrm{U}_{\text {authigenic }}$ correlate to $\mathrm{Cd}, \mathrm{U}$ and Mo (Table 5.4). 

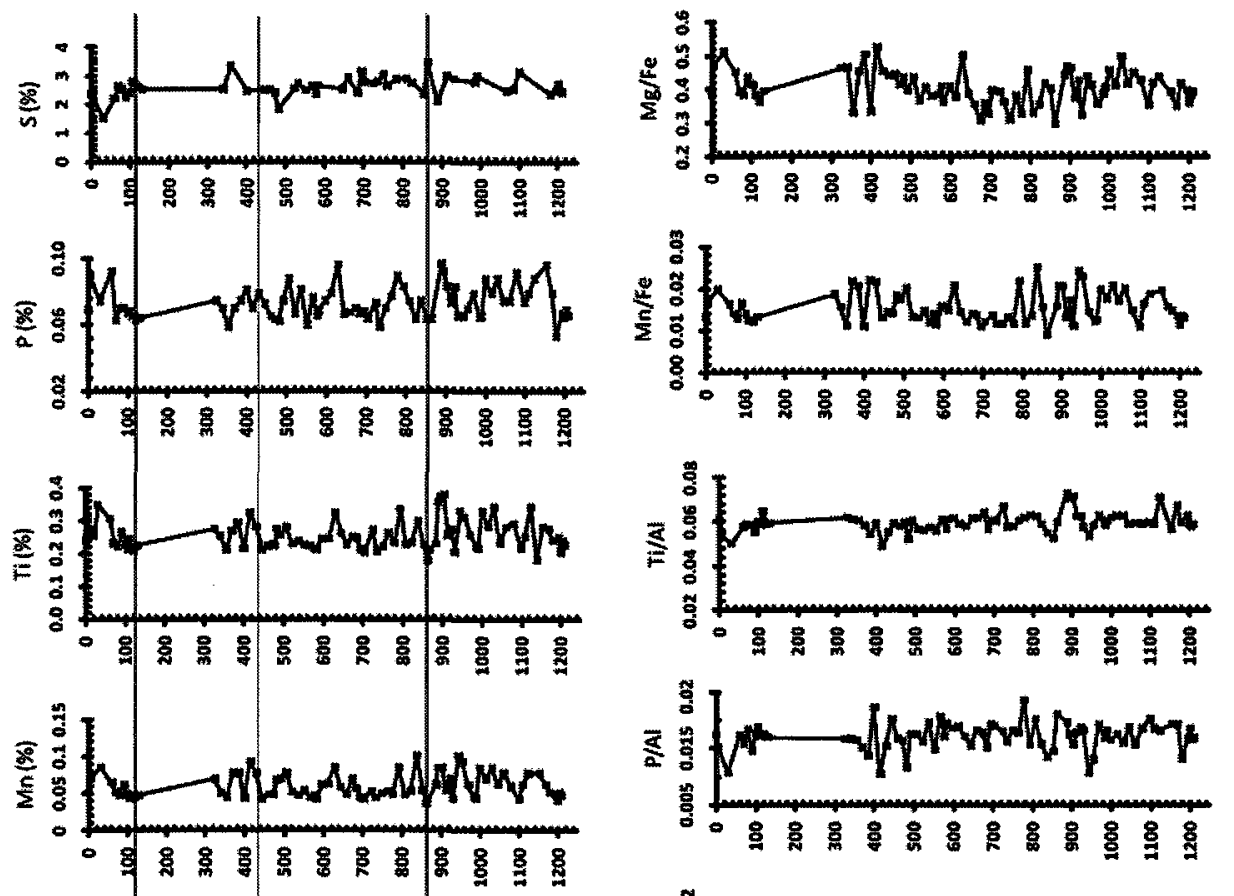

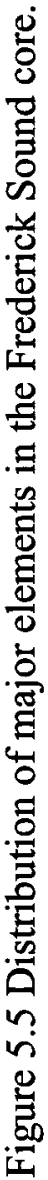
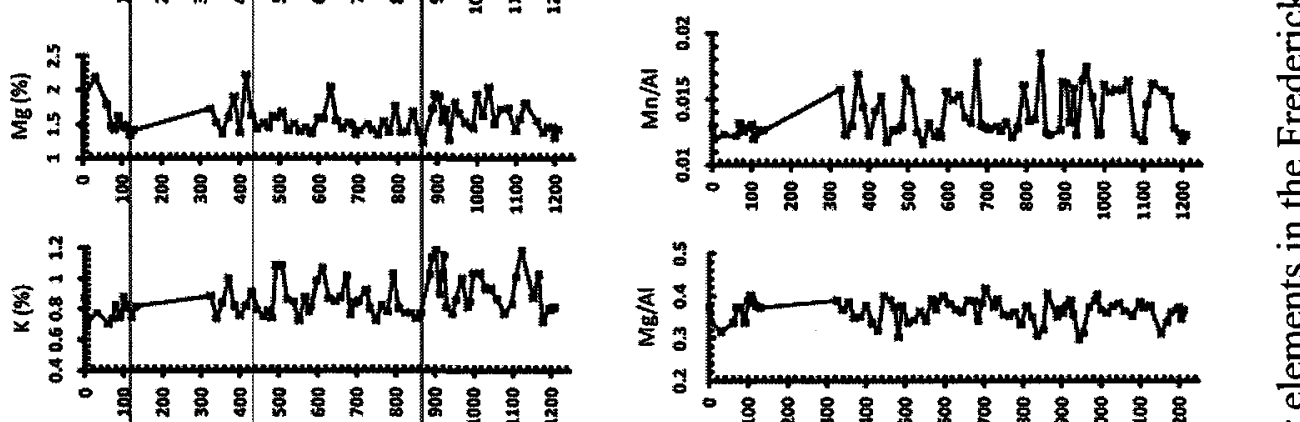

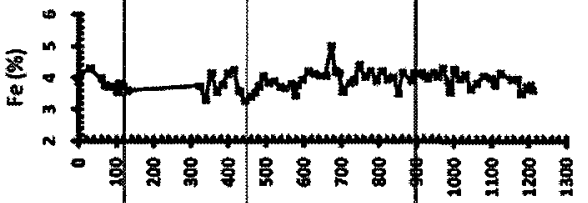
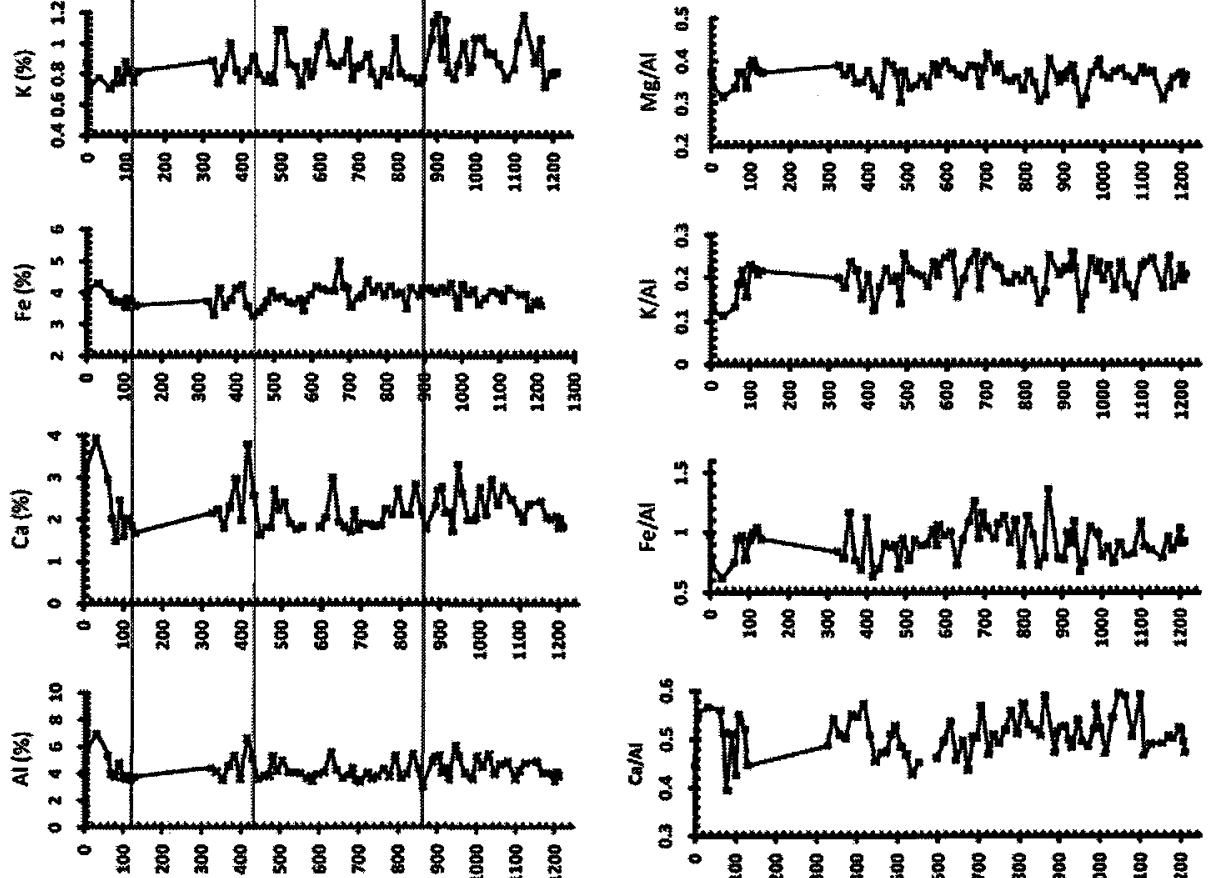

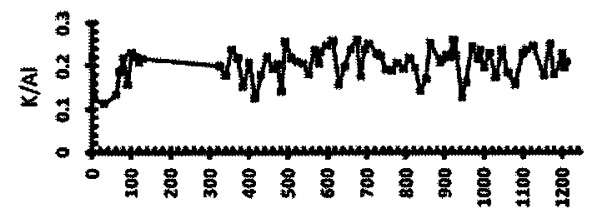

-

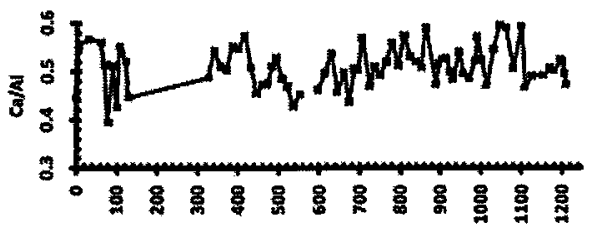

(w3) y2de0

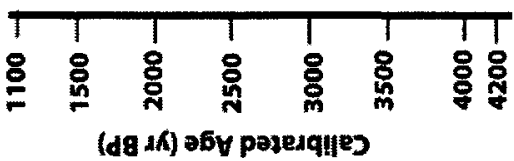

(us) usdoc

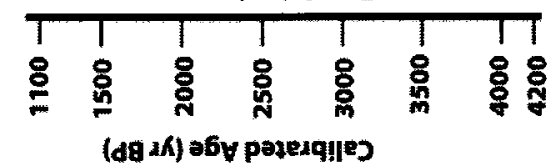



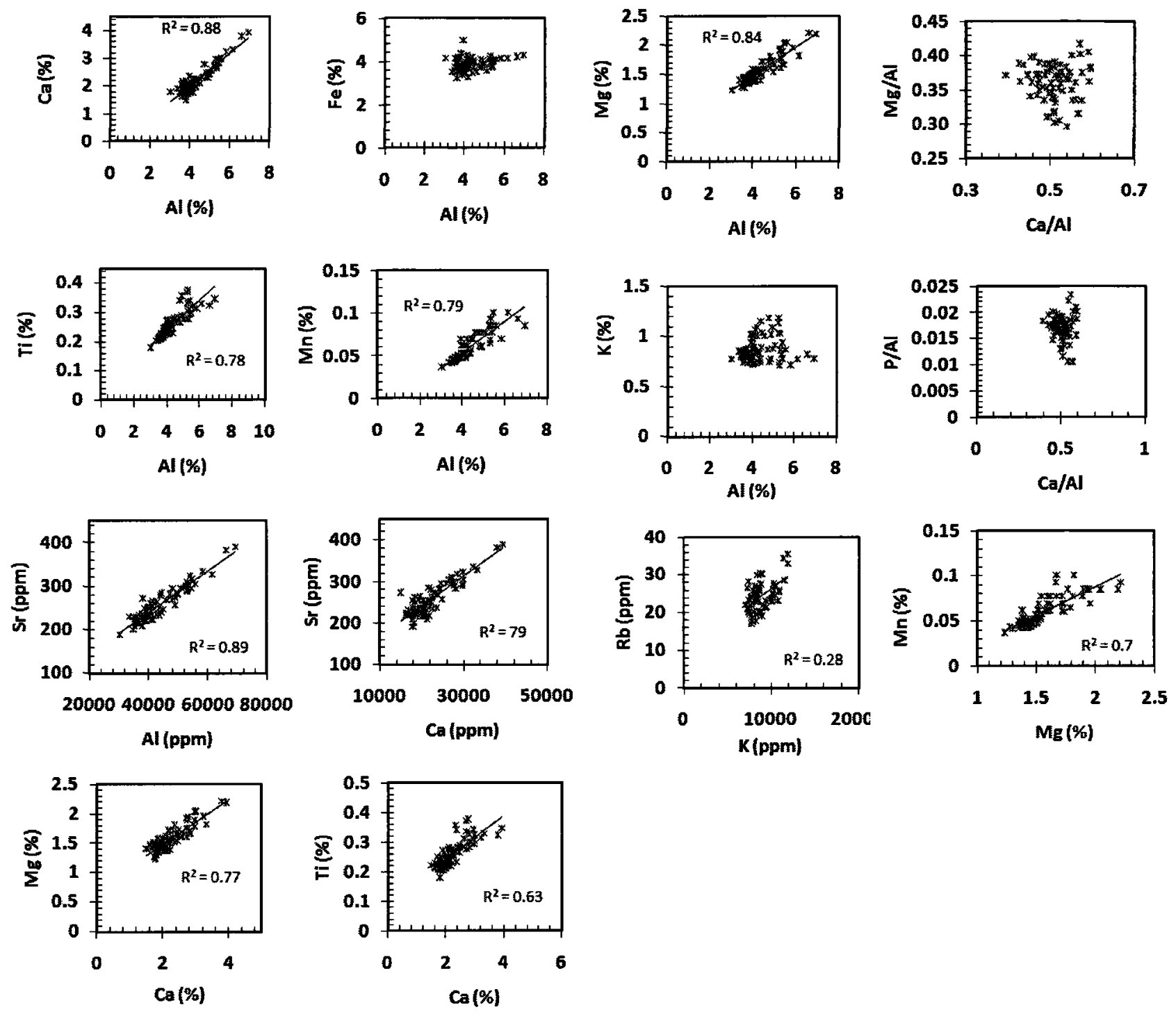

Figure 5.6. Bivariate plots showing relationships between some elements in the Frederick Sound core. 

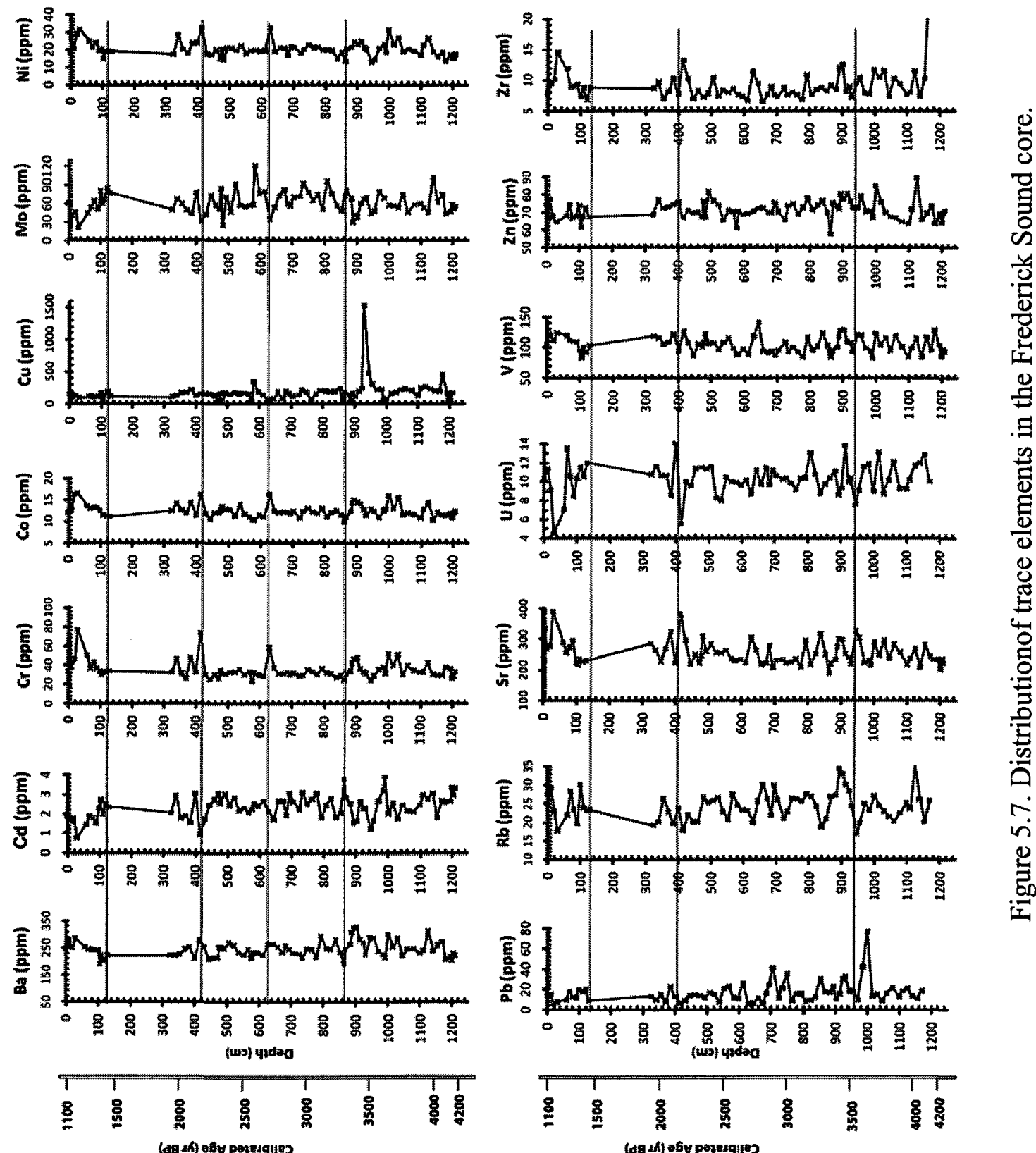


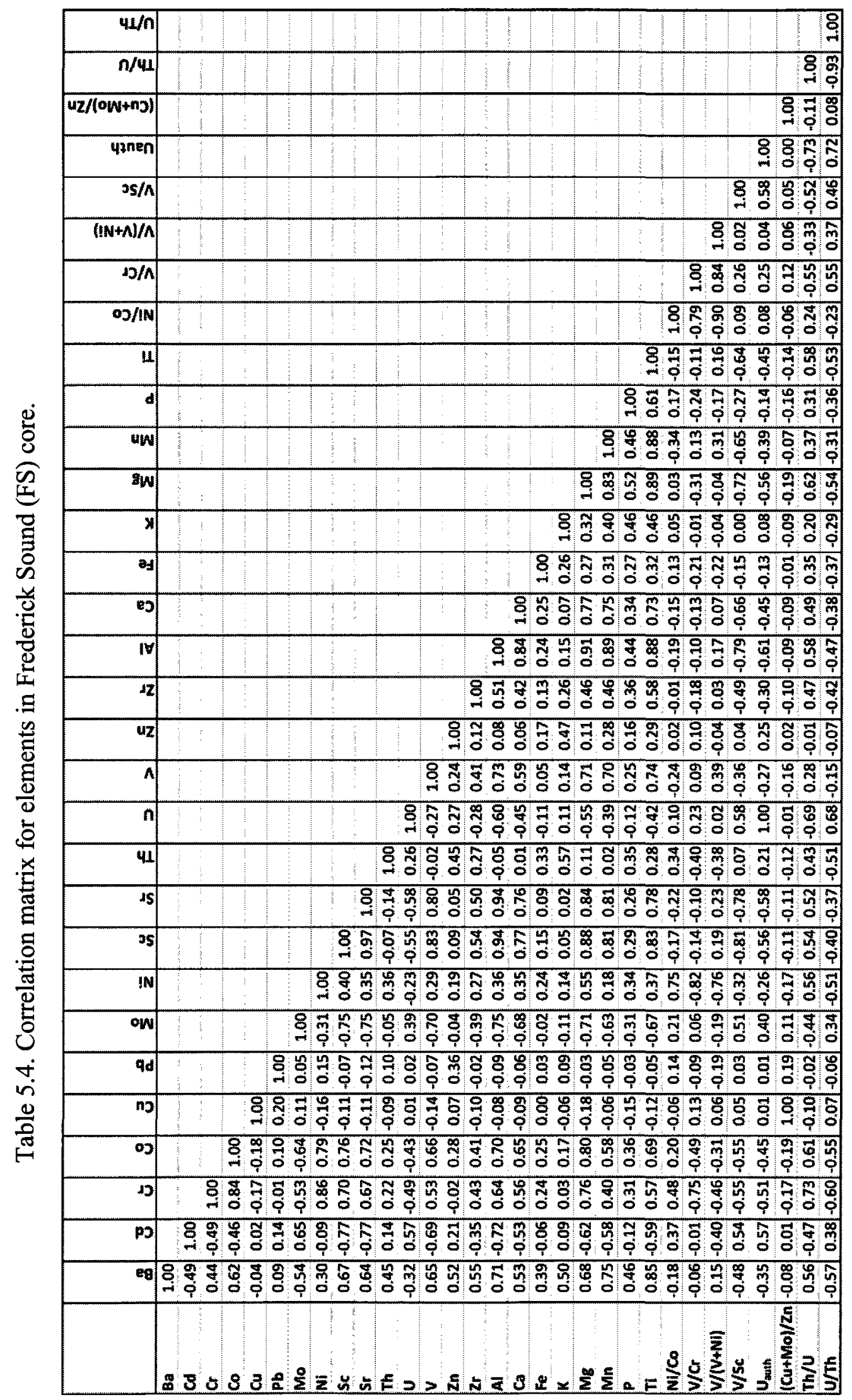

113 

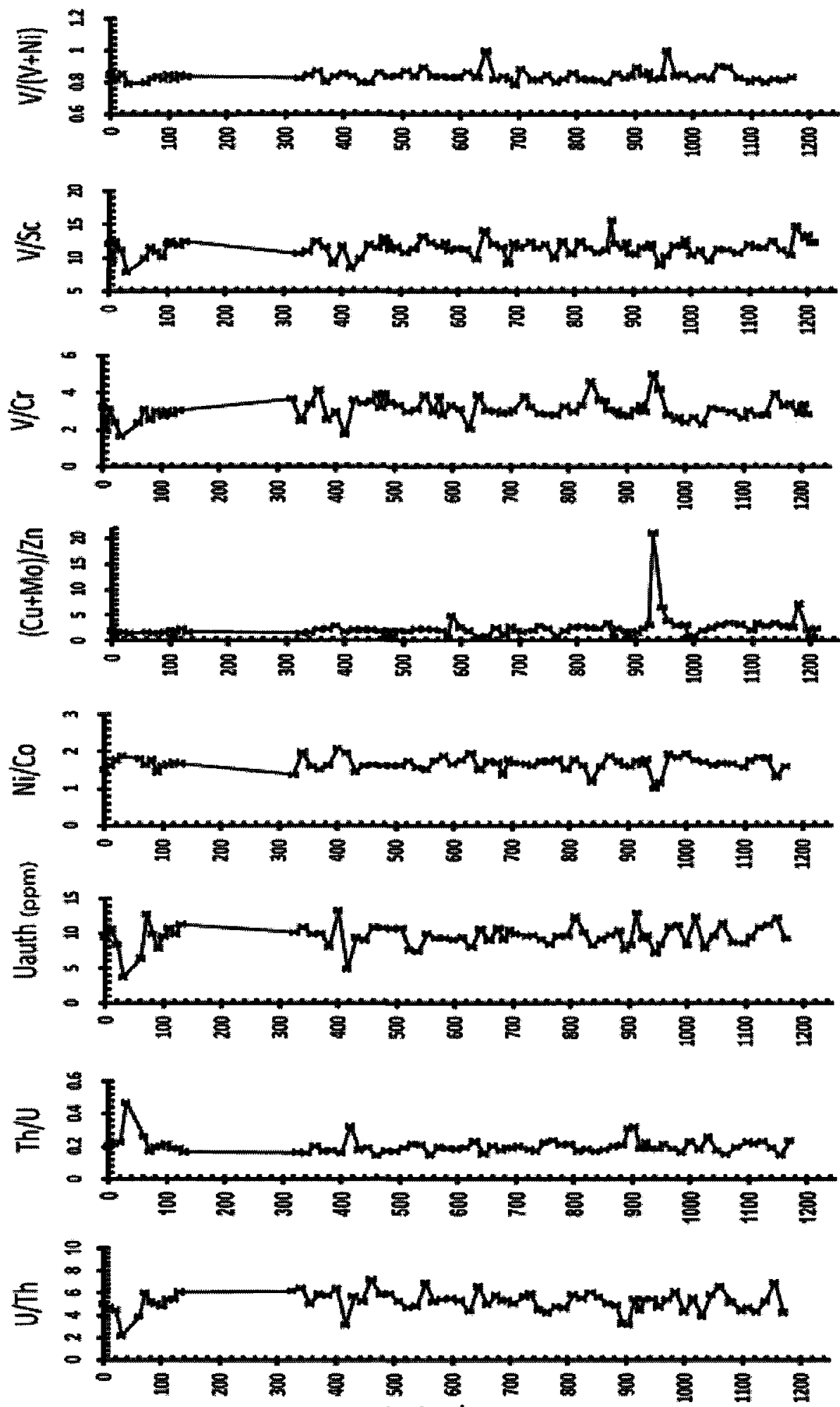
(us) ypdad

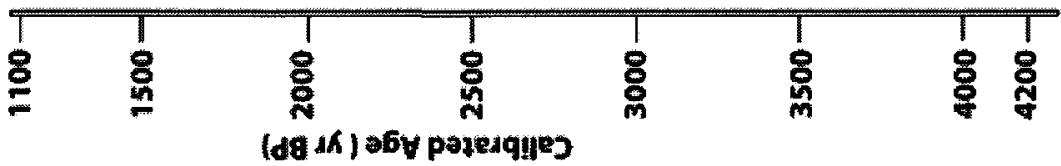




\subsubsection{Inorganic Geochemistry in the Alison Sound (ALS) core}

The major elements in the ALS core are almost similarly distributed (Figures 5.9). With the exception of $\mathrm{Al}, \mathrm{Ca}$ and $\mathrm{Si}$, almost all major and trace elements exhibit decreasing trend within the slump $(177-182 \mathrm{~cm})$ and sand $(394-399 \mathrm{~cm})$ intervals. Aluminum, $\mathrm{Ca}$ and $\mathrm{Si}$ are highly concentrated in the core (Table 5.3; Figure 5.9). An examination of Table 5.5 and Figure 5.10 indicates that $\mathrm{Al}$ correlates strongly to $\mathrm{Ca}\left(\mathrm{r}^{2}=0.78\right), \mathrm{Mn}\left(\mathrm{r}^{2}=0.56\right)$ and $\mathrm{Si}\left(\mathrm{r}^{2}=0.58\right)$ and weakly to $\mathrm{Ti}\left(\mathrm{r}^{2}=0.25\right)$. Iron $(\mathrm{Fe})$ also has a strong relationship with $\mathrm{Ti}\left(\mathrm{r}^{2}=0.7\right), \mathrm{K}\left(\mathrm{r}^{2}=0.71\right)$ and $\mathrm{Mg}\left(\mathrm{r}^{2}=66\right)$ while $\mathrm{Ca}$ and $\mathrm{Sr}$ are moderately correlated $\left(\mathrm{r}^{2}=0.54\right)$ in this core. Phosphorous and $\mathrm{S}$ are almost uniformly distributed throughout the ALS core. Phosphorous, however, has subtle positive excursions from the $269-243 \mathrm{~cm}$ and $187-147 \mathrm{~cm}$ intervals (Figure 5.9).

The trace elements in the ALS core also exhibit similar distribution patterns (Figure 5.11). All trace elements are characterized by reduced concentrations within the major sand $(394-399 \mathrm{~cm})$ and slump $(177-182 \mathrm{~cm})$ intervals. The average concentrations of $\mathrm{Cd}, \mathrm{Cu}, \mathrm{Mo}, \mathrm{V}$ and $\mathrm{Zn}$ in ALS are above their upper crustal values (Table 5.3). As shown in Table 5.5, Mo, Cd, $\mathrm{U}$ and $\mathrm{Pb}$ are strongly correlated in this core. In addition $\mathrm{Mo}$ and $\mathrm{U}$ are correlated to $\mathrm{Co}, \mathrm{Cu}, \mathrm{Ni}$, and $\mathrm{Pb}$. Nickel, $\mathrm{Cr}, \mathrm{V}, \mathrm{Zn}$ and $\mathrm{Zr}$ are also strongly correlated in the inlet. Aluminum is generally poorly correlated to most of the redox related elements (Table 5.8). It only has weak correlations to $\mathrm{Cr}, \mathrm{Zn}$ and $\mathrm{Zr}$.

The redox indices $\left(\mathrm{V} / \mathrm{Cr}\right.$ and $\mathrm{V} /(\mathrm{V}+\mathrm{Ni}) \quad \mathrm{U}_{\text {authigenic, }} \mathrm{U} / \mathrm{Th}, \mathrm{Th} / \mathrm{U},(\mathrm{Cu}+\mathrm{Mo}) / \mathrm{Zn}, \mathrm{NiCo}$, and $\mathrm{V} / \mathrm{Sc}$ ) in the ALS core display a similar distributional pattern to the redox sensitive elements in the ALS core (Figure 5.12). The decreasing trends shown by trace elements within the slump and sand intervals are also present in the redox indices records. $U_{\text {authigenic, }} \mathrm{U} / \mathrm{Th},(\mathrm{Cu}+\mathrm{Mo}) / \mathrm{Zn}, \mathrm{Ni} / \mathrm{Co}$, 
童:
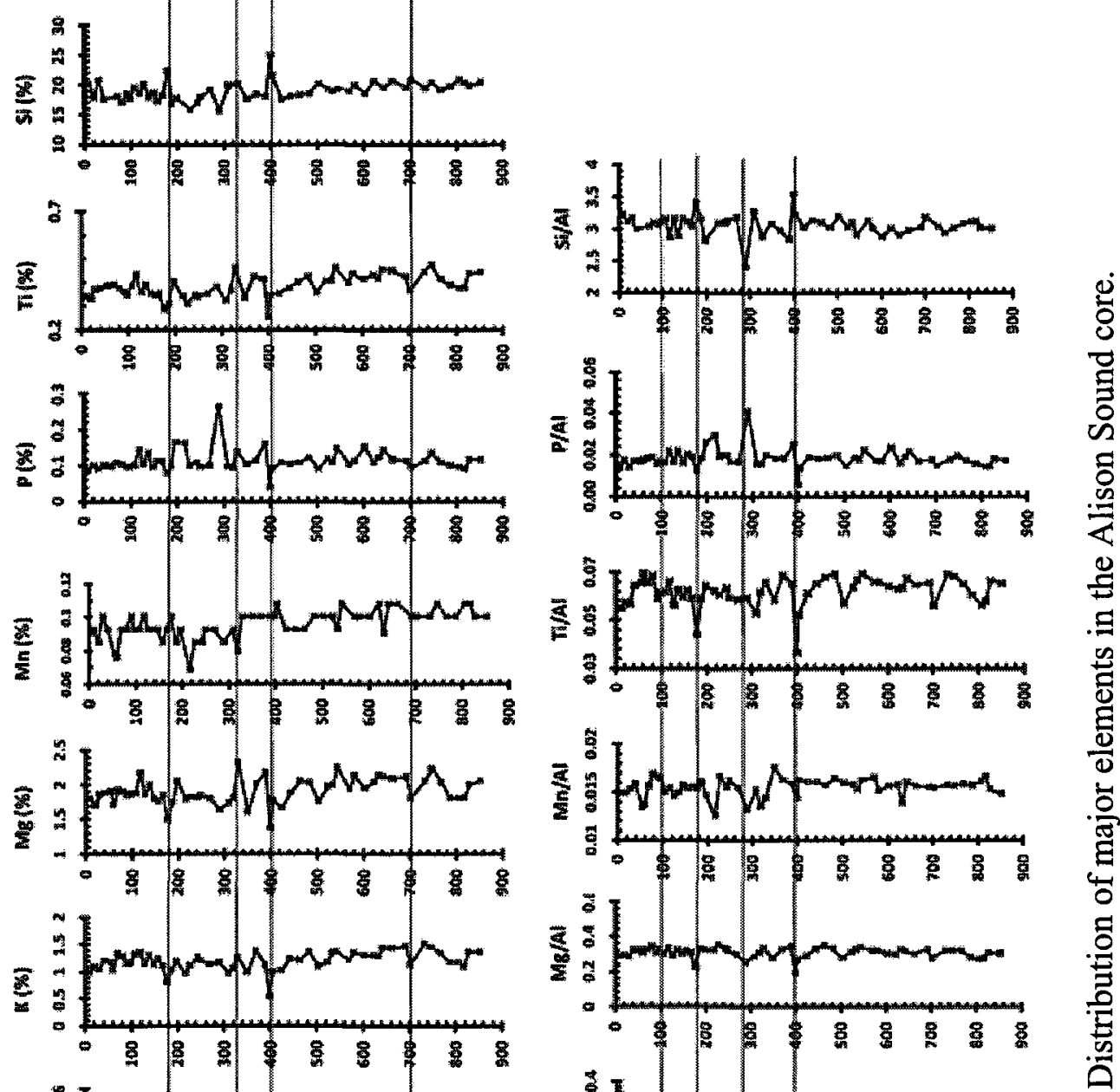

要:
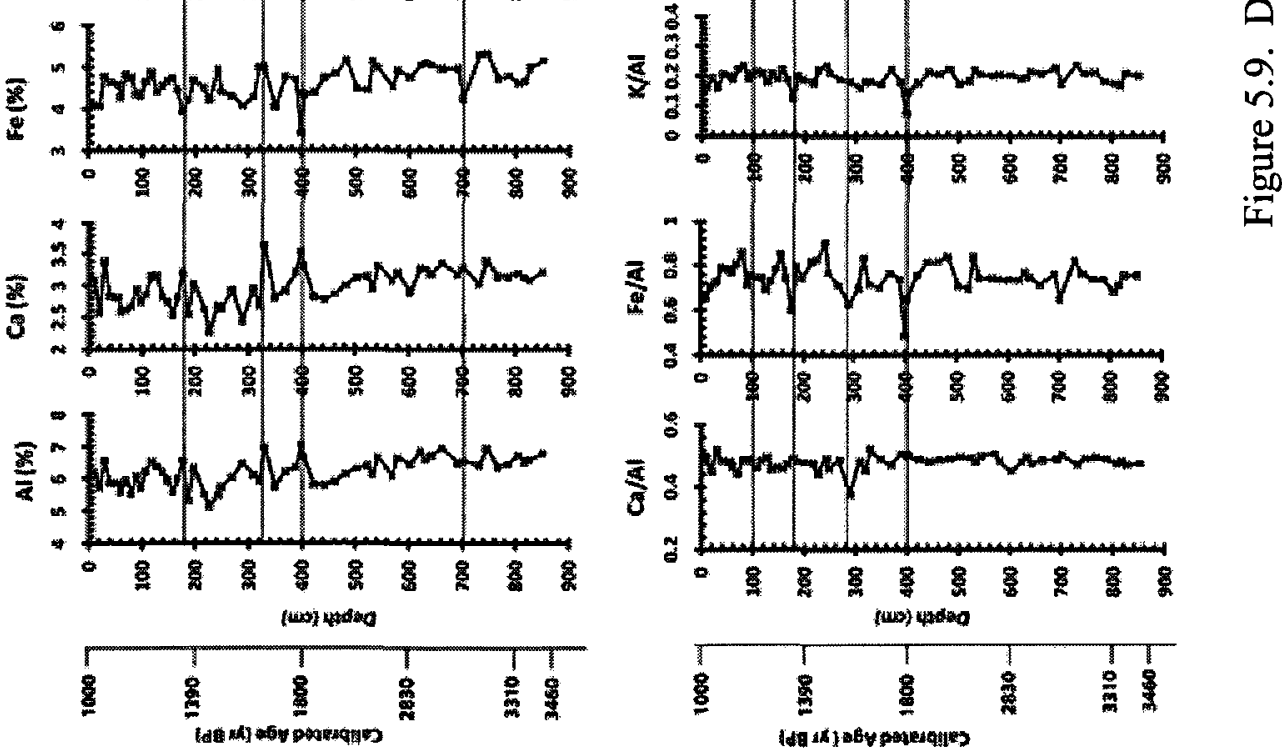

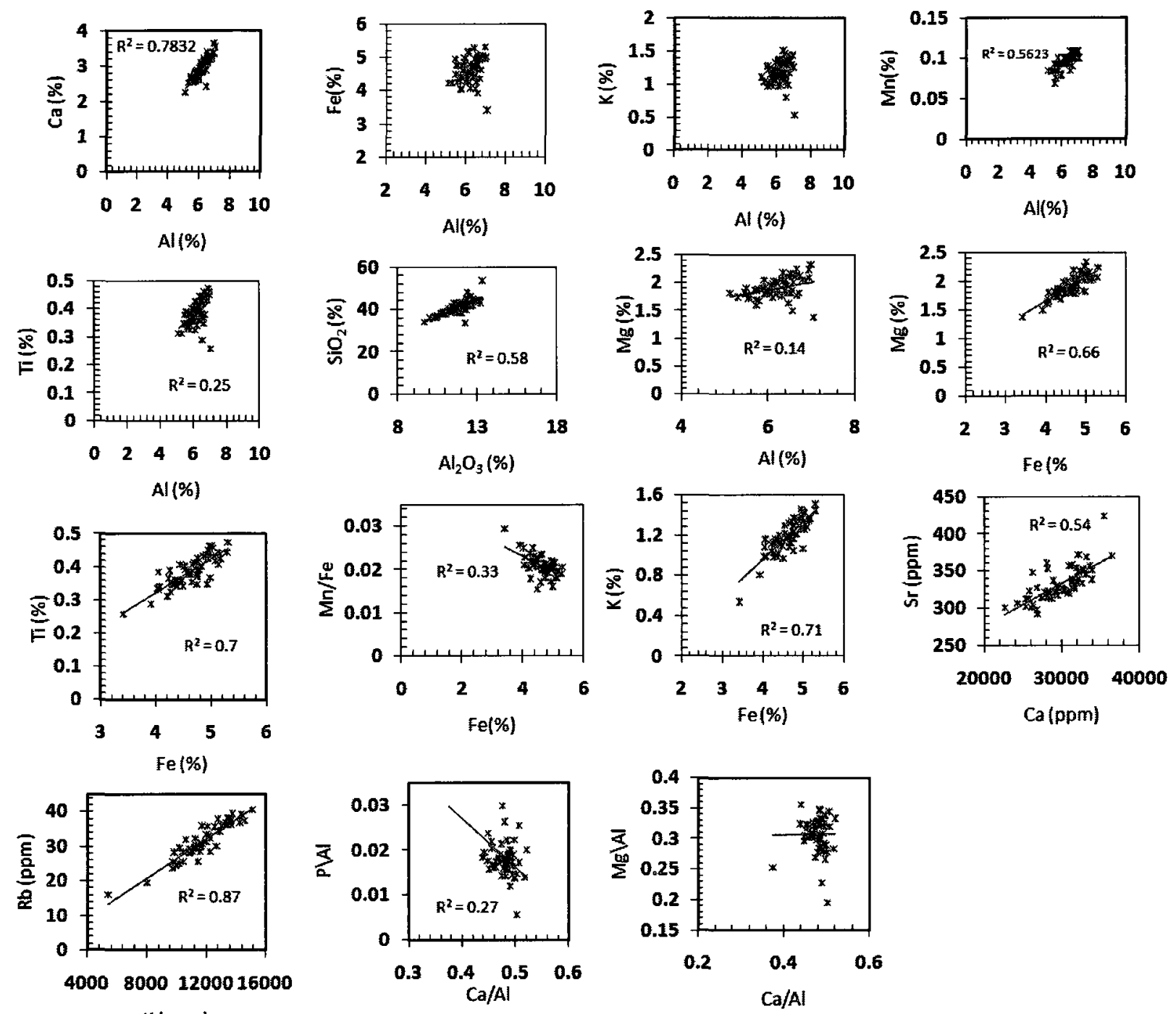

K(ppm)

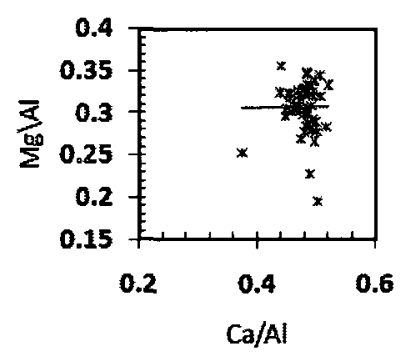

Figure 5.10. Bivariate plots of some elements and oxides in the Alison Sound core. 

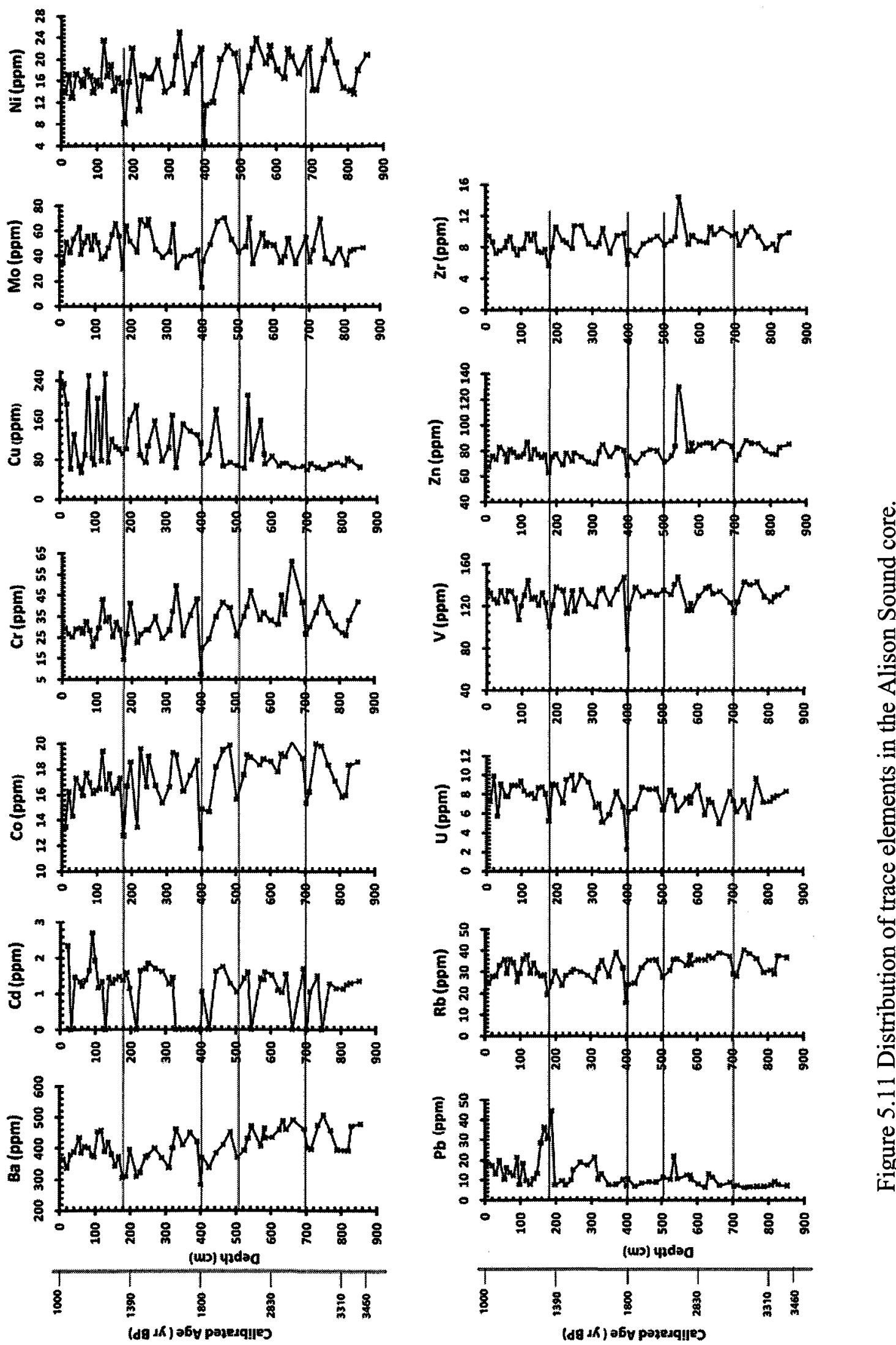


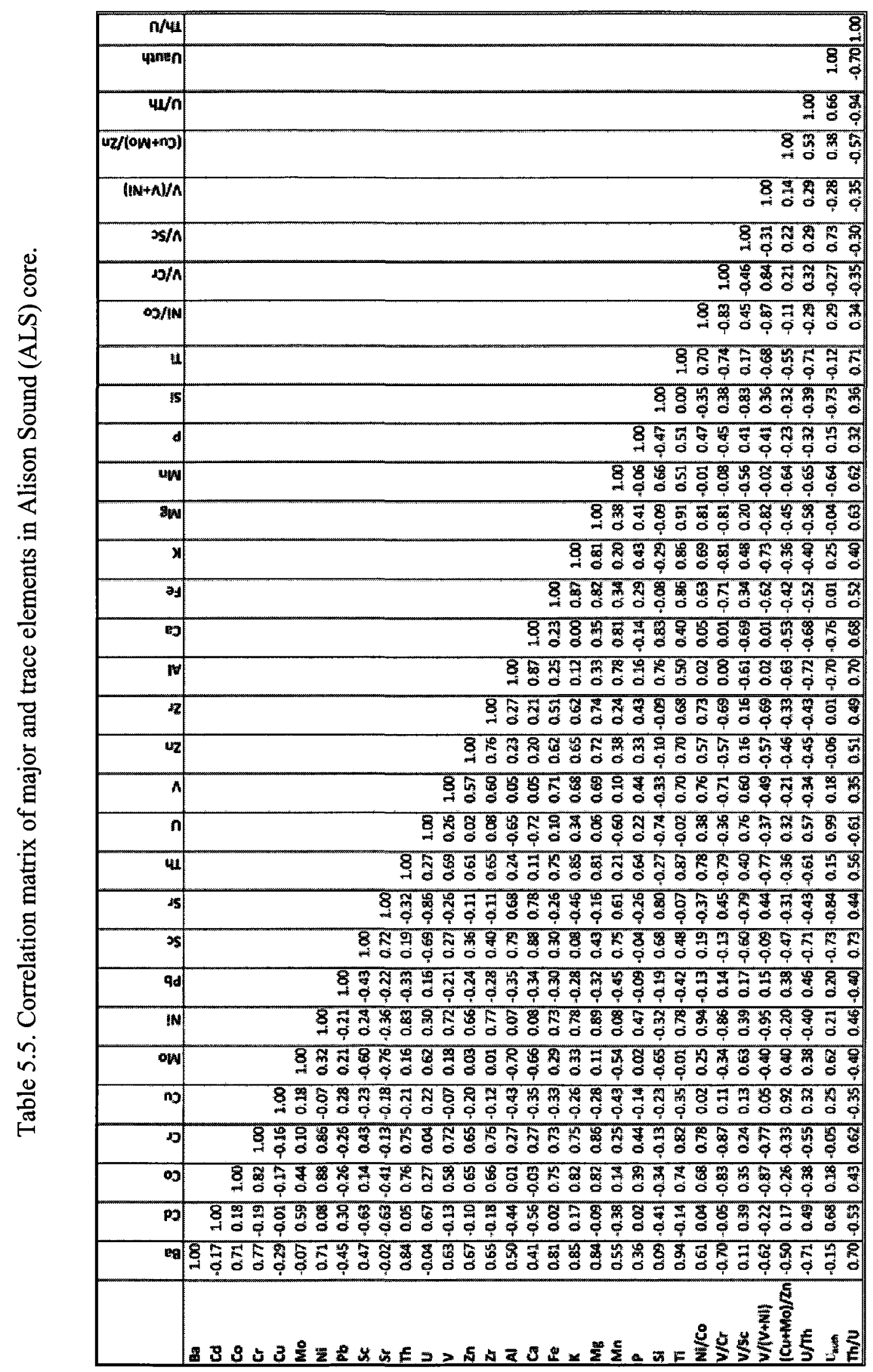




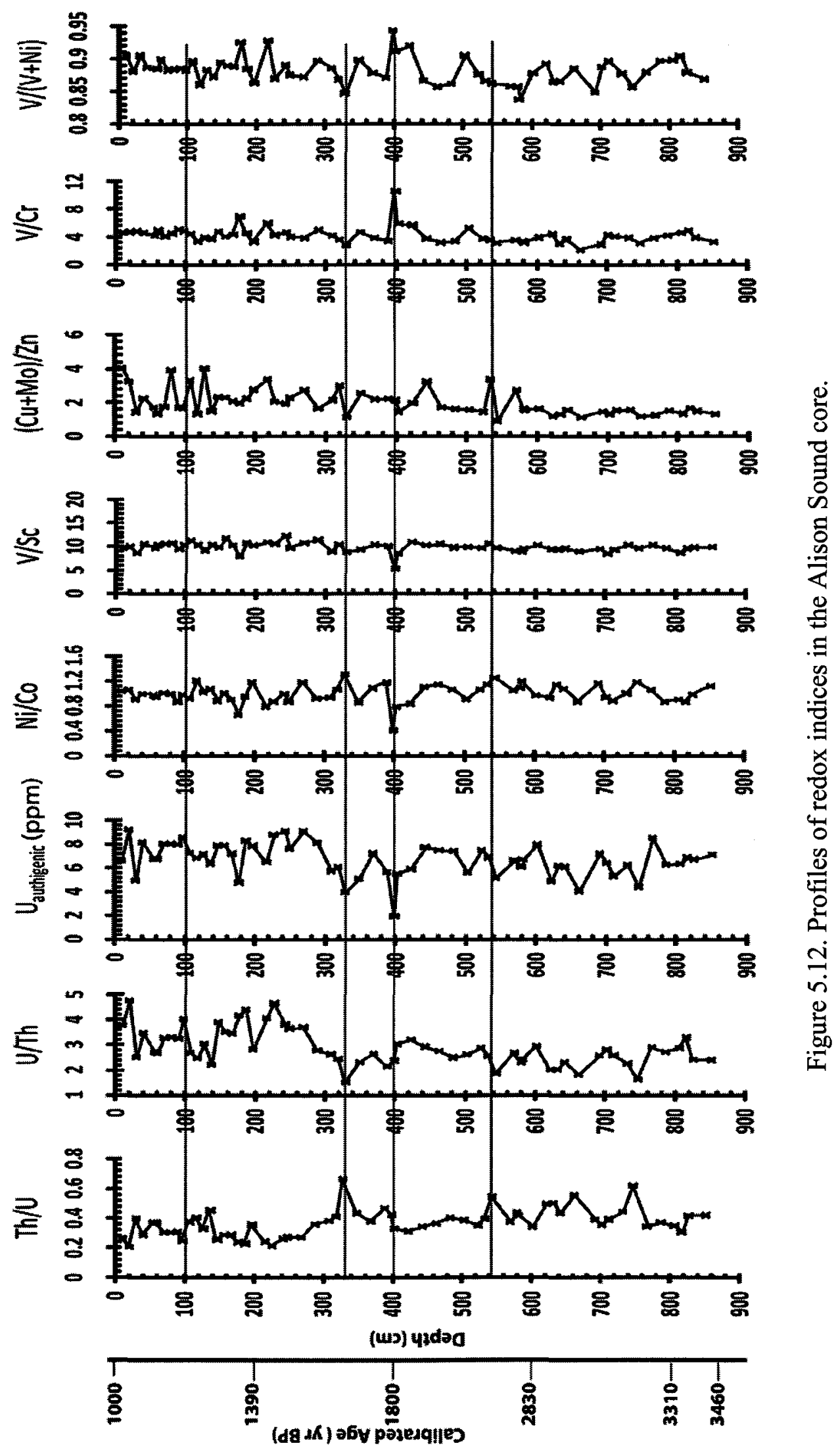


and $\mathrm{V} / \mathrm{Sc}$ are characterized by decreasing trend within the $403-289 \mathrm{~cm}$ interval. The values of $\mathrm{Th} / \mathrm{U}, \mathrm{V} / \mathrm{Cr}$ and $\mathrm{V} /(\mathrm{V}+\mathrm{Ni})$ increase at $399 \mathrm{~cm}$ while those of $\mathrm{U}_{\text {authigenic }}$ and $\mathrm{U} / \mathrm{Th}$ are characterized by increasing values through the uppermost $289 \mathrm{~cm}$ of the core. $U / T h, U_{\text {authigenic }}$ and $\mathrm{V} / \mathrm{Sc}$ correlate to $\mathrm{Cd}$, $\mathrm{Mo}$ and $\mathrm{U}$ while $(\mathrm{Cu}+\mathrm{Mo}) / \mathrm{Zn}$ correlates to $\mathrm{Mo}, \mathrm{Pb}$, and $\mathrm{U}$.

\subsubsection{Biogenic Indices}

The ratios of organic carbon to aluminum, biogenic silica, biogenic barium and $\mathrm{P} / \mathrm{Al}$ ratios are often used as indices to measure paleoproductivity (Dean et al., 1997; Kienast et al., 2002; Barron et al., 2004; McKay et al., 2004). These productivity indices are examined in the FS and ALS piston cores.

\subsubsection{Biogenic Indices in the Frederick Sound (FS) core}

Biogenic silica, $\mathrm{Ba} / \mathrm{Al}$ and $\mathrm{P} / \mathrm{Al}$ ratios vary throughout the entire core interval (Figure 5.13). The biogenic silica is generally poorly correlated to sediment mean grain size. High values of this proxy correlate predominantly to the siltier intervals while low values are associated with coarser grained sediments (Figure 5.1). Biogenic silica is also poorly correlated with organic carbon, $\mathrm{P} / \mathrm{Al}$ and $\mathrm{Ba} / \mathrm{Al}$. Figure 5.13 shows that $\mathrm{Ba} / \mathrm{Al}$ exhibits peak concentrations in most parts of the core. The $\mathrm{P} / \mathrm{Al}$ and the $\mathrm{C}_{\mathrm{org}} / \mathrm{Al}$ ratios have nearly even distributional trends and are moderately correlated in the FS core.

\subsubsection{Biogenic Indices in the Alison Sound core}

The $\mathrm{Si} / \mathrm{Al}$ ratio is used in the ALS core to access diatom productivity since biogenic silica was not measured in the investigated samples. The $\mathrm{Si} / \mathrm{Al}$ ratio which is evenly distributed throughout the core displays an inverse relationship with $\mathrm{Ba} / \mathrm{Al}$ and $\mathrm{P} / \mathrm{Al}$ (Figure 5.14). This proxy is also poorly correlated to the organic carbon content in the sediments. A 


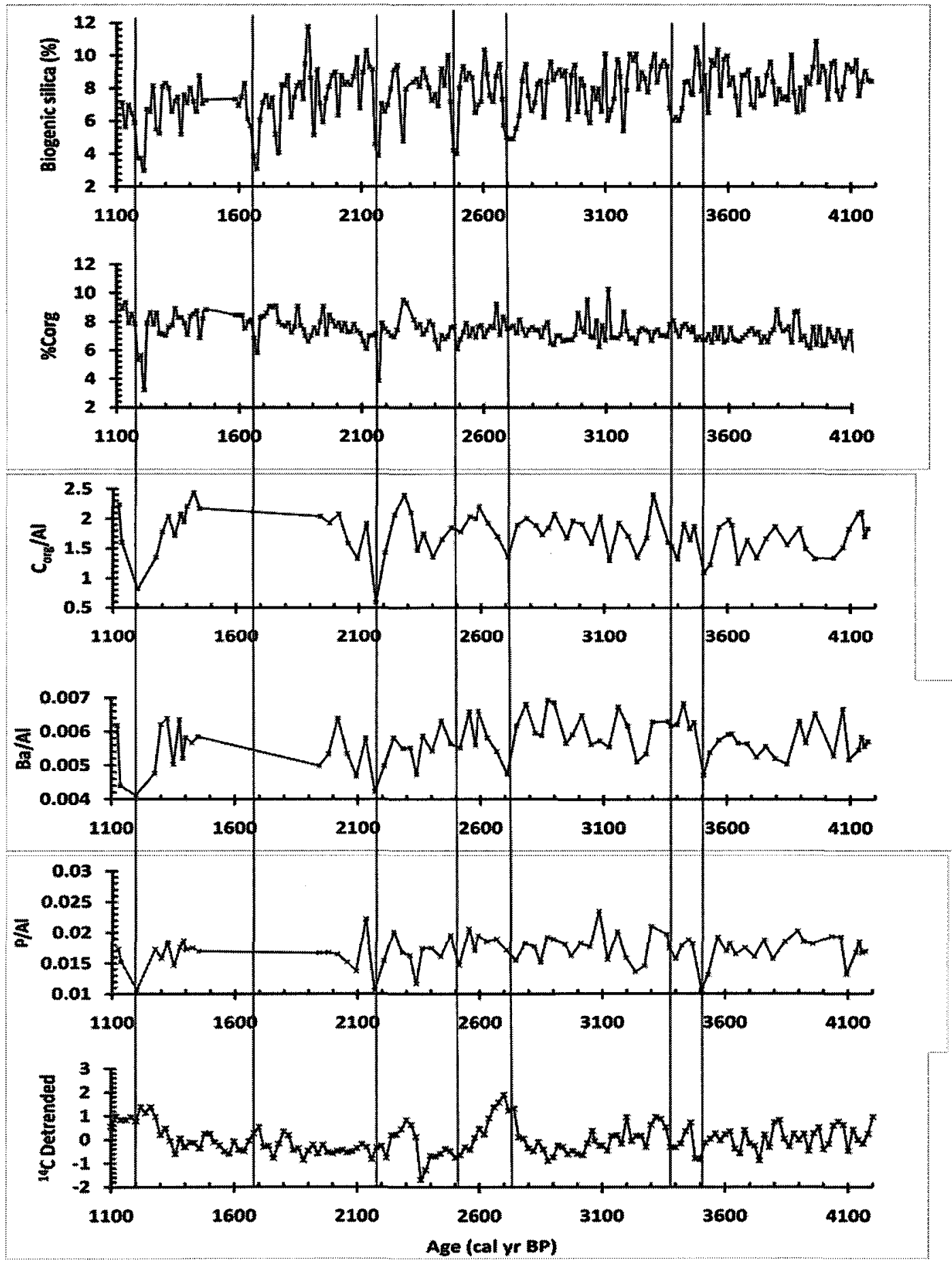

Figure 5.13. Comparison of productivity indices in the Frederick Sound core to the Bond et al. (2001) ${ }^{14} \mathrm{C}$ production rate. Low productivity intervals are indicated by vertical lines. 


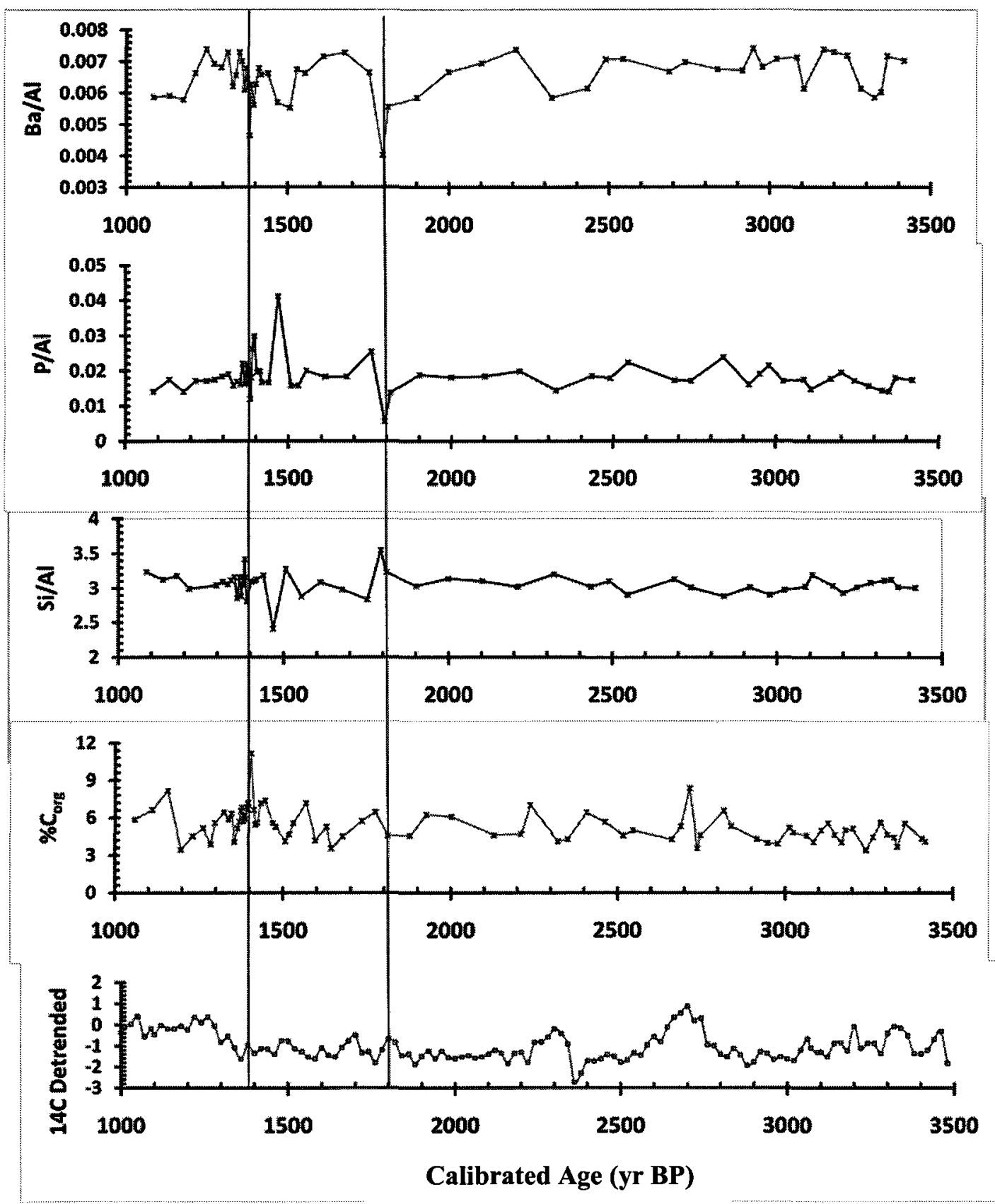

Figure 5.14. Comparison of productivity indices in the Alison core to the Bond et al. (2001) ${ }^{14} \mathrm{C}$ production rate. Low productivity intervals are indicated by vertical lines. 
decrease in its record from the $399-197 \mathrm{~cm}$ interval culminates in major low values at the 289 $\mathrm{cm}$ core depth. The $\mathrm{Ba} / \mathrm{Al}$ and $\mathrm{P} / \mathrm{Al}$ ratios are uniformly distributed in the sediments, exhibiting a subtle decrease trend from $420-399 \mathrm{~cm}$ interval where the $\mathrm{Si} / \mathrm{Al}$ is elevated (Figure 5.14). Elevated values of $\mathrm{P} / \mathrm{Al}$ ratios are restricted to $310-170 \mathrm{~cm}$ interval.

\subsubsection{Results of Time-Series Analysis}

Using Redfit software, spectral analysis was conducted on the organic matter and elemental proxies in both the FS and ALS cores to identify climate cycles archived in their sediments. Spectral analysis was carried out on all the organic matter proxies $\left(\mathrm{C}_{\mathrm{org}}, \mathrm{N}_{\text {total }}\right.$, $\mathrm{C}_{\text {org }} / \mathrm{N}_{\text {total }}, \delta^{15} \mathrm{~N}$, and $\delta^{13} \mathrm{C}$ ) and almost all major and trace elements in both cores. The biogenic silica in the FS core was also analyzed. Due to the large volume of data only the results of the organic matter proxies, those of four redox sensitive elements $(\mathrm{Cd}, \mathrm{Mo}, \mathrm{U}$, and $\mathrm{V})$ and that of productivity related $(\mathrm{Ba})$ are discussed in this chapter.

The ${ }^{14} \mathrm{C}$ production data of Bond et al. (2001) within the age ranges of the FS core ( $1100-4200$ cal yr BP) and ALS core (1000-3500 cal yr BP) were also analyzed to determine the reliability of the temporal spectral signals derived from the examined geochemical proxies. In addition, wavelet analysis was carried out on the organic geochemical proxies to confirm the temporal distribution of some of the cycles identified by the spectral analysis.

\subsubsection{Time -Series Results in the Frederick Sound (FS) core}

Spectral analysis of the geochemical data in the FS core yields periodicities at the decadal and millennial range (Tables 5.9; Figures 5.15-5.16) Periodicities at the 90-95\% confidence level are present in the 76-133 and 146-208-year cycles in both the organic matter and trace elements proxies. Periodicities of 34-67-years with low amplitudes are also 
significantly represented in the proxies. A longer 250-381-year cycle is also significantly present in the data set.

Analysis of the ${ }^{14} \mathrm{C}$ production rate for the core's time interval indicates that a multicentury 625 -year cycle is the most prominent periodicity with a significance at the $95 \%$ confidence level (Figure 5.15). Other significant periodicities at the $95 \%$ confidence level, but with lower amplitudes in ${ }^{14} \mathrm{C}$, are $213, \sim 152,128,103, \sim 91, \sim 86$ and 76-year cycles. The wavelet analysis results reveal that non-stationary 65-75-year and 88-year cycles, which occur repeatedly throughout the core interval, are the most intense cycles in the FS core. The 65-75 year cycle is recorded in the biogenic silica record whereas the 88-year cycle is strongly present in the $\delta^{13} \mathrm{C}$ and $\delta^{15} \mathrm{~N}$ records (Figures 5.17-5.19). The 113-year cycle is the most intense periodicity in $\mathrm{C}_{\text {org }}$ (Figure 5.20). This cycle is less intense in the $\delta^{13} \mathrm{C}$. The $\mathrm{C}_{\text {org }}$ is additionally characterized by a non-stationary and less intense $\sim 76$-year periodicity.

The 176-189-year cycle is also present in the $\delta^{13} \mathrm{C}$ and $\delta^{15} \mathrm{~N}$ records. All examined proxies $\left(\delta^{13} \mathrm{C}, \delta^{15} \mathrm{~N}, \mathrm{C}_{\text {org }}\right.$ and biogenic silica) are also characterized by less intense 220-302year periodicities. Persistent multi-centennial (403-882-year) and (1000-2519-year) millennial cycles occurring throughout the 3100 years of the depositional history of this core are also present in the examined organic matter proxies. The age intervals of the above described discussed cycles are presented in Table 5.7.

\subsubsection{Time Series Results in the Alison Sound core (ALS)}

The 71-139-year and 146-236 periodicities, significant at the 90-95\% confidence level exist in the examined organic matter and redox sensitive elements in ALS (Table 5.8, Figures 5.21-5.22). Low amplitude 34-67-year and longer 259-476-year cycles are also significantly present in the proxies. An examination of the ${ }^{14} \mathrm{C}$ production rate during the depositional 
Table 5.6. Results of the spectral analysis of geochemical proxies from the Frederick Sound core.

\begin{tabular}{|c|c|c|c|c|c|}
\hline Proxy & 31-69-year & 76-140-year & $\begin{array}{c}\text { 146-250- } \\
\text { year }\end{array}$ & 250-500-year & 625-year \\
\hline $\mathrm{C}_{\text {org }}$ & $31-65$ & $86-87,122$ & & $340^{*}$ & \\
\hline $\mathrm{N}_{\text {total }}$ & $45-68$ & $76,80^{*}, 87,98,109,113$ & & 254 & \\
\hline $\mathrm{C}_{\text {org }} / \mathrm{N}_{\text {total }}$ & $38-63$ & $76-113$ & & $277,381^{*}$ & \\
\hline Bio Silica & $45-68$ & $78-109^{*}, 133$ & & & \\
\hline$\delta^{13} \mathrm{C}$ & $59-69$ & $82,86,128$ & $177^{*}$ & & \\
\hline$\delta^{15} \mathrm{~N}$ & 66 & 86,108 & $177^{*}$ & 252 & \\
\hline $\mathrm{Ba}$ & & $105,133^{*}$ & 177 & & \\
\hline $\mathrm{Cd}$ & & $77,83,108,127$ & $156-171$, & $323^{*}$ & \\
\hline $\mathrm{Mo}$ & & $83,112-117,133$ & $146,171^{*}$ & & \\
\hline $\mathrm{U}$ & & $77-109$ & $208^{*}$ & & \\
\hline $\mathrm{V}$ & & 108,133 & $146,208^{*}$ & & \\
\hline${ }^{14} \mathrm{C}$ & & $76,86-91,103,128$ & 152,213 & & $625^{*}$ \\
\hline
\end{tabular}

*Indicates most significant cycle in each of the proxies

Table 5.7. Wavelet results showing temporal distribution of cycles in Frederick Sound core.

\begin{tabular}{|c|c|c|c|c|c|c|c|}
\hline Proxy & $\begin{array}{l}65-75 \\
\text { year* }\end{array}$ & 88-year* & 113 year* & $\begin{array}{c}\text { 176-189 } \\
\text { year }\end{array}$ & $\begin{array}{c}220-302 \\
\text { year }\end{array}$ & $\begin{array}{c}\text { 403-882- } \\
\text { year }\end{array}$ & $\begin{array}{c}1000-2519 \\
\text { year }\end{array}$ \\
\hline $\mathrm{C}_{\text {org }}$ & $\begin{array}{l}1100-1505 \\
2140-2399 \\
3057-3213 \\
3775-3926 \\
\end{array}$ & & $1100-1505$ & & $1100-2399$ & $1100-4200$ & \\
\hline $\begin{array}{l}\text { Bio } \\
\text { silica }\end{array}$ & $\begin{array}{l}1100-1301 \\
2205-2606\end{array}$ & & & & $\begin{array}{l}1100-2936 \\
2936-4200\end{array}$ & $1100-4200$ & $1100-4200$ \\
\hline$\delta^{13} \mathrm{C}$ & & $\begin{array}{l}1100-1598 \\
2351-2606 \\
3210-3588\end{array}$ & $\begin{array}{l}1100-1598 \\
2628-3210\end{array}$ & $\begin{array}{l}1100-1505 \\
3588-4200\end{array}$ & $\begin{array}{l}1100-1198 \\
2351-2628\end{array}$ & $1100-4200$ & $1100-4200$ \\
\hline$\delta^{15} \mathrm{~N}$ & & $\begin{array}{l}1946-2341 \\
3299-3745\end{array}$ & & $1946-4200$ & $1946-2745$ & $1100-4200$ & \\
\hline
\end{tabular}

*Most intense cycles in the proxies. 

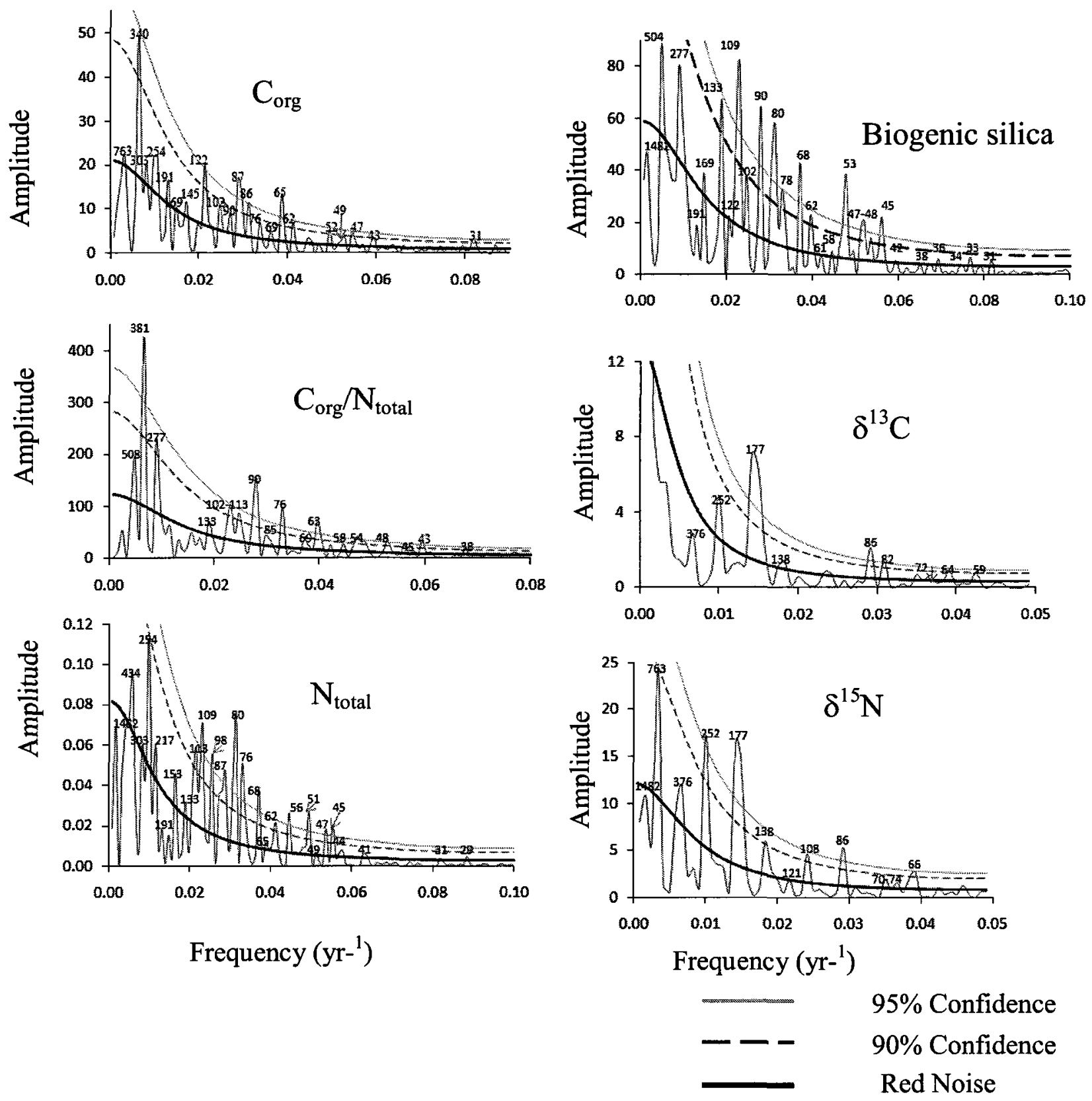

Figure 5.15. Spectral analysis of organic matter proxies in the Frederick Sound core. 

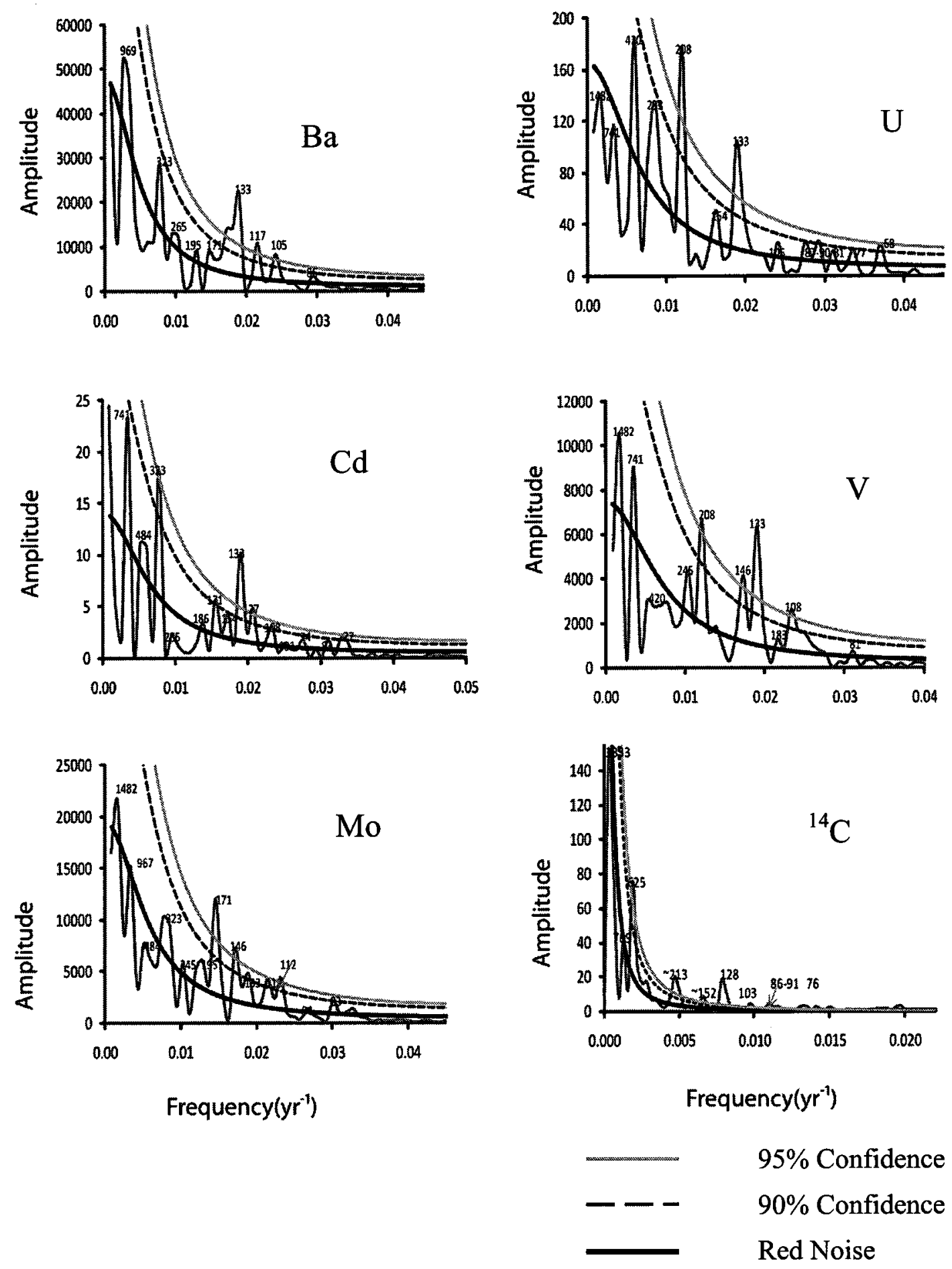

Figure 5.16. Spectral analysis of redox sensitive elements in Frederick Sound core and ${ }^{14} \mathrm{C}$ production rate. 


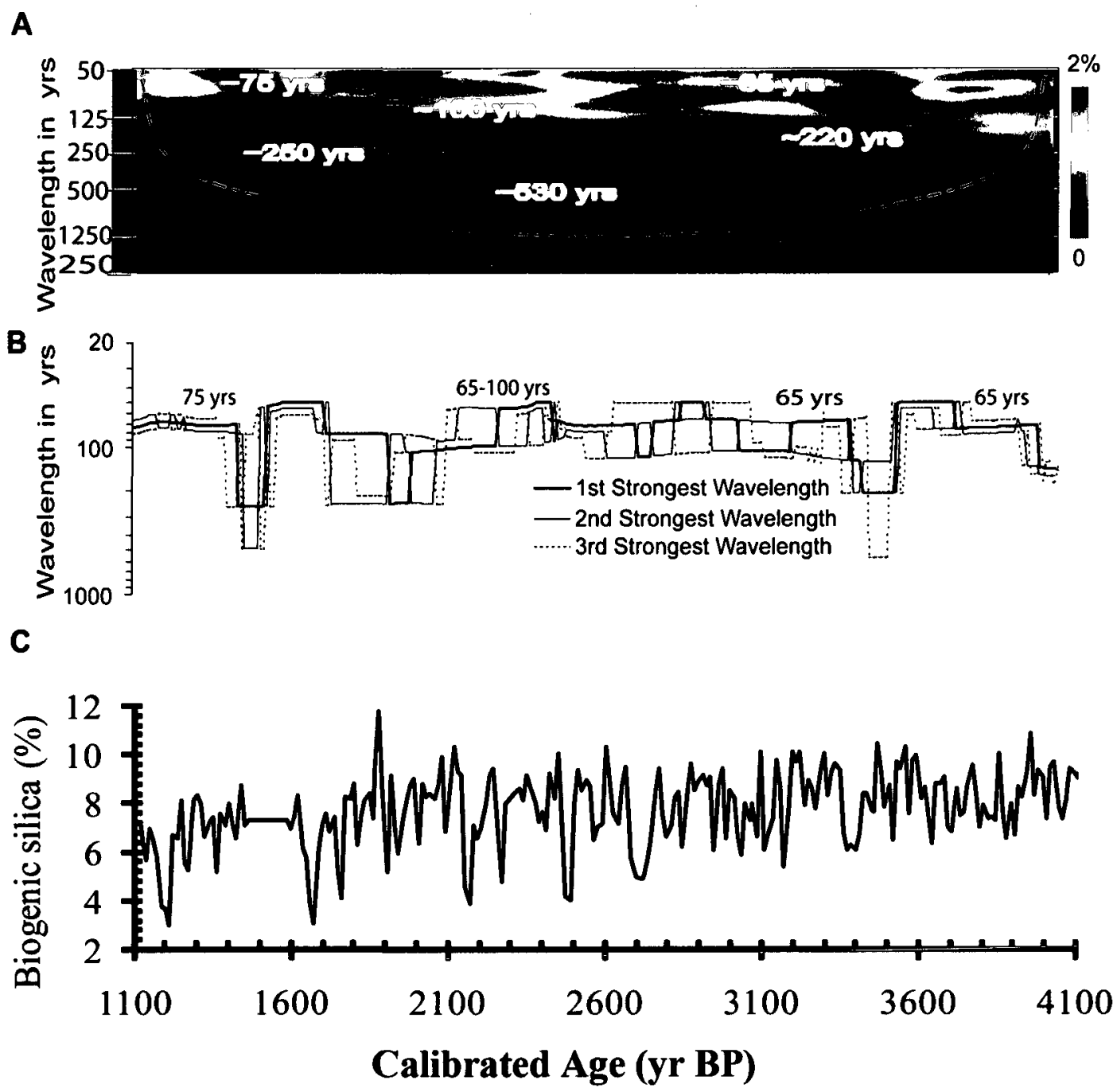

Figure 5.17. Wavelet analysis of biogenic silica in the Frederic Sound core. 

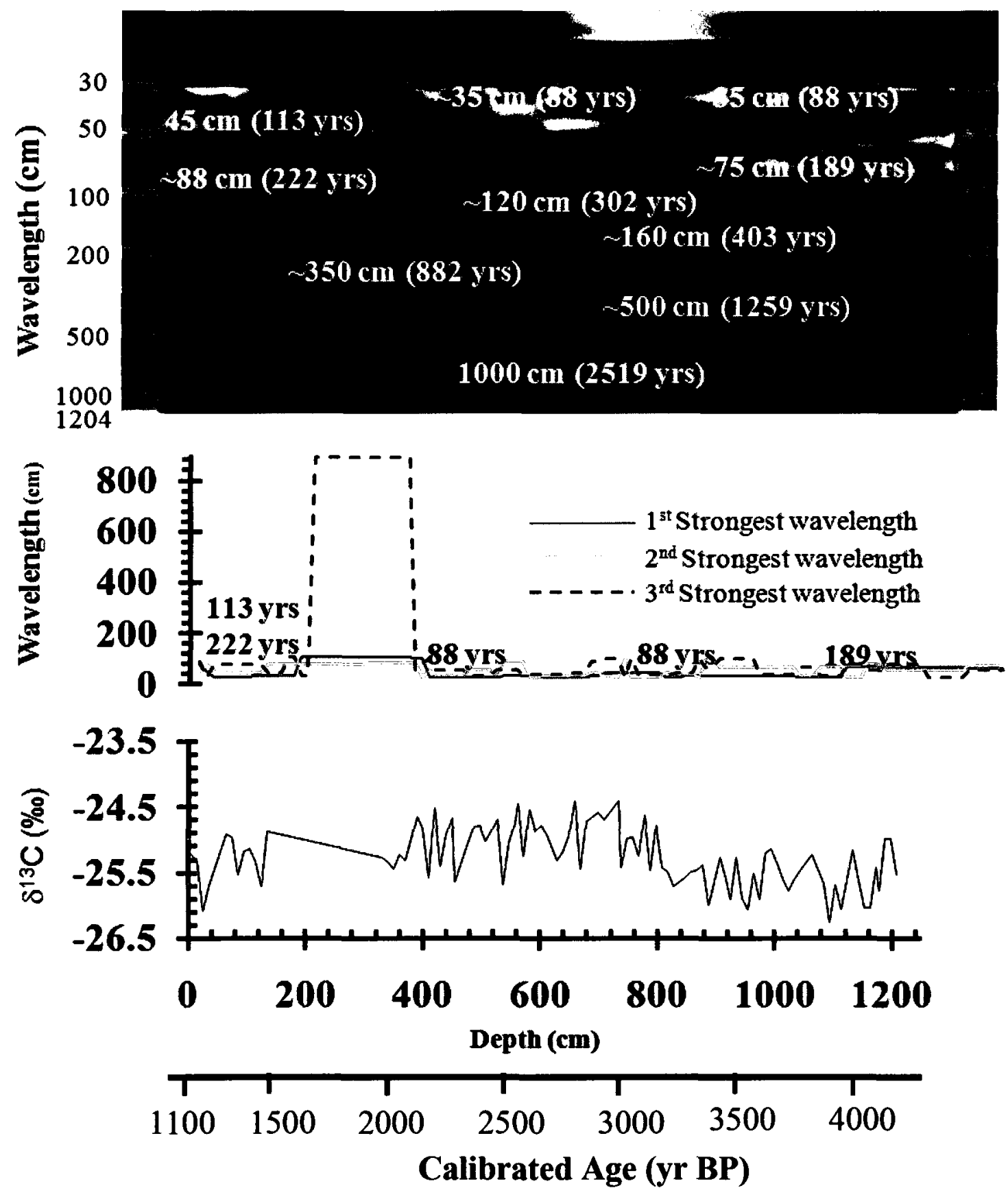

Figure 5.18. Wavelet analysis of $\delta^{13} \mathrm{C}$ in the Frederick Sound core. 


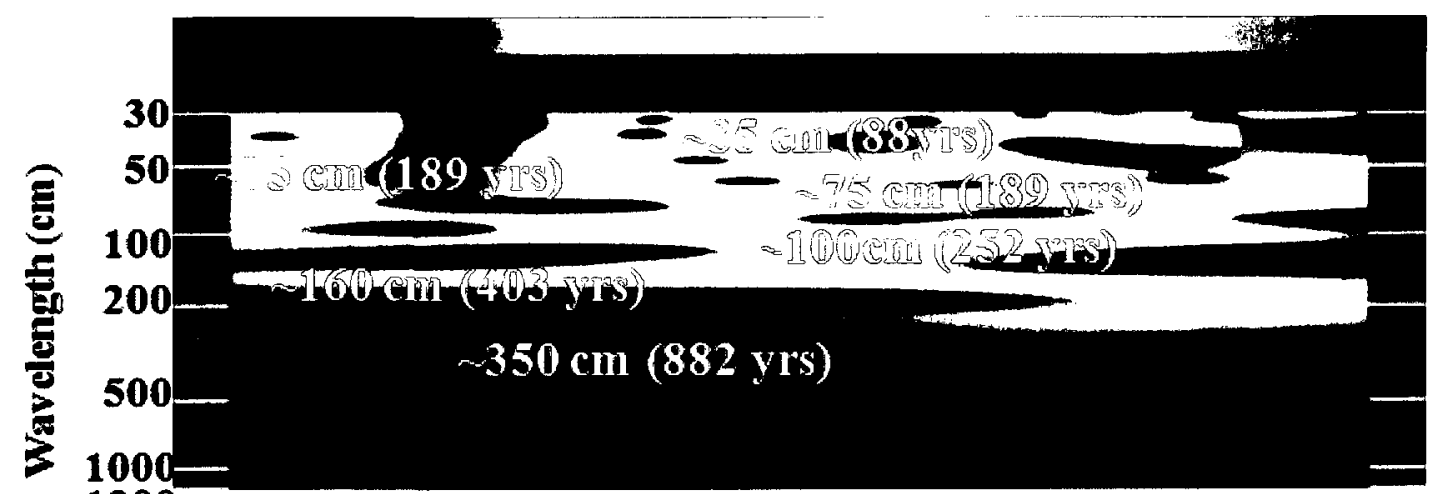
1200

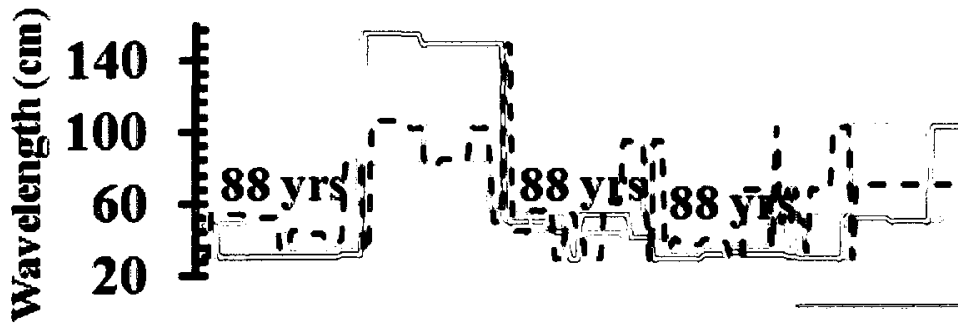

$1^{\text {st }}$ Strongest wavelength $2^{\text {nd }}$ Strongest wavelength

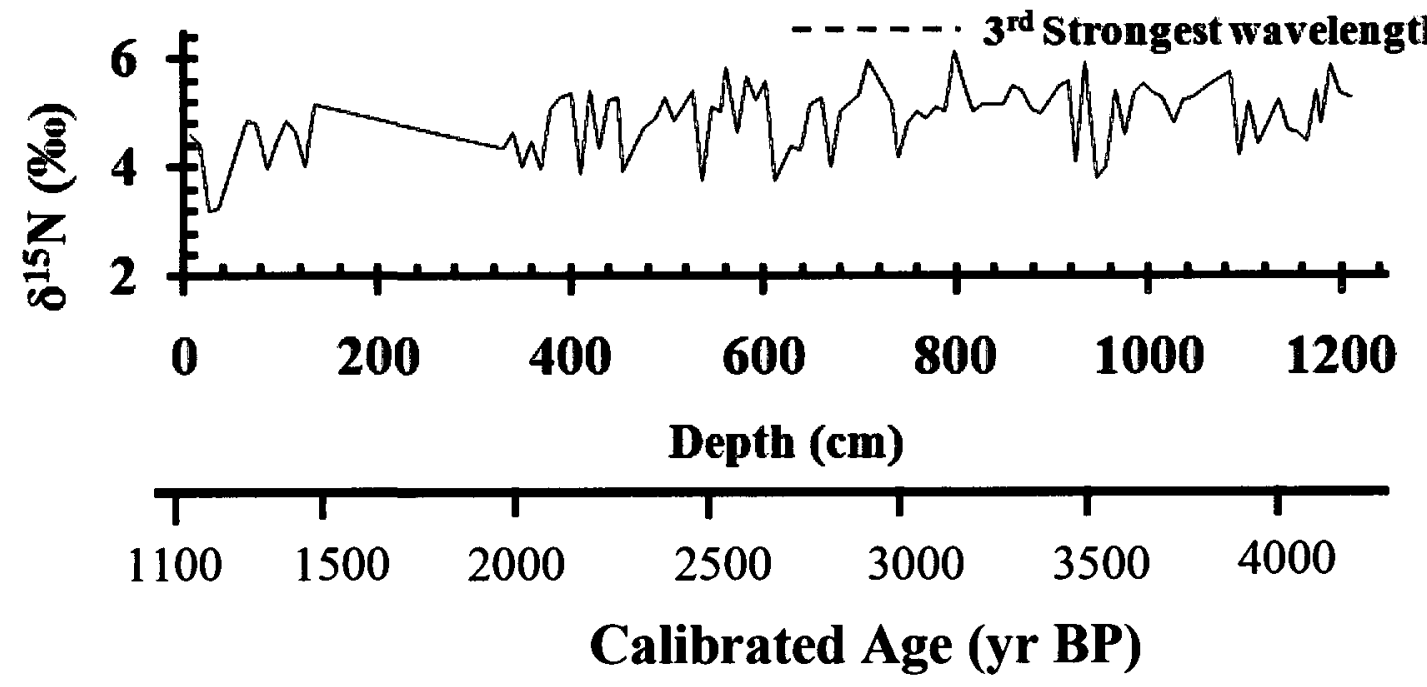

Figure 5.19. Wavelet analysis of $\delta^{15} \mathrm{~N}$ in the Frederick Sound core. 

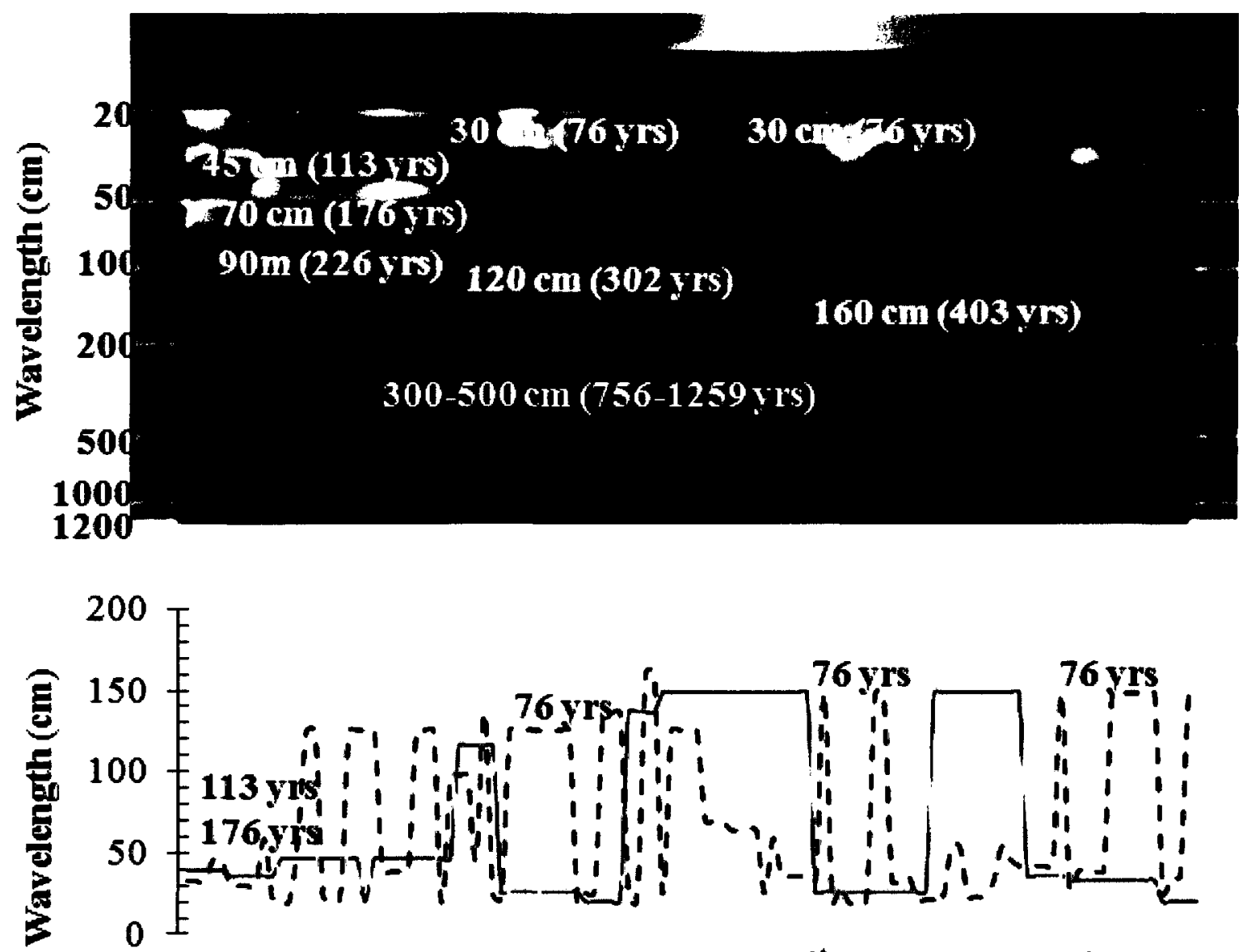
$1^{\text {st }}$ Strongest wavelength $2^{\text {nd }}$ Strongest wavelength

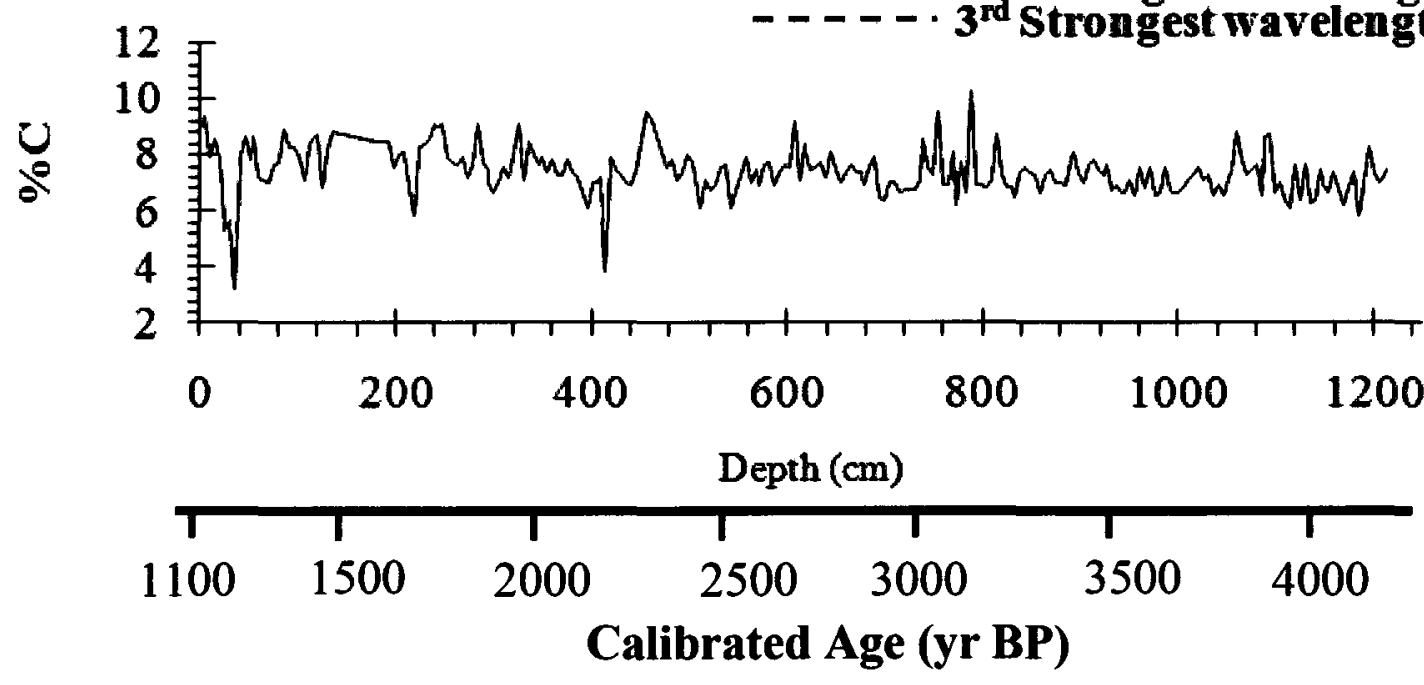

Figure 5.20. Wavelet analysis of $\% \mathrm{C}_{\text {org }}$ in the Frederick Sound core. 
period of the ALS core (1000-3500 cal yr BP) indicates a predominance of a 500-year cycle (Figure 5.21). Cycles with 208 and 125-year periodicities are the next most prominent ones while the 147, 96-104, and 66-year cycles with low amplitudes, are also significantly present. Wavelet analysis of the organic carbon, $\delta^{13} \mathrm{C}$ and $\delta^{15} \mathrm{~N}$ data reveals the presence of weak and non-persistent 750-1000-year cyclicity spanning throughout the $\sim 2500$ year ofdeposition of the ALS core interval (Table 5.9, Figures 5.23-5.25). A non-stationary 70-80year cycle is the most intense periodicity in all proxy records. This wavelength band occurs as a 70-year cycle in the $\delta^{13} \mathrm{C}$ and $\delta^{15} \mathrm{~N}$ and as a 75-80-year periodicity in the $\mathrm{C}_{\text {org }}$ records. A 100-140-year cycle is the next most intense cycle in the organic matter proxies. This cycle is represented as a 120 -year cycle in the $\delta^{15} \mathrm{~N}$ and as a 140 year periodicity in the organic carbon record and a 100-140-year cycle in $\delta^{13} \mathrm{C}$. The less intense $250-350$-year cycle is present in all the three proxies, occurring as a $250-280$-year band in the $\delta^{13} \mathrm{C}$ and $\delta^{15} \mathrm{~N}$, and as a 250-350year cycle in the organic carbon data. The time spanned by each cycle is provided as cal yr BP. 
Table 5.8. Results of the spectral analysis of geochemical proxies from the Alison Sound (ALS) core.

\begin{tabular}{|c|c|c|c|c|}
\hline Proxy & 34-67-year & 71-139-years & $\sim$ 150-236-years & 250-500-years \\
\hline $\mathrm{C}_{\text {org }}$ & $44-62$ & $79,98,112,139$ & $156,213^{*}$ & 294 \\
\hline $\mathrm{N}_{\text {total }}$ & 67 & $71-76,107,139$, & $156,213^{*}$ & 337 \\
\hline $\mathrm{C}_{\text {org }} / \mathrm{N}_{\text {total }}$ & $34-67$ & $81,94,108^{*}, 139$ & & \\
\hline$\delta^{13} \mathrm{C}$ & & $76,92,117,139$ & $157^{*}, 236$ & \\
\hline$\delta^{15} \mathrm{~N}$ & $44,47-50,64$ & $81,98,118^{*}$ & $196^{*}$ & \\
\hline $\mathrm{Ba}$ & & 97 & 167,213 & $476^{*}$ \\
\hline $\mathrm{Mo}$ & & $97^{*}, 111$ & 156,179 & \\
\hline $\mathrm{U}$ & & $78-101,137$ & $155,194^{*}$ & 259 \\
\hline $\mathrm{V}$ & & $75-101$ & $146,167,212^{*}$ & 333 \\
\hline${ }^{14} \mathrm{C}$ & 66 & $96-104,125$ & $125,147,208$ & $500^{*}$ \\
\hline
\end{tabular}

*The most significant cycle in each proxy

Table 5.9. Wavelet Results showing temporal distribution of cycles in Alison Sound (ALS) core.

\begin{tabular}{|l|l|l|l|l|}
\hline Proxy & 70-80-year * & 100-140-year * & 250-350-year & 750-1000-year \\
\hline $\mathrm{C}_{\text {org }}$ & $1156-1628$ & $1000-1628$ & $1000-1705$ & \\
\hline$\delta^{13} \mathrm{C}$ & $\begin{array}{l}2198-2651 \\
2965-3500\end{array}$ & $1156-1785$ & $1000-3500$ & $1000-3500$ \\
\hline$\delta^{15} \mathrm{~N}$ & $\begin{array}{l}1156-1805 \\
2252-3500\end{array}$ & $1156-1805$ & $1000-1705$ & $1000-3500$ \\
\hline
\end{tabular}

${ }^{*}$ Most intense cycle length in each proxy. 

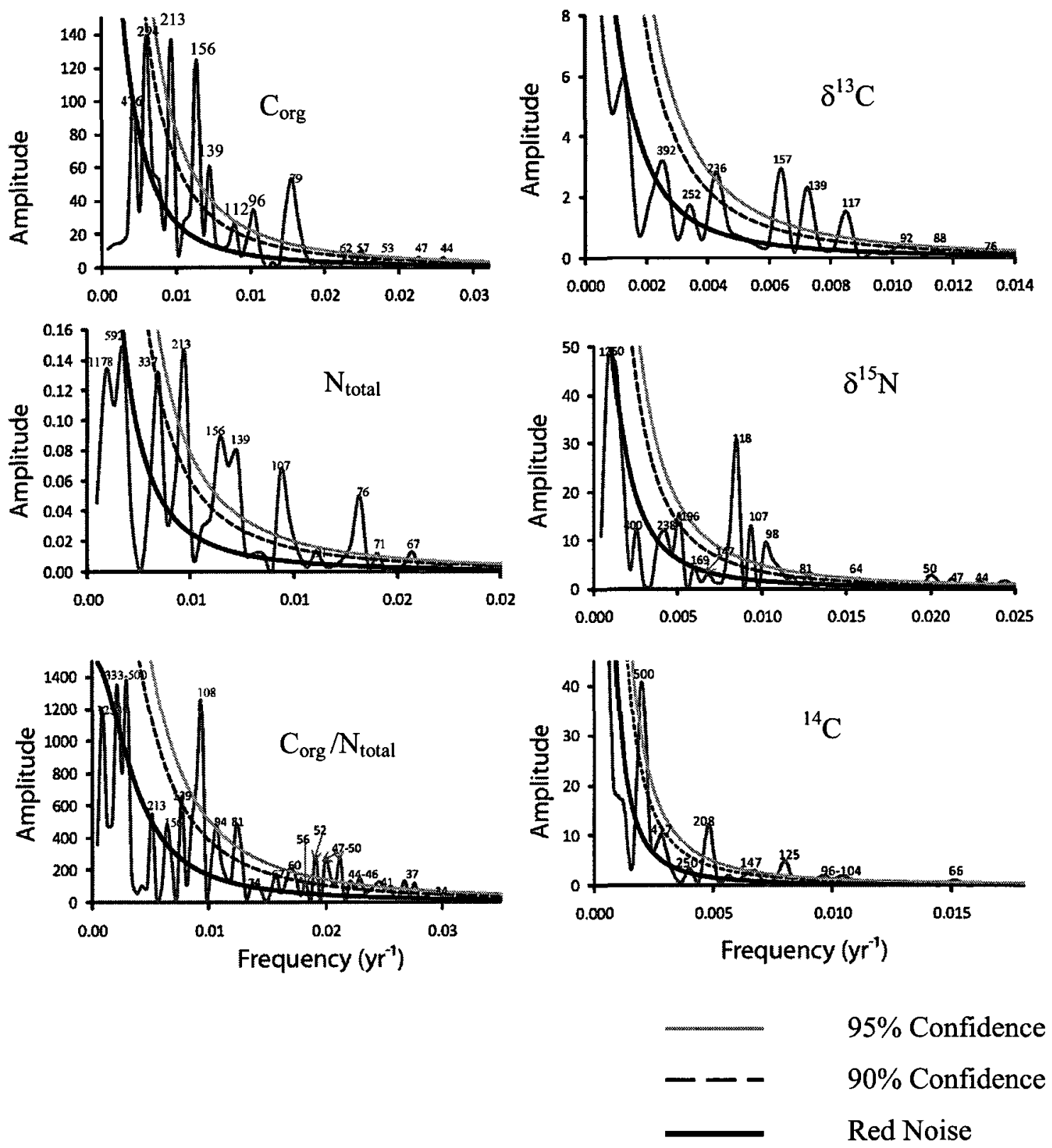

Figure 5.21. Spectral analysis of organic matter proxies in the Alison Sound core and ${ }^{14} \mathrm{C}$ production rate. 

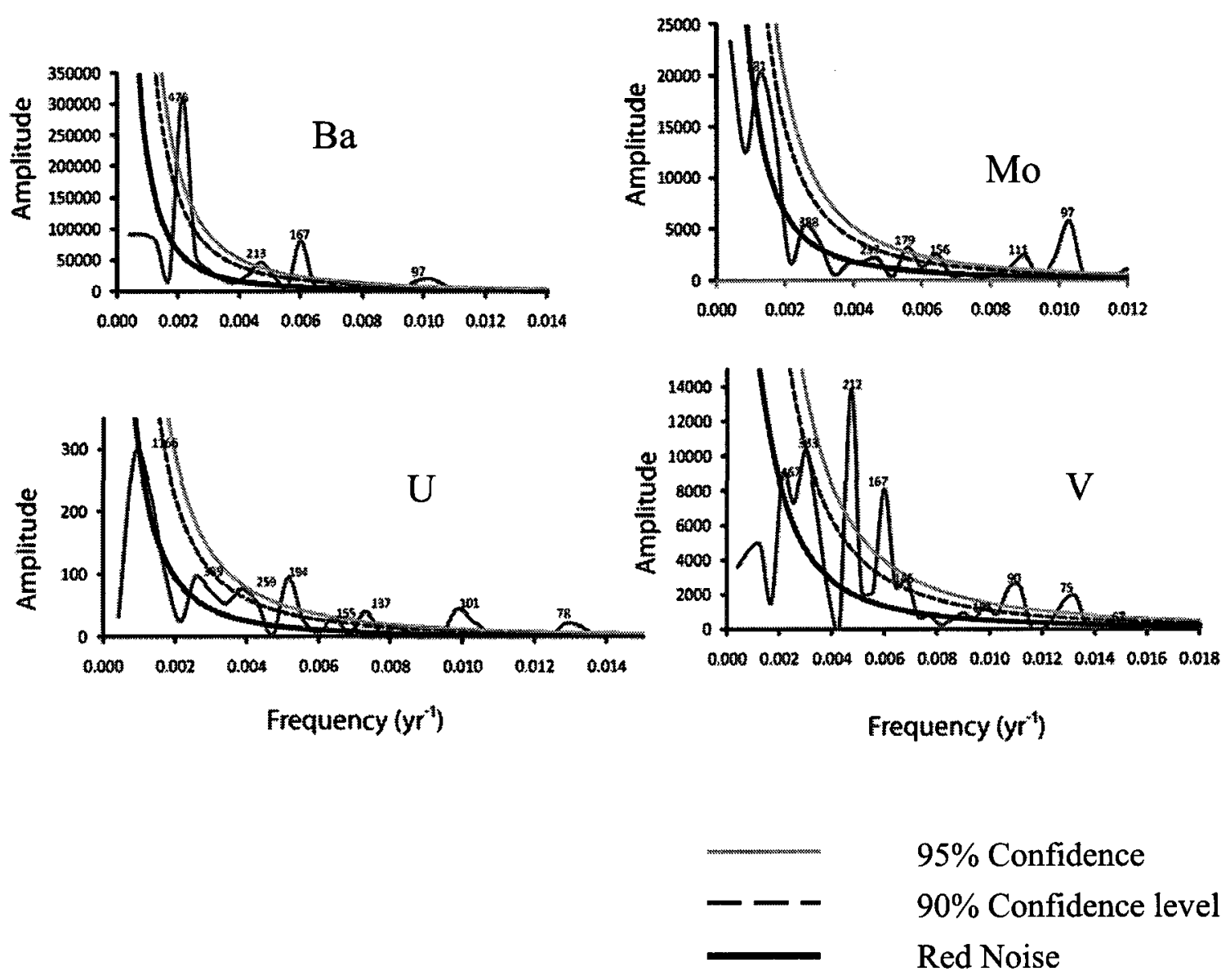

Figure 5.22. Spectral analysis of some redox related elements in the Alison Sound core. 

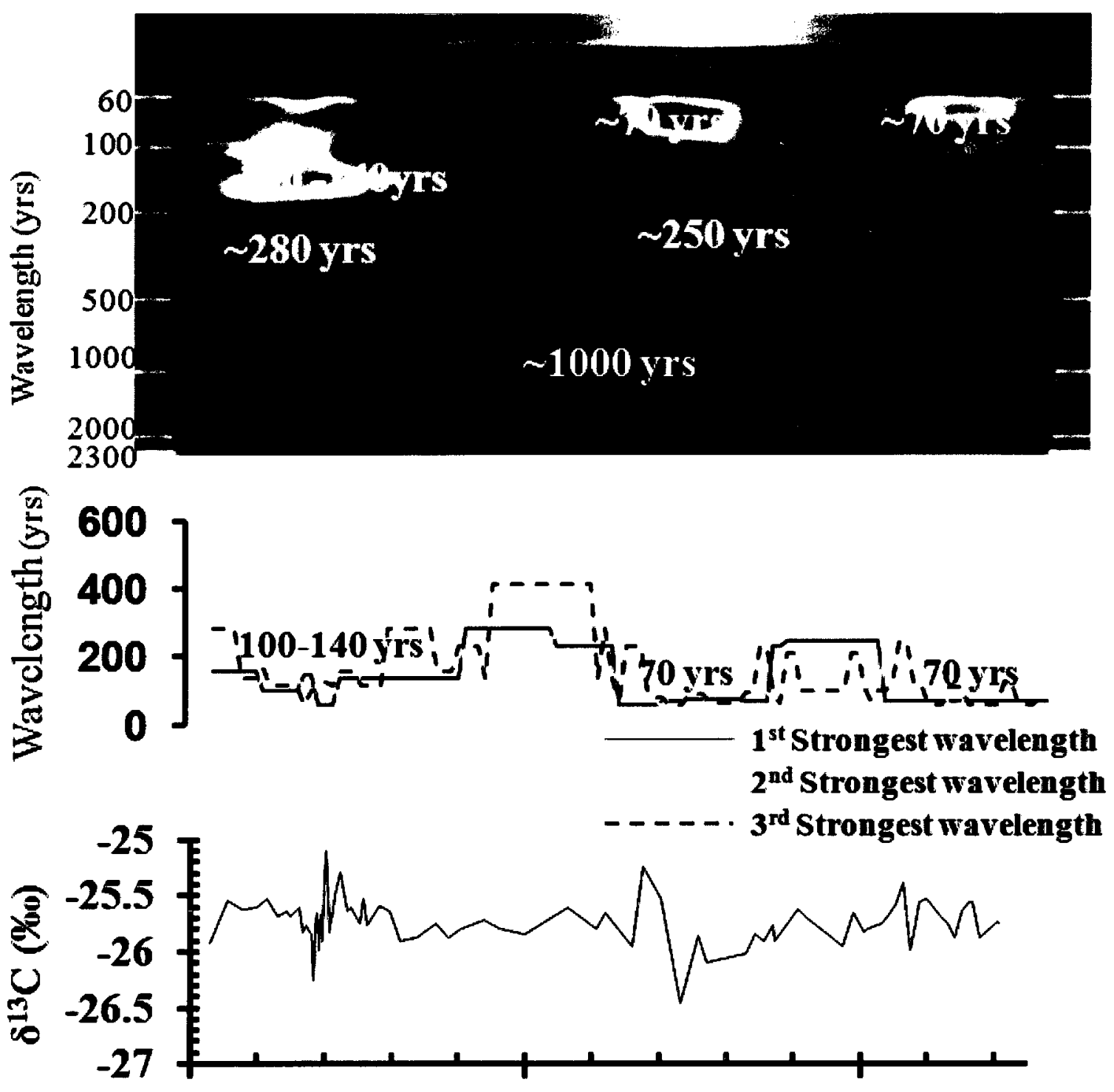

1000

2000

3000

Calibrated Age (yr BP)

Figure 5.23. Wavelet analysis of $\delta^{13} \mathrm{C}$ in the Alison Sound core. 


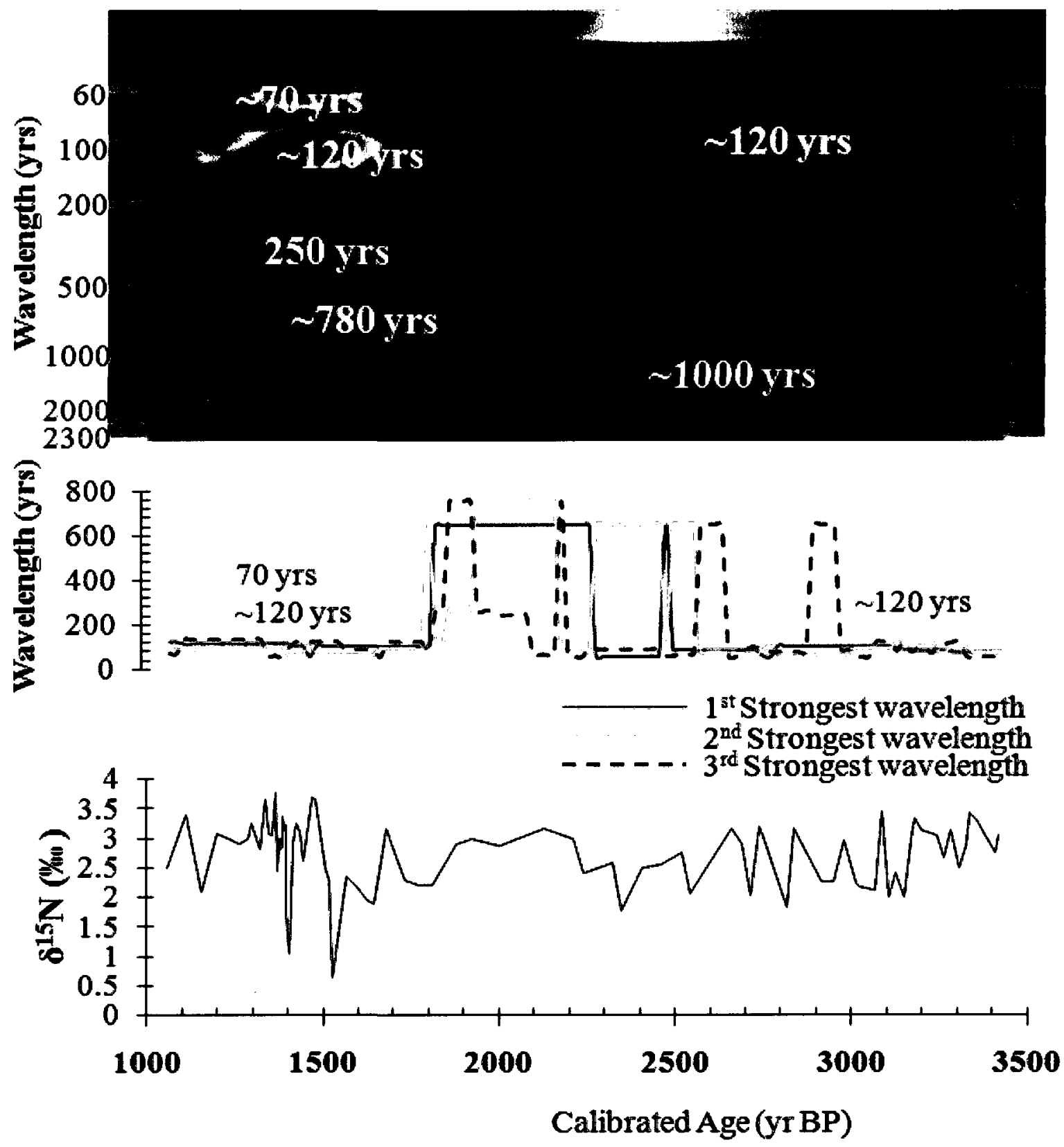

Figure 5.24. Wavelet analysis of $\delta^{15} \mathrm{~N}$ in the Alison Sound core. 


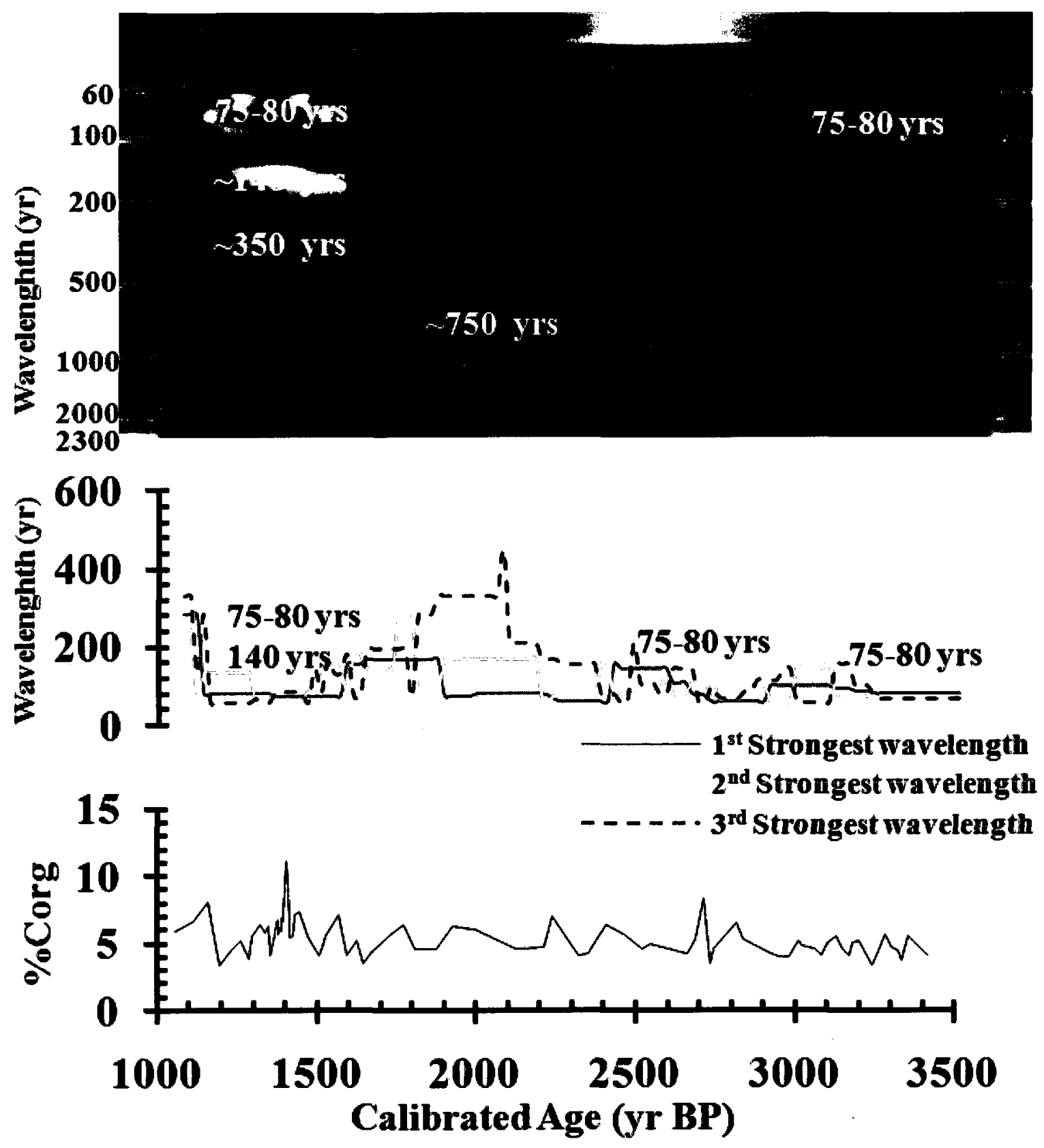

Figure 5.25. Wavelet analysis of $\% \mathrm{C}_{\text {org }}$ in the Alison Sound core. 


\subsubsection{Climate Intervals}

In this section, the organic geochemical data and wavelet results are compared with the 14-carbon $\left({ }^{14} \mathrm{C}\right)$ production rate data of Bond et al. (2001) to identify climate events archived in the core sediments from both the FS and ALS cores. A comparison of the ${ }^{14} \mathrm{C}$ production rate data with the geochemical data shows that it is positively related to the $\delta^{13} \mathrm{C}$ data (Figures 5.26-5.27). High values of $\delta^{13} \mathrm{C}$ are recorded at or near the age intervals where ${ }^{14} \mathrm{C}$ production rates are high. On the other hand lighter values of the proxy are observed where ${ }^{14} \mathrm{C}$ production rates are low. The $\delta^{15} \mathrm{~N}$, biogenic silica, organic carbon and $\mathrm{Ba} / \mathrm{Al}$ ratio are inversely related to ${ }^{14} \mathrm{C}$ (Figures $5.13 ; 5.26-5.27$ ). There are appreciable time lags between the ${ }^{14} \mathrm{C}$ events and those of the organic matter proxies.

The distribution of the $\delta^{13} \mathrm{C}$ and $\delta^{15} \mathrm{~N}$, their wavelet patterns and variations in laminae thickness indicate the existence of five climate intervals throughout the entire $\sim 3100$ years of the FS core and $\sim 2500$ years of the ALS core depositional records (Figures 5.26-5.27). The characteristics of these climate intervals are summarized in Tables 5.10-5.11. 
Table 5.10. Climate Intervals in the Frederick Sound (FS) core.

\begin{tabular}{|c|c|c|c|}
\hline $\begin{array}{l}\text { Climate Interval } \\
\text { (Depth (cm)) }\end{array}$ & $\begin{array}{c}\text { Calibrated } \\
\text { Age (yr BP) }\end{array}$ & Conditions & Attributes \\
\hline $\begin{array}{l}\text { CLI5 } \\
(65-0)\end{array}$ & $1288-1100$ & Cool/Wet & $\begin{array}{ll}\text { - } & \text { Light } \delta^{13} \mathrm{C} \text {; light } \delta^{15} \mathrm{~N} \\
\text { - } & \text { Increased in laminae thickness } \\
\text { - } & \text { Low productivity } \\
\text { - } & \text { Prominent } 65-88-y e a r \text { cycle in biogenic } \\
& \text { silica, } \delta^{13} \mathrm{C} \text { and } \delta^{15} \mathrm{~N}\end{array}$ \\
\hline $\begin{array}{c}\text { CLI4 } \\
(135-65)\end{array}$ & $1464-1288$ & Cooler/Dry & $\begin{array}{l}\text { - Heavy } \delta^{13} \mathrm{C} \text {; light } \delta^{15} \mathrm{~N} \\
\text { - } \quad \text { Decreased laminae thickness } \\
\text { - } \text { Reduced productivity } \\
\text { - } 75-88 \text {-year and } 176-226 \text {-year cycles are } \\
\text { present in } \delta^{13} \mathrm{C} ; \delta^{15} \mathrm{~N} \text { and biogenic silica; } \\
\text { - } 113 \text {-yr cycle in the } \mathrm{C}_{\text {org }}\end{array}$ \\
\hline $\begin{array}{c}\text { CLI3 } \\
(330-135)\end{array}$ & 1956-1464 & Cool/Wet & $\begin{array}{l}\text { - Gradual uphole increase in laminae } \\
\text { - } 75 \text {-year, } 113 \text {-year and } 250 \text {-year cycles } \\
\text { are present in the biogenic silica and } \\
\mathrm{C}_{\text {org records }} \\
\text { - High productivity } \\
\text { - Lack of isotope data }\end{array}$ \\
\hline $\begin{array}{c}\text { CLI 2 } \\
(798-330)\end{array}$ & $3135-1956$ & Cooler/Dry & $\begin{array}{l}\text { - Heavy } \delta^{13} \mathrm{C} \text { (shift to heavy values at } \\
3135 \text { cal yr BP) } \\
\text { - } \delta^{15} \mathrm{~N} \text { fluctuates, mostly below the } \\
\text { average } \\
\text { - Intense } 65-88-y e a r, 113 \text {-year and } 189- \\
\text { year cycles in } \delta^{13} \mathrm{C} ; \delta^{15} \mathrm{~N} \text { and biogenic } \\
\text { silica records } \\
\text { - Laminae thickness increases towards the } \\
\text { top } \\
\text { - High productivity }\end{array}$ \\
\hline $\begin{array}{c}\text { CLI1 } \\
(1226-798)\end{array}$ & $\begin{array}{c}4200-3135 \\
\text { cal yr BP }\end{array}$ & Cool/Wet & $\begin{array}{l}\text { - } \text { Light } \delta 13 \mathrm{C} \text { (below the average of } \\
-25.27 \% \text { ) } \\
\text { - Heavy } \delta 15 \mathrm{~N} \text { (above the average of } \\
4.9 \% \text { ) } \\
\text { - High laminae thickness } \\
\text { - } 65-88 \text {-year, } 176-189 \text {-year and } 220-302- \\
\text { year cycles are present in biogenic silica } \\
\text { and } \delta 13 \mathrm{C} \text {, and } \delta 15 \mathrm{~N} \text { records } \\
\text { - High productivity }\end{array}$ \\
\hline
\end{tabular}


Table 5.11. Climate Intervals in the Alison Sound (ALS) core.

\begin{tabular}{|c|c|c|c|}
\hline $\begin{array}{l}\text { Climate Interval } \\
\text { (Depth (cm)) }\end{array}$ & $\begin{array}{c}\text { Calibrated } \\
\text { Age (yr BP) }\end{array}$ & Conditions & Attributes \\
\hline $\begin{array}{l}\text { CLI5 } \\
(232-0)\end{array}$ & $1405-1000$ & Cool/Wet & $\begin{array}{l}\text { Predominantly light } \delta^{13} \mathrm{C} \\
\text { - } \delta^{15} \mathrm{~N} \text { fluctuations } \\
\text { - Laminae thickness and grain size increase } \\
\text { uphole } \\
\text { - Intense } 70-80-y r \text { and } 100-140-y r \text { cycles in } \\
\delta^{13} \mathrm{C} \text { and } \delta^{15} \mathrm{~N} \\
\text { - Moderately intense } 280-350-y r \text { cycle in } \\
\delta^{13} \mathrm{C} \text { and } \mathrm{C}_{\text {org }} \text { records }\end{array}$ \\
\hline $\begin{array}{c}\text { CLI4 } \\
(354-232)\end{array}$ & $1627-1405$ & Cooler/Dry & $\begin{array}{ll}\text { - } & \text { Peak } \delta^{13} \mathrm{C} \text { values } \\
\text { - } & \text { Light } \delta^{15} \mathrm{~N} \\
\text { - } & \text { Reduced laminae thickness and mean grain } \\
\text { size } \\
\text { - } \\
\text { - } \\
\text { Promh productivity } \\
\text { in } \delta^{13} \mathrm{C} \text { and } 70-80 \text {-yr and } 100-140 \text {-yr cycles } \\
\text { - } 280-350 \text {-yr cycle present in } \delta^{13} \mathrm{C} \text { and } \mathrm{C}_{\text {org }}\end{array}$ \\
\hline $\begin{array}{c}\text { CLI3 } \\
(488-354)\end{array}$ & $2238-1627$ & $\mathrm{Cool} / \mathrm{Wet}$ & $\begin{array}{l}\text { - Light } \delta^{13} \mathrm{C} \text {; heavy } \delta^{15} \mathrm{~N} \\
\text { - High laminae thickness, reduced grain size } \\
\text { - } 75 \text {-yr and } 100 \text {-yr cycles in } \delta 13 \mathrm{C} ; 250-280 \\
\text { and } 780-1000 \text { in } \delta^{13} \mathrm{C} \text { and } \delta^{15} \mathrm{~N} \\
\text { - } \quad \text { Low productivity } \\
\end{array}$ \\
\hline $\begin{array}{c}\text { CLI } 2 \\
(528-488)\end{array}$ & $2462-2238$ & Cooler/Dry & $\begin{array}{l}\text { - Shift to heavy } \delta^{13} \mathrm{C} \text { at } 2462 \text { cal yr } \mathrm{BP} \text {; } \\
\text { predominantly light } \delta^{15} \mathrm{~N} \\
\text { - Prominent } 70-80 \text { cycle in } \delta 13 \mathrm{C} \text { and } \mathrm{C}_{\text {org; }} \text {; } \\
100-120 y r \text { cycle in } \mathrm{C}_{\text {org }} \\
\text { - Low laminae thickness } \\
\text { - Low productivity }\end{array}$ \\
\hline $\begin{array}{c}\text { CLI1 } \\
(872-528)\end{array}$ & $3500-2462$ & Cool/Wet & $\begin{array}{l}\text { - } \text { Light } \delta 13 \mathrm{C} \text { (uphole decrease) } \\
\text { - } \delta 15 \mathrm{~N} \text { fluctuations } \\
\text { - } \quad \text { High laminae thickness } \\
\text { - } \quad \text { Prominent } 75-80 \text { and } 100 \mathrm{yr} \text { cycles in Corg; } \\
\text { 100-140-yr cycle in } \delta 13 \mathrm{C} \text { and } \delta 15 \mathrm{~N} \\
\text { - High productivity }\end{array}$ \\
\hline
\end{tabular}




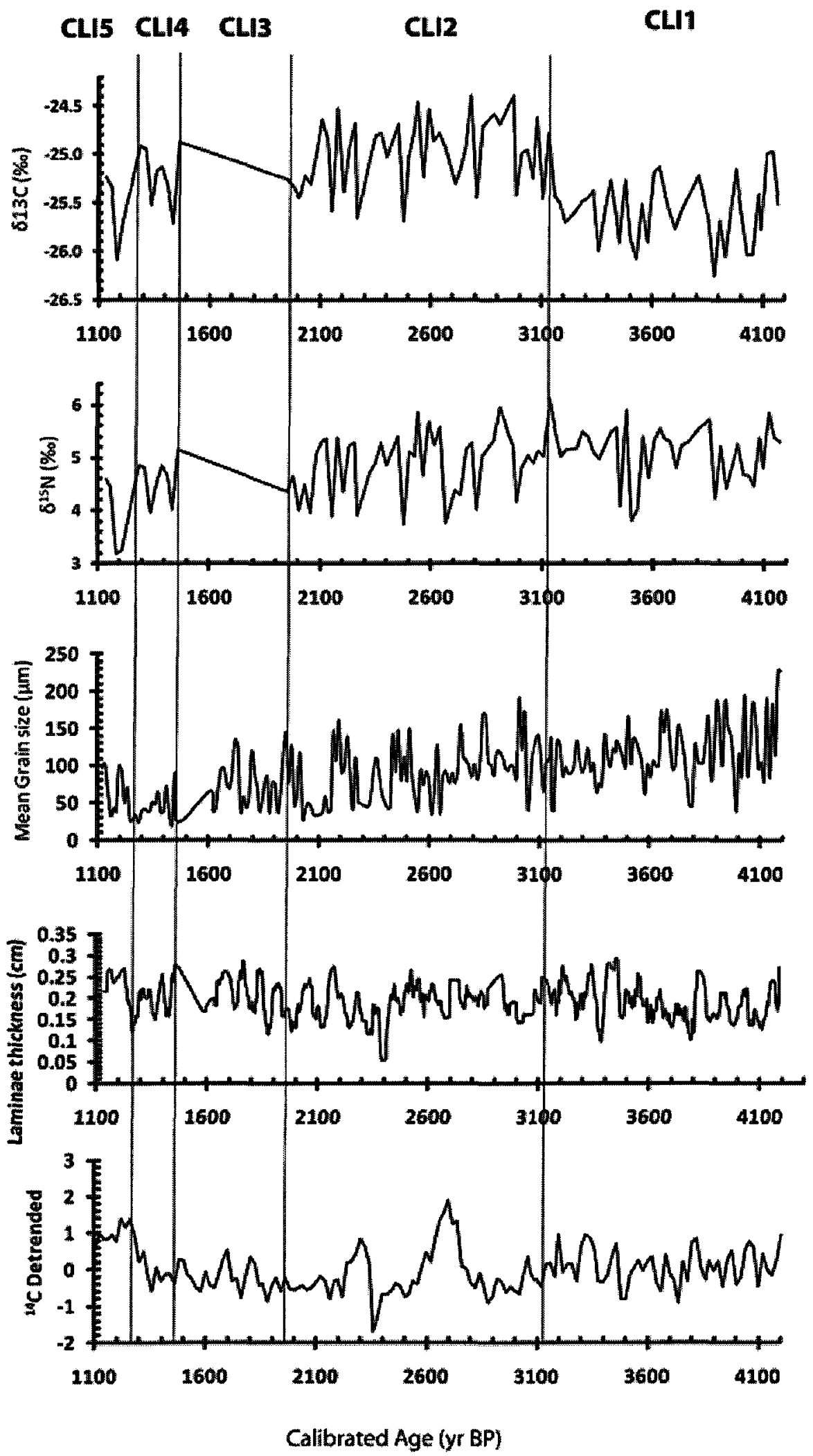

Figure 5.26. Climate proxies in the Frederick Sound core. Distribution of the $\delta^{13} \mathrm{C}$ and $\delta^{15} \mathrm{~N}$ shows five climate intervals in Frederick Sound. 


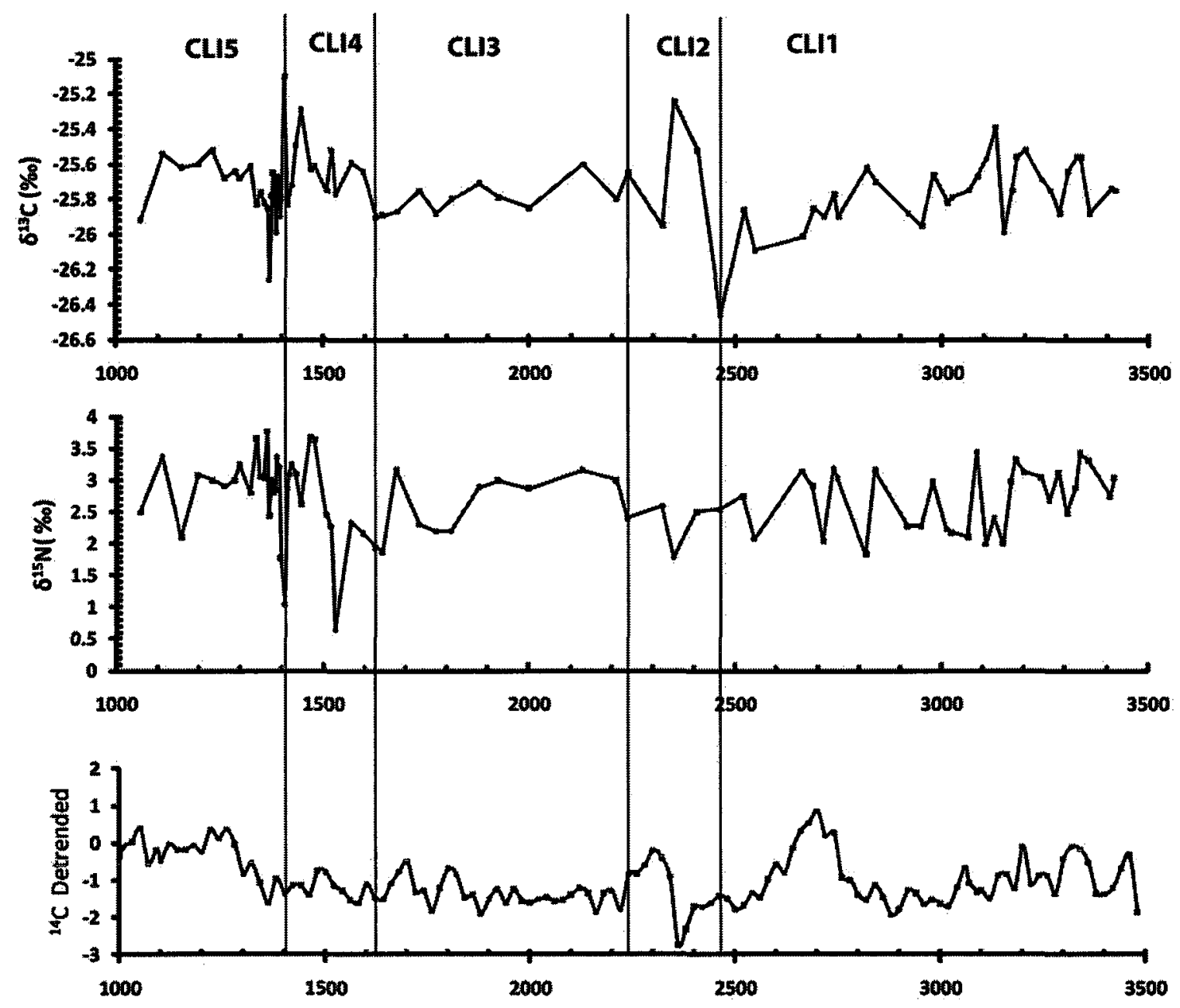

Calibrated Age (yr BP)

Figure 5.27. Climate proxies in the Alison sound core. Distribution of $\delta^{13} \mathrm{C}$ and $\delta^{15} \mathrm{~N}$ indicates five climate intervals in the Alison Sound. 


\subsection{DISCUSSION}

\subsubsection{Origin of organic matter}

The $\mathrm{C}_{\text {org }} / \mathrm{N}_{\text {total }}$ ratio, $\delta^{13} \mathrm{C}$ and $\delta^{15} \mathrm{~N}$ stable isotopes are widely used to determine sources of sedimentary organic matter (Prahl et al., 1980; Premuzic et al., 1982; Prahl et al., 1994; Meyers , 1994; 1997, McKay et al., 2004). The values of these proxies in both the FS and ALS cores are within the terrigenous materials' values. The $\mathrm{C}_{\text {org }} / \mathrm{N}_{\text {total }}$ ratio, with an average of 17.12 in the FS core and 22.15 in the ALS core, is similar to the average values of this proxy reported from neighbouring fjords to the SBIC. For example, Timothy et al. (2003) assigned a $\mathrm{C}_{\text {org }} / \mathrm{N}_{\text {total }}$ ratio value of 21 to a terrigenous source in Saanich and Javis Inlets. Similarly, Hay (2005) attributes a mean $\mathrm{C}_{\text {org }} / \mathrm{N}_{\text {total }}$ value of 14.9 in laminated sediments of Effingham Inlet, Vancouver Island, to terrigenous origin. Prahl et al. (1980) determined that any values of $\mathrm{C}_{\text {org }} / \mathrm{N}_{\text {total }}>12$ indicate a terrigenous origin. According to Tyson (1995), the values of $\mathrm{C}_{\mathrm{org}} / \mathrm{N}_{\text {total }}$ ranging from 12 and above indicate the presence of $\mathrm{C} 3$ vascular plants whereas values higher than 30 signify that of C4 plants. Meyers $(1994 ; 1997)$ and McKay et al. (2004) assigned $\mathrm{C}_{\text {org }} / \mathrm{N}_{\text {total }}$ values greater than 20 to the presence of vascular plants.

The $\delta^{13} \mathrm{C}$ mean values of $-25.27 \%$ in the FS core and $-25.74 \%$ in the ALS core are also similar to those of terrestrial plants, in particular C3 plants. The SBIC is situated within the Coastal Western Hemlock biogeoclimate $(\mathrm{CWH})$ zone where the vegetation is mainly comprised of C3 plants (Meidinger and Pojar, 1991). The C4 plants are generally rare throughout the coastal areas of Washington and British Columbia (Teeri and Sotwe, 1976). Similar light values of $\delta^{13} \mathrm{C}$ are reported from adjacent regions to the SBIC including -25.1\% and $-26.5 \%$ mean values encountered in soils around Saanich and Javis Inlets, respectively (Timothy et al., 2003). Tunnicliffe (2000) also reported an average value of $-27 \%$ for $\delta^{13} \mathrm{C}$ in 
laminated sediments from Saanich Inlet. The terrestrial plants washed down by the Fraser River are characterized by a $\delta^{13} \mathrm{C}$ average value of $-27 \%$ which is similar to the average value of $-25.7 \%$ obtained from analysis of vegetation washed down by the Columbia River (Prahl et al., 1994), and a -26\% reported from generic northwest Pacific sediments (Peters et al., 1978). The average $\delta^{15} \mathrm{~N}$ values of $4.9 \%$ in the sediments of the FS core and $2.72 \%$ in those of the ALS core are comparable to the previously reported average terrestrial value of $\sim 4 \%$ (Kao and Liu, 2000).

The plot of $\mathrm{C}_{\text {org }} / \mathrm{N}_{\text {total }}$ against $\delta^{13} \mathrm{C}$ is also useful in determining the level of any probable admixture of marine and terrigenous organic matter in sediments (Johnson and Grimm, 2001; McQuoid et al., 2001; Emmer and Thunnel, 2000; McKay et al., 2004) and can be used to identify the different plant sources of organic matter (Meyers, 1994; 1997; Lamb et al., 2006). The plots of the proxies $\left(\mathrm{C}_{\mathrm{org}} \mathrm{N}_{\text {total }}\right.$ and $\left.\delta^{13} \mathrm{C}\right)$ in the FS and ALS cores signify nonzero intercepts. This result suggests that there was not any mixing of marine and terrigenous derived organic matter in the core sediments of these inlets (e.g., Johnson and Grimm, 2001; McQuoid et al., 2001, McKay et al., 2004; Emmer and Thunnel, 2000). The poor correlation between $\delta^{13} \mathrm{C}$ and $\delta^{15} \mathrm{~N}$ in the FS and ALS cores provides additional evidence of the lack of mixing of marine and terrigenous organic matter in the SBIC. Stronger positive correlations between these two isotopes are required to allow the inference of a mixture of marine and terrigenous organic matter (McQuoid et al., 2001; McKay et al., 2004).

The non-zero intercept of the linear regression line between $\mathrm{C}_{\text {org }}$ and $\mathrm{N}_{\text {total }}$ also indicates that the nitrogen in the sediments of the FS and ALS cores was not completely of an organic origin. A very high level of correlation between these two proxies with a zero intercept is generally considered to indicate nitrogen derived from a mainly organic source 
(e.g., Hedges et al., 1988, Pride et al., 1999; Emmer and Thunnel, 2001; McKay et al., 2004). The observed positive intercept of the trend line in this study, however, shows that a certain proportion of the total nitrogen present in the inlets is derived from inorganic sources and presence of excess nitrogen adsorbed onto particle surfaces (Pride et al., 1999; Emmer and Thunnel, 2000; McKay et al., 2004).

\subsubsection{Lithogenic Indices}

The occurrence of high concentrations of Al in both the FS and ALS cores is consistent with the predominance of mud sediments in the sediments of both cores. This is also an indication that the sediments of these inlets are likely rich in aluminosilicates, mainly clay minerals. The existence of strong correlations between $\mathrm{Al}$ and metals such as $\mathrm{Ca}, \mathrm{Ti}, \mathrm{Mg}$ and $\mathrm{Mn}$ (Figure 5.6) suggests that these elements co-occur with $\mathrm{Al}$ in the same mineralogical phases, likely clay minerals or feldspars (Barron et al., 2004). Likewise, the strong relationship between $\mathrm{Ca}$ and $\mathrm{Al}$ suggests that non-carbonate calcium is contained in aluminosilicates (Calvert, 1976).

The high concentrations of $\mathrm{Ti}$ and its oxide also suggests the presence of titaniumbearing detrital minerals including ilmenite (Hirst, 1962), anatase and rutile (van Andel and Postma, 1954; Calvert, 1976). The positive correlation of $\mathrm{Al}$ and Ti with a non-zero intercept in their bivariate plot is an indication that the Al contained in the core was derived through diagenetic changes in the sediments (Mackin and Aller, 1984). The strong correlation between $\mathrm{Al}$ and $\mathrm{Mg}$, and the high ratio of $\mathrm{MgO} / \mathrm{Al}_{2} \mathrm{O}_{3}$ in the $\mathrm{FS}$ core indicate likely abundance of $\mathrm{Mg}$ bearing clay minerals for example, montmorillonite in the core sediments (e.g., Calvert, 1976). In contrast, $\mathrm{Mg}$ which is poorly correlated to Al in the ALS core has a strong relationship with $\mathrm{Fe}$ in the core's sediments. Since $\mathrm{Fe}$ and $\mathrm{Mg}$ replace each other in 
ferromagnesian minerals, their strong correlation in the ALS core suggests that mafic rock forming minerals and/or Fe-Mg bearing clay minerals such as illite, chlorite, montmorillonite and mica are likely present in the inlet (Calvert, 1976).

The $\mathrm{Fe}_{2} \mathrm{O}_{3} / \mathrm{Al}_{2} \mathrm{O}_{3}$ ratio (Table 5.2) in the sediments of both the FS and ALS cores are higher than the 0.52 threshold (Calvert, 1976) suggesting the presence of iron-bearing authigenic minerals such as limonite and illite in the core. The values of this ratio are also an indication that the Fe in both cores is probably held in aluminosilicate minerals. The poor correlation between $\mathrm{Ca} / \mathrm{Al}$ and $\mathrm{Mg} / \mathrm{Al}$ suggests the absence of dolomite in ALS and FS cores (e.g., Johnson and Grimm, 2001). The observed poor relationship between $\mathrm{P} / \mathrm{Al}$ and $\mathrm{Ca} / \mathrm{Al}$ indicates the lack of apatite in the sediments. Usually, the presence of a strong correlation between $\mathrm{Ca} / \mathrm{Al}$ and these two $(\mathrm{P} / \mathrm{Al}$ and $\mathrm{Mg} / \mathrm{Al})$ ratios signifies the presence of apatite or dolomite in sedimentary content (Johnson and Grimm, 2001).

Certain trace elements such as zirconium $(\mathrm{Zr})$, thorium $(\mathrm{Th})$ and rubidium $(\mathrm{Rb})$ could also serve as excellent indices of mineralogical composition of terrigenous sediments. For instance, $\mathrm{K}$ and $\mathrm{Rb}$ usually replace each other in lattice structures of minerals such as clay minerals and feldspars due to their close atomic radii (Francois, 1988; Calvert et al., 2001; Johnson and Grimm 2001; McKay et al., 2004). These elements have positive correlations in the FS $\left(r^{2}=0.28\right)$ and in ALS $\left(r^{2}=0.87\right)$ cores suggesting that they might have co-existed in the same mineralogical phase. Rubidium resides more in mica than in feldspars (Rankama and Sahama, 1950; Francois, 1988; Calvert et al., 2001) and is abundant in felsic rocks (Francois, 1988). Fine grained mica flakes are abundant in the cores, therefore, the measured rubidium concentrations were likely mainly derived from mica. 


\subsubsection{Paleooceanography}

The redox related elements and indices such as $\mathrm{Cd}, \mathrm{Cu}, \mathrm{Cr}, \mathrm{Mo}, \mathrm{U}, \mathrm{V}$ and $\mathrm{Zn}$ are highly enriched throughout the FS and ALS core intervals. The concentrations of most of these elements and indices are generally well above their crustal limits suggesting that they were enriched under suboxic to anoxic conditions. The observed poor or negative correlation of $\mathrm{Al}$ to redox related elements (e.g., $\mathrm{Cd}, \mathrm{Ni}, \mathrm{Mo}, \mathrm{U}$ and $\mathrm{Zn}$ ) in the investigated samples suggest that the redox sensitive elements were not derived from silicate sources (Calvert, 1976).

The distribution of redox potentials and concentrations of the analyzed elements are similar in both the laminated and massive sediments of the FS and ALS cores. These similar distributional patterns in the two sediment types indicate that they were likely deposited under similar environmental conditions. The absence of any bioturbation or evidence of any other benthic activities within the massive sediments provides additional support for this interpretation.

Russell and Morford (2001) observed a similar redox element distributional patterns in laminated and massive layers in a core retrieved from Ocean Drilling Project (ODP) Site 1033 (Leg 169S) in Saanich Inlet. They concluded that both the laminated and homogeneous intervals were deposited under similar redox conditions. The authors hypothesized that if the homogeneous sediments were deposited under oxygenated conditions, the concentrations of elements such as Mo, $\mathrm{U}, \mathrm{Cd}$ and $\mathrm{V}$ would have been close to their detrital levels and the laminated sediments would have been more enriched in these elements than the massive sediments. Furthermore, the enrichment of the oxic indicator-Mn would have also been significantly higher in the massive sediments than in the laminated sediments. Russell and Morford (2001) also determined that the initially laminated sediments deposited in shallow 
euxinic environments in Saanich Inlet were reworked, homogenized and redeposited as massive layers by debris flow at deeper depths. Based on sedimentary properties, Patterson et al. (2007) hypothesized a similar type of origin for the homogeneous sediments in the ALS core. According to them, the massive intervals were initially deposited as laminated sediments, then, subsequently reworked by turbidity currents, slump and mass movements (mud avalanche), and eventually redeposited as homogeneous sediments.

The high organic matter and sulphur concentrations in the sediments of both cores support the hypothesis that nearly permanent suboxic to anoxic conditions prevailed during their deposition. The sulphur, which likely occurs as dissolved hydrogen sulphide, might have enhanced the enrichment of redox sensitive elements such as $\mathrm{Cd}, \mathrm{Cu}, \mathrm{Mo}, \mathrm{U}$ and $\mathrm{Zn}$ (Taylor and McLennan, 1985, 1995; McLennan, 2000), and average shale (Wedepohl, 1971; 1991). The predominance of low oxygen tolerant agglutinated foraminifera and total absence of calcareous species also indicates low oxygenation levels in the investigated SBIC inlets.

The relative depletion of all trace elements and most of the major elements (except for $\mathrm{Al}, \mathrm{Ca}$ and $\mathrm{Si}$ ) at certain intervals, such as the sand bearing 1794-1901 cal yr BP and slump 1383-1385 cal yr BP intervals, in the ALS core is likely due to influx of detrital sediments at the time of deposition (Calvert, 1990; Calvert and Pedersen, 1993; Jacobs et al., 1987). The high concentrations of $\mathrm{Al}, \mathrm{Ca}$ and $\mathrm{Si}$ suggest aluminosilicate effect in the elemental concentrations at these intervals. In addition, the intervals are characterized by an increase in mean grain size. Chromium, Co and $\mathrm{Ni}$ are relatively more enriched than $\mathrm{Cd}$, Mo and $\mathrm{U}$ at $2709 \mathrm{cal}$ yr BP and $2182 \mathrm{cal}$ yr BP in the FS core, suggesting a likely ventilation leading to occurrence of a short-lived reducing condition within an overall anoxic setting (Piper and Isaacs, 1995). 
All of the elements $\left(\mathrm{Cd}, \mathrm{Cu}, \mathrm{Ni}\right.$ and $\mathrm{Fe}$ ) that precipitate in the presence of $\mathrm{H}_{2} \mathrm{~S}$ are highly enriched in sediment-starved anoxic basins such as those in Framvaren Fjord (Skei, 1986). However, in basins such as Saanich Inlet, the Black Sea, Cariaco Trench and SBIC inlets which are characterized by a high influx of detrital sediments, not all mentioned elements are highly enriched (Calvert, 1990; Calvert and Pedersen, 1993; Jacobs et al., 1987). The current study indicates that only $\mathrm{Cd}, \mathrm{Cu}$ and $\mathrm{Zn}$ are enriched in the investigated core sediments of both Frederick and Alison Sounds. A high sediment influx in the region is indicated by a high sedimentation rate of $\sim 0.397 \mathrm{~cm} / \mathrm{yr}$ in the FS core and average of 0.3 $\mathrm{cm} / \mathrm{yr}$ in ALS. The repeated slump events in these inlets might have diluted the authigenic concentrations of most of the elements.

The low enrichment of Mn provides further support for the hypothesized prevalence of suboxic to anoxic conditions during the deposition of sediments in the SBIC inlets (Francois, 1988; Calvert and Pedersen, 1993; Calvert et al., 2001; Russell and Morford, 2001; Morford et al., 2001; Calvert and Pedersen, 2007). Any excess concentrations of Mn beyond its crustal value of 600 ppm (Taylor and McLennan, 1985, 1995; McLennan,, 2000) in anoxic sediments likely represent contributions from the aluminosilicate fractions (Calvert and Pedersen, 1993; 2007).

Cadmium, Mo and $U$ enrichments in the investigated cores, with values much higher than their crustal and average shale concentrations, strongly confirm the presence of anoxic conditions in the SBIC (Pedersen et al., 1989; Calvert and Pedersen, 1993; Crusius et al., 1996; Calvert et al., 2001; Ivanochko and Pedersen, 2004; Calvert and Pedersen 2007). Molybdenum and $\mathrm{Cd}$ precipitate in the presence of elevated iron and dissolved hydrogen sulphide concentrations (Francois, 1988; Shaw et al., 1990; Crusius et al., 1996; Helz et al., 
1996; Zheng et al., 2000a; b). Molybdenum which is influenced by high organic matter content, is not enriched in sediments under bottom waters with oxygen levels greater than $10 \mu \mathrm{M}$ (Zheng et al., 2000a). Cadmium normally precipitates under minimal amounts of $\mathrm{H}_{2} \mathrm{~S}$ even when $\mathrm{H}_{2} \mathrm{~S}$ is below the detection limit (Rosenthal et al., 1997).

Peak enrichment of $\mathrm{Pb}$ recorded from the 3862-3568 cal yr BP and 3039-3837 cal yr BP intervals in the FS core and from the 2529-1887 cal yr BP, 1529-1396 cal yr BP and 13891372 cal yr BP intervals in the ALS core correspond to an increase in organic carbon content. The peak concentration of $\mathrm{Zn}$ recorded within the 2688-2485 cal yr BP interval in the ALS might also be due to an increase in organic matter accumulation. Francois (1988) and Calvert et al. (2001) found a similar correlation between increased organic carbon and increased concentrations of $\mathrm{Pb}$ and $\mathrm{Zn}$ in anoxic surface sediments within ODP core $1033 \mathrm{~B}$ from Saanich Inlet.

Almost all the examined redox indices (e.g. $\mathrm{V} / \mathrm{Cr}$ and $\mathrm{V} /(\mathrm{V}+\mathrm{Ni}) \mathrm{U}_{\text {authigenic, }} \mathrm{U} / \mathrm{Th}$, $\mathrm{Th} / \mathrm{U},(\mathrm{Cu}+\mathrm{Mo}) / \mathrm{Zn}$ and $\mathrm{V} / \mathrm{Sc})$ suggest the presence of persistent suboxic to anoxic conditions in the ALS and FS cores. For example, the V/Cr values, with an average of 3.1 in FS and 4.24 in the ALS core, are generally higher than the oxic threshold of 2. According to Jones and Manning (1994) and Gallego-Tores et al. (2007), a V/Cr ratio value of $<2$ normally indicates deposition under oxic conditions, while values ranging from $2-4.25$ are associated with dysoxic conditions and those $>4.25$ are typical for suboxic to anoxic environments. In an earlier study, Krecji-Graf (1975) places the transition from dysoxic to anoxic conditions at 2.

The values of $\mathrm{V} /(\mathrm{V}+\mathrm{Ni})$ has an average of 0.84 in the FS core and 0.88 in the ALS core. The values of this ratio in excess of 0.84 are typical of anoxic environments (Schovsbo, 2001). The concentrations of $U_{\text {authigenic }}$ with an average of $9.61 \mathrm{ppm}$ in FS and $9.88 \mathrm{ppm}$ in 
ALS are also within the suboxic to anoxic range. The values of this proxy in excess of $12 \mathrm{ppm}$ usually signal anoxic conditions whereas values below $5 \mathrm{ppm}$ indicate an oxic depositional environment (Wignall, 1990; Jones and Manning, 1994; Jimenez-Espejo et al., 2007).

The V/Sc ratios which are mostly $>9.1$, also indicate the existence of mainly anoxic conditions in FS and ALS. In oxic environments, the V/Sc ratio values are $<9.1$ (Jones and Manning 1994; Gallego-Tores et al., 2007). The values associated with the U/Th ratio in the inlets are higher than 1.25, an indication of suboxic to anoxic conditions (Jones and Manning 1994). Dysoxic conditions are usually associated with $U / T h$ values ranging between 0.75 and 1.25 while oxic conditions are indicated by values less than 0.75 (Jones and Manning 1994). In contrast to the other analyzed redox indices, $\mathrm{Ni} / \mathrm{Co}$ ratio values are within the range of an oxic environment (<5) (Jones and Manning, 1994). The observed Ni/Co ratio might have been altered by diagenetic processes involving formation of authigenic minerals such as siderite (Dypvik, 1984; Rimmer, 2004). Additionally, during the deposition of the core sediments, the concentrations of these elements $(\mathrm{Ni}$ and $\mathrm{Co})$ might have primarily indicated redox conditions (Rimmer, 2004).

\subsubsection{Regional Paleoclimate}

\subsubsection{Climate Interval 1 (4200-3135cal yr (FS); 3500-2462 cal yr BP (ALS))}

The light values of $\delta^{13} \mathrm{C}$ (mostly below the average of $-25.27 \%$ ) and relatively heavy values of $\delta^{15} \mathrm{~N}$ present within the basal 4200-3135 cal yr BP interval in the FS core suggest that the late Holocene climate in the SBIC commenced with warmer and moister conditions than those in the overlying interval. Similar conditions are indicated by an up-core decrease in $\delta^{13} \mathrm{C}$ values and the generally above average (2.72\%) values of $\delta^{15} \mathrm{~N}$ occurring between 3500 cal yr BP and 2462 cal yr BP in the ALS core. 
Similar to the results of this study, light $\delta^{13} \mathrm{C}$ values were recorded during warm and wet periods such as the Dansgaard-Oescheger events, and oxygen isotope stage 3 in northwestern Europe (Hatté et al., 1998; 1999; 2001; Hatté and Schwartz, 2003). Heavier values of $\delta^{15} \mathrm{~N}$ are associated with warm events during the interglacial Bølling-Allerød stage and early Holocene in sediments from the Gulf of California (Pride et al., 1999; Hendy et al., 2004), Santa Barbara Basin (Emmer and Thunell, 2000) and Vancouver Island (McKay et al., 2004).

The high $\mathrm{C}_{\text {org }} / \mathrm{N}_{\text {total }}$ ratio and relatively lighter values of $\delta^{13} \mathrm{C}$ and $\delta^{15} \mathrm{~N}$ are lighter than those characteristic of $\mathrm{C} 4$ plants and phytoplankton. The results from the core sediments are thus consistent with earlier palynological evidence signifying cool and moist conditions within this climate interval. In the FS core, Galloway, (2006) and Galloway et al. (in press) interpreted the predominance of conifer pollen, mainly Thuja plicata as an indication of cool and high precipitation conditions from $4200-3000 \mathrm{cal}$ yr BP. This palynological evidence is consistent with the location of the SBIC within the Coastal Western Hemlock biogeoclimate zone, which is mainly composed of $\mathrm{C} 3$ bearing cool temperate coniferous forests (Pojar and Meidinger, 1991). C3 plants usually grow in temperate environments with $\delta^{13} \mathrm{C}$ values of about $-26 \%$ (O'Leary, 1981; 1988). The majority of C3 vegetation could exist only with water availability all year long, hence cold periods such as the one that existed during the last glaciation translate into a linear relationship between water use efficiency for plants and precipitation (Hatté et al., 2001).

The high concentrations of biogenic silica (mainly above the average of $7.77 \%$ ) during the deposition of Climate Interval 1 in the FS core, suggest high diatom productivity in FS. The above average concentration of the $\mathrm{Si} / \mathrm{Al}$ ratio within this climate interval in the ALS core 
could also be interpreted as an indication of high diatom productivity. Likewise, the enrichments of $\mathrm{Ba} / \mathrm{Al}$ within this climate interval in both cores signal improved barite productivity. The peak enrichments of the $\mathrm{P} / \mathrm{Al}$ ratio recorded at 3309-3236 cal yr BP in the FS core are also an indication of high productivity.

In the FS core, laminae thickness is low $(\sim 0.2 \mathrm{~cm})$ at the base of the core but from 3455-3135 cal yr BP it is characterized by an overall thickening trend. The lowermost 350 years (3500-3150 cal yr BP) of deposition of the ALS core is also characterized by uniform but thick laminae. Patterson et al. (2007) interpreted the existence of these thick laminae as an indication of moister climate conditions. Therefore, the presence of thick laminae within this climate interval in FS and ALS supports the stable isotope results inferred high precipitation and is consistent with other varve based evidence for wet conditions along coastal BC. For example, Nederbragt and Thurow (2001) also used increased varve thickness to identify high precipitation in the lowermost $(6000-3250 \mathrm{cal} \mathrm{yr}$ BP) intervals of cores from Saanich Inlet, Vancouver Island. Based on the presence of thick laminae, Patterson et al. (2004a) also inferred the existence of cool and moist conditions from 3550-2050 cal yr BP in Effighman Inlet.

High precipitation indicated by the carbon isotope $\left(\delta^{13} \mathrm{C}\right)$ and laminae thickness in this section of the SBIC is likely influenced by the position and intensity of the AL atmospheric pressure. An eastward shift and/ or intensified AL leads to warm and moist air advection directed from south into the northeast of the Pacific coast, and ultimately, results into increased precipitation, cool summer and mild or warmer than normal winters (Niebauer, 1983; Cayan and Peterson, 1989; Mantua et al., 1997; Trenberth and Hurell, 1994; Niebauer et 
al., 1999; Schneider and Cornuelle, 2005; Chang et al., 2005; Anderson et al., 2005a; 2007; Patterson et al., 2007).

An intensification, or eastward movement, of the AL center of action (COA) occurs at times when the solar activity is minimal and the ${ }^{14} \mathrm{C}$ radionuclide production rate is high (Christoforou and Hameed, 1997; Hameed and Lee 2003). The presence of 70-88-year and 179-189-year cycles in the organic matter proxies in both the FS and ALS cores strongly suggests the influence of solar irradiance on the SBIC climate system.

Anderson et al. (2005a) interpreted predominantly light $\delta^{18} \mathrm{O}$ values from $4500-3000$ cal yr BP in Jelly Bean Lake, Yukon as evidence for high precipitation. They linked the high precipitation record to a strong easterly shift of the $\mathrm{COA}$ and/ or intensification of regional $\mathrm{AL}$ influence. Anderson et al. (2005a, 2007) also recognized a strong correlation between this period of increased precipitation and periods of Neoglacial activity in the Northeast Pacific (Heusser et al., 1985; Mathewes, 1985; Ryder and Thomson, 1986; Hebda, 1995, Pellatt et al., 2001).

\subsubsection{Climate Interval 2 (3135-1956 cal yr BP (FS); 2462-2238 cal yr BP (ALS)}

The distribution of $\delta^{13} \mathrm{C}$ is characterized by an increase from $-25.7 \%$ ( $3210 \mathrm{cal} \mathrm{yr} \mathrm{BP}$ ) to $-24.78 \%$ ( $3135 \mathrm{cal}$ yr BP) in the FS core, and from $-26.46 \%$ (2462 cal yr BP) to $-25.52 \%$ (2406 cal yr BP) in the ALS core. This approximately $+1 \%$ increase in $\delta^{13} \mathrm{C}$ signals a transition in the regional climate from wetter to drier conditions. The light values of $\delta^{15} \mathrm{~N}$ present within this climate zone, and mostly below the average in both cores, are an indication of cooler conditions compared to those of earlier times in the region.

Hatté and Schwartz (2003) correlate variations in $\delta^{13} \mathrm{C}$ isotopic values in $\mathrm{C} 3$ vegetation to variability in precipitation regimes during the last glaciations; the driest events are 
associated with the highest records of $\delta^{13} \mathrm{C}$. Hatté et al. $(1998,1999,2001)$ and Hatté and Schwartz (2003) also used heavy values of $\delta^{13} \mathrm{C}$ to describe the oxygen isotope 2 and 4 periods as the driest intervals during the last glacial period.

The biogenic silica record within this interval in the FS core fluctuates with most of its values being above the average. However, a major reduction present at 2477 and 2313-2170 cal yr BP most likely suggests the presence of low diatom productivity in some of the intervals of this climate zone in the inlet. Low values of the absolute $\mathrm{C}_{\text {org }}$ and of the $\mathrm{C}_{\text {org }} / \mathrm{Al}$ ratio present at $2709 \mathrm{cal} \mathrm{yr} \mathrm{BP}$ and $2170 \mathrm{cal}$ yr BP are also an indication of low productivity in the inlet. A reduction in the $\mathrm{Ba} / \mathrm{Al}$ ratio in the ALS core also signals low productivity.

This climate interval in the SBIC is characterized by a reduction in laminae thickness, with a lower than an average trend recorded throughout the basal section $(3135-2953 \mathrm{cal} \mathrm{yr}$ BP) and laminated interval $2555-1956 \mathrm{cal}$ yr BP) in FS. A major reduction in laminae thickness, which occurs from the 2555-2205 cal yr BP interval in this core, coincides with an increase in the ${ }^{14} \mathrm{C}$ production rate. Laminations are also thin within this climate interval in the ALS core, and as they are in FS core, a major reduction in thickness present at $2400 \mathrm{cal} \mathrm{yr} \mathrm{BP}$ in this inlet (ALS) coincides with an increase in ${ }^{14} \mathrm{C}$ production. The overall thin laminae characterizing these climate intervals in both inlets supports the hypothesis that regional dry climate conditions characterized by low precipitation prevailed during deposition of these sediments.

Based on reduced abundances of pollen Thuja plicata, Galloway (2006) and Galloway et al (in press) concluded that cool and moister conditions which existed from 4200-3000 cal yr BP in the FS core shifted to cooler and drier condition at $2900 \mathrm{cal} \mathrm{yr} \mathrm{BP}\left(2600{ }^{14} \mathrm{C}\right.$ cal yr BP). Wigston (2005) based his conclusions on an increase in absolute diatom valve counts, a 
decline of Cyclothella chactacheeana and an increase in the abundances of Skeletonmea costatum recognized the same regime change at 2825 cal yr BP.

A decrease in varve thickness in ALS between 2700 and 2900 cal yr BP was also correlated to a period characterized by low precipitation and cooler climate conditions (Patterson et al., 2007). On the basis of diatom and pollen assemblages as well as changes in pigments, Bennet et al. (2001) recorded dry conditions and lower lake level in Big Lake southcentral British Columbia commencing at $3600 \mathrm{cal}$ yr BP. Using observed changes in pollen assemblages from Marcella Lake, Alaska, Anderson et al. (2005b) also recognized a major regime shift from cool and wet to drier conditions at 2000 cal yr BP.

A shift to cooler conditions and reduced precipitation in the SBIC, suggests that the AL would have shifted westward and decreased in intensity as an intensified NPH moved northward to produce low levels of precipitation (Chang and Patterson, 2005; Thomson, 1981; Anderson et al., 2005a, 2007; Patterson et al., 2004a; 2007). Anderson et al. (2005a) correlated a regime shift from wetter to drier climate conditions, as indicated by an increasing trend in $\delta^{18} \mathrm{O}$ in Jelly Bean Lake, Yukon Territory from $3000-2000$ cal yr BP, to a westward and/or reduced intensity of AL.

As found many of the previous regional climate records, the shift from cool/wet to cooler/drier conditions, as indicated by carbon isotopic ratios and laminae thickness, during this climate interval in the SBIC also strongly correlates to the widespread Late Holocene neoglacial cooling in the Northeast Pacific (Denton and Karlen, 1973; Heusser et al., 1985; Mathewes, 1985; Ryder and Thomson, 1986; Hebda 1995; Pellatt et al., 2001). The transition to Neoglacial climate was generally dated from $\sim 4500$ to $3000{ }^{14} \mathrm{C}$ cal yr BP in the Northeast Pacific (Heusser et al., 1985; Mathewes, 1985; Hebda, 1995, Pellatt et al., 2001). 


\subsubsection{Climate Interval 3 (1956-1464 cal yr BP (FS); 2238-1627 cal yr (ALS))}

The observed heavier values of $\delta^{15} \mathrm{~N}$ through Climate Interval 3 in comparison to Climate Interval 2, suggests a return to a warmer climate at 2238 yr BP in the ALS core. These warmer conditions, as indicated by the low $\delta^{13} \mathrm{C}$ concentrations ranging mostly between $-25.9 \%$ to $-25.8 \%$, are accompanied by increased precipitation.

Due to the lack of organic proxies from 1956-1464 cal yr BP in the FS core, an increasing trend of laminae thickness is the only evidence to indicate a return to warmer and wetter conditions in the inlet. Galloway (2006) and Galloway et al. (in press) used an increase in the abundances of Thuja plicata within the depositional period of this climate interval in the FS core to signal a return to cool and wetter climatic conditions. Similarly, Wigston (2005) used decreasing trends in diatom abundances, characterized by reduced absolute valve counts of S. costatum, Thalssiosira nordenskioeldi, T. pacifica and T. tenera in combination with increased Cyclotella choctawacheeana and non-marine planktonic species from 2394-1100 cal yr BP, to suggest a possible return to wetter and cloudier conditions in FS.

This climate interval in the SBIC is similar to an interval of wetter conditions which existed from 3000-1200 cal yr BP in Marcella lake, southwest Yukon (Anderson et al., 2007) and the wet conditions indicated by increased varve thickness between 2100 and 1750 in Saanich Inlet (Nederbragt and Thurrow, 2001). Nederbragt and Thurow (2001) correlated the increased precipitation in the Sannich Inlet during the period under discussion to the Roman Warm Period.

As during Climate Interval 1, the enhanced levels of precipitation during this climate interval, were most likely facilitated by an eastward migration and intensification of the AL. A similar explanation is found for an increase in precipitation due to renewed abundances of 
Thuja plicata in pollen assemblages at $2150 \mathrm{cal}$ yr BP (Galloway 2006) and a decrease in diatom abundances (Wigston, 2005) in the FS core.

\subsubsection{Climate Interval 4 (1464-1288 cal yr BP (FS); 1627-1405 cal yr BP (ALS))}

The relatively enriched $\delta^{13} \mathrm{C}$ and generally low $\delta^{15} \mathrm{~N}$ values, mostly below the average from the 1456-1108 yr BP in the FS core and 1627-1405 in the ALS core suggests that the region witnessed a return to cooler and drier conditions as compared to the underlying Climate Interval 3. The presence of reduced laminae thickness in this climate zone in both inlets supports the isotopic ratio interpretations of reduced precipitation (Nederbragt and Thurow, 2002; Patterson et al., 2004a).

All productivity indices (i.e. biogenic silica, $\mathrm{C}_{\text {org }}, \mathrm{C}_{\text {org }} / \mathrm{Al}, \mathrm{Ba} / \mathrm{Al}$ and $\mathrm{P} / \mathrm{Al}$ ) have reduced concentrations within this climate interval. On the other hand, up core increases of $\mathrm{C}_{\text {org }}$ and $\mathrm{Ba} / \mathrm{Al}$, and a peak occurrence of $\mathrm{Si} / \mathrm{Al}$ indicate improved productivity in the $\mathrm{ALS}$ core within this climate interval.

Anderson et al. $(2005 \mathrm{~b}, 2007)$ attributed a shift from moister to drier climate conditions during this time interval to variations in the intensity and position of the AL. In the coastal areas of the British Columbia, a westward migration and reduced intensity of the AL combined with corresponding intense and northward migration of the NPH provide an ideal scenario for reduced precipitation (Chang and Patterson, 2005; Thomson, 1981, Anderson et al., 2005a; 2007; Patterson et al., 2004a; 2007).

\subsubsection{Climate Interval 5 (1288-1100 cal yr BP (FS; 1405- 1000 cal yr BP (ALS))}

The record of lighter values of $\delta^{13} \mathrm{C}$ and an increase in laminae thickness within this interval are an indication of a shift in climate from cooler and drier to relatively cool and 
wetter conditions during the last 188 years $(1288-1100 \mathrm{cal}$ yr BP) of the FS core history. A similar return to cool and wetter conditions is indicated by the elevated ratios of $\delta^{15} \mathrm{~N}$ and lighter values of $\delta^{13} \mathrm{C}$ recorded through the topmost $\sim 405$ years $(1405-1000 \mathrm{cal} \mathrm{yr} \mathrm{BP})$ of the ALS core. In both the FS and ALS cores, the intervals of this climate zone are characterized by thick laminae, which are also a strong indication of the prevalence of high precipitation during deposition of these portions of both cores.

The low productivity pattern which characterizes Climate Interval 4 continues throughout this interval in both cores. The biogenic silica and $\mathrm{C}_{\text {org }}$ in the FS core exhibit major reductions at $1212 \mathrm{cal}$ yr BP. In addition, generally decreasing trends in the distributions of the $\mathrm{Ba} / \mathrm{Al}, \mathrm{C}_{\text {org }} / \mathrm{Al}$ and $\mathrm{P} / \mathrm{Al}$ ratios at $1426 \mathrm{cal} \mathrm{yr} \mathrm{BP}$, culminate into a major reduction at $\sim 1200$ cal yr BP. All productivity indices in the ALS core also have low concentrations.

Climate interval 5 corresponds to a period of regime change from cooler and drier to cool and wet climate conditions as marked by a proliferation of conifer pollen, mainly Thuja plicata, in the upper 2100-1000 cal yr BP of the FS core (Galloway 2006). Similar pollen records are also interpreted as an indication of wet conditions in coastal British Columbia (Mathewes, 1973; Hebda, 1995; Heuser, 1983; Pellatt and Mathewes, 1994; 1997; Pellatt et al., 2000; Brown and Hebda, 2002). This climate interval also correlates to the wet and warmer conditions indicated by the diatom distribution patterns in the FS core (Wigston, 2005), and the wet conditions (1704-1100 cal yr BP) identified based on sedimentary properties in the ALS core (Patterson et al., 2007).

On the basis of $\delta^{18} \mathrm{O}$ distribution patterns in Jelly Bean Lake, Anderson et al. (2005a) identified the occurrence of wet conditions from $1200 \mathrm{cal} \mathrm{yr} \mathrm{BP.} \mathrm{This} \mathrm{shift} \mathrm{is} \mathrm{correlated} \mathrm{with}$ an intensified $\mathrm{AL}$, which would have facilitated a return to wetter and cool conditions during 
this interval in the SBIC. Wigston (2005) and Galloway (2006) also related changes to wetter conditions within this interval to the change in the center of action eastward and intensification of the $\mathrm{AL}$ in the inlet.

\subsection{Paleoclimate and Solar Forcing}

The Pacific Decadal Oscillation (PDO) (Mantua et al., 1997; Hare and Mantua, 2000) correlates strongly to the $\mathrm{AL}$. During winter when the $\mathrm{AL}$ is intensified and migrates eastward, the PDO has positive polarity. In summer, however, when the center of action of the AL moves westward and becomes weak, the PDO is negative (Mantua et al., 1997; Minobe, 1997; 1999; 2000; Mantua, 2002). A positive PDO and intensified AL lead to warm winter, mild summer and enhanced precipitation in the Northeast Pacific while the Central and Southern Pacific regions experience colder winters, warm summers and relatively low precipitation (van Loon and Williams, 1976; Mantua et al., 1997; Minobe, 1997, 1999, 2000; Hare and Mantua, 2000; Gedalof and Mantua, 2002; Mantua, 2002; Mantua and Hare, 2002; Neal et al., 2002). On the other hand, a negative PDO and weaken AL result in cool winter, hot summer and low precipitation in the region.

The Pacific Decadal Oscillation (PDO) is significantly represented in the spectral analysis of both the organic geochemical and trace element proxies of the FS and ALS cores. The PDO cycle occurs as 52-69-year and 31-49-year periodicities at 95\% confidence level in the $\mathrm{C}_{\text {org }} / \mathrm{N}_{\text {total }}, \delta^{13} \mathrm{C}, \delta^{15} \mathrm{~N}$ and $\mathrm{C}_{\text {org }}$ records from both the FS and ALS cores. These cycles are additionally present in biogenic silica and uranium in the FS core. Spectral analysis indicates that the cycles are of low amplitude suggests that the cycles are weak in the core records.

The strongest evidence of PDO in the FS core record is the occurrence of a 65-year periodicity in the wavelet analysis of silica opal. The strong intensity of this cycle, especially 
during the cooler and drier Climate Interval 2, suggests that the 65-year cycle might have influenced the SBIC climate. This cycle is not present in the wavelet analysis results of the organic proxies in the ALS core.

The present study results suggest that the combination of an intensified AL with an intense PDO periodicity through Climate Interval 1 resulted in relatively warmer conditions and increased precipitation than those in Climate Intervals 2 and 4 in the FS core. In the latter case (Climate Intervals 2 and 4) where the AL is less intensified, the PDO cycle (65-year periodicity) seen in the biogenic record is an indication of cooler and drier conditions. Patterson et al. (2004a) correlated PDO periodicities to the AL and precipitation in Effingham Inlet; and concluded that the high periodicity of the PDOs combined with an intensified AL resulted in weak transportation of moisture by westerlies into the Northeast Pacific while low PDOs periodicity produced cooler and wetter conditions.

Spectral and wavelet analyses of the geochemical data shows the presence of a high amplitude possible solar cycle with a 76-133-year periodicity in the organic matter and trace elements proxies records of the FS core while a 71-139-year cycle are present in similar proxies examined in the ALS core. The ${ }^{14} \mathrm{C}$ production data of Bond et al. (2001) analyzed in this study also revealed the presence of low amplitude 76-125-year periodicity, which corresponds to the 80-90-year Gleissberg cycle (Gleissberg, 1958; Garcia and Mouradian, 1998). The equivalent of this solar cycle has been detected in many other spectral analyses of atmospheric cosmogenic ${ }^{14} \mathrm{C}$ production (Sonnet and Finney, 1990; Stuiver et al., 1991; Stuvier and Braziunas, 1989). It has also been observed in many Holocene paleoclimate records. For example, the cycle is identified in tree rings in subarctic regions such as Russia 
and Scandinavia (Raspopov et al., 2000; 2004), and in tropical regions such as southern Brazil (Rigozo et al., 2004) and Chile (Rigozo et al., 2006; 2007 a, b).

Cycle periodicities corresponding to the Gleissberg cycle are also strongly represented in wet climate intervals of both the FS and ALS cores suggesting that the regional climate conditions, which existed during the deposition of these intervals, were influenced by solar activity (Gleissberg, 1958; Garcia and Mouradian, 1998). This cycle occurs prominently during deposition of cool and wet Climate Intervals 1,3 and 5 in the FS core as an 88-year cycle in $\delta^{13} \mathrm{C}$ and $\delta^{15} \mathrm{~N}$; a $75-100$-year cycle in biogenic silica; and a 76-113-year periodicity in $\mathrm{C}_{\text {org. }}$. The cycle is also predominant through cool and wet Climate Intervals 1,3 and 5 of the ALS core at 70-80-year and 100-140-year periodicities in $\delta^{13} \mathrm{C}, \delta^{15} \mathrm{~N}$ and $\mathrm{C}_{\text {org }}$ records.

The strong influence of solar irradiance during deposition of cool/wet climate intervals in the SBIC coincides with an eastward shift and intensification of the AL. Dean et al. (2002) related a stronger 100-year periodicity (likely Gleissberg cycle) in varve thickness to a shift to wetter conditions between 2500 and 1400 cal yr BP in Elk Lake, Great Plains, USA. Patterson et al. (2004 a, b; 2007) also linked the fluctuations in the AL and NPH in the Northeast Pacific to the modulation effect of solar irradiance. They concluded that fluctuations in the positions and intensities of these two major atmospheric pressure systems resulted in cyclic sedimentation probably corresponding to the Gleissberg solar cycle. The solar irradiance modulation of the AL/NPH eventually caused an upwelling in the coastal region of British Columbia (Patterson et al., 2004a; Chang and Patterson, 2005) or precipitation in nonupwelling domains and restricted regions such as the SBIC (Patterson et al., 2007).

The cycle probably also triggered the occurrences of cooler and drier climate intervals in the SBIC. This is indicated by the persistence of an 88 -year cycle in the $\delta^{13} \mathrm{C}$ and $\delta^{15} \mathrm{~N}, \mathrm{C}_{\text {org }}$, 
and a 75-100-year cycle in the biogenic silica record during the deposition of Climate Intervals 2 and 4 in the FS core. In AS, the 70-year and 100-140-year cycles are weakly to moderately present in $\delta^{13} \mathrm{C}, \mathrm{C}_{\mathrm{org}}$ and $\delta^{15} \mathrm{~N}$ in the cooler and drier Climate Interval 2 and at the top of Climate Interval 4. The presence of these cycles through the cooler and drier climate intervals suggests that maximum solar activity might have influenced the westward migration and reduced intensity of the AL, and northward movement, and intensification of the NPH during their deposition in both cores (Patterson et al., 2004a).

The pronounced occurrence of this cycle in the biogenic silica record and $\mathrm{C}_{\text {org }}$ during the cooler and drier periods in the FS core may be related to its influence on productivity in the inlet. The well above average concentrations of biogenic silica and previously observed link between diatom productivity and the Gleissberg wavelength band (Wigston, 2005; Patterson et al., 2007) support this interpretation. Patterson et al. (2004b) also inferred the presence of improved oceanic productivity based on strong correlations between the Gleissberg cycle and cyclicities in fish species populations (i.e. anchovy and Pacific herring) in Effingham Inlet.

The Suess solar cycle, commonly cited as a $180-220$ year cycle ( $\mathrm{Yu}, 2003)$, is represented in all examined geochemical proxies as a 146-220-year cycle periodicity in the FS core and a 146-236-cycle in the ALS core (Tables 5.6-5.8). The occurrence of this cycle in the SBIC is confirmed by the results of wavelet analysis of $\mathrm{C}_{\mathrm{org}}, \mathrm{C}_{\mathrm{org}}, \delta^{13} \mathrm{C}, \delta^{15} \mathrm{~N}$ and biogenic silica in FS. The analyses indicates the strong presence of a 189-220-year periodicity in the $\delta^{13} \mathrm{C}, \delta^{15} \mathrm{~N}$ and biogenic silica records during deposition of the cool and wet Climate Interval 1 (4200-3135 cal yr BP) and Climate Interval 5 (1288-1100 cal yr BP) in the FS core. The strong presence of this solar cycle at a time when the AL was intense and shifted eastward 
might be related to precipitation (Patterson et al., 2004a, b, 2007; Anderson et al., 2005a). Based on recognized cycles from varve thickness and grey-scale color data in Effngham Inlet, Patterson et al. (2004a) ascribed lower levels of solar irradiance (associated with 190-500 year cycle) to increased terrigenous input. Patterson et al. (2007) also identified an equivalent ( 135-155 \pm 8 -year) cycle in the ALS core, based on particle size analysis, especially through an interval where many turbidite units were present and suggested that the cycle could be related to turbidite deposition.

Hallett et al. (2003) linked variations in lake levels and frequency of fire events archived in Dog Lake core sediments, Southern British Columbia to large scale circulation changes and the impact of century-scale solar irradiance at the 160 and 210 -year periodicities (Suess cycle). High lake levels and reduced fire incidence correlate positively with periods of solar minima, while low lake levels and increased fire episodes characterize periods of maximum solar irradiance.

During Climate Interval 2, when the climate conditions became cooler and drier, a 220-250-year cycle is also prominent in the biogenic silica record in the FS core. Less intense 189-year cycles are present in the $\delta^{13} \mathrm{C}$ and $\delta^{15} \mathrm{~N}$ records in this core. The reoccurring cooler and drier conditions in Climate Interval 4 are associated with moderate to weak 176-226-year cycles in the $\mathrm{C}_{\text {org }}$ record and a 222-year cycle in $\delta^{13} \mathrm{C}$ record. The less intense nature of this cycle, especially in $\delta^{13} \mathrm{C}$ and $\delta^{15} \mathrm{~N}$, through the drier interval of the SBIC coincides with the time when the AL migrated westward and became less intense, and NPH moved northward and became intensified. In Rice and Elk Lakes, Northern Great Plains, USA, the cycle is associated with drought episodes (Yu and Ito, 1999; Anderson, 1992, 1993; Anderson et al., 
1993a). Hodell et al. (2001) also relate drought episodes in Yucatan Peninsula, Mexico to solar forcing in the 208-year periodicity.

Longer cycles in the range of 250 to $\sim 500$-years are also identified using spectral analysis of geochemical and elemental data from both the FS and ALS cores (Tables 5.6 and 5.8; Figures 5.15-5.16 and 5.21-5.22). As shown in wavelet analysis, the moderate occurrences of 250-252 year cycles in the $\delta^{15} \mathrm{~N}$ and biogenic silica record, and 302-year wavelength band in $\delta^{13} \mathrm{C}$ and $\mathrm{C}_{\mathrm{org}}$ (Table 5.7, Figures 5.17 and 5.19) confirm the presence of this multi-centennial scale cycle in the FS core records. A weak to moderate 403-year periodicity with moderate intensity is also present in $\delta^{13} \mathrm{C}, \delta^{15} \mathrm{~N}$ and $\mathrm{C}_{\text {org. }}$. The wavelet analysis of the organic matter in the ALS core also shows the occurrence of a 250-350-year wavelength band in $\mathrm{C}_{\mathrm{org}}$ and $250-280$-year cycle in the $\delta^{13} \mathrm{C}$ and $\delta^{15} \mathrm{~N}$ records.

As shown in Table 5.7 and Figures 5.17-5.20,this cycle appears to be very weak in the cool and wet Climate Intervals 1 and 3 and shows a slight increase in intensity through the cooler and drier Climate Interval 2 in FS, suggesting that it might have had more influence during drier conditions in the inlet than during wet intervals. The slightly increased brightness of the 252-302-year and 403-year cycles band in $\mathrm{C}_{\text {org }}, \delta^{13} \mathrm{C}$, and $\delta^{13} \mathrm{~N}$ as well as the restriction of the 250-year cycle to Climate Interval 2 likely indicates that solar activity related to this periodicity influenced the establishment of the dry conditions that prevailed during the deposition of this interval in the FS core.

A strong correlation is found between a peak in eolian activity marked by drought and a 400-year periodicity archived in geochemical proxies, particularly the $\mathrm{Al}$ (Dean, 2002) and varve thickness (Dean et al., 2002) in Elk lake, Minnesota, Great Plains. Similarly, Yu and Ito (1999) related drought events to solar influence based on a 400-year periodicity recorded in an 
ostracod $\mathrm{Mg} / \mathrm{Ca}$ proxy record in sediments from Rice Lake, Great Plains. In the same Great Plains region, Dean and Schwalb (2002) correlated drought episodes to the influence of a cycle of a similar duration obtained from geochemical proxies archived in Pickerel Lake sediments.

However, the observed moderate intensities of a 250 -year cycle during deposition of the cool/wet Climate Interval $1(3500-2462 \mathrm{cal} \mathrm{yr} \mathrm{BP})$ and a $280-350$-year periodicity in Climate Interval 5 (1405-1000 cal yr BP) also suggest that the cycle might have also had some influence on wetter periods in the SBIC. Earlier studies have related this cycle's length to relative variations in precipitation. For example, Aaby (1976) ascribed a 260 -year periodicity in Mire Peat of Draved Moss, Denmark to a shift from drier to moister conditions. A cycle of 260-280 years is also ascribed to the effect of solar irradiance on effective moisture (Niroma, 2008). The occurrence of a 250-330 -year cycle in varve thickness, grey color and grain size in ALS is interpreted as an indication of variable terrigenous sediment inputs and precipitation (Patterson et al., 2007).

A longer centennial to millennial ( $>500-2500$-year) periodicity is not statistically significant in the spectral analysis results of the examined proxies in both cores. This wavelength band is also weak in the wavelet data at the $756,882,1259$ and 2519 -year periodicities in the organic geochemical proxies $\mathrm{C}_{\mathrm{org}}, \delta^{13} \mathrm{C}$ and $\delta^{15} \mathrm{C}$ in FS. A persistent 530year cycle is also recorded in the biogenic silica record in this inlet. All periodicities in this wavelength band are persistent, spanning the entire $\sim 3100$-year long depositional history of the FS core. Spectral analysis of ${ }^{14} \mathrm{C}$ shows a prominent occurrence of the 625 -year cycle as well as statistically insignificant 769 and 3333-year periodicities. In ALS, this wavelength band is represented by the persistency of a 750-year cycle in $\mathrm{C}_{\text {org }}$, and a 780-1000-year one in 
$\delta^{15} \mathrm{~N}$ and $\delta^{13} \mathrm{C}$ (Figures 5.23-5.24). This cycle is not present in the analyzed Bond et al. (2001) ${ }^{14} \mathrm{C}$ production data.

In an earlier study in the SBIC, ALS core VEC02A07, Patterson et al. (2007) interpreted a millennial cycle identified in the core sections with frequent slump sedimentation, as a marine productivity cycle. The presence of the millennial cycle in fish scale and dinoflagellate cysts distributions as well as sedimentary properties in Effingham Inlet, Southwest SBIC, was also cautiously attributed to climate and productivity variations (Patterson et al., 2005).

\subsection{Conclusions}

Analysis of the organic matter proxies (e.g. $\mathrm{C} / \mathrm{N}, \delta^{13} \mathrm{C}$ and $\delta^{15} \mathrm{~N}$ ) from intervals in the FS and ALS cores indicated that the organic matter in the SBIC was derived from terrestrial plants, most likely from forests around the study locality. The $\mathrm{C}_{\text {org }}, \delta^{13} \mathrm{C}$ and $\mathrm{N}_{\text {total }}$ are characterized by decreasing concentrations up core in conjunction with an increase in grain size in throughout the ALS core and in the upper $500 \mathrm{~cm}$ of the FS core.

High organic carbon levels and the above crustal average concentrations of most redox sensitive elements (e.g., $\mathrm{Cd}, \mathrm{Mo}, \mathrm{U}, \mathrm{Cu}$ and $\mathrm{Zn}$ ) and ratios (e.g., $\mathrm{V} / \mathrm{Cr}, \mathrm{V} / \mathrm{Sc}, \mathrm{V} /(\mathrm{V}+\mathrm{Ni}$ ), $\mathrm{U}_{\text {authigenic, }} \mathrm{U} / \mathrm{Th}$ and $\left.(\mathrm{Cu}+\mathrm{Mo}) / \mathrm{Zn}\right)$ has permitted recognition of persistent late Holocene bottom water anoxia in the SBIC region. Based on the above average crustal levels and poor correlation to $\mathrm{Al}$, an authigenic origin is inferred for some of the examined redox sensitive elements (e.g., $\mathrm{Cd}, \mathrm{Cu}, \mathrm{Mo}, \mathrm{U}, \mathrm{V}$ and $\mathrm{Zn}$ ).

Similar distributional patterns for the redox sensitive elements and indices in both the laminated and massive sediments in the SBIC also indicate that the core sediments were deposited under the same bottom water conditions. It is hypothesized that the sediments were 
originally deposited as laminations in shallow waters, and later reworked and homogenized by gravity flow, and re-deposited as a homogenous units at depth. With the exception of $\mathrm{Al}$ and $\mathrm{Ca}$, almost all the major and trace elements are characterized by reduced concentrations within the slump and sand bearing intervals in the ALS core, an indication of detrital sediment dilution of elemental enrichment.

Fluctuations in the stratigraphic distributional patterns of the $\delta^{13} \mathrm{C}$ and $\delta^{15} \mathrm{~N}$ stable isotopes are utilized to assess late Holocene climate variability in the region. The stable isotope data indicates a total of five distinct episodes of Aleutian Low controlled cool/wet and cooler/drier climate intervals throughout the depositional history of the FS and ALS cores (Figure 5.28). These climate episodes are comparable to those previously determined based on palynology and diatoms in the region (Galloway 2006; Galloway et al., in press; Wigston 2005). A major transition from cool/wet to cooler/dry climatic conditions corresponding to Late Holocene Neoglacial advance in the NE Pacific is inferred based on the occurrence of heavier values of $\delta^{13} \mathrm{C}$ and lighter values of $\delta^{15} \mathrm{~N}$ at $3135 \mathrm{cal}$ yr BP in the FS core and $2462 \mathrm{cal}$ yr BP in the ALS core.

Time-series analysis based on the geochemical proxies suggest that regional late Holocene paleoceanography and paleoclimate were influenced by solar irradiance, predominantly the Suess ( 150-250-year cycle), Gleissberg (70-140-year cycle) and long PDO (31-69-year cycle) wavelength bands. A longer (250-500 yr cycle), weak multicentennial and millennial cycles were also observed in this study. 


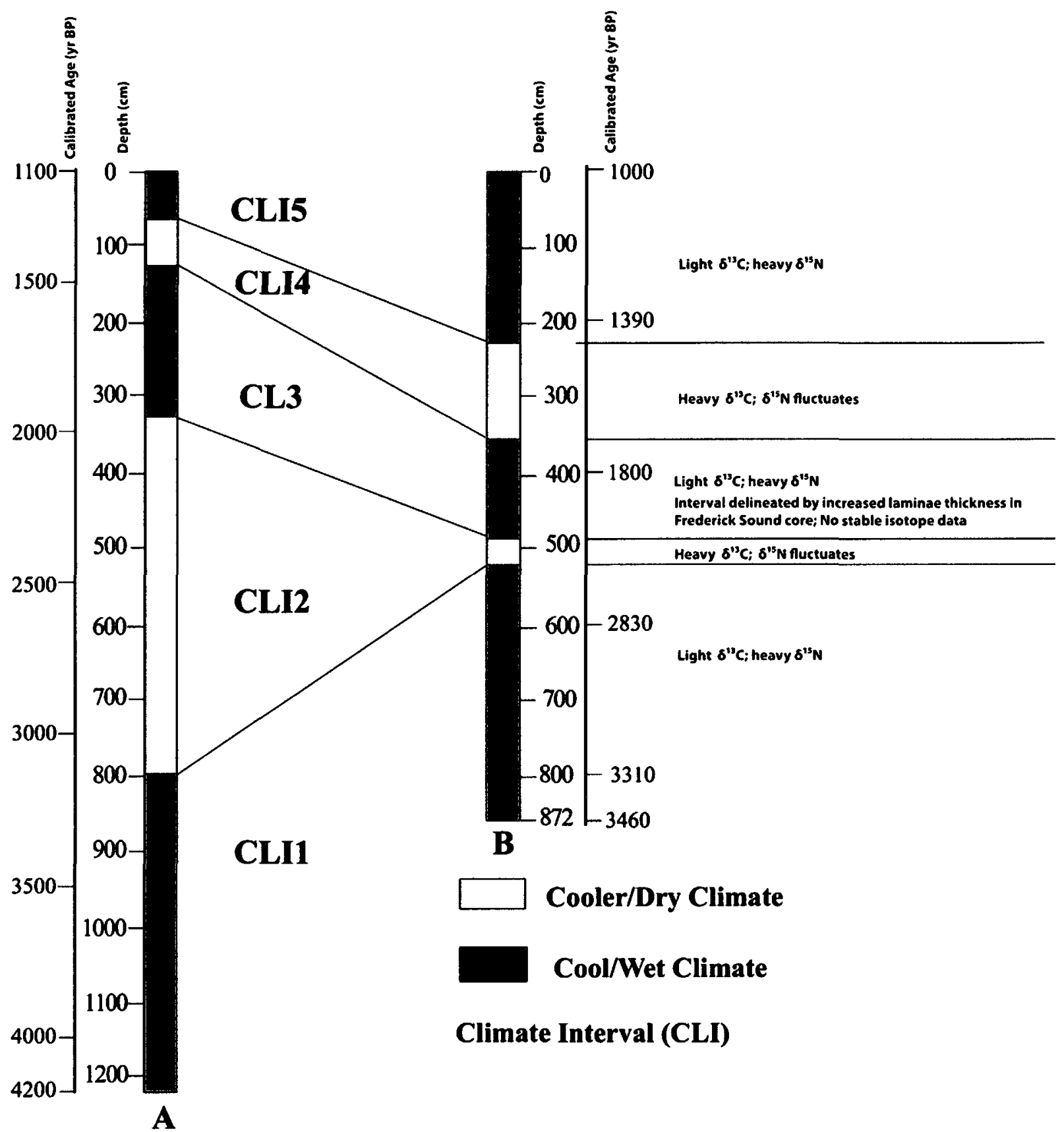

Figure 5.28. Summary of climate events in SBIC: (A). Frederick Sound core and (B). Alison Sound core. 


\section{CHAPTER SIX}

\section{FORAMINIFERAL AND GEOCHEMICAL DISTRIBUTION IN THE MEREWORTH SOUND FREEZE CORE}

\subsection{Abstract}

Trace element and foraminiferal biofacies distributional patterns were utilized to investigate variation in regional paleoceanography and paleoclimate in the Seymour-Belize Inlet Complex (SBIC) during the $\sim 1400$ years of deposition of the Mereworth Sound (MS) freeze core VEC0A13. The MS core intervals were comprised of monotonous massive mud and silt sediments with minor sandy intervals. The fossiliferous portion (1138-2002 AD) of the core was found to be sandier than the poorly fossiliferous lowermost section (577-1248 AD). A downhole increase and higher concentrations of most of the major elements, especially aluminosilicate related elements (e.g., $\mathrm{Al}, \mathrm{Ca}, \mathrm{Ti}, \mathrm{K}$ and $\mathrm{Mg}$ ) from $77.5 \mathrm{~cm}(1149$ $\mathrm{AD}$ ), are consistent with the predominance of mud sediments in the basal 129-68.5 $\mathrm{cm}(577-$ 1248 AD).

Foraminiferal assemblages were dominated by the open-marine calcareous Buccella frigida with subordinate amounts of agglutinated species. Correlation and factor analysis of the species fractional abundances together with the transfer function inferred ecological variables indicate that water mass properties such as temperature, dissolved oxygen and 
salinity are the major factors controlling the distribution of foraminifera in the core. Cluster analysis of the examined core samples and their foraminiferal fractional abundances identified four biofacies: Buccella frigida, Buccella frigida-Cribroelphidium excavatum, Haplophragmoides bradyi-Eggerella advena and Haplophragmoides bradyi-Cribroelphidium excavatum Biofacies.

The absence of foraminifera and high concentrations of redox sensitive elements (above their average crustal limits) indicate that the basal section of the core (577-1248 AD) was deposited under bottom water anoxia, partially corresponding to the Medieval Warm Period (MWP) event. The overlying fossiliferous (1248-1386 AD) interval dominated by cool water species Buccella frigida and Cribroelphidium excavatum is characterized by high oxic, cool bottom water conditions, corresponding to the onset of the Little Ice Age (LIA). The overall prevailing cool condition during the LIA in the region was interrupted by slightly depressed bottom water oxygen and warmer conditions from 1386-1518 AD. Climate conditions during deposition of the uppermost section of the core (1518-2002 AD) were slightly cooler indicating a return to LIA conditions in the SBIC.

\subsection{Introduction}

This research is part of a major multidisciplinary project mandated to assesses the paleoceanographic and climate cycles influencing the Seymour-Belize Inlet Complex (SBIC). In the previous chapters the significance of foraminifera, thecamoebians and geochemical proxies examined from long sedimentary records in piston cores collected from Frederick Sound and Alison Sound (chapters 4 and 5) were discussed. In this chapter the paleoceanographic record archived in freeze core (VEC02A13), collected from Mereworth Sound (MS), is described. In this core foraminiferal and geochemical proxies were utilized to 
detect fluctuations in regional oceanographic and climatic conditions through the late Holocene. Although the temporal record contained in a freeze core is shorter than those recovered from piston cores they yield higher quality information on the soft near surface sediment layers, which are easily disturbed and not easily sampled using a piston core.

The specific objectives of this study are to:

- Use foraminiferal biofacies and trace elements proxies to determine variations in bottom water during the last 1400 years.

- Correlate foraminiferal biofacies to regional paleoclimate conditions.

- Apply transfer function models derived from a modern foraminiferal training set in the SBIC to assess the effects of environmental variables on the foraminiferal species distribution patterns.

\subsection{Results}

\subsubsection{Age Model}

Out of the five ${ }^{14} \mathrm{C}$ dates obtained from this core, only two were considered reliable for age modeling (Table 3.3). The date obtained from a bulk sediment sample at $108 \mathrm{~cm}$ was anomalously old $\left(3060 \pm 50{ }^{14} \mathrm{C}\right.$ yr BP) while a wood fragments samples obtained from 124 and $125 \mathrm{~cm}$ yielded radiocarbon dates that were too young $(90 \pm 40$ and $230 \pm 50 \mathrm{yr} \mathrm{BP}$, respectively) (Table 3.3) to be utilized in the age/depth model. The wood fragments may have been brought to the basal part of the core due to disturbance during coring. A linear regression of the depth-age plot of the two dates utilized produced a considerably higher sedimentation rate $(1.97 \mathrm{~cm} / \mathrm{yr})$ than the $0.124 \mathrm{~cm} / \mathrm{yr}$ value calculated for the freeze core FC04 from Belize Inlet (Vázquez-Riveiros, 2006) and $0.48-0.8 \mathrm{~cm} / \mathrm{yr}$ sedimentation rate obtained from the Alison Sound piston core VEC02A07 age/depth model (Patterson et al., 2007). Based on the 
assumption that freeze cores normally sample the topmost interval including the present-day sediment/water interface the age of the core was determined by extrapolating the linear regression equation's intercept of the depth-age bivariate plot to zero (Figure 6.1). This method yielded a sedimentation rate of $0.091 \mathrm{~cm} / \mathrm{yr}$ for the calibrated calendar ages and $\sim 0.1063 \mathrm{~cm} / \mathrm{yr}$ for the radiocarbon ages. These sedimentation rates were used to calculate the age of the core interval. The determined age ranges from 0-1425 cal yr BP (577-2002 AD) or $0-1214{ }^{14} \mathrm{Cyr} \mathrm{BP}$ (radiocarbon age).

\subsubsection{Sedimentology}

Freeze core VEC02A13 was comprised of monotonous massive mud and silt sediments (Figure 6.2). Laminations were completely absent throughout the core interval and there was no obvious evidence of benthic activities on the sediments. The basal section of the core $129-68.5 \mathrm{~cm}$ was dominantly composed of mud pellets with abundant particles of organic matter, wood fragments and mica flakes with minor amounts of quartz grains. Sand proportion in the sediments increased between depths $49 \mathrm{~cm}$ and $68.5 \mathrm{~cm}$. Sand-sized quartz were particularly abundant at $56 \mathrm{~cm}$ where biogenic quartz and diatom frustules were also abundant. The interval between 49 and $35 \mathrm{~cm}$ was predominantly composed of faecal pellets with mica flakes and organic matter particles also being relatively common. The upper $35 \mathrm{~cm}$ of the core was mainly characterized by mud pellets with frequent fine-grained sand (abundant quartz), and frequent to abundant fine organic matter and mica. Gastropod shell fragments were also present in the upper portion of the core. 


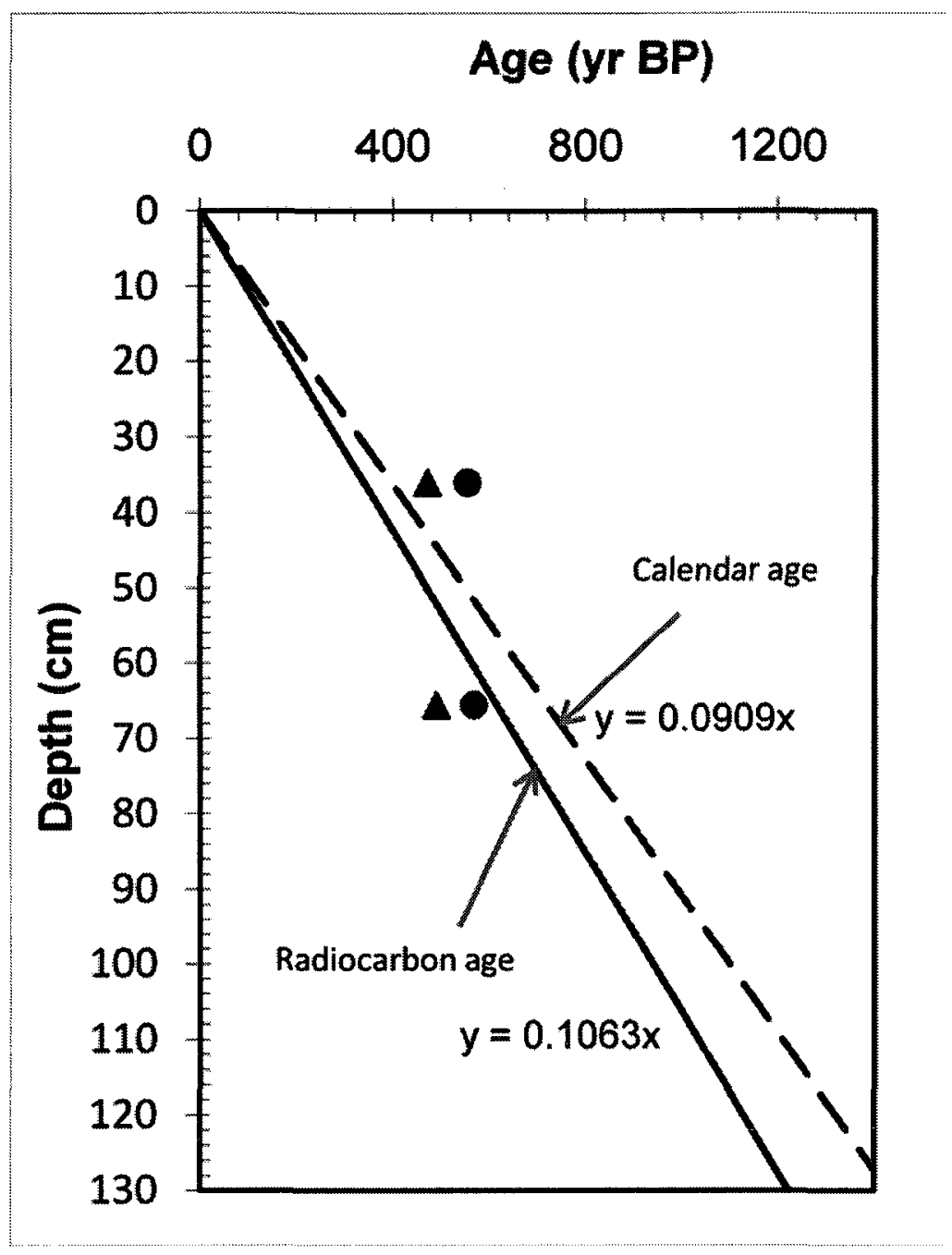

Figure 6.1. Age-Depth model of the Mereworth Sound freeze core. 


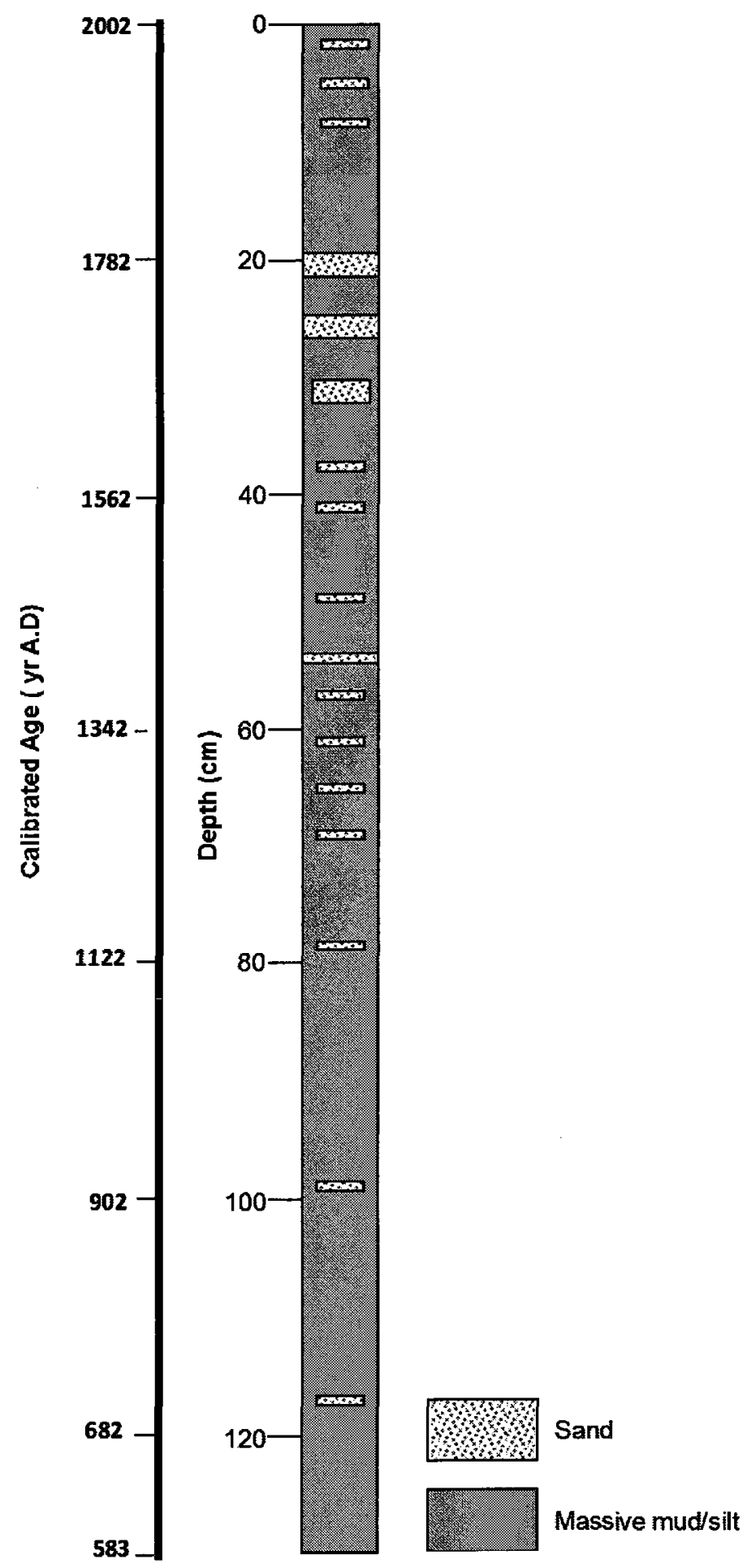

Figure 6.2. Stratigraphic column of Mereworth freeze core. 


\subsubsection{Foraminiferal Distribution}

Foraminifera were primarily restricted to the top $78.5 \mathrm{~cm}$ of the core. Samples from the $35-44 \mathrm{~cm}$ and $78.5-129 \mathrm{~cm}$ intervals were poorly fossiliferous. Most of the samples from these intervals were barren and only a few of them contained a statistically significant number of specimens. Calcareous foraminiferal species, characterized by low abundances and diversity, dominated the faunal assemblages. Specimen counts reached a maximum of 170 in some samples with a total of 37 species comprised of 24 calcareous and 8 agglutinated foraminiferal and 5 thecamoebian species being identified. The species fractional abundances are presented in Appendix B.

Out of the 101 samples examined in the MS core VEC02A13, only 58 contained relatively abundant foraminiferal populations. Out of the 58 fossiliferous samples, only 46 contained statistically significant populations. Due to low number of specimens, some of these 46 samples had to be combined with adjacent samples to obtain large enough populations to be retained for the cluster analysis. A total of 20 composite samples were created in this manner. The remaining twelve fossiliferous samples had only a few specimens. As the populations in these samples were statistically insignificant they were rejected from subsequent statistical analysis.

Buccella frigida was the most abundant species in the core. This species accounted for over $50 \%$ of the assemblages in the majority of analyzed samples. Other important species encountered in this core included Cribroelphidium excavatum, Epistominella vitrea, Stainforthia feylingi and Euuvigerina peregrina. Subspecies of $C$. excavatum were mostly represented by $C$. excavatum clavata and $C$. excavatum excavata. Cribroelphidium excavatum magna also occurred sparsely in some samples. Due to the generally low abundance of the 
Cribroelphidium formae in this study, they were treated as one species $C$. excavatum. Out of the eight agglutinated species identified, only Haplophragmoides bradyi, Eggrella advena and Recurvoides turbinatus were fairly abundant in some samples. Thecamoebians predominantly represented by freshwater Centropyxis and Difflugia spp as well as Cyclopyxis kahli, were present in statistically insignificant numbers throughout the core.

\subsubsection{Biofacies}

The Q-mode cluster analysis of 20 samples based on 12 foraminiferal species yielded four foraminiferal biofacies: Haplophragmoides bradyi Eggerella advena (HB-EA), Buccella frigida (BF), Buccella frigida-Cribroelphidium excavatum (BF-CE) and Haplophragmoides bradyi-Cribroelphidium excavatum (BF-CE) Biofacies (Figures 6.3-6.4).

\subsubsection{Haplophragmoides bradyi-Eggerella advena (HB-EA) Biofacies}

A total of four composite samples from $17-23 \mathrm{~cm}, 44-56 \mathrm{~cm}$ and $68.5-78.5 \mathrm{~cm}$ intervals characterized this biofacies (Figure 6.4). This biofacies was characterized by moderately abundant Haplophragmoides bradyi (range: 2.1-27.1\%, mean: 13.5\%), Eggerella advena (range: 3.2-16.7\%, mean: $7.8 \%$ ) and Stainforthia feylingi (range: $0-19 \%$, average: $7.4 \%$ ). Of all the four biofacies recognized in this core, the HB-EA Biofacies has the least abundances of Buccella frigida (range: 31.3-47.6\%, mean: 42.7\%). Recurvoides turbinatus (0-16.1\%), Cribroelphidium excavatum (2.1$10.6 \%)$ and Epistominella vitrea (0-6.4\%) were other important species. Bolivina minuta and Euuvigerina peregrina were rare in this biofacies. Bolivina minima is also present in a single sample. Shannon-Weaver Diversity (SDI) values ranged from 0.5 to 1.04 suggesting a stressed environment (Sageman and Bina 1997). 


\subsubsection{Buccella frigida-Cribroelphidium excavatum (BF-CE) Biofacies}

The Cribroelphidium excavatum-Buccella frigida Biofacies is characterized by high abundances of Buccella frigida (range: 59.7-68.8\%, mean: 63.4\%) and subordinate numbers of Cribroelphidium excavatum (range: $10.7-21.9 \%$, mean: $15.6 \%$ ). This biofacies is present in seven samples from the $57-58 \mathrm{~cm}, 60-62 \mathrm{~cm}$ and $66.5-68.5 \mathrm{~cm}$ core intervals (Figure 6.4). Bolivina minuta (0-6.5\%), Epistominella vitrea (0-6\%) and Euuvigerina peregrina (0-4.8\%) are the other important species in the biofacies. Stainfothia feylingi (0-9.7\%) also occurs in two samples. A lone occurrence of Lobatula mckannai is also recorded within the zone. The SDI values (0.59-1) are low.

\subsubsection{Buccella frigida (BF) Biofacies}

Four samples within the $62-66.5 \mathrm{~cm}$ interval belong to this biofacies (Figure 6.4). Buccella frigida with an $86.6 \%$ mean abundance dominates the assemblage. Cribroelphidium excavatum $(5.8 \%$ mean) is also an important species through the interval. Bolivina minuta, Angulogerina angulosa, Epistominella vitrea and Euuvigerina peregrina with their abundances $\leq 3 \%$, are also present in the biofacies. A lone occurrence of Eggerella advena is also recorded in this biofacies. The SDI of the biofacies is very low $(0.08$ and 0.39$)$ indicating a highly stressed environment. This biofacies is similar to the $B$. frigida sub-biofacies of Blais-Stevens and Patterson (1998) and the Buccella Assemblage of Patterson et al. (2000) from Sannich Inlet and a Buccella frigida assemblage reported from the Canadian Arctic (Saidova, 2002).

\subsubsection{Haplophragmoides bradyi-Cribroelphidium excavatum (HB-CE) Biofacies}

This biofacies is represented by seven samples from $0-17 \mathrm{~cm}, 23-35 \mathrm{~cm}$ and $56-57 \mathrm{~cm}$ and $58-60 \mathrm{~cm}$ intervals (Figure 6.4). High abundances of Buccella frigida (68\% mean) as 


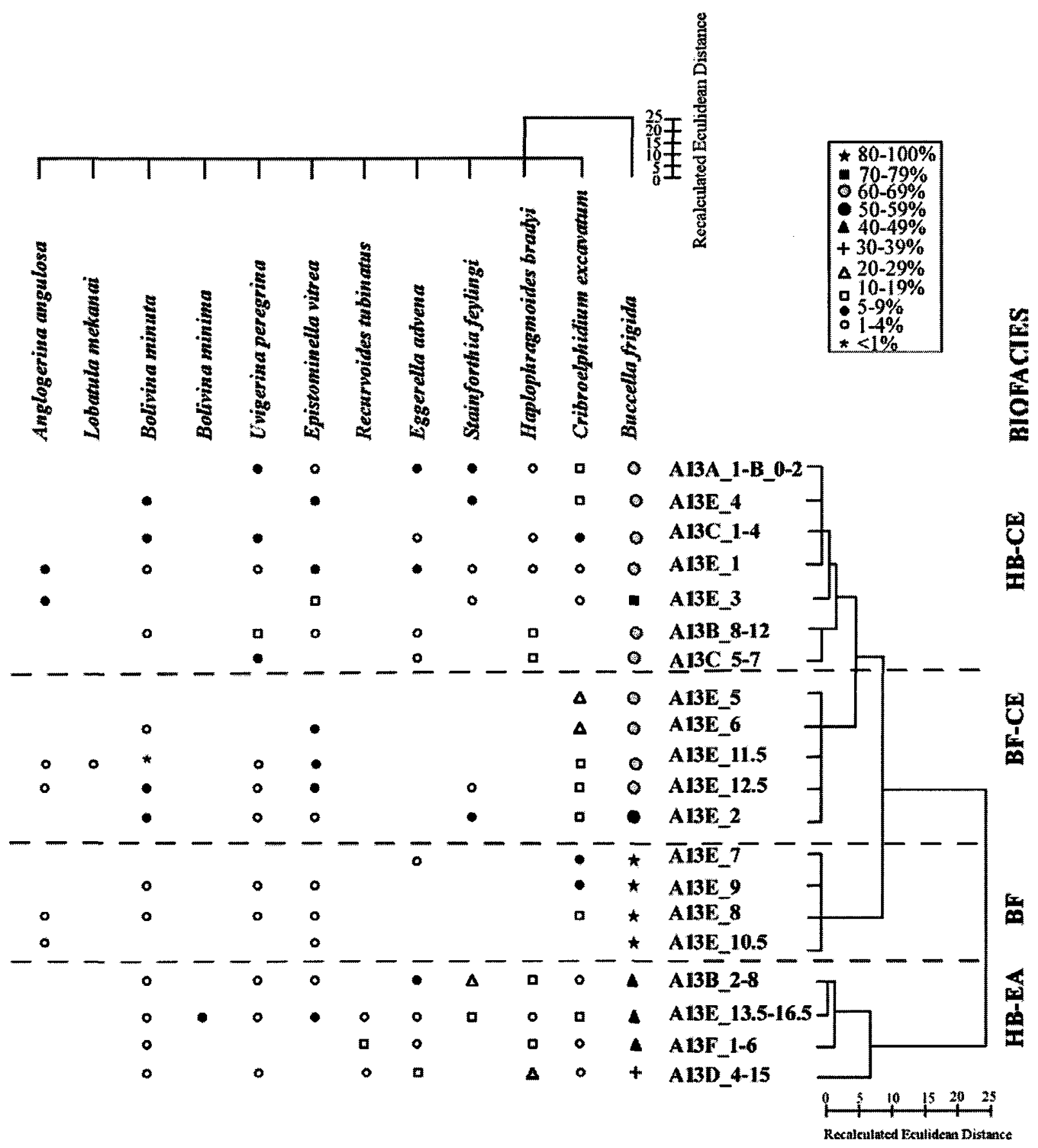

Figure 6.3 Q-mode and R-mode cluster dendrogram showing foraminiferal biofacies in Mereworth Sound. Haplphragmoides bradyi-Eggerella advena (HB-EA), Buccella frigida (BF), Buccella frigida-Cibroelphidum excavatum (BF-CE) and Haplphragmoides bradyiCibroelphidum excavatum Biofcaies (HB-CE). Range of abundances (\%) of species are indicated by symbols. 


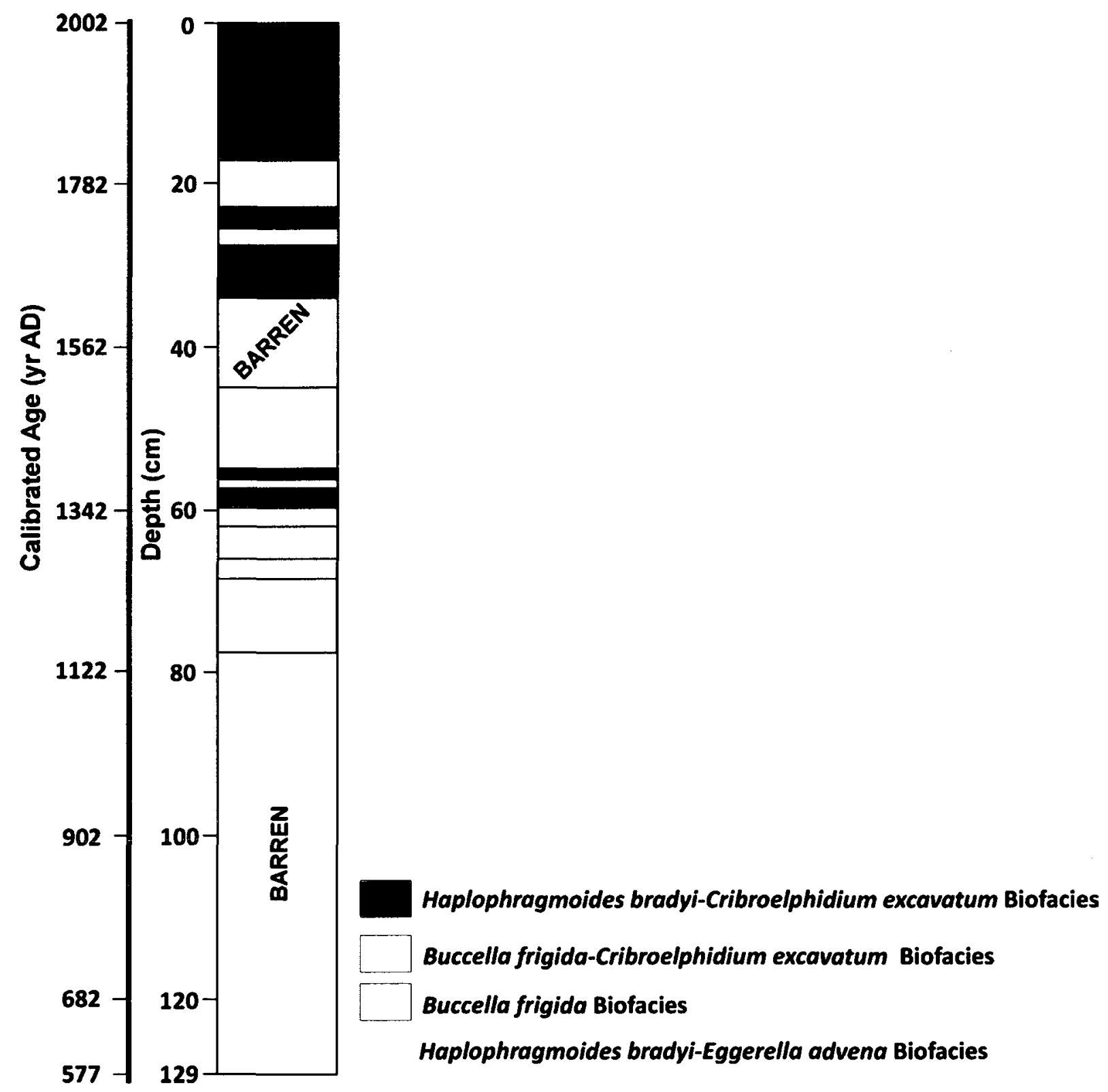

Figure 6.4. Stratigraphic distribution of foraminiferal biofacies in Mereworth Sound freeze core. 
recorded in the underlying Buccella frigida Biofacies are also present through this interval. Haplophragmoides bradyi (0-15.8\%) and Cribroelphidium excavatum (2.9-10.3\%) are also common. When compared to the Haplophragmoides bradyi-Eggerella advena Biofacies, $E$. advena, $H$. bradyi and $S$. feylingi show lower abundances in this biofacies. Angulogerina angulosa is present in two samples. The SDI values in this biofacies are low, ranging between 0.28 and 0.8 .

\subsubsection{Transfer Functions}

\subsubsection{Reconstructed Environmental Variables}

As discussed in chapter 4, the performance of transfer function regression models are evaluated by their statistical parameters, RSME, $\mathrm{r}^{2}$ and maximum bias. Both the WA and WA-TOL deshrinking models show relatively low RSME and maximum bias values indicating that they have good predictive ability (Table 4.1). The observed high $\mathrm{r}^{2}$ values are an indication of very strong relationships between the measured and predicted values of all variables.

The estimated environmental variables and foraminiferal fractional abundances are presented in Figure 6.5 and Appendix B3. The estimated paleotemperature ranges mostly from $8.1^{\circ} \mathrm{C}$ to $8.3^{\circ} \mathrm{C}$. The observed distributional pattern shows low values from the $68.5 \mathrm{~cm}$ to 56 cm interval where agglutinated species are sparse or absent. There is a slight increase in the abundance of agglutinated taxa within the $78.5-68.5 \mathrm{~cm}$ and $44-56 \mathrm{~cm}$ intervals where Haplophragmoides bradyi, Eggerella advena and Recurvoides turbinatus are common. The estimated paleotemperature is almost uniform within the $35-0 \mathrm{~cm}$ interval. Reconstructed oxygen concentrations are estimated to have ranged from $3.75-4.51 \mathrm{~mL} / \mathrm{L}$ during deposition of this core. The oxygen values ( $>4 \mathrm{~mL} / \mathrm{L}$ ) estimated within $68.5-56 \mathrm{~cm}$ interval, declined to a 


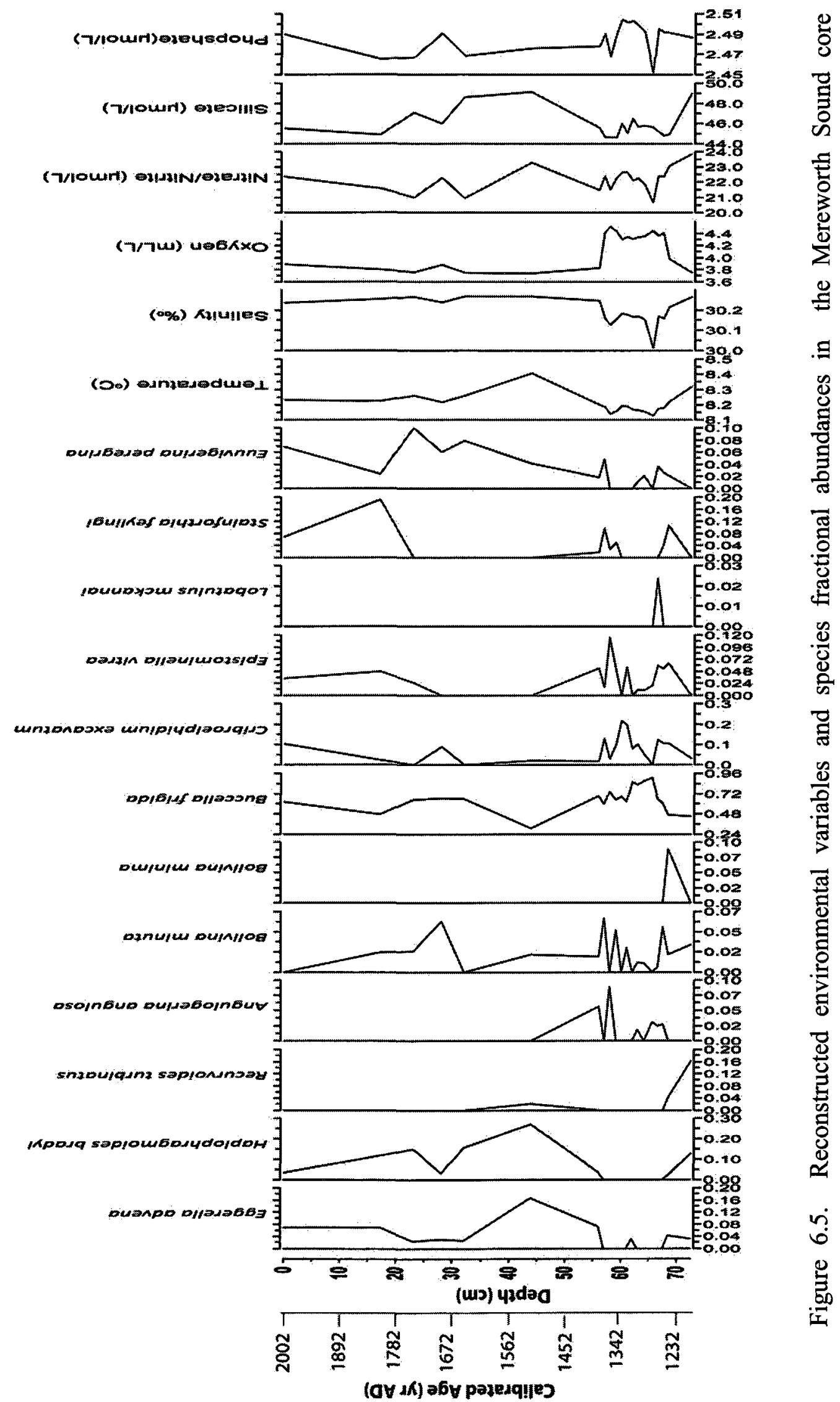


relatively lower value of $3.83 \mathrm{~mL} / \mathrm{L}$ at $56 \mathrm{~cm}$ depth, a drop which persists to the top of the core.

The estimated salinity and nitrate/nitrite values follow a similar distributional pattern as temperature. These variables record low values within the $78.5-56 \mathrm{~cm}$ interval and become largely uniform throughout the upper $56 \mathrm{~cm}$. The phosphate trend is similar to that of oxygen with elevated values within the $78.5-56 \mathrm{~cm}$ interval. As with temperature, salinity and nitrate/nitrite phosphate values are uniformly distributed through the upper $56 \mathrm{~cm}$ of the core.

Correlation between the reconstructed environmental variables and species fractional abundances (Table 6.1) indicate that Eggerella advena, Haplophragmoides bradyi and Recurvoides turbinatus are positively correlated to temperature, salinity, nitrate, and silicate. These same species are, however, negatively correlated to oxygen concentration. The relative abundance of both Eggerella advena and Haplophramoides bradyi are poorly correlated to phosphate concentration.

Euuvigerina peregrina is the only calcareous species that shows a positive significant correlation to temperature, silica and salinity. Buccella frigida is negatively correlated to both temperature and salinity. Angulogerina angulosa, Cribroelphidium excavatum, Buccella frigida, and Epistominella vitrea are positively correlated to dissolved oxygen. In addition, Cribroelphidium excavatum, Bolivina minuta and Bolivina minima are positively correlated to nitrate/nitrite while Cribroelphidium excavatum shows a strong relationship with phosphate.

\subsubsection{Factor Analysis}

In order to determine the factors that control the distribution of foraminiferal taxa the principal component R-mode factor analysiss with varimax rotation was carried out on the response variables and reconstructed environmental parameters. A total of five factors which account for $80.59 \%$ of the cumulative variance were extracted (Table 6.2). 
Factor 1 is characterized by positive loadings for $E$ advena, H. bradyi, R. turbinatus, $E$. peregrine, temperature, salinity and silicate. Buccella frigida, C. excavatum, E. vitrea and oxygen are negatively correlated in factor 1 . The positive association of agglutinated species (Haplophragmoides bradyi and Eggerella advena) with temperature, salinity and silicate within this factor suggests that these ecological variables are important contributors to distribution of Haplophragmoides bradyi and Eggerella advena. The negative loading for oxygen (-0.9) in this factor is consistent with the low oxygen tolerance of these agglutinated species.

Cribroelphidium excavatum, B. minuta, L. mckannai, phosphate and nitrate are positively correlated with Factor 2. The positive loadings for both phosphate and nitrate within this factor suggest 2 is related nutrient availability in the inlet. Factor $3(12.38 \%$ variance $)$ is characterized by positive loadings for $S$. feylingi, B. minuta, B. minima and negative loadings for $B$. frigida and silicate. Positive loadings for $R$. turbinatus, $B$ minuta, nitrate, silicate and temperature define Factor 4. E. peregrina is also negatively correlated with this factor. Factor 5 is characterized by positive loadings for $B$. minuta and $S$. feylingi, and negative loadings for $A$. angulosa and $L$. mckannai. None of the environmental variables are significantly represented within Factor 5.

\subsubsection{Geochemistry}

\subsubsection{Major Elements}

An examination of the sediments in the core indicates that the upper $78.5 \mathrm{~cm}$, which are characterized by relatively abundant foraminiferal faunas, are coarser grained than the sediments of the lower $78.5-129 \mathrm{~cm}$ interval. This lower section of the core is mainly comprised of organic matter-rich mud and silt. The distribution of major and minor elements was assessed to determine if the observed difference in sedimentology was due to sediment source composition. 


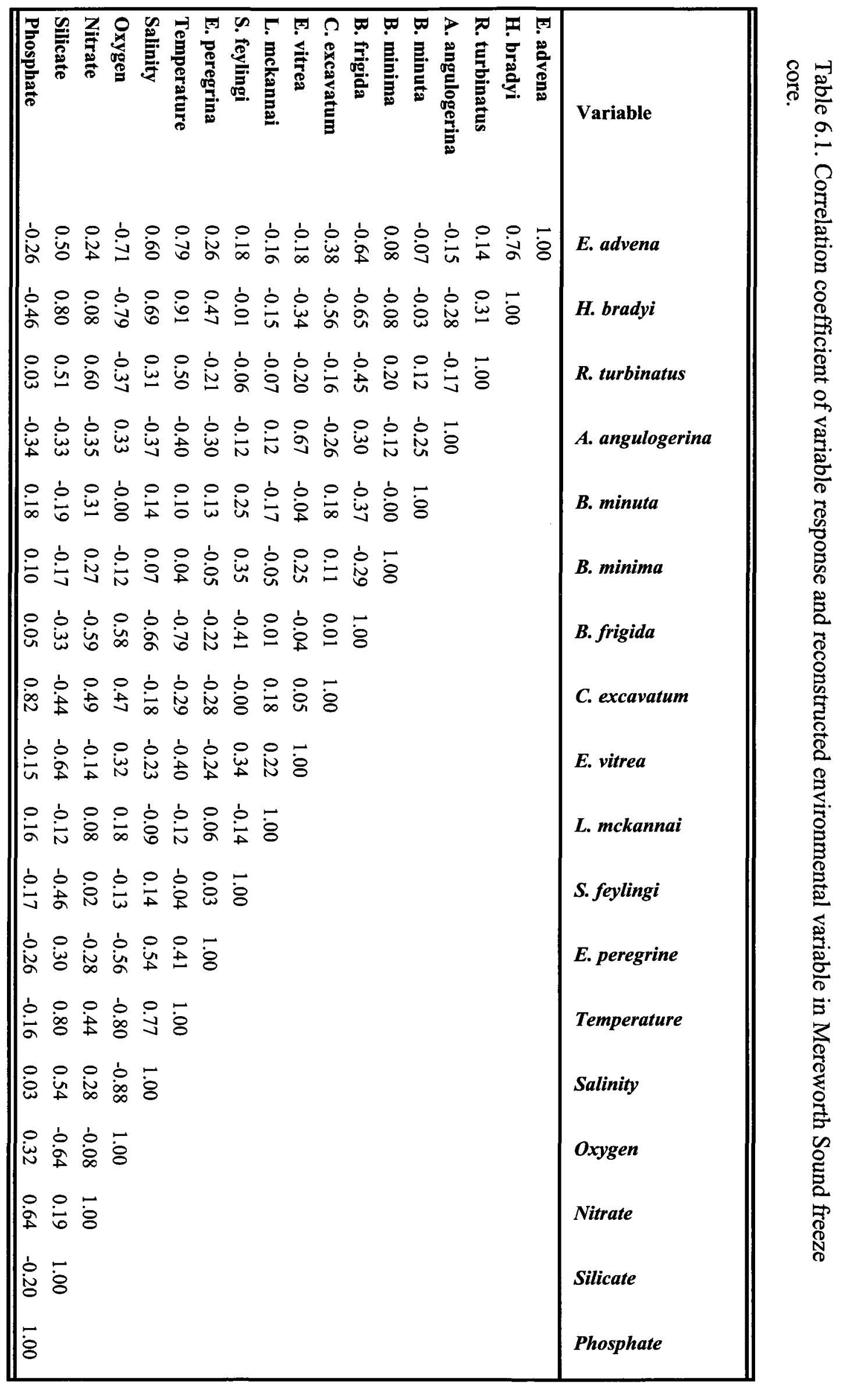


Table 6.2. R-mode Principal Component (Varimax Rotated) Factor loadings for foraminiferal species and environmental variables in Mereworth Sound freeze core.

\begin{tabular}{|l|c|c|c|c|c|}
\hline Variable & Factor 1 & Factor 2 & Factor 3 & Factor 4 & Factor 5 \\
\hline E. advena & $\mathbf{0 . 7 9}$ & -0.18 & 0.11 & 0.08 & 0.00 \\
H. bradyi & $\mathbf{0 . 9 1}$ & -0.26 & -0.14 & 0.03 & 0.10 \\
R. turbinatus & 0.39 & 0.08 & -0.04 & 0.77 & 0.12 \\
A. angulosa & -0.39 & -0.60 & 0.14 & 0.15 & -0.46 \\
B. minuta & 0.07 & 0.38 & 0.37 & -0.08 & 0.44 \\
B. minima & 0.08 & 0.11 & 0.56 & 0.25 & 0.00 \\
B. frigida & $\mathbf{- 0 . 7 7}$ & -0.20 & -0.47 & -0.23 & 0.00 \\
C. excavatum & -0.36 & $\mathbf{0 . 8 4}$ & 0.12 & 0.02 & -0.12 \\
E. vitrea & -0.33 & -0.29 & 0.67 & 0.04 & -0.49 \\
L. mckannai & -0.02 & 0.23 & -0.06 & -0.14 & $\mathbf{- 0 . 8 4}$ \\
S. feylingi & 0.09 & -0.04 & $\mathbf{0 . 8 4}$ & -0.16 & 0.22 \\
E. peregrina & 0.57 & -0.02 & -0.07 & -0.70 & 0.02 \\
Temperature & $\mathbf{0 . 9 5}$ & 0.04 & -0.09 & 0.21 & 0.08 \\
Salinity & $\mathbf{0 . 8 7}$ & 0.15 & 0.08 & -0.09 & 0.03 \\
Oxygen & $\mathbf{- 0 . 9 0}$ & 0.16 & -0.01 & 0.06 & -0.14 \\
Nitrate/Nitrite & 0.29 & 0.68 & 0.15 & 0.61 & -0.04 \\
Silicate & 0.72 & -0.11 & -0.60 & 0.26 & 0.11 \\
Phosphospahte & -0.22 & $\mathbf{0 . 8 9}$ & -0.07 & 0.15 & -0.09 \\
\hline Eigen & $\mathbf{6 . 3 2}$ & $\mathbf{3 . 1 1}$ & $\mathbf{2 . 2 3}$ & $\mathbf{1 . 6 0}$ & $\mathbf{1 . 2 5}$ \\
Variance (\%) & $\mathbf{3 5 . 1 3}$ & $\mathbf{1 7 . 2 9}$ & $\mathbf{1 2 . 3 8}$ & $\mathbf{8 . 8 7}$ & $\mathbf{6 . 9 2}$ \\
\hline
\end{tabular}


The distribution of major and trace elements and their ratios relative to aluminum are presented in Tables 6.3-6.4, Appendices C13-C15 and Figures 6.6 and 6.7. Almost all of these elements display similar distributional patterns. The basal $129-77.5 \mathrm{~cm}$ interval is characterized by a high but uniform distributional pattern of most elements. The concentrations of all the major elements (except $\mathrm{P}, \mathrm{Fe}$ and $\mathrm{S}$ ) decrease from $77.5 \mathrm{~cm}$, and remain low but uniformly distributed to the top of the core (Figure 6.6).

Aluminum concentrations display a similar distributional pattern with most other measured major elements $\left(\mathrm{Ca}\left(\mathrm{r}^{2}=0.87\right), \mathrm{K}\left(\mathrm{r}^{2}=\sim 0.7\right), \mathrm{Mg}\left(\mathrm{r}^{2}=0.55\right), \mathrm{Mn}(0.86)\right.$, Ti (Figure $\left.6.8, r^{2}=0.84\right)$ and $\left.\operatorname{Sr}\left(r^{2}=0.87\right)\right)$, with the notable exceptions of $\mathrm{Fe}\left(r^{2}=26\right), P\left(r^{2}=0.25\right)$ and $\mathrm{S}\left(\mathrm{r}^{2}=0.25\right)$ (Figure 6.8). Calcium is strongly correlated to $\mathrm{Sr}\left(\mathrm{r}^{2}=0.96\right.$ while $\mathrm{CaAl}$ is also positively correlated to $\mathrm{P} / \mathrm{Al}\left(\mathrm{r}^{2}=0.38\right)$ and $\mathrm{Mg} / \mathrm{Al}\left(\mathrm{r}^{2}=0.56\right)$. Sulphur shows a similar distributional pattern as phosphorous, being mostly evenly distributed with a major excursion at $52-85 \mathrm{~cm}$ (Figure 6.6).

\subsubsection{Redox sensitive elements distribution}

The distribution of the redox sensitive elements in the core follows the same pattern as the major elements. Most of the elements are predominantly uniformly distributed with a few positive excursions (Figure 6.7). Cadmium is only detected in samples within the $15-85.5 \mathrm{~cm}$ interval. Chromium, $\mathrm{Cu}, \mathrm{V}$ and $\mathrm{Zn}$ are relatively highly concentrated in the sediments whereas $\mathrm{Co}$, Mo and Ni are largely low to moderately concentrated.

As shown in Figure 6.7, the distributions of $\mathrm{Ba}, \mathrm{Co}, \mathrm{Mo}, \mathrm{Ni}$, and $\mathrm{Sr}$ are characterized by a major down hole increase from the $70.5 \mathrm{~cm}$ to $129 \mathrm{~cm}$. Molybdenum displays an

additional peak excursion within the $58-52 \mathrm{~cm}$ interval. The distribution pattern $\mathrm{V}$ exhibits an upward increase from the $129-70.5$ and $52-28 \mathrm{~cm}$ intervals (Figure 6.7). This metal is also 
Table 6.3. Summary of concentrations of major elements in Mereworth Sound freeze core. Upper crust data (Taylor and McLennan, 1985, modified by Taylor and Mclennan, 1995; Mclennan, 2000); Average shale data (Wedepohl 1971; 1991).

\begin{tabular}{|c|c|c|c|c|}
\hline \multirow[b]{2}{*}{ Element/Ratio } & \multirow[t]{2}{*}{ Upper Crust } & \multirow[t]{2}{*}{ Average Shale } & \multicolumn{2}{|c|}{ Mereworth Sound $(n=37)$} \\
\hline & & & Range & Mean \\
\hline $\mathrm{Al}(\%)$ & 8.04 & 8.84 & $2.44-6.45$ & 4.28 \\
\hline $\mathrm{Ca}(\%)$ & 3 & 1.57 & $1.42-3.25$ & 2.23 \\
\hline $\mathrm{Fe}(\%)$ & 3.5 & 4.83 & $4.25-9.53$ & 5.72 \\
\hline $\mathrm{K}(\%)$ & 2.2 & 2.99 & $0.38-0.92$ & 0.69 \\
\hline $\operatorname{Mg}(\%)$ & 1.33 & 1.57 & $0.93-1.91$ & 1.48 \\
\hline $\mathrm{Mn}(\%)$ & 0.06 & 0.085 & $0.013-0.072$ & 0.0394 \\
\hline$P(\%)$ & 0.07 & 0.0698 & $0.12-1.64$ & 0.42 \\
\hline $\operatorname{Ti}(\%)$ & 0.41 & 0.47 & $0.11-0.35$ & 0.22 \\
\hline $\mathrm{S}(\%)$ & & & $1.78-4.28$ & 2.66 \\
\hline $\mathrm{Al} / \mathrm{Ti}$ & & & $17.5-47.31$ & 20.05 \\
\hline $\mathrm{Ca} / \mathrm{Al}$ & & & $0.33-0.73$ & 0.54 \\
\hline $\mathrm{Fe} / \mathrm{Al}$ & & & $0.82-3.91$ & 1.56 \\
\hline $\mathrm{K} / \mathrm{Al}$ & & & $0.059-0.2$ & 0.17 \\
\hline $\mathrm{Mg} / \mathrm{Al}$ & & & $0.15-0.66$ & 0.37 \\
\hline $\mathrm{Mn} / \mathrm{Al}$ & & & $0.003-0.012$ & 0.009 \\
\hline $\mathrm{Na} / \mathrm{Al}$ & & & $0.098-0.78$ & 0.59 \\
\hline $\mathrm{P} / \mathrm{Al}$ & & & $0.031-067$ & 0.13 \\
\hline Ti/Al & & & $0.021-0.057$ & 0.051 \\
\hline $\mathrm{Ca} / \mathrm{Sr}$ & & & $79.12-108.6$ & 91.54 \\
\hline $\mathrm{Mn} / \mathrm{Fe}$ & & & $0.0014-0.014$ & 0.0074 \\
\hline $\mathrm{Mg} / \mathrm{Fe}$ & & & $0.15-0.38$ & 0.27 \\
\hline $\mathrm{Al}_{2} \mathrm{O}_{3}(\%)$ & & 16.7 & $4.61-12.19$ & 8.09 \\
\hline $\mathrm{CaO}(\%)$ & & 2.2 & $1.02-2.32$ & 1.59 \\
\hline $\mathrm{Fe}_{2} \mathrm{O}_{3}(\%)$ & & 6.9 & $3.3-7.41$ & 4.45 \\
\hline $\mathrm{K}_{2} \mathrm{O}(\%)$ & & 3.6 & $0.3-0.77$ & 0.57 \\
\hline $\mathrm{MgO}(\%)$ & & 2.6 & $0.56-1.15$ & 0.89 \\
\hline $\mathrm{MnO}(\%)$ & & $\sim 0.11$ & $0.01-0.056$ & 0.03 \\
\hline $\mathrm{Na}_{2} \mathrm{O}(\%)$ & & 1.6 & $0.5-1.68$ & 1.08 \\
\hline $\mathrm{P}_{2} \mathrm{O}_{5}(\%)$ & & 0.16 & $0.066-0.88$ & 0.23 \\
\hline $\mathrm{TiO}_{2}(\%)$ & & 0.78 & $0.066-0.21$ & 0.13 \\
\hline $\mathrm{Fe}_{2} \mathrm{O}_{3} / \mathrm{Al}_{2} \mathrm{O}_{3}$ & & 0.41 & $0.34 \sim 1.61$ & 0.64 \\
\hline
\end{tabular}


Table 6.4. Summary of concentrations of trace elements in Mereworth Sound freeze core.Upper crust data (Taylor and McLennan, 1985, modified by Taylor and Mclennan, 1995; Mclennan, 2000); Average shale data (Wedepohl 1971; 1991).

\begin{tabular}{|c|c|c|c|c|}
\hline \multirow[b]{2}{*}{$\begin{array}{c}\text { Element/ } \\
\text { Ratio }\end{array}$} & \multirow[b]{2}{*}{ Upper Crust } & \multirow[b]{2}{*}{ Average Shale } & \multicolumn{2}{|c|}{ Mereworth Sound $(n=37)$} \\
\hline & & & Range & Mean \\
\hline $\mathrm{Ba}(\mathrm{ppm})$ & 550 & 580 & $113.24-291.03$ & 183.7 \\
\hline $\mathrm{Cd}(\mathrm{ppm})$ & 0.098 & 0.13 & $1.16-4.18$ & 2.37 \\
\hline Co (ppm) & 17 & 19 & $4.88-18.56$ & 10.99 \\
\hline $\mathrm{Cr}(\mathrm{ppm})$ & 83 & 90 & $32.26-104.55$ & 45.85 \\
\hline $\mathrm{Cu}(\mathrm{ppm})$ & 25 & 45 & $57.91-873.3$ & 295.44 \\
\hline Mo (ppm) & 1.5 & 1 & $3.64-17.28$ & 9.15 \\
\hline $\mathrm{Ni}$ (ppm) & 44 & 68 & $12.33-31.67$ & 20.71 \\
\hline $\mathrm{Sr}(\mathrm{ppm})$ & 350 & 300 & $170.43-330.04$ & 241.54 \\
\hline $\mathrm{V}(\mathrm{ppm})$ & 107 & 130 & $134.85-185.88$ & 156.44 \\
\hline $\mathrm{Zn}(\mathrm{ppm})$ & 71 & 95 & $73.19-214.4$ & 103.56 \\
\hline $\mathrm{Ba} / \mathrm{A} 1$ & & 0.0066 & $0.002-0.005$ & 0.004 \\
\hline $\mathrm{Ba} / \mathrm{K}$ & & 0.019 & $0.018-0.37$ & 0.026 \\
\hline $\mathrm{Cd} / \mathrm{Al}$ & & 0.0000015 & $0.019-0.16$ & 0.056 \\
\hline $\mathrm{Co} / \mathrm{Al}$ & & 0.00021 & $0.0006-0.0037$ & 0.0012 \\
\hline $\mathrm{Cr} / \mathrm{Al}$ & & 0.00102 & $0.00009-0.00031$ & 0.00025 \\
\hline $\mathrm{Cu} / \mathrm{Al}$ & & 0.00051 & $0.0011-0.028$ & 0.0085 \\
\hline $\mathrm{Mo} / \mathrm{Al}$ & & 0.000015 & 0.000090 .00054 & 0.00023 \\
\hline $\mathrm{Ni} / \mathrm{Al}$ & & 0.00077 & $0.00029-0.0011$ & 0.00053 \\
\hline $\mathrm{Sr} / \mathrm{Al}$ & & 0.0034 & $0.003-0.008$ & 0.006 \\
\hline $\mathrm{V} / \mathrm{Al}$ & & 0.0015 & $0.0021-0.0061$ & $\sim 0.0041$ \\
\hline $\mathrm{Zn} / \mathrm{Al}$ & & 0.0011 & $0.00093-0.0021$ & 0.0017 \\
\hline
\end{tabular}



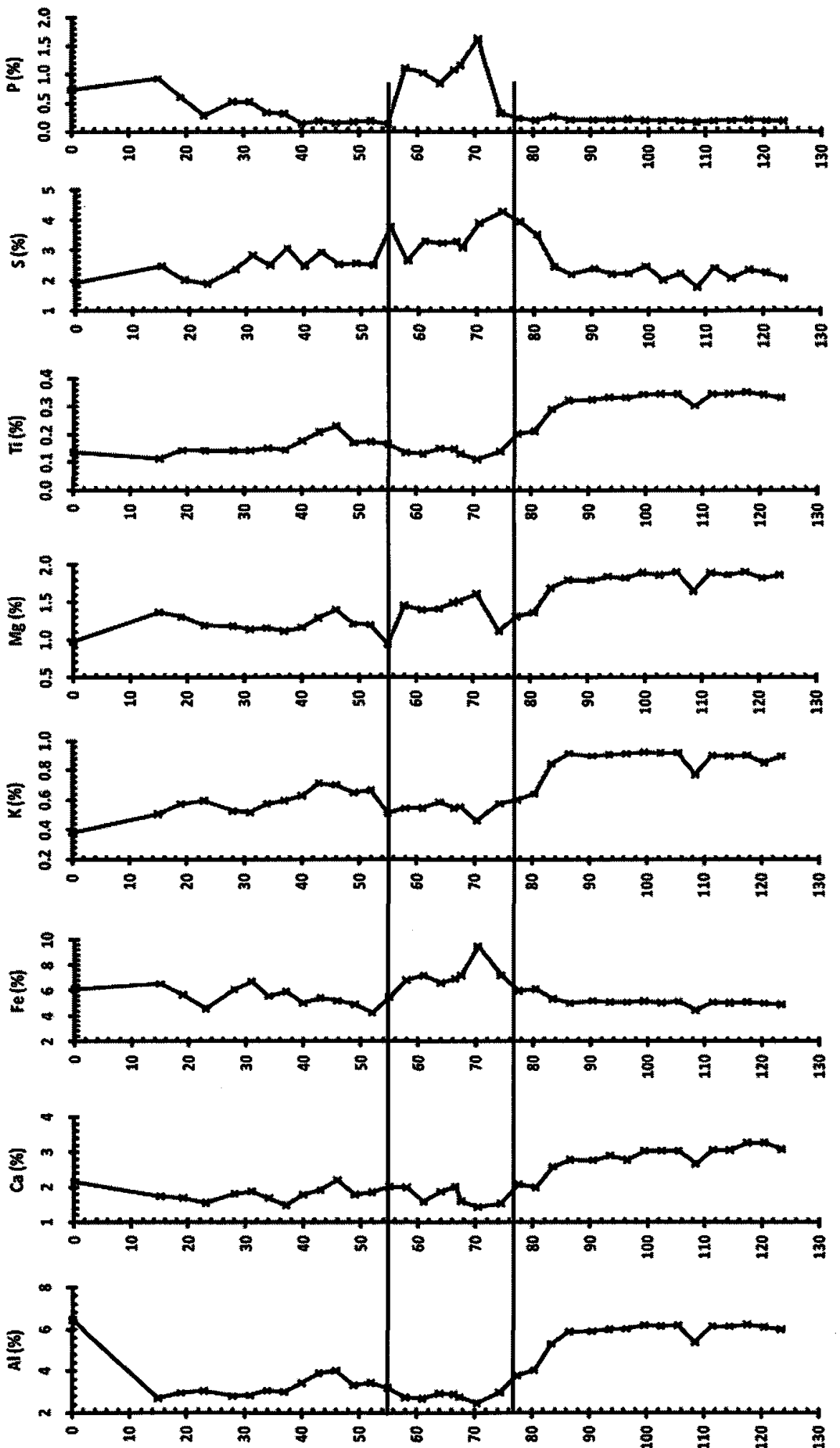

(ui) प1dəa

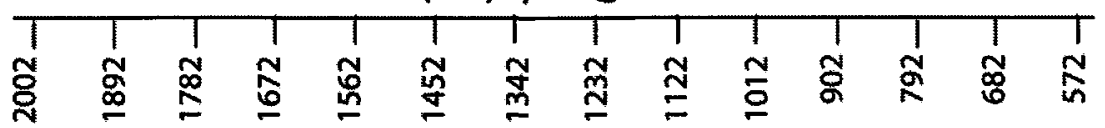

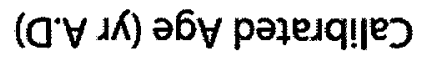



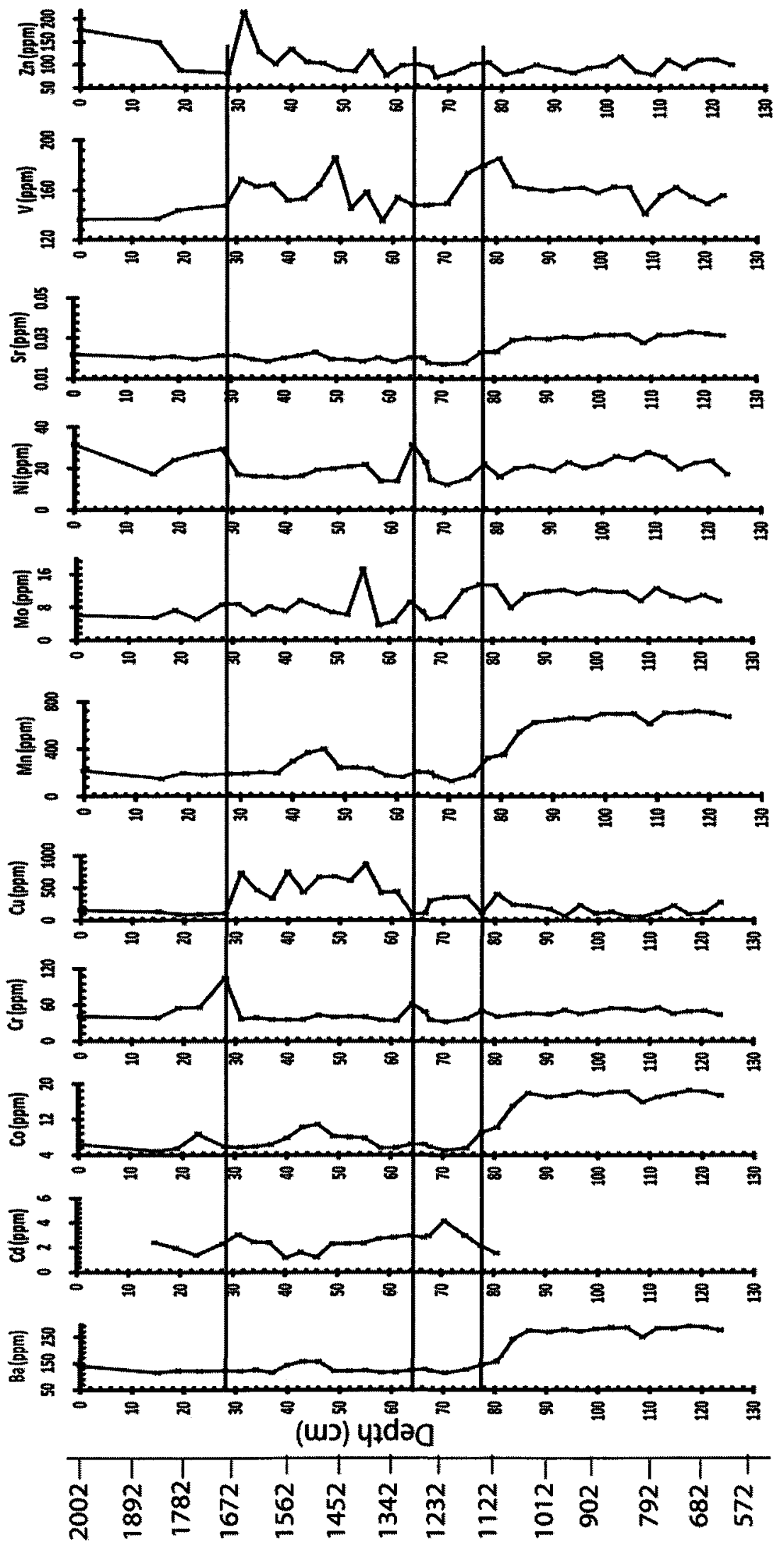

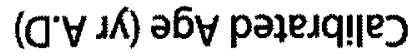




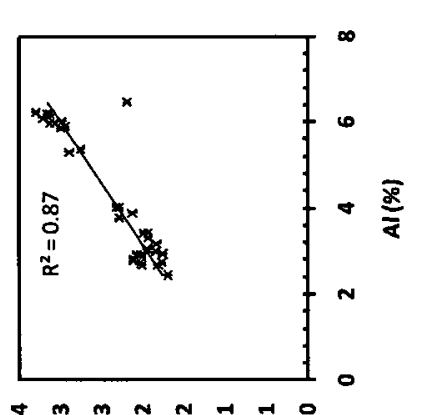

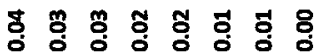

(\%) 15

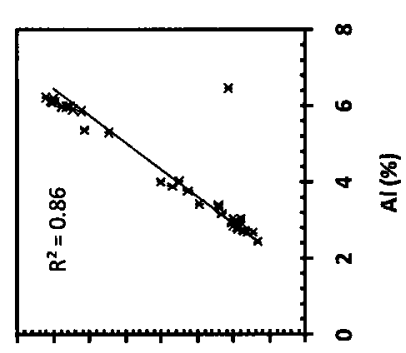

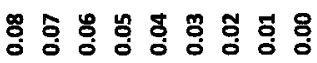

(\%) un

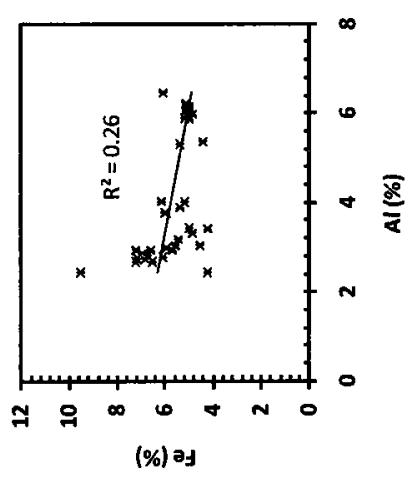

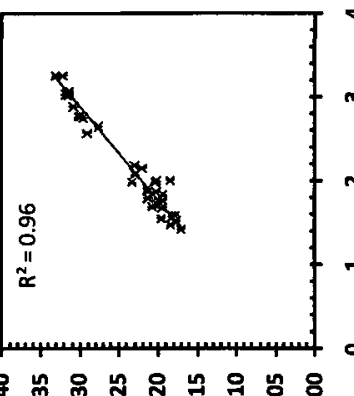

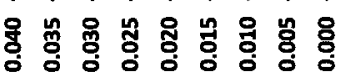

(\%) 15

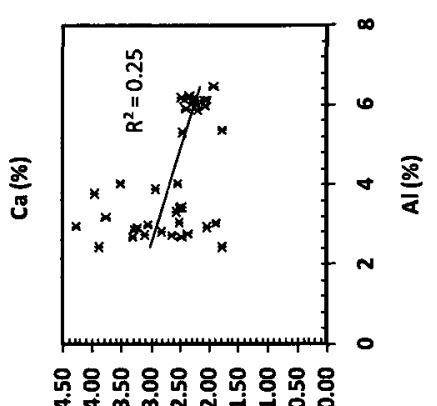

(\%) 5
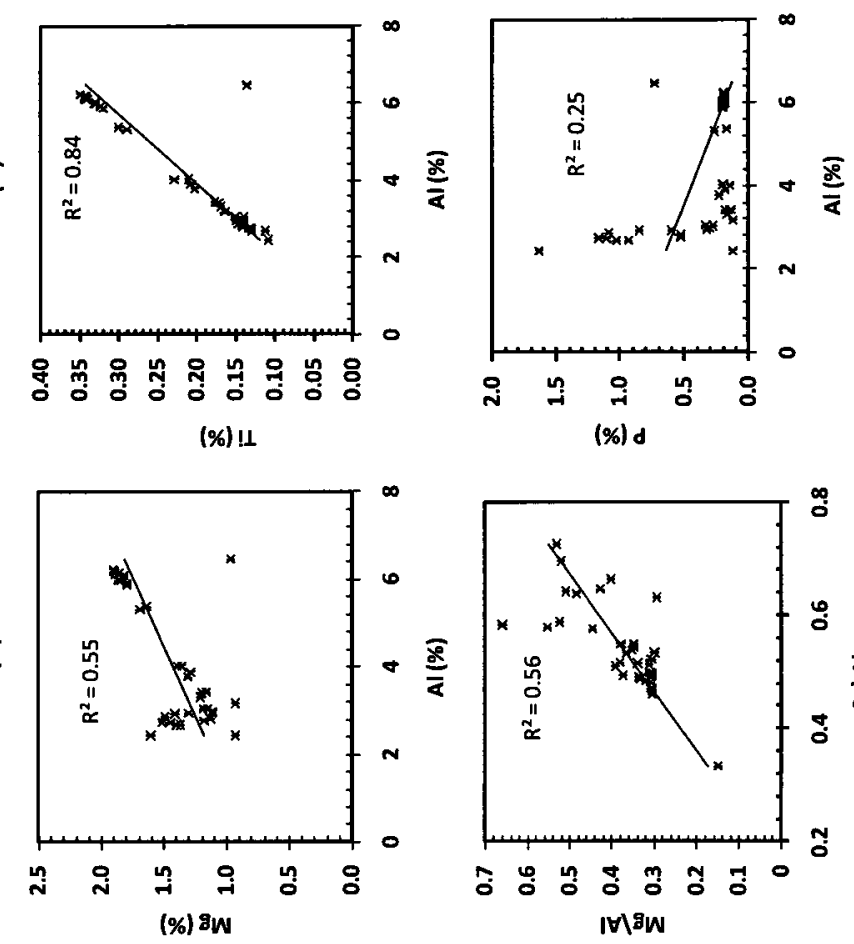

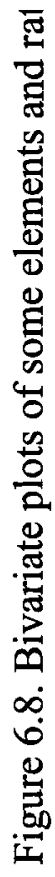


characterized by a decreasing trend within the $70-52 \mathrm{~cm}$ and $52-28 \mathrm{~cm}$ intervals (Figure 6.7). Nickel is characterized by two major peaks within the $67-61 \mathrm{~cm}$ and $31-15 \mathrm{~cm}$ intervals.

\subsubsection{Spectral Results}

The spectral analysis of the elemental data reveals existence of predominantly 71-112 and 122-225-year cycles in $\mathrm{Cu}, \mathrm{Cr}, \mathrm{Mo}, \mathrm{Ni}$ and $\mathrm{V}$ (Table 6.5 and Figure 6.9). A short amplitude 67 periodicity is also present in Mo while longer cycle of 450 -year periodicity is seen in $\mathrm{Cr}$.

Table 6.5. Spectral Results from Mereworth Sound core.

\begin{tabular}{|c|c|c|c|c|}
\hline Proxy & 67-year & 71-112-year & 135-225-year & 450-year \\
\hline $\mathrm{Cu}$ & & 75,90 & & \\
$\mathrm{Cr}$ & & 80,103 & 135,225 & 450 \\
$\mathrm{Mo}$ & 67 & 103 & 135 & \\
$\mathrm{Ni}$ & & 85,112 & 150,225 & \\
$\mathrm{~V}$ & & 71,90 & 170 & \\
\hline
\end{tabular}



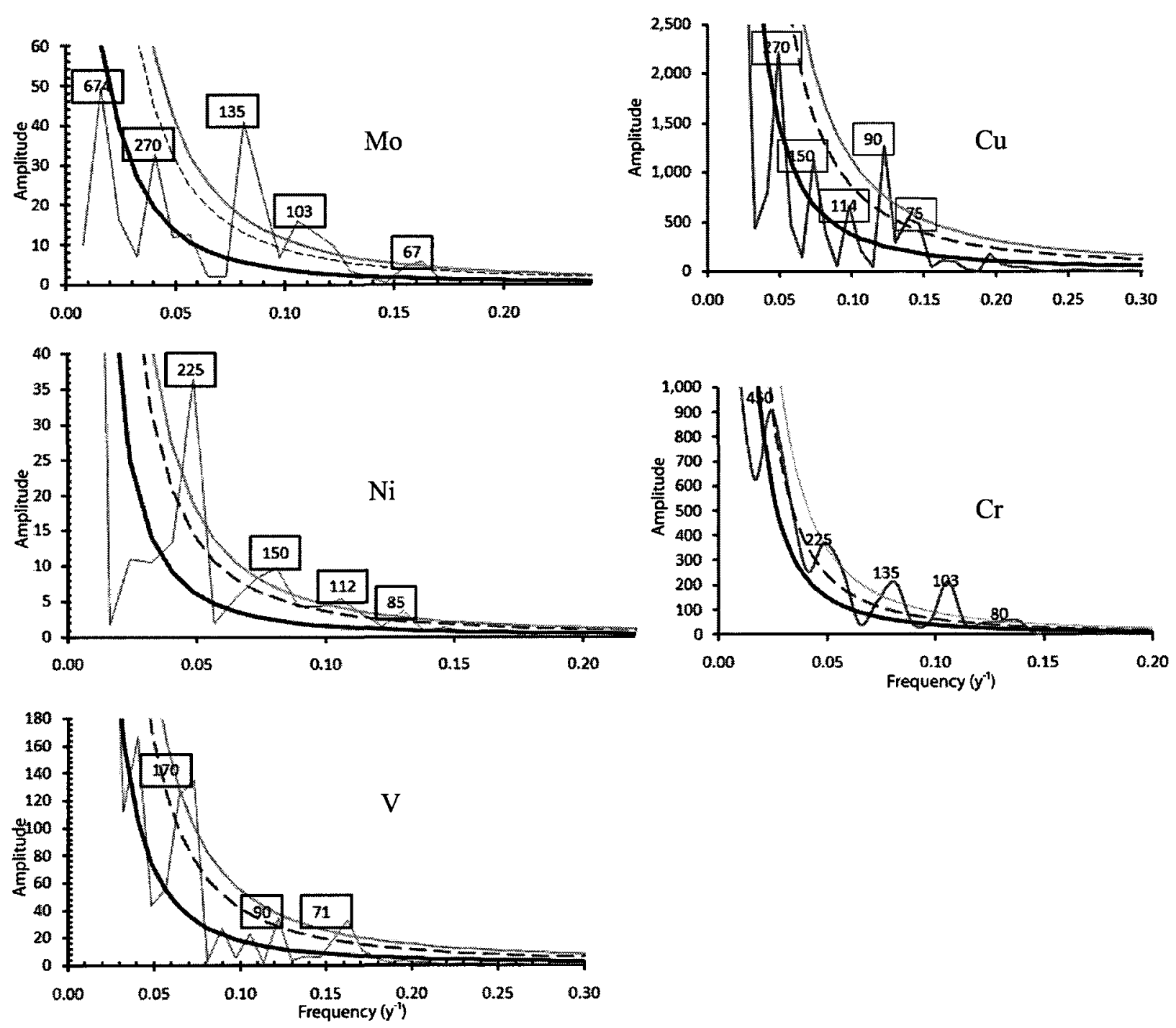

95\% Confidence level

- - - $\quad 90 \%$ Confidence level

$\longrightarrow$ Red Noise

Figure 6.9. Spectral times series of some elements in Mereworth Sound core. 


\subsection{Discussion}

\subsubsection{Lithogenic Indices}

The major elements are used to determine the sediment variation in the inlet. The concentrations of $\mathrm{Al}$ and other aluminosilicate related elements (e.g., $\mathrm{Ca}, \mathrm{Ti}, \mathrm{K}$ and $\mathrm{Mg}$ ) are characterized by an uphole decreasing trend, commencing from $77.5 \mathrm{~cm}$ (Figure 6.6). Similar to the major elements, almost all the trace elements also exhibit a dramatic shift recording reduced concentrations within upper section of the core. This observed change in the elemental distribution is consistent with the major sedimentological change from predominantly mud and silt-rich sediments in the basal section to sand-rich sequence in the upper part of the core.

The values of $\mathrm{Fe}_{2} \mathrm{O}_{3} / \mathrm{Al}_{2} \mathrm{O}_{3}$ ratio (0.6 -1.6, Table 6.3 and Appenixe C13) in the upper $83.5 \mathrm{~cm}$ of the core are higher than the 0.52 threshold for the precipitation of Fe-bearing authigenic minerals (e.g., limonites, glauconite and illite) suggesting that these minerals are present throughout the upper portion of the core (Calvert, 1976). The absence of these minerals in the lower $83.5-129 \mathrm{~cm}$ interval is indicated by much lower values ranging from $0.337-0.412$.

The similar distribution of $\mathrm{Ca}$ and $\mathrm{Al}$ (Figure 6.6) and their strong correlation (Figure 6.8) in the core suggests that both elements were likely enriched in the same mineralogical phase, probably aluminosilicates (Calvert, 1976). The low values of $\mathrm{Ca} / \mathrm{Sr}$ ratio and strong correlation between $\mathrm{Ca}$ and $\mathrm{Sr}\left(\mathrm{r}^{2}=0.96\right)$ in this core are an indication that both elements are most likely derived from non-marine sediment. $\mathrm{Ca} / \mathrm{Sr}$ values $>210$ normally indicate sediments enriched in marine calcite while ones enriched in non-marine shales are characterized by values less than 70 (Weldephol, 1971). The values of this ratio are mostly 
with shale threshold values. Calcium and $\mathrm{Sr}$ might also be primarily enriched in the same mineralogical phase such as plagioclase feldspar (Francois 1988).

The strong correlation between $\mathrm{Al}$ and $\mathrm{Mg}$ and high $\mathrm{Mg} / \mathrm{Al}$ ratios in the sediments (Figure 6.8) can be interpreted as a likely indication of magnesium bearing clay minerals such as montmorillonite (Calvert, 1976). A strong correlation of $\mathrm{Ti}$ to $\mathrm{Al}$ suggests the presence of titanium-rich heavy minerals including ilmenite (Hirsi, 1962), anatase and rutile (Calvert, 1976) in the core sediments. Barron et al. (2004) associated the presence of a strong correlation between these elements to their co-existence in the same terrigenous phase. The observed strong correlation between these elements ( $\mathrm{Al}$ and $\mathrm{Ti}$ ) and the non-zero intercept in the bivariate plot trendline (Timothy and Calvert, 1998) might also suggest the presence of aluminosilicates in the sediments (Calvert and Pedersen, 2007).

The strong relationship between $\mathrm{Mg} / \mathrm{Al}$ and $\mathrm{Ca} / \mathrm{Al}\left(\mathrm{r}^{2}=0.56\right)$ indicates that certain amount of dolomite is present in the sediments (Johnson and Grimm, 2001) as well as that $\mathrm{Ca}$ in the sediments is partially derived from carbonate sources. A moderate correlation of $\mathrm{P} / \mathrm{Al}$ with $\mathrm{Ca} / \mathrm{Al}$ in the core is also an indication that certain proportion of apatite is present in the core.

\subsubsection{Paleoceanography}

The basal section 129-78.5cm (1425-864 cal yr BP/577-1138 AD) of core VEC02A13 is sparsely fossiliferous with most intervals totally barren of microfauna. This section of the core is dominantly composed of non-bioturbated, homogenous, organic matter rich mud and silt sediments deposited under bottom water anoxia. The concentrations of redox sensitive elements (e.g., Mo, Co, V, Cu and $\mathrm{Zn}$ ) in this portion of the core are higher than their crustal limits (Taylor and McLennan, 1985; 1995; McLennan, 2000), indicating the existence of 
anoxic conditions. The application of transfer function models derived from modern foraminifera distribution from surface samples in Belize Inlet and Alison Sound (VázquezRiveiros, 2006) to the samples from the MS freeze core VEC02A13 provides the basis for evaluation of the paleoceanographic records in the top $78 \mathrm{~cm}$ section of the core (Figure 6.5). The inferred oxygen concentrations $(3.75-4.51 \mathrm{~mL} / \mathrm{L})$ suggest that the fossiliferous intervals of the core were deposited under higher oxygen conditions than those in the $129-78.5 \mathrm{~cm}$ (1425-864 cal yr BP/1214-1138 cal AD) and 44-35 cm (484-385 cal yr BP, 1518-1617 cal AD) where foraminifera are sparse or totally absent.

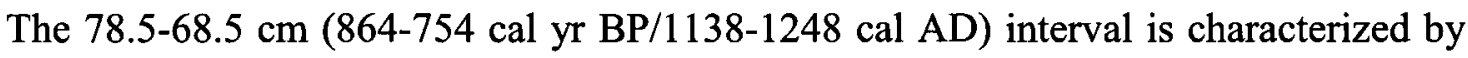
slightly depressed oxygen, elevated salinity and temperatures than in the overlying $68.6-56 \mathrm{~cm}$ (754-616 cal yr BP/1138-1386 cal AD) interval. This part of the core belongs to the HB-EA Biofacies which is characterized by moderate abundances of low oxygen tolerant agglutinated foraminifera $H$. bradyi, E. advena, and $R$. turbinatus and calcareous Stainforthia feylingi in association with highly reduced $B$. frigida and $C$. excavatum.

The bottom water conditions became highly oxygenated during the deposition of the $68.5-56 \mathrm{~cm}$ interval (754-616 cal $\mathrm{yr} \mathrm{BP} / 1138-1386 \mathrm{AD})$. This portion of the core is dominated by the CE-BF and BF Biofacies as well as a couple of samples from the HB-CE Biofacies (Figure 6.4). These biofacies are mainly characterized by typical high oxygen cool-water calcareous formainiferal species $B$. frigida and $C$. excavatum.

The estimated oxygen $(4.3-4.51 \mathrm{~mL} / \mathrm{L})$, paleotemperatures $\left(8.1 \sim 8.2^{\circ} \mathrm{C}\right)$ and salinities (30.16-30.18\%) within this interval are similar to the values of these ecological variables found from the $64-11 \mathrm{~cm}$ interval (1574-1943 cal AD) in the FC04 core from Belize Inlet (Vázquez-Riveiros, 2006). The inferred salinities which are close to values found in stable 
open shelf environments (Schafer et al., 1989, Sen Gupta, 2002, Alve, 2000), are consistent with the open marine nature of $B$. frigida (Murray, 2006), the most dominant species in the core.

In the MS core, B. frigida and $C$. excavatum as well as dissolved oxygen are negatively loaded in the principal component factor analysis (Factor 1, Table 6.2). This trend is consistent with the strong relationship between these species and oxygen. Therefore, their distributions in the inlet are likely mostly controlled by the level of bottom water oxygenation.

High abundances of $B$. frigida and moderate representations of $C$. excavtaum in this part (754-616 cal yr BP/1138-1386 AD) of the core are an indication that the sediments within the intervals were deposited in a well-oxygenated normal open shelf cool-environment (e.g., Patterson, 1993; Ishman and Foley, 1996; Murray, 2006). Vázquez-Riveiros (2006) interprets assemblages characterized by high abundances of these two species in surface samples and freeze core from a nearby Belize Inlet as open shelf assemblages. William (1989) and Cooper (1964) also describe similar shallow water assemblages dominated by high abundances of $B$. frigida and Cribroelphidium spp. from the Fraser River and the Chukchi Sea, respectively. In their study of the foraminiferal distributions in the Svalbard Achipelago shelf in the high Arctic region, NW Barrents Sea, Slubowska-Woldengen et al. (2007) correlate high abundances of C. excavatum and Buccella sp to an increase in sea ice cover, low temperatures and salinities.

Buccella frigida, the most abundant species within this interval and the entire core, is a typical open shelf, temperate waters species usually found in cool nearshore environments with salinities close to those of normal marine waters in coastal British Columbia (e.g., Zellers, 1990; Patterson 1993; Blais-Stevens and Patterson, 1998; Patterson et al., 2000; 
Murray, 2006). Kerr (1984) attributed faunal assemblages that include the genus Buccella to shallow water of $20-40 \mathrm{~m}$ in depth.

Cribroelphidium excavatum, the second most important species within this interval, is widely distributed in shallow cold, normal-salinity, marine waters of the temperate and polar seas (Phleger, 1952; Loeblich and Tappan, 1953; Patterson 1993; Hald et al., 1994; Hald and Korsun, 1997; Korsun and Hald, 2000, Patterson and Kumar, 2000b). This species is very abundant in high latitude shelves of North America and Europe (Cockbain, 1963; Miller, 1982; Miller et al., 1982; Patterson, 1993). Cribroelphidium excavatum is described as an indicator of depressed salinities (Lesile, 1965; Schafer and Cole, 1978; Patterson, 1993). Cribroelphidium excavatum can live in substrates characterized by highly variable grain size and organic carbon content (Alve and Murray, 1999). It survives in polluted waters and low oxygen concentration environments.

Cribroelphidium excavatum clavata, the most dominant forma of the C. excavatum in the MS core is usually restricted to relatively low-salinity, shallow water environments such as estuaries (Loeblich and Tappan, 1953; Walton, 1964; Kerr, 1984). Sen Gupta (2002) concludes that the distribution range of the species is restricted to the high northern latitude belt in the Pacific and Atlantic Oceans. The species which usually inhabits less than 10-20 m depth of waters (Bartlett and Molinsky, 1972) is found in high abundance along with other Cribroelphidium species in less than $30-50 \mathrm{~cm}$ and littoral zones in Alaska (Lagoe, 1979b; Bergen and O'Neil, 1979; Zellers, 1990). It is a dominant species near glacier environments in Svalbard (Nagy, 1965; Lučinskaja, 1974; and Aasgaard, 1978) and in ice margins in northwestern Europe (Feyling-Hanssen et al., 1971; Miller, 1979; Osterman, 1984; Hald and Vorren, 1987; Hald et al., 1989). The species is described as the most glacier-proximal 
foraminiferal species favored by seasonal ice covers, turbidity and high sedimentation rates near-glacier settings (Hald et al., 1994, 2001; Hald and Korsun, 1997; Korsun and Hald 2000; Majewski and Zajaczkowski, 2007).

The relatively lower salinity in this section of the MS core compared to the upper 56-0 cm (616-0 cal yr BP/1386-2002 cal AD) part of the core could be explained by the salinity tolerance of $C$. excavatum. The species tolerates a wide range of salinities ranging from 1535\% (Smith, 1970; Zellers, 1990). Guilbault et al. (2003) encountered Cribroelphidium dominated assemblage under hyposaline conditions with $<30 \%$ water salinities in the Strait of Georgia. Scott and Vilks (1991) associated the abundance of C. excavatum clavata in a marginal marine environment to freshwater plume.

Epistominella vitrea is an important species in the BF-CE Biofacies. This offshore indicator species (Klitgaard-Kristensen and Buhl-Mortensen, 1999) is dominant in outer shelf environments along the coastlines of the Pacific Northwest (Patterson, 1993). Bergen and O'Neil (1979) found this species at water depths of $100-200 \mathrm{~m}$ in the Gulf Alaska while Snyder et al. (1990) reported the species at water depth of $143 \mathrm{~m}$ off the coastal region of northern Oregon. According to Gustafsson and Nordberg (2000), E. vitrea thrives and survives under dysoxic conditions.

This interval (754-616 cal yr BP/1138-1386 AD) of the MS core is characterized by reduced enrichments of redox related elements and ratios including $\mathrm{Cu}, \mathrm{Mo}, \mathrm{V}, \mathrm{Zn}$ and $\mathrm{Mn} / \mathrm{Fe}$ (Figure 6.7). This trend supports the inference of high oxic conditions based on the estimated oxygen and presence of certain foraminiferal species (e.g., B. frigida and C. excavatum) in this interval. 
Subtle shifts in oxygen, salinity and temperature from the $56-44 \mathrm{~cm}$ interval (616-484 cal yr BP/1386-1518 AD) indicate a change in oceanography of the inlet from a highly oxygenated, cooler and less saline to slightly depressed oxygen, warmer and more saline conditions. Dissolved oxygen became slightly depressed $(3.74-3.89 \mathrm{~mL} / \mathrm{L})$ while both salinity $(30.23-30.27 \%)$ and temperature $\left(8.2-8.4^{\circ} \mathrm{C}\right)$ increased during the deposition of this short interval in the MS core. The observed depressed bottom water oxygenation continued throughout the top $56 \mathrm{~cm}$ of the core. Similar conditions existed during the deposition of the basal part (78.5-68.5 cm, 864-754 cal yr BP/1138-1248 AD) of the fossiliferous intervals of this core. These changes in water mass correspond to increased proportions of low oxygen tolerant agglutinated foraminifera $H$. bradyi, E. advena and $R$. turbinatus as well as calcareous S. feylingi.

The HB-CE and HB-EA Biofacies characterized by the presence of $H$. bradyi, E. advena and Stainforthia feylingi in combination with high abundances of $B$. frigida, and common occurrences of $C$. excavatum are predominantly restricted to this upper section of the core $(56-0 \mathrm{~cm})$. The HB-EA Biofacies is differentiated from the HB-CE Biofacies by its relatively lower proportion of $B$. frigida (43\% average) and higher abundances of the $H$. bradyi, E. advena and $R$. turbinatus. $R$. turbinatus is totally absent in the HB-CE Biofacies. The co-occurrence of agglutinated species with the shallow open shelf $B$. frigida and $S$. feylingi in these biofacies (Murray, 2006; Patterson, 1993; Patterson et al., 2000) suggests sediment deposition in a shallow water environment.

Haplophragmoides bradyi, E. advena and $R$. turbinatus along with temperature, salinity and silicate loadings are positive in Factors 1 and 4 (Table 6.4). These relationships are an indication that the distributions of these species are mostly controlled by water mass 
properties, especially temperature and salinity. A strong negative loading of oxygen in both of these factors is consistent with the known tolerance of these species to low oxygen conditions. Moderate representations of these species and the low SDI in the biofacies suggest that the paleoxygen condition was probably lower than the estimated values. Vázquez-Riveiros (2006) reached a similar conclusion from an assemblage dominated by $S$. feylingi in Belize Inlet. Elevated concentrations of the redox sensitive elements $\mathrm{Mo}, \mathrm{Ni}$, and $\mathrm{Cd}$ as well as sulphur (Figure 6.7) within the zonal intervals are consistent with low level of oxygenation indicated by the presence of agglutinated foraminifera and calcareous $S$. feylingi.

Haplophragmoides bradyi, an important species in this biofacies, prefers cool muddy shallow waters where organic matter enrichment is low (Klitgaard-Kristensen and BulMortensen, 1999, Murray, 1973). The infaunal habit of this species, enables it adapt to dysoxic conditions (Sen Gupta and Machain-Castillo, 1993). Haplophragmoides species are typically found in a wide range of depths in cold to temperate regions (Murray, 2006).

As discussed in chapter 4, Eggerella advena, another common agglutinated species in the biofacies tolerates and thrives in highly polluted oxygen depleted organic-rich environments (Watkins, 1961; Clark, 1971; Schafer and Cole, 1974; Alve, 1993; 1995; Alve and Nagy, 1986; 1990; Blais-Steven and Patterson, 1998). It is one of the pioneer species to repopulate and recolonize recovering sewage dump sites (Schafer, 1972; Schafer and Cole, 1974; Schafer and Young, 1977; Schafer, 1982; Schafer et al., 1991). This species mainly inhabits nearshore environments (Cushman, 1922a; Leslie, 1965; Vilks, 1967; 1969; Bartlett, 1972; Schafer, 1972; Vilks and Deomarine, 1988; Madsen and Knudsen, 1994; Hald and Korsun, 1997; Murray, 2006). 
Eggerella scabra a morphologically similar species to E. advena is also known to live in low oxygen shallow brackish water environments in fjords and shelves in northern Europe (Alve and Nagy, 1986; Alve, 1990; Murray, 2006). It survives in oxygen conditions that are as low as $0.5 \mathrm{~mL} / \mathrm{L}$ (Olsson, 1989, personal comm. cited in Alve, 1995). Agglutinated species including E. advena are usually tolerant to hyposalinity (Guilbault et al., 2003). Species of Eggerella such as E. scabra live in brackish waters with salinity $>24 \%$ (Murray, 2006). Eggerella advena is abundantly present in waters characterized by $29-30 \%$ in the Canadian arctic (Saidova, 2002).

Stainforthia feylingi, a low oxygen tolerant species which survives under dysoxic conditions (0.1-0.3 $\mathrm{mL} / \mathrm{L}$, Patterson et al., 2000) is also common within the Haplophragmoides bradyi-Eggerella advena and Haplophragmoides bradyi-Cribroelphidium excavatum Biofacies in the upper section of the MS core. This species lives in a wide range of depths in the arctic and boreal environments of Greenland, Canada and Norwaygian continental margins (Knudsen and Seidenkrantz, 1994). The ecological distribution of $S$. feylingi in coastal British Columbia is typically associated with depressed oxygen conditions (Blais-Stevens and Patterson, 1998; Patterson et al., 2000; Patterson and Kumar, 2002b; Vázquez-Riveiros, 2006).

S. fusiformis which is morphologically similar to $S$. feylingi is dominant in stressed environments in Europe where the level of oxygenation is low (Murray, 2006). This species is one of the early species to recolonize recovering anoxic environments in several fjords in Norway (Alve, 1995, Alve, 2000; Sen Gupta and Machain-Castillo, 1993). Knudsen and Seidenkrantz (1994) ascribed high frequencies of S. fusiformis in fossil records to transitional 
environments between arctic and boreal regions which is an indication that this species is tolerant to unstable conditions.

Euuvigerina peregrina, a deep water species, is substantially represented within the interval. It inhabits environment with high organic carbon flux provided that oxygen depletion is moderate (Schmiedl et al., 1997; Miller and Lohmann, 1982; Lutze and Coulboum, 1984; Lutze et al., 1986). A strong correlation of E. peregrina to E. advena and $H$. bradyi in the MS core is consistent with the strong relationship of the species to organic matter. The increase of the proportion of this species within this interval likely suggests an increase in organic matter flux within this upper portion of the core.

Angulogerina angulosa which is common in the HB-CE Biofacies of this study is found in a wide range of environments; varying from shelf to continental slope (Mackensen et al., 1990). In the MS core, $A$. angulosa has a positive correlation coefficient with oxygen ( $\mathrm{r}=$ 0.33; Table 6.1). Along with oxygen, it is negatively represented in Factor 1 (Table 6.2). This trend is an indication of oxygen being the main factor influencing the distribution of $A$. angulosa in the core. Mackensen (1987) and Mackensen et al. (1985, 1990) establish that the distribution of $A$. angulosa is independent of water salinity and temperature. The observed inverse relationship between this species and these variables (salinity and temperature) in the MS core supports this conclusion. A. fluens, a closely related species, is found in cold bottom water with seasonal influx of organic nutrients (Korsun and Polyak, 1989; Steinsund et al., 1994; Polyak et al., 2002; Sejrup et al., 2004). It is also known to increase in abundance when the influence of Coastal Current on the inner shelf is stronger (Slubowska-Woldengen et al., 2007). High organic matter contents and turbulent estuarine circulation might have also influenced the distribution of $A$. angulosa in SBIC. 


\subsubsection{Paleoclimate Implication}

The climate conditions were warmer and drier during the deposition of the barren 129$78.5 \mathrm{~cm}(1425-864 \mathrm{cal} \mathrm{yr} \mathrm{BP} / 577-1138 \mathrm{cal} \mathrm{AD})$ interval in MS. The presence of agglutinated foraminifera $E$. advena and $H$. bradyi and slightly higher inferred paleotemperatures within the $78.5-68.5 \mathrm{~cm}(864-732 \mathrm{cal}$ yr BP/1138-1270 cal AD) interval are also likely representation of continuation of the warm dry climate conditions in the inlet. The climate conditions at this time in SBIC correspond to the warmer and more stable with less wind conditions that existed during the Medieval Warm Period (MWP) in Greenland (Jennings and Weiner, 1996). During MWP, precipitation (Clague et al., 2004; Jennings and Weiner, 1996; Overpeck et al., 1997; Saenger et al., 2006) and ice cover (Roncaglia and Kuijpers, 2004) records were low.

The prevalence of warm and dry conditions in SBIC during the period under discussion was likely in response to the influence of the regional atmospheric circulation systems-the Aleutian Low (AL) and the North Pacific High (NPH). A westward shift and/or reduced intensity of AL with corresponding northward shift and/or strengthened NPH would result in low precipitation, diminished estuarine circulation and consequently reduced exchange between the fjord and open ocean. Based on high $\delta^{18} \mathrm{O}$ record from lacustrine carbonate in Jelly Bean Lake in the Yukon Territory, Andersen et al. (2005a) identified MWPlike warmer and drier conditions between the last $500 \mathrm{yr}$ BP (1500 AD) and $300 \mathrm{yr}$ BP (1700 AD). They concluded that the AL had moved westward and/or became weak during that time interval.

Evidence for this warm and dry climate conditions prior to the Little Ice Age are found throughout the northern hemisphere. For example, foraminiferal based evidence reveals the existence of these climate conditions from 900-1495 AD in Belize Inlet (Vázquez-Riveiros, 
2006). This MWP-like period dominated by agglutinated foraminifera with corresponding elevated paloetemperatures (a constant of $8.6^{\circ} \mathrm{C}$ ) is attributed to the influence of weakened $\mathrm{AL}$ and intensified NPH, resulting in low precipitation and warmer conditions in SBIC than the present time. Water discharge and precipitation model also reveal the existence of drier and warmer conditions from 1200-600 cal yr BP (800-1400 AD) in northern Chesapeake Bay, east coast of North America (Saenger et al., 2006). Paleoclimate records between 855 AD and $1235 \mathrm{AD}$ in Igaliku fjord in southern Greenland also indicate the prevalence of warmer and drier conditions in southern Greenland (Lassen et al., 2004). An extended period of glacier retreat prior to $1400 \mathrm{AD}$ in the eastern Barrents Sea region before the Little Ice Age (LIA) is also related to the mild climate conditions that existed throughout the Northern Hemisphere during the MWP event (Polyak et al., 2004).

A regime change from warm/dry to cooler/wetter conditions in SBIC is indicated by the predominance of cool water indicators $B$. frigida and $C$. excavatum and the near absence of agglutinated species between the $68.5 \mathrm{~cm}(732 \mathrm{cal} \mathrm{yr} \mathrm{BP} / 1270 \mathrm{cal} \mathrm{AD})$ and $56 \mathrm{~cm}(616 \mathrm{cal}$ yr BP/ 1386 cal AD) levels in the MS core. Similar foraminiferal evidence was used to identify cooler and wetter conditions from calibrated 1495 to $1943 \mathrm{AD}$ in the nearby Belize Inlet (Vázquez-Riveiros, 2006). The estimated temperatures $\left(8.1-8.2^{\circ} \mathrm{C}\right)$ within this interval (732 cal yr BP/1270 AD-616 cal yr BP/ $1386 \mathrm{AD}$ ) in MS core are lower than those in the intervals above and below. The climate conditions at this period in SBIC are similar to cooler and wetter conditions that existed during the LIA (Lamoureux et al., 2001; Lewis and Smith, 2004; Clague et al., 2004; Lassen et al., 2004; Saenger et al., 2006).

The LIA in western Canada occurred from the 13th century through to the middle of the 19th century (Mathews, 1939 cited from Clague et al., 2004; Luckman, 2000; Lewis and 
Smith, 2004; Clague et al., 2004). Similar to the SBIC record, Clague et al. (2004) found evidence of the LIA episode from about $1200 \mathrm{AD}$ through $1800 \mathrm{~s}$ in the northern coastal Mountains area of British Columbia. They concluded that glacier accumulations during this period were greater than those of the past 3000 years and probably in the last 10000 years. Evidence for LIA glacier advance from the $13^{\text {th }}$ century through the $19^{\text {th }}$ century are also found in the Mt. Waddington Mountains region of British Columbia (Larocque and Smith, 2003; 2005) and Strathcona Provincial Park, Vancouver Island, British Columbia (Lewis and Smith, 2004). Along the same lines, Nederbragt and Throw (2001) used increasing trend of varve thickness in Saanich Inlet cores, southern British Columbia to infer cool and wetter conditions after $600 \mathrm{cal} \mathrm{yr}$ BP. The authors linked the conditions to variations in regional temperature trends which are comparable to the LIA episodes. The Canadian high Arctic is known to have experienced significant cooling conditions between 1350 and 1400 cal AD (Koerner and Fisher, 1990). Elsewhere in southern Alaska, LIA events are recorded between 1190 to mid 1800s (Wiles and Calkin, 1994; Wiles et al., 1999; Calkin et al., 2001).

The cooler and moister conditions that existed during this period (1270-1386 AD) in SBIC would correspond to an eastward shift in the center of action (COA) and/or an increase in the intensity of the regional Aleutian Low pressure system. Precipitation and cooler conditions characterize central coastal British Columbia when the Aleutian Low is intensified and its COA moves eastward (Cayan and Peterson, 1989; Trenberth and Hurrel, 1994; Gershunov et al., 1999; Dean and Kemp, 2004). Anderson et al. (2005a) interpret asimilar high precipitation evidence derived from $\delta^{18} \mathrm{O}$ record in Jelly Bean Lake in the Yukon territory between $1700 \mathrm{AD}$ and $1900 \mathrm{AD}$ as an indication of eastward shift/intensification of Aleutian Low. The authors compared the conditions to a LIA-like episode. Polyak et al. 
(2004) correlated glaciers expansion in the Barrents Sea region to increased precipitation and/or cooler summers from $1400 \mathrm{AD}$ to a LIA episode. Similar to the Aleutian Low influence on the climate of the NE Pacific, precipitation in the Barrents Sea is dominantly controlled by fluctuations of the Icelandic Low.

Intensification or eastward movement of the center of action of the Aleutian Low occurs at a time when the solar activity is minimal (Christoforou and Hameed, 1997; and Hameed and Lee, 2003). Spectral analysis carried out on the elemental data set indicates significant representation of the Suess (135-225-year), Gleissberg (71-112-year) and PDO-like (67-year) cycles as well as a longer 450-year one. The unavailability of wavelet results from this data set did not allow assigning age range to these cycles in MS. However, their significant presence in the spectral analysis is an indication of the regional climate being influenced by variations in the solar activity for the last 1400 years. The Suess, Gleissberg and PDO-like cycles are related with AL induced precipitation and/or coastal upwelling in several regions of coastal British Columbia (Patterson et al., 2004a; Patterson et al., 2005; Patterson et al., 2007; Chang and Patterson, 2005). The cycles derived from the stable isotopes and trace elemental data in Alison and Frederick Sounds are also associated with varying levels of precipitation during the late Holocene (Chapter 5).

An increase in the paleotemperatures from a $8.1^{\circ} \mathrm{C}$ to $8.4^{\circ} \mathrm{C}$ between $56 \mathrm{~cm}(616 \mathrm{cal} \mathrm{yr}$ $\mathrm{BP} / 1386 \mathrm{AD})$ and $44 \mathrm{~cm}(484 \mathrm{cal} \mathrm{yr} \mathrm{BP} / 1518 \mathrm{AD})$ suggests a likely retreat in the glacier advance during a LIA event in this region. This increase in paleotemperature coincides with the peak abundances of agglutinated $E$. advena and $H$. bradyi. The warm condition might have persisted throughout the overlying barren $44-35 \mathrm{~cm}$ (cal yr BP/1518-1617 cal AD) interval. The climatic conditions in the uppermost 35-0 $\mathrm{cm}(385-0 \mathrm{cal}$ yr BP/1617-2002 cal AD) 
interval of the core with almost constant temperature of $8.2^{\circ} \mathrm{C}$ is slightly cooler than the underlying 56-44 $\mathrm{cm}(616-484 \mathrm{cal}$ yr BP/1386-1518 cal AD) interval and warmer than the cooler $68.5-56 \mathrm{~cm}(732-616 \mathrm{cal}$ yr BP/1270-1386 cal AD) interval. This trend probably indicates a gradual return to cooler conditions in the region around $1617 \mathrm{AD}$.

Based on the stratigraphic disappearance of warm water Melonis barleanus and increase in cool water indicator Cibicides neoteretis, Lassen et al. (2004) identify similar stepwise cool events in the southern Greenland coast. The first episode which occurred at about $1405 \mathrm{AD}$ was terminated by a warm condition around $1520 \mathrm{AD}$. This warm episode was followed by a long and final cooling event (Lassen et al., 2004). A similar climate warming occurring at about $1470 \mathrm{AD}$ was earlier identified within LIA glacier advances in the eastern region of Greenland coast (Jennings and Weiner, 1996).

The warm conditions present during the late LIA (1386-1518 AD) in the MS core record were not previously recognized in the main inlet (Belize Inlet) to which MS is a distributary. The cool and wetter LIA event in Belize Inlet spanned from $1495 \mathrm{cal}$ AD through 1943 cal AD (Vázquez-Riveiros, 2006). This disparity in climate records of both inlets could be due to differential estuarine circulation patterns. The sill present in MS and/or increased spring-summer precipitation may have restricted complete estuarine circulation during the LIA (Thomson, personal comm., 2009).

Estuarine circulation in SBIC is mainly controlled and restricted by the main sill - the Nakwakto Rapids which are situated at the junction of the SBIC complex and Queen Charlotte Sound. The additional sills present within the different arms of the SBIC further restrict circulation. There is not a sill directly situated within the Belize Inlet, however, a $37 \mathrm{~m}$ deep sill is present in MS. This sill might have, in addition to the the Nakwakto Rapids, restricted 
water circulation in SBIC during the LIA period, thereby, reducing exchange and mixing between the warm freshwater from the head of the inlet and cool open ocean waters from Queen Charlotte Sound. This process would have allowed the development of thick warmer less saline surface water.

The development of thick warm surface water layer at this time (1386-1518 cal AD) in the inlet was also probably facilitated by an increase in spring-summer precipitation. High spring/summer precipitation would normally lead to stabilization of the warm surface layer water thereby preventing turbulent flow and mixing with cooler and denser open ocean waters around the sill. Such a process would allow higher heat retention within the thick surface layer than when circulation is at its peak.

\subsection{Conclusions}

A high-resolution investigation of foraminiferal biofacies and trace element enrichment characterizing freeze core VEC02A13 from Mereworth Sound (MS) provided information on paleoceanographic and paleoclimate conditions in younger sediments, which were not assessed with the piston cores due to core over penetration.

The sediments of the MS freeze core indicate that the upper $68.5 \mathrm{~cm}(1248-2002 \mathrm{AD})$ of the MS core contains a higher percentage of sand sediments than the basal $129-68.5 \mathrm{~cm}$ (AD) section. Higher values of almost all major and trace elements are found in the basal muddier portion of the core than in the sandier upper section of the core.

The foraminiferal assemblages from the MS freeze core were primarily comprised of low numbers of calcareous species. Agglutinated species comprised a minor part of the foraminiferal fauna. The cluster Q- and R-modes analyses resulted in recognition of four biofacies; the Buccella frigida, Buccella frigida-Cribroelphidium excavatum, 
Haplophragnmoides bradyi-Eggerella advena and Haplophragmoides bradyiCribroelphidium excavatum Biofacies.

A dearth of foraminifera and high concentrations of redox-related elements in the lower section of the core (1425-754 cal yr BP/577-1248 AD) were used to indicate the existence of low levels bottom water oxygenation, most likely anoxic conditions. The paleoceanographic and climatic conditions inferred for this portion of the MS core probably correspond to the latest Late Holocene warm climate events during the Medieval Warm Period. The estimated paleotemperature, oxygen and salinity levels, and dominance of cool water indicators - Buccella frigida and Cribroelphidium excavatum, from 754-616 cal yr BP (1248-1386 cal AD) indicate a shift to cool, highly oxygenated, normal marine conditions, which most likely corresponded to conditions as existed during the Little Ice Age (LIA). Increased proportions of agglutinated foraminiferal species Haplophragmoides bradyi, Eggerella advena, Recurvoides turbinatus and the calcareous low-oxygen, indicator species Stainforthia feylingi, observed within the 1386-1518 cal AD intervals, were used to infer the presence of slightly depressed oxygen levels and warmer, bottom-water conditions during the LIA period. The decrease in abundances of agglutinated foraminiferal species and corresponding increase in abundances of $B$. frigida and $C$. excavatum within the topmost 1518-2002 cal AD section of the MS core are interpreted as an indication of a return to relatively cool climatic conditions in the region. 


\section{CHAPTER SEVEN}

\section{CONCLUSIONS}

The utilization of a multiproxy approach in the study of laminated and homogenous sediments from two piston cores from Frederick Sound (FS) and Alison Sound (ALS) respectively, and a freeze core from Mereworth Sound (MS) has provided valuable information on the depositional environments present in the Seymour-Belize Inlet Complex (SBIC) as well as an indication of the variability in regional paleoceanography and paleoclimate which has influenced the SBIC through the Holocene.

The piston cores were generally characterized by a considerably higher than average concentration of the redox sensitive elements (e.g., Mo, $\mathrm{Cd}, \mathrm{U} \mathrm{Cu}$ and $\mathrm{Zn}$ ) and indices (e.g., $\mathrm{V} / \mathrm{Cr}, \mathrm{V} / \mathrm{Sc}, \mathrm{V} /(\mathrm{V}+\mathrm{Ni}), \mathrm{U}$ authigenic, $\mathrm{U} / \mathrm{Th}$ and $(\mathrm{Cu}+\mathrm{Mo}) / \mathrm{Zn})$, as well as a generally high organic matter content and the overwhelming dominance of low oxygen indicating agglutinated foraminiferal species. These indicators are interpreted as an indication of the presence of anoxic to suboxic bottom water conditions in the SBIC during intervals of the Late Holocene.

Similar suboxic to anoxic paleoceanographic conditions were infered for both laminated and homogenous sedimentary intervals of the FS and ALS cores based on the observed similarity in their microfaunal composition as well as the same levels of enrichment of redox sensitive elements/indices. The absence of any evidence of bioturbation in the homogenous sediments also provided additional evidence of the prevalence of bottom water anoxia during their deposition. 
The distributional patterns of $\delta^{13} \mathrm{C}$ and $\delta^{15} \mathrm{~N}$ stable isotopes in the cores permitted the discrimination of five climatic episodes characterized by alternating relatively cool/moist and cooler/dry conditions in the region. The distribution of foraminiferal species and biofacies in the investigated cores also indicated the presence of alternating warm and cool climate conditions during the late Holocene (Figures 7.1-7.2).

A major change in the regional climate from warmer/wetter to cooler/drier conditions is suggested by heavier values of $\delta^{13} \mathrm{C}$ and relatively lighter values of $\delta^{15} \mathrm{~N}$ at $3135 \mathrm{cal}$ yr BP in the FS core, and 2462 cal yr BP in the ALS core, respectively (Figures 7.1-7.2). The continuous occurrence of the Eggerella advena-Spiroplectammina biformis Biofacies from 4200-2835 cal yr BP in the FS core provided foraminiferal evidence for this late Holocene climate shift. The increased proportions of cool-water foraminiferal species in combination with the decreased abundance of the warmer-water indicator species, Zavodovskina nana and eurythymal E. advena, characterized this portion of the core. The reduced presence of thecamoebians and increased foraminiferal abundances at $2860 \mathrm{cal} \mathrm{yr}$ BP served as faunal evidence for this Late Holocene regime shift in the ALS core.

An apparent difference in the timing of identified climate intervals in both the FS and ALS cores was likely due to differences in the age-depth models used to interpret the two cores. The polynomial age-depth model used for the ALS core indicated varied sedimentation rates during deposition and resulted in a differential age increment between the top and bottom of the core. In contrast, the linear regression interpolation age-model utilized in the FS core yielded a uniform sedimentation rate and therefore uniform increment in the age 


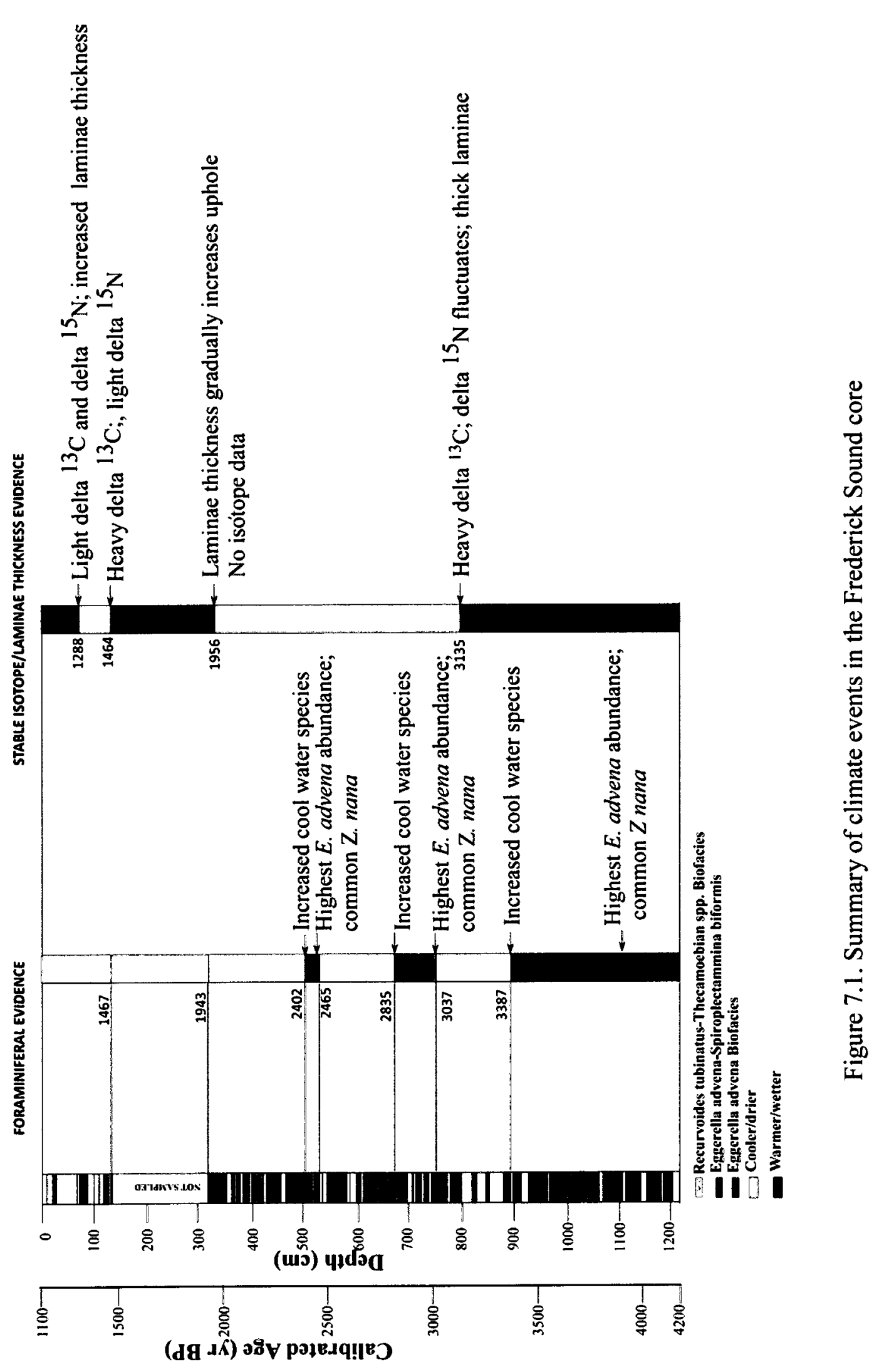




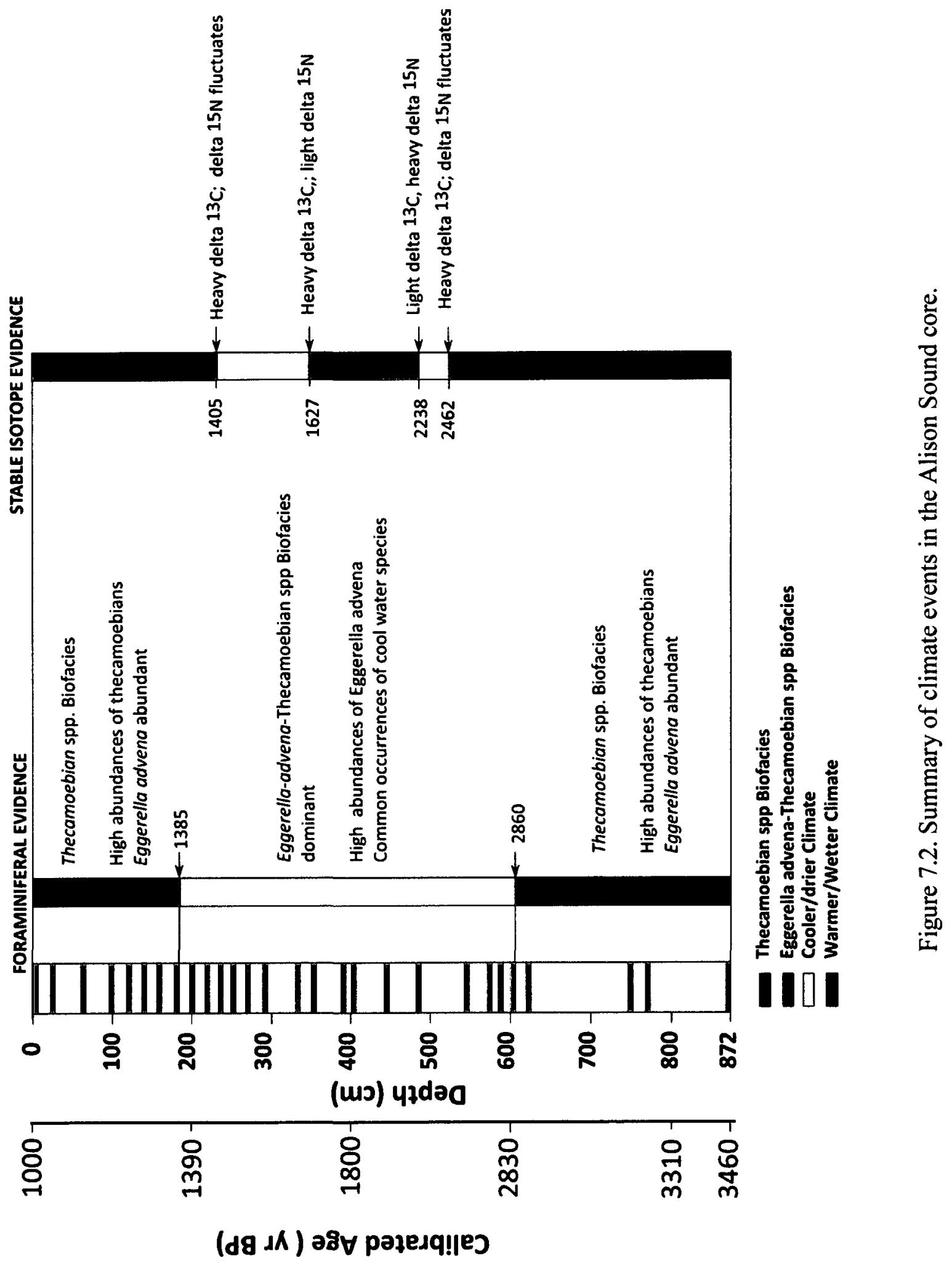


throughout the entire core interval. Thus, any potential higher-frequency fluctuation or nonlinear increments in the sedimentation rate are smoothed out in the FS core. More confidence relating to the timing of the climate shifts is therefore given to the results obtained from the ALS core.

The observed distributional patterns of both trace elements and benthic foraminiferal species in the Mereworth Sound (MS) freeze core indicated that the bottom water anoxia in the Late Holocene persisted to around $754 \mathrm{cal} \mathrm{yr} \mathrm{BP} \mathrm{(1138} \mathrm{cal} \mathrm{AD)} \mathrm{in} \mathrm{SBIC} \mathrm{(Figure} \mathrm{7.3).} \mathrm{This}$ period of low oxygenation generally corresponds to the global Medieval Warm Period (MWP). A transition to high oxic bottom water and cool climate conditions, likely equivalent to the Little Ice Age event in the region, is indicated by a predominance of cool and oxygenrich water preferring foraminiferal species, from 754-616 cal yr BP (1248-1386 AD). The prevalence of these cool climate conditions was interrupted by relatively warmer and slightly depressed levels of oxygenation during the 1386-1518 AD interval. A return to slightly cooler conditions was observed in the uppermost section of the MS core (1518-2002 AD).

The presence of Suess, Gleissberg and long PDO cycles in the geochemical data from the FS and ALS piston cores indicated that the regional climate patterns, mainly controlled by the strength and positions of the regional atmospheric pressures - the Aleutian Low (AL) and North Pacific High (NPH), might have been in response to variations in solar activity in addition to Pacific oceanic oscillations during the Late Holocene. 


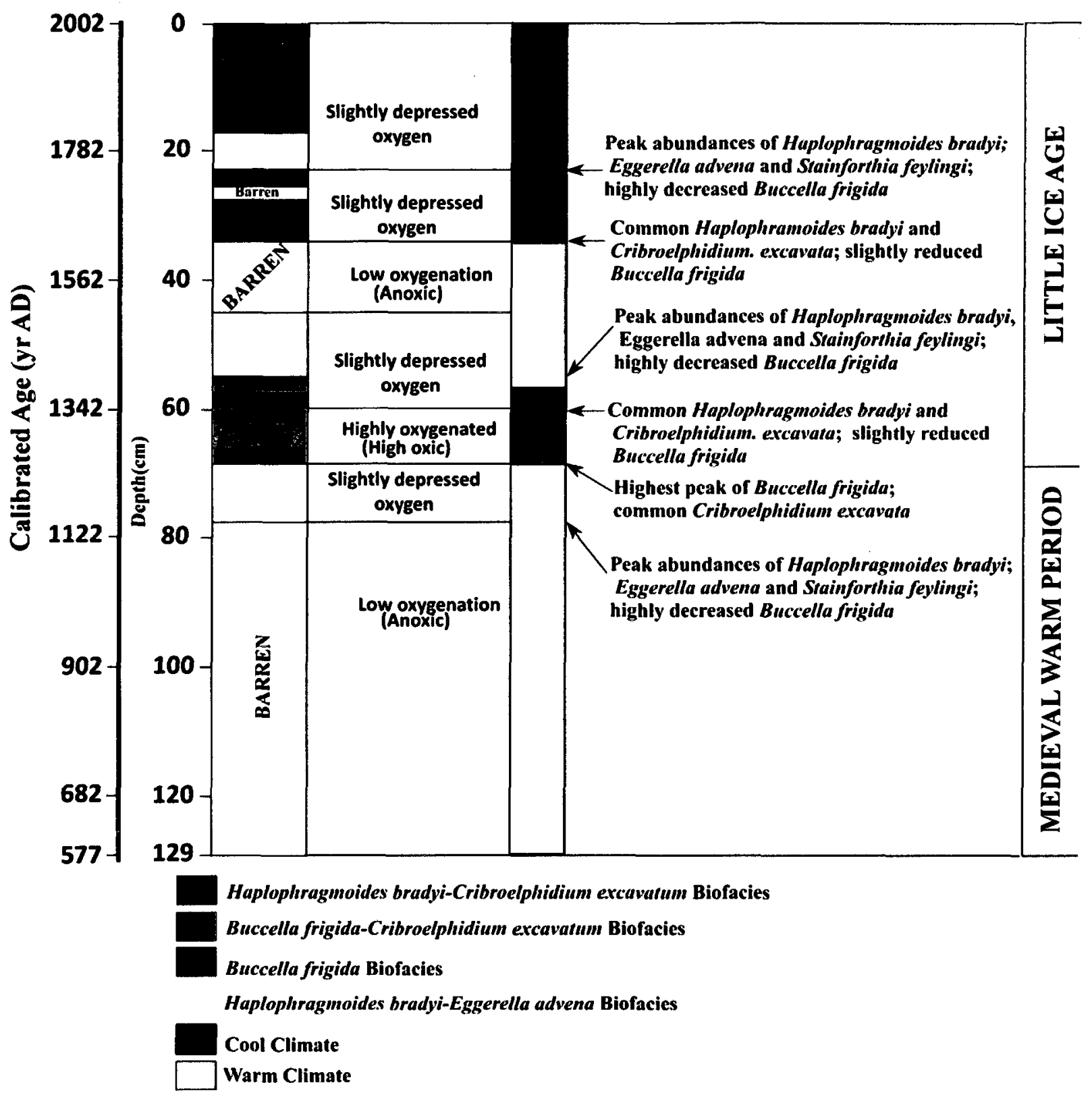

Figure .7.3. Depositional environments and climate events in the Mereworth Sound freeze core. 


\section{CHAPTER EIGHT}

\section{SYSTEMATIC PALEONTOLOGY}

The Suprageneric classification used herein follows that of Loeblich and Tappan (1987).

Illustrated specimens are housed in the Department of Earth Sciences, Carleton University, Ottawa, Ontario

Phylum PROTOZOA

Subphylum SARCODINA Schmarda, 1871

Class RHIZOPODA von Siebold, 1845

Order FORAMINIFERIDA Eichwald, 1830

Superfamily LITUOLACEA de Blainville, 1927

Family HAPLOPHRAGMOIDIDAE Maync, 1952

Genus Cribrostomoides CUSHMAN 1910

Cribrostomoides crassimargo (NORMAN. 1892)

Plate 1, Figure 1a-c, 2a-c

Haplopragmoides crassimargo NORMAN, 1892, p. 17, P1. 7-8

Labrospira crassimargo (Norman, 1892). HÖGLUND, 1947, p. 141, pl. 11, fig. 1.

Alveolophramium crassimargo (Norman, 1892). LOEBLICH AND TAPPAN, 1953, p. 29,

P1. 3, figs. 1-3.

Cribrostomoides crassimargo (Norman, 1892). TODD AND LOW, 1967, p. 15, pl. 1, fig. 24. 
Description: Test free, planispiral, partially involute, wall thick and coarsely agglutinated, 2 to 4 whorls, chambers numerous, gradually increasing as added, later chambers somewhat inflated, 7-10 chambers in the last whorl; suture distinct, radial, straight, slightly depressed, depressed umbilicus, broadly rounded to lobulate periphery; interior-areal aperture forming an arched linear slit which parallels the base of the chamber face; upper and lower lips are well developed.

Cribrostomoides jeffreysii (WILLIAMSON, 1858)

Plate 1, Figures 3a-c, 4a-c

Nonionina jeffreysii WILLIAMSON, 1858, p. 34, pl. 3, figs. 72-73.

Alveophramium jeffreysii (Williamson, 1858), LOEBLICH and TAPPAN, 1953, p. 31, P1.3, figs. 4-7.

Labrospira jeffreyssi (Williamson, 1858), HÖGLUND, 1947, p. 146, pl. 11, fig. 3; PARKER, 1952, p. 401., pl. 2, figs. 15, 17-20.

Cribrostomoides jeffreysii (Willamson, 1858). MURRAY, 1971, p. 23, pl. 4 figs. 1-5.

Description: Test free, planispiral, almost involute, laterally compressed; biumblicate, wall very thin, fragile, finely agglutinated; brown; 6 to 8 chambers in the last whorl, increasing rapidly in size, final chamber occasionally more inflate and tending to uncoil slightly; rounded to slightly lobulate periphery; suture distinct, slightly depressed and radial sutures; aperture oval in shape, interiomarginal, near the base of the final chamber, well developed lip.

Cribrostomoides subglobosum (CUSHMAN, 1910)

Plate 1, Figure 6a-b, Plate 2, Figure 1a-c

Haplophramoides subglobosum CUSHMAN, 1910, p. 105, figs. 162-164.

Labrospira subglobosum (Cushman, 1910), HÖGLUND, 1947, p. 144, pl. 11, fig. 2.

Cribrostomoides subglobosum (Cushman, 1910), SCHRÖDER, 1986, p.48, pl. 17, figs. 15-16. 
Description: Test suglobose, planispiral, two to three whorls, 5 to 8 chambers in the last whorl, chambers broad and low involute; depressed at the umbilicus; slightly depressed sutures, somewhat roughened, usually smooth; aperture more or less elongated, curved slit at the base of the apertural face.

\section{Cribrostomoides sp.}

Plate 2, Figure 2a-c

Description: Test planispiral, involute, slightly depressed at the umbilicus; wall agglutinated somewhat roughened; chambers broad and low, 5 to 7 in the last whorl; last chamber is inflated and wider; sutures strait and depressed aperture an areal slit surrounded by a distinct lip.

Remarks: This species is similar to the Cribrostomoides sp. A of Vazquez-Rivieros and Patterson (2008).

Cribrostomoides wiesneri (PARR, 1950)

Plate 1, Figure 5a-c

Labrospira wiesneri PARR, 1950, p. 272, pl. 4, figs. 25, 26.

Labrospira artica PHLEGER, 1952, pl. 13, fig. 17.

Aveolophragmoides wiesneri (Parr, 1950) BARKER, 1960, pl. 40, figs. 14, 15.

Cribrostomoides wiesneri (Parr, 1950), MILAM and ANDERSON, 1981, pl. 2, fig.6

Cribrostomoides wiesneri (Parr), SCHRÖDER, 1986, p. 48, p1. 17, fig. 10, 12; POAG, 1981, p. 57, pl. 9, fig.1.

Description: Test free, planispiral, involute, depressed, not completely involute; wall finely agglutinated smooth; depressed at the umbilicus, about 3 whorls, chambers of the earlier whorls visible; 7 to 9 chambers in the last whorl; suture lightly depressed; aperture a short narrow slit slightly above base of the apertural face. 
Genus Haplophragmoides CUSHMAN, 1910

Haplophragmoides bradyi (BRADY, 1887)

Plate 3, Figures 1a-c, 2a-c

Trochammina robertsoni BRADY, 1887, p. 893, pl. 20, fig. 4.

Trochammina bradyi ROBERTSON, 1891, p. 388.

Haplophragmoides bradyi (BRADY, 1887), HÖGLUND,1947, p. 134, pl. 10, fig. 1;

MURRAY, 1971, p. 24, pl, 5, figs. 1,2; SCHRÖDER, 1986, p. 46, pl. 17, fig. 8.

Description: Test planispiral, partly evolute, discoidal or compressed, nearly symmetrical bilaterally; wall composed of very fine agglutinated grains, brown with a very smooth; 5 chambers in outer whorl, somewhat inflated; sutures distinct, depressed; aperture interiomarginal, bordered by a lip.

\section{Haplophragmoides sp.}

Plate 3, Figure 3a-c

Description: Test planispiral, wall agglutinated, periphery rounded, up to 6 chambers visible in ventral and dorsal sides, increased as added; depressed umbilicus, suture straight, slightly depressed; aperture interiomarginal slit surrounded by a narrow lip.

Superfamily HAPLOPHRAGMIACEA Eimer and Fickert, 1899

Family AMMOSPHAEROIDINIDAE Cushman, 1927

Subfamily RECURVOIDINAE Alekseychik-Mitskevich, 1973

Genus Recurvoides EARLAND, 1934

Recurvoides turbinatus (BRADY 1881)

Plate 2, Figures 3-5

Lituola (Haplophragmium) turbinatum BRADY, 1881, p. 50, pl. 35, fig. 9.

Recurvoides turbinatus (Brady 1881). LOEBLICH and TAPPAN, 1953 p. 27, pl. 2, fig. 11;

RODRIGUES, 1980, p. 66, pl. 3-3, fig. 8; JONASSON, 1994, p. 58, pl. 7, fig. 2.

Description: Test free, streptospiral, later portion coiled in a different direction than the early portion, involute on one side and evolute on the other; wall finely agglutinated, somewhat roughened but variable; chambers not inflated but somewhat irregular in shape, numerous, 5 
to 8 chambers in the last whorl; distinct, depressed and almost straight sutures, periphery rounded; aperture an ovate to elongated interio-areal slit.

Suborder TROCHAMMINIDA Saidova, 1981

Superfamily TROCHAMMINACEA Schwager, 1877

Family TROCHAMMINIDAE Schwager, 1877

Subfamily TROCHAMMININAE Schwager, 1877

Genus Lepidoparatrochammina BRÖNNIMANN and WHITTAKER 1986

Lepidoparatrochammina charlottensis (CUSHMAN, 1925)

Plate 5, Figures 3a-c, 4a-b, 5a-c

Trochammina charlottensis CUSHMAN, 1925, p. 39, pl. 6, fig. 4a, b.

Trochammina charlottensis (Cushman, 1925). BLAIS, p. 92, pl. 2-3, fig. 1; PATTERSON, BURBIDGE and LUTERNAUER, 1998, p. 4, pl. 26, figs. 5, 6.

Description: Test free, compressed, very flat trochospiral; wall coarsely agglutinated, smoothly finished, opaque; all chambers visible on the spiral side, those of the umblical side of the final whorl visible, 4 to 5 chambers in the final whorl, last chamber large, inflated; sutures distinct, radiate, much curve on the dorsal side; rounded periphery; aperture a low interiomarginal arch opening into the open umbilicus and depressed, especially on the umbilical side.

Genus Lepidodeuterammina BRÖNNIMANN AND WHITTAKER, 1983

Lepidodeuterammina ochracea (WILLIAMSON, 1858)

Plate 4, Figure 5a-b

Rotalina ochracea WILLIAMSON, 1958, p. 55, pl. 5, fig. 113.

Lepidodeuterammina ochracea (Williamson, 1858). LOEBLICH and TAPPAN, 1987, pl. 135, figs. 10-14.

Trochammina ochracea (Williamson, 1858). MURRAY, 1971, p. 37, pl. 11, figs. 1-5; ALVES MARTINS and RUIVO DRAGÃO GOMES, 2004, p. 29, fig. 2.12. 
Description: Test free, trochospiral, depressed; wall agglutinated; two-and-one-half whorls in dorsal side, with 8 or 9 chambers each, filled with dark organic matter on umbilical side; slightly convex on dorsal side, correspondingly concave on ventral side; periphery round, very slightly lobulate at last chambers; sutures sometimes raised, arcuate, flexuous and very prominent; aperture a peripheral interiomarginal arch, secondary umbilical apertures at umbilical inflated portions of chambers.

\section{Genus Deuterammina BRÖNNIMANN 1976 \\ Deuterammina discorbis (EARLAND, 1934) \\ Plate 3, Figure 4}

Trochammina discorbis EARLAND, 1934, p. 104, pl. 3, figs. 28-31; Blais, 1995, p. 93, pl. 23 , figs. 7,8 .

Deuterammina discorbis (Earland, 1934), BRÖNNIMANN and WHITTAKER, 1988, p. 101, fig. 36A-I.

Description: Test free, minute, trochopspiral; highly convex spiral side, showing all the whorls, appearing slightly 'stepped' above and below each other, umbilicus side nearly flat but with deeply sunk umbilicus; very finely agglutinated wall, with much cement, smooth and well polished 3 to 4 whorls, with 4 to 5 chambers in the last whorl visible on the umbilical side; subacuate periphery; sutures recurved on spiral side, straight on the ventral side, slightly depressed; aperture small slit on inner edge of the last chamber on ventral side.

Deuterammina grisea (EARLAND, 1934)

Plate 4, Figure 7

Trochammina grisea EARLAND, 1934, p. 100, pl. 3, figs. 35-37.

Deuterammina (Deuterammina) grisea (Earland, 1934), BRÖNNIMANN and WHITTAKER, 1988, p. 107-110, fig. 39D-I.

Description: Test free, large, trochospiral; wall agglutinated, fine, smooth, unpolished; 3 whorls with 6 chambers each on dorsal side, only 6 last chambers visible on umbilical side, very slightly inflated; dorsal side flattened, umbilical side deeply depressed at umbilicus; sutures on dorsal side straight and distinct, slightly depressed, sutures more depressed on 
umbilical side; periphery round, slightly lobulate at last few chambers; aperture a narrow slit on inner apertural face of last chamber.

\author{
Deuterammina rotaliformis (HERON-ALLEN and EARLAND, 1911) \\ Plate 3, Figures 5a-c, 6
}

Trochammina rotaliformis HERON-ALLEN and EARLAND, 1911, p. 309; CUSHMAN and TODD, 1947, p. 9, Pl. 1, fig. 14; LOEBLICH AND TAPPAN, 1953, p. 51, pl. 8, figs. 6-9; MURRAY, 1971, p. 39, pl. 12, figs. 1-5; BLAIS, 1995, p. 93, pl. 2-3, figs. 1-3.

Description: Test free, trochospiral; wall agglutinated, imperforate; 20 elongated chambers arranged in 3 whorls on dorsal side, 5 chambers broadly triangular on umbilical side; strongly convex on dorsal side, shallow-concave on umbilical side; periphery rounded, slightly lobulate; sutures not well defined, more depressed on umbilical side; umbilical depression star-shaped, open and deep with 5 arms; primary aperture interiomarginal extraumbilical, secondary posterior aperture umbilical-sutural.

\title{
Genus Polystomammina SEIGLIE, 1965 \\ Polystomammina nitida (BRADY, 1881) \\ Plate 4, Figure 6
}

Trochammina nitida BRADY, 1881, p. 52, Figure in Brady, 1884, pl. 41, figs. 5, 6; SNYDER, HALE and KONTROVITZ, 1990, p. 277, pl. 7, fig. 3.

Description: Test free, regular, rotaliform, compressed, nearly flat spiral side, convex umbilical side, somewhat excavated umbilicus, consist of 2 to 3 whorls, up to 9 chambers in final whorl, increase as added; rounded periphery; sutures slightly depressed; aperture a curved or angled slit, beginning at base of apertural face in equatorial position and curving openly upward onto umbilical side of chamber. 
Genus Portatrochammina ECHOLS, 1971

Portatrochammina bipolaris BRÖNNIMANN and WHITTAKER, 1980

Plate 5, Figures 1a-c, 2a-b

Portatrochammina bipolaris BRÖNNIMANN and WHITTAKER, 1980, pp. 181, 183, figs. $15,16,18,19,20-31$.

Description: Test free, low trochospiral; elongate to ovate in umbilical and spiral views, final whorl somewhat lobulate, edge view flat, almost compressed, almost flat spirally, concave umblically; wall agglutinated, imperforate; about 14 chambers, 6 to 8 chambers in the final whorl, increasing rapidly in size; shallow umbilicus covered by flap from each successive chamber; periphery rounded to sub-acute; final chamber characteristically flat on spiral side and strongly convex on umbilical side; radial sutures straight to sinuous on umbilical side and slightly curved on spiral side; color dark brow grading into light brown; aperture begins as low interiomarginal opening near periphery, extends as slit around umbilical flap.

Genus Tiphotrocha SAUNDERS, 1957

Tiphotrocha comprimata CUSHMAN and BRÖNNIMANN, 1948)

Plate 6, Figure 9a-c

Trochammina comprimata CUSHMAN and BRÖNNIMANN, 1948a, p. 41, pl. 8, figs. 1-3

Triphotrocha comprimata (Cushman and Brönnimann). SAUNDERS, 1957, p. 11; PARKER and ATHEARN, 1959, p.341, Pl. 50, figs ]. 14-17, SCOTT and others, 1977, p. 1589, pl. 4, figs. 3, 4; ZANNETTI and others, 1977, p. 176, pl. 1, figs. 4, 6, SCOTT, 1977, p. 176, pl. 5, figs, 14-16.

Description: Test free, trochospiral, very much compressed, concave ventral side, dorsal slightly converx, rounded periphery, early portion regularly trochoid, later chambers becoming irregular, chambers in early portion with 4 to 5 in a whorl, increase as added, later becoming irregular and elongate; wall fine agglutinated, smooth; sutures slightly depressed, ventrally depressed and regularly curved in the early stages; aperture elongate, interomarginal, axially directed, at the end of central axial extension of chamber. 
Genus Trochammina PARKER and JONES, 1859

Trochammina sp. 3

Plate 4, Figures 1a-b, 2a-b

Trochmmina sp. 3 SCHRÖDER, 1986, p. 77, pl. 20, figs. 1-4.

Description: Test free, depressed trochospiral, wall finely agglutinated, occasionally with coarse grains; three whorl slowly increasing in size; 5 to 6 chambers in the final whorl, visible on the umbilical side; low umbilicus, extraumbilical aperture at the inner margin of the last chamber on the umbilical side.

Trochammina squamata JONES and PARKER, 1860

Plate 4, Figures 3a-c, 4a-c

Trochammina squamata JONES and PARKER, 1860, fig. in HEDLEY, HURDLE and BURDETT, 1964, p. 422, fig. 1, p. 424, figs. 1-3.

Trochammina astrifica (Rhumbler, 1938), HÖGLUND, 1947, p. 206, pl. 15, fig. 2.

Trochammina squamata (Jones and Parker, 1860), SNYDER, HALE and KONTROVITZ, 1990, p. 279, pl. 8, fig. 1 .

Description: Test free, small, low trochoidal, excavated on umbilical side; wall finely agglutinated, with occasional larger grains, smoothly finished; 2 whorls visible on spiral side; sutures distinct, apparently flush with surface of test, visible on spiral side as dark brown curved backwards lines; periphery angular in outline, slightly lobulate; chambers not inflated, lunate shaped; aperture a narrow slit at inner margin of umbilical side of last chamber.

Genus Zavodovskina BRÖNNIMANN AND WHITTAKER, 1988

Zavodovskina nana (BRADY 1881)

Plate 5, Figure 6a-c

Haplophragmium nana BRADY, 1881, p.50.

Haplophragmium nana (Brady, 1881), BRADY, 1884, p. 311, P1. 35, fig. 6-8; PATTERSON, BURBIDGE AND LUTERNAEUER, 1998, p. 27, Pl. 1, figs. 1-3. 
Description: Test free, trochospiral, with dorsal side almost flattened and ventral side more convex; medium grained agglutinated wall; chambers somewhat inflated, particularly on the umbilical side results in lobualte periphery, wall agglutinated, opaque, smooth, all chambers visible on the spiral side, final 6 to 7 chambers visible on the umbilical side; distinct, radiate and depressed sutures both on the umbilicus and spiral sides, aperture low interiomarginal arch, extends to the umbilicus.

Suborder TEXTULARIINA Delage and Hérouard, 1896

Superfamily SPIROPLECTAMMINACEA Cushman, 1927

SPIROPLECTAMMINIDAE Cushman, 1927

Subfamily SPIROPLECTAMMININAE Cushman,1927

Genus Spiroplectammina CUSHMAN, 1927

Spiroplectammina biformis (PARKER and JONES, 1865)

Plate 7, Figures 1-8

Textularia agglutinans d'Orbigny var. biformis PARKER AND JONES, 1865, p. 370, pl. 15, figs. 23, 24.

Spiroplectammina biformis (PARKER and JONES 1865). HÖGLUND, 1947, p. 163, Pl. 12, fig. 1; LOEBLICH and TAPPAN, 1953, p. 34, pl. 4, figs. 1-6; SCHRÖDER, 1986, p. 51, pl. 21, fig. 14.

Description: Test free small, narrow, elongate, ovoid in section, margins broadly rounded, sides nearly parallel; wall finely agglutinated, surface smoothly polished; large early planispiral coil of few 5 to 6 chambers followed by biserially arranged chambers, coil commonly of greater breadth than first few parts of biserial chambers; chambers very slightly inflated; rounded periphery; sutures distinct, only slightly depressed; aperture a low arch at inner margin of final chamber. 
Superfamily TEXTULARIACEA Ehrenberg, 1838

Family EGGERELLIDAE Cushman, 1937

Subfamily EGGERELLINAE Cushman, 1937

Genus Eggerella CUSHMAN, 1933

Eggerella advena (CUSHMAN 1922a)

Plate 6, Figures 1a-c, 5-8

Verneuilina advena CUSHMAN, 1922a, p.141.

Eggerella advena (Cushman, 1922), LOEBLICH and TAPPAN, 1953, p. 36, pl. 3, figs. 8-10;

PATTERSON, BURBIDGE and LUTERNAUER, 1998, p. 5, pl. 28, fig. 6.

Description: Test free, elongate, sharply tapering, early portion with 4 to 5 chambers in a whorl, later portion triserial; wall finely agglutinated with occasional larger grains; chambers numerous, low and broad in early portion, increase in relative height as added, those of final whorl approximately equal in height and breadth; sutures distinct and depressed; aperture small, central, low arch at base of final chamber.

Eggerella beliziensis (new species)

Plate 6, Figures 2-4

Eggerella advena (Cushman, 1922a), RESIG, 1963, p. 125, fig. 2.

Eggerella sp. VÁZQUEZ-RIVEIROS and PATTERSON, 2008, p. 13, figs. 5.5a-d.

Description: Test free, elongate, sharply tapering, early portion with 4 to 5 chambers in a whorl, later portion triserial, triangular in cross-section; wall finely agglutinated with occasional larger grains; normally 4 to 5 whorls; chambers numerous, low and broad in early portion, increasing slowly in relative height as added, normally three chambers in final whorl, very inflated and extending outwards of the axis of the test, giving the test a triangular outline in apertural view and an almost flat apertural face; sides straight, except for sutures, increasing at $25^{\circ}$ from the axis; sutures distinct and depressed; aperture small, central, low arch at base of final chamber, sometimes with a narrow lip. 
Remarks. Eggerella advena is differentiated from this species by the more elongated nature of its chamber and the tapering of the final chamber.

Superfamily RZEHAKINACEA Cushman, 1933

Family RZEKAKINIDAE Cushman, 1933

Subfamily MILIAMMININAE Saidova, 1981

Genus Miliammina HERON-ALLEN and EARLAND, 1922

Miliammina fusca (BRADY, 1870)

Plate 2, Figure 6

Quinqueloculina fusca BRADY, 1870, p. 286, pl. 11, figs. 2a-c, 3a-b.

Miliammina cf. Fusca (Brady, 1870), SAUNDERS, 1958, p. 86, pl. 1, fig. 9a-c.

Miliammina fusca (Brady, 1870). MURRAY, 1971, p. 21, pl. 3, figs. 1-6.; MURRAY, 1979, p. 23, fig. 5D-F; TODD and LOW, 1981, p. 15,.

Miliammina petila (Saunders, 1958), HULME, 1961, p.325; GREGORY, 1973, figs. 3.2, TOPPING, 1973, p. 17, pl. 1, figs. 3-6.

Description: Slender, quinqueloculine test, about twice as long as wide; oval in section, relatively thick wall, consists of moderately cemented, well-sorted, coarse silt or fine sand; moderately roughened surface, aperture terminal, circular with a thick lip, typically with a narrow bar-like tooth.

Suborder ROTALIINA Delage and Hérouard, 1896

Superfamily CHILOSTOMELLACEA Brady, 1881

Family TRICHOHYALIDAE Saidova, 1981

Genus Buccella ANDERSEN, 1952

Buccella frigida (CUSHMAN, 1922b)

Plate 9, Figures 1-3, 5-6; Plate 10, Figure 1a-c

Pulvinulina frigida CUSHMAN, 1922b, p. 144

Buccella frigida (Cushman, 1922b) ANDERSEN, 1952, p 144, fig 4a-c, 5, 6a-c; LOEBLICH and TAPPAN, 1953, p. 115, pl. 22, figs. 2, 3; MURRAY, 1971, p. 129, pl. 53, figs. 1-5; 
SCHAFER and COLE, 1978, p. 27, pl. 8, fig. 1, 2; REINHARDT, EASTON, and PATTERSON, 1996, p. 41, fig. 3; PATTERSON, BURBIDGE and LUTERNAUER, 1998, p. 22, pl. 25 figs. 6-8.

Buccella cf. depressa (Andersen, 1952). HULME, 1964, p. 334.

Description: Test free, small, trochospiral, biconvex to planoconvex; wall calcareous, hyaline, smooth, finely perforated; all chambers visible on convex, spiral side; only 6 to 7 slightly inflated chambers gradually increase in size as added are visible on flattened umbilical side; sutures oblique on spiral side, slightly curved and radial and depressed on umbilical side; pustulose material most concentrated on the umbilicus partially obscures.

\section{Buccella frigida (CUSHMAN, 1922b) sensu stricto}

Plate 9, Figures 4a-c

Pulvinulina frigida CUSHMAN, 1922b, p. 144

Buccella frigida (Cushman, 1922b) ANDERSEN, 1952, p 144, fig 4a-c, 5, 6a-c; LOEBLICH and TAPPAN, 1953, p. 115, pl. 22, figs. 2, 3; MURRAY, 1971, p. 129, pl. 53, figs. 1-5; SCHAFER and COLE, 1978, p. 27, pl. 8, fig. 1, 2; REINHARDT, EASTON, and PATTERSON, 1996, p. 41, fig. 3; PATTERSON, BURBIDGE and LUTERNAUER, 1998, p. 22, pl. 25 figs. 6-8.

Buccella cf. depressa (Andersen, 1952). HULME, 1964, p. 334.

Description: Test free, small, trochospiral, biconvex to planoconvex; wall calcareous, hyaline, smooth, finely perforated; all chambers visible on convex, spiral side; only 6 to 7 slightly inflated chambers gradually increase in size as added are visible on flattened umbilical side; sutures oblique on spiral side, slightly curved and radial and depressed on umbilical side; pustulose material most concentrated on the umbilicus partially obscures.

Remarks: The absence of keel differentiates this species from the Buccella frigida. 


\section{Buccella tenerrima (BANDY, 1950)}

Plate 10, Figure 2a-c

Rotalia tenerrima BANDY, 1950, p. 278, pl. 42, fig. 3.

Buccella tenerrima (Bandy 1950), REINHARDT, EASTON and PATTERSON, 1996, p. 41, fig. 3 .

Description: Test free, trochospiral, biconvex; wall calcareous, hyaline, smooth and finely perforated; periphery slightly lobulate, carinate; umbilicus pustulose; three-and-one-half whorls, 8 to 10 chambers in last whorl; dorsal sutures somewhat oblique and slightly curved, ventral sutures depressed, nearly radial; pustulose material covering umbilicus and sutures; aperture a series of pores at base of last septal face.

Superfamily DISCORBINELLACEA Sigal, 1952

Family PSEUDOPARRELLIDAE Voloshinova, 1952

Genus Epistominella HUSEZIMA and MARUHASI, 1944

Epistominella vitrea PARKER, 1952

Plate 10, Figures 4a-c; 6a-c

Epistominella vitrea PARKER,1953 in PARKER, PHLEGER and PEIRSON, 1953, p. 9, pl. 4, figs. 34-36, 40, 41; MURRAY, 1971, p. 131 pl. 54, figs. 1-6; PATTERSON, BURBIDGE and LUTERNAUER, 1998, p. 19, pl. 20, figs. 3-5.

Description: Test free, trochospiral, biconvex, periphery rounded, and slightly lobulate; wall calcareous, hyaline, smooth, finely perforate; spiral side with all 3 whorls and chambers visible and sutures straight, depressed, and oblique; only final 6 chambers visible on umbilical side with sutures radial and depressed; aperture narrow lipped slit oriented slightly oblique to peripheral margin. 
Superfamily CASSIDULINACEA d'Orbigny, 1839

Family CASSIDULINIDAE d'Orbigny, 1826

Genus Cassidulina D’ORBIGNY, 1826

Cassidulina crassa D'ORBIGNY, 1839

Plate 10, Figures 3-5

Cassidulina crassa D'ORBIGNY, 1839, p. 56, pl. 7, figs. 18-20.

Cassidulina crassa (d'Orbigny), ALVES MARTINS and RUIVO DRAGÃO GOMES, 2004, p. 118, fig. 2.67.

Description: Test free, circular to oval, biconvex; periphery slightly rounded; chambers slightly inflated, last chamber rectangular to trapezoidal; sutures slightly depressed; wall calcareous, delicate, translucent, shiny, finely perforated; aperture a simple slit in the middle of a central, triangular depression of the basal suture of the last chamber, partially closed by an apertural plate.

Superfamily ROTALIACEA Ehrenberg, 1839

Family ELPHIDIIDAE Galloway, 1933

Genus Cribroelphidium CUSHMAN and BRÖNNIMANN, 1948

Cribroelphidium excavatum forma clavata (CUSHMAN, 1930)

Plate 11, Figures 1-4; Plate 12, Figures 3a-c, 4a-c

Elphidium incertum (Williamson) var. clavatum CUSHMAN, 1930, p. 20, Pl. 7, fig. 10.

Elphidium clavatum (Cushman), LOEBLICH and TAPPAN, 1953, p. 98, Pl. 19, figs. 8-10.; TODD and LOW, 1967, p. A33, pl. 4, figs. 16-17; LAGOE, 1979, pl. 1, fig 3, 5-6.

Elphidium excavatum (Terquem, 1876) forma clavata (Cushman) AUSTIN and SJERUP, 1994, p. 120, pl. 12, fig 11; OSTERMAN, 1996, p. 192, pl. 1, fig. 3.

Elphidium excavatum (Terquem, 1876) forma clavata (Cushman), HAYWARD, GRENFELL, REID and HAYWARD, 1999, p. 165, P1. 17, figs. 11-12.

Elphidium excavatum (Terquem, 1876) forma clavata (Cushman). HAYWARD, HOLLIS and GRENFELL, 1997, p.76, pl. 8, figs., 14-17, pl. 9 figs. 1-8. 
Description: Test small, disc-shaped, planispiral involute, sharp periphery; often with an umbilicus boss or bosses; chambers distinct, 10-14 chambers in final whorl, slightly inflated, increased gradually in size as added; sutures curved backwards, ornamented by papillae; wall calcareous hyaline, smooth coarsely perforate; imperforate umblical boss and apertural face; aperture interio-marginal.

Cribroelphidium excavatum forma excavata (TERQUEM, 1876)

Plate 12, Figure 5a-b

Polystomella excavata TERQUEM, 1876, p. 429, Pl. 2, fig 2a-d; CUSHMAN, 1930, p 21, pl 8, figs. 1-3; Cushman, 1939, p. 57, pl. 16, figs. 7-9; LEVY and others, 1969, p. 93, pl. 1, figs. $1-3$.

Elphidium excavata (Terquem, 1876). HERON-ALLEN and EARLAND, 1932, p. 439, pl. 16, figs. 21-23.

Elphidium translucens NATLAND, 1938, p. 144, pl. 5, figs. 3-4.; PARKER and others, 1953, p. 9, pl 3., figs 27; TODD and BRÖNNIMANN, 1957, p.39, Pl. 7, figs. 6a-b, TODD and LOW, 1961, p. 20, pl. 2, fig. 4.

Elphidium excavatum (Terquem, 1876). Murray, 1972 . 159, pl. 66, figs. 1-7.

Cribroelphidium excavatum (Terquem, 1876). PATTERSON, BURBIDGE and LUTERNAUER, 1998, p. 22, pl. 25, figs. 4, 5; pl. 26, figs. 1, 2.

Description. Test small, plainispral, involute, biumbonate, wall calcareous, thin, smooth except concentrations of pustules found along sutures, in umbilicus, and around aperture; fine circular pores less concentrated along septa and on apertural face; no pores in central extensions of chamber walls; lobate periphery; 9-11 chambers in the last whorl, straight sutures extending into the umbilicus and wall, wall perforations extend to umbilicus.

Cribroelphidium excavatum (TERQUEM, 1876) forma lidoensis (CUSHMAN, 1936)

Plate 11, Figure 5

?Polystomella arctica (Parker and Jones), TERQUEM, 1876, p. 428, P1. 2, fig 1.

Elphidium florentinae SHUPACK, 1934, p. 9, fig. 5a-b.

Elphidium lidoensis, CUSHMAN 1936, p. 86, pl. 15, fig 6a-b; ACCORDI and SOCIN, 1950, p. 12,15 , pl 1., fig. 8 . 
Cribroelphidium salsum CUSHMAN and BRÖNNIMANN, 1948, p. 19, pl. 4, fig. Cribroelphidium vadescens CUSHMAN and BRÖNNIMANN, 1948, p. 18, pl. 4, fig. 5.

Description: Test planispiral, compressed, sutures curved, backwards, filled with papillae and distinctly broadening towards the umbilicus; ponticuli absent, umbilicus open and large, filled with papillae or irregular bosses.

Cribroelphidium excavatum (TERQUEM, 1876) forma magna

(MILLER, SCOTT and MEDIOLI, 1982)

Plate 12, Figures 1-2

Elphidium discordale (d'Orbigny), CUSHMAN, 1939, p. 56, pl. 15, fig 7; PHLEGER and PARKER (part), 1951, p. 10, p1 5, fig. 10.

Elphidium incertum (Williamson) var. clavatum (Cushman, 1939), CUSHMAN (part), 1948, p. 59, pl. 6, fig. 8, PARKER, 1952a, p. 412, pl. 5, fig. 11; PARKER and others, 1953,p. 7, pl. 3 , figs 13,14 .

Elphidium clavatum (Cushman, 1939). LOEBLICH and TAPPAN, 1953, p. 98, pl. 19, figs 810; TODD and LOW, 1967, p. A33, pl. 4, fig. 17.

Elphidium clavatum “Complex” GREGORY, 1970, p. 226, pl. 14, fig. 2.

Cribroelphidium incertum (Cushman, 1939), SCOTT, 1977, p. 170, pl. 6, fig 4, 5.

Cribrononion excavatum incertum, (Cushman, 1939), SCOTT and others, 1980, p. 228, pl. 2, figs. 5-6.

Cribroelphidium excavatum (Terquem, 1876) forma magna, MILLER, SCOTT and MEDIOLI, 1982, p. 127, pl. 1, figs1-4, p. 135, pl. 5, figs 1-3.

Description: Test often large, planispiral involute, biumbonate, walls thick, convex, giving umbilicus raised appearance, distinctly perforate, pores round, septal and apertural face with 
few pores; umbilicus large, usually filled with large knobby boss, sometimes absent; periphery subarcuate, peripheral outline smooth to slightly loblate, chambers 10-13 in the final whorl, increase gradually as added, , sutures smooth, depressed, curved backwards with ponticuli and some papillae sutures, some sutures constricts before reaching umbilicus, forming imperforate collar around umbilicus; aperture single row of pores at the base of apertural face.

\section{Cribroelphidium foraminosum (CUSHMAN, 1939)}

Plate 13, Figure 1a-c

Elphidium hughesi var. CUSHMAN and GRANT, 1927, p. 75, P1. 7, fig. 5.

Elphidium hughesi var. foraminosum CUSHMAN, 1939, p. 49, PI. 13, fig 8a-b

Elphidium hughesi (Cushman and Grant, 1927), BERGEN and O'NEIL, 1979, p. 1290, pl. 1, fig. 1-2, 5 .

Description: Test free, planispiral, involute, biumbonate, periphery rounded; wall calcareous, hyaline, smooth, coarsely perforate, except on apertural face, 10 to 11 chambers in the last whorl visible and gradually increase in size as added, sutures depressed, backward-curved, with single row of large oblong sutural pores separated by short sutural bridges, aperture multiple, interiomarginal.

Superfamily PLANORBULINACEA Schwager, 1877

Family CIBICIDIDAE Cushman, 1927

Subfamily CIBICIDINAE Cushman, 1927

Genus Lobatula FLEMING, 1828

Lobatula fletcheri (GALLOWAY and WISSLER, 1927)

Plate 12, Figure 6a-b, Plate 13, Figures 2a, b, 3a-c

Cibicides fletcheri GALLOWAY and WISSLER, 1927. P. 64, pl. 10, fig. 8-9.

Lobatula fletcheri (Galloway and Wissler). PATTERSON, BURBIDGE, LUTERNAUER, 1998, p. 63, fig. 4-5. 
Description: Test free, plano-convex, trochospiral with spiral side flattened, umbilical side rounded and convex,; wall calcareous and transluscent, smooth, coarsely perforate on spiral side; 8 to 9 slightly inflated chambers visible on the umbilica side; all chambers visible on the spiral side, side with well developed umbilical boss, sutures slightly curved and depressed; low interiomarginal aperture lipped.

\author{
Superfamily BOLIVINACEA Glaessner, 1937 \\ Family BOLIVINIDAE Glaessner, 1937 \\ Genus Bolivina D'ORBIGNY, 1839 \\ Bolivina minuta NATLAND, 1938 \\ Plate 13, Figure 4a-c, 5
}

Bolivina minuta NATLAND, 1938, p. 146, pl. 5, fig.10.

Description: Test free, very compressed, sides nearly parallel, periphery angled, flattened, forming a slightly concave side; wall thin, calcareous, finely perforated; 8 to 10 pairs of chambers biserially arranged, rapidly increasing in size; sutures distinct, curved, quite oblique; loop shaped in the top of the last chamber.

Superfamily BULIMINACEA Jones, 1875

Family BULIMINIDAE Jones, 1875

Genus Protoglobobulimina HOFKER, 1951

Protoglobobulimina pupoides (D'ORBIGNY, 1846)

Plate 13, Figure 6.

Bulimina pupoides D'ORBIGNY, 1846, p. 185, Pl. 11, figs. 11, 12.

Protoglobulimina pupoides (d'Orbigny). PATTERSON, BURBIDGE and LUTERNAUER, 1998 p. 17, pl. 17, figs. $7,8$.

Description: Test free, elongate, broadest near base, almost circular in cross-section; wall calcareous, hyaline, smooth, finely perforate; chambers inflated, much higher than wide and strongly overlapping, triserially arranged, in 2 or 3 whorls; sutures depressed; aperture elongate, extends up from base of final chamber; successive chambers connected by an internal toothplate; tooth plate final tip can be seen in aperture. 
Family BULIMINELLA Cushman, 1911

Genus Buliminella CUSHMAN, 1911

Buliminella eligantissima (D’ORBIGNY, 1839)

Plate 14, Figure 1a-b

Bulimina elegantissima D'ORBIGNY, 1839, p. 51, pl. 7, figs 13-14;

Buliminella elegantissima (d'Orbigny, 1839). MURRAY, 1971, p. 105, pl. 42, figs. 1-4;

PATTERSON, BURBRIDGE and LUTERNAUER, 1998, p. 17, pl. 16, figs. 6-7.

Description: Test free, elongate, with a high and close spiral formed by numerous high narrow chambers in 3 to 4 whorls; wall calcareous, hyaline, smooth, finely perforate; aperture loop-shaped with internal tooth plate connecting aperture with foramen of previous chamber.

Family UVIGERINDAE d'Orbigny, 1826

Subfamily ANGULOGERININNAE Galloway, 1933

Genus Angulogerina CUSHMAN, 1927

Angulogerina angulosa (WILLIAMSON, 1858)

Plate 14, Figure 5a-b

Uvigerina angulosa WILLIAMSON, 1858, p. 67, pl. 5, fig. 4.

Uvigerina semitrigona GALLOWAY and WISSLER, 1927, p. 77, pl. 11, fig. 21.

Angulogerina semetrigona (Galloway and Wissler, 1927), CUSHMAN and GRAY, 1946b, p. 37, Pl. 6, fig. 16.

Description: Test free, elongate, trigonal in cross section, angles carinate, wall calcareous, hyaline, surface finely perforate and covered by numerous discontinuous longitudinal costate cross sutures; 4 to 5 whorls triserially arranged chambers increase gradually as added, sutures slightly curved and depressed, aperture terminal, ovate, produced on neck bordered by narrow lip; internal tooth plate extend from foramen to foramen, characterized by wing-like flange, externally visible s narrow projection in aperture. 
Angulogerina fluens TODD, 1948

Plate 14, Figures 6a-b, 7a-b

Angulogerina fluens TODD in CUSHMAN and MCCULLOCH, 1948, p. 288, pl. 36, fig. 1; TODD and LOW, 1967, p. A30, pl. 4, fig 5; SMITH, 1978, p. 144, pl. 2, figs. 11-12; PATTERSON, BURBRIDGE and LUTERNAUER, 1998, p. 18, Pl.16, figs. 4-5.

Trifarina fluens (Todd, 1948), FINGER, LIPPS , WEAVER, and MULLER 1990, p. 49, pl. 10, fig 5.; POLYAK, KORSUM, FEBO, STANOVOY, KHUSID, HALD, PAULSON and LUBINSKI, 2002, p. 269, pl. 2, fig. 18.

Description: Test free, elongate, slender, trigonal in cross section, angles subrounded and carinate slightly tapered towards the base; wall calcareous, hyaline, smooth except numerous discontinuous longitudinal costae cross suture lines and extend from base to aperture, finely perforate; chambers arranged in 4 to 5 whorls, initially triserial, become cuneate, irregularly inflated, slightly angled with flattened/compressed walls; sutures depressed and curved; aperture terminal, elongate, reniform, produced on very short neck and bordered by pronounced lip; internal toothplate extends from foramen to foramen, externally visible as narrow projection in aperture.

\author{
Subfamily UVIGERININAE, Haeckel, 1894 \\ Genus Euuvigerina THALMANN, 1952 \\ Euuvigerina cf. aculeata (D'ORBIGNY 1846)
}

Plate 14, Figure 4a-b

Uvigerina aculeata D'ORBIGNY, 1846, p. 191, pl. 11, figs. 27, 28.

Euuvigerina aculeata (d'Orbigny, 1846). PATTERSON, BURBIDGE and LUTERNAUER, 1998, p. 17, pl. 16, figs. 1-3.

Description: Test free, elongated, rounded in section; wall calcareous, hyaline, surface finely perforate and covered with numerous cone-shaped spines occasionally uniting to form discontinuous rib-like elements; 4 to 5 whorls of inflated, triserially arranged chambers 
become cuneate in later whorls; aperture small and circular within a phialine lip at top of tubular neck; toothplate a narrow twisted ribbon extending from the aperture to fasten against the previous foramen.

Remarks: Unlike the specimen illustrated by Patterson, Burbidge and Luternauer (1998), spines of this species are not well developed in the specimens from the SBIC.

\section{Euuvgerina peregrina CUSHMAN, 1923}

Plate 14, Figures 2a-b, 3a-b

Uvigerina peregrina CUSHMAN, 1923, p. 166, P1. 42, figs. 7-10.

Uvigerina peregrina (Cushman, 1923), PHLEGER, 1939, p. 1404, P1. 3, figs 5-6.

Euuvigerina peregrina (Cushman, 1923), HOFKER, 1951, p. 219, figs. 148a-b, 149.

Euuvigerina peregrina (Cushman 1923), ALVES MARTINS and RUIVO DRAGÃO GOMES, 2004, p. 162, figs. 2.93, 2.94.

Description: Test free, elongate, triserial to biserial, about two and a half as long as broad, widest in the middle; chambers fairly numerous, inflated, sutures indistinct and depressed; wall calcareous, perforate, surface with generally discontinuous longitudinal costae ornamentation; rounded aperture distinctly positioned at the end of the tubular neck, bordered by phialine lip, narrow ribbon like and twisted toothplate extends within from aperture to fasten against previous foramen. 
Superfamily TURRILINACEA Delage and Hérouard, 1896

Family STAINFORTHIIDAE Reiss, 1963

Genus Stainforthia HOFKER, 1956

Stainforthia feylingi KNUDSEN and SEIDENKRANTZ, 1994

Plate 14, Figures 8a-b, 9a-b

Virgulina schreibersiana (Czjzek). FEYLING-HANSEN, 1964, p. 309, Pl. 14 figs. 19-21; NAGY, 1965, p. 120, P1., 1, fig 30; FEYLING-HANSEN and others, 1971, p. 240, pl, 7, figs. 6-8.

Stainforthia schreibersiana (Czjzek). MICHELSEN, 1967, p. 226-227, P1. 2, fig. 12;

ELVERHOI and others, 1980, pl. 1, figs 23, 24.

Fursenkoina fusiformis (Williamson). SCHRÖDER-ADAMS and others, 1990, p. 34, pl. 6, fig 17; SCOTT and VILKS, 1991, p. 30, pl. 4, fig. 11.

Stainforthia feylingi KNUDSEN and SEIDENKRANTZ, 1994, p.9, pl. 1, figs. 1-32, p. 2, pl. 2, figs 1-6. 8; PATTERSON, BURBIDGE and LUTERNAUER, 1998, p. 16, pl. 14, figs. 5, 6.

Description: Test narrow, elongate, streamlined, fusiform, three to four times as long as broad, compressed and ovate in cross-section and bluntly pointed at both ends; thin, fragile, calcareous, translucent, calcareous, hyaline, smooth, finely and densely perforated wall; 7 to 11 narrow and slightly inflated chambers, chambers triserially arranged in early stages, later biserial and often slightly twisted; sutures depressed and slightly curved at $45^{\circ}$ to $50^{\circ}$ to longitudinal axis; aperture depressed in an elongate often narrow loop extending from the base of the final chambers and across the face of the final chamber, aperture bordered by serrate lip partially closing the apertural opening. 


\section{Superfamily NONIONACEA Schultze, 1854 \\ Family NONIONIDAE Schultze, 1854 \\ Subfamily NONIONINAE Schultze, 1854 \\ Genus Nonionella CUSHMAN, 1926}

Nonionella sp.

Plate 13, Figure 7

Description: Test free, trochospiral, slightly compressed; wall calcareous, translucent, smooth, finely perforate; 4 inflated low chambers rapidly increase in size as added; large umbilical flap extends from last chamber and covers umbilical region; all chambers visible on spiral side; aperture low arch extending somewhat onto umbilical side, at base of large flat apertural face, thick lipped.

Remarks: This specimen is likely a juvenile form of Nonionella stella.

Suborder MILIOLINA Delage and Hérouard, 1896

Superfamily MILIOLACEA Ehrenberg, 1839

Family MILIOLIDAE Ehrenberg, 1839

Subfamily MILIOLINAE Ehrenberg, 1839

Genus Quinqueloculina D'ORBIGNY, 1826

Quinqueloculina sp.

Plate 14, Figure 10a-b

Description: Test elongate, slender, about 3 times longer than broad, periphery rounded; base protrude, wall smooth, translucent, chambers quinqueloculine, very long and narrow; suture distinct, depressed, somewhat oblique to test angle,; aperture terminal, elongate, no evident of tooth. 
Subphylum SARCODINA Schmarda, 1871

Class RHIZOPODEA von Siebold, 1864

Subclass LOBOSA Carpenter, 1861

Order ARCELLINIDA Kent, 1880

Superfamily ARCELLACEA Ehrenberg, 1830

Family DIFFLUGGIDAE Stein, 1859.

Genus Difflugia LECLERC in LAMARCK 1816

Difflugia urceolata Carter, 1864 Strain 'elongata' PENARD, 1905

Plate 7, Figure 13

Difflugia elongata PENARD, 1905, p. 33, fig. on p. 34.

Difflugia urceolata (Carter, 1864) MEDIOLI and SCOTT, 1983, p. 31-33, pl. 3, figs. 1-23.

Difflugia urceolata (Carter, 1864) REINHARDT, DALBY, KUMAR and PATTERSON, 1998, Pl. 2, fig. $2 \mathrm{a}$

Difflugia urceolata (Carter, 1864), KUMAR and DALBY, 1998, fig. 22-2.

Description: Test elongate with a distinct constriction below the apertural lip.

\author{
Difflugia oblonga EHRENBERG, 1832 Strain 'oblonga' \\ REINHARDT, DALBY, KUMAR, AND PATTERSON, 1998 \\ Plate 7, Figures 9-11
}

Difflugia oblonga EHRENBERG, 1832, p. 90.

Difflugia oblonga (Ehrenberg, 1832), OGDEN and HEDLEY, 1980, p. 148, p1. 63, fig. a-c.

Difflugia oblonga (Ehrenberg, 1832). HAMAN, 1982, p. 367, pl. 3, figs. 19-25.

Difflugia oblonga strain 'oblonga' REINHARDT, DALBY, KUMAR, and PATTERSON, 1998, pl. 2, fig. 10.

Description: Test pyriform, elongate to oblong, fundus rounded; neck long, aperture circular without lip, test generally composed of sand grains.

Remarks: Some of the specimens have fine reticulate ornamentation; few others specimens are coarsely agglutinated. 


\section{Difflugia oblonga EHRENBERG, 1832 Strain 'glans' \\ REINHARDT, DALBY, KUMAR, AND PATTERSON, 1998 \\ Plate 8, Figures 9-12}

Difflugia oblonga 'glans' PENARD, 1902.

Difflugia oblonga strain 'glans' REINHARDT, DALBY, KUMAR, and PATTERSON, 1998, pl 2, fig. 7.

Description: Test oval to ovoid, slightly elongated; fundus rounded; neck absent; aperture large, circular with smooth lip; test small, composed of sand grains,

Difflugia oblonga (Ehrenberg, 1832) strain 'lanceolata' PENARD, 1890

REINHARDT, DALBY, KUMAR, AND PATTERSON, 1998

Plate 8, Figure 15

Difflugia lanceolata PENARD, 1890, p. 145, Pl. 4, figs. 59-60.

Difflugia lanceolata (Penard, 1890), OGDEN and HEDLEY, 1980, p. 140, pl. 59, figs. a-d.

Description: Test elongate, pyriform and smooth; fundus rounded, long neck; aperture circular without a lip.

Difflugia protaeiformis LAMARCK, 1816 strain 'claviformis'

REINHARDT, DALBY, KUMAR, AND PATTERSON, 1998

Plate 8, Figure 13

Difflugia protaeiformis LAMARCK, 1816.

Difflugia pyriformis var. claviformis PENARD, 1899, p. 25, pl. 2, figs. 12-14.

Difflugia calviformis OGDEN and HEDLEY, 1980, p. 126, pl. 52, figs. a-d.

Difflugia protaeiformis Strain 'protaeiformis' ASIOLI, MEDIOLI, and PATTERSON, 1996, p. 250, pl. 2, fig 1a-b.

Description: This strain is distinguished from Difflugia protaeiformis Strain 'acuminata' by its thicker wall, coarser sand particles 'claviformis' (Reinhardt, Dalby, Kumar, and Patterson, 1998). 
Difflugia protaeiformis LAMARCK, 1816 Strain 'acuminata'

REINHARDT, DALBY, KUMAR, AND PATTERSON, 1998

Plate 8, Figure14

Difflugia protaeiformis LAMARCK, 1816, p. 95.

Difflugia acuminata EHRENBERG, 1830.

Difflugia acuminata (Ehrenberg, 1830). OGDEN and HEDLEY, 1980, p. 118, pl. 4, figs. a-c.; SCOTT and MEDIOLI, 1983, p. 818, fig. 9d.

Difflugia protaeformis (Lamarck, 1816) Strain 'acuminata' REINHARDT, DALBY, KUMAR and PATTERSON, 1998, p. 145, pl. 2, fig 5.

Description: Test elongate, almost cylindrical, fundus, acuminate, tapering to form blunt spine; neck absent; aperture circular, narrow with indistinct lip. Test composed of sand grains.

Family CENTROPYXIDIDAE Deflandre, 1953

Genus Centropyxis STEIN, 1859

Centropyxis aculeata (EHRENBERG, 1832) strain 'aculeata'

REINHARDT, DALBY, KUMAR and PATTERSON, 1998

Plate 8, Figures 3, 7

Arcella aculeata EHRENBERG, 1832, p. 91.

Centropyxis aculeata (Ehrenberg, 1832), MEDIOLI and SCOTT, 1983, p. 39, figs. 11.711.16, pl. 7, figs. 10-12, 18, 19.

Centropyxis aculeata (Ehrenberg, 1832) strain 'aculeata' REINHARDT, DALBY, KUMAR and PATTERSON, 1998, pl. 1, fig. 1.

Description: Test depressed; in dorsal view, usually large and more or less circular; anterior slope large, with small $\left(15^{\circ}\right.$ to $\left.45^{\circ}\right)$ anterior angle; posterior slope ill-defined, practically absent, fusing into fundus; fundus quite posterior; 1 to 8 spines in posterio-lateral margin; wall basically organic, agglutinated, with siliceous particles completely covering the membrane; aperture subcentral, usually slightly anterior, invaginated. 
Centropyxis aculeata EHRENBERG, 1832 strain 'discoides'

REINHARDT, DALBY, KUMAR and PATTERSON, 1998

Plate 7, Figure 15, Plate 8, Figure 8

Arcella discoides EHRENBERG, 1843, p. 139.

Arcella discoides (Ehrenberg, 1843), EHRENBERG, 1872, p. 259, Pl. 3, fig 1.

Arcella discoides (Ehrenberg, 1843), LEIDY, 1879, p. 173, pl. 28, figs. 14-18.

Centropyxis aculeata var. discoides PENARD, 1890, p. 151, pl. 5, figs. 38-41.

Centropyxis discoides (Penard, 1890), OGDEN and HEDLEY, 1980, p. 54, pl. 16, figs. A-E.

Centropyxis aculeata strain 'discoides' REINHARDT, DALBY, KUMAR and PATTERSON, 1998, pl. 1, fig. 2.

Description: Test depressed; in dorsal view, usually large and circular almost "doughnut shaped; anterior slope large, with small $\left(15^{\circ}\right.$ to $\left.45^{\circ}\right)$ anterior angle; posterior slope ill-defined, practically absent, fusing into fundus; fundus quite posterior; wall basically organic, agglutinated, with siliceous particles completely covering the membrane; aperture subcentral, usually slightly anterior, invaginated, spine absent.

Centropyxis constricta (EHRENBERG, 1843) Strain 'aerophila'

REINHARDT, DALBY, KUMAR and PATTERSON, 1998

Plate 8, Figure 1, 2

Centropyxis aerophila DEFLANDRE. 1929

Centropyxis aerophila (Deflandre, 1929), OGDEN andD HEDLEY, 1980, p. 48-49.

Centropyxis constricta (Ehrenberg, 1843). MEDIOLI and SCOTT, 1983, p. 41, figs. 12.6, 12.8-12.12, 12.15, 12.18-12.26, pl. 7, fig. 5 .

Cucurbitella [sic.] constricta REINHARDT, DALBY, KUMAR, and PATTERSON, 1998, pl. 1, fig. 6.

Centropyxis constricta (Ehrenberg, 1843) strain aerophila KUMAR AND DALBY, 1998, fig. 5.1. 
Description: Test varies from spherical, subspherical to elongated; aperture antero-marginal with a very high, apertural lip, inclined at $45^{\circ}$ to $60^{\circ}$ with variable degree of invagination; spines absent.

Centropyxis constricta (Ehrenberg 1843) Strain 'constricta'

REINHARDT, DALBY, KUMAR, and PATTERSON, 1998

Plate 8, Figures 4-6

Arcella constricta EHRENBERG, 1843, p. 410, pl. 4, fig. 35, pl. 5, fig. 1.

Centropyxis constricta (Ehrenberg, 1843). MEDIOLI and SCOTT, 1983, p. 41, figs. 12.7, $12.14,12.16,12.17$, pl. 7 , figs. 1-4, 6-9.

Centropyxis constricta (Ehrenberg, 1843) strain constricta REINHARDT, DALBY, KUMAR and PATTERSON, 1998, pl. 1, fig. 4.

Description. Test much less depressed than in C. aculeata, flattened, usually elliptical on dorsal view, with profile usually raised posteriorly; large $\left(40^{\circ}\right.$ to $\left.65^{\circ}\right)$ anterior angle; posterior angle well-defined; fundus raised in uppermost position; ventral side often small; three or fewer spines on fundus; wall agglutinated, completely covered with mineral particles of various nature; aperture antero-marginal, thick lipped at angle of 45 to $60^{\circ}$ with respect to the rest of the test; with variable degree of invagination.

\section{Genus Cyclopyxis DEFLANDRE, 1929 \\ Cyclopyxis kahli DEFLANDRE 1929 \\ Plate 7, Figure 14}

Centropyxis kahli DEFLANDRE, 1929, p. 330.

Cyclopyxis kahli (Deflandre, 1929). OGDEN and HEDLEY, 1980, p. 70-71, pl. 24, figs. a-e; ROE and PATTERSON, 2006, p. 29, pl. 1, fig. 7, p. 33, pl. 3, figs. 1-6.

Description. Test plano-convex, radially symmetrical, hemispherical; wall agglutinated; aperture circular, large, centered, symmetrical. 
Family HYALOSPHENIIDAE Schulze, 1877

Genus Heleopera LEIDY, 1879

Heleopera sphagni LEIDY, 1874

Plate 7, Figure 12

Difflugia sphagni LEIDY, 1874, p. 157.

Heleopera picta LEIDY. 1879.

Heleopera sphagni (Leidy, 1879), MEDIOLI and SCOTT, 1983, p. 37-38, fig. 9, pl. 6, figs. 15-18.

Description: Test strongly compressed, ovoid; oral pole narrower in broadside view; test composed of siliceous idiosomes, substituted more or less extensively by xenosomes; aperture at narrow end of test, an elongated, narrow ellipse with acute commissures. 


\section{REFERENCES}

Aaby, B., 1976. Cyclic climatic variations in climate over the past 5,500 years reflected in raised bogs. Nature, 263: 281-284.

Aasgaard, K., 1978. Foraminiferfaunaen i Kongstjorden, Svalbard. Unpublished thesis. University of Oslo, Norway : 138

Accordi, B., and Socin, C., 1950. Le formazioni quaternarie del pozzo di correzzola (Padova). Bollettina della Societa Adriatica di Science Naturali in Trieste, 45: 9-26, plates 1, 2.

Alekseychik-Mitskevich, L.S., 1973. Klassifikatsii foraminifer semeystva Haplophragmiidae (Towards the classification of the foraminiferal family Haplophragmiidae). Trudy vsesoyuznogo neftyanogo nauchnoissledovatel'skogo geologorazvedochnogoinstituta (VNIGRI), 343: 12-44.

Allen M.R., 1992. Interactions between the atmosphere and oceans on time scales of weeks to years. Ph.D. Thesis, University of Oxford.

Allen, M. R., and Smith, L. A., 1994. Investigating the origins and significance of lowfrequency modes of climate variability. Geophysical Research Letters, 21: 883-886.

Allen, G.B., Brown, K.J., and Hebda, R.J., 1999. Surface pollen spectra from southern Vancouver Island, British Columbia, Canada. Canadian Journal of Botany, 77: 786-799.

Allen S.E., Vindeirinho C., Thomson R.E., Foreman M.G.G., Mackas D.L., 2001. Physical and biological processes over a submarine canyon during an upwelling event. Canadian Journal of Fisheries and Aquatic Sciences, 58 (4): 671-684.

Alve, E., 1990. Variations in estuarine foraminiferal biofacies with diminishing oxygen conditions in Drammensfjord, S.E. Norway. In: C. Hemleben, D.B. Scott, M. Kaminski, and W. Kuhnt (eds.). Paleoecology, Biostratigraphy, Paleoceanography, and Taxonomy of Agglutinated Foraminifera. NATO ASI Series C: Mathematical and Physical Sciences, Kluwer Academic Publishers: 661-694.

Alve, E., 1991a. Benthic foraminifera reflecting heavy metal pollution in Sørfjord, Western Norway. Journal of Foraminiferal Research, 21: 1-19.

Alve, E., 1991b. Foraminifera, climatic change and pollution: A study of Late Holocene sediments in Drammensfjord, SE Norway. The Holocene, 1: 243-261.

Alve, E., 1993. Benthic foraminiferal responses to estuarine pollution: A review. Geological Society of America, Abstract with programs, 25: A137.

Alve, E., 1995. Benthic foraminiferal distribution and recolonization of formerly anoxic environments in Drammesfjord, southern Norway. Marine Micropaleontology, 25: 169-186. 
Alve, E., 2000. Environmental stratigraphy: a case study reconstructing bottom water oxygen conditions in Frierfjord, Norway, over the past five centuries. In: Martin, R., (ed.), Environmental Micropaleontology. Kluwer Academic/Plenum Publishers, New York: 323350.

Alve, E., and Bernhard, J.M., 1995. Vertical migratory response of benthic foraminifera to controlled oxygen concentrations in an experimental mesocosm. Marine Ecology Progress Series, 116: 137-151.

Alve, E. and Murray, J.W., 1999. Marginal marine environments of the Skagerrak and Kattegat: a baseline study of living (stained) benthic foraminiferal ecology. Palaeogeography Palaeoclimatology Palaeoecology, 146(1-4): 171-193.

Alve, E., and Nagy, J., 1986. Estuarine foraminiferal distribution in Sandebukta, a branch of the Oslo Fjord. Journal of Foraminiferal Research, 16: 261-284.

Alve, E., and Nagy, J., 1990. Main features of foraminiferal distribution reflecting estuarine hydrography in Oslo Fjord. Marine Micropaleontology, 16: 181-206.

Alves Martins, M.V., and Ruivo Dragão Gomes, V.D.C., 2004. Foraminíferos da margem continental NW ibérica: sistemática, ecologia e distribuição. Agenda Comum - Comunicação lda.

Andersen, H.V., 1952. Buccella, a new genus of the rotalid foraminifera. Journal of the Washington Academy of Sciences, 42: 143-151.

Armstrong, J.E., Crandell, D.R., Easterbrook, D.J., and Noble, J.B., 1965. Late Pleistocene stratigraphy and chronology in southwestern British Columbia and northwestern Washington. Geological Society of America Bulletin, 76: 321-330.

Anderson, L., Abbott, M.B., Finney, B.P., and Burns, S.J., 2005a. Regional atmospheric circulation change in the North Pacific during the Holocene inferred from lacustrine carbonate oxygen isotopes, Yukon Territory, Canada. Quaternary Research, 64: 21-35.

Anderson, L., Abbott, M.B., Finney, B.P., and Edwards, M.E., 2005b. Paleohydrology of the southwest Yukon Territory, Canada, based on multi-proxy analyses of lake sediment cores from a depth transect, The Holocene, 15: 1172-1183.

Anderson, L., Abbott, M.B., and Finney, B.P., and Burns, S.J., 2007. Late Holocene moisture Balance Variability in the Southwest Yukon Territory, Canada. Quaternary Science Reviews, 26: 130-140.

Anderson, R.Y., 1992. Possible connection between changes in climate, solar activity, and Earth's magnetic field: Evidence in varved sediments from a Minnesota lake: Nature, 358: 5153. 
Anderson, R.Y., Bradbury, J.P., Dean, W.E., and Stuiver, M., 1993a. Chronology of Elk Lake sediments: Coring, sampling, and time-series construction, in Bradbury, J.P., and Dean, W.E., eds., Elk Lake, Minnesota: Evidence for rapid climate change in the north-central United States: Geological Society of America Special Paper, 276: 37-43.

Anderson, T.W., 1993. The varve chronometer in Elk Lake: record of climatic variability and evidence for solar/geomagnetic ${ }^{14} \mathrm{C}$ climate connection. In: Bradbury, J.P. and Dean, W.E., editors, Elk Lake, Minnesota: evidence for rapid climate change in the north-central United States, Boulder, Colorado: Geological Society of America Special Paper, 276: 1-6.

Anderson, T. W., Mathewes, R.W., and Schweger, C.E., 1989. Holocene Climatic Trends in Canada with Special Reference to the Hypsithermal Interval. In Quaternary Geology of Canada and Greenland. Part of Chapter 7: Quaternary Environments in Canada as Documented by Paleobotanical Case Histories. Volume also published as Geological Society of America, The Geology of North America, Vol. K-1, edited by R. J. Fulton: 520-528. Geology of Canada No. 1. Geological Survey of Canada.

Asioli, A., Medioli, F.S., and Patterson, R.T., 1996. Thecamoebians as a tool for reconstruction of paleoenvironments in some Italian lakes in the foothills of the southern Alps (Orta, Varese and Candia). Journal of Foraminiferal Research, 2: 248-263.

Austin, W. E. N. and Sejrup, H. P., 1994. Recent shallow water benthic foraminifera from western Norway: ecology and paleoecological significance. Cushman Foundation for Foraminiferal Research, Special Publication, 32:103-125.

Bagg, R.M., Jr., 1912. Pliocene and Pleistocene foraminifera from Southern California. United States Geological Survey Bulletin, 513: 153.

Bailey, J., and Nyberg, C., 2006. Nakwakto Rapids: A treacherous gateway to Magical crusing grounds. $48^{\circ}$ North sailing Magazine. http://www.48north.com/jun_2006/ nakwakto.htm.

Bandy, O.L., 1950. Some later Cenozoic foraminifera from Cape Blanco, Oregon. Journal of Paleontology, 24 (3): 269-281.

Barker, R.W., 1960. Taxonomic notes. Society of Economic Paleontologists and Mineralogists Special Publication 9, Tulsa, Oklahoma: 238.

Barnosky, C.W., 1981. A record of Late Quaternary vegetation from Davis Lake, southern Puget Lowland, Washington, Quaternary Research, 16: 221-239.

Barrie, J.V., and Conway, K.W., 1999. Late Quaternary glaciation and postglacial stratigraphy of the northern Pacific margin of Canada. Quaternary Research, 51: 113-123.

Barrie, J.V., and Conway, K.W., 2002. Rapid sea level changes and coastal evolution on the Pacific margin of Canada; Journal of Sedimentary Geology, 150: 171-183. 
Barron, J.A., David Bukry, D., and Bischoff, J.L., 2004. High resolution paleoceanography of the Guaymas Basin, Gulf of California, during the past 15000 years. Marine Micropaleontology, 50 (3-4): 185-207.

Bartlett, G.A., 1972. Ecology and the Concentration and Effect of Pollutants in Nearshore Marine Environments, Intl. Symp. Ident. and Measurement of Environmental Pollutants, National Research Council, Canada, 277.

Bartlett, G.A., and Molinsky, L., 1972. Foraminifera and the Holocene history of St. Lawrence, Canadian Journal of Earth Sciences, 9(9): 1204-1215.

Batchelder, H.P., and Powell, T.M., 2002. Physical and biological conditions and processes in the northeast Pacific Ocean, Progress in Oceanography, 53: 105-114.

Baumgartner, T., Ferreira-Bartina, V., Schrader, H., and Soutar, A., 1985. A 20-year varve record of Siliceous phytoplankton variability in the Central Gulf of California. Marine Geology, 64: 113-129.

Beamish, R.J., 1993. Climate and exceptional fish production off the west coast of North America. Canadian Journal of Fisheries and Aquatic Science, 50: 2270-2291.

Beamish, R.J.D., Noakes, J., McFarlane, G.A., Klyashtorin, L., Ivanov, V.V., and Kurashov, V., 1999. The regime concept and natural trends in the production of Pacific salmon. Canadian Journal of Fisheries and Aquatic Science, 56: 516-526.

Bellefontaine, K., and Alldrick, D., 1994. Geological compilation of Mid-Coast area, Southwestern British Columbia. British Columbia Ministry of Energy, Mines and Petroleum Resources, Open File 1994-17.

Bennett, J.R., Cumming, B.F., Leavitt, P.R., Chiu, M., Smol, J.P., and Szeicz, J., 2001. Diatom, pollen, and chemical evidence of postglacial climatic change at Big Lake, southcentral British Columbia. Quaternary Research, 55: 332-343.

Berg, H.C., Jones, D.L., and Coney, P.J., 1978. Map showing pre-Cenozoic tectonostratigraphic terranes of southeastern Alaska and adjacent areas. Unite States Geological Survey Open-File Report Map, 78-1085, scale 1:1,000,000.

Bergen, F.W., and O'Neil, P., 1979. Distribution of Holocene foraminifera in the Gulf of Alaska. Journal of Paleontology, 53 (6): 1267-1292.

Bermúdez, P.J., 1961. Contribución al estudio de las Globigerinidea de la region CaribeAntillana (Paleoceno- Reciente). Boletín de Geologia, Venezuela, Publicación Especial, 3: 1119-1393. 
Bernhard, J.M., 1989. The distribution of benthic forainifera with respect to oxygen concentration and organic carbon levels in shallow-water Antarctic sediments. Limnology and Oceanography, 34: 1131-1141.

Bernhard, J.M., 1993. Experimental field evidence of Antartic foraminiferal tolerance to anoxia and hydrogen sulphide. Marine Micropaleontology, 20: 203-213.

Bernhard, J.M. and Alve, E., 1996. Survival, ATP pool, and ultrastructural characterization of benthic foraminifera from Drammensfjord (Norway): response to anoxia. Marine Micropaleontology, 28: 5-17.

Bernhard, J.M., Alve, E., and Reilly, A.A., 1996. Response to the Comment by Moodley et al., Marine Ecology Prorgess Series, 145: 305-307.

Bernhard, J.M., Sen Gupta, B.K., Borne, P.F., 1997. Benthic foraminiferal proxy to estimate dysoxic bottom-water oxygen concentrations. Santa Barbara Basin, U.S Pacific continental margin. Journal of Foraminiferal Research, 27: 301-310.

Bernhard, J.M., and Sen Gupta, B.K., 2002. Foraminifera of Oxygen-depleted environments. In: Sen Gupta, B.K. (ed.), Modern foraminifera, Kluwer Academic Publishers, Dordrecht, $2^{\text {nd }}$ edition: 201-216.

Birks. H.J.B., Line, J.M., Juggins, S., Stevenson, A.C., and ter Braak, C.J.F., 1990. Diatom and $\mathrm{pH}$ reconstruction: Philosophical Transactions of the Royal Society of London, 327: $263-278$.

Birks. H.J.B., 1995. Quantitative palaeoenvironmental reconstructions, in Maddy, D., and Brew, J., (eds.), Statistical modelling of Quaternary science data, Technical Guide No. 5: Quaternary Research Association, Cambridge : 161-236.

Birks. H.J.B., 1998. Numerical tools in palaeolimnology - progress, potentialities and problems: Journal of Palaeolimnology, 20: 307-332.

Blackwelder, P., Hood, T., Alvarez-Zarikian, Nelsen, T., and Mckee, B., 1996. Benthic foraminifera from the NECOP study area impacted by the Mississippi River plume and seasonal hypoxia. Quaternary International, 31: 11-36.

Blais, B., Clague, J.J., and R.W. Mathewes, R.W., 1990. Time of maximum Late Wisconsin glaciation, West Coast of Canada. Quaternary Research, 34: 282-295.

Blais, A., 1995. Foraminiferal biofacies and Holocene sediments from Saanich Inlet, British Columbia: Implications of environmental and neotectonic research, unpublished $P h D$. Dissertation, Carleton University, Ottawa, Canada: 280p.

Blais-Stevens, A., and Patterson, R.T., 1998. Environmental Indicator Potential of Foraminifera From Saanich Inlet, Vancouver Island, British Columbia, Canada. Journal of Foraminiferal Research, 28, no. 3: 201-219. 
Blais-Stevens A., Bornhold, B.D., Kemp A.E.S., Dean J.M., and Vaan A.A, 2001. Overview of Late Quaternary stratigraphy in Saanich Inlet, British Columbia: results of Ocean Drilling Program Leg 169S. Marine Geology,th'd 174 (1): 3-20.

Bond, G.C., Kromer, B., Beer, J., Muscheler, R., Evans, M., Showers, W., Hoffmann, S., Lotti-Bond, R., Hajdas, I., and Bonani, G. 2001. Persistent solar influence on north Atlantic climate during the Holocene. Science, 294: 2130-2136.

Boudreau, R.E., Galloway, J., Patterson, R.T., Kumar, A., and Frederick A. Michel, F.A., 2005. A paleolimnologic record of Holocene climate and environmental change in the Temagami region, notheastern Ontario. Journal of Paleolimnology, 33: 445-461.

Brady, H.B., 1870. Analysis and descriptions of the foraminifera. Annuals and Magazine of Natural History, Series 4, 6: 273-309.

Brady, H.B., 1881. Notes on some of the relicularian Rhizopoda of the "Challenger" Expedition; part III. Quarterly Journal of Microscopy Science, new series, 21: 31-71.

Brady, H.B., 1884. Report on the foraminifera dredged by H.M.S. Challenger, during the years 1873-1876, Report on the scientific results of the voyage of the H.M.S. Challenger during the years 1873-1876, Zoology.

Brady, H.B., 1887. A synopsis of the British recent foraminifera. Journal of the Royal Microscopic Society of London 1887: 872-927.

Brönnimann, P., 1976. Two new genera of Recent Trochamminidae (Foraminifera). Archives des Sciences, Genève, 29: 215-218.

Brönnimann, P., and Whittaker, J.E., 1980. A redescription of Trochammina nana (Brady) (Protozoa: Foraminiferida), with observations on several other recent Trochamminidae in the Collections of the British Museum (Natural History). British Museum of Natural History Bulletin, Zoology Series, 38 (4): 181-183.

Brönnimann, P., and Whittaker, J.E., 1983. Zaninettia n. gen., a spicular-walled remaneicid (Foraminiferida, Trochamminacea) from the Indian and South Atlantic Oceans with remarks on the origin of the spicules. Revue de Paléobiologie, Genève, 2: 13-33.

Brönnimann, P., and Whittaker, J.E., 1986. On the morphology of Paratrochammina (Lepidoparatrochammina) haynesi (Atkinson) from south Cardigan Bay, Wales, and validation of Paratrochammina (Lepidoparatrochammina) Brönnimann and Whittaker. Revue de Paléobiologie, Genève, 5: 117-125.

Brönnimann, P., and Whittaker, J.E., 1988. The Trochamminacea of the Discovery Reports. British Museum of Natural History: 1-152. 
Brown, K.J., and Hebda, R.J., 2002. Origin, development, and dynamics of coastal temperate conifer rainforests of southern Vancouver Island, Canada. Canadian Journal of Forest Research 32: 353-372.

Brown, K.J., and Hebda, R., 2003. Coastal rainforest connections disclosed through a Late Quaternary vegetation, climate, and fire history investigation from the Mountain Hemlock Zone on southern Vancouver Island, British Columbia, Canada. Review of Palaeobotany and Palynology, 123: 247-269.

Buchner, P., 1940. Die Lagenen des Golfes von Neapel und der marinen Ablagerungen auf Ischia (Beitrage zur Naturgeschichte der Insel Ischia 1). Nova Acta Leopoldino, new series, 9 (62): $364-560$.

Burnham, O.M., and Schweyer, J., 2004. Trace element analysis of geological samples by ICP-MS at the Geoscience Laboratories: revised capabilities due to improvements to instrumentation. In Summary of Field Work and Other Activities 2004, Ontario Geological Survey, Open File Report 6145: 54-1 to 54-20.

Calkin, P.E., Wiles, G.C., and Barclay, D.J., 2001. Holocene coastal glaciation of Alaska. Quaternary Science Reviews, 20: 449-461.

Calvert, S.E., 1976. The mineralogy and geochemistry of nearshore sediments. In: J.P. Riley and R. Chester, Editors, Chemical Oceanography, University Press, New York: 187-280.

Calvert, S.E., 1990. Geochemistry and origin of Holocene sapropel in the Black sea. In: Ittektot, V., Kempe, S., Michaelis, W., Spitz, A. (eds.), Facets of Modern Biogeochemistry. Springer, Berlin: 326-352.

Calvert, S.E., and Pedersen, T.F., 1993. Geochemistry of Recent oxic and anoxic marine sediments: implications for the geological record. Marine Geology 113: 67-88.

Calvert, S.E., and Pedersen, T.F., 2007. Elemental proxies for paleoclimatic and paleoceanographic variability in marine sediments: interpretation and application. In: Calvert, S.E. and Pedersen, T.F. (eds). Elseviers, Developments in Marine geology, 1: 567-644.

Calvert, S.E., Pedersen, T.F., Karlin, R.E., 2001. Geochemical and isotopic evidence for post-glacial palaeoceanographic changes in Saanich Inlet, British Columbia. Marine Geology, 174 (1-4): 287-305.

Carpenter, W.B., 1861. On the systematic arrangement of the Rhizopoda. Natural History Review, 1 (4): 456- 472.

Carpenter, W.B., 1869. On the rhizopodal fauna of the deep sea. Proceedings of the Royal Society of London, 18: 59-62.

Carpenter, W.B., 1875. The microscope and its revelations. J. \& A. Churchill, London.

Carpenter, W.B., Parker, W.K., and Jones, T.R., 1862. Introduction to the study of the Foraminifera. Ray Society, London. 
Carter, H.J., 1864. On freshwater Rhizopoda of England and India. Annuals and Magazine of Natural History, Series 3, 13: 18-39.

Cayan, D.R., and Peterson, D.H., 1989. Influence of North Pacific atmospheric circulation on streamflow in the Western Americas. American Geophysical Union, Geophysical Monograph, 55: 375-397.

Chamberlain, V. E., and Lambert, R. St. J., 1985. Cordilleria, a newly defined Canadian microcontinent: Nature, 314: 707-713.

Chang, A.S., 2004. Ultra-high resolution sediment analysis and diatom paleoecology from Effingham Inlet, British Columbia, Canada: Implications for Late Holocene Environmental change. Ph.D Dissertation, Carleton University, Ottawa, Canada: 537.

Chang, A.S. and Patterson, R.T., 2005. Climate shift at 4400 years BP: evidence from highresolution diatom stratigraphy, Effingham Inlet, British Columbia, Canada; Palaeogeography, Palaeoclimatology, Palaeoecology, 226 (2-3): 72-92.

Chang, A.S., Patterson, R.T., and McNeely, R., 2003. Seasonal sediment and diatom record from the late Holocene laminated sediments, Effingham Inlet, British Columbia, Canada; Palaios, 18: 477-494.

Chaster, G.W., 1892. Report upon the foraminifera of the Southport Society of Natural Science District. First Report Southport Society of Natural Science (1890-1891), Appendix: 54-72.

Chernykh, V.V., 1967. Novye Pozdnesiluriyskie foraminifery Urala (New Late Silurian Foraminifera of the Urals). Paleontologischeskiy Zhurnal, 2: 37-43.

Christoforou, P., and Hameed, S., 1997. Solar cycle and the Pacific 'centers of action'. Geophysical Research Letters, 24: 293-296.

Clague, J.J., 1977. Quadra Sand: a study of the late Pleistocene geology and geomorphic history of coastal southwest British Columbia. Geological Survey of Canada, Paper, no. 1777.

Clague, J.J., 1981. Landslides at the south end of Kluane Lake, Yukon Territory. Canadian Journal of Earth Sciences 18: 959-971.

Clague, J.J., 1994. Formation and failure of natural dams in the Canadian Cordillera. Geological Survey of Canada Bulletin, 464: 35.

Clague, J.J., Harper, J.R., Hebda, R.J., and Howes, D.E., 1982. Late Quaternary sea levels and crustal movements, coastal British Columbia. Canadian Journal of Earth Sciences 19: 597-618. 
Clague, J.J., and James, T.S., 2002. History and Isostatic Effects of the Last Ice Sheet in Southern British Columbia. Quaternary Science Reviews, 21: 71-87.

Clague, J.J., and Mathewes, R.W., 1989. Early Holocene Thermal Maximum in Western North America: New Evidence from Castle Peak, British Columbia. Geology, 17: 277-280.

Clague, J.J., and Mathewes, R.W., 1996. Neoglaciation, Glacier-Dammed Lakes, and Vegetation Change in Northwestern British Columbia, Canada. Arctic and Alpine Research, 28: $10-24$.

Clague, J.J., Mathewes, R.W., Guilbault, J.P., Hutchinson, I., and Ricketts. B.D., 1997. Pre-Younger Dryas Resurgence of the Southwestern Margin of the Cordilleran Ice Sheet, British Columbia, Canada. Boreas, 26: 261-278.

Clague, J. J. and MacDonald, G. M., 1989. Paleoecology and paleoclimatology [Canadian Cordillera], p. 70-74. In R. J. Fulton, éd., Quaternary geology of Canada and Greenland. Geological Survey of Canada, Geology of Canada, 1: 839 p. [also Geological Society of America, The Geology of North America, v. K-1].

Clague, J.J., Wohlfarth, B., Ayotte, J., Eriksson, M., Hutchinson, I., Mathewes, R.W., Walker, I.R., and Walker, L., 2004. Late Holocene environmental change at treeline in the northern Coast Mountains, British Columbia, Canada. Quaternary Science Reviews, 23: 24132431.

Clark, D.F., 1971. Effects of aquaculture outfall on benthonic foraminifera in Clam Bay, Nova Scotia. Maritime Sediments, 7: 76-84.

Cockburn, J.M.H., Scott, F., and Lamoureux, S.F., 2008. Inflow And Lake Controls On Short-Term Mass Accumulation And Particle Size: Implications For Interpreting Varved Lacustrine Sedimentary Records, Journal of Paleolimnology, 40: 923-942.

Cockbain, A.E., 1963. Distribution of foraminifera in Juan de Fuca and Georgia Straits, British Columbia, Canada. Contributions from the Cushman Foundation for Foraminiferal Research, 14: 37-57.

Coney P.J., Jones D.L., and Monger J.W.H., 1980. Cordilleran suspect terranes. Nature 288: 329-333.

Cooper, S.C., 1964. Benthonic foraminifera of the Chukchi Sea. Cushman Foundation for. Foraminifera Research Contributions. 15: 79-104.

Crusius, J., Calvert, S.E.T., Pederson, T.F., and Sage, D., 1996. Rhenium and molybdenum enrichments in sediments as indicators of oxic, sub-oxic and sulfidic conditions of deposition. Earth and Planetary Science Letters, 145: 67-78.

Culver, S.J., 1993. Foraminifera. In: J.E. Lipps (ed.), Fossil prokaryotes and protists. Blackwell Scientific Publications: 203-247. 
Cushman, J.A., 1910. A monograph of the foraminifera of the North Pacific Ocean. Pt. I Astrorhizidae and Lituolidae. United State National Museum Bulletin, 71 (1): 1-134.

Cushman, J.A., 1911. A monograph of the foraminifera of the North Pacific Ocean. Pt. II Textulariidae. U.S. National Museum Bulletin, 71 (2): 1-108.

Cushman, J.A., 1913. A monograph of the foraminifera of the North Pacific Ocean. Pt. III Lagenidae. U.S. National Museum Bulletin, 71 (3): 1-125.

Cushman, J.A., 1922a. Results of the Hudson Bay expedition, 1920; I -The foraminifera. Contributions of Canadian Biology, 1921, Biological Board of Canada, 9: 135-147.

Cushman, J.A., 1922b. Foraminifera of the Atlantic Ocean. Part 3: Textulariidae. Bulletin of the United States National Museum, 104 (3): 1-143.

Cushman, J.A., 1923. The foraminifera of the Atlantic Ocean; Part 4 - Lagenidae. U.S. National Museum Bulletin, 104 (4): 1-228.

Cushman, J.A., 1925. Recent foraminifera from British Columbia. Contributions from the Cushman Foundation for Foraminiferal Research, 1: 38-47.

Cushman, J.A., 1926. Foraminifera of the typical Monterey of California. Contributions from the Cushman Foundation for Foraminiferal Research, 2 (3): 53-69.

Cushman, J.A., 1927. An outline of a re-classification of the foraminifera. Contributions from the Cushman Foundation for Foraminiferal Research, 2: 94-95.

Cushman, J.A., 1930. The foraminifera of the Atlantic Ocean, pt. 7: Nonionidae, Camerinidae, Peneroplidae, and Alveolinellidae. U.S. National Museum Bulletin, 104 (7): 179.

Cushman, J.A., 1933. Foraminifera, their classification and economic use. Cushman Foundation Special Publication, 4: 1-349.

Cushman, J.A., 1936. Some new species of Elphidium and related genera. Contributions from the Cushman Laboratory for Foraminiferal Research, 12 (4): 78-89.

Cushman, J.A., 1937. A monograph of the foraminiferal family Valvulinidae. Special Publication Cushman Laboratory for Foraminiferal Research, 7: 1-157.

Cushman, J.A., 1939. A monograph of the foraminiferal family Nonionidae. Professional Papers United States. Geological Survey, 191: 1-100.

Cushman, J.A., 1944. Foraminifera from the shallow water of the New England coast. Cushman Laboratory for Foraminiferal Research, Special Publication, 12: 1-37. 
Cushman, J.A., and Brönnimann, P., 1948. Some new genera and species of foraminifera from brackish water of Trinidad. Contributions from the Cushman Laboratory for Foraminiferal Research, 24: 15-21.

Cushman, J.A., and Grant, H.S., 1927. Late Tertiary and Quaternary Elphidium of the West Coast of North America. San Diego Society of Natural History, Transactions, 5 (6): 69-82.

Cushman, J.A., and Gray, H.B., 1946. A foraminiferal fauna from the Pliocene of Timms Point, California. Cushman Laboratory for Foraminiferal Research, Special Publication, 19: $1-46$.

Cushman, J.A., and McCulloch, I., 1942. Some Virgulininae in the collections of the Allan Hancock Foundation. Allan Hancock Pacific Expeditions, 6: 179-230.

Cushman, J.A., and McCulloch, I., 1948. The species of Bulimina and related genera in the collections of the Allan Hancock Foundation. Allan Hancock Pacific Expedition., 6 (5). Los Angeles. [ii]: 231-294.

Cushman, J.A., and Moyer, D.A. 1930. Some recent foraminifera from off San Pedro, California. Contributions from the Cushman Laboratory for Foraminiferal Research, 6: 4962.

Cushman, J.A., and Todd, R., 1947. A foraminifera fauna from Amchitka Island, Alaska. Contributions from the Cushman Laboratory for Foraminiferal Research, 23: 60-72.

Cushman, J.A., and Valentine, W.W., 1930. Shallow water foraminifera from the Channel Islands of southern California. Contributions from the Department of Geology of Stanford University, 1: 5-51.

Dalimore, A., 2001. Late Holocene geologic, oceanographic and climate history of an anoxic fjord: Effingham Inlet, West coast, Vancouver Island. Ph.D Dissertation, Carleton University, Ottawa: 465 .

Davis, J.R., 1986. Statistics and Data Analysis in Geology (second edition revised). Wiley, New York, : 656p.

Dawson, J.W., 1860. Notice of Tertiary fossils from Labrador, Maine, etc., and remarks on the climate of Canada in the newer Pliocene or Pleistocene period. Canadian Natural Geology, 5: 188-200.

de Blainville, H.M.D., 1927. Manuel de malacologie et de conchyologie. F.G. Levrault, Paris.

de Monfort, P.D., 1808. Conchyliologie systématique et classification méthodique des coquilles, 1. F. Schoell, Paris.

Dean, W.E., 2002. A 1500-year record of climatic and environmental change in Elk Lake, Minnesota II: Geochemistry, mineralogy, and stable isotopes: Journal of Paleolimnology, 27: 301-319. 
Dean, W., and Schwalb, A., 2002. The Lacustrine Carbon Cycle as Illuminated by the Waters and Sediments of Two Hydrologically Distinct Headwater Lakes in North-Central Minnesota, U.S.A. Journal of Sedimentary Research; 72 ( 3): 416-431.

Dean, W., Anderson, R., Bradbury, J.P., and Anderson, D., 2002. A 1500-year record of climatic and environmental change in Elk Lake, Minnesota I: Varve thickness and gray-scale density. Journal of Paleolimnology 27: 287-299.

Dean, W.E., Gardner, J.V., and Piper, D.Z., 1997. Inorganic geochemical indicators of glacial-interglacial changes in productivity and anoxia on the California continental margin, Geochimica et Cosmochimica Acta, 61: 4507-4518.

Dean, W.E., Piper, D.Z., and Peterson, L.C., 1999. Molybdenum accumulation in Cariaco Basin sediment over the past 24,000 years: A record of water-column anoxia and climate. Geology, 27: 507-510.

Dean, J.M., and Kemp, A.E.S., 2004. 2100 year BP record of the Pacific Decadal Oscillation, El Niño Southern Oscillation and Quasi-Biennial Oscillation in marine production and fluvial input from Saanich Inlet, British Columbia. Palaeogeography, Palaeoclimatology, Palaeoecology, 213 (3-4): 207-229.

Deflandre, G., 1929. Le genre Centropyxis Stein. Archiv fur Protistenkunde, 67: 322-375.

Deflandre, G., 1953. Ordres des Testaceolobosa (De Saedeleer 1934), Testaceofilosa (De Saedeleer 1934), Thalamia (Haeckel 1862) ou Thecamoebiens (Auct.) (Rhizopoda Testacea): 97-148. In: Grasse, P.P. (ed.), Traite de Zoologie. Masson, Paris.

Defrance, M.J.L., 1824. In: Blainville, H.M.D.. (ed.), Dictionnaire des sciences naturelles, 32, mollus-morf. F.G. Levrault, Paris.

Delage, Y., and Hérouard, E., 1896. Traité de Zoologia Concrète, 1: La cellule at le protozoaires. Schleicher Frères, Paris.

Denton, G.H., and Karlen, W., 1973. Holocene glacial and tree-line variations in the White River Valley and Skolai Pass, Alaska and Yukon Territory. Quaternary Research, 7: 63-111.

Doherty, C.T., 2005. The Late-Glacial and Holocene relative sea-level history of the Seymour Inlet Complex, British Columbia, Canada. Unpublished PhD dissertation, The Queen's University of Belfast: 524.

d'Orbigny, A., 1826. Tableau méthodique de la classe des Céphalopodes. Annales des Sciences Naturelles, 7: 245-314.

d'Orbigny, A., 1839. Voyage dans l'Amérique Méridionale; Foraminifêres, 5. Levrault, Strasbourg, France.

d'Orbigny, A., 1846. Foraminiferes fossiles du bassin tertiare de Vienne (Autriche). Gide et Comp., Paris. 
Douglas, R.G., Walch, C., and Blake, G., 1976. Benthic microfauna.: BLM southern California baseline study, Final Report, III, Report 2.5, Washington.

Douglas, R.G., Cotton, M.L., and Wall, L., 1979. Distributional and variability analysis of benthic foraminifera in the southern California Bight, Bureau of Land Mangement, Department of Interior Contract AA550-CT6-40: 219.

Dypvik, H., 1984. Geochemical compositions and depositional conditions of Upper Jurassic and Lower Cretaceous Yorkshire clays, England: Geological Magazine, 121 (5): 489-504.

Earland, A., 1933. Foraminifera; Part II - South Georgia. "Discovery" Reports, 7: 27-138.

Earland, A., 1934. Foraminifera; Part III - The Falklands sector of the Antartic (excluding South Georgia). "Discovery" Reports, 10: 1-208.

Echols, R.J., 1971. Distribution of foraminifera in sediments of the Scotia Sea area, Antarctic waters, p. 93-168. In Reid, J.L. (ed.), Antarctic Oceanography I. Antarctic Research Series. American Geophysical Union, Washington D.C., USA.

Edwards, R.J., Van de Plassche, O., Gehrels, W.R., and Wright, A.J., 2004. Assessing sea-level data from Connecticut, USA, using a foraminiferal transfer function for tide level, Marine Micropaleontology 51: 239-255.

Ehrenberg, G.C., 1830. Organisation systematik und geographisches Verhaltnis der Infusionsthierchen. Druckerei del Koniglichen Akademie del Wissenschaften, Berlin.

Ehrenberg, G.C., 1832. Beitrage zur Kenntnis del Organisation der Infusorien und ihrer geographischen Verbreitung, besonders in Sibirien. Koningliche Akademie der Wissenschaften zu Berlin Abhandlungen: 1-88.

Ehrenberg, G.C., 1838. Über dem blossen Auge unsichtbare Kalkthierchen und Kieselthierchen als Hauptbestandtheile der Kreidegebirge. Bericht uber die zur Bekanntmachung geeigneten Verhanlungen del Königlichen Preussischen Akademie der Wissenschaften

Ehrenberg, G.C., 1839. Über die Bildung der Kreidefelsen und des Kreidemergels durch unsichtbare Organismen. Physikalische Abhandlungen der Königlichen Akademie der Wissenschaften zu Berlin, 1838 (1840: separate 1839): 59-147.

Ehrenberg, G.C., 1843. Verbreitung und Einfluss des mikroskopischen Lebens in Sud-und Nord-Amerika: Konigliche Akademie der Wissenschaften zu Berlin Abhandlungen, 1841. Physikalische Abhandlungen: 291-446.

Ehrenberg, G.C., 1848. Fortgesetzte Beobachtungen uber jetzt herrschende atmospharische mikroskopische Verhaltnisse. Bericht uber die zur Bekanntmachung geeigneten Verhanlungen del Koniglichen Preussischen Akademie der Wissenschaften zu Berlin. 
Ehrenberg, G.C., 1861. Elemente des tiejen Meeresgrundes in Mexikanischen Golfstrome bei Florida; Über die Tiefgrund-Verhältnisse des Oceans am Eingange der Davisstrasse und bei Island. Monatsbericht der Koniglichen Preussischen Akademie der Wissenscraften zu Berlin, 1858: 295-311, 324-337.

Ehrenberg, C.G., 1872. Nachthrag zur bersicht der organischen AtmosphŠrilien. Kšnigliche Akademie der Wissenschaften zu Berlin Physikalische Abhandlungen, 1871: 233-275.

Eichwald, C.E.v. 1830. Zoologia specialis, 2. D.E. Eichwaldus, Vilnae.

Eimer, G.H.T., and Fickert, C., 1899. Die Artibildung und Verwandtschaft bei den Foraminiferen. Entwurf einer natürlichen Eintheilung derselben. Zeitschrift fur wissenschaftliche Zoologie, 65: 599-708.

Elverhoi, A., Liestel, O., and Nagy, J., 1980. Glacial erosion, sedimentation and microfauna in the inner part of Kongsforde, Spitsbergen. North Polarinst. Skrifer, Nr 172: 33-61.

Emery, W.J., and Hamilton, K., 1985. Atmospheric forcing of interannual variability in the northeast Pacific Ocean: Connections with El Nino. Journal of Geophysical Research, 90: 857-868.

Emmer, E., and Thunell, R. C., 2000. Nitrogen isotope variations in Santa Barbara Basin sediments: Implications for denitrification in the eastern tropical North Pacific during the last 50000 years. Paleoceanography, 15, 377- 387.

Environment Canada. www.climate.weatheroffice.ec.gc.ca/climate_normal, assessed 2007.

Favorite, F.A., Dodimead, A.J., and Nasu, K., 1976. Oceanographny of the subarctic Pacific region, 1960-1971. International North Pacific Fisheries Commission Bulletin, 33: 187.

Fedje D.W., 1993. Sea-levels and prehistory in Gwaii Haanas. MA thesis, University of Calgary: $160 \mathrm{p}$.

Feyling-Hanssen, R.W., 1964. Foraminifera in Late Quaternary deposits from the Oslofjord area. Norway Geological Unders. 225: 1-383.

Feyling-Hanssen, R.W., Jdrgensen, J.A., Knudsen, K.L., and Andersen, A.L., 1971. Late Quaternary Foraminifera from Vendsyssel, Denmark and Sandnes. Norway Bulletin Geological. Society of Denmark, 21: 67-317.

Feyling-Hanssen, W., and Buzas, M.A., 1976. Emendation of Cassidulina and Islandiella helenae new species. Journal of Foraminiferal Research, 6 (2): 154-158.

Finger, K.L., 1990. Atlas of California Neogene Foraminifera. Cushman Foundation for Foraminiferal Research, Special Publication, 28: 1-271.

Finger, K.L., Lipps, J.H., Weaver, J.C.B., and Miller, P.L., 1990. Biostratigraphy and 
depositional environments of calcareous microfossils in the lower Monterey Formation (lower to middle Miocene), Graves Creek area, Central California. Micropaleontology, 36 (1): 1-55.

Fishbein, E., and Patterson, R.T., 1993. Error weighted maximum likelihood (EWML): A new statistically valid method to cluster quantitative micropaleontological data. Journal of Paleontology, 67: 475-486.

Fisheries, and Oceans, C., 2003. Tides, currents and water levels. http:// www.tides.gc.ca.

Fleming, J., 1828. A history of British animals, exhibiting the descriptive characters and systematic arrangement of the genera and species of quadrupeds, birds, fishes, mollusca and radiata of the United Kingdom. Bell and Bradfute, Edinburgh.

Francis, R.C., Hare, S.R., Hollowed, A.B., and Wooster, W.S., 1998. Effects of interdecadal climate variability on the oceanic ecosystems of the NE Pacific. Fisheries Oceanography, 7: 1-21.

Francis, R.C., and Hare, S.R., 1994. Decadal-scale regime shifts in the large marine ecosystems of the Northeast Pacific: a case for historical science. Fisheries Oceanography, 3 (4): 279-291.

Francois, B., 1988. A study on the regulation of the concentrations of some trace metals $(\mathrm{Rb}$, $\mathrm{Sr}, \mathrm{Zn}, \mathrm{Pb}, \mathrm{Cu}, \mathrm{V}, \mathrm{Cr}, \mathrm{Ni}, \mathrm{Mn}$ and $\mathrm{Mo}$ ) in Saanich Inlet sediments, British Columbia, Canada. Marine Geology 83: 285-308.

Gallagher, M. T., 1979. Substrate controlled biofacies: recent foraminifera from the continental shelf and slope of Vancouver Island, British Columbia. Ph.D.. University of Calgary, Calgary, Alberta, 232p.

Galloway, J.M., 2006. Post-glacial climate and vegetation change in the Seymour-Belize Inlet Complex, Central Coastal British Columbia. Unpublished Ph.D Dissertation, Carleton University, Ottawa: 176.

Galloway, J.M., Patterson, R.T., and Roe, H.M., (In press). A high resolution marine palynological record from the central mainland coast of British Columbia, Canada: evidence for a mid-late Holocene dry climate interval.

Galloway, J.M., Patterson, R.T., Doherty, C.T., Roe, H.M., 2007. Multi-proxy evidence of postglacial climate and environmental change at Two Frog Lake, central mainland coast of British Columbia, Canada. Journal of Paleolimnology, 38: 569-588.

Galloway, J.M., Doherty, C.T., Patterson, R.T., and Roe, H.M., 2008. Postglacial vegetation and climate dynamics in the Seymour-Belize Inlet Complex, central coastal British Columbia, Canada: palynological evidence from Tiny Lake. Journal of Quaternary Science, 24: 322-335.

Galloway, J.J., 1933. A manual of foraminifera. Principia Press, Bloomington. 
Galloway, J.J., and Wissler, S.G., 1927. Pleistocene foraminifera from the Lomita Quarry, Palos Verdes Hills, California. Journal of Paleontology, 1: 35-87.

Garcia, A., and Mouradian, Z., 1998. The Gleissberg cycle of minima. Solar Physics, 180: 495-498.

Gardner, M.C., Bergman, S.C., Cushing, G.W., MacKevet, E.M. Jr., Plafker, G., Campbell, R.B., Dodds, C.J., McClelland, W.C., and Mueller, P.A., 1988. Pennsylvanian pluton stitching of Wrangellia and the Alexander terrane, Wrangell Mountains, Alaska. Geology, 16: 967-971.

Gedalof, Z., and Nathan, J., Mantua, N.J., 2002. A multi-century perspective of variability in the Pacific Decadal Oscillation: new insights from tree rings and coral. Geophysical Research Letters, 29, No. 24, 2204: 57-1 57-4.

Gedalof, Z., and Smith, D.J., 2001. Interdecadal climate variability and regime-scale shifts in Pacific North America; Geophysical Research Letters, 28: 1515 - 1518.

Geolabs Manual, 2003. Precise analysis quality results: $28 \mathrm{p}$.

Gershunov, A., Barnett, T., and Cayan, D., 1999. North Pacific interdecadal oscillation seen as factor in ENSO-related North American climate anomalies, EOS Transcations, America Geophysiccal Union, 80: 25-30.

Gilman, D.L., Fuglister, F.J., and Mitchel Jr., J.M., 1963. On the power spectrum of red noise. Journal of the Atmospheric Sciences, 20 (2): 182-184.

Glaessner, M.F., 1937. Die Entfaltung der Foraminiferen familie Buliminidae. Problemy Paleontologii, Paleontologicheskaya Laboatoriya Moskovskogo Gosudarstvennogo Universiteta, 2-3: 411-422.

Gleissberg, W., 1958. The eighty-year sunspot cycle. Journal of British Astronomical Association, 68: 1148-1152.

Green, R.N., and Klinka, K., 1994. A field guide to site identification and interpretation for the Vancouver Forest Region, Land Management Handbook No. 28. British Columbia Ministry of Forests: 285p.

Greene' A.R., Scoates, J.S., and Weis, D., 2005. Wrangellia Terrane on Vancouver Island, British Columbia: Distribution of Flood Basalts with Implications for Potential Ni-Cu-PGE Mineralization in Southwestern British Columbia. Geological Fieldwork 2004, Paper 1: 209220.

Gregory, M. J., 1970. Distribution of benthic foraminifera in Halifax Harbour, Nova Scotia, Canada: Unpublished Ph.D. Thesis, Department of Geology, Dalhousie University, Halifax, Nova Scotia, 274: 1-15. 
Gregory, M. R., 1973. Benthonic foraminifera from a Mangrove swamp. Whangaparapara, Great Barrier Island. Tane, 19: 193-204.

Guilbault, J-P., Clague. J.J., and Lapointes, M., 1996. Foraminiferal evidence for the amount of coseismic subsidence during a Late Holocene earthquake on Vancouver Island, West Coast of Canada. Quaternary Science Reviews, 15: 913-937.

Guilbault, J.P., Patterson, R.T., Thomson, R.E., Barrie, J.V., and Conway, K. 1997. Late Quaternary paleoceanographic changes in Dixon Entrance, Northwest British Columbia, Canada: evidence from the foraminiferal faunal succession. Journal of Foraminiferal Research, 27 (3): 151-174.

Guilbault, J.P., Radi, T., Barrie, J.V., Conway, K., and Lapointe, M., 2003. Paleoenvironments of the Strait of Georgia, British Columbia during the last deglaciation: Microfaunal and microfloral evidence. Quaternary Science Reviews, 22 (8-9): 839-857.

Gustafsson, M. and Nordberg, K., 2000. Living (stained) benthic foraminifera and their response to the seasonal hydrographic cycle, periodic hypoxia and to primary production in Havstens Fjord on the Swedish west coast, Estuarine, Coastal and Shelf Science, 51 (6): 743761.

Haeckel, E. 1894. Systematische Phylogenie. Entwurfeines Natürlichen Systems der Organismen auf Grund ihrer Stammesgeschichte. Systematische Phylogenie der Protisten und Pflanzen, 1. Georg Reimer, Berlin.

Haggarty, D.R., McCorquodale, B. Johannessen, D.I. Levings, C.D. and Ross., P.S., 2003. Marine environmental quality in the central coast of British Columbia, Canada: A review of contaminant sources, types and risks. Canadian Special Publication in Fish and Aquatic Science. 2507: 153p.

Hald , M. and Korsun, S., 1997. Distribution of nmodern benthic foraminifera from fjords of Salvard, European arctic. Journal of Foraminiferal Research, 27: 101-122.

Hald, M., Danielsen, T.K. and Lorentzen, S. 1989. Late Pleistocene and Holocene benthic foraminiferal distribution in the southwestern Barents Sea: paleoenvironmental implications. Boreas, 4: 367-388.

Hald, M., Dahlgren, T., Olsen, T.E., and Lebesbye, E., 2001. Late Holocene palaeoceanography in Van Mijenfjorden, Svalbard: Polar Research, 20 (1): 23-35.

Hald, M, Steinsund, P. I., Dokken, T., Korsun, S., Polyak, L., and Aspeli, R., 1994. Recent and Late Quaternary distribution of Elphidium excavatum f. clavatum in Arctic seas, in Sejrup, H. P., and Knudsen, K. L. (eds.), Late Cenozoic Benthic Foraminifera: Taxonomy, Ecology and Stratigraphy: Cushman Foundation Special Publication No. 32: 141-153.

Hald, M., and Vorren, T.O., 1987. Foraminiferal stratigraphy and environments of Late Weichselian deposits on the continental shelf off Troms, Northern Norway. Marine Micropaleontology, 12: 129 - 160 . 
Hallett D.J., Mathewes R.W. and Walker R.C., 2003. A 1000-year record of forest fire, drought and lake level change in southeastern BritishColumbia,Canada. The Holocene, 13:751-761.

Haman, D., 1982. Modern Thecamoebinids (Arcellinida) from the Balize Delta, Louisiana. Transactions, Gulf Coast Association of Geological Societies, 32: 353-376.

Hameed, S., and Lee, J.N., 2003. Responses of the Atmospheric Centers of Action to the Solar Cycle in the East and West phases of the Quasi-Biennial Oscillation.

Hare, F.K., and Thomas, M.K., 1979. Climate Canada. John Wiley \& Sons, Toronto.

Hare, S.R., and Francis, R.C., 1994. Climate change and salmon production in the Northeast Pacific Ocean. In: Beamish, R.J. (Ed.), Climate Change and Northern Fish Populations, Canadian Special Publication in Fish and Aquatic Science, 121: 1 -33.

Hare S.R., and Mantua, N.J., 2000. Empirical evidence for North Pacific regime shifts in 1977 and 1989. Progress in Oceanography, 47: 103-146.

Hasselmann, K., 1976. Stochastic climate models: Part I. Theory. Tellus, 28 (6): 473-485.

Hatté, C., Antoine, P., Fontugne, M., Lang, A., Rousseau, D.D., 2001. $\delta^{13} \mathrm{C}$ of loess organic matter as a potential proxy for paleoprecipitation. Quaternary Research, 55: 33-38.

Hatté, C., Fontugne, M.R., Rousseau, D.D., Antoine, P., Tisn'erat-Laborde, N., and Bentaleb, I., 1998. $\delta^{13} \mathrm{C}$ variations of loess organic matter as a record of the vegetation response to climatic changes during theWeichselian. Geology, 26: 583-586.

Hatté, C., Pessenda, L.C.R., Fontugne, M.R., Zöller, L., Antoine, P., Rousseau, D.D., and Lang, A., 1999. ${ }^{14} \mathrm{C}$-AMS dating of loess organic matter of the Nussloch loess sequence, Rhine Valley, Germany. In "Loessfest '99." Bonn/Heidelberg.

Hatté, C., and Schwartz, D., 2003. Reconstruction of paleoclimates by isotopic analysis: What can the fossil isotopic record tell us about the plant life of past environments? Phytochemistry Reviews, 2, Numbers 1-2: 163-177.

Hay, M.B., 2005. Reconstitution des conditions océanographiques et climatiques de l'holocène supérieur à effingham inlet, colombie britannique. Ph.D. dissertation, université Laval, Québec. (in English and French). http://www. theses.ulaval.ca/2005/23241/23241.pdf

Hay, M.B., Audrey Dallimore, A., Thomson, R.E., Stephen E. Calvert, S.E., and Pienitz, R., 2007. Siliceous microfossil record of late Holocene oceanography and climate along the west coast of Vancouver Island, British Columbia, Canada. Quaternary Research 67, Issue 1: 33-49.

Hayward, B.W., Hollis C.J., and Grenfell H.R., 1997. Recent Elphidiidae (Foraminiferida) of the South-west Pacific and fossil Elphidiidae of New Zealand. New Zealand Geological Survey Paleontological Bulletin, 72: 166. 
Hayward, B.W., Grenfell H.R., Reid, C.M., and Hayward, K.A., 1999. Recent New Zealand shallow-water benthic foraminifera: Taxonomy, ecologic distribution, biogeography, and use in paleoenvironmental assessment. Institute of Geological and Nuclear Sciences Monograph, 21: 258.

Hebda, R.J., 1983. Late-glacial and postglacial vegetation history at Bear Cove Bog, northeast Vancouver Island, British Columbia. Canadian Journal of Botany, 61: 3172-3192.

Hebda, R.J., 1995. British Columbia vegetation and climate history with focus on 6 ka BP. Ge'ogr Phys Quaternarie, 49: 55-79.

Hebda, R. J., and Mathewes, R.W., 1984. Holocene history of cedar and Native Indian cultures of the North American Pacific coast. Science, 255: 711-713.

Hedges, J.I., Blanchette, R.A., Weliky, K. and Devol, A.H., 1988. Effects of fungal degradation on the $\mathrm{CuO}$ oxidation products of lignin: a controlled laboratory study. Geochimica et Cosmochimica Acta, 52: 2717-2726.

Hedley, R.H., Hurdle, C.M., and Burdett, I.D.J., 1964. Trochammina squamata Jones and Parker (foraminifera) with observations on some closely related species. New Zealand Journal of Science, 7 (3): 419-425.

Heinrichs, M.L., Wilson, S.E., Walker, I.R., Smol., J.P., Mathewes R.W., and Hall, K.J., 1997. Midge and diatom-based paleosalinity reconstructions for Mahoney Lake, Okanagan Valley, British Columbia, Canada. International Journal of Salt Lake Research, 6: 249-267.

Helz, G.R., Miller, C.V., Charnock, J.M., Mosselmans, J.F.W., Patrrick, R.A.D., Gardner, C.D., and Vaughan, D.J., 1996. Mechanism of molybdenum removal from the sea and its concentration in black shales: EXAFS evidence. Geochimica et Cosmochimica Acta, 60: 3631-3642.

Hemingway, R., and Douglas, D., 1999. Beyond Nakwakto Rapids. Pacific Yachting.

Hendy, I.L., Pedersen, T.F., Kennett, J.P., and Tada, R., 2004. Intermittent existence of a southern Californian upwelling cell during submillennial climate change of the last $60 \mathrm{kyr}$, Paleoceanography, 19, PA3007.

Heron-Allen, E., and Earland, A., 1911. On the recent and fossils foraminifera of the shoresands of Selsey Bill, Sussex, IV. Journal of the Royal Microscopy Society: 436-448.

Heron-Allen, E., and Earland, A., 1930. Some new foraminifera for the South Atlantic; III. Miliammina, a new siliceous genus. Journal of the Royal Microscopicalogical Society of London, series 3 (50): 38-45.

Heron-Allen, E. and Earland, A., 1922. Protozoa, Pt. II. Foraminifera. British Antarctic ("Terra Nova") Expedition, 1910. Zoology 6: 225-268. 
Heron-Allen, E., and Earland, A., 1932. Foraminifera; Part I - The ice-free area of the Falkland Islands and adjacent seas, p. 440, "Discovery" Reports, issued by the "Discovery" Committee, Colonial Office, London. University Press, Cambridge, UK.

Heusser, L.E., 1983. Palynology and paleoecology of postglacial sediments in an anoxic basin, Saanich Inlet, British Columbia. Canadian Journal of Earth Sciences, 20: 873-885.

Heusser, C.J., Heusser, L.E., Peteet, D.M., 1985. Late-Quaternary climatic change on the American North Pacific coast. Nature, 315: 485-487.

Heusser, C.J., 1985. Quaternary pollen records from the Pacific Northwest Coast: Aleutians to the Oregon-California border. In Bryant, V.M., Jr., and Holloway, R.G. (Eds.), Pollen Records of Late-Quaternary North American Sediments. American Association of Stratigraphic Palynologists: 141-165.

Hickman, M., and Schweger, C. E., 1993. Late glacial-early Holocene palaeosalinity in Alberta, Canada - Climatic implications. J. Paleolimnology 8: 149-161.

Hirst, D.M., 1962. The geochemistry of modern sediments from the Gulf of Paria-I. The relationship between the mineralogy and the distribution of major elements. Geochimica Cosmochimica. Acta, 26: 309-334.

Hodell, D.A., Brenner, M., Curtis, J.H., and Guilderson, T., 2001. Solar Forcing of Drought Frequency in the Maya Lowlands. Science, 292 (5520): 1367-1370.

Hofker, J., 1951. The foraminifera of the Siboga expedition. Part III. Siboga-Expeditie, Monographie IVa. E.J. Brill, Leiden: 513p.

Hofker, J., 1956. Tertiary foraminifera of coastal Ecuador: Part II, Additional notes on the Eocene species. Journal of Paleontology, 30: 891-958.

Höglund, H., 1947. Foraminifera in the Gullmar Fjord and the Skagerak. Zoologiske Bidrag från Uppsala, 26: 1-328.

Höglund, H., 1948. New names for four homonym species described in "Foraminifera in the Gullmar Fjord and the Skagerak". Contributions from the Cushman Foundation for Foraminiferal Research, 24: 45.

Horton, B.P., and Edwards, R.J., 2006. Quantifying Holocene sea-level change using intertidal foraminifera: lessons from the British Isles. Cushman Foundation for Foraminiferal Research Special Publication, 40: 97.

Horton, B.P., Gibbard, P.L., Milne, G.M., and Stargardt, J.M., 2005. Holocene sea levels and paleoenvironments of the Malay-Thai Peninsula, Southeast Asia. The Holocene, 15: 1199-1213.

Horton, B.P., Corbett, R., Culver, S.J., Edwards, R.J., and Hillier, C., 2006. Modern saltmarsh diatom distributions of the Outer Banks, North Carolina, and the development of a 
transfer function for high-resolution reconstructions of sea level. Estuarine, Coastal and Shelf Science, 69: 381-394.

Hsieh, W.W., Ware, D.M., and Thomson, R.E., 1995. Wind-induced upwelling along the West Coast of North America, 1899-1988. Canadian Journal Fisheries and Aquatic Sciences, 52: 325-334.

Hulme, S.G., 1961. A mechanized method of breaking down and washing foraminiferal rocks amples. Micropaleontology, 7 ( 1): 107-113.

Hulme, S. G., 1964. Recent Foraminifera from Manukau Harbour, Auckland, New Zealand. New Zealand Journal of Science 7(3): 305-340.

Hunt, A.S., and Corliss, B.H., 1993. Distribution and microhabitats of living (stained) benthic foraminifera from the Canadian Arctic Archipelago. Marine Micropaleontology, 20: 321-345.

Husum, K., and Hald, M., 2004. Modern foraminiferal distribution in the subarctic Malangen Fjord and adjoining shelf, northern Norway. Journal of Foraminiferal Research, 34: $34-48$.

Huntley, D.H., Bobrowsky, P.T., and Clague, J.J., 2001. Ocean Drilling program Leg 169S: Surfacial geology, stratigraphy and geomorphology of the Saanich Inlet area, southeastern Vancouver Island, British Columbia. Marine Geology, 174: 27-41.

Husezima, R., and Maruhasi, M., 1944. A new genus and thirteen new species of foraminifera from the cores ample of Kasiwazaki oil field, Niigata-ken. Journal Sigenkagaku Kenkyusyo, 1 (3): 391-400.

Imbrie, J., and Kipp, N.G. 1971. A new micropaleontological method for quantitative paleoclimatology: application to a Late Pleistocene Caribbean core. In Late Cenozoic glacial ages. Edited by K. K. Turekian. Yale University Press, New Haven, CT: 71-181.

Imbrie, J., and Webb, T., 1981. Transfer functions: Calibrating micropaleontological data in climatic terms. In: A. Berger (editor), Climate Variations and Variability: Facts and Theories. Reidel, Dordrecht (1981), pp. 125-134.

Iqbal, J., 1973. Sedimentology and benthonic foraminifera in M'Clure Strait (Canadian Arctic Archipelago): unpublished MS. Thesis, Dalhousie University, Halifax : 265.

Ishman, S.E. and Foley, K.M., 1996. Modern benthic foraminifer distribution in the Amerasian Basin, Arctic Ocean. Micropaleontology, 42: 206-220.

Ivanochko, T.S., and Pedersen. T.F., 2004. Determining the influences of Late Quaternary ventilation and productivity variations on Santa Barbara Basin sedimentary oxygenation: A multi-proxy approach. Quaternary Science Review, 23: 467-480. 
Jacobs, L., Emerson, S., and Huested, S.S., 1987. Trace metal geochemistry in the Cariaco Trench. Deep-Sea Research, 34: 965-981.

Jiménez-Espejo, F.J., Marténez-Ruiz, F., Finlayson, C., Paytan, A., Sakamoto, T., Ortega-Huertas, M., Finlayson, G., Iijima, K., Gallego-Torres, G., and Darren F,D., 2007. Climate forcing and Neanderthal extinction in Southern Iberia: insights from a multiproxy marine record Quaternary Science Reviews, 26: 836-852.

Jennings, A.E., 1993. The Quaternary history of Cumberland Sound, southeastern Baffin Island, Canada: the marine evidence: Geographic physique et Quaternaire, 47: 21-42.

Jennings, A.E., Nancy J., Weiner, N.J., Helgadottir, G., and Andrews, J.T., 2004. Modern foraminiferal faunas of the Southwestern to Northern Iceland shelf: Oceanographic and environmental Controls. Journal of Foraminiferal Research, 34 (3): 180-207.

Jennings, A.E., and Helgadottir, G., 1994. Foraminiferal assemblages from the fjords and shelf of eastern Greenland. Journal of Foraminiferal Research, 24: 123-144.

Jennings, A.E., and Weiner, N., 1996. Environmental change in Eastern Greenland during the last 1300 years: evidence from foraminifera and lithofacies in Nansen Fjord, $68^{\circ} \mathrm{N}$ : The Holocene, 6: 179-191.

Jensen, K.G., Kuijpers, A., Koç, N., and Heinemeier, J., 2004. Diatom evidence of hydrographic changes and ice conditions in Igaliku Fjord, South Greenland, during the past 1500 years. The Holocene, 14: 152-164.

Johnson, K.M., and Grimm, K.A., 2001. Opal and organic carbon in laminated diatomaceous sediments : Saanich Inlet, Santa Barbara Basin and the Miocene Monterey Formation. Marine Geology, 174: 159-175.

Jonasson, K.E., 1994. Benthic foraminiferal distribution at Middle Valley, Juan de Fuca Ridge: a northeast Pacific hydrothermal venting site. MS thesis, Carleton University, Ottawa, ON, Canada.

Jonasson, K.E., and Patterson, R.T., 1992. Preservation potential of marsh foraminifera from the Fraser River Delta, British Columbia. Micropaleontology, 38: 289-301.

Jones., 1875. In Griffith, J.W., and Henfrey, A. (eds.), The Micrographic Dictionary. van Voorst, London. Jones, R.W. 1984. A revised classification of the unilocular Nodosariida and Buliminida (Foraminifera). Revista Española de Micropaleontología, 16: 91-160.

Jones, V.J., and Juggins, S., 1995. The construction of a diatom-based chlorophyll $a$ transfer function and its application at three lakes on Signy Island (maritime Antarctica) subject to differing degrees of nutrient enrichment. Freshwater Biology. 34: 433-445.

Jones, B., and Manning, D.A.C., 1994. Comparison of geochemical indices used for the interpretation of palaeoredox conditions in ancient mudstones. Chemical Geology $111(1-4)$ : 111-129. 
Jones, D.L., and Silberling, N.J., 1979. Mesozoic stratigraphy - The key to tectonic analysis of southern and central Alaska. US Geological Survey Open-File Report, 79 (1200): 37.

Jones, D.L., Silberling, N.J., and Hillhouse, J., 1977. Wrangellia; a displaced terrane in northwestern North America; Canadian Journal of Earth Sciences, 14: 2565-2577.

Jones, G.D., and Ross, C.A., 1979. Seasonal Distribution of Foraminifera in Samish Bay, Washington. Journal of Paleontology, 53 (2): 245-257.

Jones, T.R., and Parker, W.K. 1860. On the Rhizopodal fauna of the Mediterranean, compared with that of the Italian and some other Tertiary deposits. Quarterly Journal of the Geological Society of London, 16: 304.

Juggins, S., 2005. C2 version 1.4: Software for ecological and paleoecological data analysis and visualization. University of Newcastle, Newcastle upon Tyne.

Kaiho, K., 1994. Benthic foraminiferal dissolved-oxygen index and dissolved-oxygen levels in the modern ocean. Geology, 22: 719-722.

Kao, S.J., and. Liu K.K., 2000. Stable carbon and nitrogen isotope systematics in a humandisturbed watershed (Lanyang-Hsi) in Taiwan and the export of biogenic particulate matter. Global Biogeochemical Cycles, 14 (1): 189-198.

Keigwin, L.D., and Boyle, E.A., 2000. Detecting Holocene changes in Thermohaline circulation. Proceedings of the National. Academy of Science of the United States of America, 97 (4): 1343-1346.

Kemp, A.E.S., 1996. Palaeoclimatology and Palaeoceanography from Laminated Sediments. Geological Society Special Publication, 116: 258p.

Kemp, A.E.S., 2003. Evidence for abrupt climate changes in annually laminated marine sediments. Philosophical Transactions of the Royal Society, London. A, 361: 1851-1870.

Kent, W.S., 1880. A manual of the Infusoria: including a description of all known Flagellate, Ciliate, and Tentaculiferous Protozoa, British and foreign, and an account of the organisation and affinities of the Sponges. Bogue, 1: 1-472.

Kerr, D.E., 1984. Marine Regression and paleoenvironments during the Holocene in the Richardson River Basin, District of Mackenzie, N.W.T. Géographie physique et Quaternaire, 38 (2): 185-192.

Kiaer, H., 1900. Synopsis of the Norwegian marine Thalamophora. Norwegian Fisheries Marine Investigation, 1 (7): 1-58.

Kienast, S.S., Calvert, S.E., and Pedersen, T.F., 2002. Nitrogen isotope and productivity variations along the northeast Pacific margin over the last 120 kyr: Surface and subsurface Paleoceanography, Paleoceanography 17(4): 1055, doi:10.1029/2001PA000650. 
Klitgaard-Kristensen, D., and Buhl-Mortensen, L., 1999. Benthic foraminifera along an offshore-fjord gradient: a comparison with amphpods and molluscs. Journal of Natural History, 33: 317-350.

Koerner, R.M., and Fisher, D.A., 1990. A record of Holocene summer climate froma Candian high arctic core. Nature 343: 630-631.

Korsun, S., and Hald, M., 1998. Modern benthic foraminifera off Novaya Zemlya tidewater glaciers, Russian Arctic. Arctic and Alpine Research, 30 (1): 61-77.

Korsun, S., and Hald, M., 2000. Seasonal dynamics of benthic foraminifera in a glacially fed fjord of Svalbard, European Arctic; Journal of Foraminiferal Research, 30 (4): 251-271.

Korsun, S.A., and Polyak, L.V., 1989. Distribution of benthic foraminiferal morphogroups in the Barents Sea. Oceanology, 29: 838-844.

Knudsen, K.L., and Seidenkrantz, M.S., 1994. Stainforthia feylingi new species from artic to subartic environments, previously recorded as Stainforthia schreibersiana (Czjzek). Cushman Foundation for Foraminiferal Research Special Publication, 32: 5-13.

Krejci-Graf, K., 1975. Geochemische Faziesdiagnostik. Freiberger Forschungsheft C, 224: 80.

Kumar, A., and Dalby, A.P., 1998. Identification key for Holocene lacustrine Arcellacean (Thecamoebian) taxa. Palaeontologia Electronica, 1(1): 34 http://www.palaeoelectronica.org/1998_1/dalby/issuel.htm.

Kumar, A., and Patterson, R.T., 2002. Dinoflagellate cyst assemblages from Effingham Inlet, Vancouver Island, British Columbia, Canada. Palaegeography, Palaeoclimatology, Palaeoecology, 180: 187-206.

Kutzbach, J.E. and Bryson, R.A., 1974. 'Variance Spectrum of Holocene Climatic Fluctuations in the North Atlantic Sector, Journal of Atmospheric Science, 31: 1958-1963.

Lagoe, M.B., 1979a. Recent Benthonic Foraminiferal Biofacies in the Arctic Ocean. Micropaleontology, 25 (2): 214-224.

Lagoe, M.B., 1979b. Modern benthic foraminifera from Prudhoe Bay, Alaska. Journal of Paleontology, 53: 258-262.

Lamb A.L., Wilson, G.P., and Leng, M.J. 2006. A review of coastal palaeoclimate and relative sea-level reconstructions using $\delta^{13} \mathrm{C}$ and $\mathrm{C} / \mathrm{N}$ ratios in organic material. Earth-Science Reviews, 75 (2006): 29-57.

Lamarck, J.B., 1816. Histoire naturelle des animaux sans vertebres, 2. Verdiere, Paris. 
Lamoureux, S.F.A., England, J.H., Sharp, M.J., and Bush, B.G., 2001. A varve record of increased 'Little Ice Age' rainfall associated with volcanic activity, Arctic Archipelago, Canada. The Holocene, 11 (2): 243-249.

Lacourse, T., and Mathewes, R.W., 2005. Terrestrial paleoecology of Haida Gwaii and continental shelf: vegetation, climate, and plant resources of the coastal migration route. In: D.W. Fedje and R.W. Mathewes (eds.), Haida Gwaii: Human History and Environment from the Time of Loon to the Time of the Iron People. University of British Columbia Press, Pacific Rim Series, Vancouver: 38-58.

Lacourse, T., 2005. Late Quaternary dynamics of forest vegetation on northern Vancouver Island, British Columbia, Canada, Quaternary Science Reviews, 24 :105-121

Larocque, S.J., and Smith, D.J., 2005. Little Ice Age proxy glacier mass balance records reconstructed from tree rings in the Mt. Waddington area, British Columbia Coast Mountains, Canada. The Holocene, 15: 748-757.

Larocque, S.J., and Smith, D.J., 2003. Little Ice Age glacial activity in the Mt. Waddington area, British Columbia coat Mountains, Canada. Canadian Journal of Earth Sciences, 40 (10): 1413-1435

Lassen, S.J., Kuijpers, A., Kunzendorf, H., Hoffmann-Wieck, G., Mikkelsen, N., and Konradil, P., 2004. Late-Holocene Atlantic bottom-water variability in Igaliku Fjord, South Greenland, reconstructed from foraminifera faunas. The Holocene, 14 (2): 165-171

Lees, J.M., and Park, J., 1995. 'Multi-Taper Spectral Analysis: A Stand-Alone CSubroutine, Computers and Geology, 21: 199-236.

Legendre, P., and Legendre, L., 1998. Numerical Ecology. 2nd English edition. Elsevier Science BV, Amsterdam: 853 pages.

Leidy, J., 1874. Notice of some Rhizopods. Academy of Natural Sciences of Philadelphia Proceedings series, 3: 13-15.

Leidy, J., 1879. Fresh-water Rhizopods of North America. United States Geological Survey of the Territories Report, 12: 1-324.

Leslie, R.J., 1963. Foraminiferal study of a cross-section of Hudson Bay Canada. Geological Survey of Canadian Papers, 63 (16): 28.

Leslie, R.J., 1965. Ecology and paleoecology of Hudson Bay foraminifera. Bedford Institute Oceanography of Report, 65 (6); (unpublished manuscript).

Levy, A., Mathieu, R., Moreni, I., Poignant, A., Rosset-Moulinier, M., Roug villois, A., and Ubaldo, M., 1969. Le representants de la famille des Elphidiidae (foraminiferes) dans les sables des plages des environs de Dunkerque: remiques sur les especces de Polystomella signalees par O, Rerquem. Revue de Microplaontologie, 12 (2): 92-98, pls 1, 2, text fig 1. 
Lewis, D.H., and Smith, D.J., 2004. Little Ice Age glacial activity in Strathcona Provincial Park, Vancouver Island , British Columbia, Canada. Canadian Journal of Earth Sciences, 41 (3): 285-297.

Llyod, J.M., 2006. Modern distribution of benthic foraminifera from Disko Bugt, West Greenland. Journal of Foraminiferal Research, 36 (4): 315-331.

Loeblich, A.R., and Tappan, H., 1953. Studies of Arctic foraminifera. Smithsonian Miscellaneous Collections, 121 (7): 1-150.

Loeblich, A.R., and Tappan, H., 1954. New names for two foraminiferal homonyms. Journal of the Washington Academy of Sciences, 44: 384.

Loeblich, A.R., and Tappan, H., 1961. Remarks on the systematics of the Sarcodina (Protozoa), renamed homonyms and new and validated genera. Proceedings of the Biological Society of Washington, 74: 213-234.

Loeblich, A.R., and Tappan, H., 1987. Foraminiferal Genera and Their Classification. Van Norstrand Reinhold Company, New York: 2047p.

Loeblich, A.R., and Tappan, H., 1994. Foraminifera of the Sahul Shelf and Timor Sea. Cushman Foundation for Foraminiferal Research Special Publication, 31. 661 p.

Lomb, N.R., 1976. Least-squares frequency analysis of unequally spaced data. Astrophysics and Space Science, 39: 447-462

Lowe, D.J., Green, J.D., Northcote, T.G., and Hall, K.J. , 1997. Holocene Fluctuations of a Meromictic Lake in Southern British Columbia. Quaternary Research, 48: 100-113.

Lučinskaja, T.N., 1974. Quantity of foraminifera in Quaternary deposits of Spitsbergen (Svalbard). In Kotljakov. V. M. (ed.): Materials of Investigations of the Area glaciations of Spitsbergen (Svalbard), 45 (62).

Luckman, B.H., 2000. Little ice Age in the Canadian Rockies. Geomorphology, 32: 357-384.

Luckman, B.H., Holdsworth, G., and Osborn G.D., 1993. Neoglacial fluctuations in the Canadian Rockies. Quaternary Resouces, 39: 144-153.

Luaternauer, J.L., Conway, K.W., Barrie, J.V., Blais, B., and Mathewes, R.W., 1989. Late Pleistocene terrestrial deposits on the continental shelf of western Canada: Evidence for rapid sea-level change at the end of the last glaciation. Geology, 17: 357-360.

Lutze, G.F and Coulbourn, W.T., 1984. Recent benthic foraminifera from the continental margin of northwest Africa: Community structure and distribution. Marine Micropaleontology, $8: 361-401$.

Lutze, G.F., Pflaumann, U., and Weinholz, P., 1986. Jungquartare Fluktuationen der benthischen Foraminiferenfaunen in Tiefsee- Sedimenten vor NW-Afrika-Eine Reaktion auf 
Produktivitat-sanderungen im Oberflichenwasser: "Meteor" Forschungs-Ergeb-nisse, Series C, 40: 163-180.

Lutze, G.F., 1965. Zur Foraminiferen-Fauna der Ostsee, Meyniana, 15: 75-142.

Mackensen, A., 1987. Benthische Foraminiferen auf dem Island- Schottland Riicken: Umwelt-Anzeiger an der Grenze zweier ozeanischer Raume. Palaontologische Zeitschrift, 61 (3/4): 149-179.

Mackensen, A., Grobe, H., Kuhn, G., and Futterer, D.K., 1990. Benthic foraminiferal assemblages from the eastern Weddell Sea between 68 and $70^{\circ} \mathrm{S}$ : Distribution, ecology and fossilization potential. Marine Micropaleontology, 16: 241-283.

Mackensen, A., Sejrup, H.P., and Jansen, E., 1985. The distribution of living benthic foraminifera on the continental slope and rise off southwest Norway. Marine Micropaleontology, 9: 275-306.

Mackin, J.E., and Aller, R.C., 1984. Ammonium adsorption in marine sediments. Limnology and Oceanography, 29: 250-257.

Madsen, H., and Knudsen, K.L., 1994. Recent foraminifera in shelf sediments of the Scoresby Sund fjord, East Greenland: Boreas, 23: 495-504.

Majewski, W., and Zajaczkowski, M., 2007. Benthic foraminifera in Advetfjoorden, Svalbard: Last 50 years of local hydrographic changes. Journal of Foraminiferal Research, 37 (2): 107-124.

Mann, M.E., and Lees, J.M., 1996. Robust estimation of background noise and signal detection in climatic time series. Climatic Change, 33 (3): 409-445.

Mantua, N.J., and Hare, S.R., 2002. The Pacific Decadal Oscillation. Journal of Oceanography, 58: 35-44.

Mantua, N.J., 2002. Pacific-Decadal Oscillation (PDO). Encyclopedia of Global Environmental Change, 1: 592-594.

Mantua, N.J, Hare, S.R., Zhang, Y., Wallace, J.M., and Francis, R.C., 1997. A Pacific interdecadal climate oscillation with impacts on salmon production. Bulletin of the American Meteorologist Society, 78: 1069-1079.

Massey, N.W.D., McIntyre, D.G., Desjardins, P.J., and Cooney, R.T., 2005. Digital geology map of British Columbia: whole province; British Columbia Ministry of Energy, Mines and Petroleum Resources, Geofile 2005 (1).

Massey, A.C., Gehrels, W.R., Charman, D.J., and White, S.V., 2006. An Intertidal Foraminifera-Based Transfer Function for Reconstructing Holocene Sea-Level Change In Southwest England. Journal of Foraminiferal Research, 36 (3): 215-232. 
Mathewes, R.W., 1973. "A Palynological Study of Postglacial Vegetation Changes in the University Research Forest, Southwestern British Columbia”. Canadian Journal of Botany, 51: 2085-2103.

Mathewes, R.W., 1979. "A Paleoecological Analysis of Quadra Sand at Point Grey, British Columbia, Based on Indicator Pollen." Canadian Journal of Earth Sciences, 16: 847-858.

Mathewes, R.W., 1985. "Paleobotanical Evidence for Climatic Change in Southern British Columbia During Late-Glacial and Holocene Time". Syllogeus, 55: 397-422.

Mathewes, R.W., 1989. The Queen Charlotte Islands refugium: A paleoecological perspective. In: R. J. Fulton, Editor, Quaternary Geology of Canada and Greenland, Geological Survey of Canada: 486-491.

Mathewes, R.W., 1993. Evidence for Younger Dryas-Age Cooling on the North Pacific Coast of America. Quaternary Science Reviews, 12: 321-331.

Mathewes, R.W., and Heusser, L.E., 1981. A 12,000 Year Palynological Record of Temperature and Precipitation Trends in Southwestern British Columbia. Canadian Journal of Botany, 59: 707-710.

Mathewes, R.W., Heusser, L.E., and Patterson, R.T., 1993. Evidence for a Younger Dryaslike cooling event on the British Columbia coast. Geology, 21, 101-104.

Mathewes, R. W., and King, M., 1989. Holocene vegetation, climate, and lake-level changes in the Interior Douglas-fir Biogeoclimatic Zone, British Columbia. Canadian Journal of Earth Sciences 26: 1811-1825.

Mathewes, R.W., and Rouse, G.E., 1975. Palynology and paleoecology of postglacial sediments from the lower Fraser River Canyon of British Columbia. Canadian Journal of Earth Sciences, 12: 745-756.

Maync, W., 1952. Critical taxonomy study and nomenclatural revision of the Lituolidae based upon the prototype of the family, Lituola nautiloidea Lamarck, 1804. Contributions to the Cushman Foundation for Foraminiferal Research, 3: 35-56.

McCulloch, I., 1977. Qualitative observations on Recent foraminiferal tests with emphasis on the eastern Pacific. University of Southern California, Los Angeles, California.

McDermott, F., Mattey, D.P., and Hawkesworth, C., 2001. Centennial-scale Holocene climate variability Revealed by a High Resolution Speleothem $\delta^{18} \mathrm{O}$ Record from SW Ireland. Science, 294: 328-1331.

McKay, J.L., Pedersen, T.F., and Kienast, S.S., 2004. Organic carbon accumulation over the last $16 \mathrm{kyr}$ off Vancouver Island, Canada: evidence for increased marine productivity during the deglacial. Quaternary Science Reviews, 23 (3-4): 261-281. 
McKay, J.L., Pedersen, T.F., and Mucci A., 2007. Sedimentary redox conditions in continental margin sediments (N.E. Pacific): Influence on the accumulation of redox-sensitive trace metals. Chemical Geology, 23: 180-196.

McLennan, S.M., 2001. Relationships between the trace element composition of sedimentary rocks and upper continental crust. Geochemical Geophysical Geosystem, 2: 2000GC000109.

McQuoid, M.R., and Hobson, L.A., 1997. A 91-year record of seasonal and interannual variability of diatoms from laminated sediments in Saanich Inlet, British Columbia. Journal of Plankton Research, 19: 173-194.

McQuoid, M.R., Whiticar, M.J., Calvert, S.E., and Pedersen, T.F., 2001. A post-glacial isotope record of primary production and accumulation in the organic sediments of Saanich Inlet, ODP Leg 169S. Marine Geology, 174 (1-4): 273-286.

Medioli, F.S., and Scott, D.B., 1983. Holocene Arcellacea (Thecamoebians) from eastern Canada. Cushman Foundation Special Publication, 21: 63.

Meidinger, D., and Pojar. J. (editors), 1991. Ecosystems of British Columbia. Special Report Series No. 6. B.C. Ministry of Forests. Victoria, British Columbia

Meyers, P.A., 1994. Preservation of elemental and isotopic source identification of sedimentary organic matter. Chemical Geology, 114: 289-302.

Meyers, P.A., 1997. Organic geochemical proxies of paleoceanographic, paleolimnologic, and paleoclimatic processes. Organic Geochemistry, 27: 213-250.

Michelsen, O., 1967. Foraminifera of the Late-Quaternary deposits of Læsø. Medd. Dansk Geol. Foren., 17 (2): 205-263, several microphotos on 7 plates, 2 fold diagrams, 4 figures.

Milam, R.W., and Anderson, J.B., 1981. Distribution and ecology of recent benthonic foraminifera of the Adelie-Georg V continental shelf and slope. Marine Micropaleontology, 6: $297-325$.

Miller, K.G., and Lohmann, G.P., 1982. Environmental distribution of Recent benthic foraminifera on the northeast United States continental slope. Geological Society of America Bulletin, 93 (3): 200-206.

Miller, A.A.L., 1979. Taxonomy, morphology and microprobe analyses of the Recent foraminifer Elphidium ecavatum (Terquem) from Labrador Shelf sediment core. B.Sc Thesis, Queen's University, Kingston, Canada: 116, Plates. 1-7.

Miller, G.H., 1982. Quaternary depositional episodes. Western Spitsbergen, Norway: Aminostratigraphy and glacial history. Arctic and Alpine Research, 24: 321- 340.

Miller, A.A.L., Scott, D.B., and Medioli, F.S., 1982. Elphidium excavatum (Terquem): ecophenotypic versus subespecific variation. Journal of Foraminiferal Research, 12 (2): 116144. 
Miller, A.J., Cayan, D.R., Barnett, T.P., Graham, N.E., and Oberhuber, J.M., 1994. The 1976-77 climate shift of the Pacific Ocean. Oceanography, 7: 21-26.

Minobe, S., 1997. A 50-70 year climatic oscillation over the North Pacific and North America. Geophysical Research Letters, 24: 683-686.

Minobe, S., 1999. Resonance in bidecadal and pentadecadal climate oscillations over the North Pacific: role in climate regime shifts. Geophysical Research Letters, 26: 855-858.

Minobe, S., 2000. Spatio-temporal structure of the pentadecadal variability over the North Pacific, Progress in Oceanography, 47: 381- 408.

Minobe, S., 2002. Interannual to interdecadal changes in the Bering Sea and concurrent 1998/99 changes over the North Pacific. Progress in Oceanography, 55: 45-64.

Monger, J.W.H., and Journeay, J.M., 1994. Basement geology and tectonic evolution of the Vancouver region; in Geology and Geological Hazards of the Vancouver Region, Southwestern British Columbia, Monger, J.W.H., Editor, Geological Survey of Canada SpecialPaper, 481: 3-25.

Monger, J.W.H., Price, R.A. and Tempelman-Kluit, D.J. 1982. Tectonic accretion and the origin of the two major metamorphic and plutonic welts in the Canadian Cordillera. Geology, 10: $70-75$.

Montagu, G., 1803. Testacea Britannica, or natural history of British shells, marine, land and fresh-water, including the most minute. J.S. Hollis, Romsey, England.

Montagu, G., 1808. Testacea Britannica. S. Woolmer, Exeter, England.

Moodley, L., 1990. Southern North Sea seafloor and subsurface distribution of living benthic foraminifera. Nertherland Journal of Sea Research, 27: 51-71.

Moodley, L., van der Zwaan, G.J., Herman, P.M.J., Kempers, L., and van Breugel, P., 1997. Differential response of benthic meiofauna to anoxia with special reference to Foraminifera (Protista: Sarcodina). Marine Ecology Progress Series, 158: 151-163.

Moodley, L., and Hess, C., 1992. Tolerance of infaunal benthic foraminiferan for low and high oxygen concentrations. Biological Bulletin, 183: 94-98.

Morford, J.L., and Emerson, S., 1999, The geochemistry of redox sensitive trace metals in sediments. Geochimica et Cosmochimica Acta, 63 (11/12): 1735-1750.

Morford, J.L., Russell, A.D., and Emerson, S., 2001. Trace metal evidence for changes in the redox environment associated with the transition from terrigenous clay to diatomaceous sediment, Saanich , Inlet, BC. Marine Geology, 174 (1): 355-369.

Morlet, J., Arehs, G., Fourgeau, I., and Giard, D., 1982. Wave propagation and sampling theory: Geophysics, 47: 203. 
Murray, J.W., 1968. Living foraminifers of lagoons and estuaries. Micropaleontology, 14: 435-455.

Murray, J.W., 1970. Foraminifers of the western approaches to the English Channel. Micropaleontology, 16: 471-485.

Murray, J.W., 1971. An Atlas of British Recent Foraminiferids. Heinemann Educational Books, London.

Murray, J.W., 1973. Distribution and ecology of living benthic foraminiferds. London: Heoinemann: 274.

Murray, J.W., 1979. Recent benthic foraminiferids of the Celtic Sea. Journal of Foraminiferal Research, 9: 193-209.

Murray, J.W., 2003. An illustrated guide to the benthic foraminifera of the Hebridean shelf, west of Scotland, with notes on their mode of life. Palaeontologia Electronica, 5 (2), art. 1: 31.

Murray, J.W., 2006. Ecology and Applications of Benthic Foraminifera. Cambridge: Cambridge University Press: 426.

Nagy, J., 1965. Foraminifera in some bottom samples from shallow waters in Vestpitsbergen. Norks Polarininstut Arbok 1963: 109-125.

Narayan, Y.R., Barnes, C.R., and Johns, M.J. 2005. Taxonomy and biostratigraphy of Cenozoic foraminifers from Shell Canada wells, Tofino Basin, offshore Vancouver Island, British Columbia. Micropaleontology, 51 (2): 101-167.

Natland, M.L., 1938b. New species of foraminifera from off the west coast of North America and from the later Tertiary of the Los Angeles Basin. Scripps Institute of Oceanography Bulletin, Technical Series, 4 (5): 137-164.

Neal, E.G., Walter, M.T., and Coffeen, C., 2002. Linking the pacific decadal oscillation to seasonal stream discharge pattern in Southeast Alaska. Journal of Hydrology, 263: 188-197.

Nederbragt, A.J. and Thurow, J.W., 2001. A 6000 yr varve record of Holocene climate in Saanich Inlet, British Columbia, from digital sediment colour analysis of ODP Leg 169S cores. Marine Geology, 174: 95-110.

Niebauer, H.J., 1983. Multiyear sea ice variability in the eastern Bering Sea: an update. Journal of Geophysical Research, 88: 2733-2742.

Niebauer, H.J., Bond, N.A., Yakunin, L.P., and Plotnikov, V.V., 1999. An update on the climatology and sea ice of the Bering Sea. In: Loughlin, T. R. and Ohtani, K. (eds) Dynamics of the Bering Sea. University of Alaska Sea Grant, Fairbanks, Alaska: 29-60. Niroma, 2008.

Niroma, T. 2008. One possible explanation for the cyclicity in the Sun. Helsinki 1998, http://personal.inet.fi/tiede/tilmari/sunspots.html. Accessed 2008. 
Nixon, G.T., and. Orr, A.J., 2007. Recent Revisions to the Early Mesozoic Stratigraphy of Northern Vancouver Island (NTS 102I; 092L) and Metallogenic Implications, British Columbia. Geological Fieldwork 2006, Paper 2007 (1): 163-177.

Norman, A.M., 1892. Museum Normanianum, Durham, England.

Nørvang, A., 1945. Foraminifera. Zoology of Iceland, 2(2): 1-79.

Norvang, A., 1959. Islandiella n.g. and Cassidulina d'Orbigny. Videnskabelige Meddeleser fra Dansk Naturhistorisk Forening i Kjøbenhavn, 120: 25-41.

O'Brien, S.R., Mayewski, P.A., Meeker, L.D., Meese, D.A., Twickler, M.S. and Whitlow, S.I., 1995. Complexity of Holocene climate as reconstructed from a Greenland ice core. Science, 270: 1962-1964.

Ogden, C.G., and Hedley, R.H., 1980. An atlas of freshwater Testate Amoebae. London and Oxford University Press, Oxford,: 222p.

O'Leary, M.H., 1981. Carbon isotope fractionation in plants. Phytochemistry, 20: 553-567.

O'Leary, M.H., 1988. Carbon isotopes in photosynthesis. Bioscience, 38: 328-336.

Østby, K.L., and Nagy, J., 1982. Foraminiferal distribution in the western Barents Sea, Recent and Quaternary. Polar Research, 1: 53-87.

Osterman, L.E., 1984. Benthic foraminiferal zonation of a glacial/ interglacial transition from Frobisher Bay, Baffin Island, N. W. T., Canada, in Oertli, H. J. (ed.), Benthos 1983: Second International Symposium on Benthic Foraminifera (Pau 1983): Elf-Aqitaine, Paris, France: 471-476.

Osterman, L.E.,1996. Pliocene and Quaternary benthic foraminifers from Site 910, Yermak Plateau. In Thiede, J., Myhre, A.M., Firth, J.V., Johnson, G.L., and Ruddiman, W.F. (Eds.), Proceedings Ocean Drilling Program Scientific. Results, 151: College Station, TX (Ocean Drilling Program), 187-195.

Osterman, L.E., and Nelson A.R., 1989. Latest Quaternary and Holocene paleoceanography of the eastern Baffin Island continental shelf Canada: benthic foraminiferal evidence: Canadian Journal of Earth Science, 26: 2236-2248.

Osterman, L.E., Poore, R.Z., and Foley, K.M., 1999. Distribution of benthic foraminifers $(>125 \mu \mathrm{m})$ in the surface sediments of the Arctic Ocean. U.S. Geological Survey Bulletin, B 2164, United States Government Printing Office, Washington, DC.

Overpeck, J., Ilughen, K., Ilardy, D., Bradley, R., Case, R., Douglas, M., Finney, B., Gajewski, K., Jacoby, G., Jennings, A., Lamoureux, S., MacDonald, G., Moore, J., Retelle, M., Smith, S., Wolfe, A. and Zielinski, G., 1997: Arctic environimental change of the last four centuries. Science, 278: 1253-56. 
Palmer, S.L., Walker, I.R., Heinrichs, M.L., Hebda R.J., and Scudder, G.G.E., 2002. Postglacial Midge Community Change and Holocene Palaeotemperature Reconstructions for Treeline, Southern British Columbia (Canada). Journal of Paleolimnology, 28: 469-490.

Pamer, L., 2007. Major and Trace Element Analysis of Water Samples by Inductively Coupled Plasma Atomic Emission Spectrometry (ICP-AES) at the Geoscience Laboratories: Preliminary Data. Summary of Field Work and Other Activities 2007, Ontario Geological Survey, Open File Report, 6213: 32-1 to 32-7.

Panteleyev, A., Bailey, D.G., Bloodgood, M.A., and Hancock, K.D., 1996. Geology and mineral deposits of the Quesnel River-Horsefly map area, central Quesnel Trough, British Columbia. British Columbia Ministry of Employment and Investment, Bulletin, 97: 156.

Parker, W.C., and Arnold, A.J., 2002. Quantitative methods of data analysis in foraminiferal ecology. In: Sen Gupta, B.K., (ed), Modern Foraminifera, Kluwer Academic Publishers, Dordrecht, $2^{\text {nd }}$ edition: 71-89.

Parker, F.L., 1952. Foraminiferal distribution in the Long Island Sound - Buzzards Bay area. Bulletin of the Museum of Comparative Zoology, Harvard College, 106 (10): 428-473.

Parker, W.K., and Jones, T.R., 1859. On the nomenclature of the foraminifera. II. On the species enumerated by Walker and Montagu. Annals and Magazine of Natural History, Series 3, $4: 333-351$.

Parker, W.K., and Jones, T.R., 1865. On some foraminifera from the North Atlantic and Arctic Oceans, including Davis Straits and Baffin's Bay. Royal Society of London Philosophical Transactions, 155: 325-441.

Parker, F.L. and Athearn, W.D., 1959. Ecology of marsh Foraminifera in Poponesset Bay, Massachusetts. Journal Paleontology, 33: 323-333.

Parker, F.L., Phleger, F.B., and Peirson, J.F., 1953. Ecologyof foraminifera from San Antonio Bay and environs, southwest Texas. Cushman Foundation for Foraminiferal Research Special Publication, 2: 75.

Parr, W.J., 1947. The Lagenid foraminifera and their relationships. Proceedings of the Royal Society of Victoria, 58: 116-130.

Parr, W.J., 1950. Foraminifera. B.A.N.Z. Antarctic Research Expedition 1929-1931, Q2series $B$ (Zoology, Botany), 5 (6): 232-392.

Patterson, R.T., 1990a. Intertidal benthic foraminiferal biofacies on the Fraser River Delta, British Columbia: modern distribution and paleoecological importance. Micropaleontology, 36 (3): 229-244. 
Patterson, R.T., 1991. Three new species of Holocene benthic foraminifera from the Queen Charlotte Basin-Hecate Strait region of coastal British Columbia: Transactions of the American Microscopical Society, 110: 354-360.

Patterson, R.T., 1993. Late Quaternary benthic foraminiferal biofacies and paleoceanography of Queen Charlotte Sound and southern Hecate Strait, British Columbia. Journal of Foraminiferal Research, 23 (1): 1-18.

Patterson, R.T., Barker, T., and Burbidge, S.M., 1996. Arcellaceans (Thecamoebians) as Proxies of Arsenic and Mercury Contamination in Northeastern Ontario Lakes. Journal of Foraminiferal Research, 26: 172-183.

Patterson, R.T., Brunner, C.A., Capo, R., and Dahl, J., 1990. A paleoenvironmental study of Early to Middle Pleistocene foraminifera of the Santa Barbara Formation at Santa Barbara, California. Journal of Paleontology, 64 (1): 1-25.

Patterson, R.T., Burbidge, S.M., and Luternauer, J.L., 1998. Atlas of common benthic foraminiferal species for Quaternary shelf environments of western Canada. Geological Survey of Canada Bulletin, 503: 91p..

Patterson, R.T., and Cameron, B.E.B., 1991. Paleoenvironmental significance of the foraminiferal biofacies succession in the Late Quaternary sediments of the Fraser River Delta, British Columbia. Journal of Foraminiferal Research, 21: 228-243.

Patterson, R.T., and Fishbein, E., 1989. Re-examination of the statistical methods used to determine the number of point counts needed for micropaleontological quantitative research: Journal of Paleontology, 63: 245-248.

Patterson, R.T., Dalby, A., Kumar, A., and Henderson, L.A., 2002. Arcellaceans as indicators of land use change: settlement history of the Swan Lake area, Ontario as a case study. Journal of Paleolimnology, 28: 297-316.

Patterson, R.T., Guilbault, J.P., Thomson, R.E., and Luternauer, J.L., 1995. Foraminiferal Evidence of Younger Dryas isochronous cooling on the British Columbia shelf, west coast of Canada. Géographie physique et Quaternaire, 49 (3).

Patterson, R.T., MacKinnon, K.D., Scott, D.B., and Medioli, F.S., 1985. Arcellaceans ("Thecamoebians") in small lakes of New Brunswick and Nova Scotia: modern distribution and Holocene stratigraphic changes. Journal of Foraminiferal Research, 15 (2): 114-137.

Patterson, R.T., Guilbault, J.P., Thomson, R.E., 2000. Oxygen level control on foraminiferal distribution in Effingham Inlet, Vancouver Island, British Columbia. Journal of Foraminiferal Research 30, 321-335.

Patterson, R.T., and Kumar, A., 2002a. A review of current testate rhizopod (thecamoebian) research in Canada. Palaeogeography, Palaeoclimatology, Palaeoecology, 180: 225-251. 
Patterson, R.T., and Kumar, A., 2002b. Post-glacial paleoceanographic history of Saanich Inlet, British Columbia, based on foraminiferal proxy data. Journal of Foraminiferal Research, 32 (2): 110-125.

Patterson, R.T., and Luternauer, J.L., 1993. Holocene foraminiferal faunas from cores collected on the Fraser River delta, British Columbia: A paleoecological interpretation: In Current Research, Part A, Geological Survey of Canada, Paper 93 (1A) : 245-254.

Patterson, R.T., MacKinnon, K.D., Scott, D.B., and Medioli, F.S., 1985. Arcellaceans ("Thecamoebians") in small lakes of New Brunswick and Nova Scotia: modern distribution and Holocene stratigraphic changes: Journal of Foraminiferal Research, 15 (2): 114-137.

Patterson, R.T., Prokoph, A., Kumar, A., Chang, A.S., Roe, H.M., 2005. Late Holocene variability in pelagic fish scales and dinoflagellate cysts along thewest coast of Vancouver Island, NE Pacific Ocean. Marine Micropaleontology, 55: 183-204.

Patterson, R.T., Prokoph, A., Reinhardt, A., Roe, H.M., 2007. Climate cyclicity in late Holocene anoxic marine sediments from the Seymour-Belize Inlet Complex, British Columbia. Marine Geology, 242: 123-140.

Patterson, R.T., Prokoph, A., Chang, A.S., 2004a. Late Holocene sedimentary response to solar and cosmic ray activity influenced climate variability in the NE Pacific. Sedimentary Geology, 172: 67-84.

Patterson, R.T., Prokoph, A., Wright, C., Chang, A.S., Thomson, R.E., Ware, D.M., 2004b. Holocene Solar Variability and Pelagic Fish Productivity in the NE Pacific. Palaeontologia Electronica, 6 (1): 17.

Pedersen, T.F., Waters, R.D., and Macdonald, R.W., 1989. On the natural enrichment of cadmium and molybdenum in sediments of Ucluelet Inlet, British Columbia. Science of the Total Environment, 79: 125-139.

Pella, E., 1990. Elemental organic analysis, parts 1-2. American Laboratory, Feb. \& Aug.

Pellattt, M.G., 1996. Postglacial Changes in Vegetation and Climate Near Treeline in British Columbia. PhD Dissertation, Simon Fraser University, Burnaby, British Columbia, Canada

Pellattt, M.G. and Mathewes, R.W., 1994. Paleoecology of Postglacial Tree Line Fluctuations on the Queen Charlotte Islands, Canada. Ecoscience, 1: 71-81.

Pellattt, M.G., and Mathewes, R.W., 1997. Holocene Tree Line and Climate Change on the Queen Charlotte Islands, Canada. Quaternary Research, 48: 88-99.

Pellattt, M.G., Mathewes, R.W., and Walker, I.R., 1997. Pollen Analysis and Ordination of Lake Sediment-Surface Samples from Coastal British Columbia, Canada. Canadian Journal of Botany, 75: 799-814.

Pellattt, M.G., Smith, M.J., Mathewes, R.W., Walker, I.R., and Palmer, S.L., 2000. "Holocene Treeline and Climate Change in the Subalpine Zone near Stoyoma Mountain, 
Cascade Mountains, Southwestern British Columbia, Canada". Arctic, Antarctic, and Alpine Research, 32: 73-83.

Pellattt, M.G., Hebda R.J., and Mathewes, R.W., 2001. "High-Resolution Holocene Vegetation History and Climate From Hole 1034B, ODP leg 169S, Saanich Inlet, Canada". Marine Geology, 174: 211-226.

Pellattt, M.G., Mathewes, R.W., and. Clague, J.J., 2002. Implications of a Late Glacial Pollen Record for the Glacial and Climatic History of the Fraser Lowland, British Columbia. Palaeogeography, Palaeoclimatology, Palaeoecology, 180: 147-157.

Peters, K.E., Sweeney, R.E., and Kaplan, I.R., 1978. Correlation of carbon and nitrogen stable isotope ratios in sedimentary organic matter. Limnology and Oceanography, 23 (4): 598-604.

Penard, E., 1890. Études sur les Rhizopodes d'eau douce: Memoires de la Sociétié de Physique et d'Historie Naturalle de Geneve, 13: 1-230.

Penard, E., 1899. Les Rhiopodes de faune profonde dans le lac Léman. Revue Suissie de Zoologie, 7: 1-142.

Penard, E., 1902. Fauna rhizopodique du bassin de Léman. Henry Kundg, Geneve: 714.

Penard, E., 1905. Les Sarcodinesndesngrand lacs. Henry Kundg, Geneve: 134.

Phleger, F.B., 1939. Foraminifera of submarine cores from the continental slope. Geological Society America Bulletin, 50: 1395-1422.

Phleger, F.B., 1952. Foraminiferal distribution in some sediment samples from the Canadian and Greenland Arctic. Contributionsom the Cushman Foundation for Foraminiferal Research, 3: 80-89, pls 13, 14.

Phleger, F.B., and Parker, F.L., 1951. Ecology of Foraminifera, northwest Gulf of Mexico. Geological Society of America Memoirs, 46:1-64.

Phleger, F.B., and Souter, A., 1973. Production of bEnthic foraminifera in three east Pacific oxygen minima. Micropaleontology, 19: 110-115.

Pickard, G.L., 1961. Oceanographic features of inlets in the British Columbia mainland coast. Journal of Fisheries and Research Board of Canada, 18: 907-999.

Pickard, G.L., and Giovando, L.F., 1960. Some observations of turbidity in British Columbia inlets. Limnology and Oceanography, 5 (2): 162-170.

Pickard, G.L., and Stanton, B.R., 1980. Pacific fjords - a review of their water characteristics: 1-51. In Freeland, H.J., Farmer, D.M., and Levings, C.D. (eds.), Fjord Oceanography (Proceedings of the NATO conference on fjord oceanography, Victoria, BC, 1979). Plenum Press, New York, USA. 
Pike, J., and Kemp, A.E.S., 1997. Early Holocene decadal scale ocean variability recorded in Gulf of California laminated sediments. Paleoceanography, 12 (2): 227-238.

Pinsent, R.H., 1999. Mineral Potential of the Southern Coast Belt, Cape caution Area, British Columbia (0921L, 092M). Geological fieldwork, paper 2000 (1): 325-331.

Piper, D.Z., and Isaacs, C.M., 1995. Minor elements in Quaternary sediment from the Sea of Japan: A record of surface-water productivity and intermediate-water redox conditions. Geological Society of America Bulletin, 107 (1): 54-67.

Poag, C.W., 1981. Ecologic atlas of benthic foraminifera of the Gulf of Mexico. Marine Science International, Woods Hole, Massachusetts, 174p.

Polyak, L., Curry, W.B., Darby, D., Bischof, J., Cronin, T., 2004. Contrasting glacial/interglacial regimes in the western Arctic Ocean as exemplified by a sedimentary record from the Mendeleev Ridge. Palaeogeography, Palaeoclimatology, Palaeoecology, 203: 73-93.

Pojar, J. and Meidinger, D., 1991. British Columbia: The Environmental setting In. Meidinger and Pojar (eds), Ecosystems of British Columbia. British Columbia Special Report Series No 6, Research Branch Ministry of Forest, Victoria, 39-67.

Polyak, L., Korsun, S., Febo, L.A., Stanovoy, V., Khusid, T., Hald, M., Paulsen, B.E., and Lubinski, D.J., 2002. Benthic foraminiferal assemblages from the southern Kara Sea, a river influenced arctic marine environment: Journal of Foraminiferal Research, 32: 252-273.

Porter, S.C., and Denton, G.H., 1967. Chronology of Neoglaciation in the North American Cordillera. American Journal of Science, 265: 177-210.

Porter, S.C., and Swanson, T.W., 1998. Radiocarbon age constraints on rates of advance and retreat of the Puget lobe of the Cordillera ice sheet during the last glaciations. Quaternary Research, 50: 205-213.

Prahl, F.G., Bennett, J.T., Carpenter, R., 1980. The early diagenesis of aliphatic hydrocarbons and organic matter in sedimentary particulates from Dabob Bay, Washington. Geochimica et Cosmochimica Acta, 44: 1967-1976.

Prahl, F.G., Ertel, J.R., Goni, M.A., Sparrow, M.A., Eversmeyer, B., 1994. Terrestrial organic carbon contributions to sediments on the Washington margin. Geochimica et Cosmochimica Acta, 58: 3035-3048.

Pride, C., Thunell, T., Sigman, D., Keigwin, L., Altabet, M., and Tappa, E., 1999. Nitrogen isotopic variations in the Gulf of California since the last deglaciation: response to global climate change. Paleoceanography, 14: 397-409.

Premuzic, E.T., Benkovitz, C.M., Gaffney, J.S., and Walsh, J., 1982. The nature and distribution of organic matter in the surface sediments of world oceans and seas. Organic Geochemistry, 4: 63-77. 
Prest, V.K., 1970. Retreat of Wisconsinan and Recent ice. Geological Survey of Canada, Map 1257A, Scale 1: 5,000,000.

Prokoph, A., and Agterberg, F.P., 1999. Detection of sedimentary cyclicity and stratigraphic completeness by wavelet analysis: an application to late Albian cyclostratigraphy of the Western Canada sedimentary basin: Journal of Sedimentary Research, 60: 862-875.

Prokoph, A., and Barthelmes, F., 1996. Detection of non-stationarities in geological timeseries: wavelet-analysis of chaotic and cyclic sequences. Computers and Geosciences, 22: 1097-1108.

Puri, H.S., 1953. Contribution to the study of the Miocene of the Florida panhandle, Florida. Geological Survey Bulletin, 36: 345p.

Rankama, K., and Sahama, T.H.G., 1950. Geochemistry. The University of Chicago Press, Chicago, Ilinois.

Raspopov, O.M., Shumilov, O.I., Kasatkina, E.A., Turunen, E., and Lindholm, M., 2000. 35-year climatic Bruckner cycle - Solar control of climate variability? In: A. Wilson. Noordwijk, Proceedings of the $1^{\text {st }}$ Solar and space weather euroconference, "The Solar Cycle and Terrestrial Climate", Santa Cruza de Tenerife, Tenerife, Spain, 2000: 517-520.

Raspopov, O.M., Dergachev, V.A., and Kolström, T., 2004. Periodicity of climate conditions and solar variability derived from dendrochronological and other palaeoclimatic data in high latitudes. Palaeogeography, Palaeoclimatology, Palaeoecology, 209: 127-139.

Reimer, P. J., Baillie, M. G. L., Bard, E., Bayliss, A., Beck, J W., Bertrand, C.J.H., Blackwell, P. G., Buck, C. E., Burr, G. S., Cutler, K. B., Damon, P. E., Edwards, R L., Fairbanks, R. G., Friedrich, M., Guilderson, T. P., Hogg, A. G., Hughen, K. A., Kromer, B., McCormac, G., Manning, S., Ramsey, C. B., Reimer, R. W., Remmele, S., Southon, J. R., Stuiver, M., Talamo, S., Taylor, F.W., van der Plicht, J., Weyhenmeyer, C. E., 2004. IntCal04 Terrestrial radiocarbon age calibration, 0-26 cal kyr BP. Radiocarbon, 46 (3): 10291058.

Reinhardt, E.D., Dalby, A.P., Kumar, A., and Patterson, R.T., 1998. Utility of arcellacean morphotype variants as pollution indicators in mine tailing contaminated lakes near Cobalt, Ontario, Canada. Micropaleontology, 44: 1-18.

Reinhardt, E.D., Easton, N.A., and Patterson, R.T., 1996. Foraminiferal evidence of Late Holocene sea-level change and Amerindian site distribution at Montague Harbour, British Columbia. Géographie physique et Quaternaire, 50 (1): 35-46.

Research Branch, 1988. Biogeoclimatic zones of British Columbia, Map 1:2,000,000. Ministry of Forests, British Columbia, Victoria.

Reiss, Z., 1963. Reclassification of perforate foraminifera. Bulletin of the Geological Survey of Israel, 35: 1-111. 
Resig, J.M., 1963. Size relationships of Eggerella advena to sediment and depth of substratum. Essays in Marine Geology in honor of K.O. Emery: 121-126.

Reuss, A.E., 1850. Neues Foraminiferen aus den Schichten des österreichischen Tertiärbeckens. Denkschriften der Kaiserlichen Akademie del Wissenschaften, MathematischNaturwissenschafliche Classe, 1: 365-390.

Reuss, A.E., 1860. Die Foraminiferen der Westphälischen Kreideformation. Sitzungsberichte der Kaiserlichen Akademie der Wissenschaften in Wien, MathematischNaturwissenschaftliche Classe, 40: 147-238.

Reuss, A.E., 1862. Entwuf einer systematischen Zusammenstellung der Foraminiferen. Sitzungsberichte der Kaiserlichen Akademie der Wissenschaften in Wien, MathematischNaturwissenschaftliche Classe, 44 (1): 355-396.

Rhoads, D.C., John W., and Morse, J.W., 1971. Evolutionary and ecologic significance of oxygen-deficient marine basins. Lathia, 4 (4): 413-428.

Rhumbler, L., 1938. Foraminiferen aus dem Meeressand von Helgoland, gesammelt von A. Remane (Kiel). Kieler Meeresforschungen, 2 (2): 157-222.

Rigozo, N.R., Nordemann, D.J.R., Echer, E., and Vieira, L.E.A., 2004. Search for Solar Periodicities in Tree-ring Widths from Concórdia (S.C., Brazil). Pure and Applied geophysics, 161 (1): 221-233.

Rigozo, N.R., Nordemann, D.J.R., Echer, E., Silva, H.E., and Prestes, A., 2006. Solar and climate imprints in tree ring width time series from Chile (1587-1994 A.D.), Trend in Applied Science and Research, 1: 73-78.

Rigozo, N.R., Nordemann, D.J.R, Echer, E., da Silva, H.E., and Prestes, A., 2007a. Solar and climate imprint differences in tree ring width from Brazil and Chile. Journal of Atmospheric and Solar-Terrestrial Physics, 69 (4-5): 449-458.

Rigozo, N.R., Nordemann, D.J.R, Echer, E., da Silva, H.E., Echer, M.P., Prestes, A., and Guarnieri, F.L., 2007b. Solar activity imprints in tree ring width from Chile (1610-1991). Journal of Atmospheric and Solar-Terrestrial Physics, 69 (9): 1049-1056.

Rimmer, S.M., 2004. Geochemical paleoredox indicators in Devonian-Mississippian black shales, Central Appalachian Basin (USA), Chemical Geology, 206: 373-391.

Rioul, O., and Vetterli, M., 1991. Wavelets and signal processing. Signal Procesing Magazine, IEEE, 8 (4): 14-38.

Risso, A., 1826. Histoire naturelle des principales productions de l'Europe Méridionale et particulièrment de celles des environs de Nice et des Alpes Maritimes.

Robertson, D., 1891. Trochammina bradyi, n.n. Annual Magazine of Natural History, 7: 388. 
Rodrigues, C.G., 1980. Holocene microfauna and paleoceanography of the Gulf of St. Lawrence. Ph.D. Thesis, Carleton University, Ottawa, Canada.

Roe, H.M., and Patterson, R.T., 2006. Distribution of thecamoebians (testate amoebae) in small lakes and ponds, Barbados, West Indies. Journal of Foraminiferal Research, 36 (2): 116-134.

Rollerson, T., Millard, T., Jones, C., Trainor, K., and Thomson, B., 2001. Predicting post logging landslide activity using terrain attributes: Coast Mountains, British Columbia. Forest Research Technical Report, Geomorphology, TR-011: 1-20.

Roncaglia, L., and Kuijpers, A., 2004. Palynofacies analysis and organic walled dinoflagellate cysts in late-Holocene sediments from Igaliku Fjord, South Greenland. The Holocene, 14: 172-84.

Rosenberg, S.M., Walker, I.R., Mathewes, R.W., and Hallett, D.J., 2004. Midge-inferred Holocene climate history of two subalpine lakes in southern British Columbia, Canada. The Holocene, 14: 258.

Rosenthall, Y., Boyle, E.A., Slowey, N., 1997. Temperature control on the incorporation of magnesium, strontium, fluorite and cadmium into benthic foraminiferal shells from little Bahama Bank: Prospects for thermocline paleoceanography. Geochimica et Cosmochimica Acta, 61 (17): 3633-3643.

Russell, A.D., and Morford, J.L., 2001. The behavior of redox-sensitive metals across a laminated-massive-laminated transition in Saanich Inlet, British Columbia. Marine Geology, 174 (1): 341-354.

Ryder, J.M., 1987. Neoglacial History of the Stikine-Iskut Area, Northern Coast Mountains, British Columbia. Canadian Journal of Earth Sciences, 24: 1294-1301.

Ryder, J.M., 1989. "Holocene Glacier Fluctuations (Canadian Cordillera)". In R.J. Fulton (eds), Quaternary Geology of Canada and Greenland. Geology of Canada, No. 1. Geological Survey of Canada, Ottawa: 74-76.

Ryder, J.M., and Thomson, B., 1986. "Neoglaciation in the Southern Coast Mountains of British Columbia: Chronology Prior to the Late Neoglacial Maximum". Canadian Journal of Earth Sciences, 23: 273-287.

Rytter, F., Knudesn, K.L., Seidenkranttz, M.S and Eiríksson, J., 2002. Modern distribution of benthic foraminifera on the North Icelandic shelf and slope. Journal of Foraminiferal Research, 32 (3): 217-244.

Saenger, C., Cronin, T., Thunell, R., and Vann, C., 2006. Modelling river discharge and precipitation from estuarine salinity in the northern Chesapeake Bay: application to Holocene palaeoclimate. Holocene, 16: 1-11.

Sageman, B.B., and Bina, C.R., 1997. Diversity and Species abundances patterns in Late Cenomanian Black shale biofacies, Western interior, US. Palaios, 12: 449-466. 
Saidova, Kh.M., 1981. O sovremennom sostoyanii sistemy nadvidovykh taksonov Kaynozoyskikh bentosnykh foraminifer [On an up-to-date system of supraspecific taxonomy of Cenozoic benthonic foraminifera]. Institut Okeanologi P.P. Shirshova, Akademiya Nauk SSSR, Moscow: 73.

Saidova, M., 2002. "Benthic Foraminiferal Communities of the Basins of the Canadian Arctic Belt”. Okeanologiya, 42 (3): 394-401.

Saito, T., Thompson, P.R., and Breger, D., 1981. Recent and Pleistocene planktonic foraminifera. University of Tokyo Press, Tokyo, 90: 56p.

Sars, G.O., 1872. Undersøgelser over Hardangerfjordens Fauna. Fordhandlinger $i$ Videnskasselskabet i Kristiania, 1871: 246-255.

Saunders, J.B., 1957. Trochamminidae and certain lituolidae (foraminifera) from the recent brackish water sediments of Trinidad, British West Indies, Smithsonian Miscellaneous Collections 134 (5): 1-23.

Scargle, J.D., 1982. Studies in astronomical time series analysis. II. Statistical aspects of spectral analysis of unevenly spaced data. The Astrophysical Journal, 263 (2): 835-853.

Scargle, J.D., 1989. Studies in astronomical time series analysis. III. Fourier transforms, autocorrelation functions, and cross-correlation functions of unevenly spaced data. The Astrophysical Journal 343 (2): 874-887.

Schafer, W., 1972. Ecology and Palaeoecology of Marine Sediments Oliver and Boyd Edinburgh, 568p.

Schafer, C.T., 1973. Distribution of foraminifera near pollution sources in Chaleur Bay. Water, Air and Soil Pollution, 2: 219-233.

Schafer, C.T., 1982. Foraminiferal colonization of an offshore dump site in Chaleur Bay, New Brunswick, Canada. Journal of Foraminiferal Research, 12: 317-326.

Schafer, C.T., and Cole, F.E., 1974. Distributions of benthonic foraminifera: their use in delimiting local nearshore environments: In B. R. Pelletier, ed. Offshore Geology of Eastern Canada, Geological Survey of Canada, 1: 103-108.

Schafer, C.T., and Cole, F.E., 1978. Distribution of Foraminifera in Chaleur Bay, Gulf of St. Lawrence: Geological Survey of Canada Paper, 77-30: 55.

Schafer, C.T., and Cole, F.E., 1986. Reconnaissance Survey of Benthonic Foraminifera from Baffin Island Fiord Environments'. Arctic, 39 (3): 232-239.

Schafer, C.T., and Cole, F.E., 1988. Environmental Associations of Baffin Island Fjord agglutinated foraminifera. Abhandlungen der Geologischen Bundesanstalt, 41: 307-323. 
Schafer, C.T., Cole, F.E., and Syvitski, J.P.M., 1989. Bio and lithofacies of modern sediments in Knight and Bute Inlets, British Columbia. Palaios, 4:107-126.

Schafer, C.T., Collins, E.S., and Smith, J.N., 1991. Relationship of Foraminifera and thecamoebian distributions to sediments contaminated by pulp mill effluent: Saguenay Fiord, Quebec, Canada. Marine Micropaleontology, 17: 255-283.

Schafer, C. T., Wagner, J.E., and Ferguson, C., 1975. Occurrence of foraminifera, molluscs, and ostracods adjacent to the industrialized shoreline of Canso Strait, Nova Scotia. Water, Air aml Soil Pollution, 5:79-96.

Schafer, C.T., Smith, J.N., and Seibert, G., 1983. Significance of natural and anthropogenic sediment inputs to the Saguenay Fiord, Quebec. Sedimentary Geology, 36:177-194.

Schafer, C.T., Tan, F.C., Williams, D.F., and Smith, J.N., 1985. Late glacial to Recent stratigraphy, paleontology, and sedimentary processes: Newfoundland continental slope and rise: Canadian Journal of Earth Sciences, 22: 266-282.

Schafer, C.T., and Young, J.A., 1977. Experiments on mobility and transportabilityof some nearshore benthonic foraminifera species. Report of Activities, Geological Survey of Canada, 77-1C: $27-31$.

Shaw, T.J., Gieskes, J.M., and Jahnke, R.J., 1990. Early diagenesis in differing depositional environemnets: The response of transition metals at pore water. Geochimica et Cosmochimica Acta, 54: 1233-1246.

Schimmelman, A., and Lange, C.B., 1996. Tales of 1001 varves: A review of Santa Barbara Basin sediment studies. In: Kemp A.E.S. (ed), Palaeoclimatology and Paleoceanography from laminated sediments. Geological Society Special Publication, 116: 121-141.

Schimmelman, A., Lange, C.B., and Berger, W.H., 1990. Climatically controlled marker layers in Santa Barbara Basin sediments and fine-scale core-to-core correlation. Limnology and Oceanography, 35: 165-173.

Schmarda, L.K., 1871. Zoologie: Band I. Braumüller, Wien: 372p.

Schmiedl, G., Mackensen, A., and Muller, P.J., 1997. Recent benthic foraminifera from the eastern southern Atlantic Ocean: Dependence on food supply and water masses. Marine micropaleontology, 32: 249-287.

Schneider, N., and Cornuelle, B.D., 2005: The Forcing of the Pacific Decadal Oscillation. Journal of Climate, 18: 4355-4373.

Schovsbo, N.H., 2001. Why barren intervals? A taphonomic case study of the Scandanavian Alum Shale and its fauna. Lethaia, 34: 271-286.

Schröder, C., 1986. Deep-water arenaceous Foraminifera in the northwest Atlantic Ocean. Canadian Technical Report of Hydrography and Ocean Sciences, 71: 191. 
Schröder, C., Scott, D.B., and Medioli, F.S., 1987. Can smaller benthic foraminifera be ignored in paleoenvironmental analyses? Journal of Foraminiferal Research, 17: 101-109.

Schröder-Adams, C.J., Cole, F.E., Medioli, F.S., Mudie, P.J., Scott, D.B., and Dobbin, L., 1990a. Recent Arctic shelf foraminifera: seasonally ice covered vs. perennial ice covered areas: Journal of Foraminiferal Research, 20: 8-36.

Schröder-Adams, C.J., Cole, F.E., Mudie, P.J., and Medioli, F.S., 1990b, Late Holocene benthic foraminifera beneath perennial sea ice on an Arctic continental shelf. Marine Geology, 93: 225-242.

Schultze, M.S., 1854. Über den Organismus der Polythalamien (Foraminiferen), nebst Bermekungen über die Rhizopoden im Allgemeinen. Wilhelm Engelmann, Leipzig.

Schulz, M., and Mudelsee, M., 2002. REDFIT: Estimating red-noise spectra directly fom unevenly spaced paleoclimatic time series. Computers and Geosciences, 28 (3): 421-426.

Schulz, M., Stattegger, K., 1997. SPECTRUM: Spectral analysis of unevenly spaced paleoclimatic time series. Computers and Geosciences, 23 (9): 929-945.

Schulze, F.E., 1877. Rhizopodenstudien VI. Archiv fur Mikroskopische Anatomie, 13:9-30.

Schwager, C., 1866. Fossile foraminiferan von Kar-Nicobar: reise der osterreichischen fregatte novarra. Geologica Theil, 2: 187-268.

Schwager, C., 1877. Quadro del proposto sistema di classificazione dei foraminiferi con guscio. Bolletino R. Comitato Geologico d'Italia, 8:18-27.

Scott, D.B., 1977. Distribution and population dynamics of Marsh estuarine foraminifera with applications to relocating Holocene sea-levels. Unpublished Ph.D dissertation, Dalhousie University: 252 .

Scott, D.B., Schafer, C.T. and Medioli, F.S., 1980. Eastern Canadian Estuarine Foraminifera: a framework comparison. Journal of Foraminiferal Research 10 (3): 205-234.

Scott, D.B., and Medioli, F.S., 1983. Agglutinated rizhopods in Lake Erie: modern distribution and stratigraphic implications. Journal of Paleontology, 57 (4): 809-820.

Scott, D.B., Medioli, F.S. and C. T. Schafer, C.F., 1977. Temporal changes in foraminiferal distributions in Miramichi River estuary, New Brunswick. Canadian Journal of Earth Science, 14:1566-1587.

Scott, D.B., Medioli, F.S., and Schafer, C.T., 2001. Monitoring in coastal environments using foraminifera and thecamoebian indicators, Cambridge University Press: 177. 
Scott, D.B., and Vilks, G., 1991. Benthonic foraminifera in the surface sediments of the deep-sea Arctic Ocean. Journal of Foraminiferal Research, 21: 20-38.

Seiglie, G.A., 1965. Un género nuevo y dos species nuevas de foraminíferos de Los Testigos, Venezuela. Caribbean Journal of Sciences, 4: 497-512.

Sejrup, H.P., Birks, H.J.B., Kristensen, D.K., and Madsen, H., 2004. Benthonic foraminiferal distributions and quantitative transfer functions for the northwest European continental margin. Marine Micropalaeontology, 53: 197-226.

Sen Gupta, B.K., 2002. Foraminifera in the marginal marine environments. In: Sen Gupta, B.K. (ed.), Modern foraminifera, Kluwer Academic Publishers, Dordrecht, $2^{\text {nd }}$ edition: 141 158.

Sen Gupta, B.K., and Machain-Castillo, M.L., 1993. Benthic foraminifera in oxygen-poor habitats. Marine Micropaleontology, 20: 183-201.

Sen Gupta, B.K., Turner, E.R., and Rabalais, N.N., 1996. Seasonal oxygen depletion in continental shelf waters of Louisiana: historical record of benthic foraminifers. Geology, 24: 227-230.

Shannon, C. E., and Weaver, W., 1949, The Mathematical Theory of Communication. University of Illinois Press, Urbana, $55 \mathrm{p}$.

Shupack, B., 1934. The benthic foraminifera of western Long Island and New Yorkor harbor. American Museum Novitates, 737: 12, figures, 1-10.

Sigal, J., 1952. Aperçu stratigraphique sur la micropaleontology du Crétacé. XIX Congrés Géologique International, Monographies Régionales, Série I, Algérie, 26: 1-47.

Silvestri, A., 1923. Lo stipite della Elissoforme e le sue affinità. Memorie della Pontificia Accademia della Scienze, Nuovi Lincei, series 2 (6): 231-270.

Skei, J.M., 1986. The biogeochemistry of Framvaren. A permanent Anoxic Fjord Near Farsund, South Norway. Data Report 1931-1985, Norwegian Institute for Water Research.

Ślubowska-Woldengena, M., Rasmussenb, T.L., Nala^n Koç, N., Klitgaard-Kristensenc, D., Nilsena, F., and Solheim, A., 2007. Advection of Atlantic Water to the western and northern Svalbard shelf since 17,500 cal yr BP. Quaternary Science Reviews, 26: 463-478.

Smith, R.K., 1978. Systematics of the North American high northern latitude very shallow cold water foraminiferal fauna: Archives des Sciences, Geneve, 31: 133-162.

Smith, M.J., Pellattt, M.G., Walker, I.R., and Mathewes, R.W., 1998. Postglacial Changes in Chironomid Communities and Inferred Climate near Treeline at Mount Stoyoma, Cascade Mountains, Southwestern British Columbia". Journal of Paleolimnology, 20: 277-293. 
Smith, M.J., 1997. Postglacial changes in chironomid communities and inferred climate near treeline at Mount Stoyoma, Cascade Mountains, southwestern British Columbia. Journal of Paleolimnology, 20: 277-293.

Snyder, S.W., Hale, W.R., and Kontrovitz, M., 1990. Distributional patterns of modern benthic foraminifera of the Washington shelf. Micropaleontology, 36: 245-258.

Sonnet, C.P., and Finney E.A., 1990. The spectrum of radiocarbon, Phil. Trans. R. SOC. A, 330: $15-21$.

Stein, S.F.N., 1859. Uber die ihm aus eigener Untersuchung bekannt gewordenen SuswasserRhizopoden. Konigliche Bohmishce Gesellschaft der Wissenchaften Abhandlungen, 10 (5): 41-43.

Steinsund, P.I., Polyak, L., Hald, M., Mikhailov. V., and Korsun, S., 1994. Distribution of calcareous benthic foraminifera in recent sediments of the Barents and Kara Seas: 61-102. In: Steinsund, P. I: Benthicforaminifera in surface sediments of the Barents and Kara Seas: modern and late Quatenary applications. Unpublished. PhD. Thesis, Department of Geology, University of Tromsø, Norway.

Stolze, S., Roe, H.M., Patterson, R.T., Monecke, T., 2007. A record of Lateglacial and Holocene vegetation and climate change from Woods Lake, Seymour Inlet, coastal British Columbia, Canada. Review of Palaeobotany and Palynology, 147: 112-127.

Stuiver, M., and Braziunas, T., 1989. Atmospheric ${ }^{14} \mathrm{C}$ and century scale oscillations. Nature, 338: 405-408.

Stuiver, M., Braziunas, T., Becker, B., and Kromer, B., 1991. Climatic, solar, oceanic, and geomagnetic influences on late-glacial and Holocene atmospheric ${ }^{14} \mathrm{C} /{ }^{12} \mathrm{C}$ change. Quaternary Research, 35: 1-24

Stuiver, M., Reimer, P.J., 1993. Extended ${ }^{14} \mathrm{C}$ data base and revised CALIB $3.014 \mathrm{C}$ calibration program. Radiocarbon, 35: 215-230.

Stuiver, M., Reimer, P.J., Bard, E., Beck. J.W., Burr, G.S., Hughen, K.A., Komar, B., McCormac, F.G., van der Plicht, J., and Spurk, M., 1998. INTCAL98 radiocarbon age calibration 24,000-0 cal BP. Radiocarbon, 40: 1041-1083.

Stuiver, M., Reimer, P.J., and Reimer, R.W., 2005. CALIB 5.1.WWWprogram and documentation, http://calib.qub.ac.uk/calib/manual/ [21 August 2008].

Sutherland, D.G., 1980. Problems of radiocarbon dating deposits from newly deglaciated terrain: examples from the Scottish Lateglacial. In Studies in the Lateglacial of Northwest Europe, Lowe, J.J., Grey, J.M., and Robinson, J.E., (eds). Pergamon Press: Oxford: 139-149.

Syvitski, J.P.M., and Shaw, J., 1995. Geomorphology and sedimentology of fjords. In: Perillo, G.M.E. (Ed.), Geomorphology and Sedimentology of Estuaries. Developments in. Sedimentology. 53: 113-178. 
Tait R.V., 1981. Elements of marine ecology - an introductory course. 3rd edition. London: Butterworths: 356p.

Taylor, G.T., Iabichella, M., Ho, T.Y., Mary I., Scranton, M.I., Thunell, R.C., MullerKarger, F., Varela, R., 2001. Chemoautotrophy in the Redox Transition Zone of the Cariaco Basin: A Significant Midwater Source of Organic Carbon Production. Source: Limnology and Oceanography, 46, No. 1: 148-163

Taylor, S.R, and McLennan, S.M, 1985. The Continental Crust: Its Compasition and Evolution, Blackwell, London: $57-72$.

Taylor, S.R., and McLennan, S.M., 1995. The geochemical evolution of the continental crust, Reviews of Geophysics, 33: 241-265.

Teeri, J.A., and Stowe, L.G., 1976. Climate patterns and the distribution of C4 grasses in North America. Oecologia 23: 1-12.

Telford, R.J., Heegaard, E., Birks, H.J.B., 2004. All age-depth models are wrong: but how badly? Quaternary Science Reviews, 23: 1-5.

Telford, R.J., and Birks, H.J.B., 2005. The secret assumption of transfer functions: problems with spatial autocorrelation in evaluating model performance, Quaternary Science Reviews, 24: 2173-2179.

Tempelman-Kluit, D.J., 1979. Evolution of physiography and drainage in southern Yukon. Canadian Journal of Earth Sciences, 17: 1189-1203.

ter Braak, C.J.F., and Juggins, S., 1993. Weighted averaging partial least squares regression (WA-PLS): An improved method for reconstructing environmental variables from species assemblages: Hydrobiologia, 269/270: 485-502.

Terquem, O., 1876. Essai sur le classement des animaux qui vivent sur la plage et dans les environs de Dunkerque, pt. 1. Mémoires de la Société Dunkerquoise pour l'Encouragement des Sciences, des Lettres et des Arts (1874-1876), 19: 405-457.

Thalman, H.E., 1952. Bibliography and index to new genera, species and varieties of foraminifera for the year 1951. Journal of Paleontology, 26: 953-992.

Thomson, R.E., 1981. Oceanography of the British Columbia coast. Canadian Special Publication of Fisheries and Aquatic Sciences, 56: 291.

Thomson, R.E., and Gower, J.F.R., 1998. A basin-scale oceanic instability event in the Gulf of Alaska. Journal of Geophysical Research, 103: 3033-3040.

Thomson, R.E., Hickey, B.M., and. LeBlond, P.H., 1989. The Vancouver Island coastal current: fisheries barrier and conduit. In: R. J. Beamish \& G. A. McFarlane, editors. Effects of 
ocean variability on recruitment and an evaluation of parameters used in stock assessment models. Canadian Special Publication of Fisheries and Aquatic Sciences, 108: 265-295.

Thompson, R.S., Whitlock, C., Bartlein, P.J., Harrison, S.P., and Spaulding, W.G., 1993: Climatic changes in the western United States since 18,000 yr B.P. In: Wright, H.E. Jr, Kutzbach, J.E., Webb, T. III, Ruddiman, W.F., Street-Perrott, F.A. and Bartlein, P.J., editors, Global climates since the last glacial maximum, Minneapolis: University of Minnesota Press: 468-513.

Timothy, D.A. and Calvert, S.E., 1998. Systematics of variations in excess $\mathrm{Al}$ and $\mathrm{A} / \mathrm{Ti}$ in sediments from the central equatorial Pacific. Paleoceanography 13 (2): 127-130.

Timothy, D.A., and Soon, M.Y.S., 2001. Primary production and deep-water oxygen content of two British Columbian fjords. Marine Chemistry, 73 (1): 37-51.

Timothy D.A., Soon, M.Y.S., and Calvert, S.E., 2003. Settling fluxes in Saanich and Jervis Inlets, British Columbia, Canada: sources and seasonal patterns. Progress in Oceanography, 59 (1): 31-73.

Todd, R., 1948. Subfamily Uvigerininae: 288. In Cushman, J.A., and McCulloch, I. (eds.), The species of Bulimina and related genera in the collections of the Allan Hancock Foundation. University of Southern California Publication, Allan Hancock Pacific Expedition, Los Angeles, California, USA.

Todd, R., and Brönnimann, P., 1957. Recent Foraminifera and Thecamoebina from the Eastern Gulf of Paria. Cushman Foundation for Foraminiferal Research, Special Publication 3: $1-43$.

Todd, R., and Low, D., 1967. Recent foraminifera from the Gulf of Alaska and southeastern Alaska. Geological Survey Professional Paper, 573-A: 55.

Todd, R., and Low, D., 1961. Near-shore foraminifera of Martha's Vineyard Island, Massachusetts, Contribution to Cushman Foundation for Foraminiferal Research, 12 (1): 521.

Todd, R. and Low, D., 1981. Marine flora and fauna of the northeastern United States:

Protozoa: Sarcodina: benthic foraminifera, NOAA Technical Report NMFS CIRC 439.

Topping, R.M., 1973. Benthonic foraminifera from Puhoi estuary, Auckland. Unpublished B.Sc. thesis, University of Auckland.

Tombs, R.B., 1956. Some characteristics of Bute Inlet sediments. Transaction of the Royal Society Canada series, 111 (50): 59-65.

Trenberth, K.E., 1990. Recent observed interdecadal climate changes in the northern hemisphere. Bulletin of American Meteorological Society, 71: 988-993. 
Trenberth, K.E., and Hurrell, J.W., 1994. Decadal atmosphere-ocean variations in the Pacific. Climate Dynamics. 9: 303-319.

Trites, R.W., 1955. A study of the oceanographic structures in British Columbia inlets and some of the determining factors. Ph.D thesis, University of British Columbia, Vancouver, British Columbia: 125p.

Tunnicliffe, V., 2000. A Fine-Scale Record of 130 Years of Organic Carbon Deposition in an Anoxic Fjord, Saanich Inlet, British Coulumbia. Limnology and Oceanography, 45 (6): 13801387.

Tyson, R.V., 1995. Sedimentary Organic Matter: Organic Facies and Palynofacies, Chapman and Hall, London.

Tyson, R.V., and Pearson, T.H., 1991. Modern and ancient continental shelf anoxia: an overview. Geological Society, London, Special Publications, 58: 1-24.

van Andel, T.H., and Postma, H., 1954. Recent sediments of Gulf of Paria: Verh Konik. Nedesl. Akad van Wetenschapen, D. Natuurkunde, Series I, 20: 1-240.

van der Heyden, P., 1992. A middle Jurassic to early Tertiary Andean-Sierran arc model for the coast belt of British Columbia; Tectonics, 11: 82-97.

Vario, E.L., III Instruction Manuals for the elementary VarioEL III or the CE Instruments EA1110, and the Thermo Finnigan DeltaPlus or DeltaPlus Advantage.

Vázquez-Riveiros, N., 2006. Paleoceanographic history of the Seymour-Belize Inlet Complex, British Columbia, Canada, through the last 1100 years, based on foraminiferal data. M.Sc. Thesis, Carleton University, Ottawa: 216.

Vázquez-Riveiros, N., Babalola, A.O., Boudreau, R.E.A., Patterson, R.T., Roe, H.M., and Doherty, C., 2007. Modern distribution of salt marsh foraminifera and thecamoebians in the Seymour-Belize Inlet Complex, British Columbia, Canada. Marine Geology, 242 (1-3): 39-63.

Vázquez-Riveiros, N., and Patterson, R.T., 2008. An illustrated guide to fjord foraminifera from the Seymour-Belize Inlet Complex, northern British Columbia, Canada. Palaeontologia Electronica Vol. 11, Issue 1; 2A: 45.

Vilks, G., 1964. Foraminiferal study of East Bay, Mackenzie King Island, District of Franklin (Polar Continental Shelf Project): Geological Survey of Canada, Paper 64-53: 26.

Vilks, G., 1967. Circulation of Surface Waters in Parts of the Canadian Arctic Archipelago Based on Foraminiferal Evidence. Arctic, 23 (2): 100-111.

Vilks, G., 1969. Recent foraminifera from the Canadian Arctic: Micropalaeontology, 15: 3560 . 
Vilks, G., 1989. Ecology of recent foraminifera on the Canadian continental shelf of the Arctic Ocean, in Herman, Y. (ed.), The Arctic Seas - Climatology, Oceanography, Geology and Biology: Van Nostrand Reinhold, New York: 497-569.

Vilks, G., and Deonarine, B., 1988. Labrador shelf benthic foraminifera and stable oxygen isotopes of Cibicides lobatulus related to the Labrador Current: Canadian Journal of Earth Science, 25: 1240-1255.

Vilks, G., Maclean, B., Deonarine, B., Currie, C.G., and Moran, K., 1989. Late Quaternary paleoceanography and sedimentary environments in Hudson Strait: Géographie physique et Quaternaire, 43: 161-176.

Villanueva Guimerans, P., and Cervera Currado, J.L., 1999. Distribution of Planorbulinacea (benthic foraminifera) assemblages in surface sediments on the northern margin of the Gulf of Cadiz. Boletin del Instituto Espanol de Oceanografia, 15 (1-4): 181190.

Voloshinova, N.A., 1952. : 1-151. In Voloshinova, N.A., and Dain, L.G. (eds.), Iskopaemye Foraminifery SSRS. Nonionidy, Kassidulinidy i Khilostomellidy (Fossil foraminifera of the USSR. Nonionidae, Cassidulinidae and Chilostomellidae. Vsesoyuznogo Neftyanogo Nauchnoissledovatel'skogo Geologorazvedochnogo Instituta (VNIGRI).

Voloshinova, N.A., 1958. O novy sistematike Nonionid(On new systematics of the Nonionidae). Trudy vsesoyuznogo neftyanogo nauchnoissledovatel'skogo geologorazvedochnogo instituta (VNIGRI), 115: 117-191.

van Loon, H., and Williams, J., 1976. The Connection between Trends of Mean Temperature and Circulation at the Surface: Part I. Winter. Monthly Weather Review, 104: 365-380.

von Siebold, C.T.E., 1864. Wirbellose Thiere: part 1: 679. In von Siebold, C.T.E., and von Stannius, H. (eds.), Lehrbuch del Vergleichenden Anatomie

Waitt, R.B., Jr., and Thorson, R.M., 1983. The Cordilleran ice sheet in Washington, Idaho, and Montana. In S. C. Porter, éd., Late- Quaternary Environments of the United States, Volume 1, The Late Pleistocene. University of Minnesota Press, Minneapolis: 53-70

Walker, I.R., and Mathewes, R.W., 1987. "Chironomidae (Diptera) and Postglacial Climate at Marion Lake, British Columbia, Canada". Quaternary Research, 27: 89-102.

Walker, D.A., and Jacob, E., 1798. In Kanmacher, F. (ed.), Adam's essays on the microscope; the second edition with considerable additions and improvements. Dillon \& Keating, London.

Watkins, J.G., 1961. Foraminiferal ecology around the Orange County, California, ocean sewer outfall. Micropaleontology, 7 (2): 199-206. 
Wallach, D., and Goffinet, B., 1989. Mean squared error of prediction as a criterion for evaluating and comparing system models. Ecological Modelling, 44: 299-306.

Ware, D.M., 1995. A century and a half of change in the climate of the NE Pacific. Fisheries Oceanography. 4 (4): 267-277.

Ware, D.M., and Thomson, R.E., 2000. Interannual to multidecadal timescale climate variations in the Northeast Pacific. Journal of Climate, 13: 3209-3220.

Ware, D.M., and McFarlane, G.A., 1989. Fisheries production domains in the Northeast Pacific Ocean: 359-379. In Beamish, R.J., and McFarlane, G.A. (eds.), Effects of ocean variability on recruitment and an evaluation of parameters used in stock assessment models. Canadian Special Publication of Fisheries and Aquatic Sciences, 108.

Ware, D.M. and Thomson, R.E., 1991. Link between long-term variability in upwelling and fish production in the northeast Pacific Ocean. Canadian Journal of Fisheries and Aquatic Science. 48 (12): 2296-2306.

Ware, D.M., and Thomson, R.E., 2000. Interannual to multidecadal timescale climate variations in the Northeast Pacific. Journal of Climate, 13: 3209-3220.

Warner, B.G., 1984. Late Quaternary Paleoecology of Eastern Graham Island, Queen Charlotte Islands, British Columbia Ph.D Thesis, Simon Fraser University, Burnaby, British Columbia, Canada: 190p.

Watkins, J.G., 1961. Foraminiferal ecology around the Orange County, California, ocean sewer fall. Micropaleontology, 7: 199-206.

Walton, W.R., 1964. Recent foraminiferal ecology and paleoecology: 151-237. In J. Imbrie and N. Newell (eds.), Approaches to Paleoecology. John Wiley and Sons, New York: 151237.

Wedepohl, K.H., 1971. Environmental influences on the chemical composition of shales and clays. In: L.H. Ahrens, F. Press, S.K. Runcorn and H.C. Urey, Editors, Physics and Chemistry of the Earth, 8, Pergamon Press, Oxford: 305-333.

Wedepohl, K.H., 1991. The composition of the upper earth's crust and the natural cycles of selected metals. Metals in natural raw materials. Natural Resources. In: E. Merian (editor), Metals and Their Compounds in the Environment, VCH, Weinheim: 3-17.

Welch, P.D., 1967. The use of fast Fourier transform for the estimation of power spectra: a method based on time averaging over short, modified periodograms. IEEE Transactions on Audio and Electroacoustics 15 (2): 70-73.

Wheeler, J.O., Brookfield, A.J., Gabrielese, H., Monger, J.W.H., Tipper, H.W. and Woodsworth, G.J., 1991. Terrane map of the Canadian Cordillera. Geological Survey of Canada, Map 1713, scale 1:1,000,000. 
Wheeler, J.O., and McFeely, P., (compilers), 1991. Tectonic assemblage map of the Canadian Cordillera and adjacent parts of the United States of America: Geological Survey of Canada Map 1712A, scale 1:2,000,000.

Wiesner, H., 1931. Die Foraminiferen der deutschen Südpolar Expedition 1901-1903. Deustche Südpolar-Expedition, 20 Zoologie, 12: 53-165.

Wignall, P.B., 1990. Benthic palaeoecology of the Late Jurassic Kimmeridge Clay of England: Special Papers in Palaeontology, 43, London, Palaeontological Association: 74.

Wignall, and Myers, K.J., 1988. Interpreting benthic oxygen levels in mudrocks: a new approach, Geology 16: 452-455.

Wigston, A.P., 2005. Late Holocene climate change of Frederick Sound, British Columbia, Canada, M.S. thesis, Carleton University, Ottawa: 213p.

Wiles, G.C., and Calkin, P.E., 1994. Late Holocene, high-resolution glacial chronologies and climate, Kenai Mountains, Alaska. Geological Society of America Bulletin, 106: 281-303.

Wiles, G.C., Barclay, D.J., and Calkin, P.E., 1999. Tree-ring-dated 'Little Ice Age' histories of maritime glaciers from western Prince William Sound, Alaska. The Holocene, 9: 163-173.

Williams, H.F.L., 1989. Foraminiferal zonations on the Fraser River Delta and their application to paleoenvironmental interpretations: Palaeogeography, Palaeoclimatology, Palaeoecology, 73: 39-50.

Williamson, W.C., 1848. On the Recent British species of the genus Lagena. Annals and Magazine of Natural History, Series 2 (1): 1-20.

Williamson, W.C., 1858. On the recent foraminifera of Great Britain. Ray Society, London: 107.

Wilson, J.T., Falconer, G., Mathews, W.H., and Prest, V.K. (compilers), 1958. Glacial Map of Canada. Geological Association of Canada, Toronto, scale 1:3,801,600.

Wright, J., 1886. Foraminifera of the Belfast Naturalists' Field Club's cruise off Belfast Lough in the steam-tug "Protector," June 1885; also, foraminifera found by Dr. Malcomson, at Rockport, Belfast Lough. Belfast Naturalists' Field Club Proceedings, New Series, 1: 317325.

Yorath, C.J., Clowes, R.M., Green, A.G., Sutherland Brown, A., Brandon, M.T., Massey, N.W.D., Spencer, C., Kanasewich, E.R. and Hyndman, R.D. , 1985. Lithoprobe - Phase 1: Southern Vancouver Island: Preliminary analyses of reflection seismic profiles and surface geological studies; in Current Research, part A, Geological Survey of Canada, Paper 85-1A. pages 543-554.

Geological 
Yorath, C.J., and Nasmith, H.W., 1995. The Geology of Southern Vancouver Island. Orca Book Publishers, Victoria, Canada: 172.

Yu, Z.C., and Ito, E., 1999. Possible solar forcing of century-scale drought frequency in the northern Great Plains. Geology, 27: 263-266.

Zaninetti, L., Brönnimann, P., Beurlen, G., and Moura, J.A., 1977. La mangrove de Guaratiba et la baie de Sepetiba, état de Rio de Janeiro, Brésil. Foraminifêres et écologie. Archives des Sciences de Genève, 30: 161-178.

Zellers, S., 1990. Foraminiferal biofacies analysis of the Yakataga Formation, Icy Bay, Alaska; insights into Pliocene glaciomarine paleoenvironments of the Gulf of Alaska. Palaios, 5 (3): 273-296.

Zheng, Y., van Green, A., Anderson, R.F., Gardner, J.V., and Dean, W.E., 2000a. Intensification of northeast Pacific oxygen minimum zone during the Bølling-Allerøid warm period. Paleoceanography, 15 (5): 528-538.

Zheng, Y., Anderson, R.F., van Green, A., and Kuwabara, J., 2000b, Authigenic molybdenum formation in marine sediments: A link to pore water sulfide in the Santa Barbara Basin, Geochimica et Cosmochimica Acta, 64: 4165-4178.

Zong, Y., and Hortons, B.P., 1999. Diatom-based tidal-level transfer functions as an aid in reconstructing Quaternary history of sea-level movements in Britain. Journal of Quaternary Science, 14: 153-67. 


\section{PLATES 1-14}




\section{PLATE 1}

1-2. Cribrostomoides crassimargo (Norman), Figure 1, from the Frederick Sound core, sample VEC02A04S3_35-40; 1a, umbilical view showing depressed umbilicus; 1b. apertural view showing arched aperture; $1 \mathrm{c}$. dorsal view. Figure 2, from Alison Sound core, sample VEC02A07S7_0-5; 2a, umbilical view showing depressed umbilicus and 9 chambers of the final whorl; $2 \mathrm{~b}$, side view showing lobulate periphery; $2 \mathrm{c}$, dorsal view.

3,4. Cribrostomoides jeffreysii (Williamson), Figure 3, from the Alison Sound core, sample VEC02A07S2_10-15; 3a, side view; 3b, apertural view with lipped slit-like aperture; 3c. other side view. Figure 4, from sample VEC02A07S3_0-5, 4a, sidel view; 4b, apertural view; $4 c$, other view showing ovate periphery.

5. Cribrostomoides wiesneri (Parr), specimen from the Frederick Sound core, sample VEC02A04S7_0-5, 5a, side view showing depressed umbilicus; 5b, side view of the same specimen.

6. Cribrostomoides subglobosum (Cushman), specimen from the Frederick Sound core, sample VEC02A04S1_15-20; 6a, apertural view showing typical thick lipped apertural slit; $6 \mathrm{~b}$, side view.

All scales are in $10 \mu \mathrm{m}$ except where otherwise indicated. 

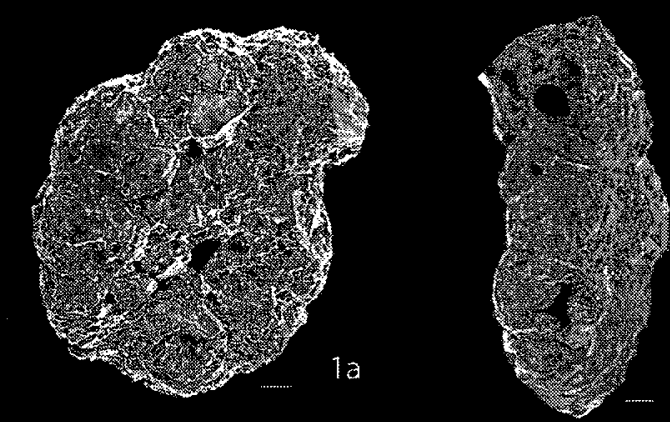

$1 b$
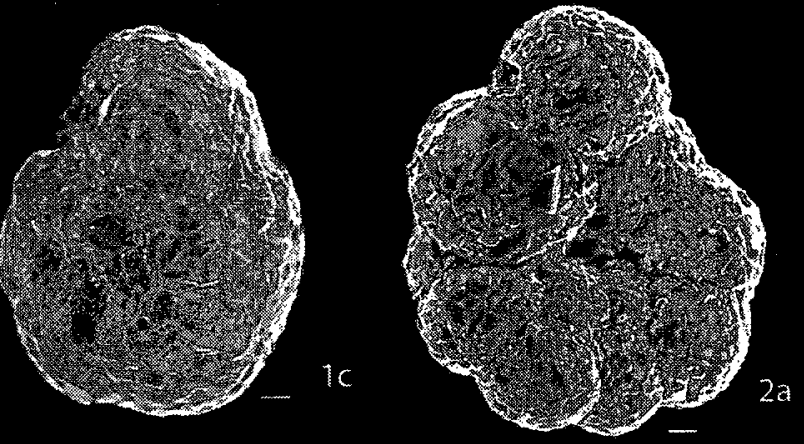
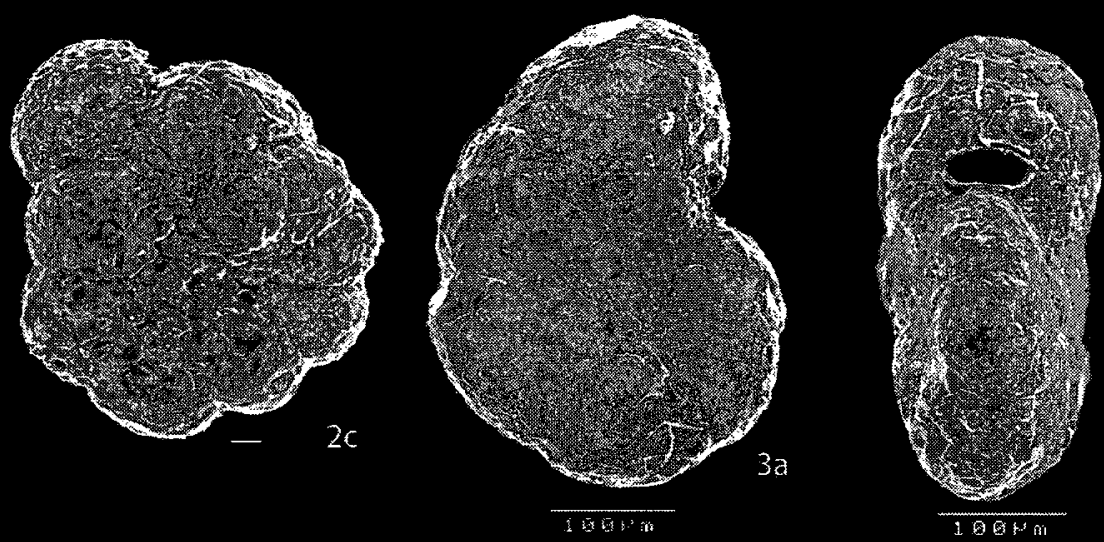

$3 b$
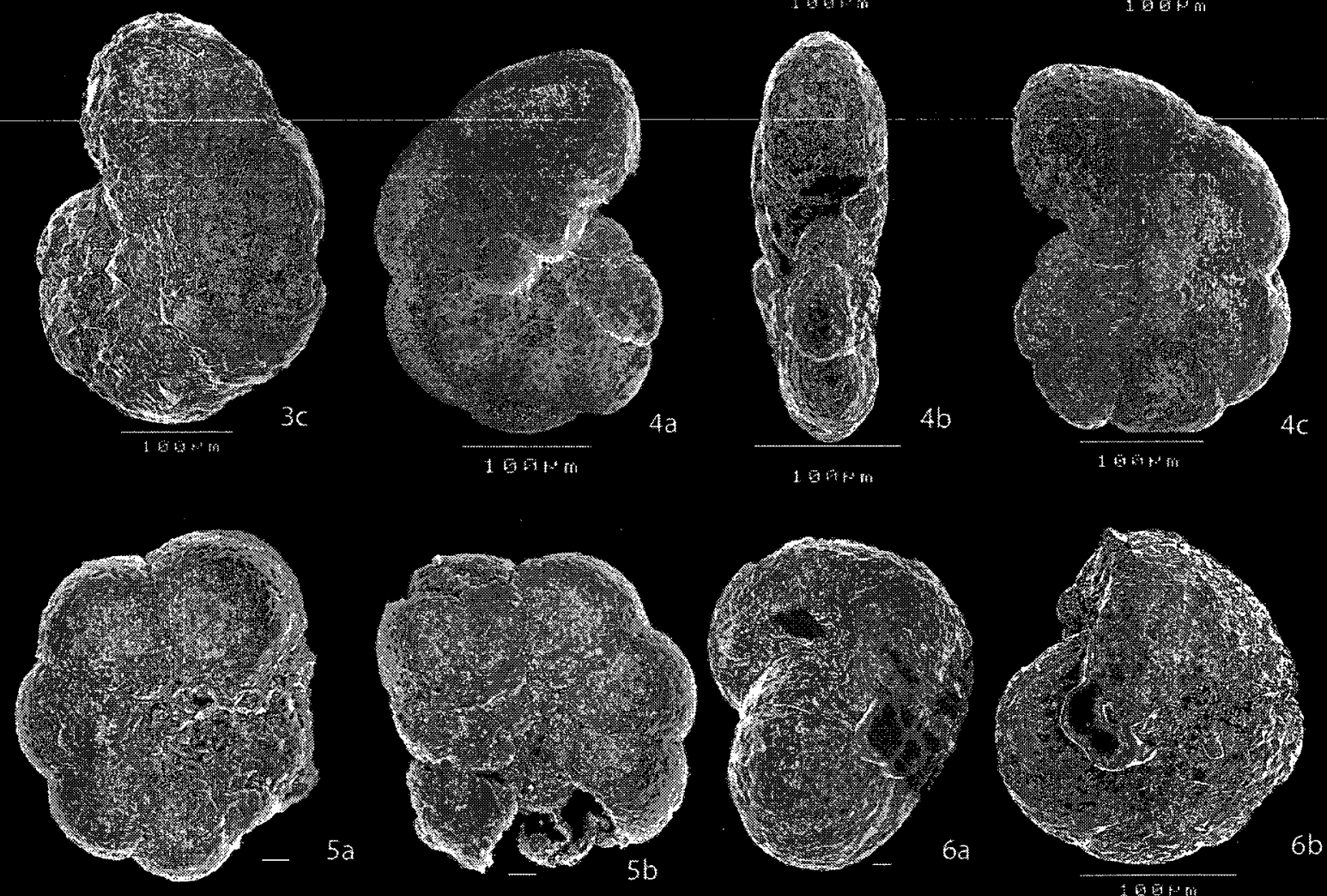


\section{PLATE 2}

1. Cribrostomoides subglobosum (Cushman), specimen from the Frederick Sound core, sample VEC02A04S1_80-85; 1a, side view; 1b, apertural view; 1c, shows another view of the same specimen.

2. Cribrostomoides sp. Specimen from the Frederick Sound core, sample VEC02A04S1_10-15; 2a, side view showing ovate periphery; $2 \mathrm{~b}$, apertural view showing lipped apertural slit; $2 \mathrm{c}$, side view.

3-5. Recurvoides turbinatus (Brady), Figure 3, from the Frederick Sound core, sample VEC02A04S1_60-65; 3a. side view; 3b, apertural view showing asymmetry test and inclined aperture; $3 \mathrm{c}$, side view. Figure 4, from the Frederick Sound core, sample VEC02A04S1_35-40; 4a, side view; 4b apertural view; 4c, side view. Figure 5, from the same sample as Figure 4; 5a, side view; 5b, apertural view showing asymmetry test and inclined lipped aperture; $5 \mathrm{c}$, other side view.

6. Miliammina fusca (Brady), specimen from Alison Sound, sample VEC02A07S3_140145 showing side view.

All scales are in $10 \mu \mathrm{m}$ except where otherwise indicated. 

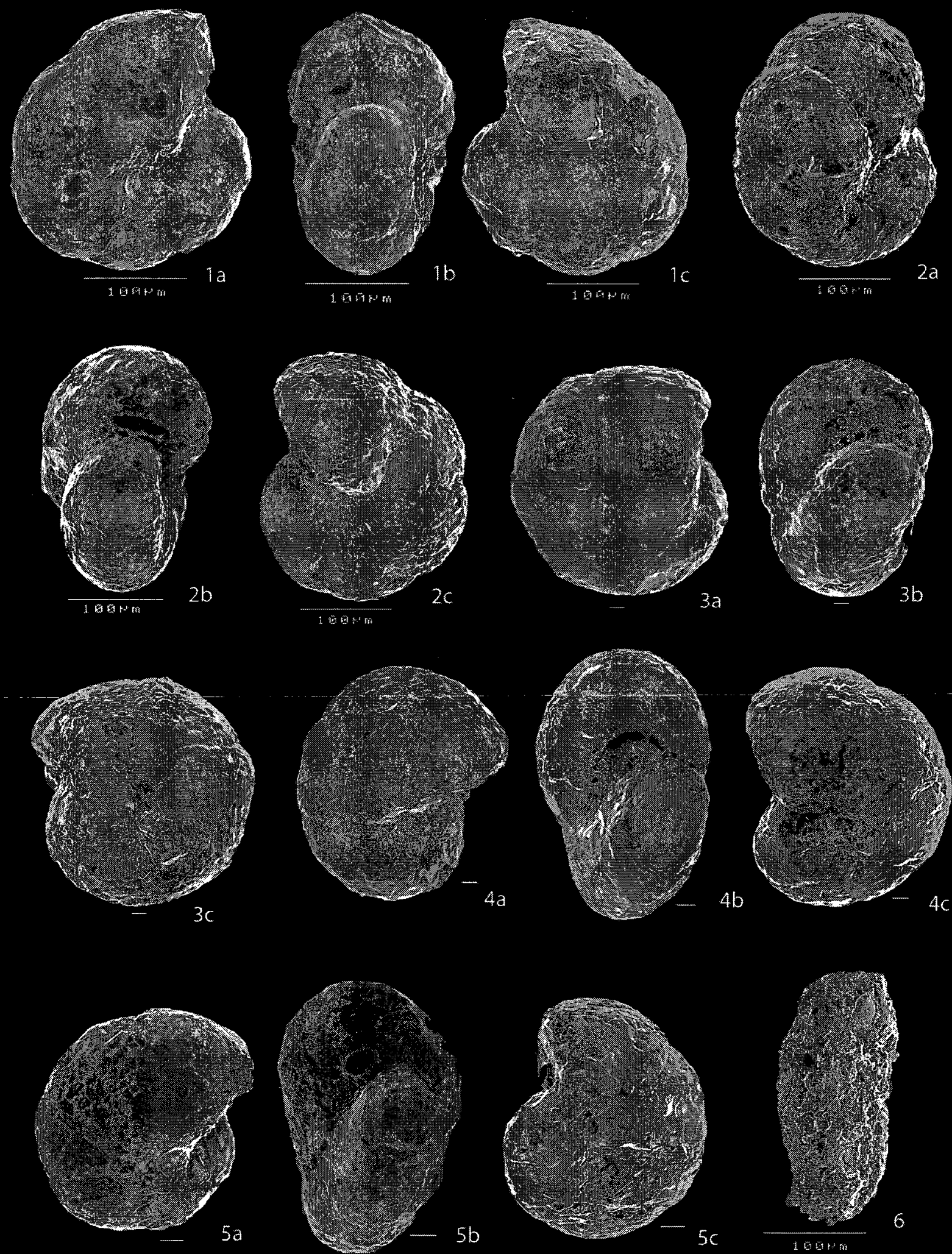


\section{PLATE 3}

1, 2. Haplophragmoides bradyi (Brady), Figure 1, from the Mereworth Sound core, sample VEC02A13D_10; 1a, side view showing very smooth test; $1 \mathrm{~b}$, apertural view showing lipped apertural slit at the base of the last chamber; $1 \mathrm{c}$, other side view of the same specimen. Figure 2, from the Mereworth Sound core, sample VEC02A13E_5; 2a, side view; $2 b$, apertural view show lipped apertural slit; $2 c$, side view.

3. Haplophragmoides sp., specimen from Frederick Sound, sample VEC02A04S4_7075; $3 a$, side view; $3 \mathrm{~b}$, apertural view showing lipped slit at the base of last chamber; $3 \mathrm{~b}$, other side view, $3 \mathrm{c}$, another side view of the same specimen.

4. Deuterammina discorbis (Earland), specimen from the Alison Sound core, sample VEC02S2_70-75, 4a. umbilical view; 4b. peripheral view; 4c, spiral view

5-6. Deuterammina rotaliformis (Heron-Allen and Earland), Figure 5, from the Alison Sound core, sample VEC02A07S2_80-85; 5a, spiral view; 5b, apertural view; 5c, umbilical view showing depressed umbilicus. Figure 6 , another specimen from the same sample as Figure 5, umbilical side shows slightly depressed umbilicus and sutures.

All scales are in $10 \mu \mathrm{m}$ except where otherwise indicated. 

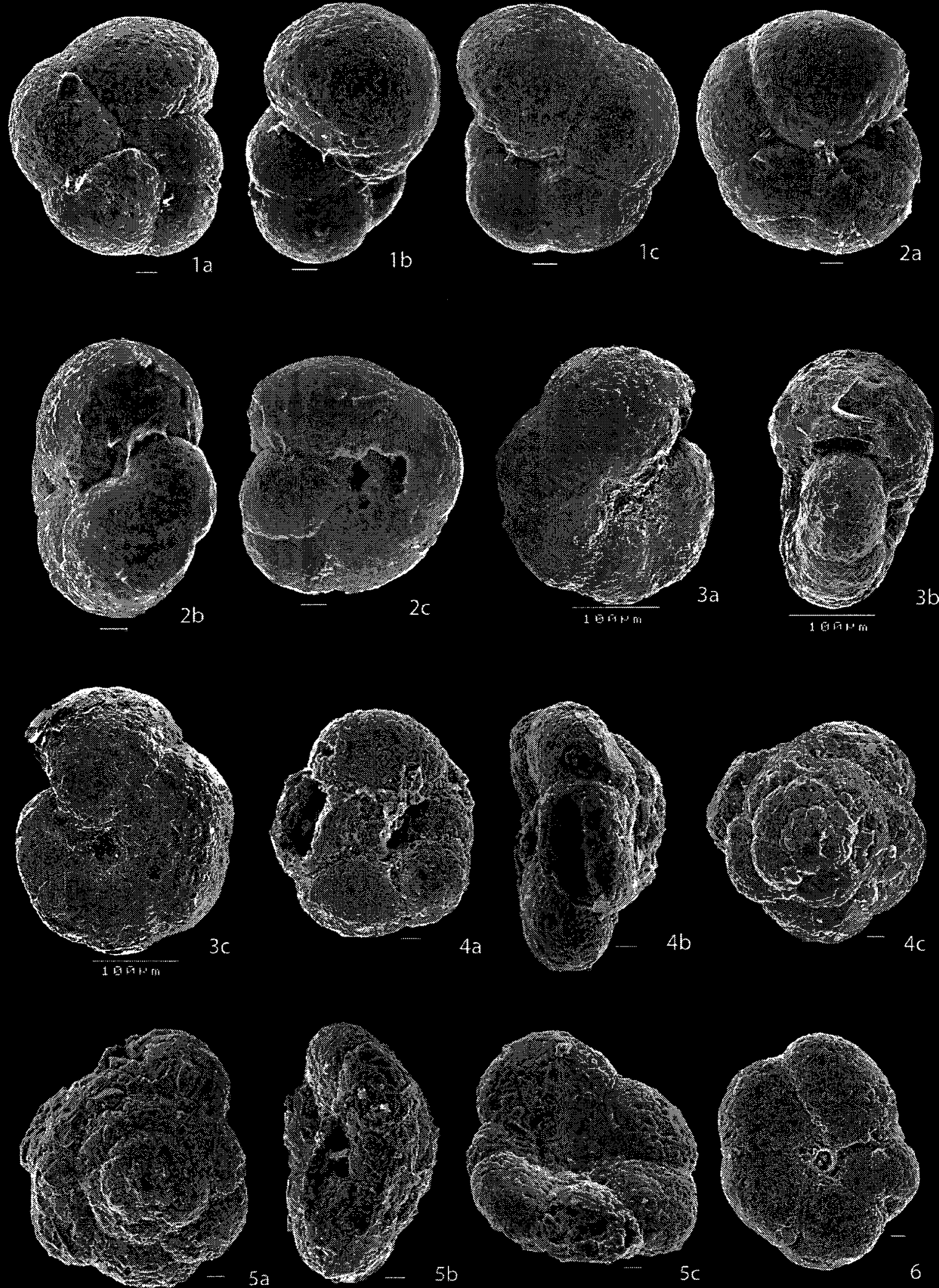


\section{PLATE 4}

1-2. Trochammina sp.3 Figure 1, from the Alison Sound core, sample VEC02A07S3_140145 ; 1a, spiral side showing all whorls; $1 \mathrm{~b}$, umbilical view showing extraumbilical aperture and slightly depressed umbilicus. Figure 2, from the Alison Sound core, sample VEC02S2_0-5, 2a, spiral view; $2 b$, umbilical view showing slightly depressed umbilicus.

3-4. Trochammina squamata (Jones and Parker), Figure 3, from the Frederick Sound core, sample VEC02A04S1_60-65; 3a, umbilical view; 3b, oblique view of the spiral side view showing coiling and apertural slit; $3 \mathrm{c}$, spiral view. Figure 4 , from the Alison Sound core, sample VEC02A07S4_40-45; 4a, dorsal view, 4b, side view; 4c, umbilical view.

5. Lepidodeuterammina ochracea (Williamson), specimen from the Alison Sound core, sample VEC02A07S3_100-105; 5a, umbilical view; 5b, spiral view.

6. Polystomammina nitida (Brady), specimen from Frederick Sound, VEC02A04S1_110115 ; $6 \mathrm{a}$, umbilical view; $6 \mathrm{~b}$, dorsal view.

7. Deuterammina grisea (Earland), specimen from the Frederick Sound core, sample VEC02A04S6_0-5; 7a, umbilical view; 7b, spirall view.

All scales are in $10 \mu \mathrm{m}$ except where otherwise indicated. 

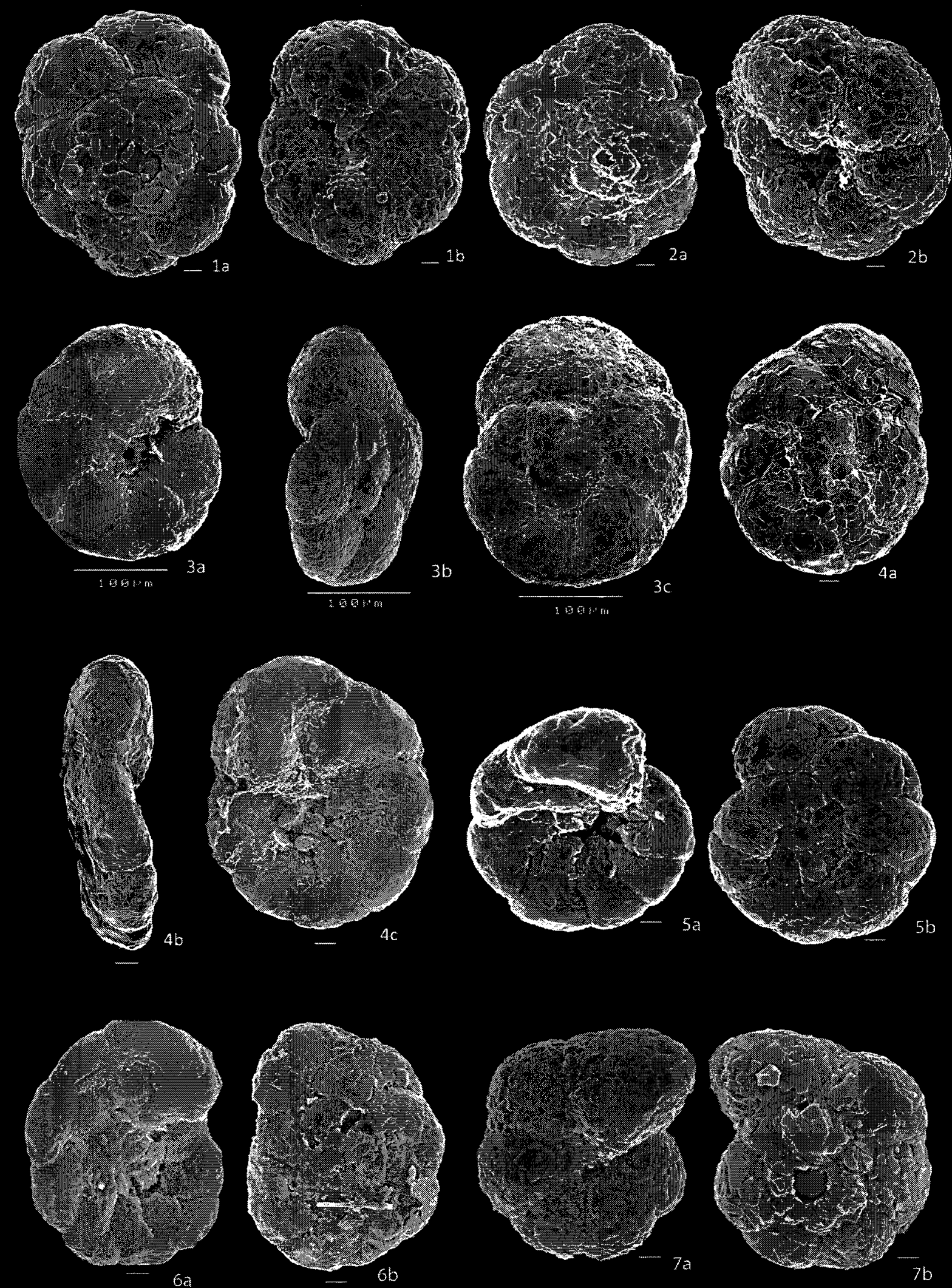


\section{PLATE 5}

1, 2. Portatrochammina bipolaris (Brönnimann and Whittaker), Figure 1, from the Alison Sound, sample VEC02A07S2_10-15; 1a. umbilical view showing characteristic umbilical flap, $1 \mathrm{~b}$, side view showing the rounded periphery and apertural slit; dorsal view. Figure 2, from the Frederick Sound core, sample VEC02A04S7_0-5; 2a, umbilical view; $2 b$, dorsal view.

3-5 Lepidoparatrochammina charlottensis (Cushman), Figure 1, from the Frederick core Sound, sampleVEC02A04S1_35-40; 3a, umbilical side; 3b, side view; 3c, dorsal view. Figure 4, from Frederick Sound, sampleVEC02A04S1_30-35; 4a, dorsal view; 4b, umbilical view. Figure 5, from the Frederick Sound core, sample VEC02A04S1_0-5; $5 a$, umbilical view; $5 b$, side view; $5 c$, dorsal view.

6. Zavodovskina nana (Brady), specimen from the Fredrick Sound core, sample VEC02A04S1_50-55; 6a, dorsal side; 6b, side view; 6c, umbilical view showing slightly depressed umbilicus.

All scales are in $10 \mu \mathrm{m}$ except where otherwise indicated. 

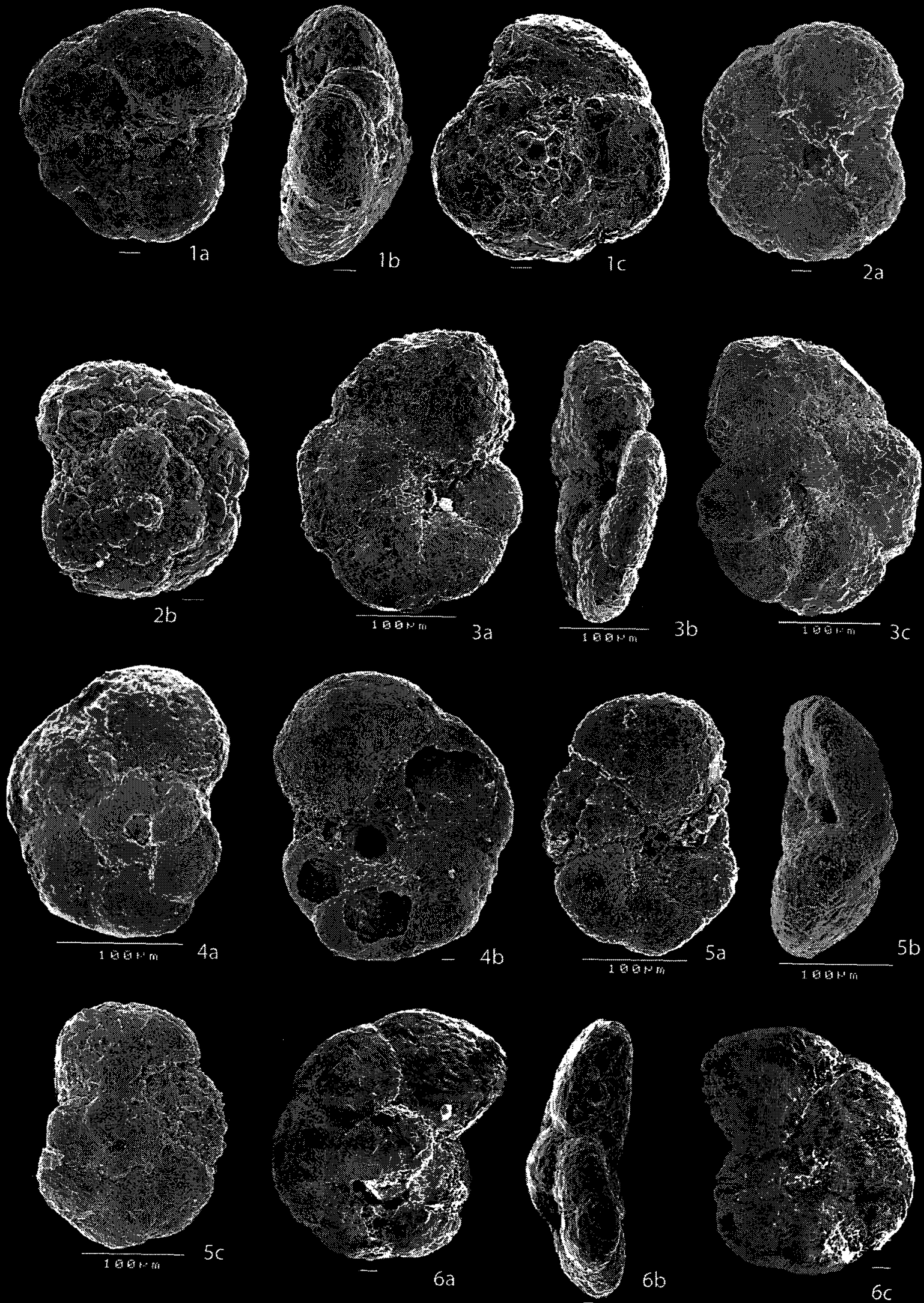


\section{PLATE 6}

1,5-8. Eggerella advena (Cushman), Figure 1, from the Frederick Sound core, sample VEC02A04S1_95-100; 1a, side view; 1b, apertural face; Figure 5, from the Frederick Sound core, sample VEC02A04S3_35-40; Figure 6, from Frederick Sound, sample VEC02A04S1_120-125; 6a, apertural view; 6b, enlarged apertural slit; Figure 7, from the Frederick Sound core, sample VEC02A07S3_20-25; 7a, showing apertural view; $7 \mathrm{~b}$, showing enlarged apertural slit; Figure 8, From the Alison Sound core, sample VEC02A07S4_40-45; 8a, apertural face; 8b,. enlarged apertural slit.

2-4. Eggerella 'belizensis', n.sp. (Vazquez-Rivieros and Patterson, 2008), Figure 2, from Alison Sound, sample VEC02A07S6_5-10; Figure 3, from Frederick Sound, sample VEC02A041_15-20; Figure 4, from the Frederick Sound core, sample VEC02A04S3_80-85.

9. Tiphotrocha comprimata (Cushaman and Brönnimann), specimen from Frederick Sound, sample VEC02A04S1_50-55; 9a, umbilical view; 9b, apertural view; 9c, dorsal view.

All scales are in $100 \mu \mathrm{m}$ except where otherwise indicated. 

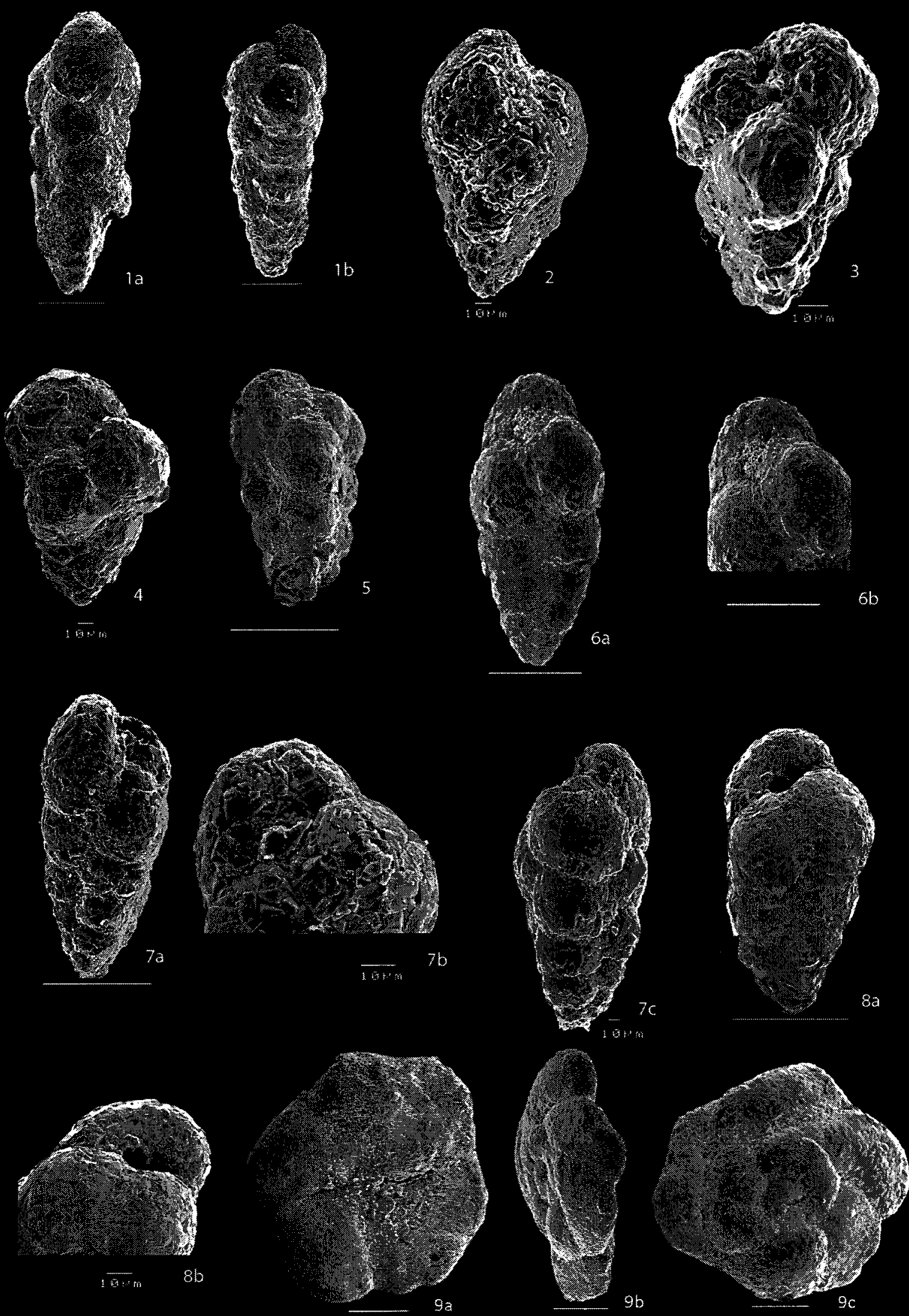


\section{PLATE 7}

1-8. Spiroplectammina biformis (Parker and Jones), Figure 1, from the Alison Sound core, sample VEC02A7S4_40-45; Figure 2 from the Frederick Sound core, sample VEC02A04S1_95-100; Figure 3 from the Alison Sound core, sample VEC02A07S4_40-45; Figure 4, from the Alison Sound core, sample VEC02A05A12; Figure 5, from the Frederick Sound core, sample VEC02A04S1_35-40; Figure 6, from the Frederick Sound core, sample VEC02A04S1_95-100; Figure 7 from the Frederick Sound core, sample VEC02A04S1_35-40; Figure 8, from Alison Sound, sample VEC02A07S2_10-15.

9-11. Difflugia oblonga Strain'oblonga' (Reinhardt et a.l), Figure 9, from the Fredrick Sound core, sample VEC02A04S1_95-100; 9a, side view showing reticulate ornamentation; 9b, apertural view.; Figure 10, from the Alison Sound core, sample VEC02A07S2_40-45; Figure 11, from the Alison Sound core, sample VEC02A07S3_140-145; side view showing coarse agglutination.

12. Heleopera sphagni (Leidy), specimen from the Alison Sound core, sample VEC02A07S2_80-85; side view showing compressed test.

13. Difflugia urceolata Strain 'elongata' (Kumar and Dalby), specimen from the Alison Sound core, sample VEC02A05A2; side view.

14. Cyclopyxis kahli (Deflandre), from Alison Sound, sample VEC02A07S3_0-5, side view.

15. Centropyxis aculeate Strain 'discoides' (Reinhardt et al.), from the Alison Sound core, sample VEC02A07S2_120-125; side view.

All scales are in $10 \mu \mathrm{m}$ except where otherwise indicated. 

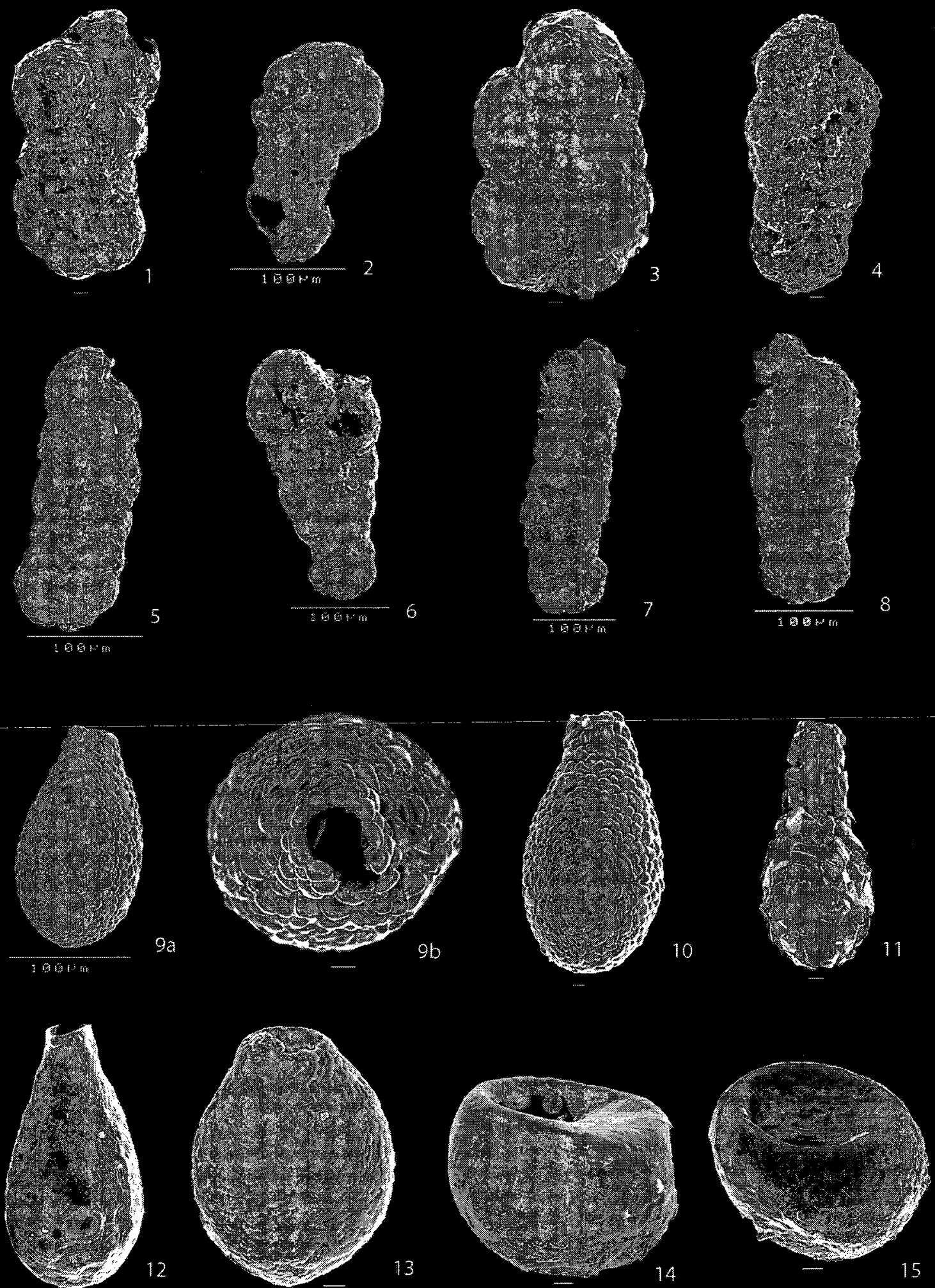


\section{PLATE 8}

1-2. Centropyxis constricta Strain 'aerophila' (Reinhardt et al.), Figure 1, from the Alison Sound core, sample VEC02A07S2_0-5; side view; Figure 2, from Frederick Sound, sample VEC02A04_S3_35-40; side view.

3,7. Centropyxis aculeate 'aculeata' (Reinhardt et al.), Figure 3 from the Alison Sound core, sample VEC02A07S2_80-85; side view; Figure 7, from Alison Sound, sample VEC02A07S2_40-45; side view.

4-6. Centropyxis constricta Strain 'constricta' (Reinhardt et al.), Figure 4 from the Alison Sound core, sample VEC02A07S2_120-125; side view; Figure 5, from the Alison Sound core, sample VEC02A07S1_0-5; side view; Figure 6, from Alison Sound, sample VEC02A07S2_40-45; side view.

8. Centropyxis aculeate Strain 'discoides' (Reinhardt et al.), from the Alison Sound core, sample VEC02A07S2_40-45; side view.

9-12. Difflugia oblonga Strain 'glans' (Reinhardt et al.), Figure 9, from the Frederick Sound core, sample VEC02A04S1_130-135; side view; Figure 10, from the Frederick Sound core, sample VEC02A04S3_105-110; 10a. side view; 10b. apertural view; Figure 11, from the Frederick Sound core, sample VEC02A04S1_60-65; side view; Figure 12, from the Alison Sound core, sample VEC02A07S2_140-145; side view.

13. Difflugia protaeformis Strain 'claviformis'(Reinhardt et al.), specimen from Frederick Sound, sample VEC02A04S3_35-40, side view.

14 Difflugia protaeformis Strain 'acuminata'(Reinhardt et al.), specimen from Frederick Sound, sample VEC02A04S3_35-40, side view.

15. Difflugia oblonga Strain 'lanceolata' (Reinhardt et al.), specimen from Frederick Sound, sample VEC02A04_S1_130-135; side view.

All scales are in $10 \mu \mathrm{m}$ except where otherwise indicated. 

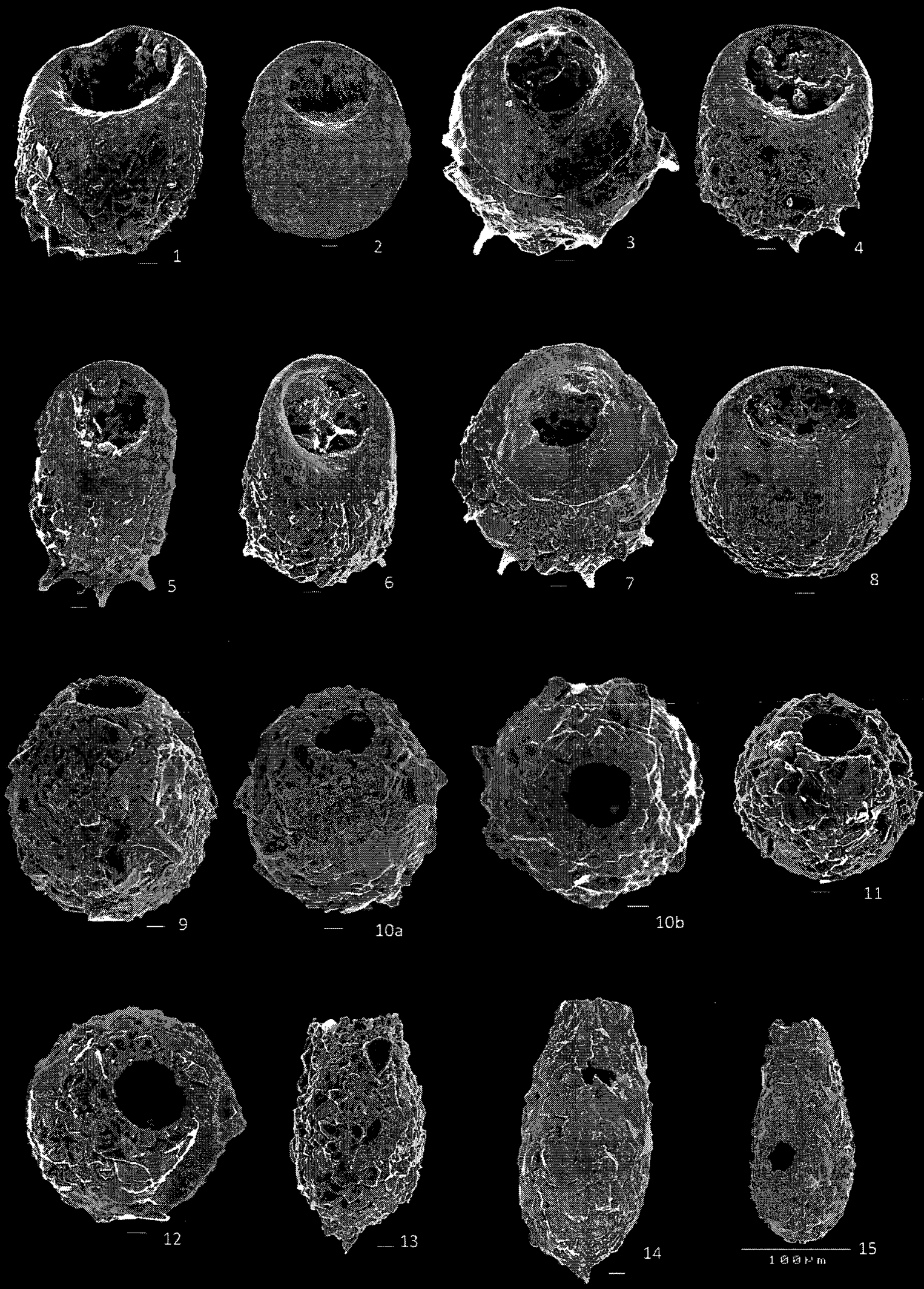


\section{PLATE 9}

All illustrated specimens are from the Mereworth Sound freeze core VEC02A13.

1-3, 5,6. Buccella frigida (Cushman), Figure 1, from samples VEC02A13E_11.5; 1a, umbilical view showing pustules along sutures; $1 \mathrm{~b}$, apertural view; $1 \mathrm{c}$, dorsal view showing smooth test. Figure 2, from VEC02A13E_10.5; 2a, dorsal view, 2b, apertural view; 2c. umbilical view. Figure 3, from sample VEC02A02A13E_5; 3a, umbilical side; $3 \mathrm{~b}$, dorsal side. Figure 5, 5a, umbilical view showing pustules along sutures and umbilicus; 5b,. apertural view; 5c, dorsal side showing smooth test. Figure 6, 6a. spiral view.

4, Buccella frigida (Cushman) sensu stricto, Specimen from sample VEC02A13E_2; 4a, umbilical view showing pustules along sutures and umbilicus; $4 \mathrm{~b}$, apertural view; $4 c$, dorsal showing smooth test. Absence of keel differentiates this species from typical Buccella frigida.

All scales are in $10 \mu \mathrm{m}$ except where otherwise indicated. 

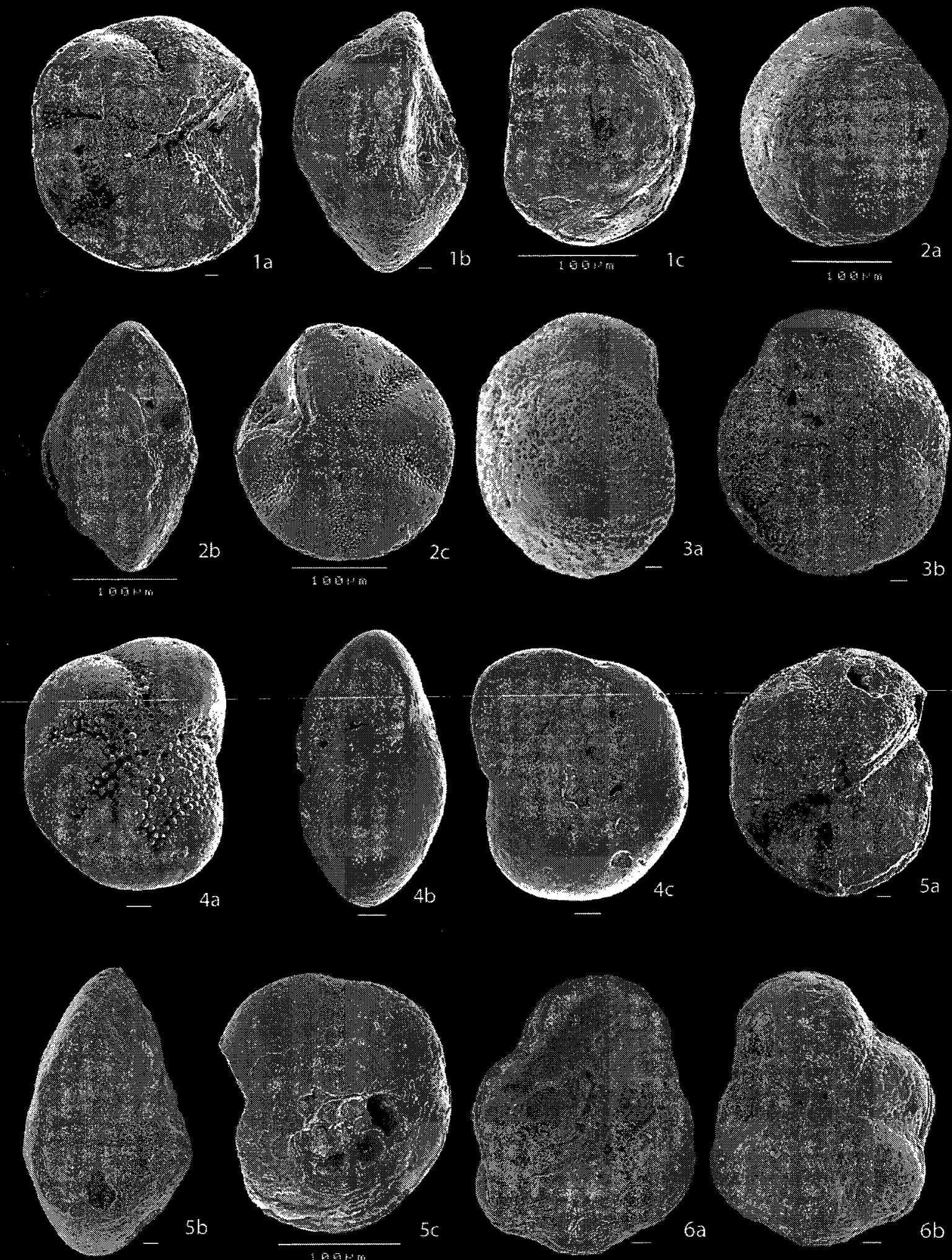


\section{PLATE 10}

All illustrated specimens are from the Mereworth Sound freeze core VEC02A13.

1. Buccella frigida (Cushman), specimen from VEC02A13E_11.5; 1a, umbilical side; 1b, apertural side; 1c, spiral side.

2. Buccella tenerrima (Bandy), specimen from sample VEC02A13E_11.5; 2a, dorsal view, $2 \mathrm{~b}$, apertural view; $2 \mathrm{c}$, umbilical view.

3, 5. Cassidulina crassa (d'Orbigny), Figure 3, from sample VEC02A13E_8; side view showing rectangular last chamber. Figure 5, from VEC02A13E_12.5; 5a, side view showing inflated chamber on apertural face; $5 \mathrm{~b}$, apertural view.

4,6. Epistominella vitrea (Parker), Figure 4, from sample VEC02A13_5; 4a, side view showing inflated chambers; 4b, apertural view; 4c; dorsal view; Figure 6, from sample VEC02A13E_2; 6a, ventral view; 6b, apertural view showing apertural lip; 6c, dorsal view.

All scales are in $10 \mu \mathrm{m}$ except where otherwise indicated. 

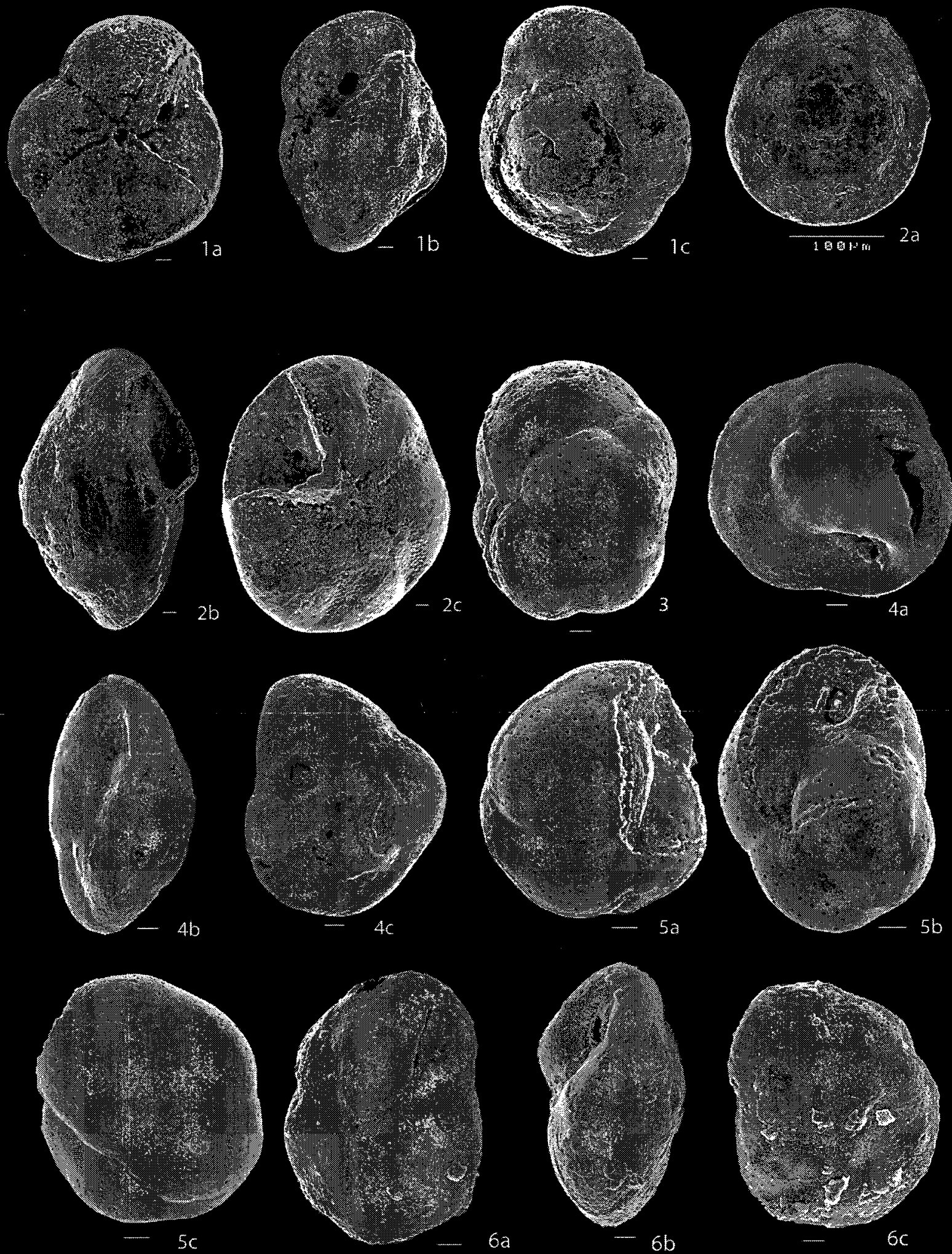


\section{PLATE 11}

All illustrated specimens are from the Mereworth Sound freeze core VEC02A13.

1-4. Cribroelphidium excavatum forma clavata (Cushman), Figure 1, from VEC02A13E_10.5; 1a, side view showing slightly curved sutures; $1 \mathrm{~b}$, apertural face showing coarse perforation; $1 \mathrm{c}$, side showing etched surface and coarse perforations. Figure 2, from sample VEC02A13E_10.5; 2a, side view showing fine perforations, slightly discontinuous, curved sutures; $2 b$, edge view showing broken last chamber; 2c, side view. Figure 3, from sample VEC02A13C_5; 3a, side view showing pustules on slightly curved sutures; $3 \mathrm{~b}$, apertural view showing pustules and ponticuli lining the apertural slit; 3c, side view showing concentration of pustules on apertural face and sutures. Figure 4, from sample VEC02A13E_5, 4a, side view; 4b, apertural view; 4c, side view; etched specimen with coarse perforations.

5. Cribroelphidium excavatum forma lidoensis (Cushman), specimen from sample VEC02A13E_6; 5a, side view showing pustules along sutures; 5b, edge view showing pustules lining apertural edges; $5 \mathrm{c}$, side view showing pustule filled open umbilicus and sutures.

All scales are in $10 \mu \mathrm{m}$ except where otherwise indicated. 

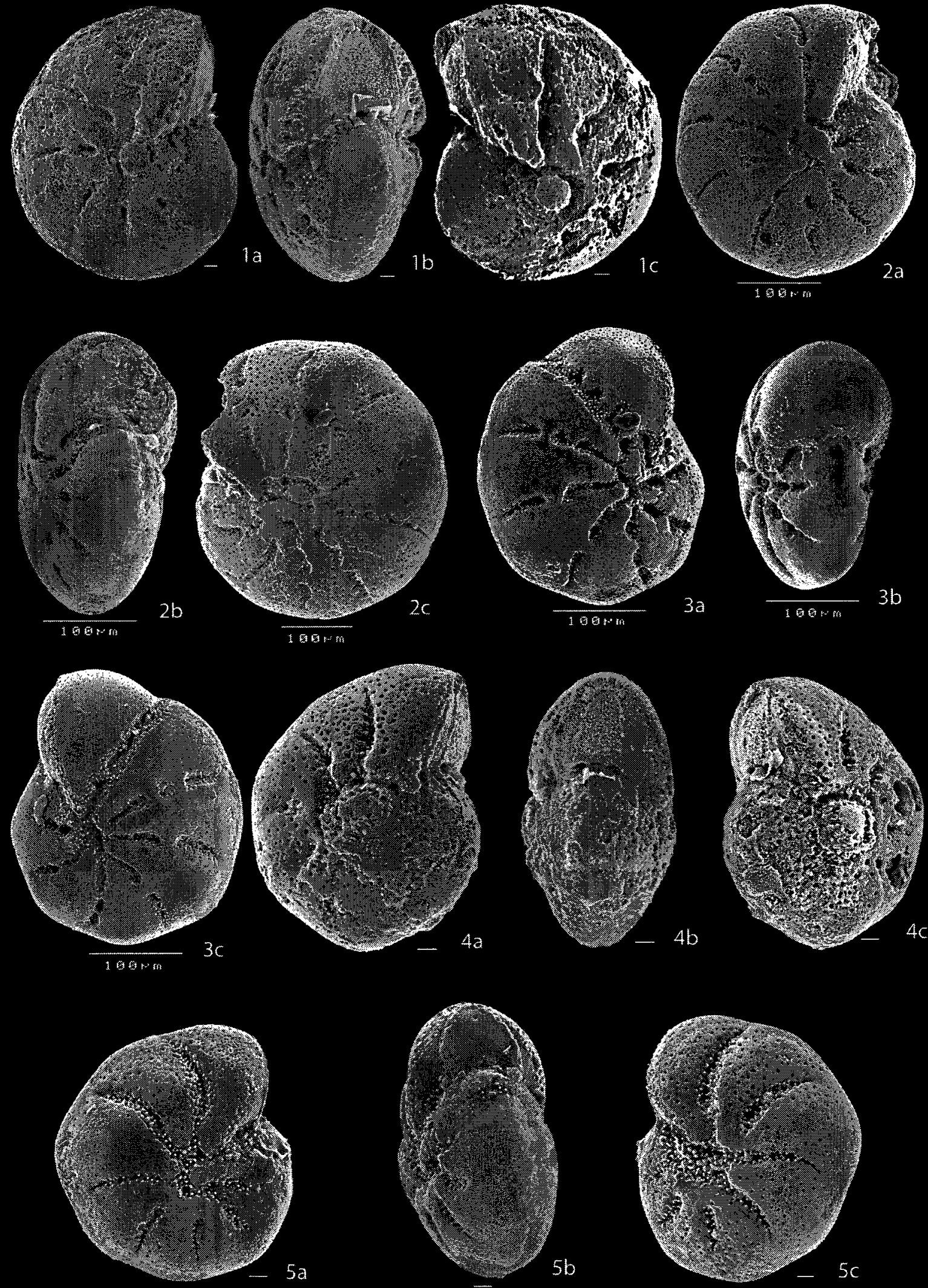


\section{PLATE 12}

All illustrated specimens are from the Mereworth Sound freeze core VEC02A13.

1,2. Cribroelphidium excavatum forma magna (Miller et al.), Figure 1, from sample VEC02A13_8; 1a, side view, 1b, apertural view showing partly broken final chamber; 1c, side view showing perforation. Figure 2, from sample VEC02A13E_10.5; 2a, side view; $2 b$, edge view; $2 c$, side view.

3, 4 Cribroelphidium excavatum forma clavata (Cushman), Figure 1, from sample VEC02A13E_8; 3a, side view showing pustules filling discontinuous sutures; $3 \mathrm{~b}$, edge view showing perforations along the apertural face; $3 \mathrm{c}$, side view showing pustules in the apertural face. Figure 4, from sample VEC02A13E_11.5; 4a, side view showing slightly curved suture partly filled by pustules; $4 \mathrm{~b}$, apertural view showing perforations; 4c, side view.

5. Cribroelphidium excavatum forma excavata (Terquem), specimen from sampleVEC02A13E_8; 5a, b side views showing sutures extending to the umbilicus and perforated surface.

6. Lobatula fletcheri (Galloway and Wissler), specimen from sample VEC02A13E_11.5; 6a, umbilical view showing coarse perforation; 6b, spiral view showing less perforation.

All scales are in $100 \mu \mathrm{m}$ except where otherwise indicated. 


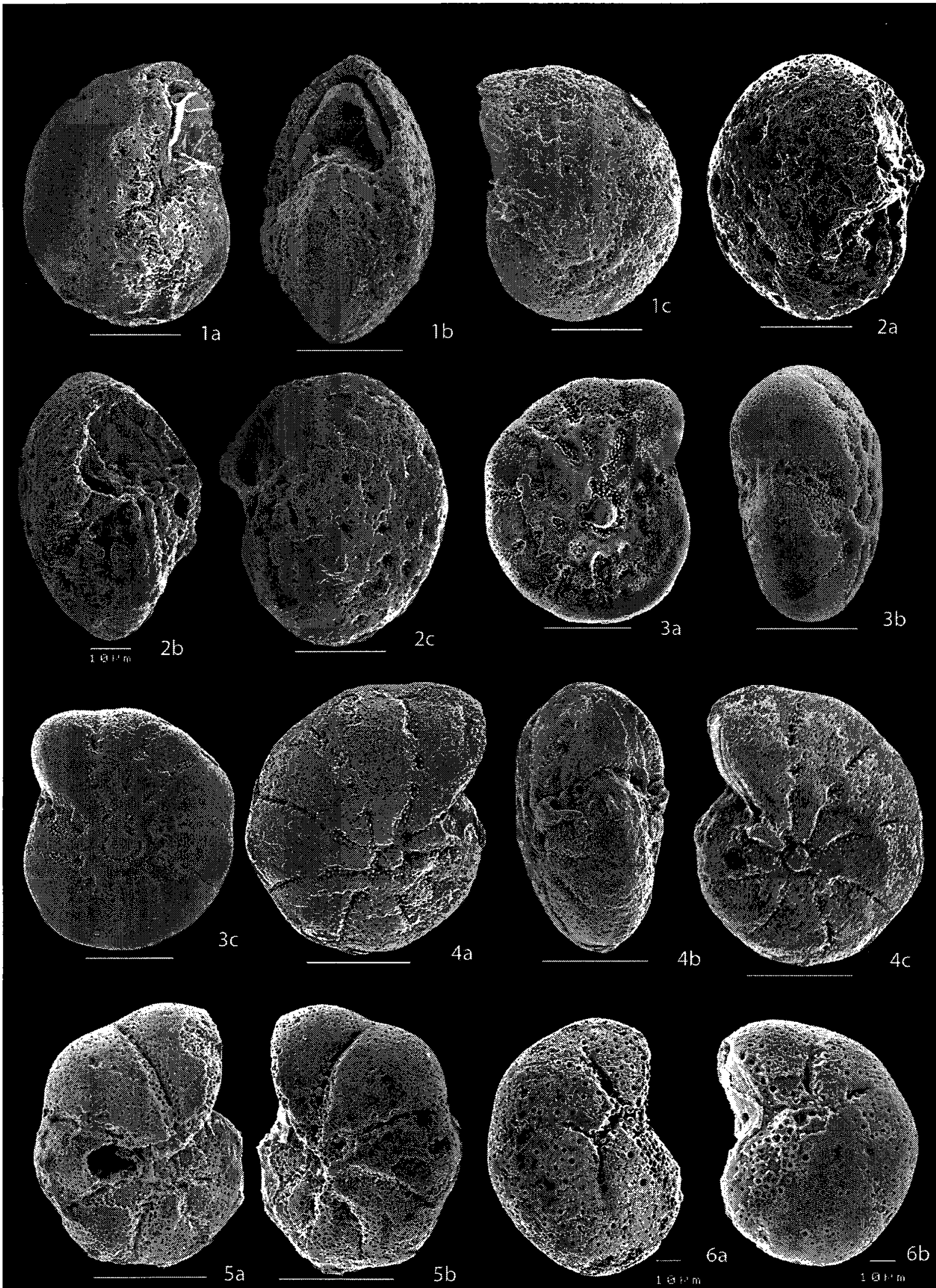




\section{PLATE 13}

All illustrated specimens are from the Mereworth Sound freeze core VEC02A13.

1. Cribroelphidium foraminosum (Cushman), specimen from sample VEC02A13E_8; 1a. side view showing coarsely perforate surface; $1 \mathrm{~b}$. edge view showing multiple apertural foramina; $1 \mathrm{c}$. side view showing less perforation.

2, 3. Lobatula fletcheri (Galloway and Wissier), Figures 1 and 2, from VEC02A13E_11.5; $2 a$, less perforate ventral view; $2 b$, edge view showing coarse perforation; $2 c$, dorsal view showing coarse perforation; $3 a$, coarsely perforated dorsal view; $3 b$, edge view showing flattened spiral side and apertural lip; $3 \mathrm{c}$, spiral view.

4-5. Bolivina minuta (Natland), Figure 4, from sample VEC02A13E_2; 4a. side view; 4b, apertural view showing lipped slit; $4 \mathrm{c}$. other side showing the apertural face. Figure 5, from VEC02A13E_10.5; shows side view.

6. Protoglobobulimina pupoides (d'Orbigny), specimen from sample VEC02A13E_6; shows strongly overlapping chambers, partially broken.

7. Nonionella sp., specimen from sample VEC02A13E_12.5, 6a, umbilical side showing depressed umbilicus, apertural opening extending to the umbilicus; $6 \mathrm{~b}$, side view showing arched, lipped aperture at the base large, final chamber, 6c, dorsal view showing straight, depressed sutures.

All scales are in $10 \mu \mathrm{m}$ except where otherwise indicated. 


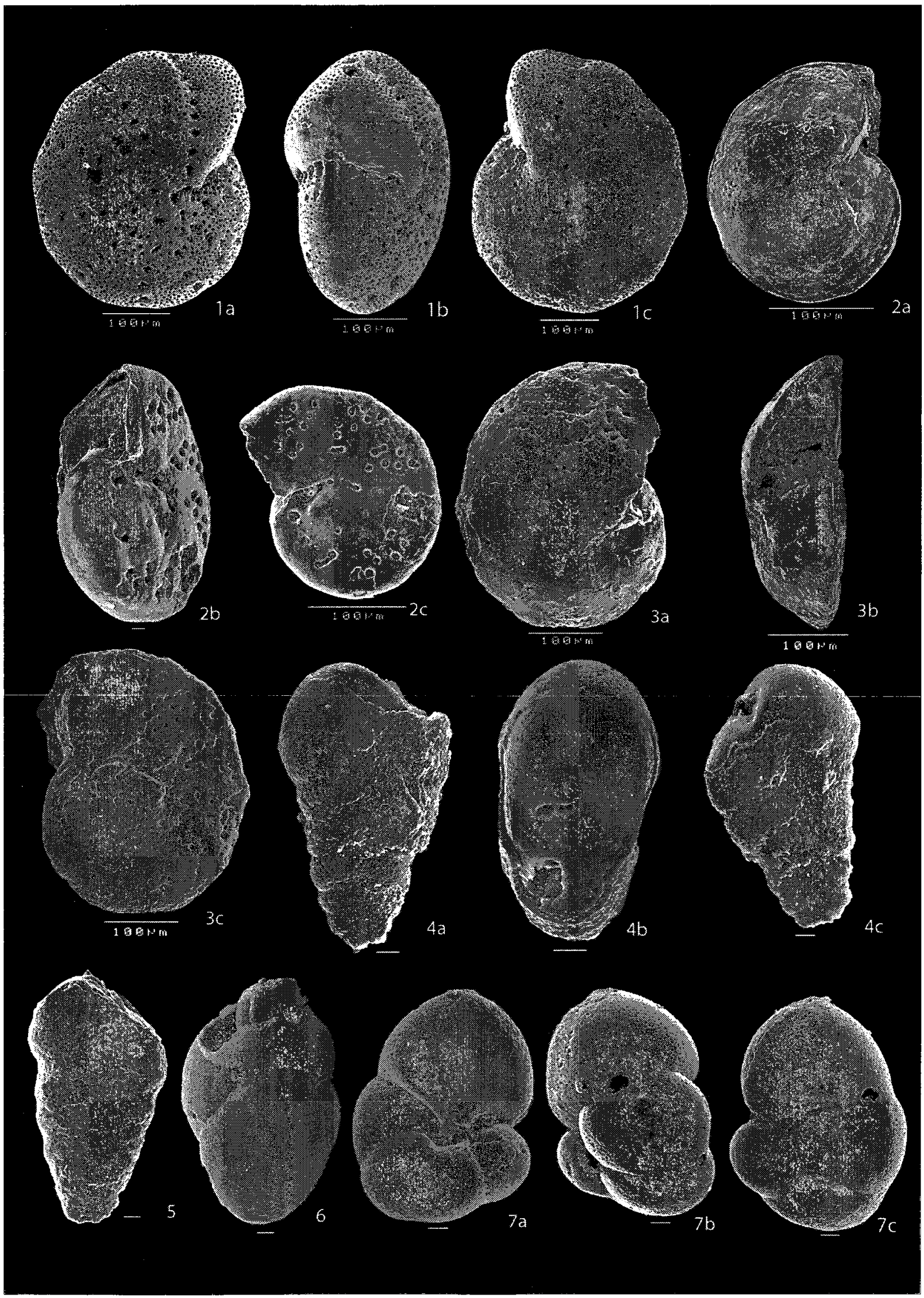




\section{PLATE 14}

All illustrated specimens are from the Mereworth Sound freeze core VEC02A13.

1. Buliminella elegantissima (d'Orbigny), from sample VEC02A13E_12.5; 1a, side view showing close spiral; $1 \mathrm{~b}$, side view showing aperture of the same specimen.

2,3. Euuvigerina peregrina (Cushman), Figure 2, from sample VEC02A13D_1; Figure 3, from sample VEC02A13C_2, $2 \mathrm{a}$ and $3 \mathrm{a}$ side views showing well developed longitudinal costae; $2 \mathrm{~b}$ and $3 \mathrm{~b}$, apertural views showing rounded aperture on top of tubular neck.

4. Euuvigerina cf. aculeata (d'Orbigny), specimen from sample VEC02A13B_10-12, 4a. side view showing elongated test, bases of eroded spines discernible; $4 \mathrm{~b}$, apertural view showing circular aperture at end of tubular neck.

5. Angulogerina angulosa (Williamson), specimen from sample VEC02A13E_11.5; 5a side view showing continuous longitudinal costae; $5 \mathrm{~b}$, apertural view showing circular aperture on short neck.

6, 7. Angulogerina fluens (Todd), Figure 6, from sample VEC02A13E_8; Figure 7, from sample VEC02A13E_6; 6a and 7a show continuous longitudinal costae in side views, costae less developed in Figure 7a; $6 \mathrm{~b}$ and $7 \mathrm{~b}$, show circular aperture on short neck of each of the specimen.

8,9. Stainforthia feylingi (Knudsen and Seidenkrantz), Figure 8 from sample VEC02A13B_6-8; Figure 9, from VEC02A13E_2; 8a, side view showing smooth, finely perforate test; $8 \mathrm{~b}$, side view showing fusiform test; $9 \mathrm{a}$, side view showing smooth, perforate test; $9 \mathrm{~b}$, enlarged apertural view showing toothplate.

10 Quinqueloculina sp, specimen from sample VEC02A13E_11.5, 10a, side view showing 3 chambers; 10b, apertural view.

All scales are in $10 \mu \mathrm{m}$ except where otherwise indicated. 

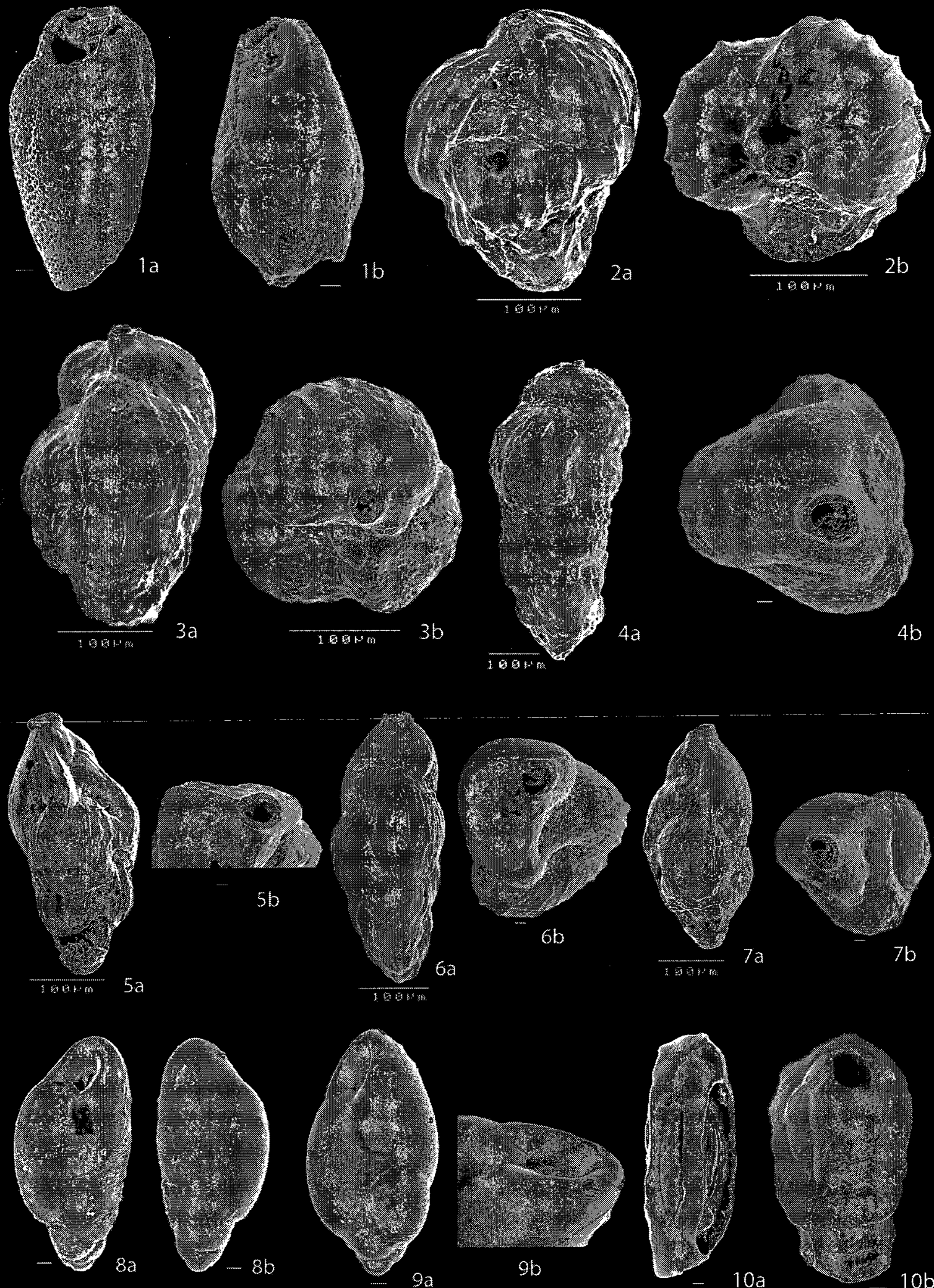
APPENDICES 
Appendix A. AMS Radiocarbon $\left({ }^{14} \mathrm{C}\right)$ Dating Results 


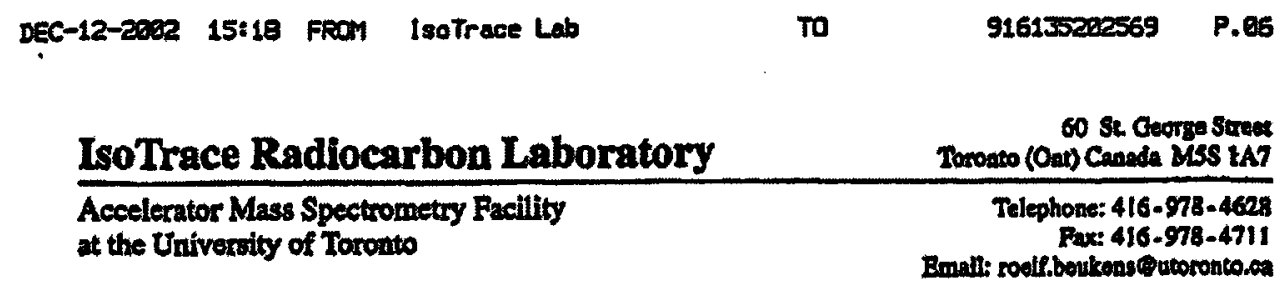

\section{Radiocarben Analysis Report}

December 12, 2002

Submitter. R.Thomson, Dept of Earth Sciences, Univ of BC, Vancouver BC

These reoults ane the average of 2 separate analyses (nommal precision) and ane comected for antural and aputtering isotope fractionation to a base of $8^{13} \mathrm{C}-25 \%$, using the measured ${ }^{13} \mathrm{CJ}^{12} \mathrm{C}$ ratios. The sample ag are quoted as unealibrated cocrventional radiocarbon dates in years beione present (BF), using the Libby ${ }^{14} \mathrm{C}$ menilfe of 8033 years. The exrors repreant $68.3 \%$ confidenoce timits.

\begin{tabular}{|c|c|c|c|c|}
\hline $\begin{array}{l}\text { Sample } \\
\text { Ldontifieation }\end{array}$ & lesertpdon & $\begin{array}{l}\text { Welght } \\
\text { used (mg) }\end{array}$ & $\begin{array}{l}\text { Isotrace } \\
\text { Lab nomber }\end{array}$ & $\begin{array}{c}\text { Ag* } \\
\text { (yeass BD) }\end{array}$ \\
\hline $\begin{array}{l}\text { VECO } \\
\text { VECO }\end{array}$ & $\begin{array}{l}\text { wood frats } \\
\text { wood fraps }\end{array}$ & $\begin{array}{l}283 \\
272\end{array}$ & $\begin{array}{l}\text { T0-10793 } \\
\text { To-10799 }\end{array}$ & $\begin{array}{l}3770 \pm 60 \\
5720 \pm 70\end{array}$ \\
\hline
\end{tabular}

I would like to hote your comments on these resultes If these results are used in a publication, I would appreciate it if you could send me a reprins. 
IsoTrace Radiocarbon Laboratory

Accelerator Mass Spectrometry Facility

at the University of Toronto
60 St, Georgo Street Toronto (On) Canads MSS IAT

Telephone: 416-978-4623

Fax: 416-978-4711

Email: roelf.beokens@utoronto.cs

\section{Radlocarbon Analysis Report}

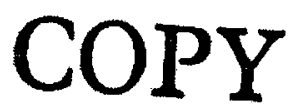

July 28,2003

Submitter: R.Thomson, Dept of Earth Sciences, Univ of BC, Vancouver BC

These results are the average of 2 separate analyses (normal precision) and are corrected for natural and aputtering isotope fractionation to a base of $\delta^{13} \mathrm{C}=-25 \%$, using the measured ${ }^{13} \mathrm{C}^{12} \mathrm{C}$ ratios. The samplis ages are quoted as uncalibrated conventional radiocarbon dates in years before present (BP), using the Libby ${ }^{14} \mathrm{C}$ meanlife of 8033 years. The errors represent $68.3 \%$ confidence limits.

\begin{tabular}{llccc}
$\begin{array}{l}\text { Sample } \\
\text { Identification }\end{array}$ & Description & $\begin{array}{c}\text { Weight } \\
\text { used (mg) }\end{array}$ & $\begin{array}{c}\text { IsoTrace } \\
\text { Lab number }\end{array}$ & $\begin{array}{c}\text { Age } \\
\text { (years BP) }\end{array}$ \\
\hline VEC02A04-1-97 & wood frage & 148 & TO-10788 & $1510 \pm 60$ \\
$*$ VEC02A04-3-132a & wood frag & 9 & TO-10789 & $2560 \pm 80$ \\
* VEC02A04-3-132b & wood frag & 47 & TO-10790 & $3050 \pm 60$ \\
* VECO2A04-7-126 & wig & 66 & TO-10791 & $4350 \pm 80$ \\
VEC02A07-1-27 & wood stick & 160 & TO-10794 & $1210 \pm 50$ \\
VEC02A07-2-118 & wood frag & 437 & TO-10795 & $1580 \pm 50$ \\
VEC02A07-2-134 & wood frags & 210 & TO-10796 & $1510 \pm 60$ \\
VECO2A07-3-140 & wood frag & 665 & TO-10797 & $1960 \pm 60$ \\
\hline
\end{tabular}

I would like to hear your comments on these results. If these results are used in a publication, I would appreciale it if you could send me a reprint. 
IsoTrace Radiocarbon Laboratory

Accelerator Mass Spectrometry Facility at the University of Tononto
60 St. George Street Tozonto (Ont) Canada MSS LAT

Tolephone: 416-978-4628

Fax: 416-978-4711

Email: roelf,beukens @utoronto.ca

\section{Radlocarbon Analysis Report}

April 24, 2003

Submitter: A.Dallimore, Geological Survey of Canada, Sidney BC

These rults are the average of 2 separate analyses (normal precision) and are corrected for atural and sputtering isotope fractionation to a base of $8^{13} \mathrm{C}=-25 \%$, using the measured ${ }^{13} \mathrm{C}^{12} \mathrm{C}$ ratios. The sample ages are quoted as uncalibrated correntional radiocarbon dates in years before present (BP), using the Libby ${ }^{14} \mathrm{C}$ meanifie of 8033 years. The enrors represent $68.3 \%$ confidence limits.

\begin{tabular}{llccc}
$\begin{array}{l}\text { Sample } \\
\text { Identification }\end{array}$ & Description & $\begin{array}{c}\text { Weight } \\
\text { used (mg) }\end{array}$ & $\begin{array}{c}\text { IsoTrace } \\
\text { Lab number }\end{array}$ & $\begin{array}{c}\text { Age } \\
\text { (years BP) }\end{array}$ \\
\hline EVEC02A04-2/3-16 & wood frag & 217 & T0-11082 & $3070 \pm 70$ \\
* VEC02A04-5-115 & pine cone & 146 & T0-11084 & $2540 \pm 70$ \\
VEC02A07-3-59 & wood fras & 111 & TO-11086 & $1460 \pm 60$ \\
VEC02A07-5-72 & wood tag & 200 & TO-L1088 & $2830 \pm 70$ \\
\hline
\end{tabular}

I would like to bear your comments on these results. If these resulis are used in a publication, I would appreciate it if you could send me a reprint. 
Iso'Trace Radiocarbon Laboratory

Accelerator Mass Spectrometry Facility at the University of Toronto
60 St. George Street Toronto (Ont) Canada MSS IA.7

Telephone: 416-978-4628

Fax: 416-978-4711

Bmail: roelf.beukens utoronto.cs

\section{Radiocarbon Analysis Report}

January 31, 2004

Submitter: A.Dallimore, Geological Survey of Canada, Sidney BC

These results are the average of 2 separate analyses (normal precision) and are corrected for natural and sputtering isotope fractionation, using the measured ${ }^{13} \mathrm{C}^{12} \mathrm{C}$ ratios. The sample ages are quoted as uncalibrated conventional radiocarbon dates in years before present (BP), using the Libby ${ }^{14} \mathrm{C}$ meanlife of 8033 years. The errons represent $68.3 \%$ confidence limits. TO- 11083 was badly preserved and did not yield suffieient datable carbon for a reliable analysis.

\begin{tabular}{llcccc}
$\begin{array}{l}\text { Sample } \\
\text { Ideatification }\end{array}$ & Deseription & $\begin{array}{c}\text { Weight } \\
\text { used (mg) }\end{array}$ & $\begin{array}{c}\text { LsoTrace } \\
\text { Lab number }\end{array}$ & $\begin{array}{c}\text { Age } \\
\text { (years Bp) }\end{array}$ \\
\hline VEC02A04-109 & twig & 11 & TO-11083 & & \\
VEC02A07-2-79 & wood frag & 89 & TO-11085 & $1490 \pm 100$ \\
VECO2A07-4/5-18 & wood frag & 479 & TO-11087 & $2640 \pm 60$ \\
VECO2A07-5-108 & wood frag & 55 & TO-11089 & $2910 \pm 60$ \\
VECO2A07-4-124 & wood frag & 17 & TO-10798 & $3720 \pm 60^{-}$ \\
\hline
\end{tabular}

I would like to hear your comments on these results. If these results are used in a publication, I would appreciate it if you could send me a reprint. 
IsoTrace Radiocarbon Laboratory

Accelerator Mass Spectrometry Facility

at the University of Toronto
$60 \mathrm{St}$ George Street Toronto (Ont) Canada MSS LA?

Telephone: $416-978-4628$

Fax: 416-978-4711

Email: roelf.beukens (utoronto.ca

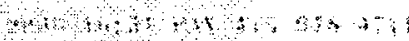

\author{
Radlocarbon Analysts Report \\ October 28, 2006
}

Submitter. R.T.Patterson, Dept of Earth Sciences, Carteton Univ, Ottawa ON

These results are the average of 2 separate analyses (normal precision) and are conrected for natural and sputtering isotope fractionation, using the measured ${ }^{13} \mathrm{C}^{12} \mathrm{C}$ ratios. The sample ages are quoted as uncalibrated conventional radiocarbon dates in years before present (BP), using the Libby ${ }^{14} \mathrm{C}$ meanlife of 8033 years. The errors represent $68.3 \%$ confidence limits.

\begin{tabular}{|c|c|c|c|c|}
\hline $\begin{array}{l}\text { Sample } \\
\text { Identification }\end{array}$ & Deseription & $\begin{array}{l}\text { Weight } \\
\text { used (mg) }\end{array}$ & $\begin{array}{l}\text { IsoTrace } \\
\text { Lab number }\end{array}$ & $\begin{array}{c}\text { Age } \\
\text { (years BP) }\end{array}$ \\
\hline VBC02A05B-17 & wood frags & 18 & T0-13056 & $580 \pm 60$ \\
\hline VEC02A05D-8 & bulk sediment & 942 & TO-13057 & $1720 \pm 50$ \\
\hline $\begin{array}{l}\text { VECO2A13C-9 } \\
\text { VECO2A13H-3 }\end{array}$ & $\begin{array}{l}\text { plant materials } \\
\text { balk sediments }\end{array}$ & $\begin{array}{l}80 \\
1200\end{array}$ & $\begin{array}{l}\text { TO-13058 } \\
\text { TO-13059 }\end{array}$ & $\begin{array}{r}470 \pm 60 \\
3060 \pm 50\end{array}$ \\
\hline
\end{tabular}

I would like to hear your comments on these cesults. If these results are used in a publication, I would eppreciate it if you could send me a reprint. 
ISOTRACE RADIOCARBON CALIBRATION REPORT

output by calibration program C14CALO4 Copyright (c) R.P.Beukens

28-0ct-06

TO-13058 VEC02A13C-9 plant materials

Radiocarbon date : $470 \pm 60 \mathrm{BP}$

All solutions, with a probability of 50 f or greater for the calibrated age of this radiocarbon date, have been calculated from the dendro calibration data. The $68 \%$ and 958 confidence intervals, which are the 10 and $2011 \mathrm{mits}$ for a normal distribution, are aloo given. A probability of 100 meane the radiocarbon date intersects the dendro calibration curve at this age.

All results are rounded to the nearest multiple of 5 years.

\begin{tabular}{cccc} 
Probability & $\mathrm{cal}$ Age & $68.3 \mathrm{c.1}$ & $95.5 \mathrm{c.1}$ \\
\hline $100 *$ & $1435 \mathrm{cal} \mathrm{AD}$ & $1410 \mathrm{AD}-1450 \mathrm{AD}$ & $1390 \mathrm{AD}-1510 \mathrm{AD}$
\end{tabular}

Calibrated with the standard data set from:

Irrcal04 Texrestrial Radiocarbon Age Calibration, $0-26$ cal kyx BP

P.J.Reimer et al.; Radiocarbon $46 \$ 3$ (2004) p1029

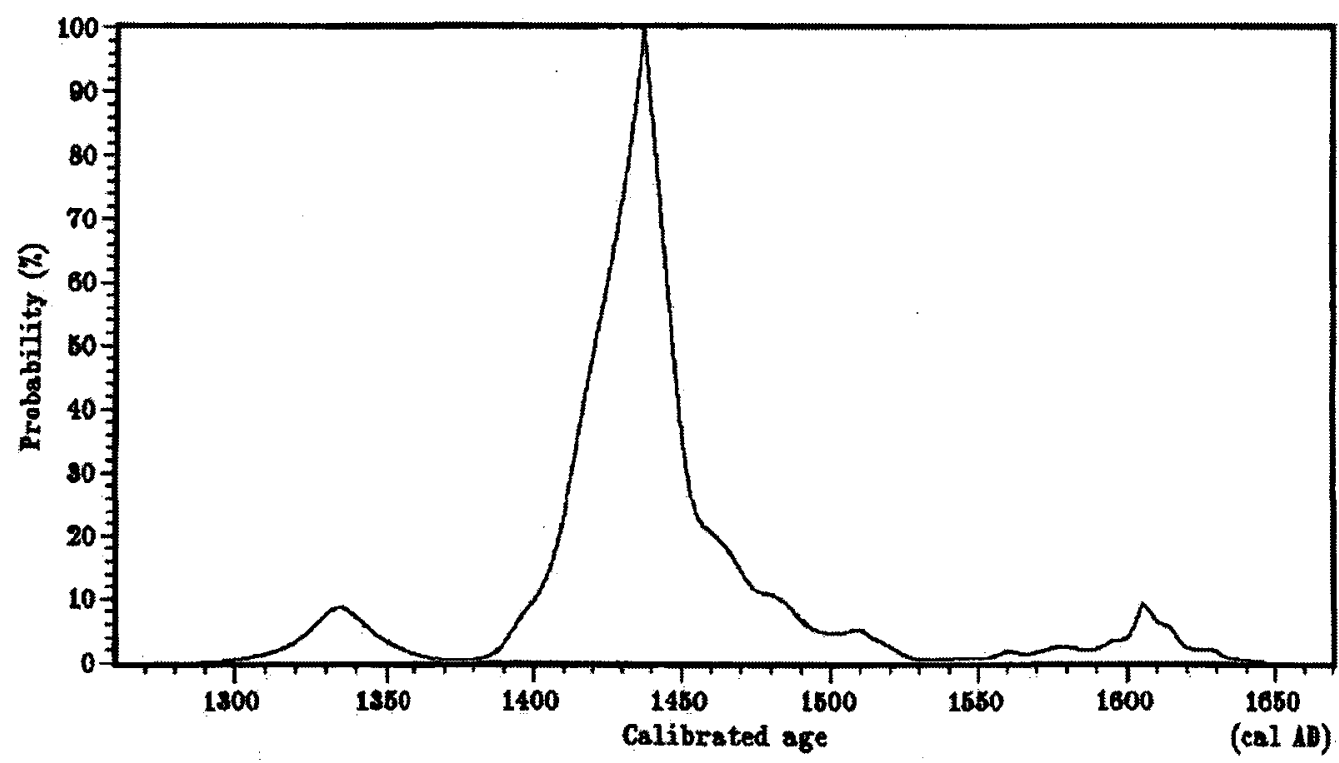


ISOTRACB RADTOCARBON CALTBRATION RBPORT

output by calibration program C14CALO4

Copyright (c) R.P. Beukeno

28-0ct-06

TO-13059 VBC02A13R-3 bulk Bedimenta

Radlocarbon date: $3060 \pm 50 \mathrm{BP}$

All solutions, with a probability of 50 or gxeater for the calibrated age of this radiocarbon date, have been calculated from the dendro calibration data. The $68 \%$ and $95 \%$ confidence intervals, which are the 10 and 20 limits for noxmal distribution, are also given. A probability of 100 means the radiocarbon date intersects the desdro calibration curve at this age. All resulta are rounded to the nearest multiple of 5 years.

\begin{tabular}{ccccc} 
Rrobability & cal Age & $68.3 * c .1$. & $95.5 * 0 . \dot{ }$ \\
\hline 100 & $1370 \mathrm{cal} \mathrm{BC}$ & $1405 \mathrm{BC}-1260 \mathrm{BC}$ & $1430 \mathrm{BC}-1190 \mathrm{BC}$ \\
100 & $1340 \mathrm{cal} \mathrm{BC}$ & $1405 \mathrm{BC}-1260 \mathrm{BC}$ & $1430 \mathrm{BC}-1190 \mathrm{BC}$ \\
100 & $1315 \mathrm{cal} \mathrm{BC}$ & $1405 \mathrm{BC}-1260 \mathrm{BC}$ & $1430 \mathrm{BC}-1190 \mathrm{BC}$
\end{tabular}

Calibrated with the standard data set from:

INTCALO4 Terrestrial Radiocarbon Age Calibration, $0-26 \mathrm{cal} \mathrm{kyr}$ BP P.J.Reimer et al.; Radiocarbon $46 \% 3$ (2004) p1029

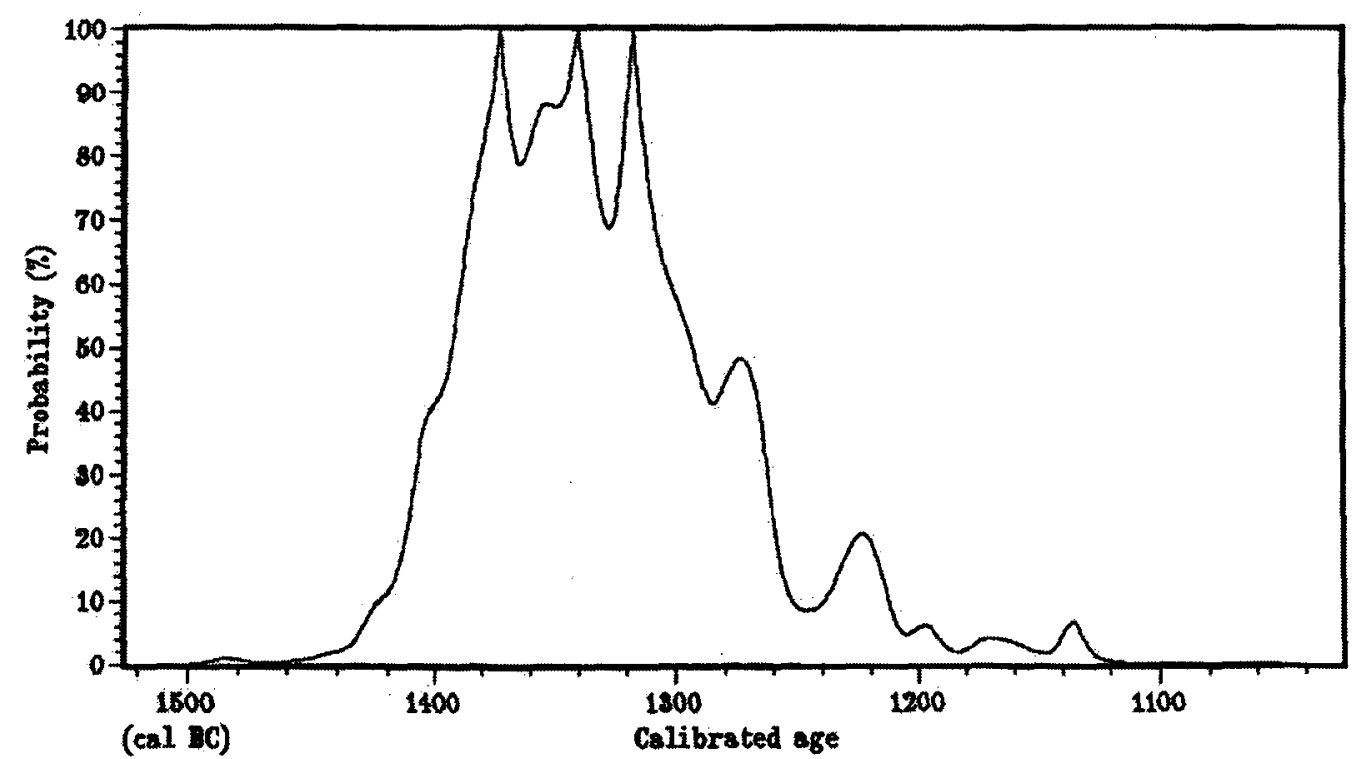


ISOTRACE RADIOCARBON CALIBRATION GUMMARY Output by calibration progran C14CAL04 Copyright (c) R.p.Beukens

28-0ct-06

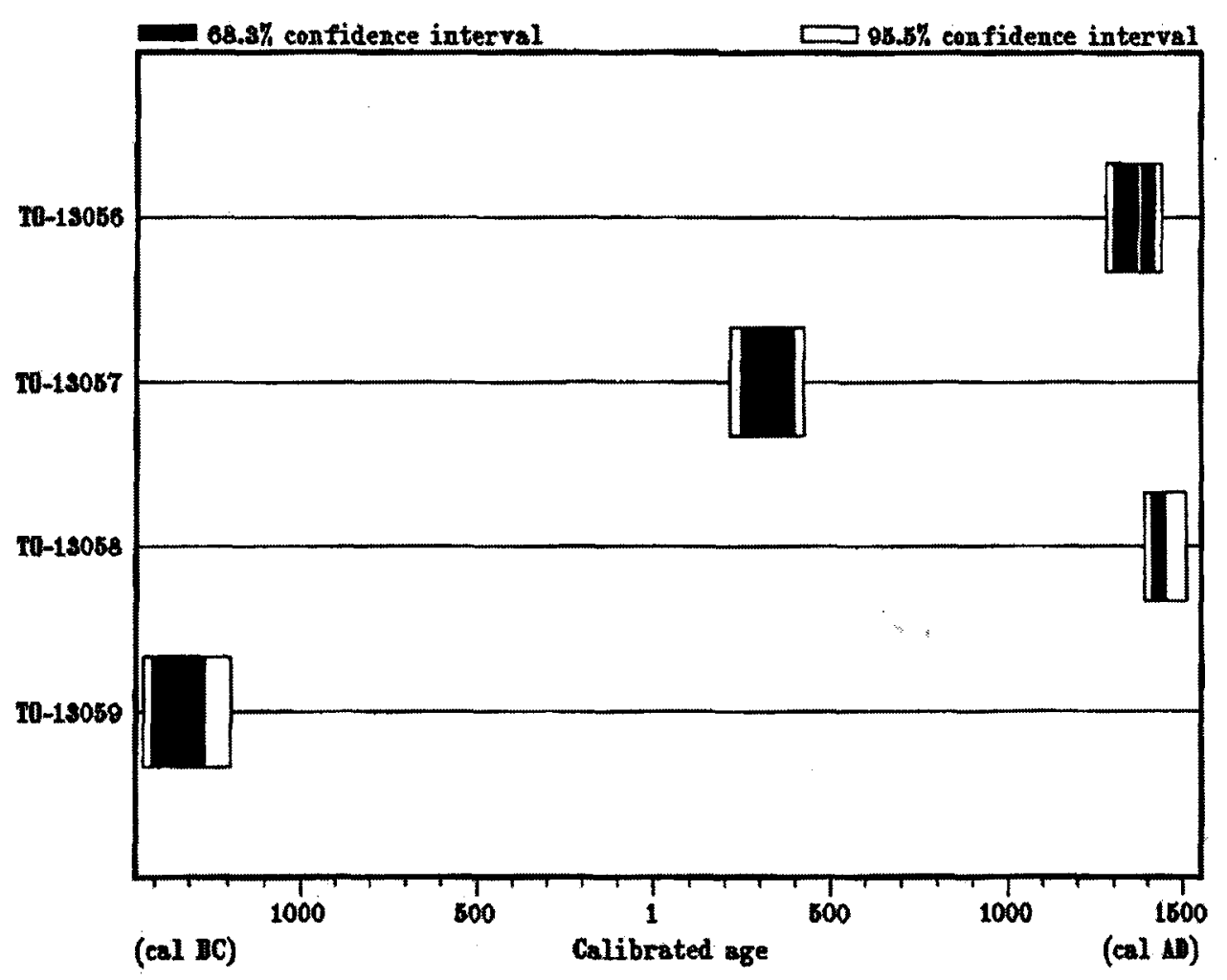




\section{IsoTrace Radiocarbon Laboratory}

Accelerator Mass Spectrometry Facility at the University of Toronto
60 St. George Street Toronto (Ont) Canada MSS IA7

Telephone: $416-978-4628$

Fax: $416-978-4711$

Email: roelf.beukens@utoronto.ca

\section{Radiocarbon Analysis Report}

December 15,2006

Submitter: T.Patterson, College of Natural Sciences, Carleton Univ, Ottawa ON

These results are the average of 2 separate analyses (normal precision) and are corrected for natural and sputtering isotope fractionation, using the measured ${ }^{13} \mathrm{C} /{ }^{12} \mathrm{C}$ ratios. The sample ages are quoted as uncalibrated conventional radiocarbon dates in years before present (BP), using the Libby ${ }^{14} \mathrm{C}$ meanlife of 8033 years. The errors represent $68.3 \%$ confidence limits.

\begin{tabular}{llccc}
$\begin{array}{l}\text { Sample } \\
\text { Identification }\end{array}$ & Description & $\begin{array}{c}\text { Weight } \\
\text { used (mg) }\end{array}$ & $\begin{array}{c}\text { IsoTrace } \\
\text { Lab number }\end{array}$ & $\begin{array}{c}\text { Age } \\
\text { (years BP) }\end{array}$ \\
\hline VEC02A05D_I & wood frags & 16 & TO-13153 & $780 \pm 50$ \\
VEC02A13E_10.5 & wood frags & 24 & TO-13154 & $490 \pm 50$ \\
\hline
\end{tabular}

I would like to hear your comments on these results. If these results are used in a publication, I would appreciate it if you could send me a reprint. 
ISOTRACE RADIOCARBON CALIBRATION SUMMARY

Output by calibration program C14CALO4

copyright (c) R.P.Beukens

15-Dec-06

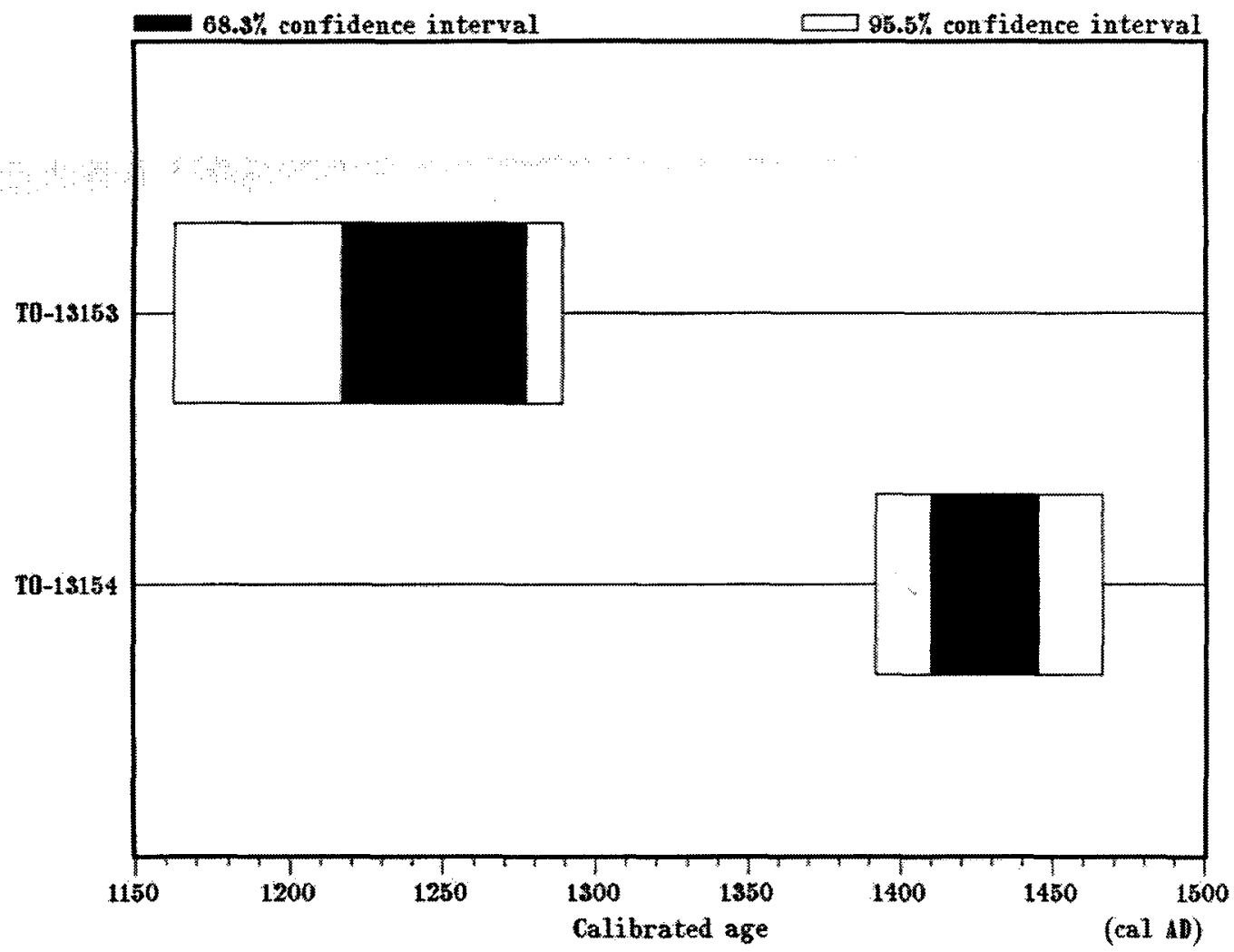


IsoTrace Radiocarbon Laboratory

Accelerator Mass Spectrometry Facility at the University of Toronto
60 St. George Street Toronto (Ont) Canada MSS IA7

Telephone: $416 \cdot 978 \cdot 4628$ Fax: $416-978-4711$

Email: roelf.beukens@utoronto.ca

\section{Radiocarbon Analysis Report}

February 10,2007

Submitter. T.Patterson, College of Natural Sciences, Carleton Univ, Ottawa ON

This result is the average of 2 separate analyses (normal precision) and is corrected for natural and sputtering isotope fractionation, using the measured ${ }^{13} \mathrm{C}^{12} \mathrm{C}$ ratio. The sample age is quoted as an uncalibrated conventional radiocarbon date in years before present (BP), using the Libby ${ }^{14} \mathrm{C}$ meanlife of 8033 years. The error represents the $68.3 \%$ confidence limit.

\begin{tabular}{llccc}
$\begin{array}{l}\text { Sample } \\
\text { Identification }\end{array}$ & Description & $\begin{array}{c}\text { Weight } \\
\text { used (mg) }\end{array}$ & $\begin{array}{c}\text { IsoTrace } \\
\text { Lab number }\end{array}$ & $\begin{array}{c}\text { Age } \\
\text { (years BP) }\end{array}$ \\
\hline VEC02A13H_17 & wood frag & 53 & TO-13190 & $230 \pm 50$ \\
\hline
\end{tabular}

I would like to hear your comments on this result. If this result is used in a publication, I would appreciate it if you could send me a reprint. 


\begin{abstract}
ISOTRACE RADIOCARBON CAIIBRATION REPORT Output by calioration program C14CALOA Copyright (c) F.P.Beukens
\end{abstract}

10-Feb-07

TO-13190 VEC02A13H】_17 wood frag

Radiocarbon date : $230 \pm 50 \mathrm{BP}$

All solutions, with a probability of $50 \%$ or greater for the calibrated age of this radiocarbon date, have been calculated from the dendro calibration data. The 68\% and $95 \%$ confidence intervals, which are the 10 and 20 ilmits for a normal distribution, are also given. A probability of 100 means the radiocarbon date intersects the dendro calibration curve at this age. All results are rounded to the nearest multiple of 5 years.

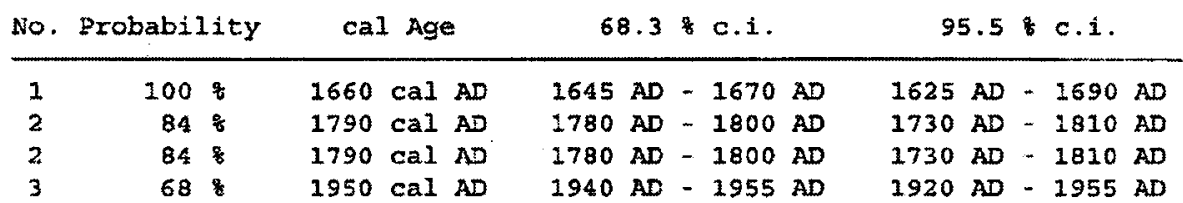

Calibrated with the standard data set from:

INTCAL04 Terrestrial Radiocarion Age Calibration, $0-26$ cal kyr bP

P.J.Reimer et al.; Radiocarbon 46.3 (2004) p1029

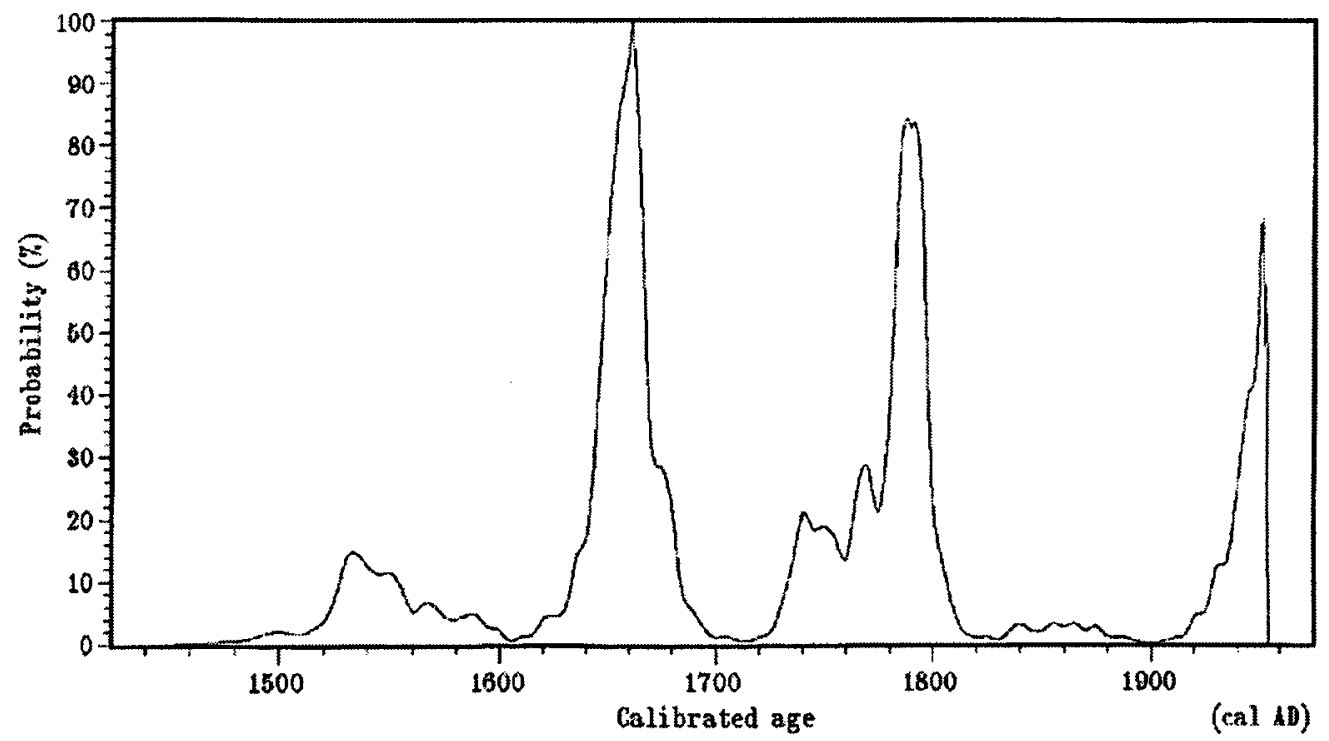




\section{BETA ANALYTIC INC.}

4985 S.W. 74 COURT

BETA

\section{REPORT OF RADIOCARBON DATING ANALYSES}

Dr. Lamidi Olabode Babalola

Carleton University
Report Date: 2/20/2009

Material Received: 1/28/2009

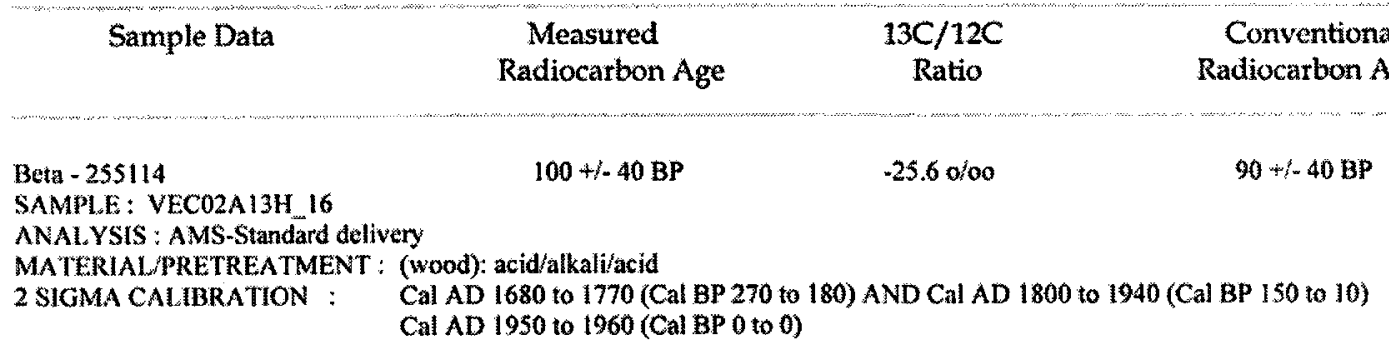

Dates are reported as RCYBP (radiocarbon years before present, "present" = AD 1950), By international convention, the modern reference standard was $95 \%$ the $14 \mathrm{C}$ activity of the National Institute of Standards and Technology (NIST) Oxalic Acid (SRM 4990C) and calculated using the Liboy $14 \mathrm{C}$ half-iffe $(5568$ years). Quoted errors represent 1 relative standard deviation statistics (68\% probability) counting errors based on the combined measurements of the sample, background, and modern reference standards. Measured $13 \mathrm{C} / 12 \mathrm{C}$ ratios (delta $13 C$ ) were calculated relative to the PDB 1 standard
The Conventional Radiocarbon Age represents the Measured Radiocarbon Age corrected for isotopic fractionation, calculated using the delta $13 \mathrm{C}$. On rare occasion where the Conventional Radiocarbon Age was calculated using an assumed delta $13 \mathrm{C}$ the ratio and the Conventional Radiocabon Age will be followed by The Conventionat Radiocarbon Age is not calendar calibrated. When available, the Calendar Calibrated result is calculated from the Conventional Radiocarbon Age and is listed as the "Two Sigma Calibrated Result" for each sample. 


\section{CALIBRATION OF RADIOCARBON AGE TO CALENDAR YEARS}

(Variables: $\mathrm{C} 13 / \mathrm{C} 12=-25.6: \mathrm{lab}, \mathrm{mult}=1$ )

Laboratory number: Beta-255114

Conventional radiocarbon age: $90 \pm 40 \mathrm{BP}$

2 Sigm a calibrated results: Cal AD 1680 to 1770 (Cal BP 270 to 180) and (95\% probability) Cal AD 1800 to 1940 (Cal BP 150 to 10) and

Cal AD 1950 to 1960 (Cal BP 0 to 0 )

Intercept data

Intercepts of radiocarbon age

with calibration curve:

Cal AD 1890 (Cal BP 60) and

Cal AD 1910 (Cal BP 40) and

Cal AD 1950 (Cal BP 0)

1 Sigma calibrated results: Cal AD 1690 to 1730 (Cal BP 260 to 220) and (68\% probability) Cal AD 1810 to 1920 (Cal BP 140 to 30 ) and

Cal AD 1950 to 1960 (Cal BP 0 to 0 )

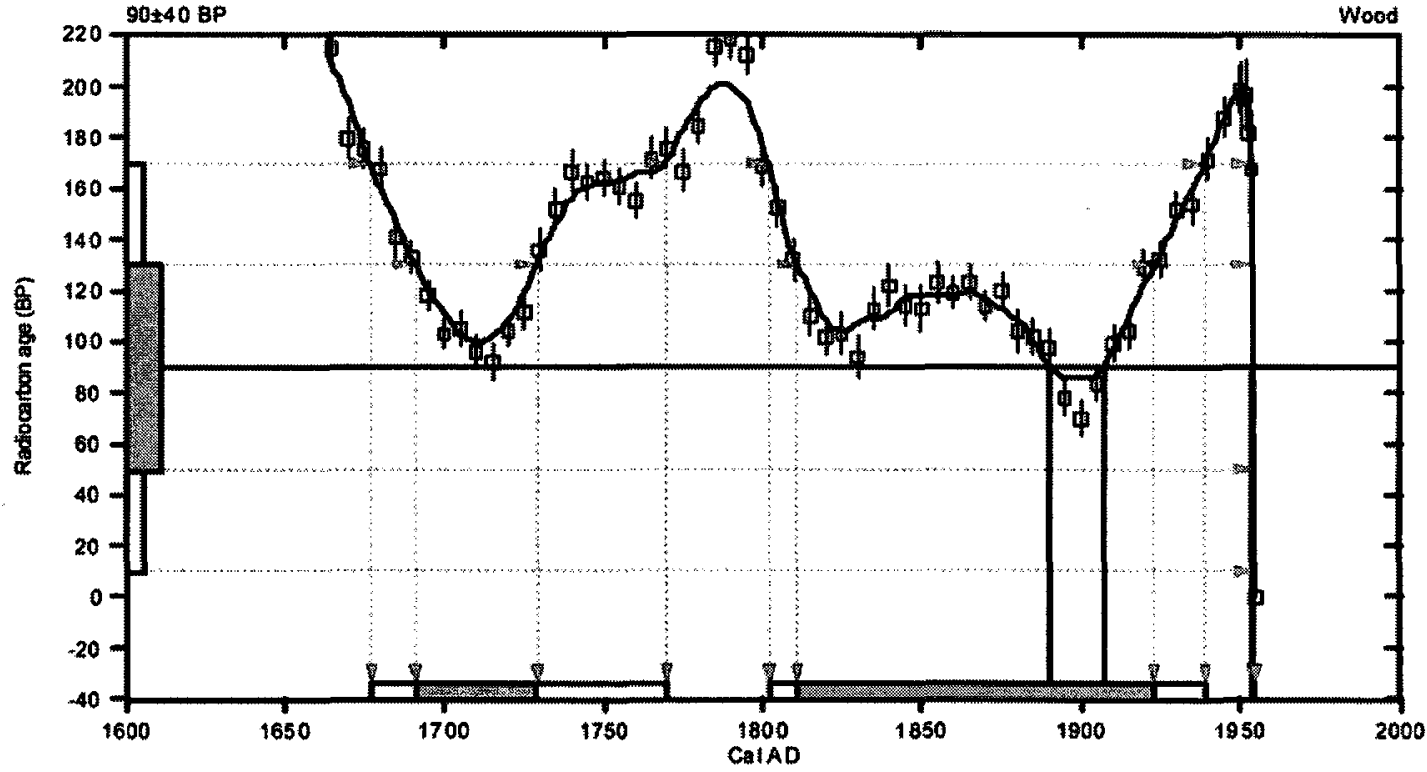

References:

Dafabase used

INTCALOA

Calibration Database

INTCALO4 Radiocarbon Age Calibration

IncalOA: Caltbration lssue of Radiocarbon (Voltume 46, $\mathrm{nr}$ 3, 2004).

Mathematics

A Simplifted Approach to Callbrating C14 Dates

Talma. A.S. Vogel. J. C., 1993, Radiocarbon 35(2), p317.322

Beta Analytic Radiocarbon Dating Laboratory

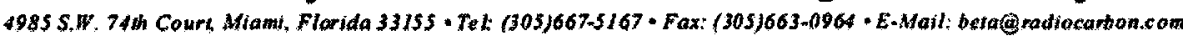


Appendix B. Fractional abundances and reconstructed variables in SBIC 
Appendix B 1. Foraminiferal and thecamoebian fractional abundances in the Frederick Sound.

\begin{tabular}{|c|c|c|c|c|c|c|c|c|c|c|c|c|c|c|}
\hline 苋 & 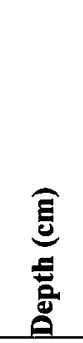 & 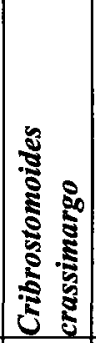 & 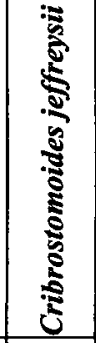 & 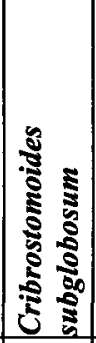 & 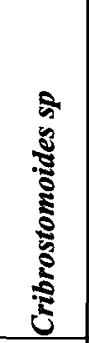 & 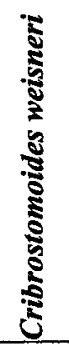 & 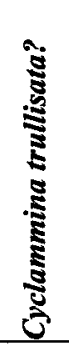 & 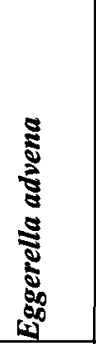 & 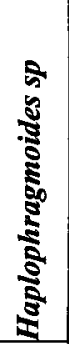 & 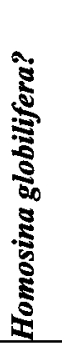 & 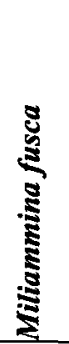 & 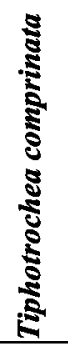 & 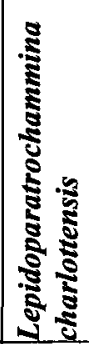 & 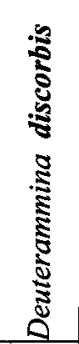 \\
\hline VEC02A04S1_10-20 & 10 & & 0.025 & 0.017 & 0.008 & & & 0.59 & & & & & 0.033 & \\
\hline VEC02A04S1_20-30 & 20 & & 0.048 & 0.016 & & & & 0.68 & & & & & 0.032 & \\
\hline VEC02A04S1_30-45 & 30 & & 0.026 & 0.038 & & & & 0.53 & & & & & 0.064 & 0.013 \\
\hline VEC02A04S1_45-60 & 45 & & 0.026 & 0.026 & & & & 0.58 & & & & & & \\
\hline VEC02A04S1_60-70 & 60 & 0.022 & 0.055 & & & & & 0.50 & & & & & 0.132 & \\
\hline VEC02A04S1_70-80 & 70 & & 0.011 & & & & & 0.69 & & & & & & \\
\hline VEC02A04S1_80-85 & 80 & & 0.011 & 0.011 & & & & 0.83 & & & & & 0.043 & \\
\hline VEC02A04S1_85-90 & 85 & & 0.016 & & & & & 0.54 & & & & & 0.016 & \\
\hline VEC02A04S1_90-95 & 90 & & 0.041 & 0.020 & & & & 0.53 & & & & & 0.020 & \\
\hline VEC02A04S1_95-100 & 95 & 0.010 & 0.020 & & 0.020 & & & 0.61 & & & & & 0.060 & \\
\hline VEC02A04S1_110-120 & 110 & & 0.091 & & & & & 0.57 & & & & & 0.057 & \\
\hline VEC02A04S1_120-130 & 120 & & 0.009 & & & & & 0.80 & & & & & 0.018 & \\
\hline VEC02A04S1_130-135 & 130 & 0.010 & 0.048 & & & & & 0.53 & & & & & 0.038 & \\
\hline VEC02A04S1_135-137 & 135 & & 0.022 & 0.022 & & & & 0.71 & & & & & & \\
\hline VEC02A04S3_0-10 & 325 & & 0.042 & & & & & 0.72 & & & & & 0.014 & \\
\hline VEC02A04S3_10-15 & 335 & 0.011 & 0.067 & & & & & 0.72 & & & & & 0.011 & \\
\hline VEC02A04S3_15-25 & 340 & & & & & & & 0.70 & & & & & 0.011 & \\
\hline VEC02A04S3_25-30 & 350 & & 0.038 & & & & & 0.57 & & & & & 0.019 & \\
\hline VEC02A04S3_30-35 & 355 & 0.017 & 0.017 & & & & & 0.58 & & & & & 0.034 & 0.017 \\
\hline VEC02A04S3_35-40 & 360 & 0.007 & 0.029 & & & & & 0.84 & & & & & 0.007 & 0.007 \\
\hline VEC02A04S3_40-45 & 365 & & 0.073 & 0.024 & & & & 0.53 & & & & & 0.019 & \\
\hline VEC02A04S3_45-50 & 370 & & 0.024 & 0.003 & & & & 0.66 & & & & & & \\
\hline VEC02A04S3_50-55 & 375 & 0.012 & 0.012 & & & & & 0.54 & & & & & & \\
\hline VEC02A04S3_55-65 & 380 & 0.017 & & 0.017 & & & & 0.81 & & & & & & \\
\hline VEC02A04S3_65-75 & 390 & 0.009 & 0.027 & & & & & 0.69 & & & & & 0.009 & 0.009 \\
\hline VEC02A04S3_75-80 & 400 & & 0.052 & & & & & 0.75 & & & & & 0.026 & \\
\hline VEC02A04S3_80-85 & 405 & & 0.016 & 0.031 & & & & 0.80 & & & & & 0.031 & 0.016 \\
\hline VEC02A04S3_85-90 & 410 & & 0.023 & & & & & 0.68 & & & & & 0.023 & \\
\hline
\end{tabular}




\begin{tabular}{|c|c|c|c|c|c|c|c|c|c|c|c|c|c|c|}
\hline 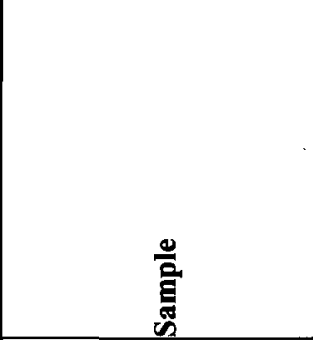 & 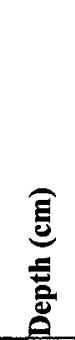 & 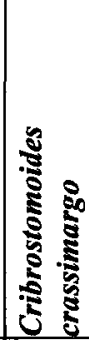 & 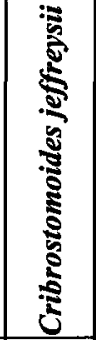 & 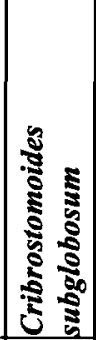 & 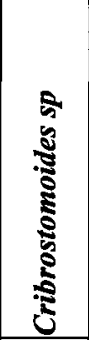 & 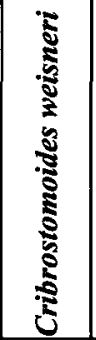 & 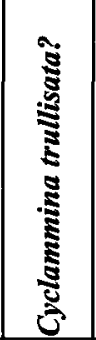 & 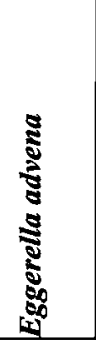 & 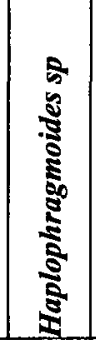 & 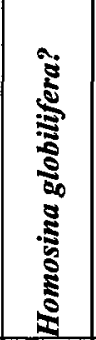 & 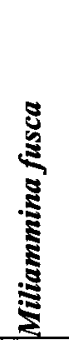 & 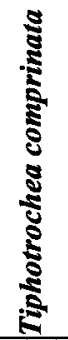 & 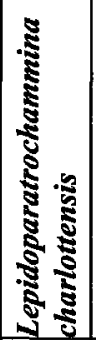 & 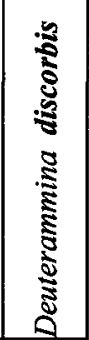 \\
\hline VEC02A04S3_90-95 & 415 & 0.032 & 0.065 & 0.048 & & & & 0.68 & & & & & 0.048 & \\
\hline VEC02A04S3_95-100 & 420 & & 0.045 & & & & & 0.73 & & 0.023 & & & & \\
\hline VEC02A04S3_105-110 & 430 & & 0.033 & & & & & 0.77 & & & & & 0.008 & \\
\hline VEC02A04S3_110-115 & 435 & 0.010 & 0.020 & & & & & 0.81 & & & & & $0.020 \mid$ & \\
\hline VEC02A04S3_115-120 & 440 & & 0.019 & & & & & 0.79 & & & & & 0.009 & \\
\hline VEC02A04S3_120-125 & 445 & 0.034 & & & & & & 0.76 & & & & & & \\
\hline VEC02A04S3_125-137 & 450 & & 0.049 & 0.024 & & & & 0.88 & & & & & & \\
\hline VEC02A04S4_10-25 & 472 & & 0.032 & & & & & 0.76 & & & & & 0.016 & \\
\hline VEC02A04S4_25-35 & 487 & & 0.032 & & & & & 0.65 & & & & & 0.016 & \\
\hline VEC02A04S4_35-40 & 497 & 0.036 & 0.036 & 0.055 & & & & 0.73 & & & & & 0.018 & \\
\hline VEC02A04S4_40-45 & 502 & 0.010 & 0.029 & & & & & 0.77 & & & & & 0.010 & \\
\hline VEC02A04S4_45-60 & 507 & & 0.026 & & & & & 0.90 & & & & & & \\
\hline VEC02A04S4_60-65 & 522 & & 0.031 & & & & & 0.78 & & & & & & \\
\hline VEC02A04S4_65-70 & 527 & & & & & & & 0.87 & & & & & & \\
\hline VEC02A04S4_70-75 & 532 & & & & 0.011 & & 0.011 & 0.32 & 0.011 & & & & 0.043 & \\
\hline VEC02A04S4_75-80 & 537 & & 0.071 & & & & & 0.64 & & & & & 0.020 & \\
\hline VEC02A04S4_80-85 & 542 & & 0.027 & & & & & 0.71 & & & & & 0.009 & \\
\hline VEC02A04S4_85-90 & 547 & & 0.020 & & & & & 0.74 & & & & & 0.020 & \\
\hline VEC02A04S4_90-100 & 552 & & 0.011 & & & & & 0.78 & & & & & 0.011 & \\
\hline VEC02A04S4_100-105 & 557 & & 0.031 & & & & & 0.67 & & & & & 0.013 & 0.004 \\
\hline VEC02A04S4_105-110 & 567 & & 0.070 & & & & & 0.70 & & & & & 0.047 & \\
\hline VEC02A04S4_110-115 & 572 & & 0.017 & & & & & 0.69 & & & & & 0.008 & 0.008 \\
\hline VEC02A04S4_115-120 & 577 & & 0.092 & & & & & 0.69 & & & & & & 0.007 \\
\hline VEC02A04S4_120-130 & 582 & 0.008 & 0.096 & & & & & 0.56 & & & & & 0.016 & 0.008 \\
\hline VEC02A04S4_130-140 & 592 & & 0.055 & & & & & 0.67 & & & & & 0.014 & \\
\hline VEC02A04S4_140-145 & 602 & & 0.022 & & & & & 0.70 & & & & & 0.015 & \\
\hline VEC02A04S4_150-155 & 612 & & 0.014 & & & & & 0.70 & & & & & 0.014 & \\
\hline VEC02A04S4_155-157 & 617 & & 0.062 & & & & & 0.68 & & & & & 0.005 & \\
\hline VEC02A04S5_0-5 & 619 & 0.015 & 0.007 & & & 0.007 & & 0.64 & & & & & & \\
\hline VEC02A04S5_5-10 & 624 & 0.021 & & & & & & 0.79 & & & & & & \\
\hline VEC02A04S5_10-15 & 629 & 0.012 & & & & & & 0.77 & & & & & 0.024 & \\
\hline VEC02A04S5_15-20 & 634 & & & & & & & 0.84 & & & & & 0.008 & \\
\hline VEC02A04S5_20-25 & 639 & 0.018 & 0.018 & & & & & 0.75 & & & & & 0.018 & \\
\hline VEC02A04S5_25-30 & 644 & & 0.023 & & & & & 0.74 & & & & & & \\
\hline VEC02A04S5_30-40 & 649 & & & & & & & 0.79 & & & & & 0.016 & \\
\hline
\end{tabular}


Appendix B1. CONTD.

\begin{tabular}{|c|c|c|c|c|c|c|c|c|c|c|c|c|c|c|}
\hline 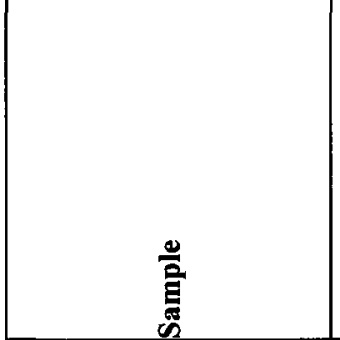 & 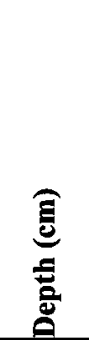 & 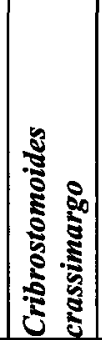 & 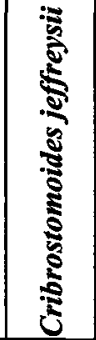 & 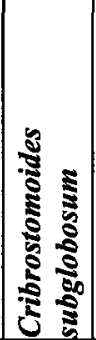 & 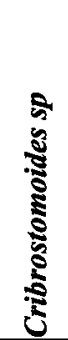 & 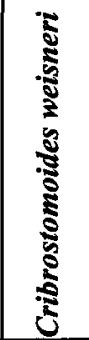 & 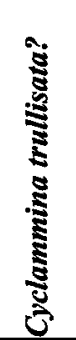 & 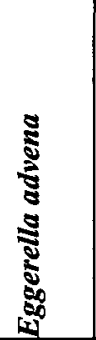 & 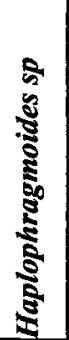 & 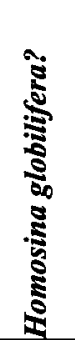 & 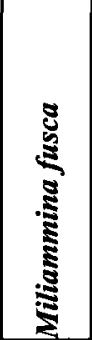 & 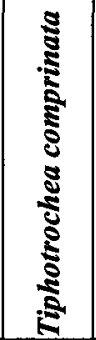 & 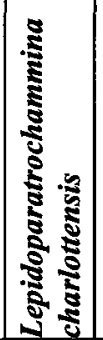 & 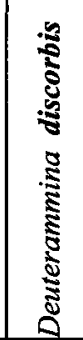 \\
\hline VEC02A04S5_40-45 & 659 & & & & & & & 0.82 & & & & & & \\
\hline VEC02A04S5_45-50 & 664 & & 0.008 & & & & & 0.79 & & & & & & \\
\hline VEC02A04S5_50-55 & 669 & & 0.008 & & & & & 0.78 & & & & & 0.030 & 0.004 \\
\hline VEC02A04S5_55-60 & 674 & 0.025 & & & & & & 0.77 & & & & & & \\
\hline VEC02A04S5_60-65 & 679 & & 0.007 & & & & & 0.86 & & & & & & \\
\hline VEC02A04S5_65-70 & 684 & & 0.013 & & & & & 0.75 & & & & & 0.025 & \\
\hline VEC02A04S5_70-80 & 689 & & & & & & & 0.86 & & & & & & \\
\hline VEC02A04S5_90-95 & 709 & & & & & & & 0.87 & & & 0.015 & & & \\
\hline VEC02A04S5_100-110 & 719 & & & & & & & 0.84 & & & & & 0.027 & 0.014 \\
\hline VEC02A04S5_115-125 & 734 & 0.022 & 0.015 & & & & & 0.79 & & & & & 0.007 & \\
\hline VEC02A04S5_130-145 & 749 & 0.042 & & & & & & 0.77 & & & & & 0.042 & \\
\hline VEC02A04S5_145-S6_5 & 764 & 0.016 & & 0.016 & & & & 0.74 & & & & & 0.016 & \\
\hline VEC02A04S6_10-25 & 783 & 0.026 & & & & & & 0.67 & & & & & & \\
\hline VEC02A04S6_40-55 & 813 & & & & & & & 0.81 & & & & & 0.029 & \\
\hline VEC02A04S6_75-95 & 848 & & 0.032 & & & & & 0.81 & & & & & 0.065 & \\
\hline VEC02A04S6_110-120 & 883 & & & & & & & 0.67 & & & & & & \\
\hline VEC02A04S6_ 125-140 & 898 & & 0.018 & & & & & 0.80 & & & & & 0.027 & 0.009 \\
\hline VEC02A04S7_0-15 & 925 & & 0.031 & & & & & 0.72 & & & & & & \\
\hline VEC02A04S7_15-25 & 940 & & 0.026 & & & & & 0.90 & & & & & & \\
\hline VEC02A04S7_25-40 & 950 & & 0.037 & & & & & 0.85 & & & & & 0.019 & \\
\hline VEC02A04S7_45-50 & 970 & 0.032 & & & & & & 0.81 & & & & & & \\
\hline VEC02A04S7_50-55 & 975 & & 0.010 & & & & & 0.69 & & & & & 0.010 & \\
\hline VEC02A04S7_55-65 & 980 & & & & & & & 0.82 & & & & & & \\
\hline VEC02A04S7_65-70 & 990 & & 0.016 & & & & & 0.80 & & & & 0.016 & & \\
\hline VEC02A04S7_70-75 & 995 & & & & & & & 0.89 & & & & & & \\
\hline VEC02A04S7_75-80 & 1000 & 0.008 & 0.008 & & & & & 0.75 & & & & & 0.039 & \\
\hline VEC02A04S7_80-85 & 1005 & & & & & & & 0.93 & & & & & & \\
\hline VEC02A04S7_85-95 & 1010 & & & & & 0.011 & & 0.91 & & & & & 0.022 & \\
\hline VEC02A04S7_95-100 & 1020 & 0.023 & 0.023 & & & 0.023 & & 0.73 & & & & & & \\
\hline VEC02A04S7_100-120 & 1025 & 0.050 & & & & & & 0.68 & & & & & & \\
\hline VEC02A04S7_120-130 & 1045 & 0.013 & & & & & & 0.87 & & & & & 0.013 & \\
\hline VEC02A04S7_130-140 & 1055 & & & & & & & 0.81 & & & & & & \\
\hline VEC02A04S8_0-15 & 1079 & & & & & & & 0.93 & & & & & 0.033 & \\
\hline VEC02A04S8_15-30 & 1094 & 0.019 & & & & & & 0.85 & & & & & 0.058 & \\
\hline VEC02A04S8_35-55 & 1114 & 0.021 & & & & & & 0.73 & & & & & 0.042 & \\
\hline
\end{tabular}




\begin{tabular}{|c|c|c|c|c|c|c|c|c|c|c|c|c|c|c|}
\hline 总 & 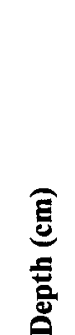 & 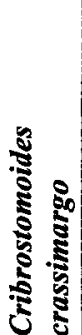 & 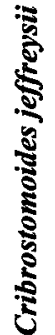 & 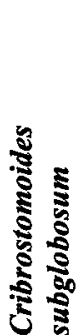 & 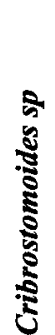 & 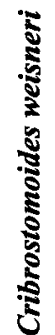 & 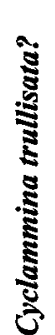 & 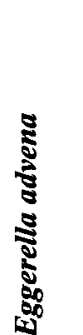 & 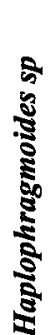 & 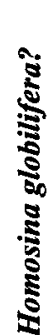 & 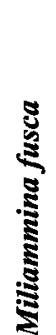 & 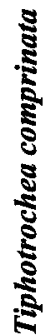 & 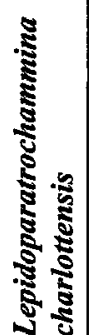 & 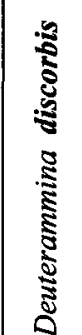 \\
\hline VEC02A04S8_75-90 & 1154 & & & & & & & 0.92 & & & & & & \\
\hline VEC02A04S8_90-105 & 1169 & 0.022 & & & & & & 0.80 & & & & & 0.044 & 0.011 \\
\hline VEC02A04S8_110-125 & 1189 & & & & & & & 0.89 & & & & & & \\
\hline
\end{tabular}

Appendix B1. CONTD.

\begin{tabular}{|c|c|c|c|c|c|c|c|c|c|c|c|c|c|c|c|}
\hline 总 & 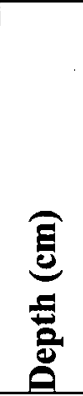 & 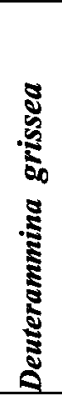 & 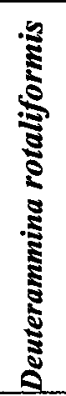 & 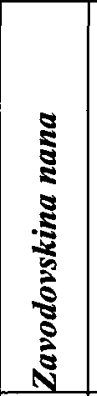 & 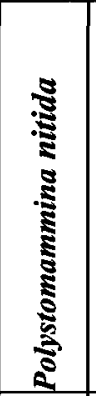 & 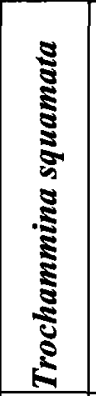 & 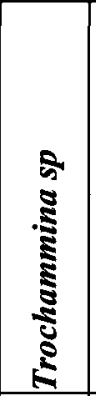 & 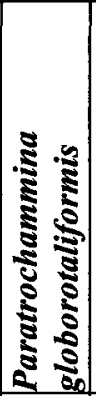 & 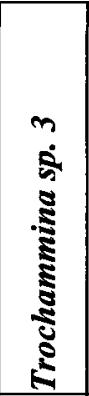 & 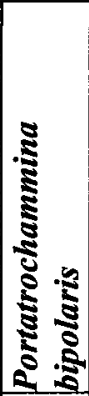 & 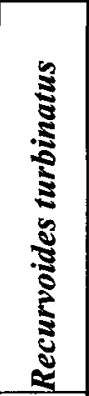 & 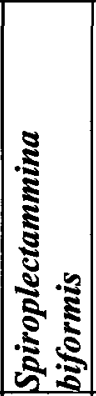 & 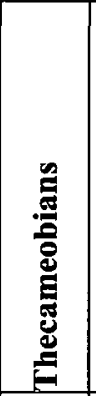 & 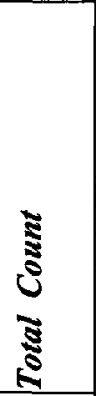 & 斿 \\
\hline VEC02A04S1_10-20 & 10 & & & & & & 0.008 & & 0.008 & & 0.264 & 0.025 & $\mid 0.025$ & 121 & 0.78 \\
\hline VEC02A04S1_20-30 & 20 & & & & & & & & & & 0.145 & 0.016 & 0.065 & 62 & 0.72 \\
\hline VEC02A04S1_30-45 & 30 & & & 0.026 & & & 0.026 & & & & 0.154 & 0.103 & 0.026 & 78 & 0.80 \\
\hline VEC02A04S1_45-60 & 45 & & & 0.026 & & & & & & & 0.263 & 0.079 & & 38 & 0.67 \\
\hline VEC02A04S1_60-70 & 60 & & & & & 0.022 & & & 0.011 & 0.011 & 0.077 & 0.055 & 0.121 & 91 & 1.23 \\
\hline VEC02A04S1_70-80 & 70 & & & 0.011 & & & 0.011 & & & & 0.115 & 0.115 & 0.046 & 87 & 0.65 \\
\hline VEC02A04S1_80-85 & 80 & & & 0.011 & & & & & & 0.022 & 0.033 & 0.033 & 0.011 & 92 & 0.29 \\
\hline VEC02A04S1_85-90 & 85 & & & 0.016 & & & & & & 0.016 & 0.098 & 0.197 & 0.098 & 61 & 0.79 \\
\hline VEC02A04S1_90-95 & 90 & & & 0.020 & & & & & & & 0.082 & 0.143 & 0.143 & 49 & 0.82 \\
\hline VEC02A04S1_95-100 & 95 & & & & & & & & & 0.010 & 0.080 & 0.110 & 0.080 & 100 & 0.87 \\
\hline VEC02A04S1_110-120 & 110 & & & 0.045 & 0.011 & & 0.011 & & & 0.023 & 0.114 & 0.011 & 0.068 & 88 & 1.27 \\
\hline VEC02A04S1_120-130 & 120 & & & 0.045 & & 0.009 & & & & & 0.073 & 0.027 & 0.018 & 110 & 0.51 \\
\hline VEC02A04S1_130-135 & 130 & & & 0.038 & & 0.010 & & 0.010 & 0.010 & 0.029 & 0.058 & 0.048 & 0.173 & 104 & 1.20 \\
\hline VEC02A04S1_135-136 & 135 & & & & & & & & & 0.044 & 0.022 & 0.044 & 0.133 & 45 & 0.51 \\
\hline VEC02A04S3_0-10 & 325 & & & & & & & & & 0.028 & 0.141 & 0.042 & 0.014 & 71 & 0.51 \\
\hline VEC02A04S3_10-15 & 335 & & & & & 0.011 & & & & 0.022 & 0.079 & 0.067 & 0.011 & 89 & 0.62 \\
\hline VEC02A04S3_15-25 & 340 & & & & & & & & & 0.011 & 0.195 & 0.069 & 0.011 & 87 & 0.57 \\
\hline VEC02A04S3_25-30 & 350 & & & 0.019 & & & & & & & 0.132 & 0.094 & 0.132 & 53 & 0.86 \\
\hline VEC02A04S3_30-35 & 355 & & & 0.017 & & 0.017 & & & & & 0.237 & 0.068 & & 59 & 0.66 \\
\hline VEC02A04S3_35-40 & 360 & & & & 0.007 & & 0.007 & & & & 0.037 & 0.051 & 0.007 & 136 & 0.37 \\
\hline
\end{tabular}




\begin{tabular}{|c|c|c|c|c|c|c|c|c|c|c|c|c|c|c|c|}
\hline 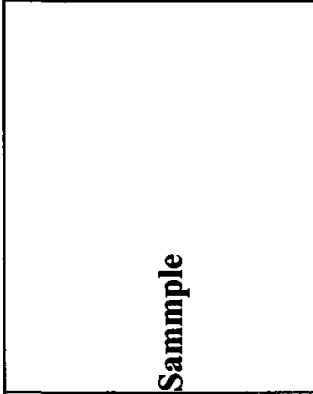 & 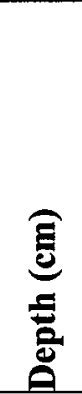 & 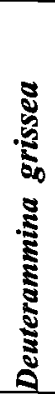 & 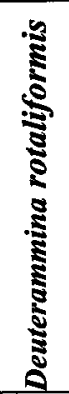 & 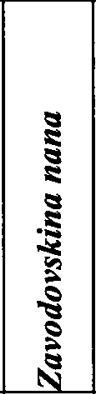 & 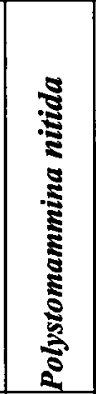 & 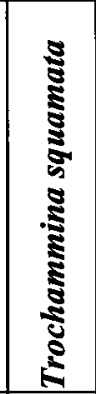 & 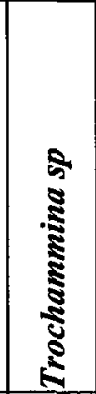 & 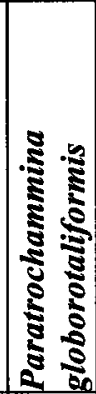 & 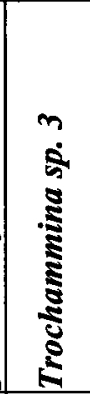 & 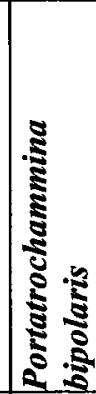 & 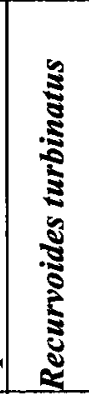 & 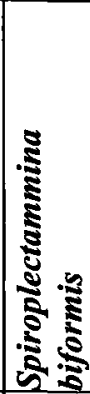 & 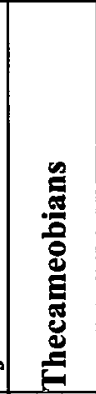 & 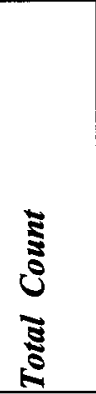 & 8 \\
\hline VEC02A04S3_40-45 & 365 & & & 0.024 & & 0.005 & & & 0.005 & 0.019 & 0.121 & 0.078 & 0.102 & 206 & 1.35 \\
\hline VEC02A04S3_45-50 & 370 & & & & & 0.017 & & & 0.003 & 0.035 & 0.149 & 0.045 & 0.062 & 289 & 1.01 \\
\hline VEC02A04S3_50-55 & 375 & & & 0.012 & & & & & 0.012 & 0.012 & 0.250 & 0.155 & & 84 & 0.68 \\
\hline VEC02A04S3_55-65 & 380 & & & & & & 0.017 & & 0.017 & & 0.069 & 0.034 & 0.017 & 58 & 0.35 \\
\hline VEC02A04S3_65-75 & 390 & & & 0.009 & & 0.009 & & & & 0.027 & 0.027 & 0.090 & 0.090 & 111 & 0.47 \\
\hline VEC02A04S3_75-80 & 400 & & & 0.009 & & 0.017 & & & & 0.026 & 0.043 & 0.061 & 0.017 & 115 & 0.68 \\
\hline VEC02A04S3_80-85 & 405 & & & & & & & & 0.016 & 0.016 & 0.016 & 0.047 & 0.016 & 64 & 0.18 \\
\hline VEC02A04S3_85-90 & 410 & & & 0.045 & & & & & 0.023 & 0.023 & 0.045 & 0.045 & 0.091 & 44 & 0.48 \\
\hline VEC02A04S3_90-95 & 415 & & & 0.032 & & & & & & & & 0.065 & 0.032 & 62 & 0.62 \\
\hline VEC02A04S3_95-100 & 420 & & & 0.045 & & & & & & 0.023 & & 0.068 & 0.068 & 44 & 0.23 \\
\hline VEC02A04S3_105-110 & 430 & & & 0.008 & & & & 0.008 & 0.008 & 0.008 & 0.033 & 0.083 & 0.042 & 120 & 0.77 \\
\hline VEC02A04S3_110-115 & 435 & & & & & 0.010 & & 0.010 & & 0.051 & 0.041 & & 0.031 & 98 & 0.46 \\
\hline VEC02A04S3_115-120 & 440 & & & 0.009 & & & & & 0.009 & 0.009 & 0.103 & 0.028 & 0.028 & 107 & 0.42 \\
\hline VEC02A04S3_120-125 & 445 & & & & & & & & 0.017 & & & 0.102 & 0.085 & 59 & 0.65 \\
\hline VEC02A04S3_125-137 & 450 & & & & & & & & & & 0.024 & & 0.024 & 41 & 0.11 \\
\hline VEC02A04S4_10-25 & 472 & & & & & & & & & & 0.111 & 0.032 & 0.048 & 63 & 0.45 \\
\hline VEC02A04S4_25-35 & 487 & & & & & 0.048 & 0.016 & & & 0.032 & 0.081 & 0.081 & 0.048 & 62 & 0.69 \\
\hline VEC02A04S4_35-40 & 497 & & & 0.036 & & & & & & & 0.073 & 0.018 & & 55 & 0.42 \\
\hline VEC02A04S4_40-45 & 502 & & & 0.010 & & 0.010 & & & & & 0.097 & 0.039 & 0.029 & 103 & 0.56 \\
\hline VEC02A04S4_45-60 & 507 & & & 0.026 & & & & & & & 0.026 & 0.026 & & 38 & 0.10 \\
\hline VEC02A04S4_60-65 & 522 & & & 0.010 & & & & & & 0.021 & 0.062 & 0.052 & 0.041 & 97 & 0.65 \\
\hline VEC02A04S4_65-70 & 527 & & & 0.043 & & & & & & 0.021 & & 0.064 & & 47 & 0.12 \\
\hline VEC02A04S4_70-75 & 532 & & & 0.011 & 0.022 & & & & & & 0.022 & 0.098 & 0.457 & 92 & 1.09 \\
\hline VEC02A04S4_75-80 & 537 & & & & & 0.010 & & & & 0.010 & 0.030 & 0.071 & 0.152 & 99 & 0.95 \\
\hline VEC02A04S4_80-85 & 542 & & & 0.018 & & & & & & 0.018 & 0.090 & 0.045 & 0.081 & 111 & 0.80 \\
\hline VEC02A04S4_85-90 & 547 & & & & & & & & & & 0.061 & 0.143 & 0.020 & 98 & 0.68 \\
\hline VEC02A04S4_90-100 & 552 & & & 0.011 & 0.011 & & & & 0.011 & 0.022 & 0.056 & 0.044 & 0.044 & 90 & 0.63 \\
\hline VEC02A04S4_100-105 & 557 & & & 0.013 & & 0.018 & 0.004 & & 0.018 & 0.009 & 0.026 & 0.162 & 0.035 & 228 & 1.03 \\
\hline VEC02A04S4_105-110 & 567 & & & & & & & & 0.023 & & 0.047 & 0.116 & & 43 & 0.50 \\
\hline VEC02A04S4_110-115 & 572 & & & 0.025 & 0.008 & & & & & 0.008 & 0.042 & 0.136 & 0.059 & 118 & 0.83 \\
\hline VEC02A04S4_115-120 & 577 & & & & & 0.007 & & & 0.014 & 0.014 & 0.057 & 0.085 & 0.035 & 141 & 0.97 \\
\hline VEC02A04S4_120-130 & 582 & & & 0.008 & & 0.032 & & 0.008 & & 0.016 & 0.048 & 0.128 & 0.072 & 125 & 1.26 \\
\hline VEC02A04S4_130-140 & 592 & & & 0.027 & 0.027 & 0.014 & & & & & 0.027 & 0.110 & 0.055 & 73 & 0.83 \\
\hline VEC02A04S4_140-145 & 602 & & & 0.022 & 0.015 & & & & & 0.007 & 0.037 & 0.119 & 0.067 & 135 & 0.81 \\
\hline VEC02A04S4_150-155 & 612 & & & & & & & & & 0.029 & 0.157 & 0.029 & 0.057 & 70 & 0.70 \\
\hline
\end{tabular}




\begin{tabular}{|c|c|c|c|c|c|c|c|c|c|c|c|c|c|c|c|}
\hline 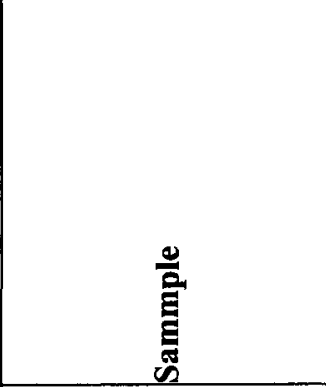 & 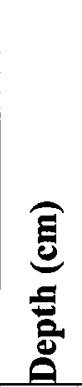 & 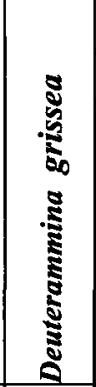 & 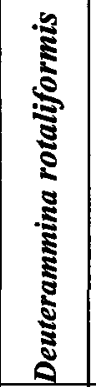 & 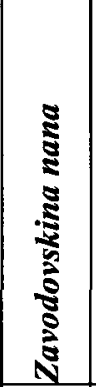 & 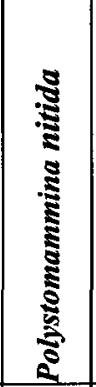 & 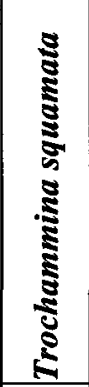 & 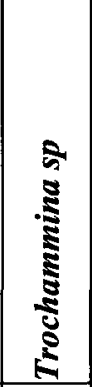 & 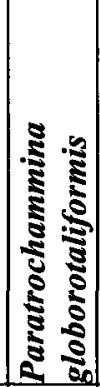 & $\begin{array}{l}n \\
5 \\
5 \\
5 \\
5 \\
5 \\
5 \\
5 \\
5 \\
5 \\
0 \\
0\end{array}$ & 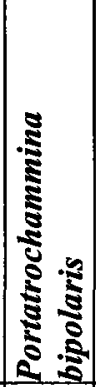 & 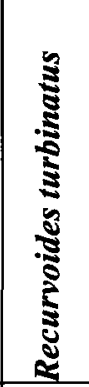 & 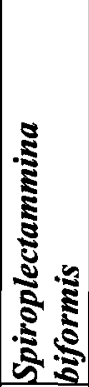 & 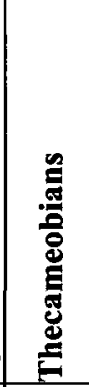 & 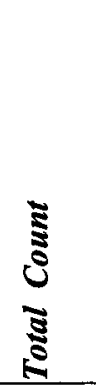 & 5 \\
\hline VEC02A04S4_155-157 & $\sqrt{617}$ & & & 0.015 & 0.010 & 0.005 & & & 0.010 & 0.021 & 0.097 & 0.067 & 0.026 & 195 & 1.01 \\
\hline VEC02A04S5_0-5 & 619 & 0.007 & 0.007 & 0.015 & 0.007 & 0.015 & & & & 0.015 & 0.201 & & 0.060 & 134 & 0.78 \\
\hline VEC02A04S5_5-10 & 624 & & & & & & & & & & 0.063 & 0.063 & 0.063 & 48 & 0.18 \\
\hline VEC02A04S5_10-15 & 629 & & & & & & & & & & & 0.143 & 0.048 & 84 & 0.62 \\
\hline VEC02A04S5_15-20 & 634 & & & 0.008 & & & & & 0.008 & 0.008 & 0.059 & 0.034 & 0.034 & 119 & 0.54 \\
\hline VEC02A04S5_20-25 & 639 & 0.018 & & 0.070 & & & & & & 0.053 & 0.018 & 0.035 & & 57 & 0.40 \\
\hline VEC02A04S5_25-30 & 644 & & & & & & & & & & & 0.209 & 0.023 & 43 & 0.55 \\
\hline VEC02A04S5_30-40 & 649 & & & 0.016 & & & & & & & 0.032 & 0.143 & & 63 & 0.46 \\
\hline VEC02A04S5_40-45 & 659 & & & 0.017 & & 0.017 & & & & & 0.033 & 0.083 & 0.033 & 60 & 0.37 \\
\hline VEC02A04S5_45-50 & 664 & & & 0.017 & & & & & & & 0.074 & 0.066 & 0.050 & 121 & 0.71 \\
\hline VEC02A04S5_50-55 & 669 & & & 0.008 & & & & & 0.004 & 0.038 & 0.072 & 0.051 & 0.004 & 237 & 0.76 \\
\hline VEC02A04S5_55-60 & 674 & & & 0.016 & & 0.008 & & & & 0.008 & 0.008 & 0.123 & 0.041 & 122 & 0.59 \\
\hline VEC02A04S5_60-65 & 679 & & & & & & & & & 0.022 & 0.067 & 0.045 & & 134 & 0.45 \\
\hline VEC02A04S5_65-70 & 684 & & & & & 0.006 & & & & 0.013 & 0.146 & 0.038 & 0.006 & 158 & 0.71 \\
\hline VEC02A04S5_70-80 & 689 & & & & & & & & & 0.045 & 0.057 & 0.023 & 0.011 & 88 & 0.43 \\
\hline VEC02A04S5_90-95 & 709 & & & & & & & & & 0.060 & 0.060 & & & 67 & 0.46 \\
\hline VEC02A04S5_100-110 & 719 & & & & & & 0.014 & & & 0.027 & 0.068 & & 0.014 & 73 & 0.33 \\
\hline VEC02A04S5_115-125 & 734 & & 0.007 & 0.022 & & & & & & 0.015 & 0.037 & 0.067 & 0.015 & 135 & 0.49 \\
\hline VEC02A04S5_130-145 & 749 & & & 0.021 & & & & & & 0.021 & & 0.042 & 0.063 & 48 & 0.20 \\
\hline VEC02A04S5_145-S6_5 & 764 & 0.016 & & 0.016 & & & & & & 0.016 & 0.066 & 0.016 & 0.082 & 61 & 0.61 \\
\hline VEC02A04S6_10-25 & 783 & & 0.051 & 0.026 & & & & & & 0.026 & 0.103 & 0.103 & & 39 & 0.74 \\
\hline VEC02A04S6_40-55 & 813 & & 0.014 & 0.014 & & & & & & & 0.058 & 0.072 & & 69 & 0.52 \\
\hline VEC02A04S6_75-95 & 848 & & 0.032 & & & & & & & & & 0.065 & & 31 & 0.17 \\
\hline VEC02A04S6_110-120 & 883 & & & 0.061 & 0.020 & & & & 0.020 & 0.082 & 0.102 & 0.020 & 0.020 & 49 & 0.70 \\
\hline VEC02A04S6_125-140 & 898 & & 0.009 & 0.009 & 0.009 & 0.009 & & & & 0.009 & 0.081 & 0.018 & & 111 & 0.38 \\
\hline VEC02A04S7_0-15 & 925 & & & 0.094 & & & & & & & 0.094 & 0.063 & & 32 & 0.24 \\
\hline VEC02A04S7_15-25 & 940 & & & & & & & & & 0.026 & 0.053 & & & 38 & 0.10 \\
\hline VEC02A04S7_25-40 & 950 & & & 0.019 & & & & & 0.019 & & 0.037 & & 0.019 & 54 & 0.14 \\
\hline VEC02A04S7_45-50 & 970 & & & 0.032 & & & & & 0.016 & 0.032 & 0.048 & 0.032 & & 63 & 0.17 \\
\hline VEC02A04S7_50-55 & 975 & & & 0.040 & & & & & & & 0.160 & 0.090 & & 100 & 0.89 \\
\hline VEC02A04S7_55-65 & 980 & & & 0.050 & 0.017 & & & & & 0.017 & 0.050 & 0.033 & 0.017 & 60 & 0.17 \\
\hline VEC02A04S7_65-70 & 990 & & & 0.063 & & 0.016 & 0.016 & & & & 0.031 & 0.047 & & 64 & 0.35 \\
\hline VEC02A04S7_70-75 & 995 & & & & & 0.023 & & & & & 0.045 & 0.045 & & 44 & 0.11 \\
\hline VEC02A04S7_75-80 & 1000 & & 0.008 & 0.023 & & & & & & & 0.102 & 0.055 & 0.008 & 128 & 0.73 \\
\hline VEC02A04S7_80-85 & 1005 & & & & & & & & & 0.035 & 0.035 & & & 57 & 0.07 \\
\hline
\end{tabular}


Appendix B1. CONTD.

\begin{tabular}{|c|c|c|c|c|c|c|c|c|c|c|c|c|c|c|c|}
\hline 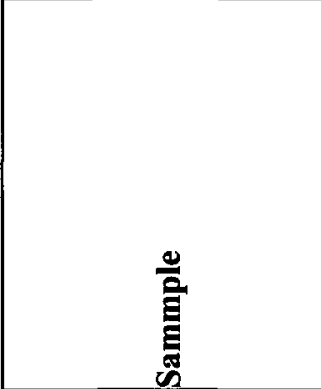 & 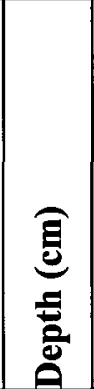 & 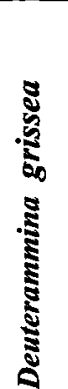 & 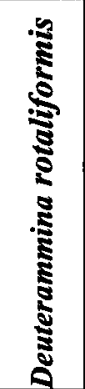 & 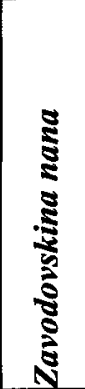 & 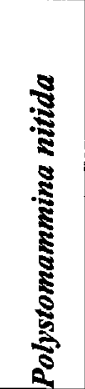 & 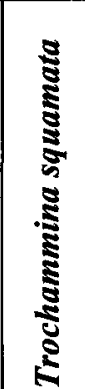 & 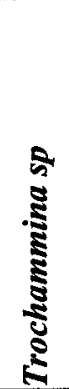 & 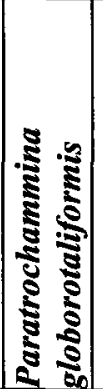 & 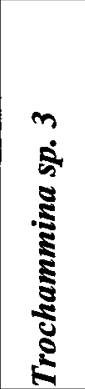 & 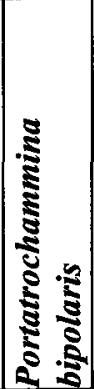 & 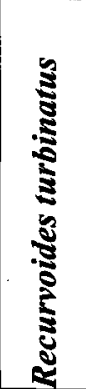 & $\mid$ & 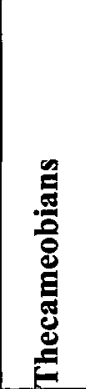 & 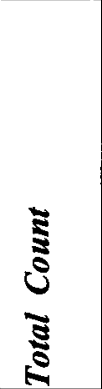 & 8 \\
\hline VEC02A04S7_85-95 & 1010 & & 0.011 & & & & & & & 0.011 & 0.022 & 0.011 & & 89 & 0.09 \\
\hline VEC02A04S7_95-100 & 1020 & & & 0.023 & & & & & & & 0.136 & 0.045 & & 44 & 0.50 \\
\hline VEC02A04S7_100-120 & 1025 & & & 0.025 & & & & & & & 0.100 & 0.125 & 0.025 & 40 & 0.76 \\
\hline VEC02A04S7_120-130 & 1045 & & & 0.013 & & & & & & 0.039 & 0.013 & 0.039 & & 76 & 0.12 \\
\hline VEC02A04S7_130-140 & 1055 & & 0.019 & 0.057 & & & & & & 0.019 & 0.038 & 0.057 & & 53 & 0.17 \\
\hline VEC02A04S8_0-15 & 1079 & & & & & & & & 0.033 & & & & & 30 & 0.06 \\
\hline VEC02A04S8_15-30 & 1094 & & & & & & & & & & 0.077 & & & 52 & 0.34 \\
\hline VEC02A04S8_35-55 & 1114 & & & 0.083 & 0.021 & & & & & 0.042 & 0.042 & 0.021 & & 48 & 0.44 \\
\hline VEC02A04S8_75-90 & 1154 & & & & & & & & & 0.028 & & 0.056 & & 36 & 0.08 \\
\hline VEC02A04S8_90-105 & 1169 & & & 0.011 & & 0.022 & & & & 0.022 & 0.067 & & & 90 & 0.50 \\
\hline VEC02A04S8_110-125 & 1189 & & & & 0.043 & & & & & & 0.022 & 0.043 & & 46 & 0.10 \\
\hline
\end{tabular}




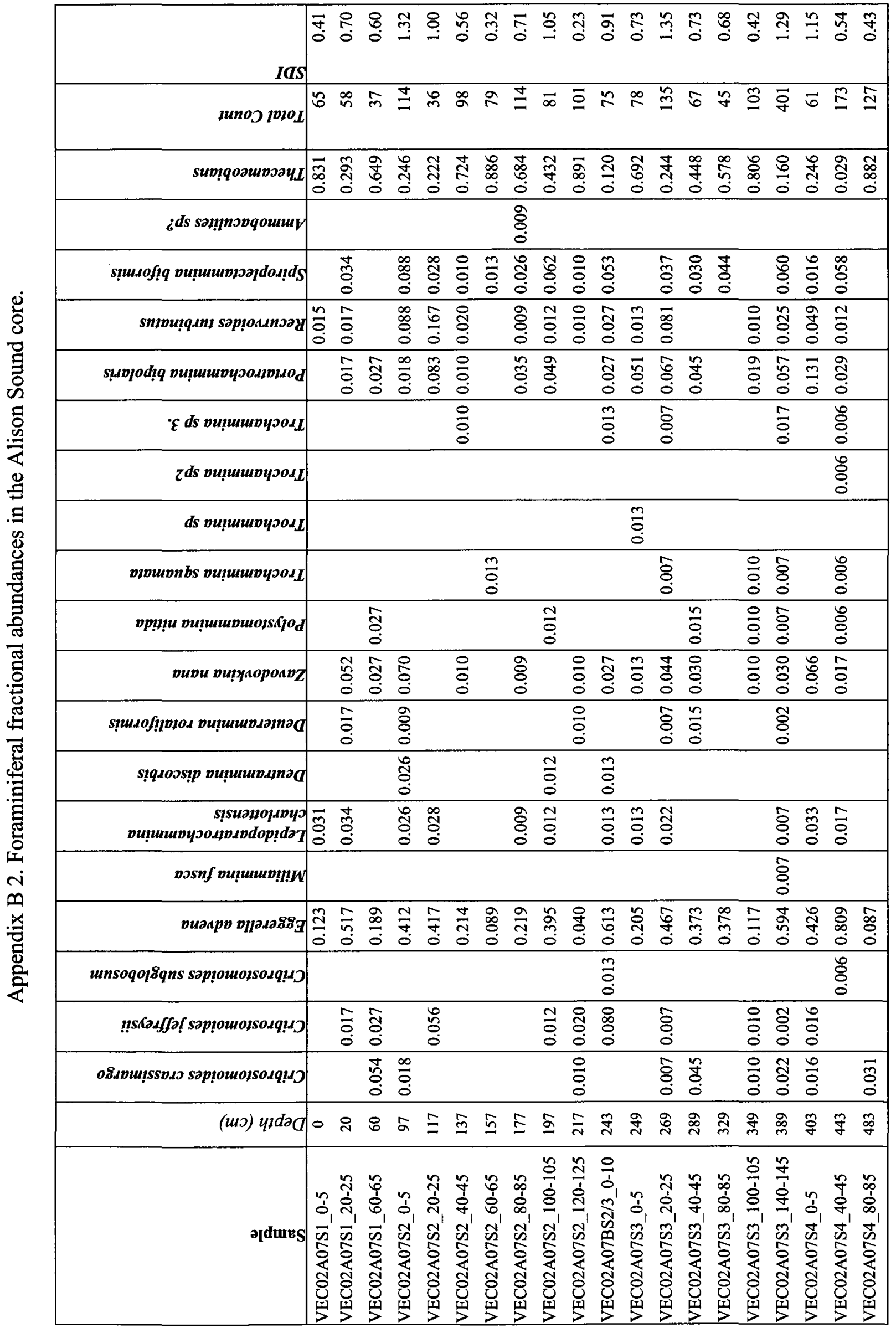




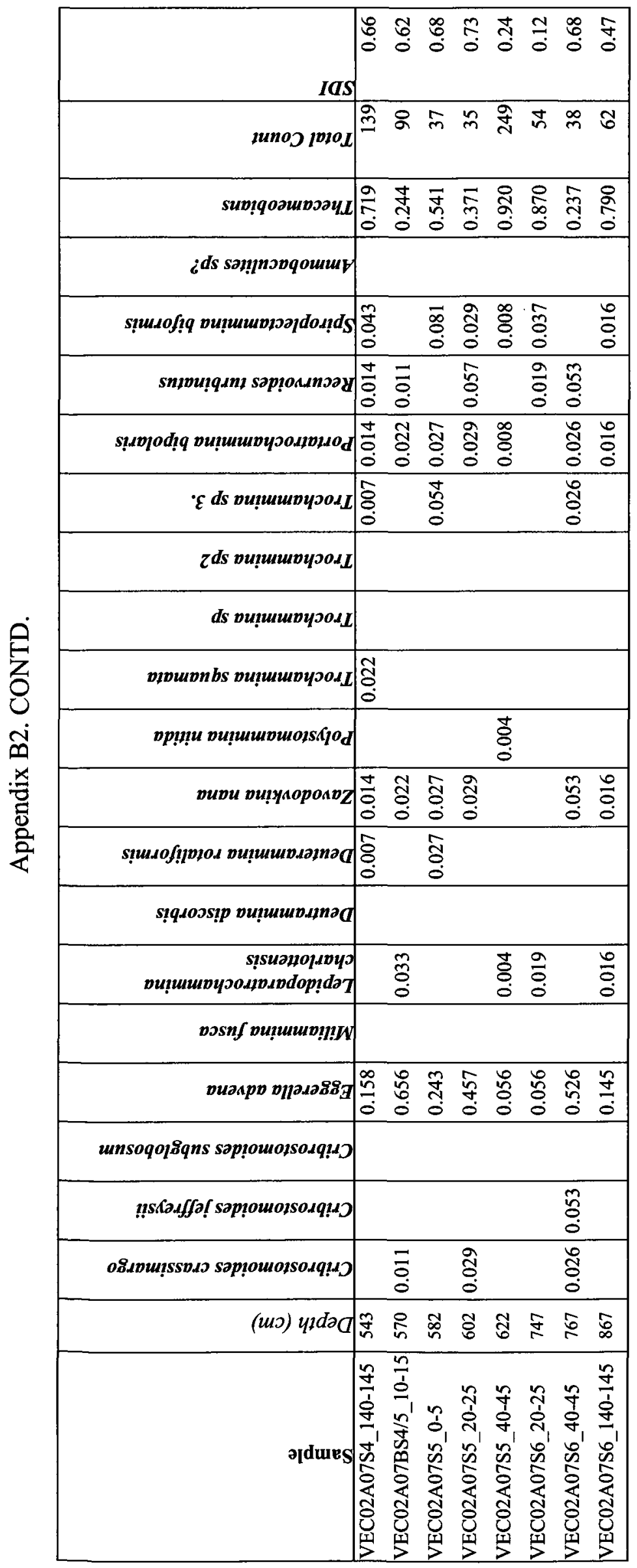


Appendix B 3. Foraminiferal fractional abundances in the Mereworth Sound core.

\begin{tabular}{|c|c|c|c|c|c|c|c|c|c|c|c|c|c|c|c|c|c|c|}
\hline 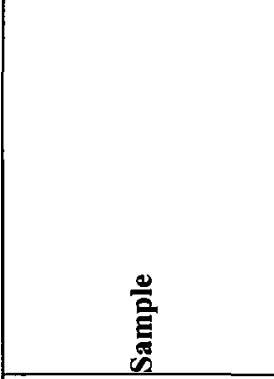 & 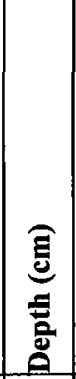 & 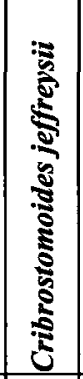 & 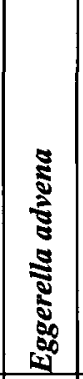 & 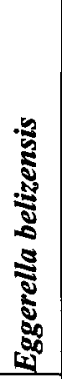 & 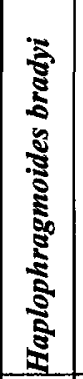 & 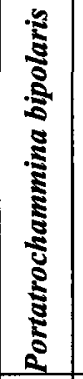 & 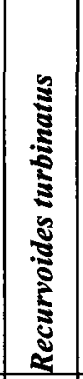 & 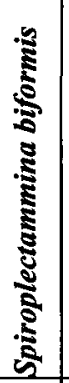 & 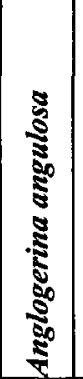 & 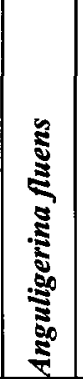 & 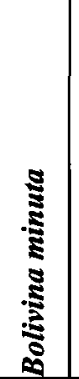 & 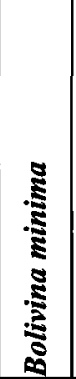 & 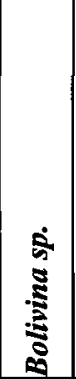 & 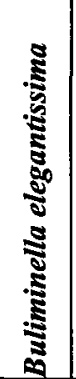 & 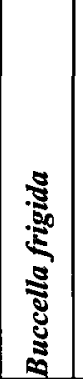 & 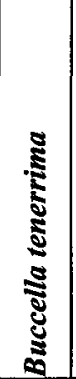 & 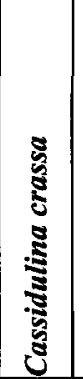 & 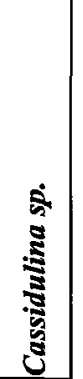 \\
\hline VEC02A13A1-B_0-2 & 0 & & 0.069 & & 0.034 & & & & & & & & & & 0.621 & & & \\
\hline VEC02A13B_2-8 & 17 & & 0.071 & & 0.119 & & & & & & 0.024 & & & & 0.476 & & & .024 \\
\hline VEC02A13B_8-12 & 23 & & 0.025 & & 0.150 & & & & & & 0.025 & & & & 0.650 & 0.025 & & \\
\hline VEC02A13C_1-4 & 28 & & 0.031 & & 0.031 & & & & & & 0.063 & & 0.031 & & 0.688 & & & \\
\hline VEC02A13C_5-7 & 32 & & 0.027 & & 0.162 & 0.027 & & & & & & & & & 0.676 & & & \\
\hline VEC02A13D_4-15 & 44 & 0.059 & 0.206 & & 0.294 & 0.029 & 0.029 & & & & 0.029 & & & & 0.235 & & & \\
\hline VEC02A13E_1 & 56 & & 0.073 & & 0.036 & & & & 0.055 & & 0.018 & & & & 0.691 & & & \\
\hline VEC02A13E_2 & 57 & & & & & & & & & & 0.065 & & & & 0.597 & & 0.016 & \\
\hline VEC02A13E_3 & 58 & & & & & & & & 0.086 & & & & & & 0.743 & & & \\
\hline VEC02A13E_4 & 59 & & & & & & & & & & 0.050 & & & & 0.650 & 0.050 & & \\
\hline VEC02A13E_5 & 60 & & & & & & & & & & & & & & 0.688 & & & \\
\hline VEC02A13E_6 & 61 & & & & & & & & & 0.014 & 0.029 & & & & 0.629 & 0.029 & & \\
\hline VEC02A13E_7 & 62 & & 0.032 & & & & & & & & & & & & 0.857 & 0.032 & & \\
\hline VEC02A13E_8 & 63 & & & & & & & & 0.018 & & 0.012 & & & & 0.824 & 0.018 & 0.006 & \\
\hline VEC02A13E_9 & 64 & & & & & & & & & & 0.011 & & & & 0.872 & & 0.011 & \\
\hline VEC02A13E_10.5 & 65.5 & & & & & & & & 0.030 & & & & & & 0.911 & 0.010 & 0.010 & \\
\hline VEC02A13E_11.5 & 66.5 & & & & & & & & 0.024 & & 0.006 & & & & 0.659 & 0.018 & 0.018 & \\
\hline VEC02A13E_12.5 & 67.5 & & & & & & & & 0.027 & & 0.053 & & & 0.013 & 0.600 & 0.013 & 0.013 & \\
\hline VEC02A13E_13.5-16.5 & 68.5 & & 0.043 & & 0.021 & & 0.043 & & & & 0.021 & 0.085 & & & 0.468 & & 0.021 & \\
\hline VEC02A13F_1-6 & 72.5 & 0.032 & 0.032 & & 0.129 & 0.032 & 0.161 & & & & 0.032 & & & & 0.452 & & 0.032 & \\
\hline
\end{tabular}




\begin{tabular}{|c|c|c|c|c|c|c|c|c|c|c|c|c|c|c|c|c|c|}
\hline 咅 & 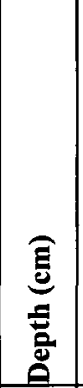 & 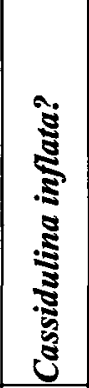 & 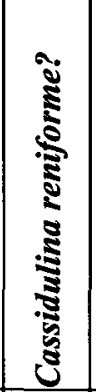 & 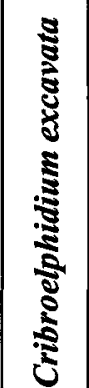 & 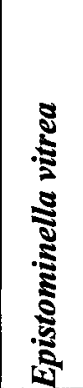 & 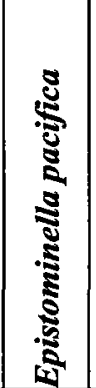 & 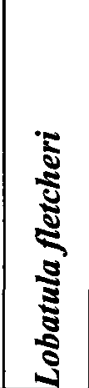 & 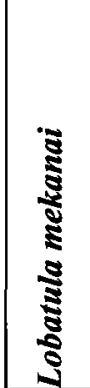 & 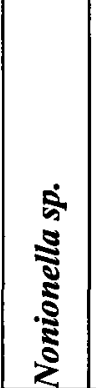 & 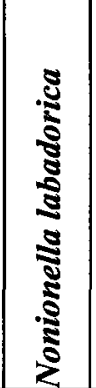 & 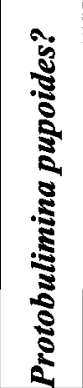 & 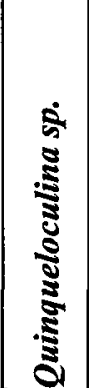 & 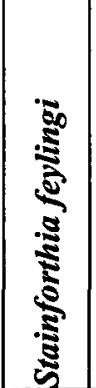 & 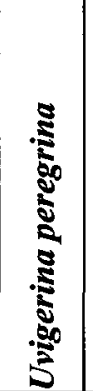 & 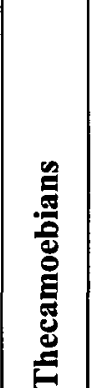 & $\underset{6}{6}$ & $\bar{\nabla}$ \\
\hline VEC02A13A1- & 0 & & & 0.103 & 0.034 & & & & & & & & 0.069 & 0.069 & & 29 & 0.30 \\
\hline VECC202A13B_2-8 & 17 & & & 0.024 & 0.048 & & & & & & & & 0.190 & 0.024 & & 42 & 0.92 \\
\hline VEC02A13B_8-12 & 23 & & & & 0.025 & & & & & & & & & 0.100 & & 40 & 0.79 \\
\hline VEC02A13C_1-4 & 28 & & & 0.094 & & & & & & & & & & 0.063 & & 33 & 0.26 \\
\hline VEC02A13C_5-7 & 32 & & & & & & & & & & & & & 0.081 & 0.027 & 38 & 0.56 \\
\hline VEC02A13D_4-15 & 44 & & & 0.029 & & & & & & & & & & 0.059 & 0.029 & 48 & 1.03 \\
\hline VEC02A13E_1 & 56 & & & 0.018 & 0.055 & & 0.018 & & & & & & 0.018 & 0.018 & & 55 & 0.45 \\
\hline VEC02A13E_2 & 57 & & 0.016 & 0.129 & 0.016 & & 0.016 & & & & & & 0.097 & 0.048 & & 62 & 0.98 \\
\hline VEC02A13E_3 & 58 & & & 0.029 & 0.114 & & & & & & & & 0.029 & & & 35 & 0.47 \\
\hline VEC02A13E_4 & 59 & & & 0.100 & 0.050 & & & & 0.050 & & & & 0.050 & & & 20 & 0.28 \\
\hline VEC02A13E_5 & 60 & & & 0.219 & & & 0.063 & & & & & 0.031 & & & & 32 & 0.59 \\
\hline VEC02A13E_6 & 61 & & & 0.200 & 0.057 & 0.029 & & & & & 0.014 & & & & & 70 & 0.78 \\
\hline VEC02A13E_7 & 62 & & & 0.079 & & & & & & & & & & & & 63 & 0.33 \\
\hline VEC02A13E_8 & 63 & & & 0.100 & 0.012 & & & & & & & & & 0.012 & & 170 & 0.39 \\
\hline VEC02A13E_9 & 64 & & & 0.053 & 0.011 & & 0.011 & & & & & 0.011 & & 0.021 & & 94 & 0.28 \\
\hline VEC02A13E_10.5 & 65.5 & & & & 0.020 & & 0.020 & & & & & & & & & 101 & 0.09 \\
\hline VEC02A13E_11.5 & 66.5 & & & 0.126 & 0.060 & & 0.012 & 0.024 & & 0.006 & & 0.012 & & 0.036 & & 167 & 1.00 \\
\hline VEC02A13E_12.5 & 67.5 & 0.013 & & 0.107 & 0.053 & 0.027 & 0.013 & & & & & & 0.040 & 0.027 & & 75 & 0.86 \\
\hline VEC02A13E_13.5 & 68.5 & & & 0.106 & 0.064 & & & & & & & & 0.106 & 0.021 & & 47 & 1.04 \\
\hline VECCO2A13F_1-6 & 72.5 & & & 0.032 & & & & & & & & & & & 0.065 & 31 & 0.92 \\
\hline
\end{tabular}


Appendix B 4. Reconstructed paleoenvironmental proxies in the Frederick Sound core.

\begin{tabular}{|c|c|c|c|c|c|c|c|c|c|c|c|c|c|c|c|c|c|}
\hline 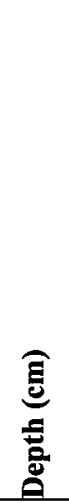 & 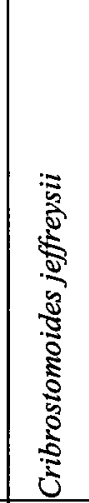 & 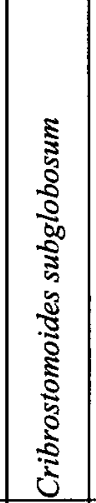 & 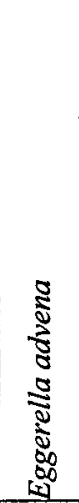 & 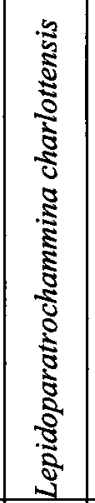 & 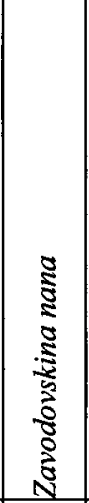 & 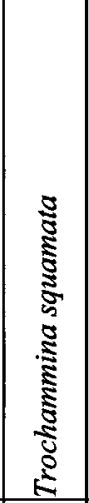 & 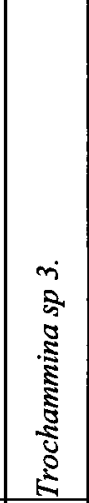 & 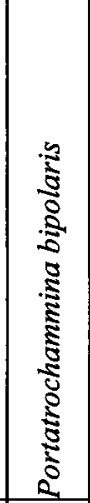 & 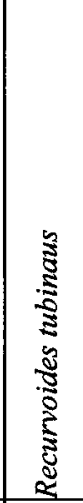 & 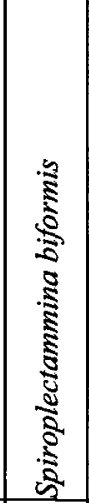 & 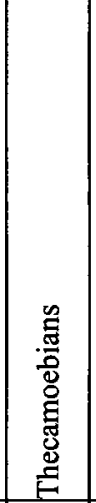 & 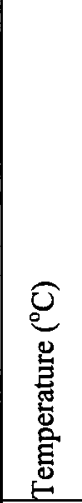 & 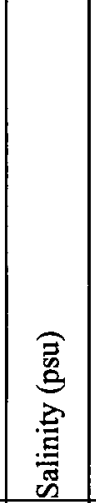 & 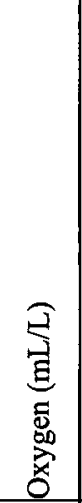 & 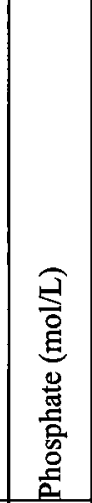 & 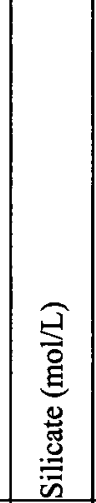 & 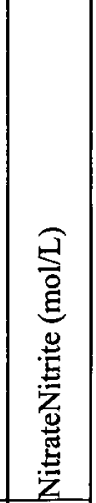 \\
\hline 10 & 0.025 & 0.017 & 0.59 & 0.033 & 0.000 & 0.000 & 0.008 & 0.000 & 0.264 & 0.025 & 0.025 & 8.61 & 28.36 & 1.36 & 3.19 & 61.25 & 24.21 \\
\hline 20 & 0.048 & 0.016 & 0.68 & 0.032 & 0.000 & 0.000 & 0.000 & 0.000 & 0.145 & 0.016 & 0.065 & 8.61 & 28.37 & 1.45 & 3.15 & 60.45 & 24.25 \\
\hline 30 & 0.026 & 0.038 & 0.53 & 0.064 & 0.026 & 0.000 & 0.000 & 0.000 & 0.154 & 0.103 & 0.026 & 8.62 & 28.20 & 1.19 & 3.21 & 61.35 & 24.24 \\
\hline 45 & .026 & 0.026 & 0.58 & 0.000 & 0.026 & $0.000 \mid$ & 0.000 & 0.000 & 0.263 & 0.079 & 0.000 & 8.61 & 28.25 & 1.18 & 3.23 & 61.74 & 24.21 \\
\hline 60 & 055 & 0.000 & 0.49 & 0.132 & 0.000 & 0.022 & 0.011 & 0.011 & 0.077 & 0.055 & 0.121 & 8.62 & 28.30 & 1.48 & 3.12 & 59.80 & 24.32 \\
\hline 70 & 0.011 & 0.000 & 0.69 & 0.000 & 0.011 & 0.000 & 0.000 & 0.000 & 0.115 & 0.115 & 0.046 & 8.62 & 28.21 & 1.23 & 3.21 & 61.28 & 24.27 \\
\hline 80 & 0.011 & 0.011 & 0.83 & 0.043 & 0.011 & 0.000 & 0.000 & 0.022 & 0.033 & 0.033 & 0.011 & 8.61 & 28.35 & 1.43 & 3.14 & 60.11 & 24.49 \\
\hline 85 & 016 & 0.000 & 0.54 & 0.016 & 0.016 & 0.000 & 0.000 & 0.016 & 0.098 & 0.197 & 0.098 & 8.62 & 28.12 & 1.19 & 3.21 & 61.30 & 24.30 \\
\hline 90 & 041 & 0.020 & 0.53 & 0.020 & 0.020 & 0.000 & 0.000 & 0.000 & 0.082 & 0.143 & 0.143 & 8.62 & 28.12 & 1.20 & 3.20 & 61.02 & 24.32 \\
\hline 93 & & 0.000 & 0.61 & 0.060 & 0.000 & 0.000 & 0.000 & 0.010 & 0.080 & 0 . & 0.080 & 8.61 & 28.25 & 1.36 & .17 & 60.66 & 24.32 \\
\hline & 1 & 0.000 & 0.57 & 0.057 & 0.045 & 0.000 & & 0.023 & & 11 & 0.068 & 8.62 & 28.28 & 1.30 & .13 & 60.07 & 24.27 \\
\hline & & 0 & 0 & 0.018 & 0.045 & 0.009 & 0.000 & 0.000 & 0.073 & 0.027 & 18 & 8.62 & 28.14 & 1.13 & 3.20 & 60.95 & 24.3 \\
\hline 130 & 048 & 0.000 & 0.53 & 0.038 & 0.038 & 0.010 & 0.010 & 0.029 & 0.058 & 0.048 & 0.173 & 8.63 & 28.12 & 1.26 & 3.14 & 60.01 & 24.3 \\
\hline 135 & 022 & 0.022 & 0.71 & 0.000 & 0.000 & 0.000 & 0.000 & 0.044 & 0.022 & 0.044 & 0.133 & 8.62 & 28.35 & 1.56 & 3.10 & 59.52 & 24.63 \\
\hline 325 & 0.042 & 0.000 & 0.72 & 0.014 & 0.000 & 0.000 & 0.000 & 0.028 & 0.141 & 0.042 & 0.014 & 8.61 & 28.44 & 1.50 & 3.14 & 60.36 & 24.25 \\
\hline 335 & 0.067 & 0.000 & 0.72 & 0.011 & 0.000 & 0.011 & 0.000 & 0.022 & 0.079 & 0.067 & 0.011 & 8.61 & 28.47 & 1.52 & 3.13 & 60.14 & 24.31 \\
\hline 340 & 000 & 0.000 & 0.70 & 0.011 & 0.000 & 0.000 & 0.000 & 0.011 & 0.195 & 0.069 & 0.011 & 8.61 & 28.32 & 1.35 & 3.19 & 61.22 & 24.23 \\
\hline 350 & 38 & 0.000 & 0.57 & 0.019 & 0.019 & 0.000 & 0.000 & 0.000 & 0.132 & 0.094 & 0.132 & 8.62 & 28.15 & 1.22 & 3.19 & $61.00 \mid$ & 24.26 \\
\hline 35 & 017 & 0.000 & 0.58 & 0.034 & 0.017 & 0.017 & 0.000 & 0.000 & 0.237 & 0.068 & 0.000 & 8.61 & 28.25 & 1.21 & 3.22 & 61.58 & 24.21 \\
\hline 36 & 029 & 0.000 & 0.84 & 0.007 & 0.000 & 0.000 & 0.000 & 0.000 & 0.037 & 0.051 & 0.007 & 8.61 & 28.37 & 1.43 & 3.16 & 60.40 & 24.4 \\
\hline 36 & 0.073 & 0.024 & 0.53 & 0.019 & 0.024 & 0.005 & 0.005 & 0.019 & 0.121 & 0.078 & 0.102 & 8.62 & 28.28 & 1.33 & 3.16 & 60.49 & 24.2 \\
\hline 37 & 0.024 & 0.003 & 0.66 & 0.000 & 0.000 & 0.017 & 0.003 & 0.035 & 0.149 & 0.045 & 0.062 & 8.61 & 28.38 & 1.48 & 3.14 & 60.40 & 24.25 \\
\hline 37 & , & 0. & 0.54 & 0.000 & 0.012 & 0.000 & 0.012 & 0.012 & 0.250 & 0.155 & 0.000 & 8.61 & 28.24 & 1.20 & 3.23 & 61.86 & 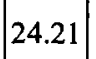 \\
\hline 380 & 0.000 & 0.017 & 0.81 & 0.000 & 0.000 & 0.000 & 0.017 & 0.000 & 0.069 & 0.034 & 0.017 & 8.61 & 28.34 & 1.39 & .18 & 60.68 & 24.33 \\
\hline 390 & 0.027 & 0.000 & 0.69 & 0.009 & 0.009 & 0.009 & 0.000 & 0.027 & 0.027 & 0.090 & 0.090 & 8.62 & 28.28 & 1.40 & 3.15 & 60.19 & 24.55 \\
\hline 400 & 0.052 & 0.000 & 0.75 & 0.026 & 0.009 & 0.017 & 0.000 & 0.026 & 0.043 & 0.061 & 0.017 & 8.61 & 28.41 & 1.48 & 3.13 & 60.02 & 24.42 \\
\hline 405 & 0.016 & 0.031 & 0.80 & 0.031 & 0.000 & 0.000 & 0.016 & 0.016 & 0.016 & 0.047 & 0.016 & 8.61 & 28.40 & 1.49 & 3.14 & 60.08 & 24.69 \\
\hline 410 & 0.023 & 0.000 & 0.68 & 0.023 & 0.045 & 0.000 & 0.023 & 0.023 & 0.045 & 0.045 & 0.091 & 8.62 & 28.13 & 1.19 & 3.17 & 60.42 & 24.42 \\
\hline
\end{tabular}




\begin{tabular}{|c|c|c|c|c|c|c|c|c|c|c|c|c|c|c|c|c|c|}
\hline 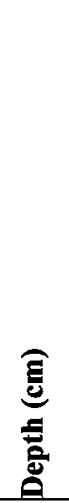 & 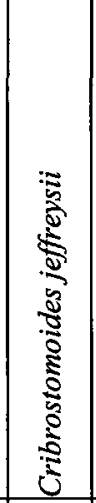 & 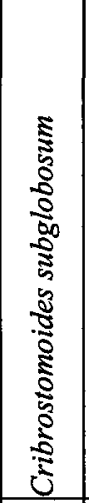 & 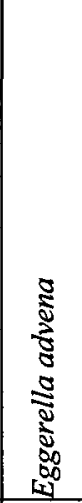 & 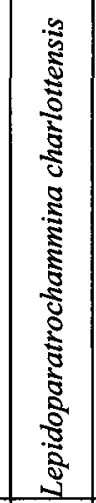 & 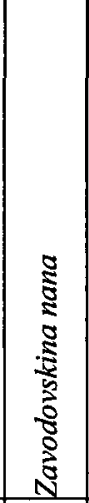 & 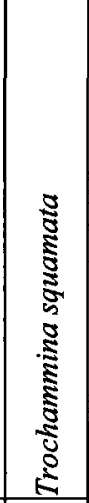 & 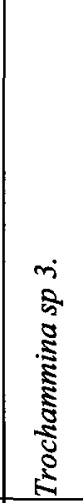 & 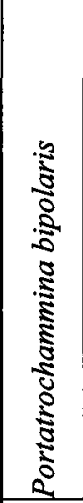 & 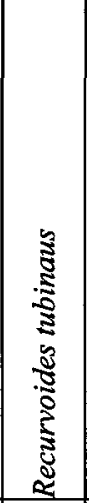 & 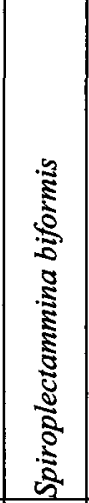 & 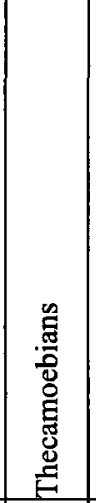 & 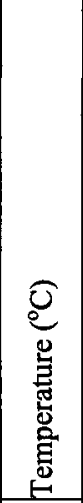 & 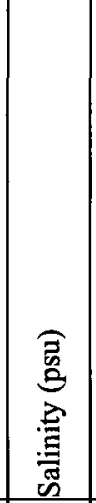 & 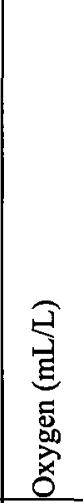 & 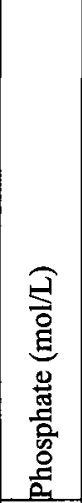 & 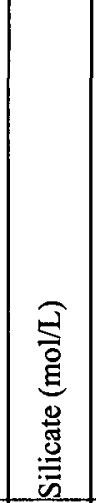 & 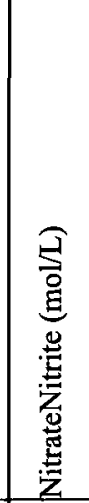 \\
\hline 415 & 0.065 & 0.048 & 0.68 & 0.048 & 0.032 & 0.000 & 0.000 & 0.000 & 0.000 & 0.065 & 0.032 & 8.62 & 28.28 & 1.29 & 3.16 & 60.29 & 25.44 \\
\hline 420 & .045 & 0.000 & 0.73 & 0.000 & 0.045 & 0.000 & 0.000 & 0.023 & 0.000 & 0.068 & 0.068 & 8.62 & 28.18 & 1.22 & 3.16 & 60.27 & 25.63 \\
\hline 430 & 0.033 & 0.000 & 0.77 & 0.008 & 0.008 & 0.000 & 0.008 & 0.008 & 0.033 & 0.083 & 0.042 & 8.61 & 28.31 & 1.37 & 3.17 & 60.46 & 4.48 \\
\hline 435 & 0.020 & 0.000 & 0.81 & 0.020 & 0.000 & 0.010 & 0.000 & 0.051 & 0.041 & 0.000 & 0.031 & 8.61 & 28.47 & 1.63 & 3.09 & 59.34 & 24.43 \\
\hline 440 & 0.019 & 0.000 & 0.79 & 0.009 & 0.009 & 0.000 & 0.009 & 0.009 & 0.103 & 0.028 & 0.028 & 8.61 & 28.33 & 1.38 & 3.16 & 60.57 & 24.28 \\
\hline 445 & 0.000 & 0.000 & 0.76 & 0.000 & 0.000 & $0.000 \mid$ & 0.017 & 0.000 & 0.000 & 0.102 & 0.085 & 8.62 & 28.21 & 1.33 & 3.19 & 60.63 & 25.65 \\
\hline 450 & .049 & 0.024 & 0.88 & 0.000 & 0.000 & 0.000 & 0.000 & 0.000 & 0.024 & 0.000 & 0.024 & 8.61 & 28.44 & 1.52 & 3.13 & 59.88 & 24.55 \\
\hline 472 & 032 & 0.000 & 0.76 & 0.016 & 0.000 & 0.000 & 0.000 & 0.000 & 0.111 & 0.032 & 0.048 & 8.61 & 28.35 & 1.42 & 3.16 & 60.54 & 24.27 \\
\hline 487 & 032 & 0.000 & 0.65 & 0.016 & 0.000 & 0.048 & 0.000 & 0.032 & 0.081 & 0.081 & 0.048 & 8.61 & 28.38 & 1.48 & 3.14 & 60.26 & 24.31 \\
\hline 4 & & 55 & 0.73 & 0.018 & 0.036 & & 0.000 & 0.000 & 0.073 & 0.018 & 0.000 & 8.62 & 28.28 & 1.25 & 3.18 & 60.70 & 4. \\
\hline 50 & 29 & 0.000 & 0.77 & 0.010 & 0.010 & 0.010 & 0.000 & 00 & 97 & 139 & 0.029 & 8.61 & 28.31 & 1.35 & 3.17 & 60.68 & $I^{2-3 .}$ \\
\hline 50 & 26 & 0.000 & 0.89 & 0.000 & 0.026 & 0.000 & 0.000 & 0.000 & 0.026 & 0.026 & 0.000 & 8.61 & 28.28 & 1.29 & 3.17 & .50 & 4.54 \\
\hline 52 & 031 & 0.000 & 0.78 & 0.000 & 0.010 & 0.000 & 0.000 & 0.021 & 0.062 & 0.052 & 0.041 & 8.61 & 28.34 & 1.41 & 3.15 & 60.29 & 24.3 \\
\hline 527 & 0.000 & 0.000 & 0.87 & 0.000 & 0.043 & 0.000 & 0.000 & 0.021 & 0.000 & 0.064 & 0.000 & 8.62 & 28.19 & 1.20 & 3.18 & 60.62 & 25.55 \\
\hline 532 & 0.000 & 0.000 & 0.32 & 0.043 & 0.011 & 0.000 & 0.000 & 0.000 & 0.022 & 0.098 & $0.457 \mid$ & 8.64 & 27.78 & 1.12 & 3.17 & 60.08 & 24.73 \\
\hline 537 & 071 & 0.000 & 0.64 & 0.020 & 0.000 & 0.010 & 0.000 & 0.010 & 0.030 & 0.071 & 0.152 & 8.62 & 28.31 & 1.48 & 3.13 & 59.80 & 24.53 \\
\hline 542 & 027 & 0.000 & 0.71 & 0.009 & 0.018 & 0.000 & 0.000 & 0.018 & 0.090 & 0.045 & 0.081 & 8.62 & 28.26 & 1.34 & 3.16 & 60.44 & 24.30 \\
\hline 34 & 20 & 0.000 & 0.73 & 0.020 & 0.000 & 0.000 & 0.000 & 0.000 & 0.061 & 0.143 & 0.020 & 8.61 & 28.28 & 1.32 & 3.20 & 61.02 & 24.3 \\
\hline J & 11 & 0.000 & 0.78 & 0.011 & 0.011 & 0.000 & 0.011 & 0.022 & 0.056 & 0.044 & 0.044 & 8.61 & 28.31 & 1.39 & 3.15 & 60.31 & 24.37 \\
\hline & 031 & 0.000 & 67 & 0.013 & 0.013 & 0.018 & 0.018 & 0.009 & 0.026 & 0.162 & 0.035 & 8.62 & 28.23 & 1.27 & 3.20 & 60.94 & 24. \\
\hline 56 & .070 & 0.000 & 0.70 & 0.047 & 0.000 & 0.000 & 0.023 & 0.000 & 0.047 & 0.116 & 0.000 & 8.61 & 28.40 & 12 & 3.17 & 60.50 & 24. \\
\hline 57 & .017 & 0.000 & 0.69 & 0.008 & 0.025 & 0.000 & 0.000 & 0.008 & 0.042 & 0.136 & 0.059 & 8.62 & 28.15 & 1.19 & 3.20 & 61.02 & 24.43 \\
\hline 57 & 092 & 0.000 & 0.69 & 0.000 & 0.000 & 0.007 & 0.014 & 0.014 & 0.057 & 0.085 & 0.035 & 8.61 & 28.46 & 1.52 & 3.14 & $60.08 \mid$ & 24.36 \\
\hline 58 & 996 & 0.000 & 0.56 & 0.016 & 0.008 & 0.032 & 0.000 & 0.016 & 0.048 & 0.128 & 0.072 & 8.62 & 28.36 & 1.43 & 3.15 & 60.24 & 24.39 \\
\hline 592 & 0.055 & 0.000 & 0.67 & 0.014 & 0.027 & 0.014 & 0.000 & 0.000 & 0.027 & 0.110 & 0.055 & 8.62 & 28.21 & 1.22 & 3.19 & 60.72 & 24.52 \\
\hline 602 & 0.022 & 0.000 & 0.70 & 0.015 & 0.022 & 0.000 & 0.000 & 0.007 & 0.037 & 0.119 & 0.067 & 8.62 & 28.18 & 1.23 & 3.19 & 60.84 & 24.46 \\
\hline 612 & 0.014 & 0.000 & 0.70 & 0.014 & 0.000 & 0.000 & 0.000 & 0.029 & 0.157 & 0.029 & 0.057 & 8.61 & 28.36 & 1.46 & 3.14 & 60.46 & 24.2 \\
\hline 617 & 0.062 & 0.000 & 0.68 & 0.005 & 0.015 & 0.005 & 0.010 & 0.021 & 0.097 & 0.067 & 0.026 & 8.61 & 28.37 & 1.40 & 3.15 & 60.42 & 24.2 \\
\hline 615 & 0.007 & 0.000 & 0.64 & 0.000 & 0.015 & 0.015 & 0.000 & 0.015 & 0.201 & 0.000 & 0.060 & 8.61 & 28.27 & 1.32 & 3.17 & 60.93 & 24. \\
\hline 62 & .000 & 0.000 & 0.79 & 0.000 & 0.000 & 0.000 & 0.000 & 0.000 & 0.063 & 0.063 & 0.063 & 8.61 & 28.26 & 1.35 & 3.18 & 60.72 & 24.3 \\
\hline 62 & 0.000 & 0.000 & 0.77 & 0.024 & 0.000 & 0.000 & 0.000 & 0.000 & 0.000 & 0.143 & 0.048 & 8.61 & 28.22 & 1.31 & 3.20 & 60.85 & | \\
\hline 634 & .000 & 0.000 & 0.84 & 00 & 0.008 & 0.00 & 0.008 & 0.00 & 0.05 & 0.034 & 0.034 & 8.61 & 28.29 & 1.36 & 3.17 & 60.51 & \\
\hline
\end{tabular}




\begin{tabular}{|c|c|c|c|c|c|c|c|c|c|c|c|c|c|c|c|c|c|}
\hline 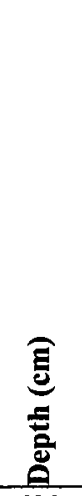 & 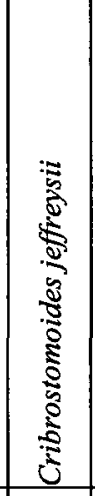 & 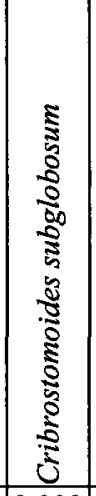 & 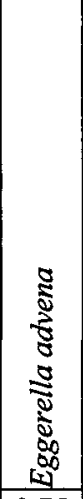 & 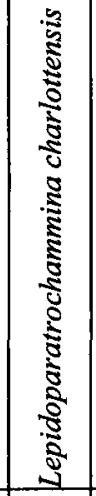 & 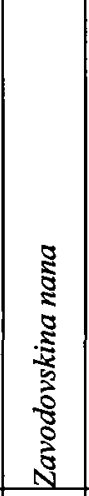 & 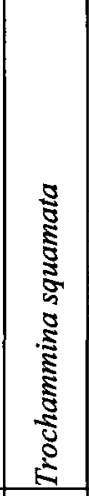 & 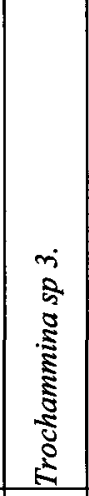 & 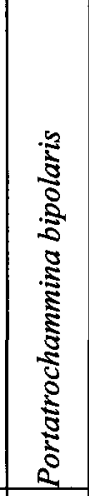 & 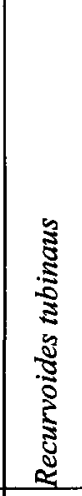 & 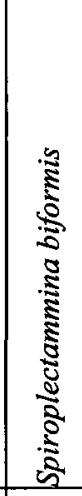 & 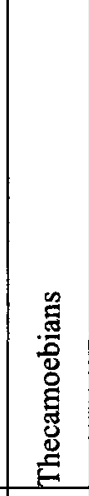 & 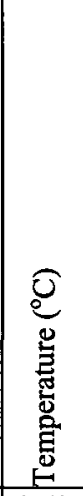 & 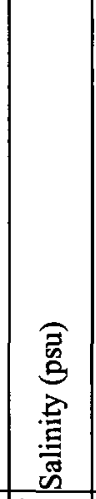 & 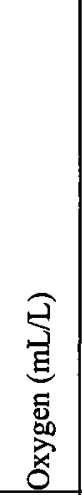 & 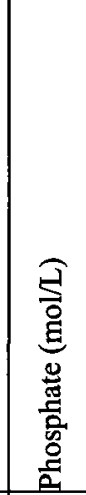 & 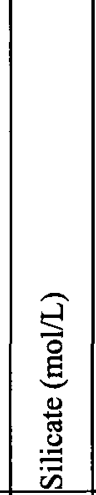 & 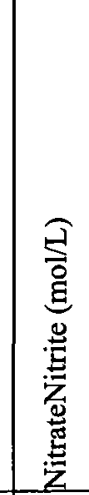 \\
\hline 639 & 0.018 & 0.000 & 0.75 & 0.018 & 0.070 & 0.000 & 0.000 & 0.053 & 0.018 & 0.035 & 0.000 & 8.62 & 28.17 & 1.17 & 3.15 & 60.24 & 24.66 \\
\hline 644 & 0.023 & 0.000 & 0.74 & 0.000 & 0.000 & 0.000 & 0.000 & 0.000 & 0.000 & 0.209 & 0.023 & 8.61 & 28.25 & 1.29 & 3.21 & 61.12 & 25.43 \\
\hline 649 & 0.000 & 0.000 & 0.79 & 0.016 & 0.016 & 0.000 & 0.000 & 0.000 & 0.032 & 0.143 & 0.000 & 8.61 & 28.20 & 1.21 & 3.22 & 61.19 & 24.50 \\
\hline 659 & 0.000 & 0.000 & 0.82 & 0.000 & $0.017 \mid$ & 0.017 & 0.000 & 0.000 & 0.033 & 0.083 & 0.033 & 8.61 & 28.21 & 1.25 & 3.20 & 60.90 & 24.49 \\
\hline 664 & 0.008 & 0.000 & 0.79 & 0.000 & 0.017 & 0.000 & 0.000 & 0.000 & 0.074 & 0.066 & 0.050 & 8.62 & 28.22 & 1.26 & 3.19 & 60.90 & 24.33 \\
\hline 669 & 0.008 & 0.000 & 0.78 & 0.030 & 0.008 & 0.000 & 0.004 & 0.038 & 0.072 & 0.051 & 0.004 & 8.61 & 28.38 & 1.45 & 3.14 & 60.22 & 24.33 \\
\hline 674 & 0.000 & 0.000 & 0.77 & 0.000 & 0.016 & 0.008 & 0.000 & 0.008 & 0.008 & 0.123 & 0.041 & 8.62 & 28.19 & 1.24 & 3.20 & 60.89 & 24.93 \\
\hline 679 & 0.007 & 0.000 & 0.86 & 0.000 & 0.000 & 0.000 & 0.000 & 0.022 & 0.067 & 0.045 & 0.000 & 8.61 & 28.39 & 1.46 & 3.15 & 60.37 & 24.34 \\
\hline 684 & 0.013 & 0.000 & 0.75 & 0.025 & 0.000 & 0.006 & 0.000 & 0.013 & 0.146 & 0.038 & 0.006 & 8.61 & 28.37 & 1.42 & 3.17 & 60.73 & 24.25 \\
\hline 689 & 0.000 & 0.000 & 0.86 & 0.000 & 0.000 & 0.000 & 0.000 & 0.045 & 0.057 & 0.023 & 0.011 & 8.61 & 28.43 & 1.55 & 3.12 & 59.90 & 24.37 \\
\hline 709 & 0.000 & 0.000 & 0.87 & 0.000 & 0.000 & 0.000 & 0.000 & 0.060 & 0.060 & 0.000 & 0.000 & 8.61 & 28.49 & 1.62 & 3.09 & 59.58 & 24.36 \\
\hline 719 & 0.000 & 0.000 & 0.84 & 0.027 & 0.000 & 0.000 & 0.000 & 0.027 & 0.068 & 0.000 & 0.014 & 8.61 & 28.40 & 1.52 & 3.13 & 59.98 & 24.34 \\
\hline 734 & 0.015 & 0.000 & 0.79 & 0.007 & 0.022 & 0.000 & 0.000 & 0.015 & 0.037 & 0.067 & 0.015 & 8.61 & 28.26 & 1.30 & 3.17 & 60.59 & 24.45 \\
\hline 749 & 0.000 & 0.000 & 0.77 & 0.042 & 0.021 & 0.000 & 0.000 & 0.021 & 0.000 & 0.042 & 0.063 & 8.62 & 28.22 & 1.33 & 3.15 & 60.09 & 25.74 \\
\hline 764 & 0.000 & 0.016 & 0.74 & 0.016 & 0.016 & 0.000 & 0.000 & 0.016 & 0.066 & 0.016 & 0.082 & 8.62 & 28.24 & 1.35 & 3.15 & 60.33 & 24.34 \\
\hline 783 & 0.000 & 0.000 & 0.67 & 0.000 & $0.026 \mid$ & 0.000 & 0.000 & 0.026 & 0.103 & 0.103 & 0.000 & 8.61 & 28.22 & 1.23 & 3.20 & 61.13 & 24.28 \\
\hline 813 & 0.000 & 0.000 & 0.81 & 0.029 & 0.014 & 0.000 & 0.000 & 0.000 & 0.058 & 0.072 & 0.000 & 8.61 & 28.25 & 1.27 & 3.19 & 60.91 & 24.36 \\
\hline 848 & 0.032 & 0.000 & 0.81 & 0.065 & 0.000 & 0.000 & 0.000 & 0.000 & 0.000 & 0.065 & 0.000 & 8.61 & 28.37 & 1.45 & 3.15 & 60.15 & 25.56 \\
\hline 883 & 0.000 & 0.000 & 0.67 & 0.000 & 0.061 & 0.000 & 0.020 & 0.082 & 0.102 & 0.020 & 0.020 & 8.62 & 28.22 & 1.26 & 3.13 & 60.21 & 24.28 \\
\hline 898 & 0.018 & 0.000 & 0.80 & 0.027 & 0.009 & 0.009 & 0.000 & 0.009 & 0.081 & 0.018 & 0.000 & 8.61 & 28.36 & 1.40 & 3.16 & 60.43 & 24.31 \\
\hline 925 & 0.031 & 0.000 & 0.72 & 0.000 & 0.094 & 0.000 & 0.000 & 0.000 & 0.094 & 0.063 & 0.000 & 8.63 & 27.97 & 0.87 & 3.24 & 61.50 & 24.29 \\
\hline 940 & 0.026 & 0.000 & 0.89 & 0.000 & 0.000 & 0.000 & 0.000 & 0.026 & 0.053 & 0.000 & 0.000 & 8.61 & 28.46 & 1.55 & 3.12 & 59.84 & 24.38 \\
\hline 950 & 0.037 & 0.000 & 0.85 & 0.019 & 0.019 & 0.000 & 0.019 & 0.000 & 0.037 & 0.000 & 0.019 & 8.61 & 28.33 & 1.37 & 3.15 & 60.17 & 24.45 \\
\hline 970 & 0.000 & 0.000 & 0.81 & 0.000 & 0.032 & 0.000 & 0.016 & 0.032 & 0.048 & 0.032 & 0.000 & 8.61 & 28.27 & 1.30 & 3.16 & 60.43 & 24.39 \\
\hline 975 & 0.010 & 0.000 & 0.69 & 0.010 & 0.040 & 0.000 & 0.000 & 0.000 & 0.160 & 0.090 & 0.000 & 8.62 & 28.14 & 1.09 & 3.23 & 61.58 & 24.24 \\
\hline 980 & 0.000 & 0.000 & 0.82 & 0.000 & 0.050 & 0.000 & 0.000 & 0.017 & 0.050 & 0.033 & 0.017 & 8.62 & 28.14 & 1.14 & 3.19 & 60.79 & 24.39 \\
\hline 990 & 0.016 & 0.000 & 0.80 & 0.000 & 0.063 & 0.016 & 0.000 & 0.000 & 0.031 & 0.047 & 0.000 & 8.62 & 28.08 & 1.03 & 3.21 & 61.06 & 24.48 \\
\hline 995 & 0.000 & 0.000 & 0.89 & 0.000 & 0.000 & 0.023 & 0.000 & 0.000 & 0.045 & 0.045 & 0.000 & 8.61 & 28.34 & 1.39 & 3.18 & 60.63 & 24.41 \\
\hline 1000 & 0.008 & 0.000 & 0.75 & 0.039 & 0.023 & 0.000 & 0.000 & 0.000 & 0.102 & 0.055 & 0.008 & 8.61 & 28.22 & 1.22 & 3.20 & 61.01 & 24.28 \\
\hline 1005 & 0.000 & 0.000 & 0.93 & 0.000 & 0.000 & 0.000 & 0.000 & 0.035 & 0.035 & 0.000 & 0.000 & 8.61 & 28.44 & 1.55 & 3.12 & 59.79 & 24.47 \\
\hline 1010 & 0.000 & 0.000 & 0.91 & 0.022 & 0.000 & 0.000 & 0.000 & 0.011 & 0.022 & 0.011 & 0.000 & 8.61 & 28.38 & 1.47 & 3.14 & 60.08 & 24.59 \\
\hline 1020 & 0.023 & 0.000 & 0.73 & 0.000 & 0.023 & 0.000 & 0.000 & 0.000 & 0.136 & 0.045 & 0.000 & 8.61 & 28.27 & 1.24 & 3.20 & 61.12 & 24.25 \\
\hline
\end{tabular}




\begin{tabular}{|c|c|c|c|c|c|c|c|c|c|c|c|c|c|c|c|c|c|}
\hline 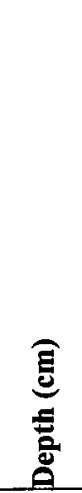 & 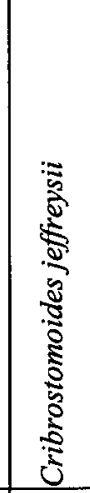 & 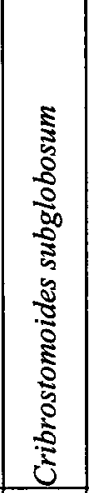 & 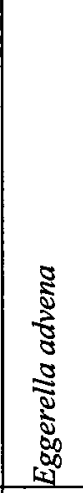 & 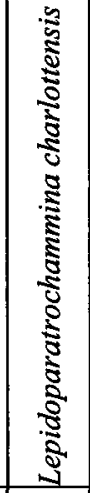 & 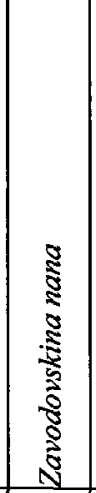 & 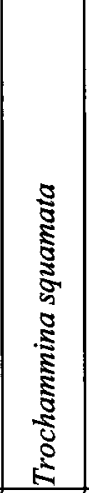 & $\begin{array}{c}\dot{2} \\
5 \\
5 \\
5 \\
5 \\
5 \\
5 \\
5 \\
5 \\
0 \\
0\end{array}$ & 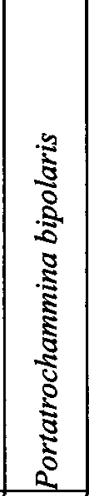 & 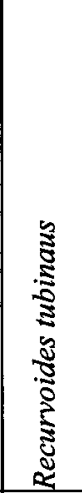 & 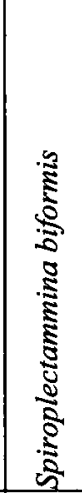 & 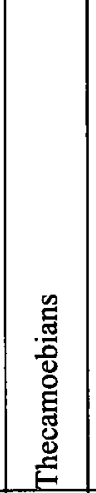 & 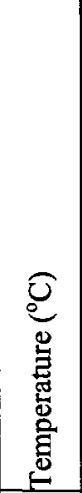 & 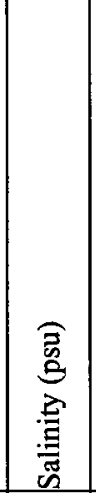 & 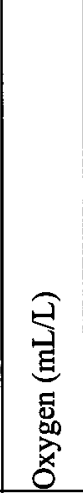 & 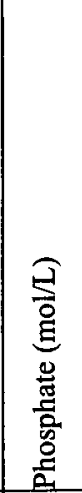 & 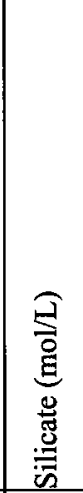 & 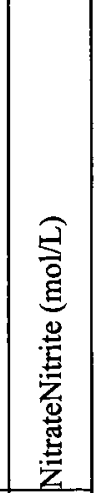 \\
\hline 1025 & 0.000 & 0.000 & 0.68 & 0.000 & 0.025 & 0.000 & 0.000 & 0.000 & 0.100 & 0.125 & 0.025 & 8.62 & 28.14 & 1.13 & 3.23 & 61.51 & 24.28 \\
\hline 1045 & 0.000 & 0.000 & 0.87 & 0.013 & 0.013 & 0.000 & 0.000 & 0.039 & 0.013 & 0.039 & 0.000 & 8.61 & 28.36 & 1.45 & 3.13 & 59.98 & 24.78 \\
\hline 1055 & 0.000 & 0.000 & 0.81 & 0.000 & 0.057 & $0.000 \mid$ & 0.000 & 0.019 & 0.038 & 0.057 & 0.000 & 8.62 & 28.12 & 1.10 & 3.20 & 60.92 & 24.45 \\
\hline 1079 & 0.000 & 0.000 & 0.93 & 0.033 & 0.000 & 0.000 & 0.033 & 0.000 & 0.000 & 0.000 & 0.000 & 8.61 & 28.37 & 1.46 & 3.15 & 60.02 & 25.64 \\
\hline 1094 & 0.000 & 0.000 & 0.85 & 0.058 & 0.000 & 0.000 & 0.000 & 0.000 & 0.077 & 0.000 & 0.000 & 8.61 & 28.36 & 1.43 & 3.16 & 60.37 & 24.32 \\
\hline 1114 & 0.000 & 0.000 & 0.73 & 0.042 & 0.083 & 0.000 & 0.000 & 0.042 & 0.042 & 0.021 & 0.000 & 8.62 & 28.06 & 1.04 & 3.17 & 60.60 & 24.42 \\
\hline 1154 & 0.000 & 0.000 & 0.92 & 0.000 & 0.000 & 0.000 & 0.000 & 0.028 & 0.000 & 0.056 & 0.000 & 8.61 & 28.39 & 1.49 & 3.14 & 60.07 & 25.60 \\
\hline 1169 & 0.000 & 0.000 & 0.80 & 0.044 & 0.011 & 0.022 & 0.000 & 0.022 & 0.067 & 0.000 & 0.000 & 8.61 & 28.35 & 1.43 & 3.14 & 60.15 & 24.33 \\
\hline 1189 & 0.000 & 0.000 & 0.89 & 0.000 & 0.000 & 0.000 & 0.000 & 0.000 & 0.022 & 0.043 & 0.000 & 8.61 & 28.34 & 1.40 & 3.17 & 60.51 & 24.59 \\
\hline
\end{tabular}




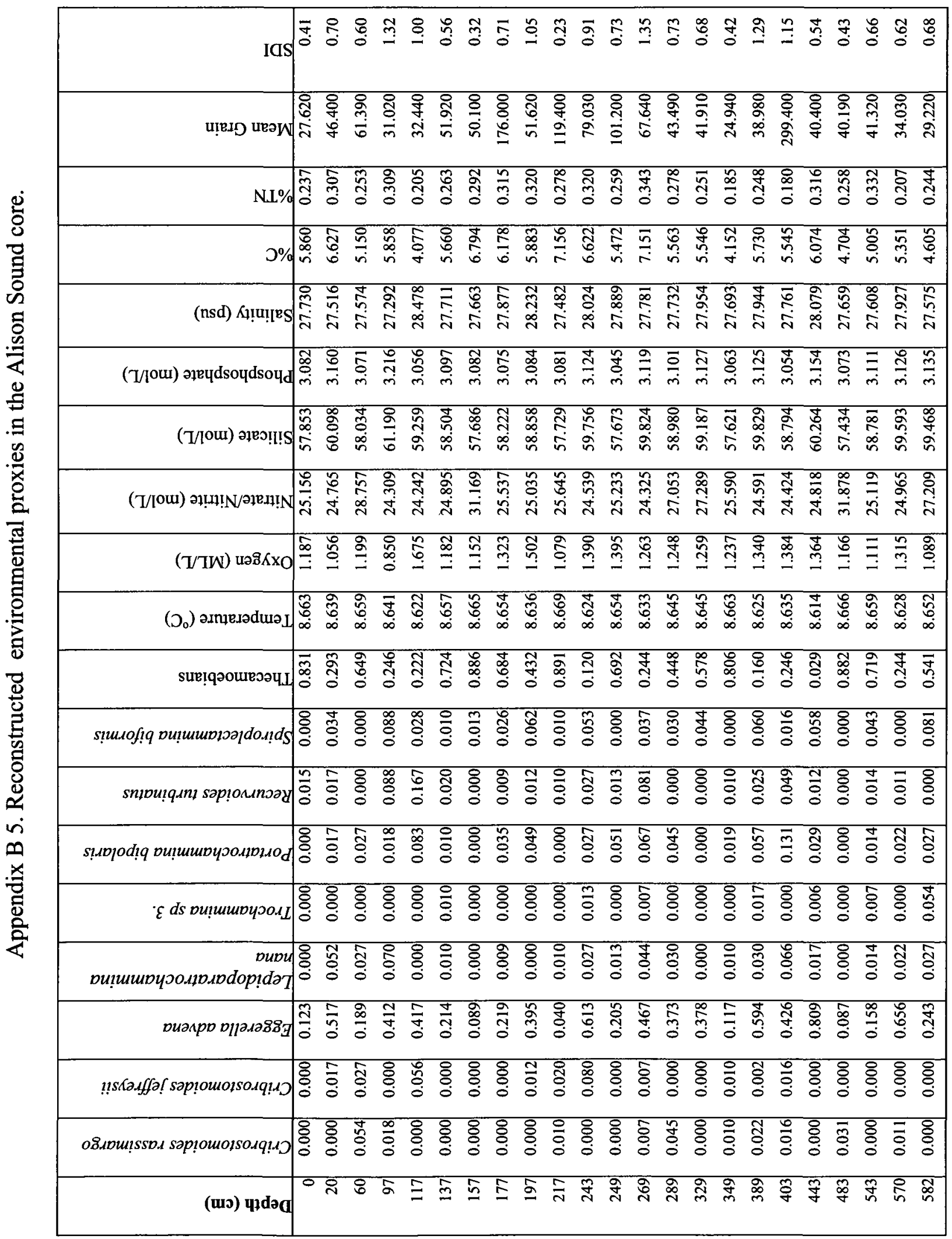




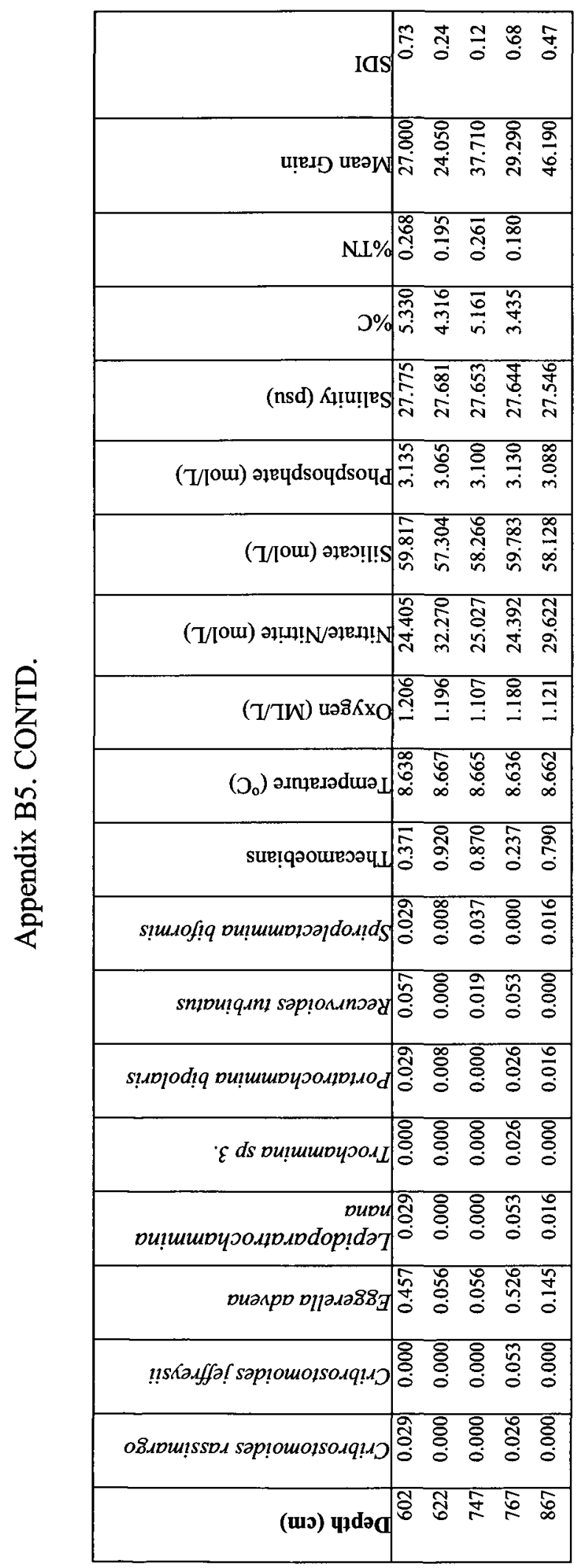




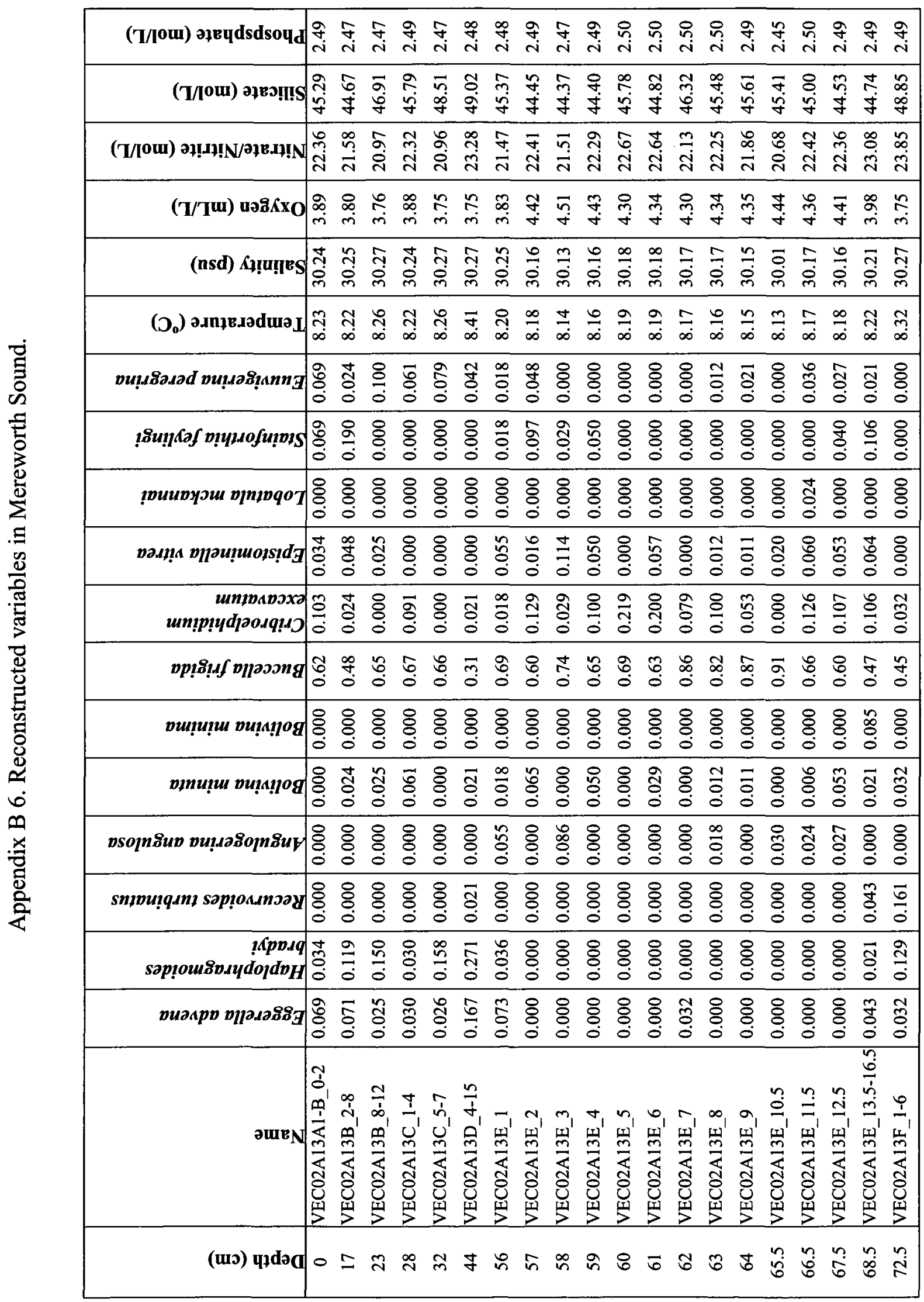


Appendix C. Geochemical Data 
Appendix C 1. Distribution of organic proxies in Frederick Sound core.

\begin{tabular}{|c|c|c|c|c|c|c|c|c|c|}
\hline Depth (cm) & Sample & $\% \mathrm{~N}_{\text {total }}$ & $\% \mathrm{C}_{\text {total }}$ & $\% \mathrm{C}_{\text {carb }}$ & $\% \mathrm{C}_{\text {org }}$ & $\mathrm{C}_{\text {org }} / \mathrm{N}_{\text {total }}$ & \%Bio-Si & $\delta^{13} \mathrm{C}(\%)$ & $\delta^{15} \mathrm{~N}(\%)$ \\
\hline 0 & VEC02A04S1_0-5 & 0.43 & 8.94 & 0.0041 & 8.94 & 20.99 & 7.12 & & \\
\hline 5 & VEC02A04S1_5-10 & 0.40 & 9.35 & 0.0056 & 9.34 & 23.37 & 5.65 & -25.23 & 4.59 \\
\hline 10 & VEC02A04S1_10-15 & 0.45 & 7.92 & 0.0087 & 7.92 & 17.64 & 6.97 & & \\
\hline 15 & VEC02A04S1_15-20 & 0.44 & 8.53 & 0.0048 & 8.52 & 19.54 & 6.48 & -25.34 & 4.44 \\
\hline 20 & VEC02A04S1_20-25 & 0.42 & 7.87 & 0.0101 & 7.86 & 18.63 & 5.91 & & \\
\hline 25 & VEC02A04S1_25-30 & 0.26 & 5.35 & 0.0039 & 5.34 & 20.28 & 3.76 & -26.09 & 3.19 \\
\hline 30 & VEC02A04S1_30-35 & 0.25 & 5.66 & 0.0069 & 5.65 & 22.44 & 3.72 & & \\
\hline 35 & VEC02A04S1_35-40 & 0.17 & 3.25 & 0.003 & 3.25 & 19.43 & 2.97 & -25.71 & 3.25 \\
\hline 40 & VEC02A04S1_40-45 & 0.45 & 7.92 & 0.0091 & 7.91 & 17.61 & 6.72 & & \\
\hline 45 & VEC02A04S1_45-50 & 0.45 & 8.65 & 0.0037 & 8.64 & 19.15 & 6.58 & & \\
\hline 50 & VEC02A04S1_50-55 & 0.48 & 7.81 & 0.0038 & 7.80 & 16.43 & 8.15 & & \\
\hline 55 & VEC02A04S1_55-60 & 0.39 & 8.63 & 0.0139 & 8.62 & 21.94 & 5.51 & & \\
\hline 60 & VEC02A04S1_60-65 & 0.37 & 7.20 & 0.0185 & 7.18 & 19.52 & 5.24 & & \\
\hline 65 & VEC02A04S1_65-70 & 0.45 & 7.16 & 0.0046 & 7.15 & 15.86 & 8.12 & -24.91 & 4.86 \\
\hline 70 & VEC02A04S1_70-75 & 0.40 & 7.06 & 0.0096 & 7.05 & 17.65 & 8.33 & & \\
\hline 75 & VEC02A04S1_75-80 & 0.46 & 7.63 & 0.0055 & 7.62 & 16.47 & 8.01 & -24.96 & 4.81 \\
\hline 80 & VEC02A04S1_80-85 & 0.47 & 7.78 & 0.0116 & 7.77 & 16.63 & 6.60 & & \\
\hline 85 & VEC02A04S1_85-90 & 0.50 & 8.92 & 0.0046 & 8.91 & 17.98 & 7.22 & -25.53 & 3.96 \\
\hline 90 & VEC02A04S1_90-95 & 0.50 & 8.30 & 0.0109 & 8.29 & 16.70 & 7.47 & & \\
\hline 95 & VEC02A04S1_95-100 & 0.46 & 8.31 & 0.0052 & 8.31 & 18.24 & 5.19 & -25.18 & 4.49 \\
\hline 100 & VEC02A04S1_100-105 & 0.45 & 7.91 & 0.0085 & 7.90 & 17.61 & 7.60 & & \\
\hline 105 & VEC02A04S1_105-110 & 0.39 & 7.10 & 0.0037 & 7.10 & 18.05 & 7.10 & -25.13 & 4.86 \\
\hline 110 & VEC02A04S1_110-115 & 0.48 & 8.37 & 0.0048 & 8.37 & 17.34 & 8.01 & & \\
\hline 115 & VEC02A04S1_115-120 & 0.46 & 8.53 & 0.0034 & 8.53 & 18.37 & 7.20 & -25.33 & 4.66 \\
\hline 120 & VEC02A04S1_120-125 & 0.50 & 8.76 & 0.0061 & 8.75 & 17.69 & 6.58 & & \\
\hline 125 & VEC02A04S1_125-130 & 0.42 & 6.90 & 0.0252 & 6.87 & 16.54 & 8.76 & -25.71 & 4.01 \\
\hline 130 & VEC02A04S1_130-135 & 0.43 & 8.25 & 0.009 & 8.24 & 19.16 & 7.09 & & \\
\hline 135 & VEC02A04S1_135-136 & 0.48 & 8.84 & 0.0034 & 8.83 & 18.33 & 7.29 & -24.87 & 5.16 \\
\hline 183 & VEC02A04S2_0-5 & 0.47 & 8.47 & 0.005 & 8.46 & 18.14 & 7.34 & & \\
\hline 188 & VEC02A04S2_5-10 & 0.48 & 8.46 & 0.0028 & 8.46 & 17.74 & 6.95 & & \\
\hline 193 & VEC02A04S2_10-15 & 0.47 & 8.43 & 0.005 & 8.43 & 18.12 & 7.48 & & \\
\hline 198 & VEC02A04S2_15-20 & 0.45 & 7.54 & 0.0024 & 7.53 & 16.88 & 8.31 & & \\
\hline 203 & VEC02A04S2_20-25 & 0.41 & 8.01 & 0.0054 & 8.00 & 19.40 & 6.13 & & \\
\hline 208 & VEC02A04S2_25-30 & 0.35 & 8.13 & 0.0029 & 8.94 & 20.99 & 7.12 & & \\
\hline 213 & VEC02A04S2_30-35 & 0.31 & 6.87 & 0.0056 & 9.34 & 23.37 & 5.65 & & \\
\hline 218 & VEC02A04S2_35-40 & 0.28 & 5.83 & 0.0035 & 7.92 & 17.64 & 6.97 & & \\
\hline 223 & VEC02A04S2_40-45 & 0.44 & 8.30 & 0.0064 & 8.52 & 19.54 & 6.48 & & \\
\hline 228 & VEC02A04S2_45-50 & 0.47 & 8.39 & 0.0034 & 7.86 & 18.63 & 5.91 & & \\
\hline
\end{tabular}


Appendix C1. CONTD.

\begin{tabular}{|c|c|c|c|c|c|c|c|c|c|}
\hline Depth (cm) & Sample & $\% \mathrm{~N}_{\text {total }}$ & $\% \mathrm{C}_{\text {total }}$ & $\% \mathrm{C}_{\text {carb }}$ & $\% \mathrm{C}_{\text {огg }}$ & $\mathrm{C}_{\text {org }} / \mathrm{N}_{\text {total }}$ & $\% \mathrm{Bio}-\mathrm{Si}$ & $\delta^{13} \mathrm{C}(\%)$ & $\delta^{15} \mathrm{~N}(\% 0)$ \\
\hline 233 & VEC02A04S2_50-55 & 0.49 & 8.60 & 0.0063 & 5.34 & 20.28 & 3.76 & & \\
\hline 238 & VEC02A04S2_55-60 & 0.49 & 9.09 & 0.0035 & 5.65 & 22.44 & 3.72 & & \\
\hline 243 & VEC02A04S2_60-65 & 0.47 & 9.02 & 0.0061 & 3.25 & 19.43 & 2.97 & & \\
\hline 248 & VEC02A04S2_65-70 & 0.45 & 9.12 & 0.0027 & 7.91 & 17.61 & 6.72 & & \\
\hline 253 & VEC02A04S2_70-75 & 0.33 & 7.96 & 0.0055 & 8.64 & 19.15 & 6.58 & & \\
\hline 258 & VEC02A04S2_75-80 & 0.48 & 7.78 & 0.0059 & 7.80 & 16.43 & 8.15 & & \\
\hline 263 & VEC02A04S2_80-85 & 0.47 & 7.68 & 0.0033 & 8.62 & 21.94 & 5.51 & & \\
\hline 268 & VEC02A04S2_85-90 & 0.50 & 7.93 & 0.0051 & 7.18 & 19.52 & 5.24 & & \\
\hline 273 & VEC02A04S2_90-95 & 0.40 & 7.25 & 0.0052 & 7.15 & 15.86 & 8.12 & & \\
\hline 278 & VEC02A04S2_95-100 & 0.43 & 7.64 & 0.0068 & 7.05 & 17.65 & 8.33 & & \\
\hline 283 & VEC02A04S2_100-105 & 0.49 & 9.08 & 0.0058 & 7.62 & 16.47 & 8.01 & & \\
\hline 288 & VEC02A04S2_105-110 & 0.48 & 7.73 & 0.006 & 7.77 & 16.63 & 6.60 & & \\
\hline 293 & VEC02A04S2_110-112 & 0.46 & 7.46 & 0.0038 & 8.91 & 17.98 & 7.22 & & \\
\hline 295 & VEC02A04BS1/2_0-5 & 0.45 & 7.07 & 0.059 & 8.29 & 16.70 & 7.47 & & \\
\hline 300 & VEC02A04BS1/2_5-10 & 0.46 & 6.68 & 0.0549 & 8.31 & 18.24 & 5.19 & & \\
\hline 305 & VEC02A04BS1/2_10-15 & 0.43 & 7.06 & 0.0201 & 7.90 & 17.61 & 7.60 & & \\
\hline 310 & VEC02A04BS1/2_15-20 & 0.36 & 7.58 & 0.0119 & 7.10 & 18.05 & 7.10 & & \\
\hline 315 & VEC02A04BS1/2_20-25 & 0.45 & 7.17 & 0.0033 & 8.37 & 17.34 & 8.01 & & \\
\hline 320 & VEC02A04BS1/2_25-30 & 0.42 & 7.98 & 0.0057 & 8.53 & 18.37 & 7.20 & & \\
\hline 325 & VEC02A04S3_0-5 & 0.42 & 9.07 & 0.0042 & 8.75 & 17.69 & 6.58 & & \\
\hline 330 & VEC02A04S3_5-10 & 0.42 & 7.11 & 0.0055 & 6.87 & 16.54 & 8.76 & -25.26 & 4.36 \\
\hline 335 & VEC02A04S3_10-15 & 0.48 & 8.46 & 0.003 & 8.24 & 19.16 & 7.09 & & \\
\hline 340 & VEC02A04S3_15-20 & 0.48 & 8.04 & 0.0037 & 8.83 & 18.33 & 7.29 & -25.33 & 4.66 \\
\hline 345 & VEC02A04S3_20-25 & 0.46 & 7.67 & 0.0028 & 8.46 & 18.14 & 7.34 & & \\
\hline 350 & VEC02A04S3_25-30 & 0.41 & 7.92 & 0.0038 & 8.46 & 17.74 & 6.95 & -25.45 & 4.01 \\
\hline 355 & VEC02A04S3_30-35 & 0.46 & 7.38 & 0.0021 & 8.43 & 18.12 & 7.48 & & \\
\hline 360 & VEC02A04S3_35-40 & 0.46 & 7.87 & 0.0047 & 7.53 & 16.88 & 8.31 & -25.22 & 4.49 \\
\hline 365 & VEC02A04S3_40-45 & 0.45 & 7.29 & 0.0027 & 8.00 & 19.40 & 6.13 & & \\
\hline 370 & VEC02A04S3_45-50 & 0.45 & 7.31 & 0.005 & 8.94 & 20.99 & 7.12 & -25.31 & 3.95 \\
\hline 375 & VEC02A04S3_50-55 & 0.48 & 7.81 & 0.0027 & 9.34 & 23.37 & 5.65 & & \\
\hline 380 & VEC02A04S3_55-60 & 0.48 & 7.37 & 0.0047 & 7.92 & 17.64 & 6.97 & -24.99 & 5.07 \\
\hline 385 & VEC02A04S3_60-65 & 0.39 & 7.19 & 0.0029 & 8.52 & 19.54 & 6.48 & & \\
\hline 390 & VEC02A04S3_65-70 & 0.43 & 6.64 & 0.0051 & 7.86 & 18.63 & 5.91 & -24.64 & 5.30 \\
\hline 395 & VEC02A04S3_70-75 & 0.43 & 6.11 & 0.0041 & 5.34 & 20.28 & 3.76 & & \\
\hline 400 & VEC02A04S3_75-80 & 0.45 & 7.01 & 0.0024 & 5.65 & 22.44 & 3.72 & -24.84 & 5.37 \\
\hline 405 & VEC02A04S3_80-85 & 0.46 & 7.06 & 0.0049 & 3.25 & 19.43 & 2.97 & & \\
\hline 410 & VEC02A04S3_85-90 & 0.35 & 7.17 & 0.0047 & 7.91 & 17.61 & 6.72 & -25.58 & 3.89 \\
\hline 415 & VEC02A04S3_90-95 & 0.22 & 3.87 & 0.0042 & 8.64 & 19.15 & 6.58 & & \\
\hline 420 & VEC02A04S3_95-100 & 0.42 & 7.91 & 0.0041 & 7.80 & 16.43 & 8.15 & -24.52 & 5.39 \\
\hline 425 & VEC02A04S3_100-105 & 0.41 & 7.49 & 0.0068 & 8.62 & 21.94 & 5.51 & & \\
\hline
\end{tabular}


Appendix C1. CONTD.

\begin{tabular}{|c|c|c|c|c|c|c|c|c|c|}
\hline Depth (cm) & Sample & $\% \mathrm{~N}_{\text {total }}$ & $\% \mathrm{C}_{\text {total }}$ & $\% \mathrm{C}_{\text {carb }}$ & $\% \mathrm{C}_{\text {org }}$ & $\mathrm{C}_{\text {org }} / \mathrm{N}_{\text {total }}$ & $\% \mathrm{Bio}-\mathrm{Si}$ & $\delta^{13} \mathrm{C}(\% 0)$ & $\delta^{15} \mathrm{~N}(\%)$ \\
\hline 430 & VEC02A04S3_105-110 & 0.42 & 7.28 & 0.003 & 7.18 & 19.52 & 5.24 & -25.39 & 4.36 \\
\hline 435 & VEC02A04S3_110-115 & 0.41 & 7.06 & 0.006 & 7.15 & 15.86 & 8.12 & & \\
\hline 440 & VEC02A04S3_115-120 & 0.43 & 6.94 & 0.0026 & 7.05 & 17.65 & 8.33 & -24.92 & 5.24 \\
\hline 445 & VEC02A04S3_120-125 & 0.45 & 7.45 & 0.0059 & 7.62 & 16.47 & 8.01 & & \\
\hline 450 & VEC02A04S3_125-130 & NA & NA & NA & 7.77 & 16.63 & 6.60 & -24.67 & 5.28 \\
\hline 455 & VEC02A04S3_130-135 & 0.32 & 9.53 & 0.009 & 8.91 & 17.98 & 7.22 & -25.65 & 3.92 \\
\hline 460 & VEC02A04S3_135-137 & 0.45 & 9.30 & 0.002 & 8.29 & 16.70 & 7.47 & & \\
\hline 472 & VEC02A04S4_10-15 & 0.48 & 8.15 & 0.0059 & 8.31 & 18.24 & 5.19 & & \\
\hline 477 & VEC02A04S4_15-20 & 0.44 & 7.61 & 0.0065 & 7.90 & 17.61 & 7.60 & -25.05 & 4.71 \\
\hline 482 & VEC02A04S4_20-25 & 0.46 & 7.81 & 0.0049 & 7.10 & 18.05 & 7.10 & & \\
\hline 487 & VEC02A04S4_25-30 & 0.45 & 7.14 & 0.003 & 8.37 & 17.34 & 8.01 & -24.80 & 4.90 \\
\hline 492 & VEC02A04S4_30-35 & 0.46 & 7.41 & 0.006 & 8.53 & 18.37 & 7.20 & & \\
\hline 497 & VEC02A04S4_35-40 & 0.45 & 8.01 & 0.0029 & 8.75 & 17.69 & 6.58 & -24.78 & 5.28 \\
\hline 502 & VEC02A04S4_40-45 & 0.44 & 7.79 & 0.0063 & 6.87 & 16.54 & 8.76 & & \\
\hline 507 & VEC02A04S4_45-50 & 0.42 & 6.75 & 0.0029 & 8.24 & 19.16 & 7.09 & -25.02 & 4.86 \\
\hline 512 & VEC02A04S4_50-55 & 0.40 & 6.12 & 0.0056 & 8.83 & 18.33 & 7.29 & & \\
\hline 517 & VEC02A04S4_55-60 & 0.43 & 7.07 & 0.0029 & 8.46 & 18.14 & 7.34 & & \\
\hline 522 & VEC02A04S4_60-65 & 0.40 & 6.79 & 0.0032 & 8.46 & 17.74 & 6.95 & & \\
\hline 527 & VEC02A04S4_65-70 & 0.50 & 6.95 & 0.0022 & 8.43 & 18.12 & 7.48 & -24.69 & 5.41 \\
\hline 532 & VEC02A04S4_70-75 & 0.43 & 7.61 & 0.005 & 7.53 & 16.88 & 8.31 & & \\
\hline 537 & VEC02A04S4_75-80 & 0.36 & 7.68 & 0.0034 & 8.00 & 19.40 & 6.13 & -25.69 & 3.74 \\
\hline 542 & VEC02A04S4_80-85 & 0.31 & 6.13 & 0.0101 & 8.94 & 20.99 & 7.12 & & \\
\hline 547 & VEC02A04S4_85-90 & 0.45 & 6.76 & 0.0025 & 9.34 & 23.37 & 5.65 & -25.04 & 5.11 \\
\hline 552 & VEC02A04S4_90-95 & 0.45 & 7.25 & 0.0072 & 7.92 & 17.64 & 6.97 & & \\
\hline 557 & VEC02A04S4_95-100 & 0.46 & 7.92 & 0.0293 & 8.52 & 19.54 & 6.48 & -24.76 & 5.02 \\
\hline 562 & VEC02A04S4_100-105 & 0.48 & 6.99 & 0.0062 & 7.86 & 18.63 & 5.91 & -24.46 & 5.85 \\
\hline 567 & VEC02A04S4_105-110 & 0.46 & 7.51 & 0.0032 & 5.34 & 20.28 & 3.76 & & \\
\hline 572 & VEC02A04S4_110-115 & 0.35 & 6.92 & 0.0068 & 5.65 & 22.44 & 3.72 & -25.24 & 4.66 \\
\hline 577 & VEC02A04S4_115-120 & 0.41 & 7.62 & 0.0031 & 3.25 & 19.43 & 2.97 & & \\
\hline 582 & VEC02A04S4_120-125 & 0.46 & 7.76 & 0.0115 & 7.91 & 17.61 & 6.72 & -24.54 & 5.68 \\
\hline 587 & VEC02A04S4_125-130 & 0.47 & 6.94 & 0.0025 & 8.64 & 19.15 & 6.58 & & \\
\hline 592 & VEC02A04S4_130-135 & 0.49 & 7.39 & 0.006 & 7.80 & 16.43 & 8.15 & -24.86 & 5.23 \\
\hline 597 & VEC02A04S4_135-140 & 0.48 & 7.69 & 0.0019 & 8.62 & 21.94 & 5.51 & & \\
\hline 602 & VEC02A04S4_140-145 & 0.43 & 7.57 & 0.006 & 7.18 & 19.52 & 5.24 & -24.78 & 5.58 \\
\hline 607 & VEC02A04S4_145-150 & 0.48 & 9.24 & 0.0038 & 7.15 & 15.86 & 8.12 & & \\
\hline 612 & VEC02A04S4_150-155 & 0.46 & 7.07 & 0.005 & 7.05 & 17.65 & 8.33 & -24.92 & 3.76 \\
\hline 617 & VEC02A04S4_155-157 & 0.44 & 8.33 & 0.0029 & 7.62 & 16.47 & 8.01 & & \\
\hline 619 & VEC02A04S5_0-5 & 0.42 & 8.12 & 0.0074 & 7.77 & 16.63 & 6.60 & & \\
\hline 624 & VEC02A04S5_5-10 & 0.38 & 7.51 & 0.0051 & 8.91 & 17.98 & 7.22 & & \\
\hline 629 & VEC02A04S5_10-15 & 0.40 & 7.58 & 0.0081 & 8.29 & 16.70 & 7.47 & -25.30 & 4.39 \\
\hline
\end{tabular}


Appendix C1. CONTD.

\begin{tabular}{|c|c|c|c|c|c|c|c|c|c|}
\hline Depth (cm) & Sample & $\% \mathrm{~N}_{\text {total }}$ & $\% \mathrm{C}_{\text {total }}$ & $\% \mathrm{C}_{\text {carb }}$ & $\% \mathrm{C}_{\text {org }}$ & $\mathrm{C}_{\text {org }} / \mathrm{N}_{\text {total }}$ & $\%$ Bio-Si & $\delta^{13} \mathrm{C}(\%)$ & $\delta^{15} \mathrm{~N}(\% 0)$ \\
\hline 634 & VEC02A04S5_15-20 & 0.35 & 7.71 & 0.0042 & 8.31 & 18.24 & 5.19 & & \\
\hline 639 & VEC02A04S5_20-25 & 0.37 & 7.22 & 0.0049 & 7.90 & 17.61 & 7.60 & -25.18 & 4.29 \\
\hline 644 & VEC02A04S5_25-30 & 0.39 & 8.13 & 0.0036 & 7.10 & 18.05 & 7.10 & & \\
\hline 649 & VEC02A04S5_30-35 & 0.44 & 7.47 & 0.0054 & 8.37 & 17.34 & 8.01 & -24.94 & 5.14 \\
\hline 654 & VEC02A04S5_35-40 & 0.44 & 7.05 & 0.0028 & 8.53 & 18.37 & 7.20 & & \\
\hline 659 & VEC02A04S5_40-45 & 0.43 & 7.43 & 0.0066 & 8.75 & 17.69 & 6.58 & -24.40 & 5.28 \\
\hline 664 & VEC02A04S5_45-50 & 0.42 & 7.63 & 0.0039 & 6.87 & 16.54 & 8.76 & & \\
\hline 669 & VEC02A04S5_50-55 & 0.43 & 7.41 & 0.009 & 8.24 & 19.16 & 7.09 & -25.45 & 4.02 \\
\hline 674 & VEC02A04S5_55-60 & 0.47 & 7.40 & 0.0006 & 8.83 & 18.33 & 7.29 & & \\
\hline 679 & VEC02A04S5_60-65 & 0.42 & 6.93 & 0.0081 & 8.46 & 18.14 & 7.34 & -24.71 & 5.03 \\
\hline 684 & VEC02A04S5_65-70 & 0.39 & 7.60 & 0.0032 & 8.46 & 17.74 & 6.95 & & \\
\hline 689 & VEC02A04S5_70-75 & 0.46 & 7.95 & 0.0076 & 8.43 & 18.12 & 7.48 & & \\
\hline 694 & VEC02A04S5_75-80 & 0.45 & 6.52 & 0.0028 & 7.53 & 16.88 & 8.31 & & \\
\hline 699 & VEC02A04S5_80-85 & 0.43 & 6.39 & 0.0087 & 8.00 & 19.40 & 6.13 & -24.58 & 5.31 \\
\hline 704 & VEC02A04S5_85-90 & 0.43 & 7.00 & 0.0027 & 8.94 & 20.99 & 7.12 & & \\
\hline 709 & VEC02A04S5_90-95 & 0.44 & 7.03 & 0.0044 & 9.34 & 23.37 & 5.65 & -24.69 & 5.97 \\
\hline 714 & VEC02A04S5_95-100 & 0.45 & 6.65 & 0.0019 & 7.92 & 17.64 & 6.97 & & \\
\hline 719 & VEC02A04S5_100-105 & 0.44 & 6.71 & 0.0055 & 8.52 & 19.54 & 6.48 & & \\
\hline 724 & VEC02A04S5_105-110 & 0.39 & 6.75 & 0.0036 & 7.86 & 18.63 & 5.91 & & \\
\hline 729 & VEC02A04S5_110-115 & 0.45 & 6.74 & 0.0042 & 5.34 & 20.28 & 3.76 & & \\
\hline 734 & VEC02A04S5_115-120 & 0.46 & 7.08 & 0.0038 & 5.65 & 22.44 & 3.72 & -24.40 & 5.21 \\
\hline 739 & VEC02A04S5_120-125 & 0.44 & 8.60 & 0.0062 & 3.25 & 19.43 & 2.97 & -25.42 & 4.16 \\
\hline 744 & VEC02A04S5_125-130 & 0.47 & 7.55 & 0.0049 & 7.91 & 17.61 & 6.72 & & \\
\hline 749 & VEC02A04S5_130-135 & 0.46 & 7.27 & 0.0026 & 8.64 & 19.15 & 6.58 & -24.99 & 4.83 \\
\hline 754 & VEC02A04S5_135-140 & 0.48 & 9.54 & 0.0034 & 7.80 & 16.43 & 8.15 & & \\
\hline 759 & VEC02A04S5_140-145 & 0.37 & 6.95 & 0.0053 & 8.62 & 21.94 & 5.51 & -24.96 & 5.04 \\
\hline 764 & VEC02A04S5_145-150 & 0.41 & 6.91 & 0.0035 & 7.18 & 19.52 & 5.24 & & \\
\hline 769 & VEC02A04S5_150-154 & 0.43 & 8.07 & 0.0028 & 7.15 & 15.86 & 8.12 & -25.25 & 4.90 \\
\hline 773 & VEC02A04S6_0-5 & 0.45 & 6.23 & 0.0026 & 7.05 & 17.65 & 8.33 & & \\
\hline 778 & VEC02A04S6_5-10 & 0.43 & 7.71 & 0.0046 & 7.62 & 16.47 & 8.01 & -24.62 & 5.12 \\
\hline 783 & VEC02A04S6_10-15 & 0.49 & 6.68 & 0.0018 & 7.77 & 16.63 & 6.60 & & \\
\hline 788 & VEC02A04S6_15-20 & 0.52 & 10.28 & 0.0043 & 8.91 & 17.98 & 7.22 & -25.46 & 5.02 \\
\hline 793 & VEC02A04S6_20-25 & 0.40 & 6.89 & 0.0034 & 8.29 & 16.70 & 7.47 & & \\
\hline 798 & VEC02A04S6_25-30 & 0.43 & 6.90 & 0.0026 & 8.31 & 18.24 & 5.19 & -24.78 & 6.11 \\
\hline 803 & VEC02A04S6_30-35 & 0.48 & 6.84 & 0.0034 & 7.90 & 17.61 & 7.60 & & \\
\hline 808 & VEC02A04S6_35-40 & 0.45 & 7.11 & 0.0048 & 7.10 & 18.05 & 7.10 & -25.42 & 5.52 \\
\hline 813 & VEC02A04S6_40-45 & 0.43 & 8.70 & 0.0061 & 8.37 & 17.34 & 8.01 & & \\
\hline 818 & VEC02A04S6_45-50 & 0.44 & 7.32 & 0.0054 & 8.53 & 18.37 & 7.20 & -25.49 & 5.03 \\
\hline 823 & VEC02A04S6_50-55 & 0.50 & 6.80 & 0.0035 & 8.75 & 17.69 & 6.58 & & \\
\hline 828 & VEC02A04S6_55-60 & 0.48 & 6.87 & 0.004 & 6.87 & 16.54 & 8.76 & -25.70 & 5.15 \\
\hline
\end{tabular}




\begin{tabular}{|c|c|c|c|c|c|c|c|c|c|}
\hline Depth $(\mathrm{cm})$ & Sample & $\% \mathrm{~N}_{\text {total }}$ & $\% \mathrm{C}_{\text {total }}$ & $\% \mathrm{C}_{\text {carb }}$ & $\% \mathrm{C}_{\text {org }}$ & $\mathrm{C}_{\text {org }} / \mathrm{N}_{\text {total }}$ & $\% \mathrm{Bio}-\mathrm{Si}$ & $\delta^{13} \mathrm{C}(\%)$ & $\delta^{15} \mathrm{~N}(\%)$ \\
\hline 833 & VEC02A04S6_60-65 & 0.49 & 6.53 & 0.033 & 8.24 & 19.16 & 7.09 & & \\
\hline 838 & VEC02A04S6_65-70 & 0.45 & 7.36 & 0.0047 & 8.83 & 18.33 & 7.29 & & \\
\hline 843 & VEC02A04S6_70-75 & 0.49 & 7.54 & 0.0043 & 8.46 & 18.14 & 7.34 & & \\
\hline 848 & VEC02A04S6_75-80 & 0.48 & 7.39 & 0.0035 & 8.46 & 17.74 & 6.95 & -25.57 & 5.17 \\
\hline 853 & VEC02A04S6_80-85 & 0.45 & 7.30 & 0.0057 & 8.43 & 18.12 & 7.48 & & \\
\hline 858 & VEC02A04S6_85-90 & 0.48 & 6.68 & 0.0056 & 7.53 & 16.88 & 8.31 & -25.48 & 5.49 \\
\hline 863 & VEC02A04S6_90-95 & 0.49 & 7.30 & 0.0033 & 8.00 & 19.40 & 6.13 & & \\
\hline 868 & VEC02A04S6_95-100 & 0.46 & 7.44 & 0.0028 & 8.94 & 20.99 & 7.12 & -25.46 & 5.40 \\
\hline 873 & VEC02A04S6_100-105 & 0.48 & 7.04 & 0.0047 & 9.34 & 23.37 & 5.65 & & \\
\hline 878 & VEC02A04S6_105-110 & 0.45 & 7.05 & 0.0025 & 7.92 & 17.64 & 6.97 & -25.38 & 5.09 \\
\hline 883 & VEC02A04S6_110-115 & 0.44 & 6.97 & 0.0081 & 8.52 & 19.54 & 6.48 & & \\
\hline 888 & VEC02A04S6_115-120 & 0.43 & 7.82 & 0.0036 & 7.86 & 18.63 & 5.91 & -25.99 & 4.98 \\
\hline 893 & VEC02A04S6_120-125 & 0.43 & 8.08 & 0.0063 & 5.34 & 20.28 & 3.76 & & \\
\hline 898 & VEC02A04S6_125-130 & 0.41 & 7.39 & 0.0026 & 5.65 & 22.44 & 3.72 & & \\
\hline 903 & VEC02A04S6_130-135 & 0.35 & 6.98 & 0.0056 & 3.25 & 19.43 & 2.97 & & \\
\hline 908 & VEC02A04S6_135-140 & 0.43 & 7.67 & 0.0034 & 7.91 & 17.61 & 6.72 & -25.27 & 5.50 \\
\hline 913 & VEC02A04S6_140-145 & 0.45 & 7.84 & 0.0067 & 8.64 & 19.15 & 6.58 & & \\
\hline 918 & VEC02A04S6_145-150 & 0.43 & 7.46 & 0.003 & 7.80 & 16.43 & 8.15 & -25.59 & 5.57 \\
\hline 923 & VEC02A04S6_150-152 & 0.44 & 7.27 & 0.0052 & 8.62 & 21.94 & 5.51 & & \\
\hline 925 & VEC02A04S7_0-5 & 0.43 & 7.63 & 0.0058 & 7.18 & 19.52 & 5.24 & -25.91 & 4.09 \\
\hline 930 & VEC02A04S7_5-10 & 0.46 & 6.72 & 0.0072 & 7.15 & 15.86 & 8.12 & & \\
\hline 935 & VEC02A04S7_10-15 & 0.44 & 6.94 & 0.0036 & 7.05 & 17.65 & 8.33 & -25.27 & 5.90 \\
\hline 940 & VEC02A04S7_15-20 & 0.38 & 6.74 & 0.0051 & 7.62 & 16.47 & 8.01 & & \\
\hline 945 & VEC02A04S7_20-25 & 0.42 & 6.69 & 0.0029 & 7.77 & 16.63 & 6.60 & -25.88 & 3.80 \\
\hline 950 & VEC02A04S7_25-30 & 0.36 & 7.11 & 0.0055 & 8.91 & 17.98 & 7.22 & & \\
\hline 955 & VEC02A04S7_30-35 & 0.45 & 6.55 & 0.0024 & 8.29 & 16.70 & 7.47 & -26.07 & 4.01 \\
\hline 960 & VEC02A04S7_35-40 & 0.46 & 7.57 & 0.0038 & 8.31 & 18.24 & 5.19 & & \\
\hline 965 & VEC02A04S7_40-45 & 0.48 & 6.81 & 0.0022 & 7.90 & 17.61 & 7.60 & -25.51 & 5.40 \\
\hline 970 & VEC02A04S7__45-50 & 0.44 & 7.60 & 0.0042 & 7.10 & 18.05 & 7.10 & & \\
\hline 975 & VEC02A04S7_50-55 & 0.44 & 6.56 & 0.0036 & 8.37 & 17.34 & 8.01 & -25.91 & 4.62 \\
\hline 980 & VEC02A04S7_55-60 & 0.47 & 6.70 & 0.0065 & 8.53 & 18.37 & 7.20 & & \\
\hline 985 & VEC02A04S7_60-65 & 0.45 & 7.54 & 0.0037 & 8.75 & 17.69 & 6.58 & -25.19 & 5.35 \\
\hline 990 & VEC02A04S7_65-70 & 0.44 & 6.79 & 0.0033 & 6.87 & 16.54 & 8.76 & & \\
\hline 995 & VEC02A04S7_70-75 & 0.42 & 6.70 & 0.0047 & 8.24 & 19.16 & 7.09 & -25.13 & 5.55 \\
\hline 1000 & VEC02A04S7_75-80 & 0.39 & 6.62 & 0.0046 & 8.83 & 18.33 & 7.29 & & \\
\hline 1005 & VEC02A04S7_80-85 & 0.44 & 6.89 & 0.0037 & 8.46 & 18.14 & 7.34 & -25.36 & 5.37 \\
\hline 1010 & VEC02A04S7_85-90 & 0.46 & 7.07 & 0.0056 & 8.46 & 17.74 & 6.95 & & \\
\hline 1015 & VEC02A04S7_90-95 & 0.48 & 7.33 & 0.0031 & 8.43 & 18.12 & 7.48 & -25.60 & 5.30 \\
\hline 1020 & VEC02A04S7_95-100 & 0.44 & 7.54 & 0.005 & 7.53 & 16.88 & 8.31 & & \\
\hline 1025 & VEC02A04S7_100-105 & 0.41 & 7.10 & 0.0031 & 8.00 & 19.40 & 6.13 & -25.77 & 4.80 \\
\hline
\end{tabular}


Appendix C1. CONTD.

\begin{tabular}{|c|c|c|c|c|c|c|c|c|c|}
\hline Depth $(\mathrm{cm})$ & Sample & $\% \mathrm{~N}_{\text {total }}$ & $\% \mathrm{C}_{\text {total }}$ & $\% \mathrm{C}_{\text {carb }}$ & $\% \mathrm{C}_{\text {org }}$ & $\mathrm{C}_{\text {org }} / \mathrm{N}_{\text {total }}$ & $\%$ Bio-Si & $\delta^{13} \mathrm{C}(\% 0)$ & $\delta^{15} \mathrm{~N}(\% 0)$ \\
\hline 1030 & VEC02A04S7_105-110 & 0.45 & 7.26 & 0.0057 & 8.94 & 20.99 & 7.12 & & \\
\hline 1035 & VEC02A04S7_110-115 & 0.42 & 6.54 & 0.0037 & 9.34 & 23.37 & 5.65 & -25.60 & 5.24 \\
\hline 1040 & VEC02A04S7_115-120 & 0.43 & 6.93 & 0.0059 & 7.92 & 17.64 & 6.97 & & \\
\hline 1045 & VEC02A04S7_120-125 & 0.44 & 6.59 & 0.0026 & 8.52 & 19.54 & 6.48 & -25.47 & 5.28 \\
\hline 1050 & VEC02A04S7_125-130 & 0.47 & 7.17 & 0.0048 & 7.86 & 18.63 & 5.91 & & \\
\hline 1055 & VEC02A04S7_130-135 & 0.46 & 7.40 & 0.0027 & 5.34 & 20.28 & 3.76 & & \\
\hline 1060 & VEC02A04S7_135-140 & 0.43 & 8.83 & 0.0058 & 5.65 & 22.44 & 3.72 & & \\
\hline 1065 & VEC02A04S7_140-145 & 0.45 & 7.84 & 0.0027 & 3.25 & 19.43 & 2.97 & -25.22 & 5.55 \\
\hline 1070 & VEC02A04BS7/8_0-5 & 0.42 & 7.32 & 0.0047 & 7.91 & 17.61 & 6.72 & & \\
\hline 1075 & VEC02A04BS8/7_5-14 & 0.42 & 7.45 & 0.0035 & 8.64 & 19.15 & 6.58 & & \\
\hline 1079 & VEC02A04S8_0-5 & 0.42 & 7.65 & 0.0038 & 7.80 & 16.43 & 8.15 & & \\
\hline 1084 & VEC02A04S8_5-10 & 0.46 & 6.54 & 0.0048 & 8.62 & 21.94 & 5.51 & -25.67 & 5.73 \\
\hline 1089 & VEC02A04S8_10-15 & 0.46 & 8.66 & 0.0037 & 7.18 & 19.52 & 5.24 & & \\
\hline 1094 & VEC02A04S8_15-20 & 0.47 & 8.74 & 0.0078 & 7.15 & 15.86 & 8.12 & -26.25 & 4.24 \\
\hline 1099 & VEC02A04S8_20-25 & 0.41 & 6.70 & 0.0026 & 7.05 & 17.65 & 8.33 & & \\
\hline 1104 & VEC02A04S8_25-30 & 0.47 & 7.00 & 0.0054 & 7.62 & 16.47 & 8.01 & -25.68 & 5.21 \\
\hline 1109 & VEC02A04S8_30-35 & 0.41 & 6.35 & 0.005 & 7.77 & 16.63 & 6.60 & & \\
\hline 1114 & VEC02A04S8_35-40 & 0.39 & 6.14 & 0.0032 & 8.91 & 17.98 & 7.22 & -26.05 & 4.43 \\
\hline 1119 & VEC02A04S8_40-45 & 0.47 & 7.61 & 0.005 & 8.29 & 16.70 & 7.47 & & \\
\hline 1124 & VEC02A04S8_45-50 & 0.48 & 6.38 & 0.0037 & 8.31 & 18.24 & 5.19 & & \\
\hline 1129 & VEC02A04S8_50-55 & 0.49 & 7.62 & 0.0049 & 7.90 & 17.61 & 7.60 & & \\
\hline 1134 & VEC02A04S8_55-60 & 0.47 & 6.31 & 0.0029 & 7.10 & 18.05 & 7.10 & -25.15 & 5.26 \\
\hline 1139 & VEC02A04S8_60-65 & 0.46 & 6.41 & 0.0099 & 8.37 & 17.34 & 8.01 & & \\
\hline 1144 & VEC02A04S8_65-70 & 0.44 & 7.51 & 0.0029 & 8.53 & 18.37 & 7.20 & -25.62 & 4.69 \\
\hline 1149 & VEC02A04S8_70-75 & 0.47 & 6.94 & 0.003 & 8.75 & 17.69 & 6.58 & & \\
\hline 1154 & VEC02A04S8_75-80 & 0.47 & 6.66 & 0.0029 & 6.87 & 16.54 & 8.76 & -26.04 & 4.65 \\
\hline 1159 & VEC02A04S8_80-85 & 0.44 & 7.42 & 0.0044 & 8.24 & 19.16 & 7.09 & & \\
\hline 1164 & VEC02A04S8_85-90 & 0.44 & 6.86 & 0.0032 & 8.83 & 18.33 & 7.29 & -26.03 & 4.47 \\
\hline 1169 & VEC02A04S8_90-95 & 0.44 & 6.20 & 0.0041 & 8.46 & 18.14 & 7.34 & & \\
\hline 1174 & VEC02A04S8_95-100 & 0.48 & 6.82 & 0.0046 & 8.46 & 17.74 & 6.95 & -25.41 & 5.39 \\
\hline 1179 & VEC02A04S8_100-105 & 0.49 & 7.37 & 0.0035 & 8.43 & 18.12 & 7.48 & -25.77 & 4.81 \\
\hline 1184 & VEC02A04S8_105-110 & 0.47 & 5.84 & 0.0031 & 7.53 & 16.88 & 8.31 & & \\
\hline 1189 & VEC02A04S8_110-115 & 0.44 & 7.03 & 0.005 & 8.00 & 19.40 & 6.13 & -24.99 & 5.86 \\
\hline 1194 & VEC02A04S8_115-120 & 0.48 & 8.33 & 0.0031 & 8.94 & 20.99 & 7.12 & & \\
\hline 1199 & VEC02A04S8_120-125 & 0.48 & 7.40 & 0.0036 & 9.34 & 23.37 & 5.65 & -24.97 & 5.38 \\
\hline 1204 & VEC02A04S8_125-130 & 0.44 & 7.01 & 0.004 & 7.92 & 17.64 & 6.97 & & \\
\hline 1209 & VEC02A04S8_130-135 & 0.44 & 7.13 & 0.004 & 8.52 & 19.54 & 6.48 & -25.52 & 5.29 \\
\hline 1214 & VEC02A04S8_135-140 & 0.46 & 7.52 & 0.0066 & 7.86 & 18.63 & 5.91 & & \\
\hline
\end{tabular}


Appendix C 2. Distribution of organic proxies in the Alison Sound core.

\begin{tabular}{|c|c|c|c|c|c|c|}
\hline Depth (cm) & Sample ID & $\delta^{13} \mathrm{C}(\%)$ & $\% \mathrm{C}$ & $\delta^{15} \mathrm{~N}(\%)$ & $\% \mathrm{~N}$ & $\mathrm{C} / \mathrm{N}$ \\
\hline 5 & VEC02A07S1_5 & -25.92 & 5.86 & 2.49 & 0.24 & 24.74 \\
\hline 15 & VEC02A07S1_15 & -25.54 & 6.63 & 3.38 & 0.31 & 21.56 \\
\hline 25 & VEC02A07S1_25 & -25.62 & 8.14 & 2.10 & 0.30 & 26.89 \\
\hline 35 & VEC02A07S1_35 & -25.6 & 3.43 & 3.08 & 0.17 & 20.34 \\
\hline 45 & VEC02A07S1_45 & -25.52 & 4.52 & 3.00 & 0.23 & 19.92 \\
\hline 55 & VEC02A07S1_55 & -25.68 & 5.15 & 2.90 & 0.25 & 20.35 \\
\hline 65 & VEC02A07S1_65 & -25.64 & 3.87 & 2.99 & 0.19 & 20.31 \\
\hline 70 & VEC02A07S1_70 & -25.68 & 5.57 & 3.24 & 0.27 & 20.35 \\
\hline 85 & VEC02A07S1_85 & -25.61 & 6.42 & 2.80 & 0.29 & 22.17 \\
\hline 95 & VEC02A07S1_95 & -25.83 & 5.86 & 3.66 & 0.31 & 18.94 \\
\hline 102 & VEC02A07S2_5 & -25.76 & 6.34 & 3.06 & 0.29 & 22.00 \\
\hline 112 & VEC02A07S2_15 & -25.82 & 4.07 & 3.04 & 0.21 & 19.84 \\
\hline 122 & VEC02A07S2_25 & -25.85 & 5.15 & 3.77 & 0.22 & 23.55 \\
\hline 132 & VEC02A07S2_35 & -26.26 & 5.66 & 2.44 & 0.26 & 21.52 \\
\hline 142 & VEC02A07S2_45 & -25.78 & 6.56 & 2.99 & 0.32 & 20.75 \\
\hline 152 & VEC02A07S2_55 & -25.65 & 6.79 & 2.82 & 0.29 & 23.26 \\
\hline 162 & VEC02A07S2_65 & -25.83 & 5.73 & 2.80 & 0.29 & 19.53 \\
\hline 172 & VEC02A07S2_75 & -25.71 & 6.18 & 2.98 & 0.32 & 19.59 \\
\hline 182 & VEC02A07S2_85 & -25.99 & 6.14 & 2.85 & 0.27 & 22.39 \\
\hline 192 & VEC02A07S2_95 & -25.67 & 5.88 & 3.37 & 0.32 & 18.39 \\
\hline 202 & VEC02A07S2_105 & -25.68 & 6.84 & 3.12 & 0.31 & 22.38 \\
\hline 212 & VEC02A07S2_115 & -25.9 & 6.67 & 3.21 & 0.31 & 21.48 \\
\hline 217 & VEC02A07S2_120 & -25.79 & 7.16 & 1.77 & 0.28 & 25.72 \\
\hline 232 & VEC02A07S2_135 & -25.1 & 11.15 & 1.04 & 0.22 & 50.56 \\
\hline 243 & VEC02A07B2/3_10 & -25.83 & 6.62 & 2.87 & 0.32 & 20.72 \\
\hline 248 & VEC02A07B2/3_15 & -25.76 & 5.47 & 3.09 & 0.26 & 21.14 \\
\hline 254 & VEC02A07S3_5 & -25.72 & 5.59 & 3.25 & 0.29 & 19.05 \\
\hline 264 & VEC02A07S3_15 & -25.49 & 7.15 & 3.10 & 0.34 & 20.88 \\
\hline 274 & VEC02A07S3_25 & -25.29 & 7.36 & 2.62 & 0.24 & 30.85 \\
\hline 289 & VEC02A07S3_40 & -25.63 & 5.56 & 3.68 & 0.28 & 20.00 \\
\hline 294 & VEC02A07S3_45 & -25.61 & 5.27 & 3.64 & 0.25 & 21.21 \\
\hline 309 & VEC02A07S3_60 & -25.75 & 4.12 & 2.46 & 0.17 & 24.15 \\
\hline 314 & VEC02A07S3_65 & -25.52 & 4.66 & 2.28 & 0.19 & 24.19 \\
\hline 319 & VEC02A07S3_70 & -25.77 & 5.55 & 0.64 & 0.25 & 22.10 \\
\hline 334 & VEC02A07S3_85 & -25.59 & 7.15 & 2.34 & 0.32 & 22.17 \\
\hline 344 & VEC02A07S3_95 & -25.64 & 4.15 & 2.17 & 0.19 & 22.40 \\
\hline 354 & VEC02A07S3_105 & -25.9 & 5.25 & 1.94 & 0.24 & 21.50 \\
\hline
\end{tabular}




\begin{tabular}{|c|c|c|c|c|c|c|}
\hline Depth (cm) & Sample ID & $\delta{ }^{13} \mathrm{C}(\%)$ & $\% \mathrm{C}$ & $\delta^{15} \mathrm{~N}(\%)$ & $\% \mathrm{~N}$ & $\mathrm{C} / \mathrm{N}$ \\
\hline 359 & VEC02A07S3_110 & -25.89 & 3.52 & 1.88 & 0.16 & 22.38 \\
\hline 369 & VEC02A07S3_120 & -25.87 & 4.48 & 3.17 & 0.23 & 19.34 \\
\hline 384 & VEC02A07S3_135 & -25.75 & 5.73 & 2.30 & 0.25 & 23.09 \\
\hline 394 & VEC02A07S3_145 & -25.88 & 6.45 & 2.20 & 0.27 & 23.95 \\
\hline 403 & VEC02A07S4_0-5 & -25.8 & 4.55 & 2.20 & 0.18 & 25.25 \\
\hline 418 & VEC02A07S4_15 & -25.71 & 4.56 & 2.89 & 0.24 & 18.92 \\
\hline 428 & VEC02A07S4_25 & -25.79 & 6.24 & 2.99 & 0.27 & 23.54 \\
\hline 443 & VEC02A07S4_40 & -25.85 & 6.07 & 2.87 & 0.32 & 19.24 \\
\hline 468 & VEC02A07S4_65 & -25.6 & 4.61 & 3.16 & 0.24 & 18.91 \\
\hline 483 & VEC02A07S4_80 & -25.8 & 4.70 & 3.00 & 0.26 & 18.23 \\
\hline 488 & VEC02A07S4_85 & -25.65 & 6.99 & 2.40 & 0.30 & 22.94 \\
\hline 503 & VEC02A07S4_100 & -25.95 & 4.09 & 2.59 & 0.22 & 18.76 \\
\hline 508 & VEC02A07S4_105 & -25.24 & 4.27 & 1.78 & 0.13 & 32.79 \\
\hline 518 & VEC02A07S4_115 & -25.52 & 6.43 & 2.50 & 0.29 & 22.46 \\
\hline 528 & VEC02A07S4_125 & -26.46 & 5.67 & 2.54 & 0.23 & 25.17 \\
\hline 538 & VEC02A07S4_135 & -25.86 & 4.60 & 2.75 & 0.23 & 20.07 \\
\hline 543 & VEC02A07S4_140 & -26.09 & 5.00 & 2.07 & 0.23 & 21.53 \\
\hline 565 & VEC02A07B4/5_5 & -26.01 & 4.29 & 3.15 & 0.21 & 20.47 \\
\hline 570 & VEC02A07B4/5_10 & -25.85 & 5.35 & 2.91 & 0.27 & 20.06 \\
\hline 575 & VEC02A07B4/5_15 & -25.9 & 8.37 & 2.04 & 0.24 & 34.48 \\
\hline 580 & VEC02A07B4/5_20 & -25.77 & 3.55 & 3.19 & 0.19 & 18.31 \\
\hline 582 & VEC02A07S5_0-5 & -25.9 & 4.60 & 3.03 & 0.24 & 18.87 \\
\hline 597 & VEC02A07S5_15 & -25.62 & 6.57 & 1.83 & 0.22 & 29.30 \\
\hline 602 & VEC02A07S5_20 & -25.7 & 5.33 & 3.16 & 0.27 & 19.88 \\
\hline 622 & VEC02A07S5_40 & -25.88 & 4.32 & 2.27 & 0.19 & 22.16 \\
\hline 632 & VEC02A07S5_50 & -25.95 & 3.99 & 2.27 & 0.20 & 19.62 \\
\hline 642 & VEC02A07S5_60 & -25.66 & 3.94 & 2.97 & 0.20 & 19.85 \\
\hline 657 & VEC02A07S5_75 & -25.82 & 5.22 & 2.22 & 0.19 & 27.12 \\
\hline 662 & VEC02A07S5_80 & -25.79 & 4.86 & 2.17 & 0.21 & 23.41 \\
\hline 682 & VEC02A07S5_100 & -25.75 & 4.58 & 2.11 & 0.24 & 19.15 \\
\hline 692 & VEC02A07S5_110 & -25.67 & 4.08 & 3.44 & 0.25 & 16.47 \\
\hline 702 & VEC02A07S5_120 & -25.57 & 5.03 & 1.99 & 0.20 & 24.63 \\
\hline 712 & VEC02A07S5_130 & -25.39 & 5.60 & 2.40 & 0.20 & 28.43 \\
\hline 722 & VEC02A07S5_140 & -25.99 & 4.64 & 2.00 & 0.21 & 21.62 \\
\hline 732 & VEC02A07S6_5 & -25.75 & 4.05 & 2.98 & 0.22 & 18.74 \\
\hline 737 & VEC02A07S6_10 & -25.56 & 5.06 & 3.32 & 0.24 & 21.44 \\
\hline 747 & VEC02A07S6_20 & -25.52 & 5.16 & 3.12 & 0.26 & 19.80 \\
\hline 767 & VEC02A07S6_40 & -25.69 & 3.43 & 3.04 & 0.18 & 19.06 \\
\hline 777 & VEC02A07S6_50 & -25.75 & 4.47 & 2.68 & 0.22 & 20.41 \\
\hline 787 & VEC02A07S6_60 & -25.88 & 5.65 & 3.12 & 0.23 & 24.88 \\
\hline 797 & VEC02A07S6_70 & -25.64 & 4.66 & 2.48 & 0.24 & 19.81 \\
\hline
\end{tabular}


Appendix C2. CONTD.

\begin{tabular}{|c|l|c|r|r|r|r|}
\hline Depth $(\mathrm{cm})$ & \multicolumn{1}{|c|}{ Sample ID } & $\delta^{13} \mathrm{C}(\%)$ & $\% \mathrm{C}$ & $\delta^{15} \mathrm{~N}(\%)$ & $\% \mathrm{~N}$ & $\mathrm{C} / \mathrm{N}$ \\
\hline 807 & VEC02A07S6_80 & -25.56 & 4.44 & 2.88 & 0.21 & 20.91 \\
812 & VEC02A07S6_85 & -25.56 & 3.71 & 3.43 & 0.23 & 15.90 \\
822 & VEC02A07S6_95 & -25.88 & 5.56 & 3.31 & 0.22 & 24.94 \\
847 & VEC02A07S6_120 & -25.74 & 4.32 & 2.75 & 0.24 & 17.99 \\
852 & VEC02A07S6_125 & -25.75 & 4.11 & 3.03 & 0.23 & 17.80 \\
\hline
\end{tabular}



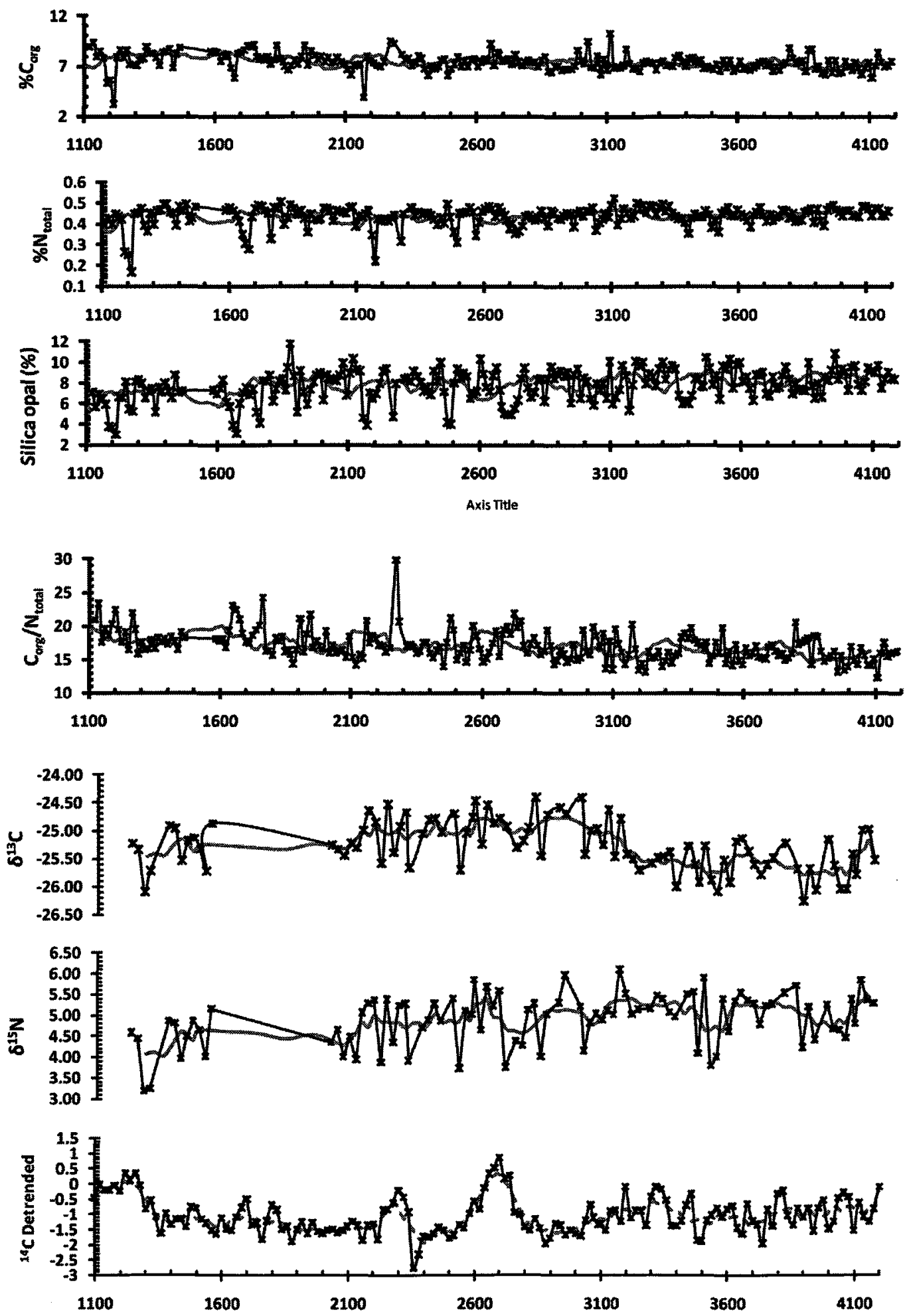

Appendix C 3. 100-year (5-sample) averaging of organic matter proxies in the Frederick Sound core. 

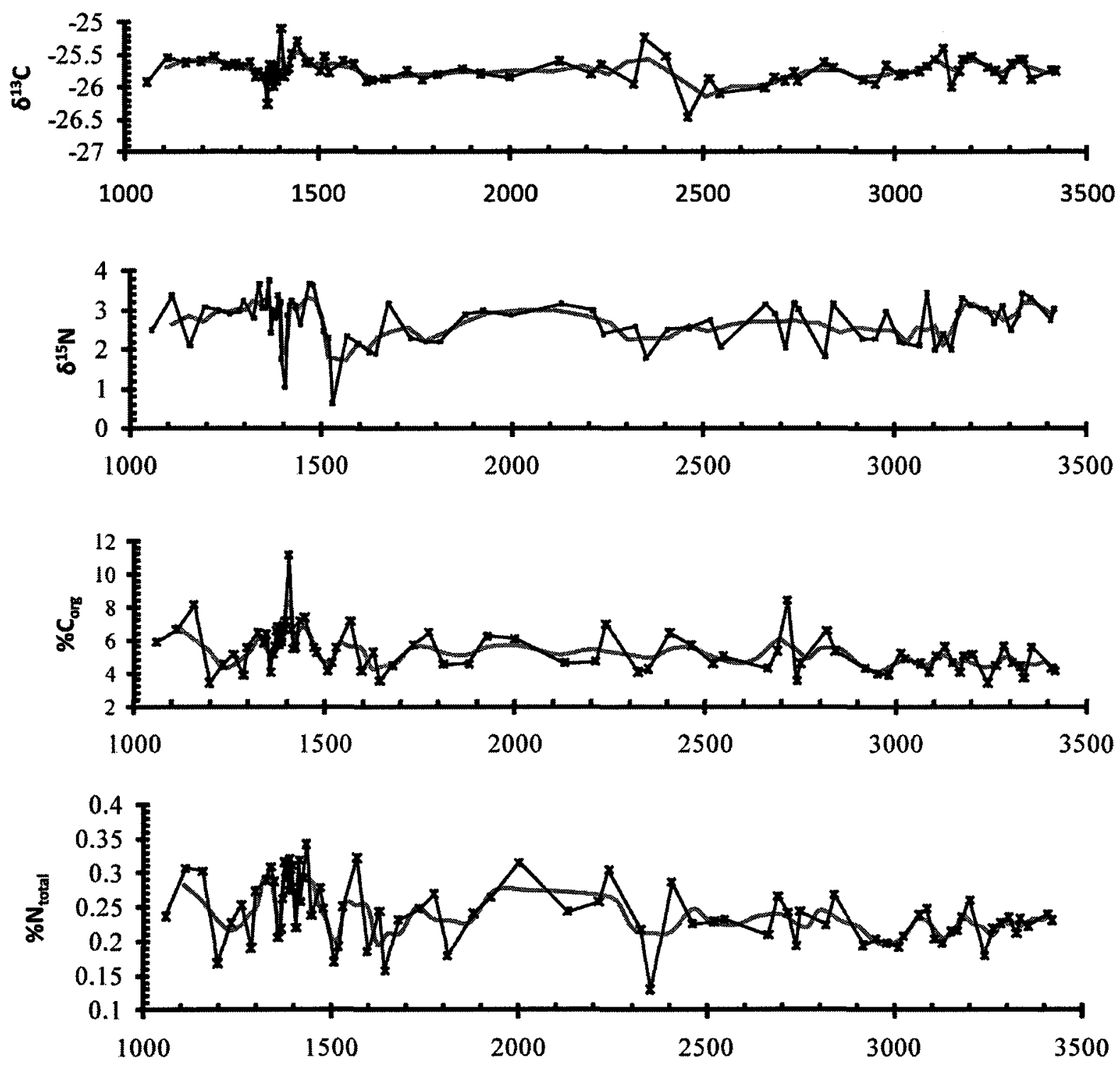

Appendix C 4. 100-year (5-sample) averaging of organic matter proxies in the Alison Sound core. 
Appendix C 5. Distribution of major elements in the Frederick Sound core.

\begin{tabular}{|c|c|c|c|c|c|c|c|c|c|c|c|}
\hline Depth (cm) & Sample & $\mathrm{Al}(\%)$ & $\mathrm{Ca}(\%)$ & $\mathrm{Fe}(\%)$ & $\mathrm{K}$ & $\mathrm{Mg}(\%)$ & Mn (\%) & $\mathrm{Na}(\%)$ & $\mathrm{P}(\%)$ & S (\%) & $\mathrm{Ti}(\%)$ \\
\hline 0 & VEC02A04S1 0-5 & 4.00 & 1.78 & 3.89 & 0.88 & 1.49 & 0.05 & 3.39 & 0.07 & 2.37 & 0.24 \\
\hline 5 & VEC02A04S1 5-10 & 5.83 & 3.22 & 4.16 & 0.72 & 1.95 & 0.07 & 2.88 & 0.09 & 2.15 & 0.31 \\
\hline 30 & VEC02A04S1 30-35 & 6.94 & 3.93 & 4.29 & 0.78 & 2.19 & 0.09 & 0.46 & 0.07 & 1.53 & 0.35 \\
\hline 60 & AVEC02A04S1 60-65 & 5.31 & 2.97 & 3.97 & 0.71 & 1.79 & 0.06 & 2.97 & 0.09 & 2.20 & 0.31 \\
\hline 70 & VEC02A04S1 70-75 & 3.96 & 2.03 & 3.75 & 0.74 & 1.47 & 0.05 & 3.32 & 0.06 & 2.64 & 0.23 \\
\hline 80 & VEC02A04S1 80-85 & 3.81 & 1.50 & 3.70 & 0.83 & 1.41 & 0.05 & 3.66 & 0.07 & 2.54 & 0.22 \\
\hline 90 & VEC02A04S1 90-95 & 4.82 & 2.47 & 3.74 & 0.75 & 1.62 & 0.06 & 3.43 & 0.07 & 2.24 & 0.27 \\
\hline 100 & VEC02A04SI 100-105 & 3.81 & 1.62 & 3.57 & 0.88 & 1.48 & 0.05 & 3.91 & 0.07 & 2.40 & 0.23 \\
\hline 105 & VEC02A04S1 105-110 & 3.64 & 2.00 & 3.54 & 0.81 & 1.46 & 0.04 & 3.95 & 0.07 & 2.80 & 0.21 \\
\hline 110 & VEC02A04S1 110-115 & 3.79 & 2.04 & 3.81 & 0.83 & 1.45 & 0.05 & 3.77 & 0.07 & 2.74 & 0.25 \\
\hline 120 & VEC02A04S1 120-125 & 3.58 & 1.86 & 3.72 & 0.75 & 1.35 & 0.04 & 3.64 & 0.06 & 2.61 & 0.21 \\
\hline 130 & VEC02A04S1 130-135 & 3.79 & 1.69 & 3.59 & 0.82 & 1.41 & 0.05 & 3.73 & 0.06 & 2.53 & 0.23 \\
\hline 325 & VEC02A04S3 0-5 & 4.44 & 2.17 & 3.73 & 0.89 & 1.73 & 0.07 & 0.36 & 0.07 & & 0.28 \\
\hline 340 & VEC02A04S3 15-20 & 4.16 & 2.26 & 3.28 & 0.74 & 1.52 & 0.05 & 3.29 & 0.07 & 2.54 & 0.26 \\
\hline 355 & VEC02A04S3 30-35 & 3.54 & 1.81 & 4.14 & 0.85 & 1.36 & 0.05 & 3.48 & 0.06 & 3.34 & 0.22 \\
\hline 370 & VEC02A04S3 45-50 & 4.60 & 2.32 & 3.53 & 1.00 & 1.60 & 0.08 & 0.36 & 0.07 & & 0.27 \\
\hline 385 & VEC02A04S3 60-65 & 5.41 & 2.98 & 3.76 & 0.82 & 1.89 & 0.08 & 0.39 & 0.07 & & 0.29 \\
\hline 400 & VEC02A04S3 75-80 & 3.65 & 1.99 & 4.12 & 0.76 & 1.37 & 0.04 & 3.60 & 0.08 & 2.47 & 0.22 \\
\hline 415 & VEC02A04S3 90-95 & 6.61 & 3.80 & 4.22 & 0.82 & 2.21 & 0.09 & 0.43 & 0.07 & & 0.32 \\
\hline 430 & VEC02A04S3 105-110 & 5.10 & 2.59 & 3.57 & 0.91 & 1.62 & 0.08 & 0.37 & 0.08 & & 0.28 \\
\hline 445 & VEC02A04S3 120-125 & 3.60 & 1.64 & 3.26 & 0.80 & 1.43 & 0.04 & 3.97 & 0.07 & 2.50 & 0.21 \\
\hline 460 & VEC02A04S3 135-137 & 3.88 & 1.84 & 3.40 & 0.75 & 1.51 & 0.05 & 3.87 & 0.06 & 2.50 & 0.22 \\
\hline 472 & VEC02A04S4 10-15 & 3.87 & 1.84 & 3.50 & 0.79 & 1.44 & 0.05 & 3.36 & 0.06 & 2.40 & 0.23 \\
\hline 482 & VEC02A04S4 20-25 & 5.32 & 2.72 & 3.71 & 0.75 & 1.61 & 0.07 & 3.01 & 0.06 & 1.85 & 0.28 \\
\hline 492 & VEC02A04S4 30-35 & 4.24 & 2.24 & 4.04 & 1.09 & 1.59 & 0.07 & 0.34 & 0.07 & & 0.26 \\
\hline 507 & VEC02A04S4 45-50 & 4.98 & 2.42 & 3.84 & 1.09 & 1.67 & 0.08 & 0.37 & 0.09 & & 0.28 \\
\hline 522 & VEC02A04S4 60-65 & 4.11 & 1.93 & 3.88 & 0.86 & 1.41 & 0.05 & 3.60 & 0.07 & 2.55 & 0.23 \\
\hline 537 & VEC02A04S4 75-80 & 4.15 & 1.78 & 3.70 & 0.85 & 1.50 & 0.05 & 3.55 & 0.08 & 2.71 & 0.24 \\
\hline 552 & VEC02A04S4 90-95 & 4.07 & 1.84 & 3.67 & 0.73 & 1.39 & 0.05 & 3.60 & 0.06 & 2.48 & 0.23 \\
\hline 567 & VEC02A04S4 105-110 & 3.70 & ND & 3.78 & 0.88 & 1.45 & 0.04 & 3.85 & 0.08 & 2.64 & 0.23 \\
\hline 577 & VEC02A04S4 115-120 & 3.81 & ND & 3.42 & 0.79 & 1.40 & 0.05 & 3.69 & 0.07 & 2.36 & 0.22 \\
\hline 582 & VEC02A04S4 120-125 & 3.51 & ND & 3.76 & 0.82 & 1.36 & 0.04 & 3.81 & 0.07 & 2.66 & 0.21 \\
\hline 597 & VEC02A04S4 135-140 & 3.99 & 1.84 & 3.91 & 0.99 & 1.59 & 0.06 & 0.32 & 0.07 & & 0.25 \\
\hline 612 & VEC02A04S4 150-155 & 4.15 & 2.07 & 4.19 & 1.07 & 1.58 & 0.06 & 0.32 & 0.08 & & 0.25 \\
\hline 629 & VEC02A04S5 10-15 & 5.58 & 3.00 & 4.10 & 0.87 & 2.04 & 0.09 & 0.43 & 0.10 & & 0.32 \\
\hline 644 & VEC02A04S5 25-30 & 4.28 & 1.95 & 4.04 & 0.85 & 1.55 & 0.06 & 3.27 & 0.07 & 2.54 & 0.26 \\
\hline 659 & VEC02A04S5 40-45 & 3.70 & 1.84 & 4.05 & 0.88 & 1.44 & 0.05 & 3.43 & 0.07 & 2.92 & 0.23 \\
\hline 674 & VEC02A04S5 55-60 & 3.93 & 1.72 & 4.99 & 1.02 & 1.52 & 0.07 & 0.33 & 0.07 & & 0.25 \\
\hline 684 & VEC02A04S5 65-70 & 4.39 & 2.22 & 4.19 & 0.77 & 1.49 & 0.06 & 3.25 & 0.07 & 2.39 & 0.25 \\
\hline 694 & VEC02A04S5 75-80 & 3.54 & 1.77 & 4.14 & 0.84 & 1.35 & 0.05 & 3.45 & 0.07 & 3.15 & 0.21 \\
\hline 704 & VEC02A04S5 85-90 & 3.37 & 1.93 & 3.54 & 0.85 & 1.41 & 0.04 & 3.98 & 0.06 & 2.77 & 0.20 \\
\hline 724 & VEC02A04S5 105-110 & 4.04 & 1.89 & 3.83 & 0.93 & 1.51 & 0.05 & 3.39 & 0.07 & 2.73 & 0.27 \\
\hline 734 & VEC02A04S5 115-120 & 3.62 & 1.85 & 3.91 & 0.81 & 1.41 & 0.05 & 3.81 & 0.06 & 2.79 & 0.21 \\
\hline 749 & VEC02A04S5 130-135 & 3.82 & 1.88 & 4.37 & 0.73 & 1.35 & 0.05 & 3.27 & 0.07 & 3.04 & 0.22 \\
\hline 764 & VEC02A04S5 $140-145$ & 4.36 & 2.26 & 4.02 & 0.83 & 1.54 & 0.05 & 3.26 & 0.08 & 2.64 & 0.27 \\
\hline 778 & VEC02A04S6 5-10 & 3.80 & 2.13 & 4.21 & 0.79 & 1.37 & 0.05 & 3.33 & 0.09 & 2.88 & 0.23 \\
\hline 793 & VEC02A04S6 20-25 & 5.32 & 2.72 & 3.89 & 1.03 & 1.77 & 0.09 & 0.44 & 0.08 & 2.89 & 0.34 \\
\hline 808 & VEC02A04S6 35-40 & 3.68 & 2.11 & 4.21 & 0.81 & 1.38 & 0.05 & 3.45 & 0.07 & 2.74 & 0.23 \\
\hline 823 & VEC02A04S6 50-55 & 3.99 & 2.11 & 3.94 & 0.78 & 1.39 & 0.05 & 3.37 & 0.06 & & 0.23 \\
\hline 838 & VEC02A04S6 65-70 & 5.47 & 2.84 & 3.99 & 0.78 & 1.67 & 0.10 & 0.40 & 0.07 & & 0.30 \\
\hline 853 & VEC02A04\$6 80-85 & 4.36 & 2.22 & 3.47 & 0.74 & 1.39 & 0.05 & 3.37 & 0.06 & 2.36 & 0.23 \\
\hline
\end{tabular}


Appendix C 5. CONTD.

\begin{tabular}{|c|c|c|c|c|c|c|c|c|c|c|c|}
\hline Depth (cm) & Sample & $\mathrm{Al}(\%)$ & $\mathrm{Ca}(\%)$ & $\mathrm{Fe}(\%)$ & $\mathbf{K}$ & $\mathrm{Mg}(\%)$ & $\operatorname{Mn}(\%)$ & $\mathrm{Na}(\%)$ & $\mathrm{P}(\%)$ & $\mathrm{S}(\%)$ & $\operatorname{Ti}(\%)$ \\
\hline 863 & VEC02A04S6 90-95 & 3.04 & 1.79 & 4.16 & 0.77 & 1.23 & 0.04 & 3.63 & 0.06 & 3.44 & 0.18 \\
\hline 888 & VEC02A04S6 115-120 & 4.90 & 2.32 & 3.88 & 1.02 & 1.72 & 0.06 & 3.32 & 0.10 & 2.10 & 0.36 \\
\hline 893 & VEC02A04S6 120-125 & 5.25 & 2.71 & 4.13 & 1.14 & 1.93 & 0.09 & 0.49 & 0.09 & & 0.37 \\
\hline 903 & VEC02A04S6 130-135 & 5.28 & 2.77 & 4.11 & 1.19 & 1.90 & 0.09 & 0.50 & 0.08 & & 0.38 \\
\hline 913 & VEC02A04S6 140-145 & 4.10 & 2.16 & 4.12 & 0.90 & 1.54 & 0.05 & 3.39 & 0.07 & 2.98 & 0.26 \\
\hline 923 & VEC02A04S6 150-152 & 4.42 & 2.20 & 4.04 & 1.15 & 1.72 & 0.07 & 0.36 & 0.08 & & 0.28 \\
\hline 930 & VEC02A04S7 5-10 & 3.59 & 1.74 & 3.94 & 0.81 & 1.28 & 0.04 & 3.22 & 0.07 & 2.89 & 0.21 \\
\hline 945 & VEC02A04S7 20-25 & 6.15 & 3.32 & 4.15 & 0.77 & 1.82 & 0.10 & 0.44 & 0.07 & & 0.33 \\
\hline 955 & VEC02A04S7 30-35 & 5.34 & 2.64 & 4.03 & 0.86 & 1.66 & 0.09 & 0.41 & 0.07 & & 0.31 \\
\hline 970 & VEC02A04S7 45-50 & 4.10 & 1.99 & 4.29 & 1.00 & 1.53 & 0.06 & 0.34 & 0.08 & & 0.26 \\
\hline 985 & VEC02A04S7 60-65 & 3.81 & 2.00 & 3.85 & 0.82 & 1.48 & 0.05 & 3.69 & 0.06 & 2.78 & 0.22 \\
\hline 990 & VEC02A04S7 65-70 & 3.60 & 2.05 & 3.55 & 0.85 & 1.45 & 0.04 & 3.76 & 0.07 & 2.98 & 0.22 \\
\hline 1000 & VEC02A04S7 75-80 & 5.31 & 2.78 & 4.25 & 1.04 & 1.94 & 0.09 & 0.44 & 0.09 & & 0.33 \\
\hline 1015 & VEC02A04S7 90-95 & 4.49 & 2.12 & 3.95 & 1.04 & 1.62 & 0.07 & 0.37 & 0.08 & & 0.28 \\
\hline 1030 & VEC02A04S7 105-110 & 5.44 & 2.97 & 4.09 & 0.94 & 2.04 & 0.09 & 0.45 & 0.09 & & 0.34 \\
\hline 1045 & VEC02A04S7 120-125 & 3.96 & 2.36 & 3.64 & 0.94 & 1.51 & 0.06 & 0.31 & 0.07 & & 0.23 \\
\hline 1060 & VEC02A04S7 135-140 & 4.74 & 2.80 & 3.82 & 0.87 & 1.72 & 0.08 & 0.37 & 0.07 & 2.47 & 0.28 \\
\hline 1079 & VEC02A04S8 5-10 & 4.91 & 2.49 & 4.05 & 0.77 & 1.73 & 0.06 & 3.26 & 0.09 & 2.51 & 0.29 \\
\hline 1099 & VEC02A04S8 20-25 & 3.65 & 2.17 & 3.98 & 0.84 & 1.40 & 0.04 & 3.52 & 0.07 & 3.12 & 0.22 \\
\hline 1109 & VEC02A04S8 30-35 & 4.25 & 1.99 & 3.77 & 1.01 & 1.58 & 0.06 & 0.33 & 0.08 & & 0.25 \\
\hline 1124 & VEC02A04S8 45-50 & 4.80 & 2.36 & 4.12 & 1.19 & 1.81 & 0.08 & 0.45 & 0.09 & & 0.34 \\
\hline 1154 & VEC02A04S8 75-80 & 4.97 & 2.44 & 3.94 & 0.88 & 1.54 & 0.08 & 0.37 & 0.10 & & 0.28 \\
\hline 1169 & VEC02A04S8 90-95 & 4.08 & 2.07 & 3.96 & 1.03 & 1.38 & 0.06 & 0.36 & 0.08 & & 0.28 \\
\hline 1179 & VEC02A04S8 100-105 & 4.04 & 2.03 & 3.49 & 0.72 & 1.46 & 0.05 & 3.26 & 0.05 & 2.37 & 0.24 \\
\hline 1194 & VEC02A04S8 115-120 & 3.99 & 2.09 & 3.68 & 0.80 & 1.46 & 0.05 & 3.34 & 0.07 & 2.49 & 0.25 \\
\hline 1199 & VEC02A04S8 120-125 & 3.49 & 1.82 & 3.63 & 0.80 & 1.30 & 0.04 & 3.39 & 0.06 & 2.71 & 0.21 \\
\hline 1204 & VEC02A04S8 125-130 & 4.13 & 2.05 & 3.75 & 0.82 & 1.43 & 0.05 & 3.36 & 0.07 & 2.44 & 0.24 \\
\hline 1209 & VEC02A04S8 130-135 & 3.89 & 1.84 & 3.61 & 0.82 & 1.42 & 0.05 & 3.47 & 0.07 & 2.43 & 0.23 \\
\hline
\end{tabular}




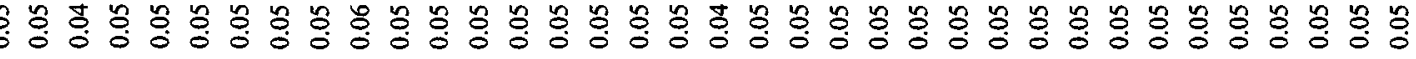

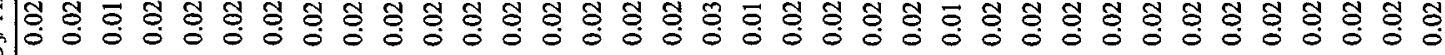

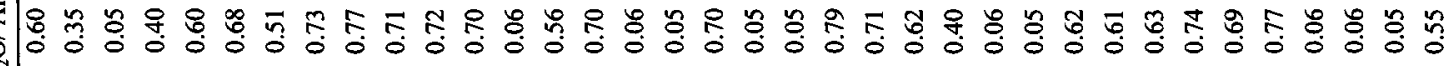

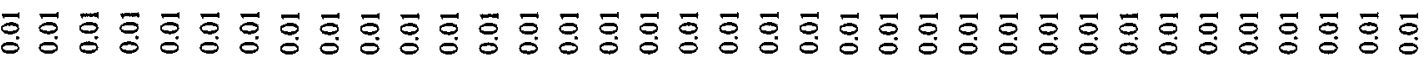

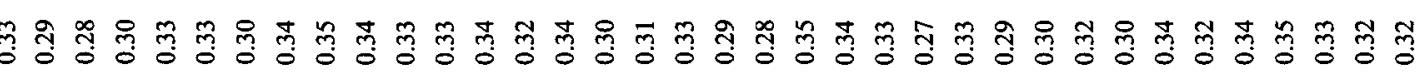

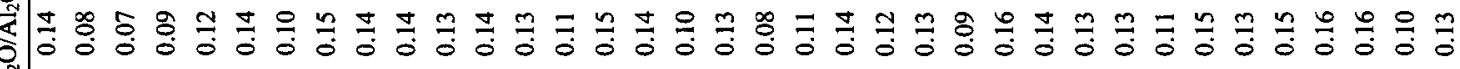

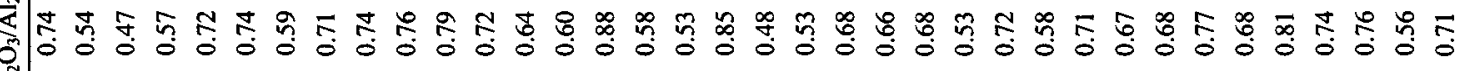
足

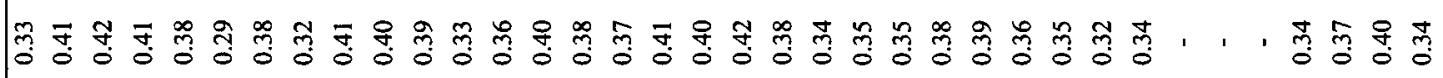

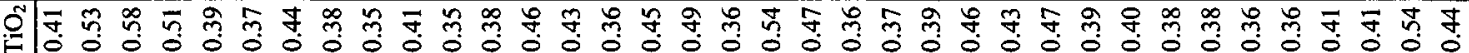

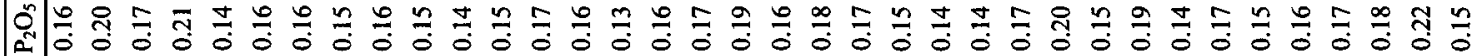

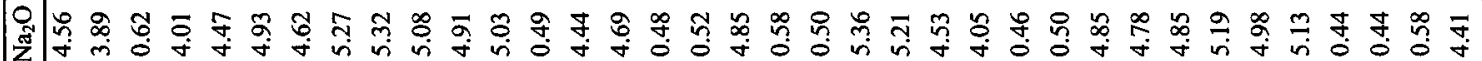

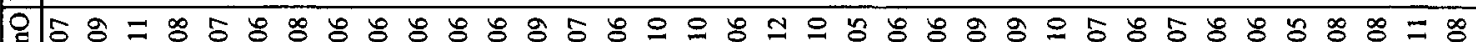

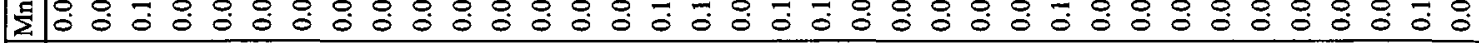

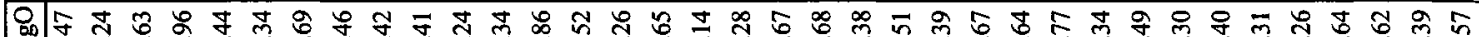
एँ

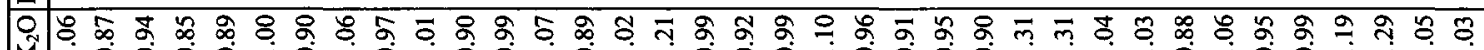

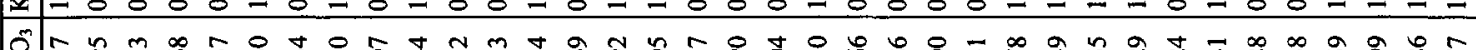

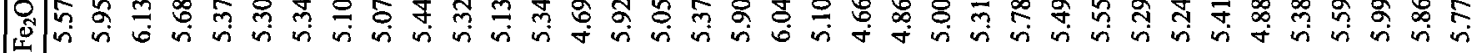
O류

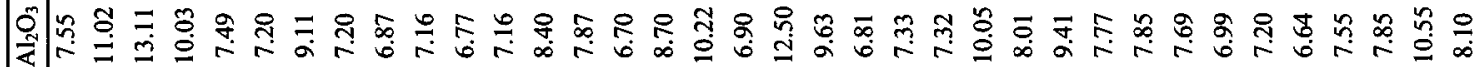

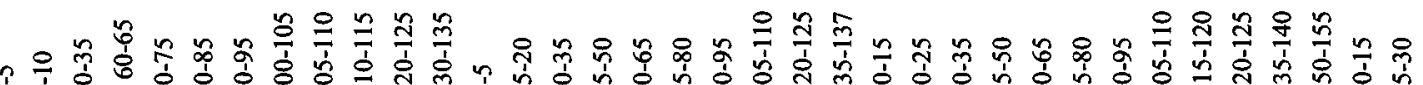

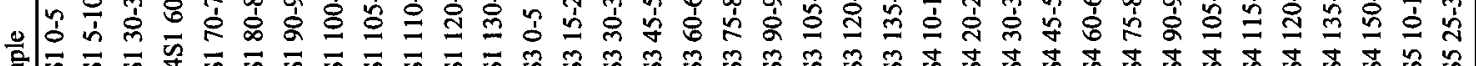

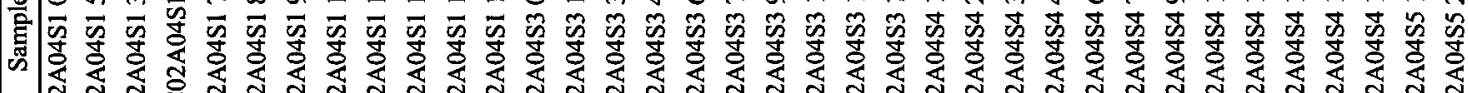

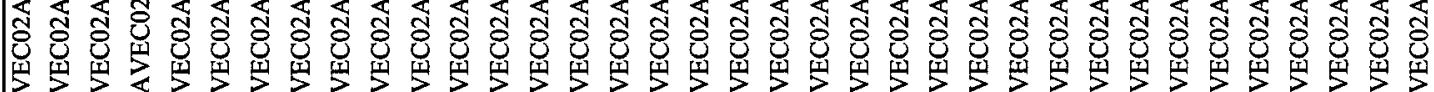
氖

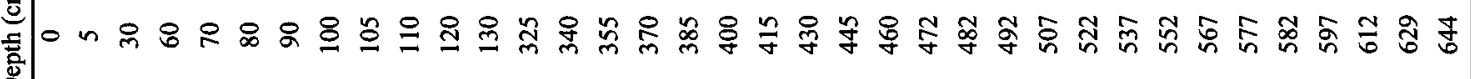




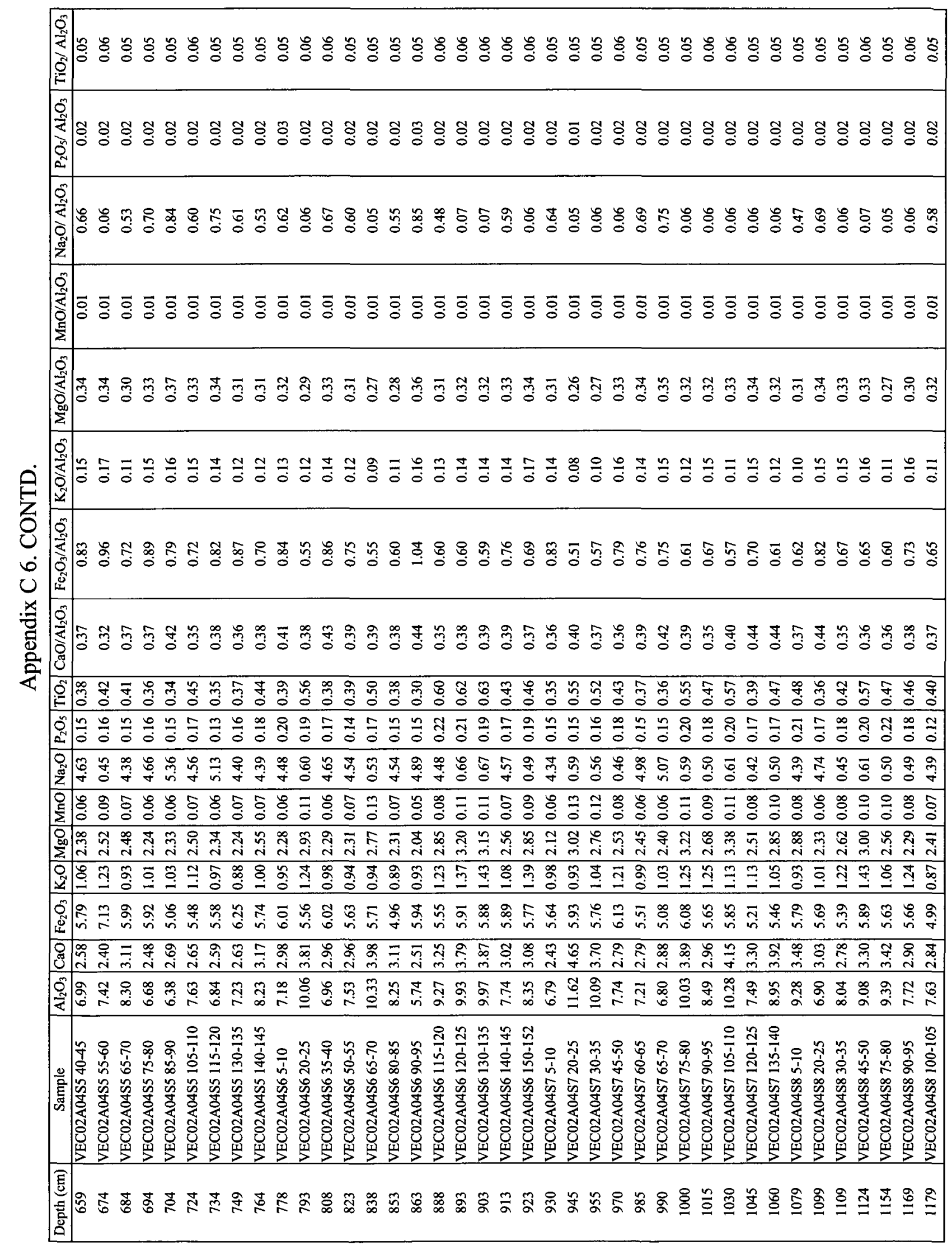




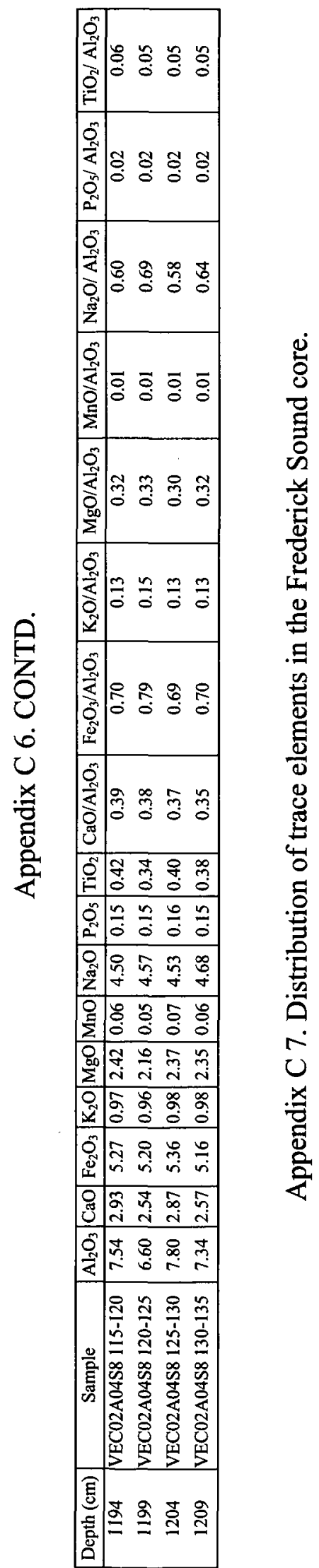

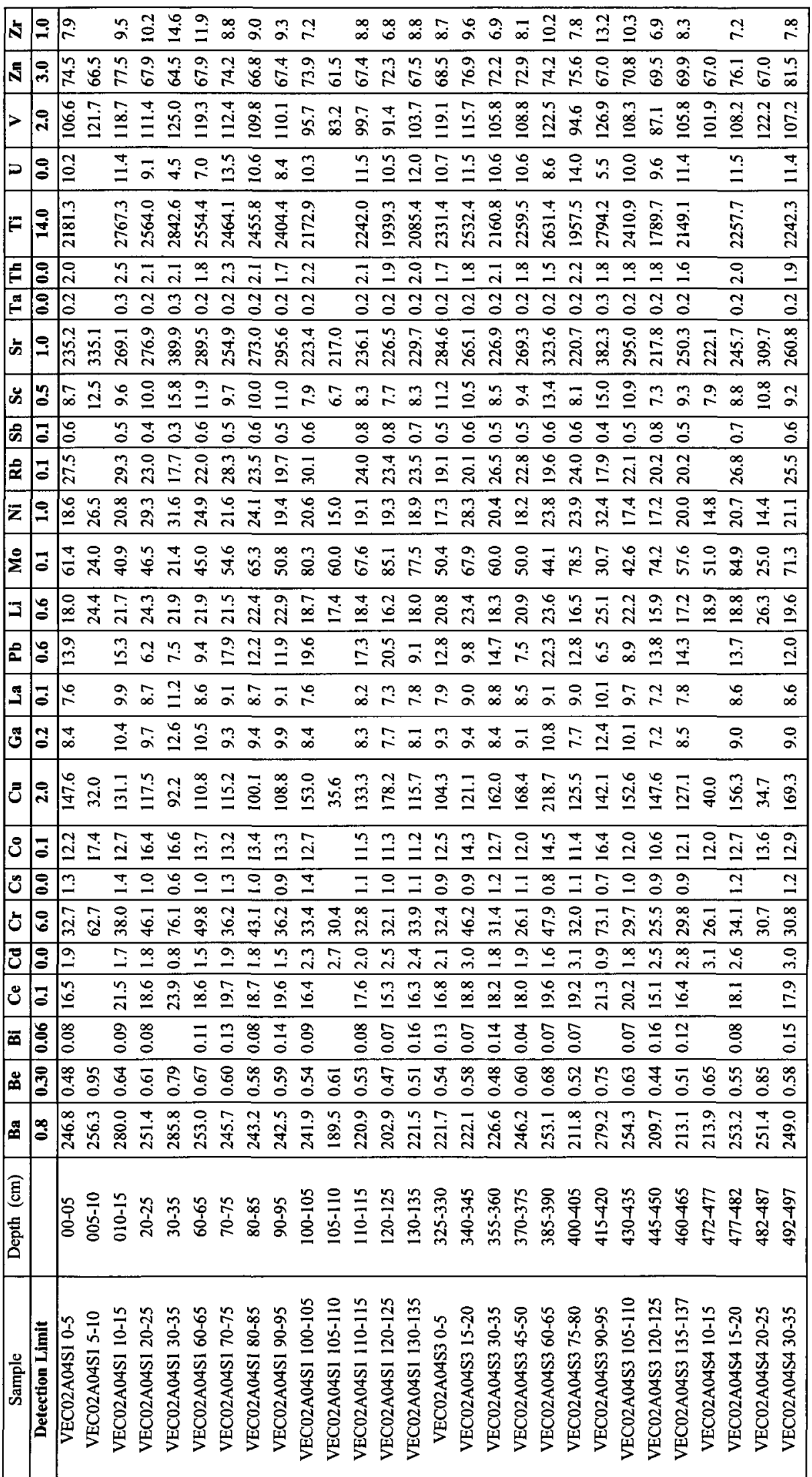




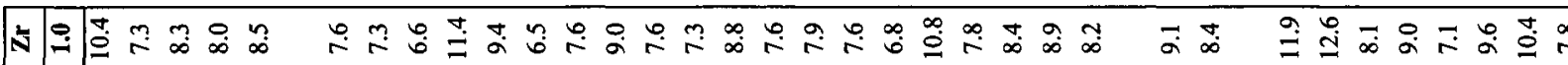

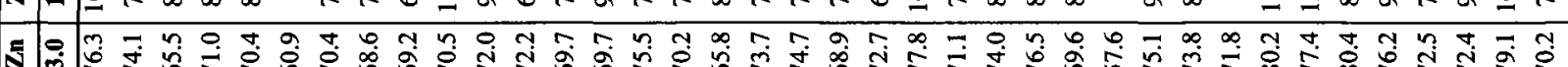

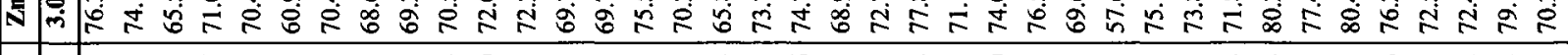

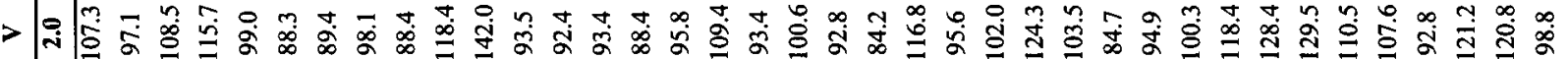

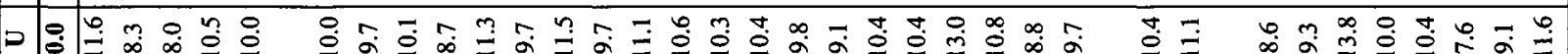

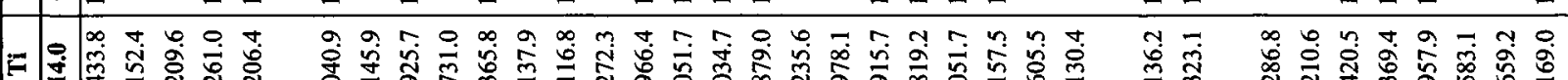

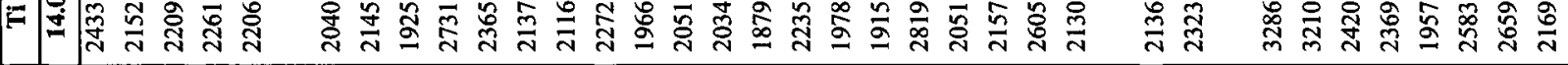

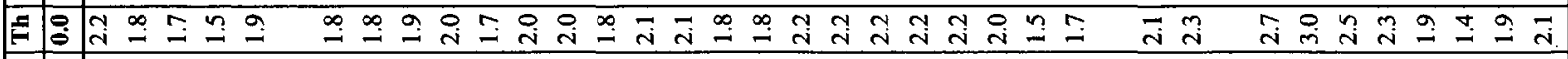

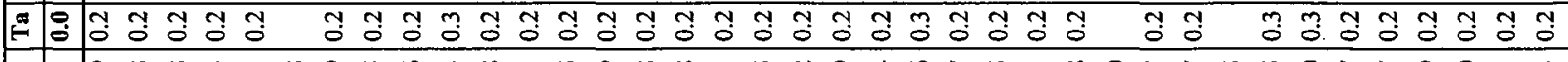
- 0 -

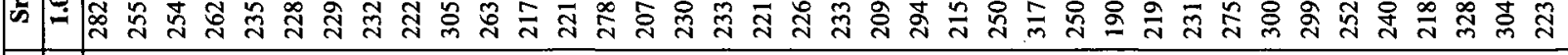

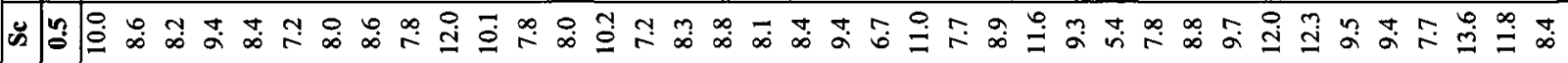
मी

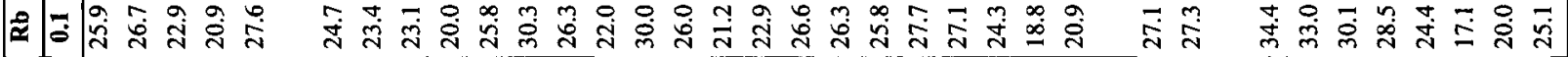

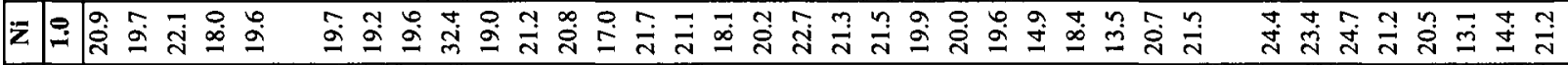

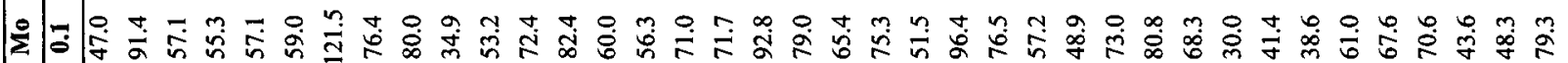

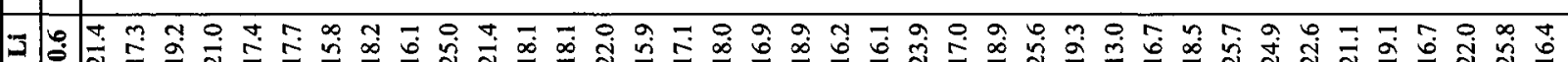
- 1 -

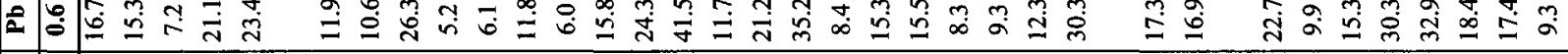

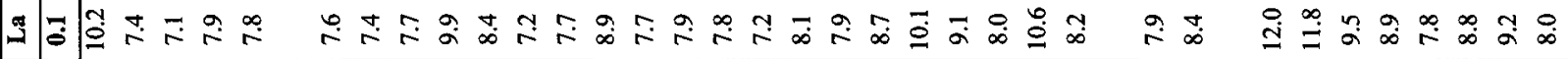

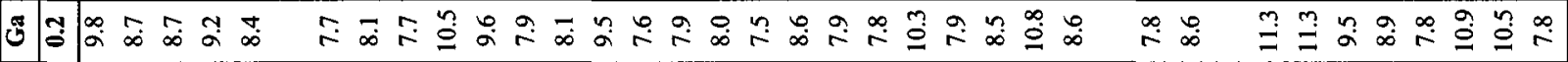

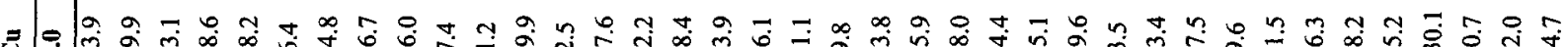

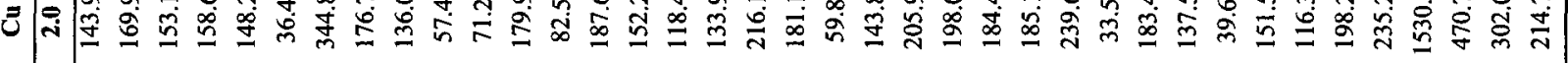

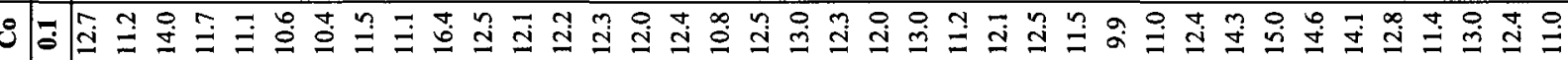

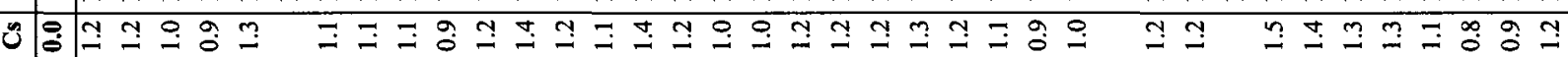
U च قี ச் 网 ¥

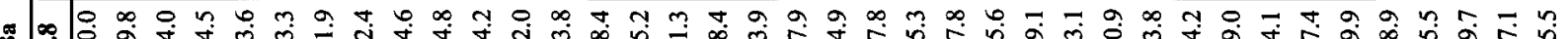

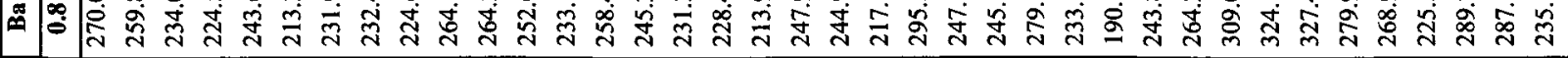
然

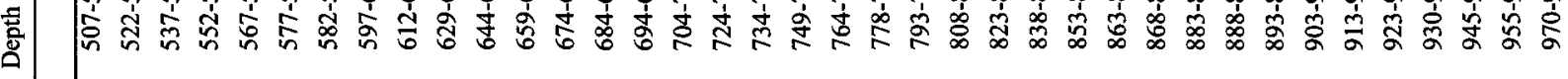

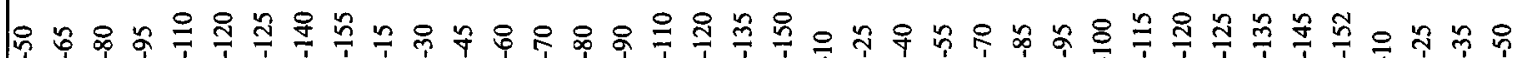

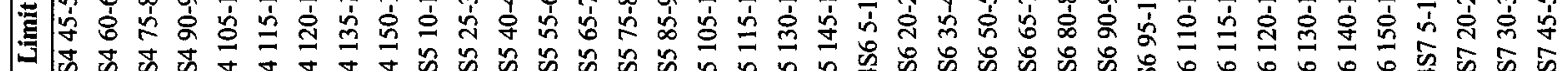

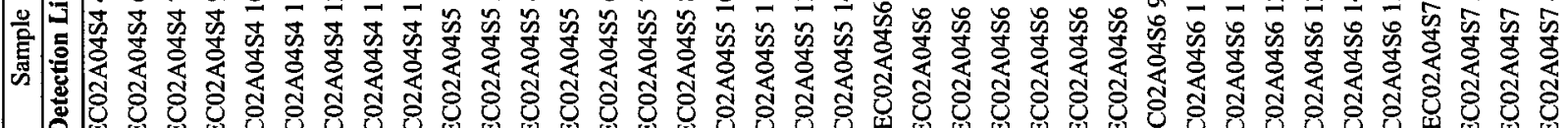

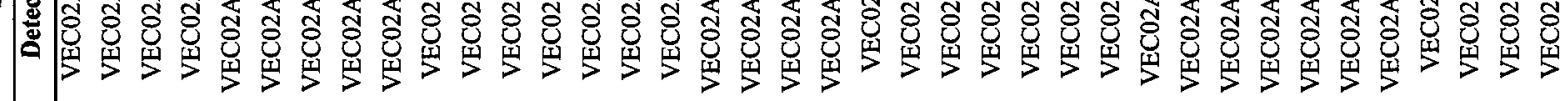




\begin{tabular}{|c|c|c|}
\hline 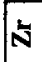 & & 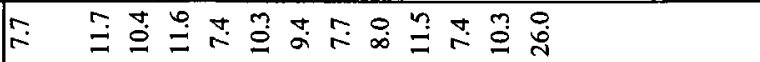 \\
\hline కే & & 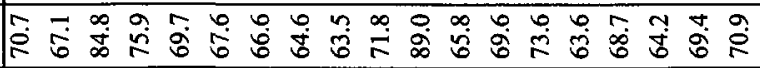 \\
\hline$>$ & & 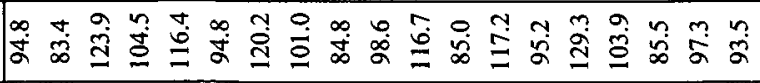 \\
\hline$P$ & 18 & 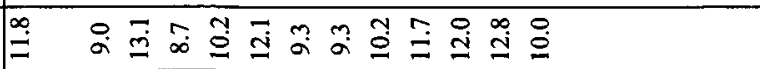 \\
\hline$F$ & \pm & 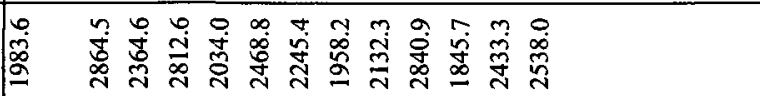 \\
\hline E & 8 & 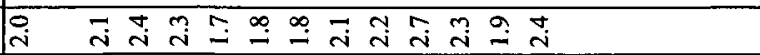 \\
\hline 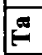 & 8 & 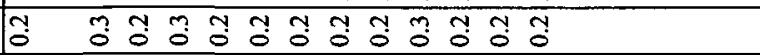 \\
\hline 点 & @ & 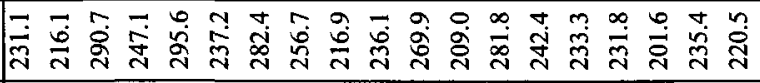 \\
\hline$\ddot{\check{n}}$ & $\stackrel{2}{2}$ & 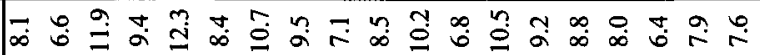 \\
\hline है & $\overline{8}$ & 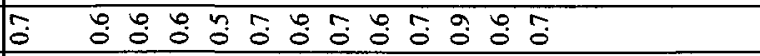 \\
\hline $\overrightarrow{\tilde{x}}$ & $\overline{5}$ & 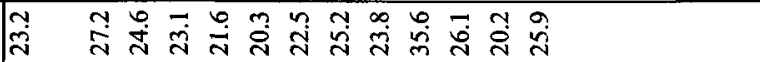 \\
\hline$\ddot{z}$ & $\Xi$ & 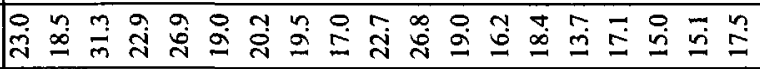 \\
\hline$\sum^{\circ}$ & 5 & 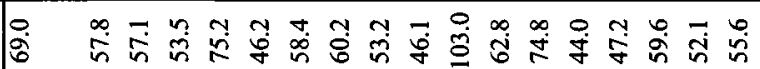 \\
\hline 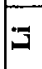 & & 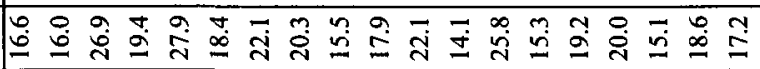 \\
\hline$\stackrel{\nexists}{\AA}$ & $\because$ & 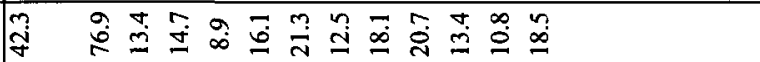 \\
\hline II & 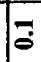 & 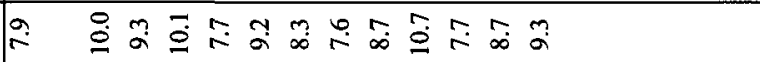 \\
\hline छี & בֶ: & 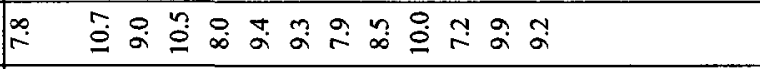 \\
\hline 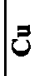 & & 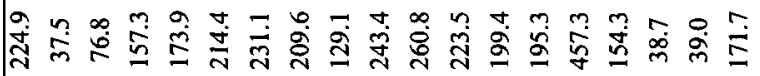 \\
\hline$\theta$ & $\overline{5}$ & 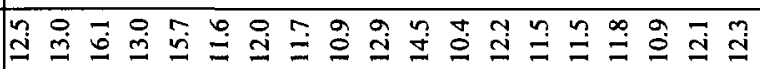 \\
\hline 8 & 8 & 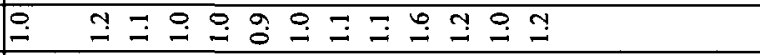 \\
\hline t & & 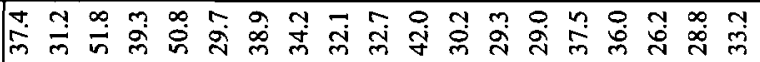 \\
\hline$\ddot{U}$ & 8 & 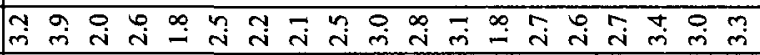 \\
\hline ن & $\overline{8}$ & 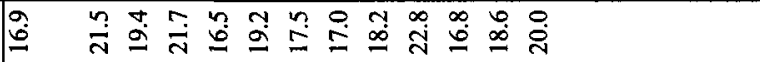 \\
\hline$\infty$ & 8 & 竞 \\
\hline 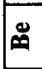 & & 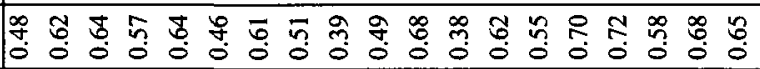 \\
\hline ఱ็ & & 莽 \\
\hline 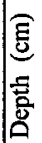 & & 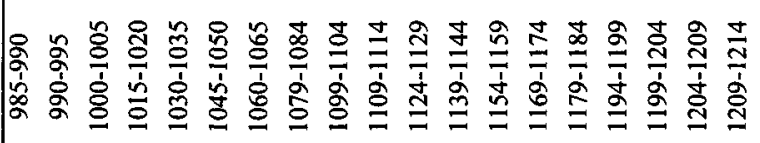 \\
\hline 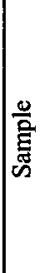 & & 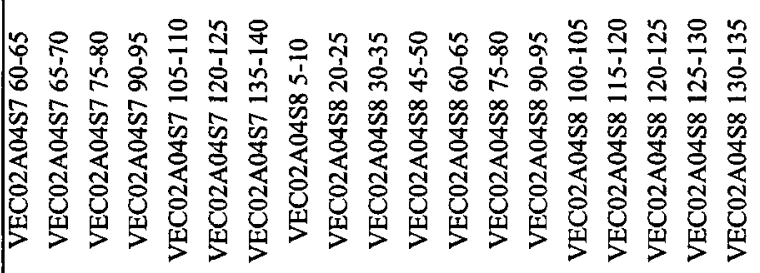 \\
\hline
\end{tabular}


Appendix C 8. Distribution of paleoredox indices in the Frederick Sound core.

\begin{tabular}{|c|c|c|c|c|c|c|c|c|c|}
\hline Sample & Depth $(\mathrm{cm})$ & $\mathrm{U} / \mathrm{Th}$ & $\mathrm{Ni} / \mathrm{Co}$ & $\mathrm{V} / \mathrm{Cr}$ & $\mathrm{V} /(\mathrm{V}+\mathrm{N} \mathrm{i})$ & $\mathrm{V} / \mathrm{Sc}$ & $\mathrm{U}_{\text {auth }}$ & $(\mathrm{Cu}+\mathrm{Mo}) / \mathrm{Zn}$ & $\mathrm{Th} / \mathrm{U}$ \\
\hline VEC02A04S1 0-5 & 0 & 5.02 & 1.53 & 3.25 & 0.85 & 12.19 & 9.54 & 2.00 & 0.20 \\
\hline VEC02A04S1 5-10 & 5 & & 1.52 & 1.94 & 0.82 & 9.71 & & 0.48 & \\
\hline VEC02A04S1 10-15 & 10 & 4.66 & 1.64 & 3.13 & 0.85 & 12.34 & 10.60 & 1.72 & 0.21 \\
\hline VEC02A04S1 20-25 & 20 & 4.41 & 1.79 & 2.41 & 0.79 & 11.16 & 8.42 & 1.76 & 0.23 \\
\hline VEC02A04S1 30-35 & 30 & 2.13 & 1.90 & 1.64 & 0.80 & 7.89 & 3.77 & 1.47 & 0.47 \\
\hline VEC02A04S1 60-65 & 60 & 3.84 & 1.82 & 2.40 & 0.83 & 9.99 & 6.42 & 1.66 & 0.26 \\
\hline VEC02A04S1 70-75 & 70 & 5.98 & 1.64 & 3.11 & 0.84 & 11.59 & 12.74 & 1.58 & 0.17 \\
\hline VEC02A04S1 80-85 & 80 & 5.15 & 1.79 & 2.55 & 0.82 & 10.95 & 9.90 & 1.52 & 0.19 \\
\hline VEC02A04S1 90-95 & 90 & 5.01 & 1.46 & 3.04 & 0.85 & 10.04 & 7.87 & 1.64 & 0.20 \\
\hline VEC02A04S1 100-105 & 100 & 4.73 & 1.63 & 2.86 & 0.82 & 12.15 & 9.59 & 2.09 & 0.21 \\
\hline VEC02A04S1 105-110 & 105 & & & 2.74 & 0.85 & 12.51 & & 0.58 & \\
\hline VEC02A04S1 110-115 & 110 & 5.38 & 1.66 & 3.03 & 0.84 & 12.04 & 10.81 & 2.00 & 0.19 \\
\hline VEC02A04S1 120-125 & 120 & 5.45 & 1.71 & 2.85 & 0.83 & 11.86 & 9.86 & 2.49 & 0.18 \\
\hline VEC02A04SI 130-135 & 130 & 6.04 & 1.69 & 3.06 & 0.85 & 12.50 & 11.32 & 1.74 & 0.17 \\
\hline VEC02A04S3 0-5 & 325 & 6.15 & 1.38 & 3.67 & 0.87 & 10.64 & 10.16 & 1.55 & 0.16 \\
\hline VEC02A04S3 15-20 & 340 & 6.44 & 1.98 & 2.50 & 0.80 & 10.97 & 10.94 & 1.60 & 0.16 \\
\hline VEC02A04S3 30-35 & 355 & 4.99 & 1.60 & 3.37 & 0.84 & 12.51 & 9.92 & 2.26 & 0.20 \\
\hline VEC02A04S3 45-50 & 370 & 5.89 & 1.52 & 4.16 & 0.86 & 11.58 & 10.04 & 2.33 & 0.17 \\
\hline VEC02A04S3 60-65 & 385 & 5.75 & 1.64 & 2.56 & 0.84 & 9.12 & 8.06 & 2.98 & 0.17 \\
\hline VEC02A04S3 75-80 & 400 & 6.36 & 2.09 & 2.95 & 0.80 & 11.73 & 13.26 & 1.68 & 0.16 \\
\hline VEC02A04S3 90-95 & 415 & 3.09 & 1.98 & 1.73 & 0.80 & 8.44 & 4.89 & 2.16 & 0.32 \\
\hline VEC02A04S3 105-110 & 430 & 5.65 & 1.46 & 3.65 & 0.86 & 9.94 & 9.45 & 2.18 & 0.18 \\
\hline VEC02A04S3 120-125 & 445 & 5.20 & 1.62 & 3.42 & 0.83 & 11.96 & 8.97 & 2.14 & 0.19 \\
\hline VEC02A04S3 135-137 & 460 & 7.14 & 1.65 & 3.56 & 0.84 & 11.42 & 10.86 & 1.84 & 0.14 \\
\hline VEC02A04S4 10-15 & 472 & & 1.23 & 3.90 & 0.87 & 12.97 & & 0.60 & \\
\hline VEC02A04S4 15-20 & 477 & 5.84 & 1.63 & 3.18 & 0.84 & 12.32 & 10.83 & 2.08 & 0.17 \\
\hline VEC02A04S4 20-25 & 482 & & 1.06 & 3.99 & 0.89 & 11.27 & & 0.52 & \\
\hline VEC02A04S4 30-35 & 492 & 5.90 & 1.64 & 3.48 & 0.84 & 11.65 & 10.73 & 2.10 & 0.17 \\
\hline VEC02A04S4 45-50 & 507 & 5.25 & 1.64 & 3.34 & 0.84 & 10.78 & 10.82 & 1.91 & 0.19 \\
\hline VEC02A04S4 60-65 & 522 & 4.66 & 1.75 & 2.98 & 0.83 & 11.36 & 7.69 & 2.31 & 0.21 \\
\hline VEC02A04S4 75-80 & 537 & 4.79 & 1.58 & 3.09 & 0.83 & 13.29 & 7.41 & 2.36 & 0.21 \\
\hline VEC02A04S4 90-95 & 552 & 6.93 & 1.54 & 3.85 & 0.87 & 12.27 & 9.98 & 2.26 & 0.14 \\
\hline VEC02A04S4 105-110 & 567 & 5.15 & 1.77 & 3.01 & 0.83 & 11.78 & 9.38 & 2.13 & 0.19 \\
\hline VEC02A04S4 115-120 & 577 & & & 3.82 & 1.00 & 12.28 & & 0.60 & \\
\hline VEC02A04S4 120-125 & 582 & 5.43 & 1.89 & 2.81 & 0.82 & 11.13 & 9.34 & 4.92 & 0.18 \\
\hline VEC02A04S4 135-140 & 597 & 5.47 & 1.67 & 3.32 & 0.84 & 11.38 & 9.07 & 2.60 & 0.18 \\
\hline VEC02A04S4 150-155 & 612 & 5.29 & 1.77 & 3.14 & 0.82 & 11.36 & 9.50 & 1.99 & 0.19 \\
\hline VEC02A04S5 10-15 & 629 & 4.33 & 1.97 & 2.04 & 0.79 & 9.83 & 8.03 & 0.84 & 0.23 \\
\hline VEC02A04S5 25-30 & 644 & 6.52 & 1.52 & 3.87 & 0.88 & 14.10 & 10.68 & 1.01 & 0.15 \\
\hline VEC02A04S5 40-45 & 659 & 4.90 & 1.75 & 3.04 & 0.82 & 12.06 & 9.03 & 2.51 & 0.20 \\
\hline VEC02A04S5 55-60 & 674 & 5.74 & 1.71 & 3.01 & 0.82 & 11.61 & 10.80 & 1.20 & 0.17 \\
\hline VEC02A04S5 65-70 & 684 & 5.30 & 1.38 & 2.91 & 0.85 & 9.20 & 9.11 & 2.72 & 0.19 \\
\hline VEC02A04S5 75-80 & 694 & 5.35 & 1.80 & 2.93 & 0.80 & 12.24 & 10.45 & 2.03 & 0.19 \\
\hline VEC02A04S5 85-90 & 704 & 5.02 & 1.70 & 3.06 & 0.82 & 11.53 & 9.93 & 1.71 & 0.20 \\
\hline VEC02A04S5 105-110 & 724 & 5.62 & 1.67 & 3.82 & 0.86 & 12.38 & 9.65 & 2.06 & 0.18 \\
\hline VEC02A04S5 115-120 & 734 & 5.89 & 1.62 & 3.22 & 0.82 & 11.50 & 9.79 & 2.95 & 0.17 \\
\hline VEC02A04S5 130-135 & 749 & 4.48 & 1.74 & 2.88 & 0.82 & 12.01 & 9.11 & 2.45 & 0.22 \\
\hline
\end{tabular}




\begin{tabular}{|c|c|c|c|c|c|c|c|c|c|}
\hline Sample & Depth (cm) & $\mathrm{U} / \mathrm{Th}$ & $\mathrm{Ni} / \mathrm{Co}$ & $\mathrm{V} / \mathrm{Cr}$ & $\mathrm{V} /(\mathrm{V}+\mathrm{Ni})$ & $\mathrm{V} / \mathrm{Sc}$ & $\mathrm{U}_{\text {auth }}$ & $(\mathrm{Cu}+\mathrm{Mo}) / \mathrm{Zn}$ & $\mathrm{Th} / \mathrm{U}$ \\
\hline VEC02A04S5 145-150 & 764 & 4.23 & 1.73 & 2.83 & 0.81 & 9.91 & 8.42 & 0.89 & 0.24 \\
\hline VEC02A04S6 5-10 & 778 & 4.75 & 1.80 & 2.81 & 0.80 & 12.52 & 9.63 & 2.00 & 0.21 \\
\hline VEC02A04S6 20-25 & 793 & 4.64 & 1.52 & 3.26 & 0.85 & 10.58 & 9.62 & 2.67 & 0.22 \\
\hline VEC02A04S6 35-40 & 808 & 5.84 & 1.79 & 3.00 & 0.83 & 12.49 & 12.30 & 2.81 & 0.17 \\
\hline VEC02A04S6 50-55 & 823 & 5.48 & 1.62 & 3.35 & 0.84 & 11.51 & 10.12 & 2.51 & 0.18 \\
\hline VEC02A04S6 65-70 & 838 & 6.03 & 1.19 & 4.64 & 0.89 & 10.73 & 8.32 & 2.45 & 0.17 \\
\hline VEC02A04S6 80-85 & 853 & 5.59 & 1.60 & 3.61 & 0.85 & 11.13 & 9.16 & 3.47 & 0.18 \\
\hline VEC02A04S6 90-95 & 863 & & 1.36 & 3.57 & 0.86 & 15.59 & & 0.58 & \\
\hline VEC02A04S6 95-100 & 868 & 5.02 & 1.88 & 3.08 & 0.82 & 12.20 & 9.73 & 2.46 & 0.20 \\
\hline VEC02A04S6 110-115 & 883 & 4.84 & 1.74 & 3.01 & 0.82 & 11.42 & 10.35 & 1.89 & 0.21 \\
\hline VEC02A04S6 115-120 & 888 & & & 2.83 & 1.00 & 12.21 & & 0.55 & \\
\hline VEC02A04S6 120-125 & 893 & 3.22 & 1.63 & 2.80 & 0.84 & 10.67 & 7.72 & 1.92 & 0.31 \\
\hline VEC02A04S6 130-135 & 903 & 3.10 & 1.60 & 2.74 & 0.85 & 10.55 & 8.31 & 1.53 & 0.32 \\
\hline VEC02A04S6 140-145 & 913 & 5.43 & 1.75 & 3.06 & 0.82 & 11.58 & 12.92 & 2.49 & 0.18 \\
\hline VEC02A04S6 150-152 & 923 & 4.41 & 1.67 & 3.31 & 0.84 & 11.48 & 9.21 & 3.11 & 0.23 \\
\hline VEC02A04S7 5-10 & 930 & 5.43 & 1.80 & 2.98 & 0.82 & 12.09 & 9.74 & 21.11 & 0.18 \\
\hline VEC02A04S7 20-25 & 945 & 5.44 & 1.01 & 5.02 & 0.90 & 8.91 & 7.12 & 6.53 & 0.18 \\
\hline VEC02A04S7 30-35 & 955 & 4.73 & 1.16 & 4.21 & 0.89 & 10.22 & 8.48 & 3.85 & 0.21 \\
\hline VEC02A04S7 45-50 & 970 & 5.43 & 1.93 & 2.79 & 0.82 & 11.80 & 10.85 & 3.08 & 0.18 \\
\hline VEC02A04S7 60-65 & 985 & 6.05 & 1.84 & 2.54 & 0.80 & 11.76 & 11.19 & 3.20 & 0.17 \\
\hline VEC02A04S7 65-70 & 990 & & 1.42 & 2.67 & 0.82 & 12.64 & & 0.56 & \\
\hline VEC02A04S7 75-80 & 1000 & 4.30 & 1.94 & 2.39 & 0.80 & 10.38 & 8.34 & 0.93 & 0.23 \\
\hline VEC02A04S7 90-95 & 1015 & 5.47 & 1.77 & 2.66 & 0.82 & 11.12 & 12.33 & 2.10 & 0.18 \\
\hline VEC02A04S7 105-110 & 1030 & 3.87 & 1.72 & 2.29 & 0.81 & 9.50 & 7.97 & 2.52 & 0.26 \\
\hline VEC02A04S7 120-125 & 1045 & 5.83 & 1.64 & 3.19 & 0.83 & 11.26 & 9.60 & 3.20 & 0.17 \\
\hline VEC02A04S7 135-140 & 1060 & 6.57 & 1.68 & 3.09 & 0.86 & 11.22 & 11.47 & 3.50 & 0.15 \\
\hline VEC02A04S8 5-10 & 1079 & 5.13 & 1.67 & 2.95 & 0.84 & 10.69 & 8.67 & 3.27 & 0.19 \\
\hline VEC02A04S8 20-25 & 1099 & 4.39 & 1.57 & 2.65 & 0.83 & 11.95 & 8.57 & 2.06 & 0.23 \\
\hline VEC02A04S8 30-35 & 1109 & 4.63 & 1.76 & 3.02 & 0.81 & 11.54 & 9.43 & 3.41 & 0.22 \\
\hline VEC02A04S8 45-50 & 1124 & 4.30 & 1.85 & 2.78 & 0.81 & 11.43 & 10.79 & 2.95 & 0.23 \\
\hline VEC02A04S8 60-65 & 1139 & 5.24 & 1.84 & 2.81 & 0.82 & 12.49 & 11.19 & 3.42 & 0.19 \\
\hline VEC02A04S8 75-80 & 1154 & 6.94 & 1.33 & 3.99 & 0.88 & 11.18 & 12.22 & 2.89 & 0.14 \\
\hline VEC02A04S8 90-95 & 1169 & 4.22 & 1.59 & 3.29 & 0.84 & 10.38 & 9.23 & 2.68 & 0.24 \\
\hline VEC02A04S8 100-105 & 1179 & & 1.19 & 3.45 & 0.90 & 14.72 & & 7.19 & \\
\hline VEC02A04S8 115-120 & 1194 & & 1.44 & 2.88 & 0.86 & 12.91 & & 2.25 & \\
\hline VEC02A04S8 120-125 & 1199 & & 1.39 & 3.26 & 0.85 & 13.39 & & 0.60 & \\
\hline VEC02A04S8 125-130 & 1204 & & 1.25 & 3.37 & 0.87 & 12.33 & & 0.56 & \\
\hline VEC02A04S8 130-135 & 1209 & & 1.42 & 2.82 & 0.84 & 12.31 & & 2.42 & \\
\hline
\end{tabular}


Appendix C 9. Distribution of major elements in the Alison Sound core.

\begin{tabular}{|c|c|c|c|c|c|c|c|c|c|c|c|}
\hline & Client ID & Al & $\mathbf{C a}$ & $\mathbf{F e}$ & $\mathbf{K}$ & $\mathbf{M g}$ & Mn & $\mathbf{N a}$ & $\mathbf{P}$ & Si & $\mathbf{T i}$ \\
\hline & Detect Limit & 0.01 & 0.01 & 0.01 & 0.01 & 0.01 & 0.01 & 0.01 & 0.00 & 0.00 & 0.01 \\
\hline 10 & VEC02A071 10-15 & 6.22 & 3.10 & 4.08 & 1.00 & 1.80 & 0.09 & 0.45 & 0.09 & 20.10 & 0.34 \\
\hline 20 & VEC02A071 20-25 & 5.74 & 2.57 & 4.06 & 1.09 & 1.70 & 0.09 & 0.44 & 0.10 & 17.92 & 0.33 \\
\hline 30 & VEC02A071 30-35 & 6.57 & 3.39 & 4.76 & 1.05 & 1.86 & 0.10 & 0.49 & 0.09 & 20.86 & 0.37 \\
\hline 40 & VEC02A071 40-45 & 5.86 & 2.83 & 4.62 & 1.20 & 1.89 & 0.09 & 0.50 & 0.10 & 17.55 & 0.38 \\
\hline 55 & VEC02A07S1_55-60 & 5.87 & 2.83 & 4.61 & 1.17 & 1.91 & 0.08 & 3.23 & 0.10 & ND & 0.39 \\
\hline 60 & VEC02A07S1_60-65 & 5.56 & 2.58 & 4.27 & 1.02 & 1.71 & 0.08 & 3.04 & 0.10 & ND & 0.39 \\
\hline 70 & VEC02A071 70-75 & 5.95 & 2.62 & 4.80 & 1.33 & 1.93 & 0.09 & 0.51 & 0.11 & 18.10 & 0.39 \\
\hline 80 & VEC02A071 80-85 & 5.51 & 2.68 & 4.75 & 1.29 & 1.91 & 0.09 & 0.50 & 0.10 & 17.04 & 0.38 \\
\hline 90 & VEC02A071 90-95 & 6.10 & 2.95 & 4.36 & 1.15 & 1.86 & 0.10 & 0.48 & 0.10 & 18.63 & 0.36 \\
\hline 97 & VEC02A072 0-5 & 5.69 & 2.75 & 4.31 & 1.16 & 1.87 & 0.09 & 0.46 & 0.10 & 17.71 & 0.35 \\
\hline 107 & VEC02A072 10-15 & 6.22 & 2.86 & 4.64 & 1.32 & 1.88 & 0.09 & 0.51 & 0.10 & 19.64 & 0.38 \\
\hline 117 & VEC02A072 20-25 & 6.52 & 3.16 & 4.87 & 1.35 & 2.18 & 0.10 & 0.57 & 0.14 & 18.65 & 0.43 \\
\hline 127 & VEC02A072 30-35 & 6.39 & 3.16 & 4.40 & 1.14 & 1.86 & 0.09 & 0.48 & 0.10 & 20.15 & 0.36 \\
\hline 137 & VEC02A072 40-45 & 6.21 & 2.82 & 4.54 & 1.30 & 2.00 & 0.09 & 0.51 & 0.14 & 17.91 & 0.39 \\
\hline 147 & VEC02A072 50-55 & 5.93 & 2.74 & 4.66 & 1.13 & 1.80 & 0.09 & 0.47 & 0.10 & 18.71 & 0.35 \\
\hline 157 & VEC02A072 60-65 & 5.57 & 2.54 & 4.75 & 1.23 & 1.77 & 0.09 & 0.46 & 0.11 & 17.28 & 0.35 \\
\hline 167 & VEC02A072 70-75 & 5.99 & 2.82 & 4.45 & 1.10 & 1.85 & 0.09 & 0.47 & 0.11 & 18.27 & 0.35 \\
\hline 177 & VEC02A072 80-85 & 6.57 & 3.22 & 3.92 & 0.81 & 1.50 & 0.10 & 0.38 & 0.08 & 22.40 & 0.29 \\
\hline 187 & VEC02A072 90-95 & 5.31 & 2.54 & 4.22 & 1.05 & 1.75 & 0.09 & 0.41 & 0.10 & 16.74 & 0.31 \\
\hline 197 & VEC02A072 100-105 & 6.33 & 2.25 & 3.54 & 0.75 & 2.06 & 1.81 & 0.06 & 2.28 & 17.77 & 0.41 \\
\hline 217 & VEC02A07S2_120-125 & 6.20 & 2.16 & 3.61 & 0.88 & 2.02 & 1.77 & 0.07 & 0.37 & 18.49 & 0.43 \\
\hline 227 & VEC02A072 130-135 & 5.13 & 2.27 & 4.22 & 1.11 & 1.82 & 0.09 & 0.41 & 0.10 & 15.84 & 0.31 \\
\hline 243 & VEC02A072/3 10-15 & 5.48 & 2.69 & 4.94 & 1.27 & 1.83 & 0.09 & 0.46 & 0.11 & 16.98 & 0.35 \\
\hline 249 & VEC02A073 0-5 & 5.74 & 2.62 & 4.40 & 1.20 & 1.85 & 0.09 & 0.45 & 0.10 & 17.95 & 0.34 \\
\hline 269 & VEC02A073 20-25 & 6.04 & 2.93 & 4.31 & 1.14 & 1.80 & 0.09 & 0.47 & 0.10 & 19.23 & 0.35 \\
\hline 289 & VEC02A073 40-45 & 6.48 & 2.43 & 4.06 & 1.16 & 1.64 & 0.09 & 0.51 & 0.27 & 15.60 & 0.38 \\
\hline 309 & VEC02A073 60-65 & 6.11 & 2.95 & 4.27 & 0.98 & 1.74 & 0.09 & 0.43 & 0.10 & 20.00 & 0.32 \\
\hline 319 & VEC02A07S3_70-75 & 5.94 & 2.68 & 4.99 & 1.07 & 1.82 & 0.08 & 0.48 & 0.09 & 0.00 & 0.37 \\
\hline 329 & VEC02A073 80-85 & 6.99 & 3.64 & 5.01 & 1.26 & 2.33 & 0.10 & 0.61 & 0.14 & 20.14 & 0.46 \\
\hline 349 & VEC02A073 100-105 & 5.74 & 2.81 & 4.04 & 0.99 & 1.60 & 0.10 & 0.44 & 0.10 & 17.69 & 0.34 \\
\hline 369 & VEC02A073 120-125 & 6.20 & 2.92 & 4.77 & 1.38 & 2.02 & 0.10 & 0.56 & 0.11 & 18.48 & 0.43 \\
\hline 389 & VEC02A073 140-145 & 6.35 & 3.22 & 4.70 & 1.13 & 2.18 & 0.10 & 0.55 & 0.16 & 18.01 & 0.41 \\
\hline 399 & VEC02A073 150-155 & 7.05 & 3.54 & 3.42 & 0.54 & 1.38 & 0.10 & 0.34 & 0.04 & 25.02 & 0.26 \\
\hline 403 & VEC02A074 0-5 & 6.67 & 3.32 & 4.35 & 1.00 & 1.78 & 0.11 & 0.46 & 0.09 & 21.55 & 0.35 \\
\hline 423 & VEC02A074 20-25 & 5.79 & 2.82 & 4.39 & 1.02 & 1.67 & 0.09 & 0.47 & 0.11 & 17.57 & 0.35 \\
\hline 443 & VEC02A074 40-45 & 5.78 & 2.78 & 4.73 & 1.23 & 1.89 & 0.09 & 0.50 & 0.10 & 18.15 & 0.38 \\
\hline 463 & VEC02A074 60-65 & 5.92 & 2.87 & 4.84 & 1.21 & 2.06 & 0.09 & 0.53 & 0.11 & 18.35 & 0.40 \\
\hline 483 & VEC02A074 80-85 & 6.14 & 3.01 & 5.17 & 1.37 & 2.03 & 0.10 & 0.56 & 0.12 & 18.57 & 0.43 \\
\hline 503 & VEC02A074 100-105 & 6.32 & 3.13 & 4.48 & 1.10 & 1.77 & 0.10 & 0.48 & 0.09 & 20.25 & 0.36 \\
\hline 523 & VEC02A074 120 & 6.40 & 3.14 & 4.45 & 1.17 & 1.98 & 0.10 & 0.54 & 0.12 & 19.33 & 0.41 \\
\hline 533 & VEC02A074 130-135 & 6.12 & 2.94 & 5.13 & 1.34 & 2.00 & 0.09 & 0.54 & 0.11 & 18.97 & 0.41 \\
\hline 543 & VEC02A074 140-145 & 6.66 & 3.32 & 4.97 & 1.37 & 2.26 & 0.11 & 0.61 & 0.15 & 19.37 & 0.46 \\
\hline 570 & VEC02A074/5 10-15 & 6.10 & 3.09 & 4.53 & 1.22 & 1.95 & 0.10 & 0.53 & 0.10 & 19.06 & 0.40 \\
\hline 580 & VEC02A074/5 20-25 & 6.66 & 3.21 & 4.92 & 1.35 & 2.14 & 0.10 & 0.58 & 0.11 & 20.03 & 0.44 \\
\hline 602 & VEC02A075 20-25 & 6.44 & 2.89 & 4.76 & 1.30 & 1.95 & 0.10 & 0.55 & 0.15 & 18.58 & 0.41 \\
\hline 622 & VEC02A075 40-45 & 6.86 & 3.28 & 5.05 & 1.30 & 2.04 & 0.11 & 0.57 & 0.11 & 20.64 & 0.43 \\
\hline 632 & VEC02A07S5_50 & 6.60 & 3.27 & 5.08 & 1.28 & 2.14 & 2.14 & 0.09 & 2.89 & 0.12 & 0.42 \\
\hline 642 & VEC02A075 60-65 & 6.75 & 3.19 & 5.04 & 1.43 & 2.12 & 0.11 & 0.60 & 0.14 & 19.58 & 0.46 \\
\hline 662 & VEC02A075 80-85 & 6.95 & 3.37 & 4.96 & 1.44 & 2.09 & 0.11 & 0.59 & 0.12 & 20.68 & 0.45 \\
\hline 692 & VEC02A075 110 & 6.49 & 3.17 & 4.95 & 1.46 & 2.12 & 0.10 & 0.56 & 0.11 & 19.63 & 0.43 \\
\hline 702 & VEC02A075 120-125 & 6.54 & 3.28 & 4.25 & 1.13 & 1.82 & 0.10 & 0.48 & 0.10 & 20.86 & 0.37 \\
\hline 732 & VEC02A076 5-10 & 6.42 & 3.02 & 5.29 & 1.51 & 2.06 & 0.10 & 0.59 & 0.11 & 19.49 & 0.44 \\
\hline
\end{tabular}




\begin{tabular}{|c|c|c|c|c|c|c|c|c|c|c|c|}
\hline & Client ID & $\mathbf{A l}$ & $\mathbf{C a}$ & $\mathbf{F e}$ & $\mathbf{K}$ & $\mathbf{M g}$ & Mn & $\mathbf{N a}$ & $\mathbf{P}$ & $\mathbf{S i}$ & $\mathbf{T i}$ \\
\hline & Detect Limit & 0.01 & 0.01 & 0.01 & 0.01 & 0.01 & 0.01 & 0.01 & 0.00 & 0.00 & 0.01 \\
\hline 747 & VEC02A076 20-25 & 6.95 & 3.39 & 5.31 & 1.44 & 2.24 & 0.11 & 0.63 & 0.14 & 20.37 & 0.47 \\
\hline 767 & VEC02A076 40-45 & 6.36 & 3.14 & 4.71 & 1.34 & 2.04 & 0.10 & 0.55 & 0.11 & 19.17 & 0.41 \\
\hline 787 & VEC02A076 60-65 & 6.44 & 3.14 & 4.76 & 1.17 & 1.82 & 0.10 & 0.51 & 0.10 & 19.83 & 0.39 \\
\hline 807 & VEC02A076 80-85 & 6.72 & 3.19 & 4.61 & 1.17 & 1.81 & 0.11 & 0.50 & 0.10 & 20.92 & 0.38 \\
\hline 817 & VEC02A076 90 & 6.52 & 3.14 & 4.64 & 1.09 & 1.81 & 0.11 & 0.50 & 0.09 & 20.38 & 0.38 \\
\hline 827 & VEC02A076 100-105 & 6.59 & 3.09 & 4.98 & 1.37 & 2.01 & 0.10 & 0.58 & 0.12 & 19.87 & 0.44 \\
\hline 852 & VEC02A076 120-125 & 6.80 & 3.22 & 5.14 & 1.36 & 2.06 & 0.10 & 0.59 & 0.12 & 20.45 & 0.44 \\
\hline
\end{tabular}

Appendix C 10. Distribution of oxides of major elements in the Alison Sound core.

\begin{tabular}{|c|c|c|c|c|c|c|c|c|c|c|c|c|c|}
\hline & Sample & $\mathrm{Al}_{2} \mathrm{O}_{3}$ & $\mathrm{CaO}$ & $\mathrm{Fe}_{2} \mathrm{O}_{3}$ & $\mathrm{~K}_{2} \mathrm{O}$ & LOI & $\mathrm{MgO}$ & $\mathrm{MnO}$ & $\mathrm{Na}_{2} \mathrm{O}$ & $\mathbf{P}_{2} \mathrm{O}_{5}$ & $\mathrm{SiO}_{2}$ & $\mathrm{TiO}_{2}$ & Total \\
\hline & Detect Limit & 0.01 & 0.01 & 0.01 & 0.01 & 0.05 & 0.01 & 0.01 & 0.01 & 0.01 & 0.01 & 0.01 & \\
\hline 10 & VEC02A071 10-15 & 11.75 & 4.34 & 5.83 & 1.20 & 22.4 & 2.99 & 0.12 & 4.60 & 0.20 & 43.0 & 0.57 & 97.03 \\
\hline 20 & VEC02A071 20-25 & 10.85 & 3.60 & 5.80 & 1.31 & 27.9 & 2.82 & 0.11 & 4.48 & 0.23 & 38.3 & 0.55 & 96.03 \\
\hline 30 & VEC02A071 30-35 & 12.41 & 4.75 & 6.81 & 1.26 & 18.9 & 3.09 & 0.13 & 4.34 & 0.21 & 44.6 & 0.62 & 97.24 \\
\hline 40 & VEC02A071 40-45 & 11.08 & 3.96 & 6.61 & 1.45 & 26.4 & 3.14 & 0.12 & 4.34 & 0.23 & 37.5 & 0.63 & 95.53 \\
\hline 55 & VEC02A07S1_55-60 & 11.10 & 3.96 & 6.58 & 1.41 & ND & 3.17 & 0.10 & 4.00 & 0.23 & ND & 0.64 & ND \\
\hline 60 & VEC02A07S1_60-65 & 10.52 & 3.61 & 6.10 & 1.23 & ND & 2.84 & 0.10 & 3.76 & 0.22 & ND & 0.65 & ND \\
\hline 70 & VEC02A071 70-75 & 11.25 & 3.66 & 6.87 & 1.60 & 25.3 & 3.20 & 0.12 & 4.64 & 0.25 & 38.7 & 0.65 & 96.32 \\
\hline 80 & VEC02A071 80-85 & 10.42 & 3.75 & 6.79 & 1.55 & 27.3 & 3.16 & 0.12 & 4.69 & 0.24 & 36.4 & 0.63 & 95.12 \\
\hline 90 & VEC02A071 90-95 & 11.52 & 4.13 & 6.23 & 1.38 & 23.8 & 3.08 & 0.13 & 4.60 & 0.22 & 39.8 & 0.60 & 95.55 \\
\hline 97 & VEC02A072 0-5 & 10.76 & 3.85 & 6.16 & 1.40 & 26.3 & 3.10 & 0.12 & 4.96 & 0.22 & 37.8 & 0.58 & 95.40 \\
\hline 107 & VEC02A072 10-15 & 11.76 & 4.00 & 6.64 & 1.59 & 22.1 & 3.11 & 0.12 & 4.32 & 0.23 & 42.0 & 0.64 & 96.61 \\
\hline 117 & VEC02A072 20-25 & 12.33 & 4.42 & 6.96 & 1.63 & 22.5 & 3.61 & 0.13 & 4.24 & 0.33 & 39.9 & 0.72 & 96.82 \\
\hline 127 & VEC02A072 30-35 & 12.07 & 4.42 & 6.29 & 1.37 & 22.0 & 3.09 & 0.12 & 4.08 & 0.24 & 43.1 & 0.60 & 97.41 \\
\hline 137 & VEC02A072 40-45 & 11.73 & 3.95 & 6.49 & 1.56 & 25.2 & 3.32 & 0.12 & 4.49 & 0.31 & 38.3 & 0.65 & 96.19 \\
\hline 147 & VEC02A072 50-55 & 11.20 & 3.84 & 6.66 & 1.36 & 24.7 & 2.98 & 0.12 & 4.40 & 0.22 & 40.0 & 0.59 & 96.19 \\
\hline 157 & VEC02A072 60-65 & 10.52 & 3.55 & 6.79 & 1.48 & 28.3 & 2.93 & 0.11 & 4.40 & 0.26 & 36.9 & 0.58 & 95.97 \\
\hline 167 & VEC02A072 70-75 & 11.33 & 3.95 & 6.36 & 1.33 & 25.2 & 3.07 & 0.12 & 4.55 & 0.26 & 39.0 & 0.59 & 95.91 \\
\hline 177 & VEC02A072 80-85 & 12.41 & 4.50 & 5.61 & 0.97 & 19.5 & 2.48 & 0.13 & 3.81 & 0.18 & 47.9 & 0.48 & 98.06 \\
\hline 187 & VEC02A072 90-95 & 10.04 & 3.56 & 6.04 & 1.26 & 29.7 & 2.90 & 0.11 & 5.00 & 0.22 & 35.8 & 0.52 & 95.25 \\
\hline 197 & VEC02A072 100-105 & 11.96 & 4.25 & 6.70 & 1.42 & 25.7 & 3.42 & 0.12 & 4.30 & 0.38 & 38.0 & 0.68 & 97.00 \\
\hline 217 & VEC02A07S2_120-125 & 11.72 & 4.08 & 6.82 & 1.66 & ND & 3.35 & 0.13 & 0.70 & 0.26 & 39.5 & 0.71 & $\mathrm{ND}$ \\
\hline 227 & VEC02A072 $130-135$ & 9.69 & 3.17 & 6.03 & 1.34 & 30.4 & 3.02 & 0.11 & 5.60 & 0.23 & 33.8 & 0.52 & 94.00 \\
\hline 243 & VEC02A072/3 10-15 & 10.35 & 3.76 & 7.06 & 1.53 & 27.4 & 3.03 & 0.11 & 4.64 & 0.25 & 36.3 & 0.58 & 95.11 \\
\hline 249 & VEC02A073 0-5 & 10.85 & 3.67 & 6.29 & 1.45 & 26.5 & 3.07 & 0.12 & 4.73 & 0.22 & 38.3 & 0.57 & 95.92 \\
\hline 269 & VEC02A073 20-25 & 11.42 & 4.10 & 6.16 & 1.37 & 24.7 & 2.98 & 0.12 & 4.07 & 0.23 & 41.1 & 0.59 & 96.87 \\
\hline 289 & VEC02A073 40-45 & 12.25 & 3.40 & 5.81 & 1.40 & 32.2 & 2.72 & 0.11 & 4.28 & 0.61 & 33.3 & 0.64 & 96.82 \\
\hline 309 & VEC02A073 60-65 & 11.54 & 4.13 & 6.11 & 1.18 & 23.0 & 2.89 & 0.12 & 4.20 & 0.22 & 42.7 & 0.54 & 96.81 \\
\hline 319 & VEC02A07S3_70-75 & 11.23 & 3.75 & 7.13 & 1.28 & ND & 3.01 & 0.10 & 3.80 & 0.21 & ND & 0.61 & ND \\
\hline 329 & VEC02A073 80-85 & 13.21 & 5.10 & 7.17 & 1.52 & 18.5 & 3.86 & 0.13 & 4.05 & 0.32 & 43.0 & 0.77 & 97.82 \\
\hline 349 & VEC02A073 100-105 & 10.85 & 3.93 & 5.77 & 1.19 & 30.5 & 2.66 & 0.13 & 3.48 & 0.24 & 37.8 & 0.56 & 97.22 \\
\hline 369 & VEC02A073 120-125 & 11.72 & 4.08 & 6.82 & 1.66 & 24.2 & 3.35 & 0.13 & 4.20 & 0.26 & 39.5 & 0.71 & 96.68 \\
\hline 389 & VEC02A073 140-145 & 12.00 & 4.50 & 6.72 & 1.36 & 25.6 & 3.62 & 0.13 & 3.91 & 0.37 & 38.5 & 0.69 & 97.50 \\
\hline 399 & VEC02A073 150-155 & 13.33 & 4.96 & 4.89 & 0.65 & 16.0 & 2.28 & 0.13 & 3.23 & 0.09 & 53.5 & 0.43 & 99.52 \\
\hline 403 & VEC02A074 0-5 & 12.61 & 4.65 & 6.22 & 1.20 & 18.6 & 2.95 & 0.14 & 4.40 & 0.21 & 46.1 & 0.58 & 97.68 \\
\hline 423 & VEC02A074 20-25 & 10.95 & 3.95 & 6.27 & 1.23 & 28.6 & 2.77 & 0.12 & 4.12 & 0.25 & 37.5 & 0.59 & 96.51 \\
\hline 443 & VEC02A074 40-45 & 10.93 & 3.89 & 6.77 & 1.48 & 25.5 & 3.14 & 0.12 & 4.46 & 0.24 & 38.8 & 0.63 & 96.01 \\
\hline 463 & VEC02A074 60-65 & 11.18 & 4.02 & 6.92 & 1.46 & 23.8 & 3.41 & 0.12 & 4.61 & 0.25 & 39.2 & 0.67 & 95.78 \\
\hline 483 & VEC02A074 80-85 & 11.61 & 4.21 & 7.39 & 1.65 & 22.2 & 3.37 & 0.13 & 4.37 & 0.28 & 39.7 & 0.71 & 95.72 \\
\hline 503 & VEC02A074 100-105 & 11.95 & 4.38 & 6.40 & 1.32 & 21.7 & 2.93 & 0.13 & 4.20 & 0.21 & 43.3 & 0.60 & 97.15 \\
\hline 523 & VEC02A074 120 & 12.09 & 4.40 & 6.36 & 1.41 & 23.0 & 3.28 & 0.13 & 4.40 & 0.27 & 41.3 & 0.68 & 97.45 \\
\hline 533 & VEC02A074 130-135 & 11.56 & 4.11 & 7.34 & 1.62 & 22.6 & 3.31 & 0.12 & 4.30 & 0.25 & 40.5 & 0.68 & 96.50 \\
\hline 543 & VEC02A074 140-145 & 12.59 & 4.64 & 7.11 & 1.65 & 20.7 & 3.74 & 0.14 & 4.09 & 0.34 & 41.4 & 0.77 & 97.24 \\
\hline 570 & VEC02A074/5 10-15 & 11.52 & 4.32 & 6.48 & 1.47 & 22.9 & 3.23 & 0.13 & 4.36 & 0.24 & 40.7 & 0.67 & 96.13 \\
\hline 580 & VEC02A074/5 20-25 & 12.58 & 4.49 & 7.03 & 1.63 & 19.1 & 3.55 & 0.13 & 4.46 & 0.26 & 42.8 & 0.73 & 96.86 \\
\hline 602 & VEC02A075 20-25 & 12.18 & 4.05 & 6.80 & 1.57 & 23.8 & 3.24 & 0.13 & 4.40 & 0.35 & 39.7 & 0.69 & 96.99 \\
\hline
\end{tabular}


Appendix C 10. CONTD.

\begin{tabular}{|c|c|c|c|c|c|c|c|c|c|c|c|c|c|}
\hline & Sample & $\mathrm{Al}_{2} \mathrm{O}_{3}$ & $\mathrm{CaO}$ & $\mathrm{Fe}_{2} \mathrm{O}_{3}$ & $\mathrm{~K}_{2} \mathrm{O}$ & LOI & $\mathrm{MgO}$ & $\mathrm{MnO}$ & $\mathrm{Na}_{2} \mathrm{O}$ & $\mathrm{P}_{2} \mathrm{O}_{5}$ & $\mathrm{SiO}_{2}$ & $\mathrm{TiO}_{2}$ & Total \\
\hline & Detect Limit & 0.01 & 0.01 & 0.01 & 0.01 & 0.05 & 0.01 & 0.01 & 0.01 & 0.01 & 0.01 & 0.01 & \\
\hline 622 & VEC02A075 40-45 & 12.96 & 4.59 & 7.22 & 1.57 & 18.3 & 3.39 & 0.14 & 4.08 & 0.25 & 44.1 & 0.72 & 97.42 \\
\hline 632 & VEC02A07S5 50 & 12.47 & 4.57 & 7.27 & 1.55 & ND & 3.56 & 0.12 & 3.58 & 0.29 & ND & 0.70 & ND \\
\hline 642 & VEC02A075 60-65 & 12.75 & 4.47 & 7.20 & 1.72 & 19.5 & 3.52 & 0.14 & 3.99 & 0.33 & 41.8 & 0.76 & 96.32 \\
\hline 662 & VEC02A075 80-85 & 13.14 & 4.71 & 7.09 & 1.73 & 17.6 & 3.47 & 0.14 & 4.10 & 0.27 & 44.2 & 0.75 & 97.27 \\
\hline 692 & VEC02A075 110 & 12.27 & 4.43 & 7.08 & 1.76 & 19.7 & 3.51 & 0.13 & 4.39 & 0.26 & 41.9 & 0.71 & 96.29 \\
\hline 702 & VEC02A075 120-125 & 12.36 & 4.59 & 6.07 & 1.36 & 19.4 & 3.01 & 0.13 & 4.18 & 0.22 & 44.6 & 0.61 & 96.57 \\
\hline 732 & VEC02A076 5-10 & 12.13 & 4.23 & 7.56 & 1.82 & 20.2 & 3.41 & 0.13 & 4.24 & 0.26 & 41.6 & 0.74 & 96.46 \\
\hline 747 & VEC02A076 20-25 & 13.13 & 4.75 & 7.59 & 1.74 & 17.4 & 3.71 & 0.14 & 3.94 & 0.31 & 43.5 & 0.79 & 97.08 \\
\hline 767 & VEC02A076 40-45 & 12.02 & 4.40 & 6.73 & 1.61 & 21.6 & 3.38 & 0.13 & 4.33 & 0.25 & 41.0 & 0.69 & 96.19 \\
\hline 787 & VEC02A076 60-65 & 12.17 & 4.40 & 6.81 & 1.41 & 21.3 & 3.01 & 0.13 & 3.92 & 0.23 & 42.4 & 0.65 & 96.45 \\
\hline 807 & VEC02A076 80-85 & 12.71 & 4.47 & 6.59 & 1.41 & 19.3 & 3.00 & 0.14 & 3.92 & 0.22 & 44.7 & 0.63 & 97.13 \\
\hline 817 & VEC02A07690 & 12.33 & 4.39 & 6.64 & 1.31 & 20.9 & 3.00 & 0.14 & 4.06 & 0.21 & 43.5 & 0.63 & 97.25 \\
\hline 827 & VEC02A076 100-105 & 12.45 & 4.32 & 7.12 & 1.65 & 20.6 & 3.33 & 0.13 & 4.08 & 0.27 & 42.5 & 0.73 & 97.22 \\
\hline 852 & VEC02A076 120-125 & 12.86 & 4.51 & 7.35 & 1.64 & 19.2 & 3.41 & 0.13 & 4.05 & 0.27 & 43.7 & 0.74 & 97.93 \\
\hline
\end{tabular}




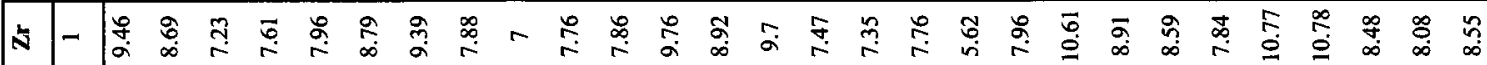

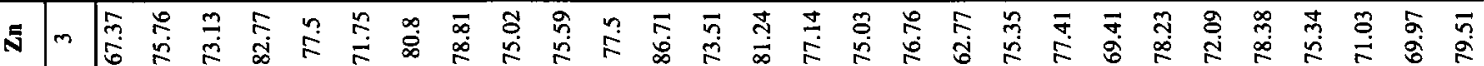

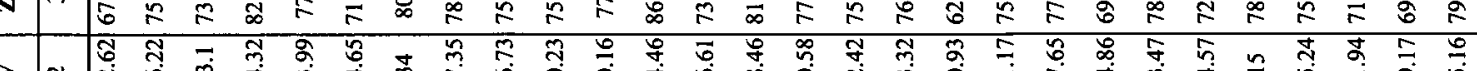
$>N \quad$ N

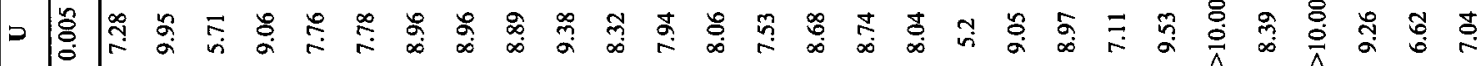
E F : E

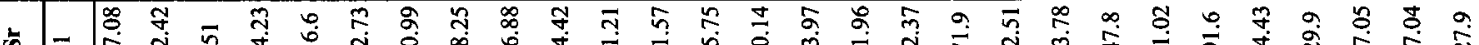

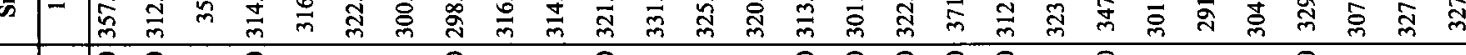

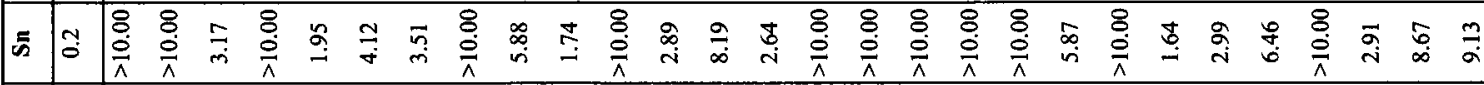

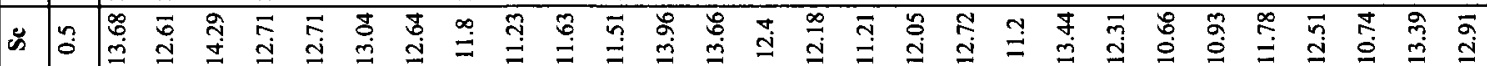
क

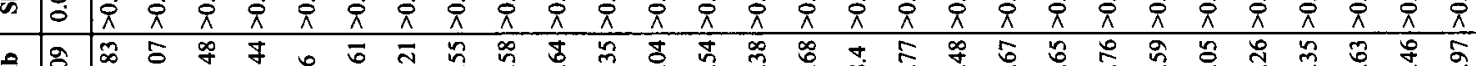

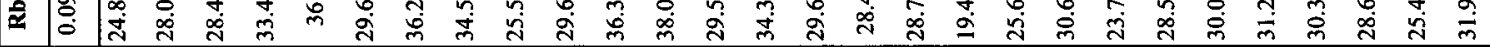
过

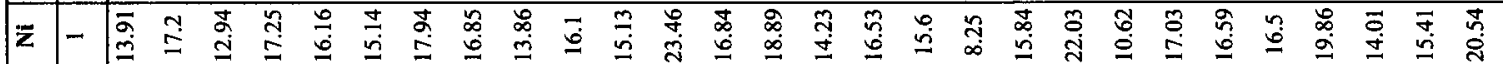

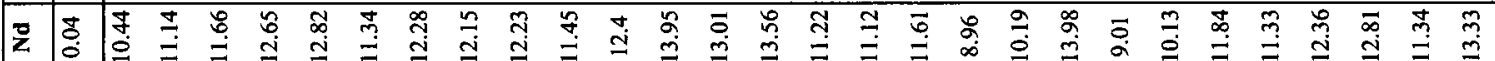
¿

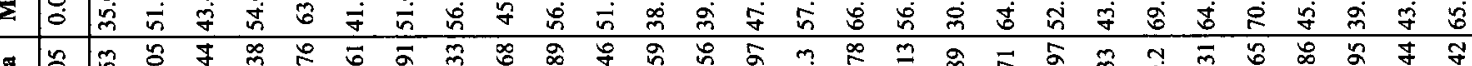
د

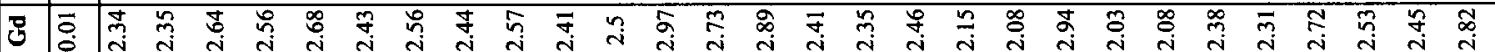
刃

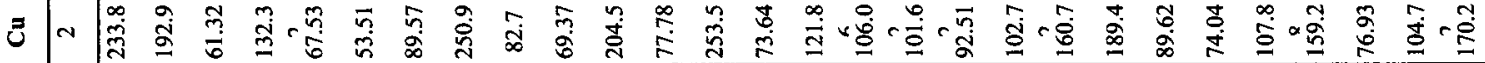
ن

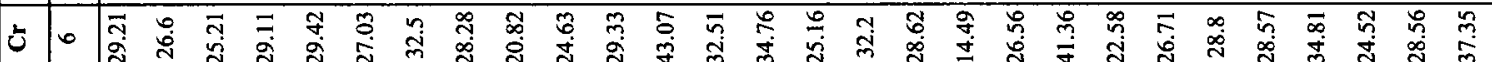

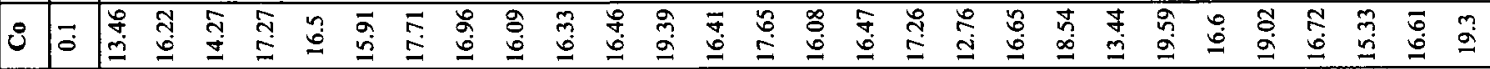

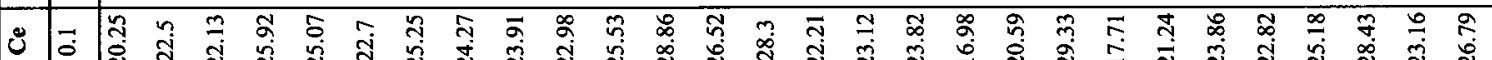

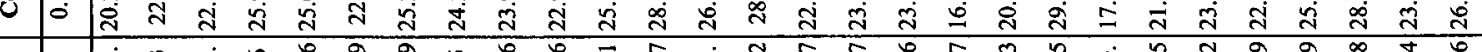

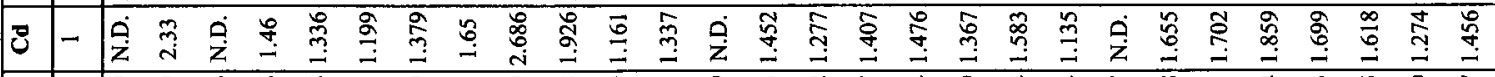

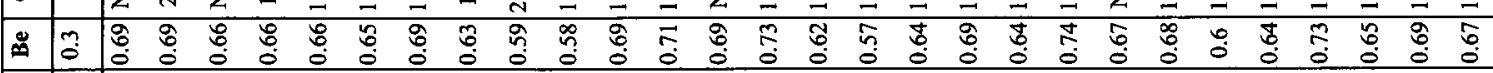

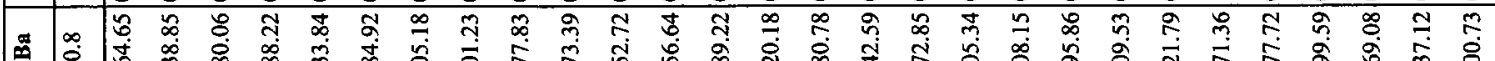

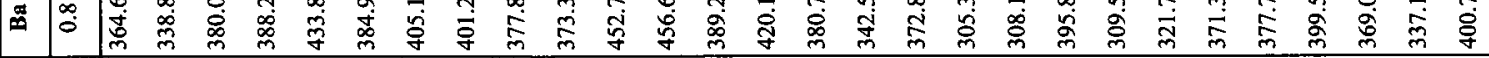
言

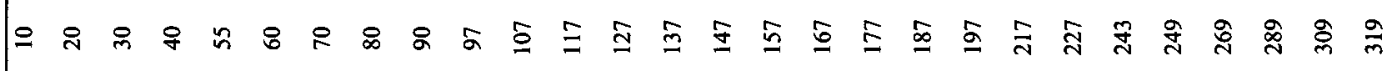

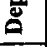

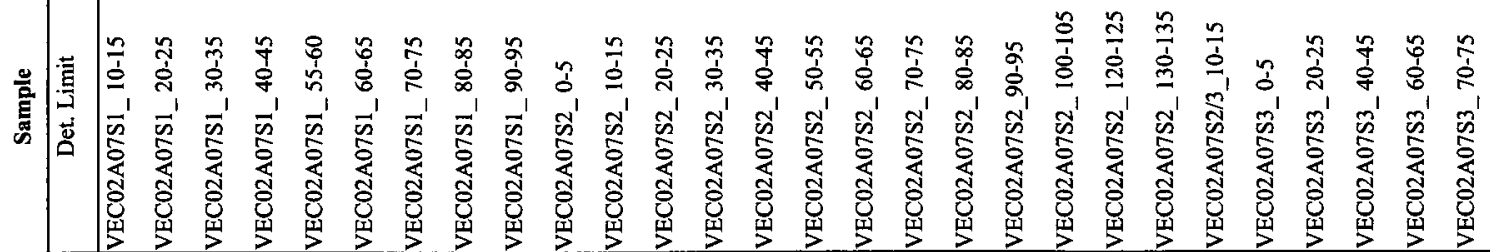




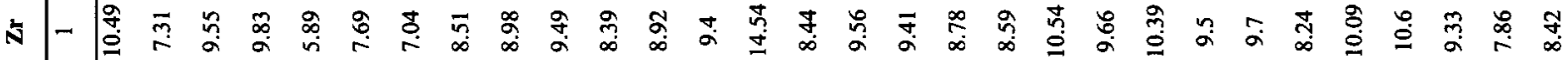

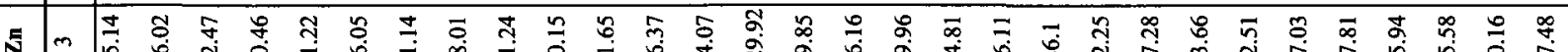

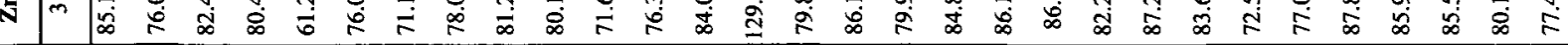

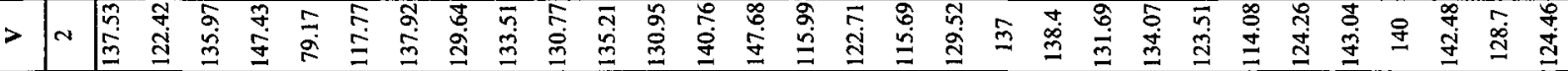

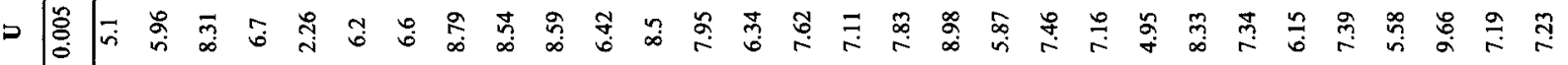

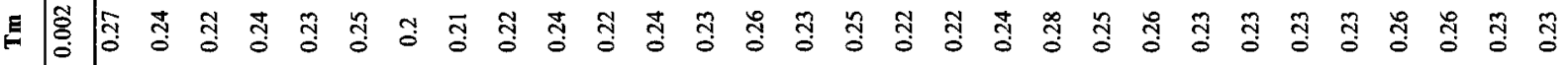

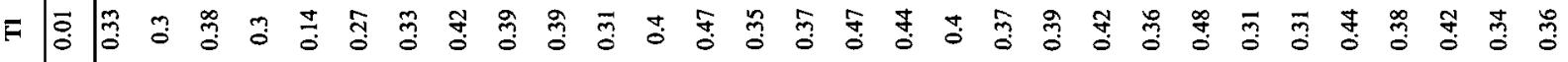
F

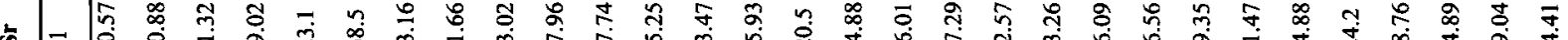

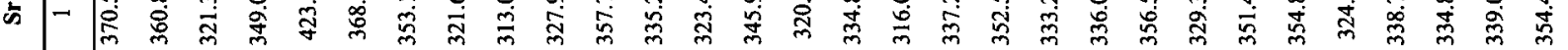

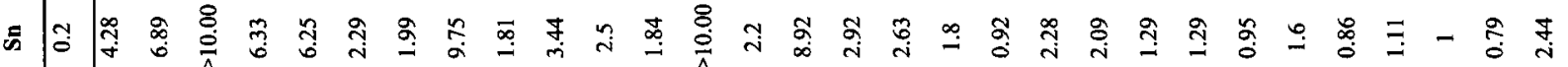

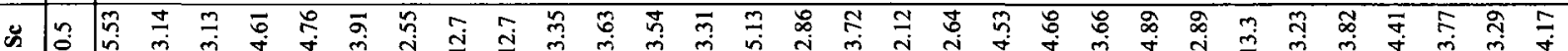
क

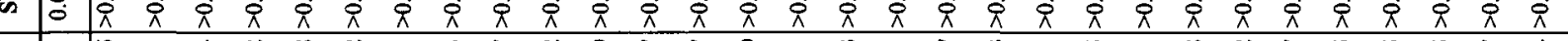

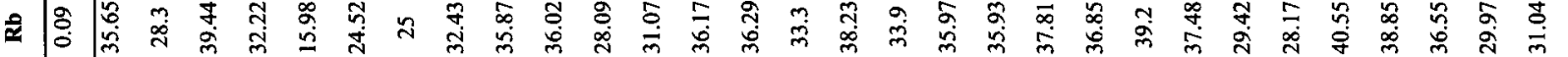
¿

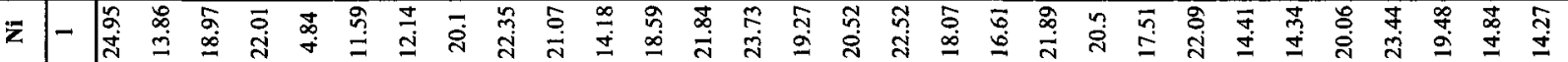

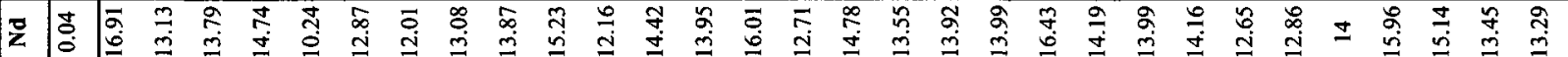

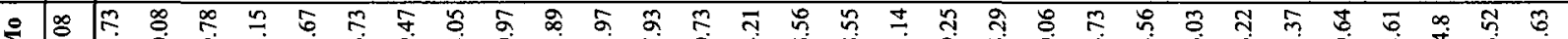

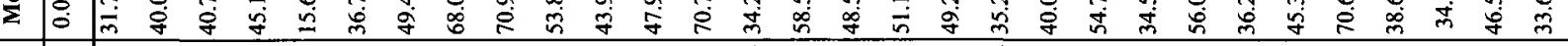
פ⿹丁口

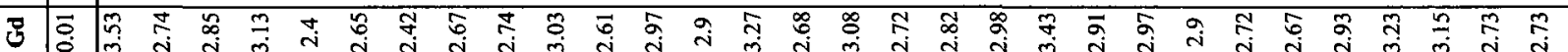

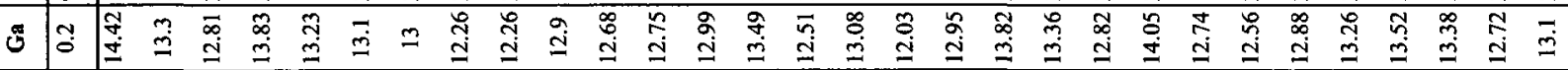

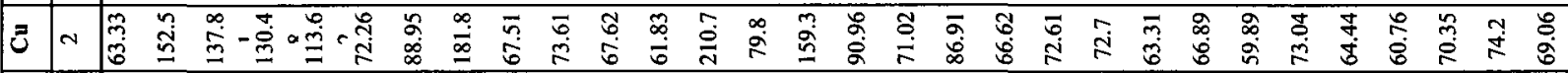
0 ¿

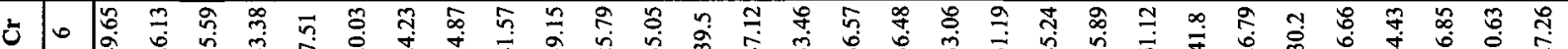

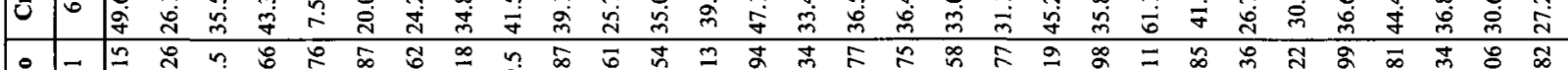

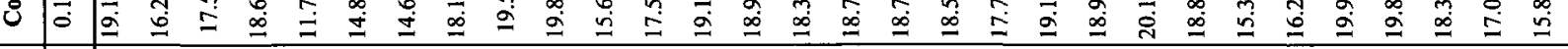

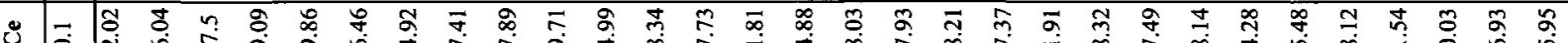

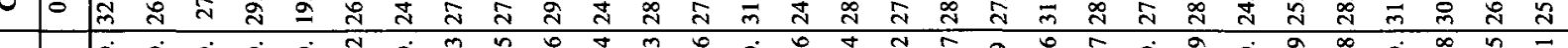

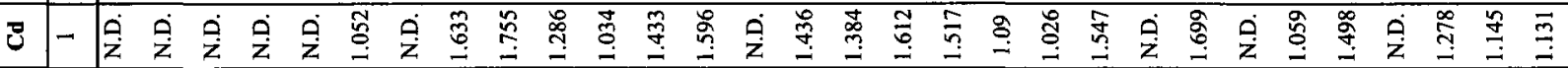

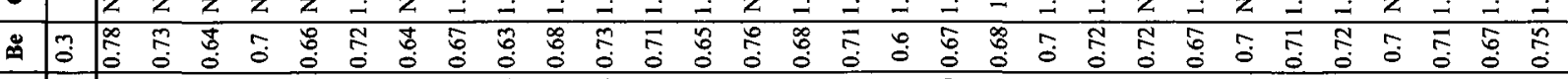

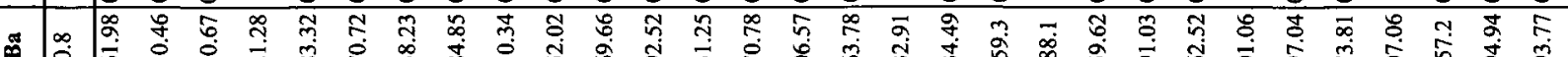

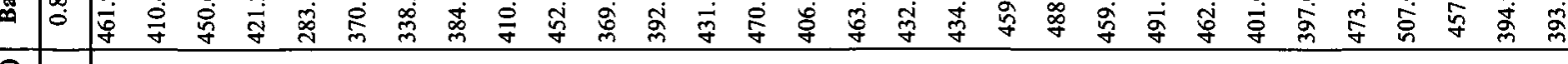

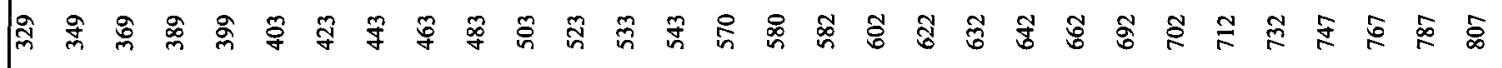

产茅

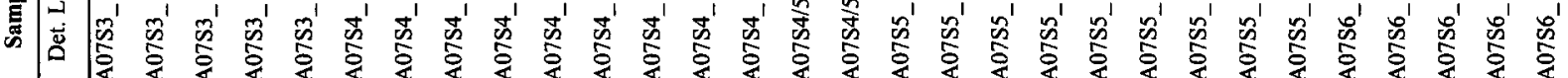

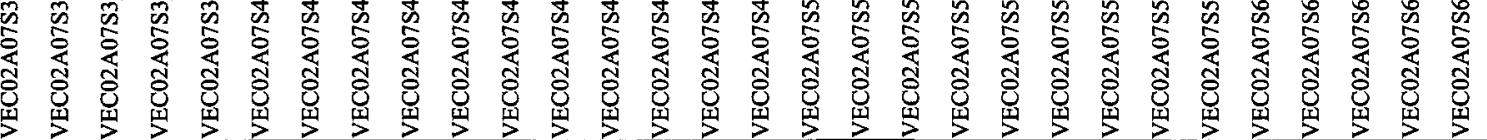




\begin{tabular}{|c|c|c|}
\hline ไ̀ & - & in $\begin{array}{lll}m & \infty \\
\sigma & 0 & 0\end{array}$ \\
\hline ง & $m$ & 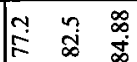 \\
\hline$>$ & $\sim$ & 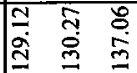 \\
\hline$p$ & 芦 & 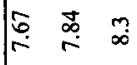 \\
\hline$E$ & §ั & đ̂̃ \\
\hline$F$ & $\overline{0}$ & है \\
\hline$E$ & $\underset{8}{0}$ & 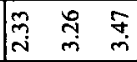 \\
\hline 市 & - & 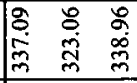 \\
\hline क & $\dddot{c}$ & $\hat{\sim}$ \\
\hline$\ddot{\infty}$ & $\because$ & 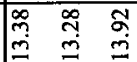 \\
\hline के & 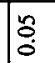 & 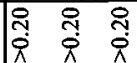 \\
\hline$\hat{x}$ & Oें & 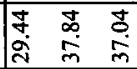 \\
\hline 2 & $\stackrel{\circ}{0}$ & 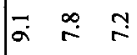 \\
\hline $\bar{z}$ & - & 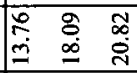 \\
\hline$z$ & 志 & 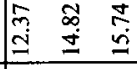 \\
\hline 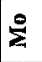 & $\underset{0}{0}$ & $\mid$\begin{tabular}{lll}
$\mathbb{C}$ \\
\hdashline
\end{tabular} \\
\hline 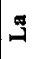 & 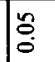 & 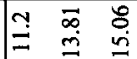 \\
\hline $\bar{\Xi}$ & $\overline{0}$ & 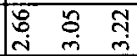 \\
\hline हु & ช & 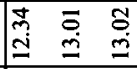 \\
\hline u & n & 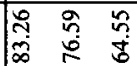 \\
\hline$\theta$ & 立 & 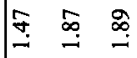 \\
\hline E & 0 & 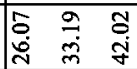 \\
\hline 8 & $\overline{0}$ & 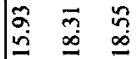 \\
\hline ت̃ & $\overline{0}$ & $\begin{array}{lll}\vec{\infty} & \bar{m} & \bar{n} \\
\tilde{n} & \bar{\alpha} & \bar{m}\end{array}$ \\
\hline$\pi$ & - & 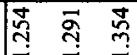 \\
\hline$\dddot{m}$ & $\stackrel{9}{0}$ & $\begin{array}{lll}0 & \overrightarrow{1} & 0 \\
0 & 0 & 0 \\
0\end{array}$ \\
\hline$\ddot{m}$ & $\stackrel{\infty}{\circ}$ & 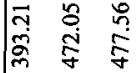 \\
\hline 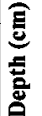 & & $\bar{\infty} \bar{\infty}$ \\
\hline$\infty$ & 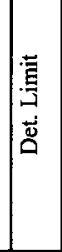 & 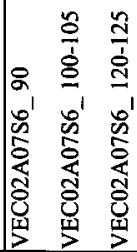 \\
\hline
\end{tabular}


Appendix C 12. Distribution of paleoredox indices in the Alison Sound core.

\begin{tabular}{|c|c|c|c|c|c|c|c|c|c|}
\hline Sample & Depth (cm) & $\mathrm{Ni} / \mathrm{Co}$ & $\mathbf{V} / \mathbf{C r}$ & $\mathbf{V} / \mathbf{S c}$ & $\mathbf{V} /(\mathbf{V}+\mathbf{N i})$ & $(\mathrm{Cu}+\mathrm{Mo}) / \mathrm{Zn}$ & $\mathbf{U} / \mathbf{T h}$ & $\mathbf{U}_{\text {suth }}$ & $\mathbf{T h} / \mathbf{U}$ \\
\hline VEC02A07S1_10-15 & 10 & 1.03 & 4.54 & 9.69 & 0.91 & 3.99 & 3.77 & 6.64 & 0.27 \\
\hline VEC02A07S1_20-25 & 20 & 1.06 & 4.75 & 10.01 & 0.88 & 3.23 & 4.76 & 9.25 & 0.21 \\
\hline VEC02A07S1_30-35 & 30 & 0.91 & 4.88 & 8.61 & 0.90 & 1.43 & 2.52 & 4.95 & 0.40 \\
\hline VEC02A07S1_40-45 & 40 & 1.00 & 4.61 & 10.57 & 0.89 & 2.25 & 3.47 & 8.19 & 0.29 \\
\hline VEC02A07S1_55-60 & 55 & 0.98 & 4.21 & 9.76 & 0.88 & 1.69 & 2.71 & 6.81 & 0.37 \\
\hline VEC02A07S1_60-65 & 60 & 0.95 & 4.98 & 10.33 & 0.90 & 1.33 & 2.68 & 6.81 & 0.37 \\
\hline VEC02A07S1_70-75 & 70 & 1.01 & 4.12 & 10.60 & 0.88 & 1.74 & 3.27 & 8.05 & 0.31 \\
\hline VEC02A07S1_80-85 & 80 & 0.99 & 4.50 & 10.79 & 0.88 & 3.90 & 3.31 & 8.06 & 0.30 \\
\hline VEC02A07S1_90-95 & 90 & 0.86 & 5.13 & 9.50 & 0.89 & 1.70 & 3.24 & 7.98 & 0.31 \\
\hline VEC02A07S2_0-5 & 97 & 0.99 & 4.88 & 10.34 & 0.88 & 1.67 & 4.03 & 8.60 & 0.25 \\
\hline VEC02A07S2_10-15 & 107 & 0.92 & 4.44 & 11.31 & 0.90 & 3.30 & 2.68 & 7.28 & 0.37 \\
\hline VEC02A07S2_20-25 & 117 & 1.21 & 3.35 & 10.35 & 0.86 & 1.34 & 2.47 & 6.87 & 0.41 \\
\hline VEC02A07S2_30-35 & 127 & 1.03 & 3.89 & 9.27 & 0.88 & 3.99 & 3.03 & 7.17 & 0.33 \\
\hline VEC02A07S2_40-45 & 137 & 1.07 & 3.70 & 10.36 & 0.87 & 1.49 & 2.21 & 6.40 & 0.45 \\
\hline VEC02A07S2_50-55 & 147 & 0.88 & 4.79 & 9.90 & 0.89 & 2.33 & 3.89 & 7.94 & 0.26 \\
\hline VEC02A07S2_60-65 & 157 & 1.00 & 4.11 & 11.81 & 0.89 & 2.29 & 3.50 & 7.91 & 0.29 \\
\hline VEC02A07S2_70-75 & 167 & 0.90 & 4.31 & 10.23 & 0.89 & 2.06 & 3.45 & 7.26 & 0.29 \\
\hline VEC02A07S2_80-85 & 177 & 0.65 & 6.97 & 7.93 & 0.92 & 1.95 & 4.16 & 4.78 & 0.24 \\
\hline VEC02A07S2_90-95 & 187 & 0.95 & 4.56 & 10.82 & 0.88 & 2.22 & 4.39 & 8.36 & 0.23 \\
\hline VEC02A07S2_100-105 & 197 & 1.19 & 3.33 & 10.24 & 0.86 & 2.75 & 2.79 & 7.90 & 0.36 \\
\hline $\mathrm{VEC} 02 \mathrm{~A} 07 \mathrm{~S} 2 \_120-125$ & 217 & 0.79 & 5.97 & 10.96 & 0.93 & 3.36 & 4.06 & 6.53 & 0.25 \\
\hline VEC02A07S2_130-135 & 227 & 0.87 & 4.25 & 10.64 & 0.87 & 2.03 & 4.65 & 8.85 & 0.22 \\
\hline VEC02A07S2/3_10-15 & 243 & 1.00 & 4.67 & 12.31 & 0.89 & 1.93 & 3.82 & 9.13 & 0.26 \\
\hline VEC02A07S3_0-5 & 249 & 0.87 & 4.03 & 9.76 & 0.87 & 2.27 & 3.65 & 7.62 & 0.27 \\
\hline VEC02A07S3_20-25 & 269 & 1.19 & 3.89 & 10.81 & 0.87 & 2.72 & 3.70 & 9.10 & 0.27 \\
\hline VEC02A07S3_40-45 & 289 & 0.91 & 4.97 & 11.35 & 0.90 & 1.64 & 2.77 & 8.15 & 0.36 \\
\hline VEC02A07S3_60-65 & 309 & 0.93 & 4.17 & 8.90 & 0.89 & 2.12 & 2.63 & 5.78 & 0.38 \\
\hline VEC02A07S3_70-75 & 319 & 1.06 & 3.62 & 10.47 & 0.87 & 2.97 & 2.44 & 6.08 & 0.41 \\
\hline VEC02A07S3_80-85 & 329 & 1.30 & 2.77 & 8.86 & 0.85 & 1.12 & 1.51 & 3.98 & 0.66 \\
\hline VEC02A07S3_100-105 & 349 & 0.85 & 4.69 & 9.32 & 0.90 & 2.53 & 2.30 & 5.10 & 0.43 \\
\hline VEC02A07S3_120-125 & 369 & 1.08 & 3.82 & 10.36 & 0.88 & 2.17 & 2.63 & 7.26 & 0.38 \\
\hline VEC02A07S3_140-145 & 389 & 1.18 & 3.40 & 10.09 & 0.87 & 2.18 & 2.14 & 5.66 & 0.47 \\
\hline VEC02A07S3_150-155 & 399 & 0.41 & 10.54 & 5.36 & 0.94 & 2.11 & 2.35 & 1.94 & 0.42 \\
\hline VEC02A07S4_0-5 & 403 & 0.78 & 5.88 & 8.47 & 0.91 & 1.43 & 3.02 & 5.52 & 0.33 \\
\hline VEC02A07S4_20-25 & 423 & 0.83 & 5.69 & 10.99 & 0.92 & 1.95 & 3.20 & 5.91 & 0.31 \\
\hline VEC02A07S4_40-45 & 443 & 1.11 & 3.72 & 10.21 & 0.87 & 3.20 & 2.92 & 7.79 & 0.34 \\
\hline VEC02A07S4_60-65 & 463 & 1.15 & 3.21 & 10.51 & 0.86 & 1.70 & 2.74 & 7.50 & 0.37 \\
\hline VEC02A07S4_80-85 & 483 & 1.06 & 3.34 & 9.80 & 0.86 & 1.59 & 2.49 & 7.44 & 0.40 \\
\hline VEC02A07S4_100-105 & 503 & 0.91 & 5.24 & 9.92 & 0.91 & 1.56 & 2.60 & 5.60 & 0.38 \\
\hline VEC02A07S4_120 & 523 & 1.06 & 3.74 & 9.67 & 0.88 & 1.44 & 2.87 & 7.51 & 0.35 \\
\hline
\end{tabular}


Appendix C 12. CONTD.

\begin{tabular}{|c|c|c|c|c|c|c|c|c|c|}
\hline Sample & Depth (cm) & $\mathrm{Ni} / \mathrm{Co}$ & $\mathrm{V} / \mathrm{Cr}$ & $\mathbf{V} / \mathbf{S c}$ & $\mathrm{V} /(\mathbf{V}+\mathbf{N i})$ & $(\mathrm{Cu}+\mathrm{Mo}) / \mathrm{Zn}$ & $\mathbf{U} / \mathbf{T h}$ & $\mathbf{U}_{\text {guth }}$ & $\mathbf{T h} / \mathbf{U}$ \\
\hline VEC02A07S4_130-135 & 533 & 1.14 & 3.56 & 10.58 & 0.87 & 3.35 & 2.53 & 6.90 & 0.39 \\
\hline VEC02A07S4_140-145 & 543 & 1.25 & 3.13 & 9.76 & 0.86 & 0.88 & 1.85 & 5.20 & 0.54 \\
\hline VEC02A07S4/5_10-15 & 570 & 1.05 & 3.47 & 9.02 & 0.86 & 2.73 & 2.67 & 6.67 & 0.37 \\
\hline VEC02A07S4/5_20-25 & 580 & 1.09 & 3.36 & 8.94 & 0.86 & 1.62 & 2.29 & 6.07 & 0.44 \\
\hline VEC02A07S5_0-5 & 582 & 1.20 & 3.17 & 9.55 & 0.84 & 1.53 & 2.40 & 6.74 & 0.42 \\
\hline VEC02A07S5_20-25 & 602 & 0.97 & 3.92 & 10.25 & 0.88 & 1.61 & 2.93 & 7.96 & 0.34 \\
\hline VEC02A07S5_40-45 & 622 & 0.93 & 4.39 & 9.43 & 0.89 & 1.18 & 2.02 & 4.90 & 0.50 \\
\hline VEC02A07S5_50 & 632 & 1.14 & 3.06 & 9.44 & 0.86 & 1.31 & 2.01 & 6.22 & 0.50 \\
\hline VEC02A07S5_60-65 & 642 & 1.08 & 3.67 & 9.64 & 0.87 & 1.55 & 2.29 & 6.12 & 0.44 \\
\hline VEC02A07S5_80-85 & 662 & 0.87 & 2.19 & 9.00 & 0.88 & 1.12 & 1.81 & 4.04 & 0.55 \\
\hline VEC02A07S5_110 & 692 & 1.17 & 2.95 & 9.58 & 0.85 & 1.47 & 2.57 & 7.25 & 0.39 \\
\hline VEC02A07S5_120-125 & 702 & 0.94 & 4.26 & 8.58 & 0.89 & 1.33 & 2.80 & 6.47 & 0.36 \\
\hline VEC02A07S5_130-135 & 712 & 0.88 & 4.11 & 9.39 & 0.90 & 1.54 & 2.56 & 5.35 & 0.39 \\
\hline VEC02A07S6_5-10 & 732 & 1.00 & 3.90 & 10.35 & 0.88 & 1.54 & 2.26 & 6.30 & 0.44 \\
\hline VEC02A07S6_20-25 & 747 & 1.18 & 3.15 & 9.72 & 0.86 & 1.16 & 1.62 & 4.43 & 0.62 \\
\hline VEC02A07S6_40-45 & 767 & 1.06 & 3.87 & 10.35 & 0.88 & 1.23 & 2.91 & 8.55 & 0.34 \\
\hline VEC02A07S6_60-65 & 787 & 0.87 & 4.20 & 9.68 & 0.90 & 1.51 & 2.70 & 6.30 & 0.37 \\
\hline VEC02A07S6_80-85 & 807 & 0.90 & 4.57 & 8.78 & 0.90 & 1.33 & 2.88 & 6.39 & 0.35 \\
\hline VEC02A07S6_90 & 817 & 0.86 & 4.95 & 9.65 & 0.90 & 1.66 & 3.29 & 6.89 & 0.30 \\
\hline VEC02A07S6_100-105 & 827 & 0.99 & 3.92 & 9.81 & 0.88 & 1.49 & 2.40 & 6.75 & 0.42 \\
\hline VEC02A07S6_120-125 & 852 & 1.12 & 3.26 & 9.85 & 0.87 & 1.32 & 2.39 & 7.14 & 0.42 \\
\hline
\end{tabular}




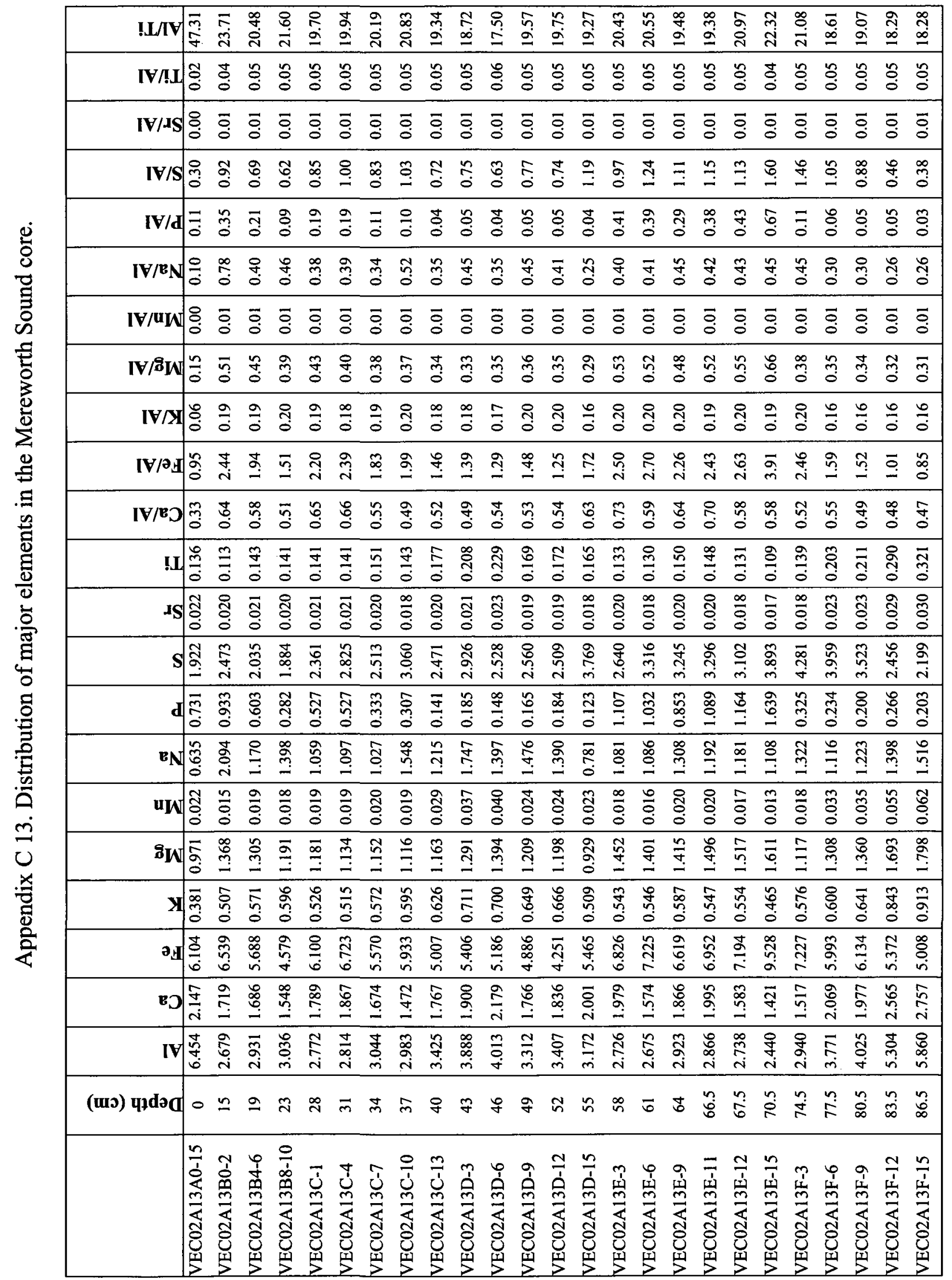




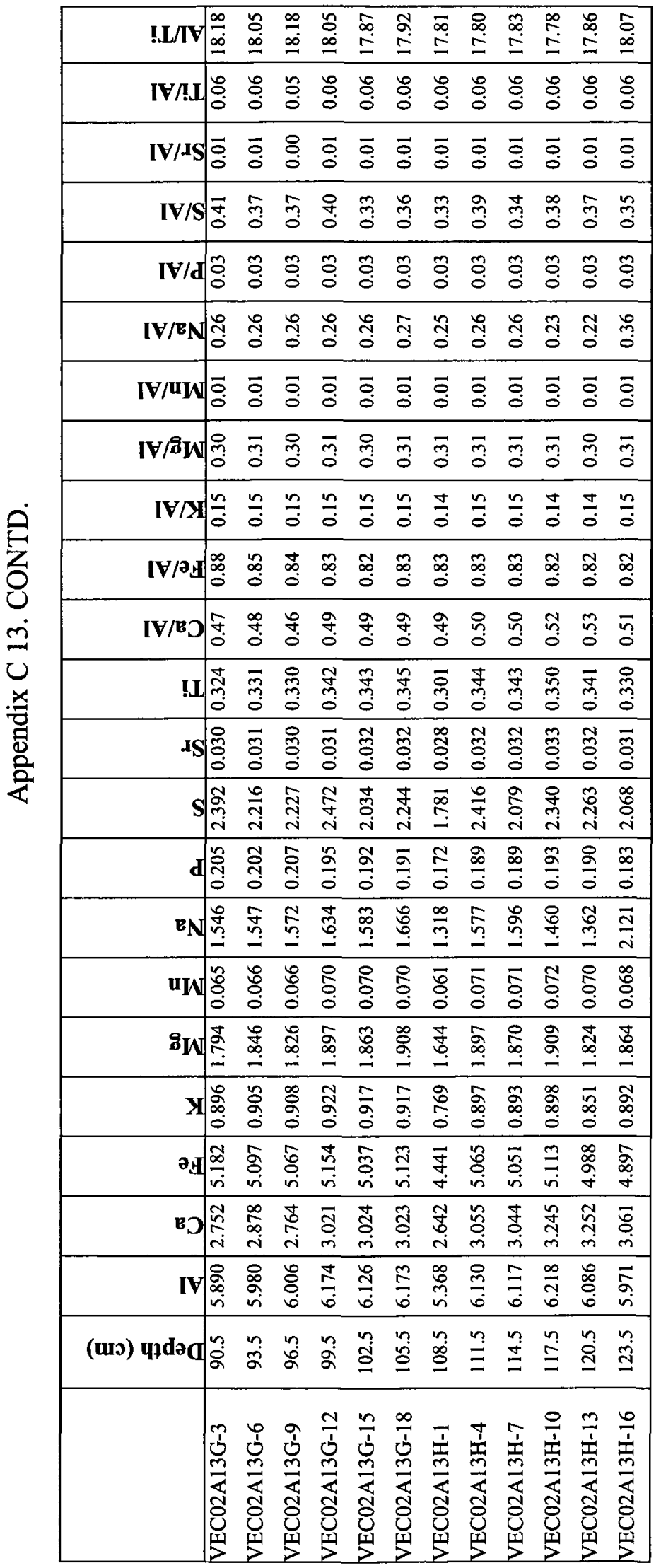


Appendix C 14. Distribution of oxides of major elements in the Mereworth Sound core.

\begin{tabular}{|c|c|c|c|c|c|c|c|c|c|c|c|}
\hline 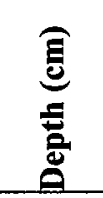 & 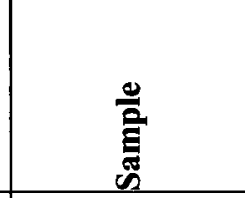 & 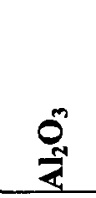 & 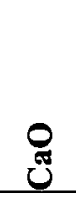 & : & $\stackrel{0}{i}$ & $\sum^{\infty}$ & $\stackrel{0}{E}$ & $\begin{array}{l}0 \\
\text { Z्ञ } \\
\end{array}$ & $\overbrace{\tilde{N}}^{n}$ & $\stackrel{0}{0}$ & $\frac{0}{0}$ \\
\hline 0 & VEC02A13A0-15 & 12.20 & 1.53 & 4.74 & 0.32 & 0.59 & 0.02 & 0.50 & 0.39 & 0.08 & 0.39 \\
\hline 15 & VEC02A13B0-2 & 5.06 & 1.23 & 5.08 & 0.42 & 0.82 & 0.01 & 1.66 & 0.50 & 0.07 & 1.00 \\
\hline 19 & VEC02A13B4-6 & 5.54 & 1.20 & 4.42 & 0.47 & 0.79 & 0.02 & 0.93 & 0.32 & 0.09 & 0.80 \\
\hline 23 & VEC02A13B8-10 & 5.74 & 1.11 & 3.56 & 0.49 & 0.72 & 0.01 & 1.11 & 0.15 & 0.08 & 0.62 \\
\hline 28 & VEC02A13C-1 & 5.24 & 1.28 & 4.74 & 0.44 & 0.71 & 0.01 & 0.84 & 0.28 & 0.08 & 0.91 \\
\hline 31 & VEC02A13C-4 & 5.32 & 1.33 & 5.23 & 0.43 & 0.68 & 0.01 & 0.87 & 0.28 & 0.08 & 0.98 \\
\hline 34 & VEC02A13C-7 & 5.75 & 1.20 & 4.33 & 0.47 & 0.70 & 0.02 & 0.81 & 0.18 & 0.09 & 0.75 \\
\hline 37 & VEC02A13C-10 & 5.64 & 1.05 & 4.61 & 0.49 & 0.67 & 0.02 & 1.23 & 0.16 & 0.09 & 0.82 \\
\hline 40 & VEC02A13C-13 & 6.47 & 1.26 & 3.89 & 0.52 & 0.70 & 0.02 & 0.96 & 0.08 & 0.11 & 0.60 \\
\hline 43 & VEC02A13D-3 & 7.35 & 1.36 & 4.20 & 0.59 & 0.78 & 0.03 & 1.38 & 0.10 & 0.12 & 0.57 \\
\hline 46 & VEC02A13D-6 & 7.58 & 1.56 & 4.03 & 0.58 & 0.84 & 0.03 & 1.11 & 0.08 & 0.14 & 0.53 \\
\hline 49 & VEC02A13D-9 & 6.26 & 1.26 & 3.80 & 0.54 & 0.73 & 0.02 & 1.17 & 0.09 & 0.10 & 0.61 \\
\hline 52 & VEC02A13D-12 & 6.44 & 1.31 & 3.30 & 0.55 & 0.72 & 0.02 & 1.10 & 0.10 & 0.10 & 0.51 \\
\hline 55 & VEC02A13D-15 & 5.99 & 1.43 & 4.25 & 0.42 & 0.56 & 0.02 & 0.62 & 0.07 & 0.10 & 0.71 \\
\hline 58 & VEC02A13E-3 & 5.15 & 1.41 & 5.31 & 0.45 & 0.88 & 0.01 & 0.86 & 0.59 & 0.08 & 1.03 \\
\hline 61 & VEC02A13E-6 & 5.06 & 1.13 & 5.62 & 0.45 & 0.85 & 0.01 & 0.86 & 0.55 & 0.08 & 1.11 \\
\hline 64 & VEC02A13E-9 & 5.52 & 1.33 & 5.14 & 0.49 & 0.85 & 0.02 & 1.04 & 0.46 & 0.09 & 0.93 \\
\hline 66.5 & VEC02A13E-11 & 5.42 & 1.43 & 5.40 & 0.45 & 0.90 & 0.02 & 0.94 & 0.58 & 0.09 & 1.00 \\
\hline 67.5 & VEC02A13E-12 & 5.18 & 1.13 & 5.59 & 0.46 & 0.92 & 0.01 & 0.93 & 0.62 & 0.08 & 1.08 \\
\hline 70.5 & VEC02A13E-15 & 4.61 & 1.02 & 7.41 & 0.39 & 0.97 & 0.01 & 0.88 & 0.88 & 0.07 & 1.61 \\
\hline 74.5 & VEC02A13F-3 & 5.56 & 1.08 & 5.62 & 0.48 & 0.67 & 0.01 & 1.05 & 0.17 & 0.08 & 1.01 \\
\hline 77.5 & VEC02A13F-6 & 7.13 & 1.48 & 4.66 & 0.50 & 0.79 & 0.03 & 0.88 & 0.13 & 0.12 & 0.65 \\
\hline 80.5 & VEC02A13F-9 & 7.61 & 1.41 & 4.77 & 0.53 & 0.82 & 0.03 & 0.97 & 0.11 & 0.13 & 0.63 \\
\hline 83.5 & VEC02A13F-12 & 10.02 & 1.83 & 4.18 & 0.70 & 1.02 & 0.04 & 1.11 & 0.14 & 0.17 & 0.42 \\
\hline 86.5 & VEC02A13F-15 & 11.08 & 1.97 & 3.89 & 0.76 & 1.08 & 0.05 & 1.20 & 0.11 & 0.19 & 0.35 \\
\hline 90.500 & VEC02A13G-3 & 11.13 & 1.97 & 4.03 & 0.74 & 1.08 & 0.05 & 1.22 & 0.11 & 0.19 & 0.36 \\
\hline 93.5 & VEC02A13G-6 & 11.30 & 2.06 & 3.96 & 0.75 & 1.11 & 0.05 & 1.22 & 0.11 & 0.20 & 0.35 \\
\hline 96.5 & VEC02A13G-9 & 11.35 & 1.98 & 3.94 & 0.75 & 1.10 & 0.05 & 1.25 & 0.11 & 0.20 & 0.35 \\
\hline 99.5 & VEC02A13G-12 & 11.67 & 2.16 & 4.01 & 0.77 & 1.14 & 0.05 & 1.29 & 0.10 & 0.21 & 0.34 \\
\hline 102.5 & VEC02A13G-15 & 11.58 & 2.16 & 3.92 & 0.76 & 1.12 & 0.05 & 1.25 & 0.10 & 0.21 & 0.34 \\
\hline 105.5 & VEC02A13G-18 & 11.67 & 2.16 & 3.98 & 0.76 & 1.15 & 0.05 & 1.32 & 0.10 & 0.21 & 0.34 \\
\hline 108.5 & VEC02A13H-1 & 10.15 & 1.89 & 3.45 & 0.64 & 0.99 & 0.05 & 1.04 & 0.09 & 0.18 & 0.34 \\
\hline 111.5 & VEC02A13H-4 & 11.59 & 2.18 & 3.94 & 0.75 & 1.14 & 0.05 & 1.25 & 0.10 & 0.21 & 0.34 \\
\hline 114.5 & VEC02A13H-7 & 11.56 & 2.18 & 3.93 & 0.74 & 1.13 & 0.05 & 1.26 & 0.10 & 0.21 & 0.34 \\
\hline 117.5 & VEC02A13H-10 & 11.75 & 2.32 & 3.97 & 0.75 & 1.15 & 0.06 & 1.16 & 0.10 & 0.21 & 0.34 \\
\hline 120.5 & VEC02A13H-13 & 11.50 & 2.32 & 3.88 & 0.71 & 1.10 & 0.05 & 1.08 & 0.10 & 0.20 & 0.34 \\
\hline 123.5 & VEC02A13H-16 & 11.28 & 2.19 & 3.81 & 0.74 & 1.12 & 0.05 & 1.68 & 0.10 & 0.20 & 0.34 \\
\hline
\end{tabular}


巾

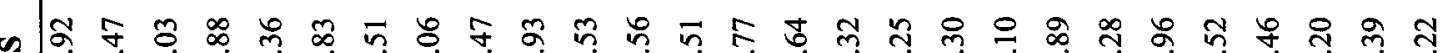

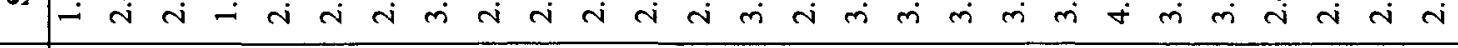

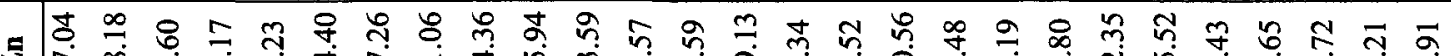

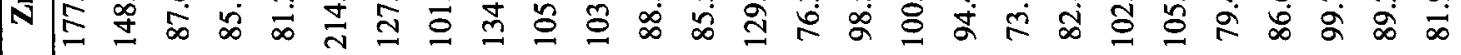

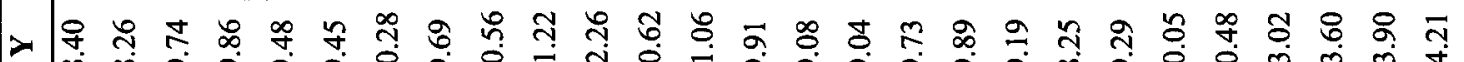
๓

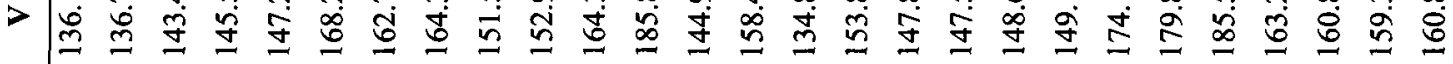

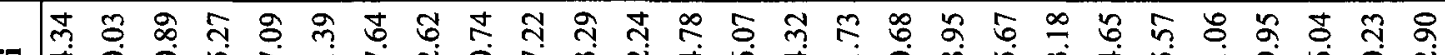

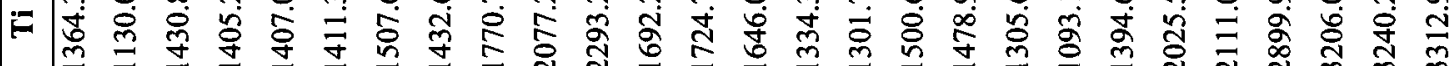

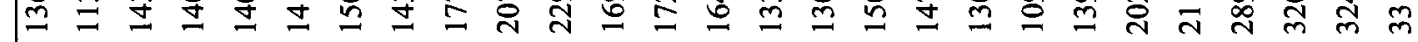

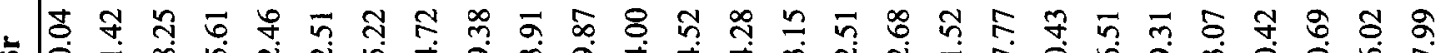

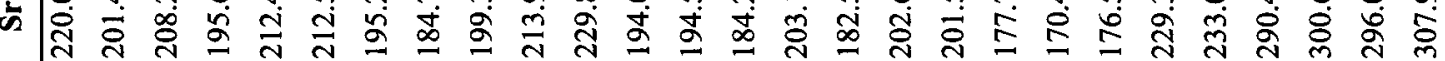
ஜ

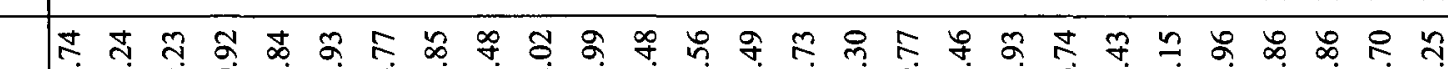

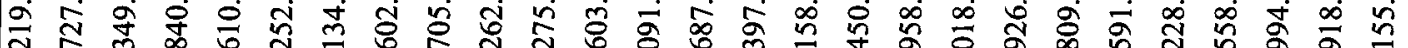

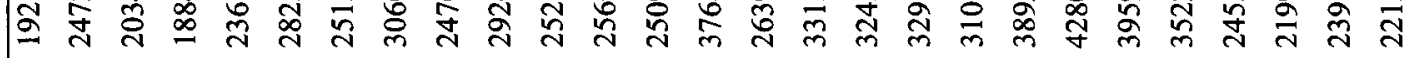
$\bar{z}$ โ र

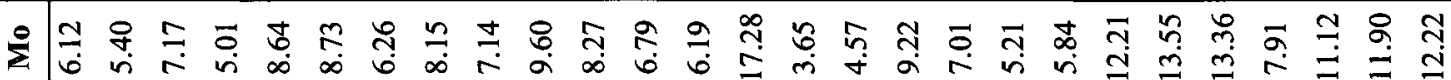
ᄀ

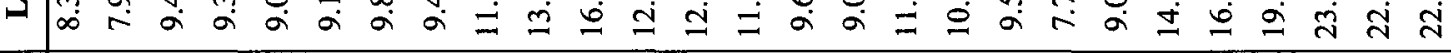

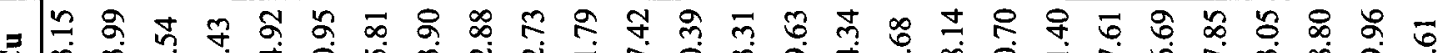

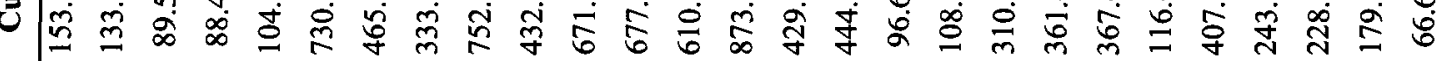
낭

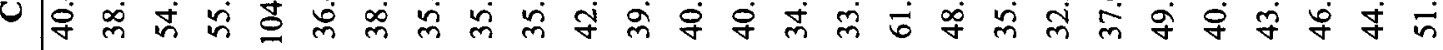
ช ఫิ

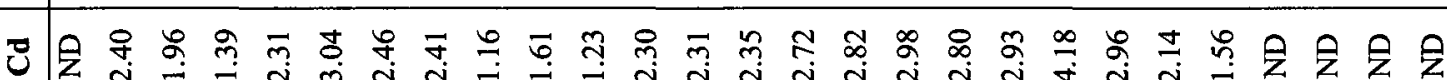
J ఫ f

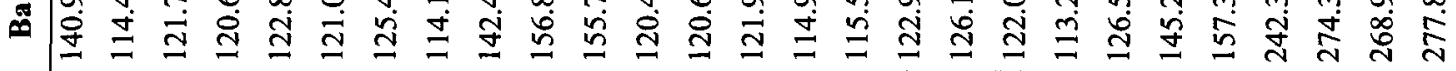
产

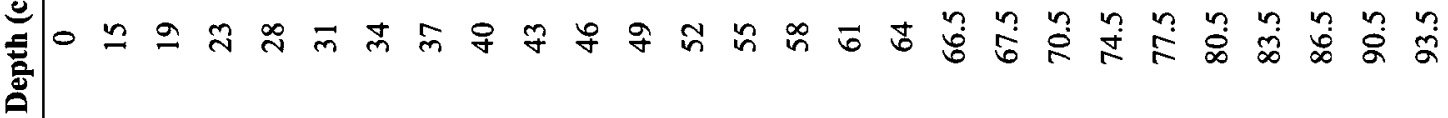

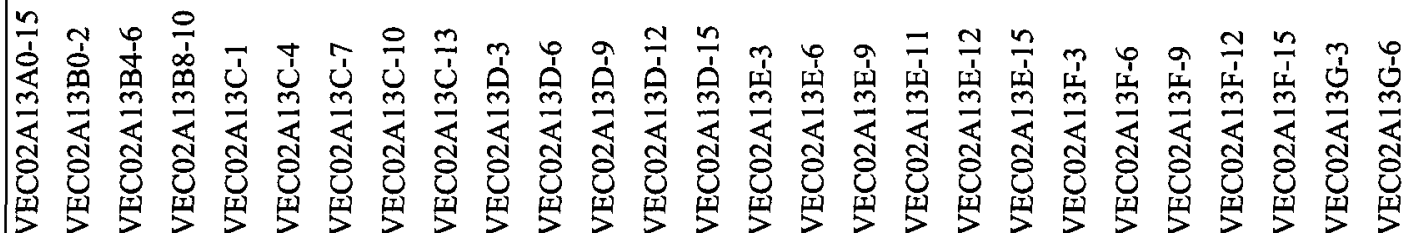




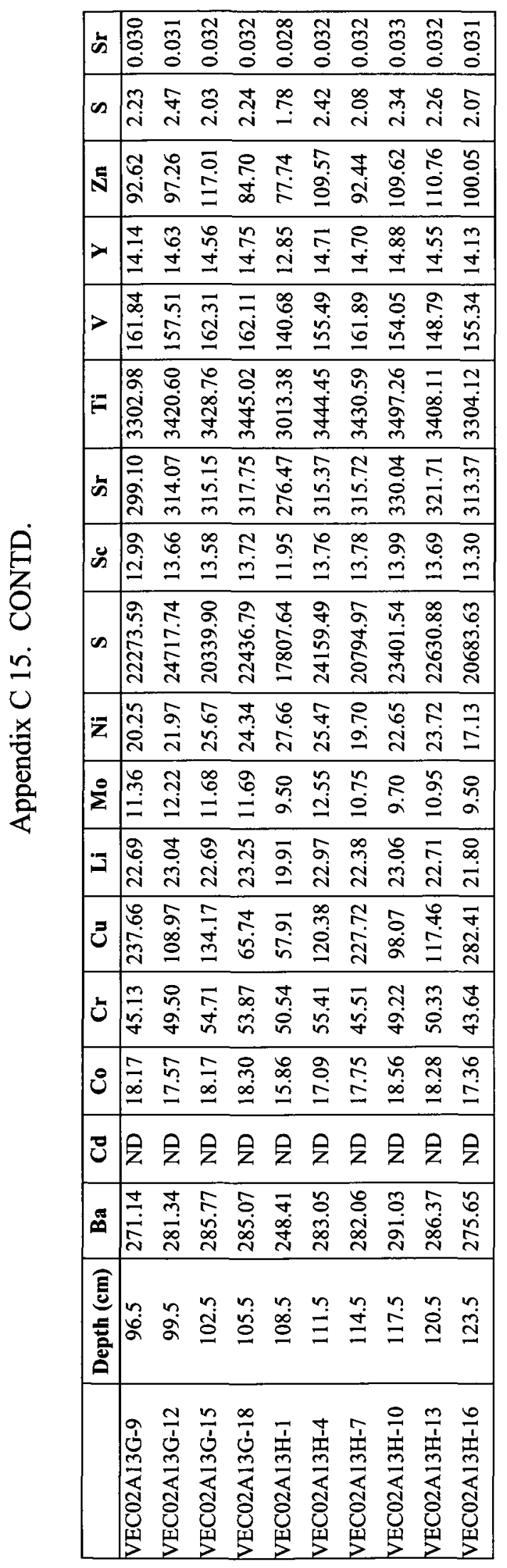




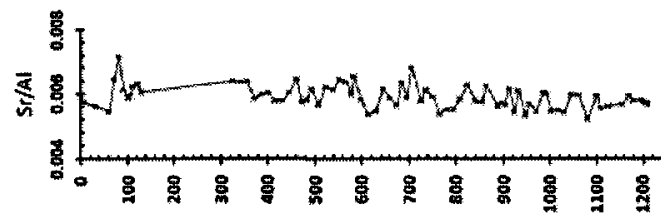

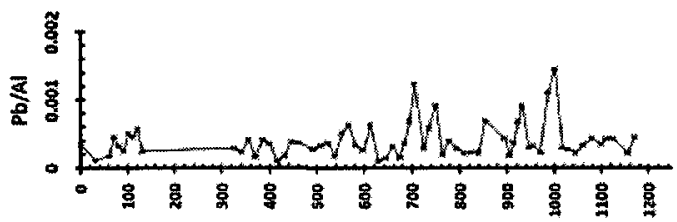

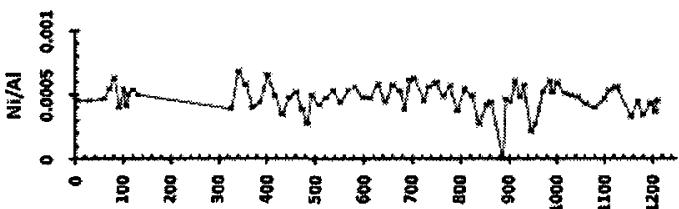

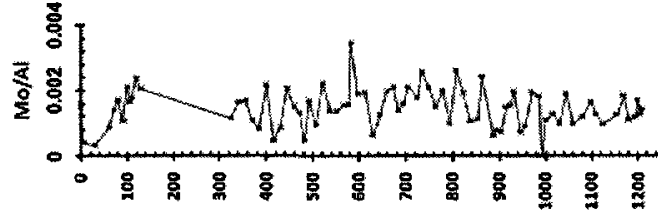

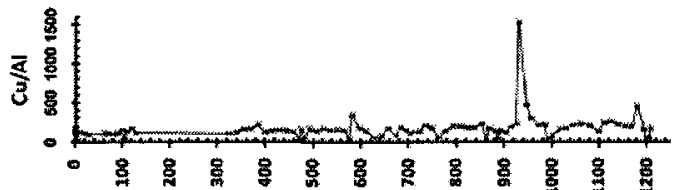

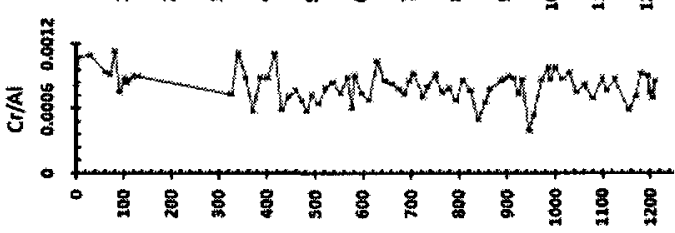

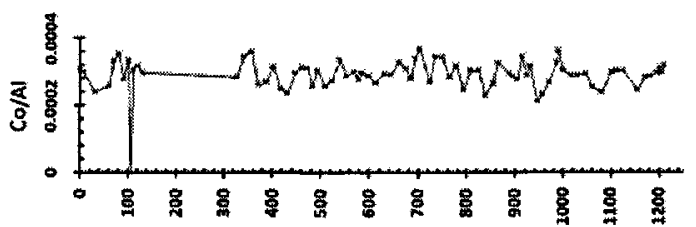

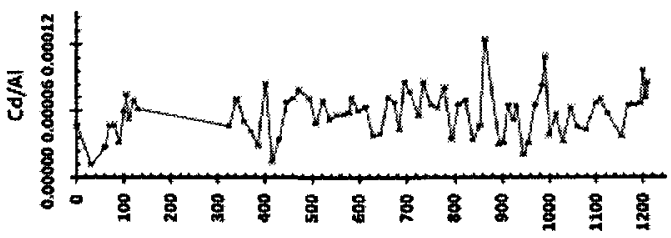

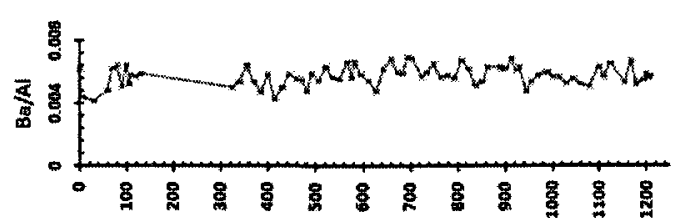

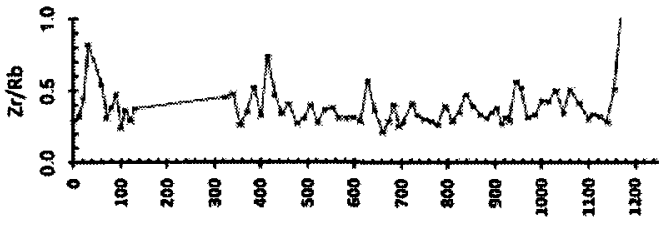

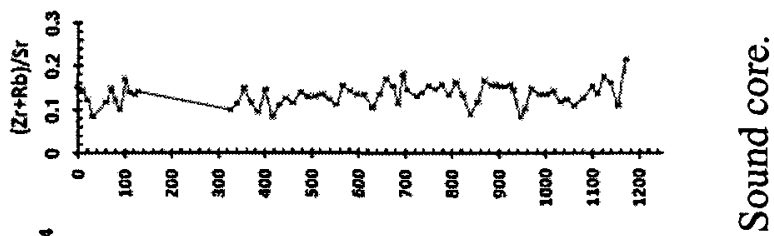

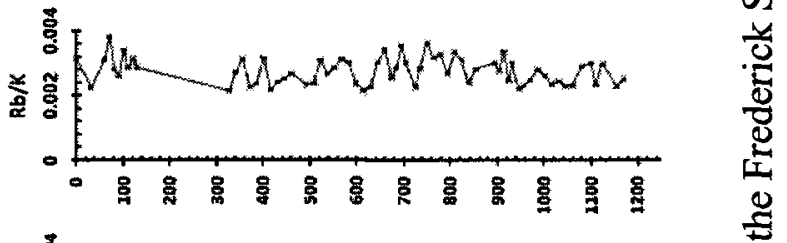

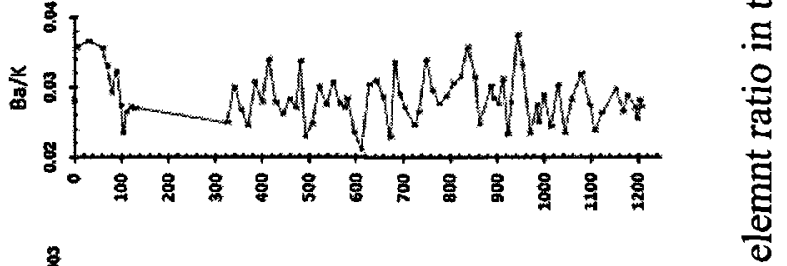

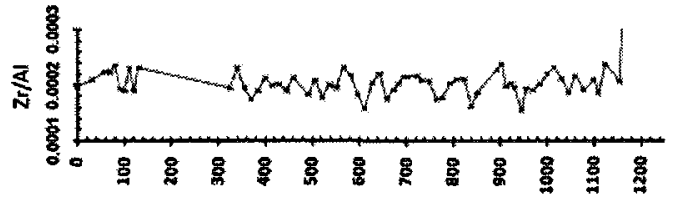

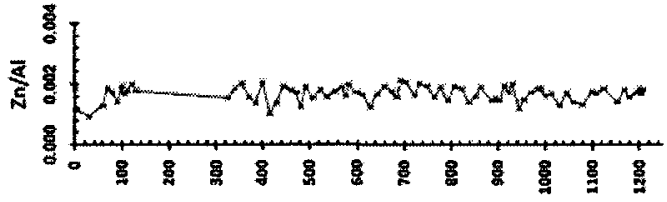

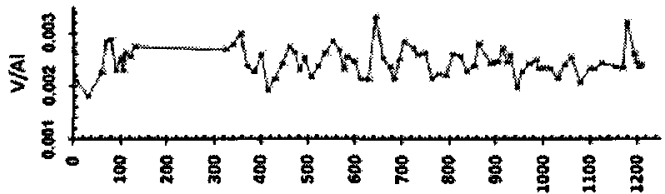

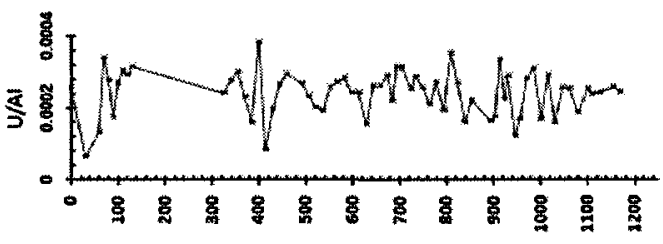

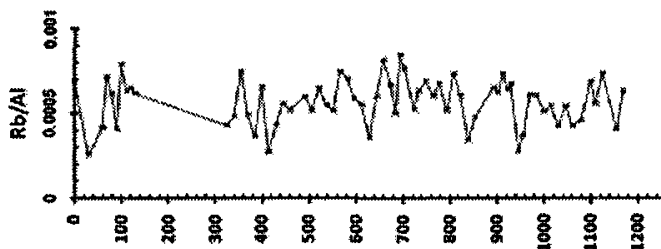



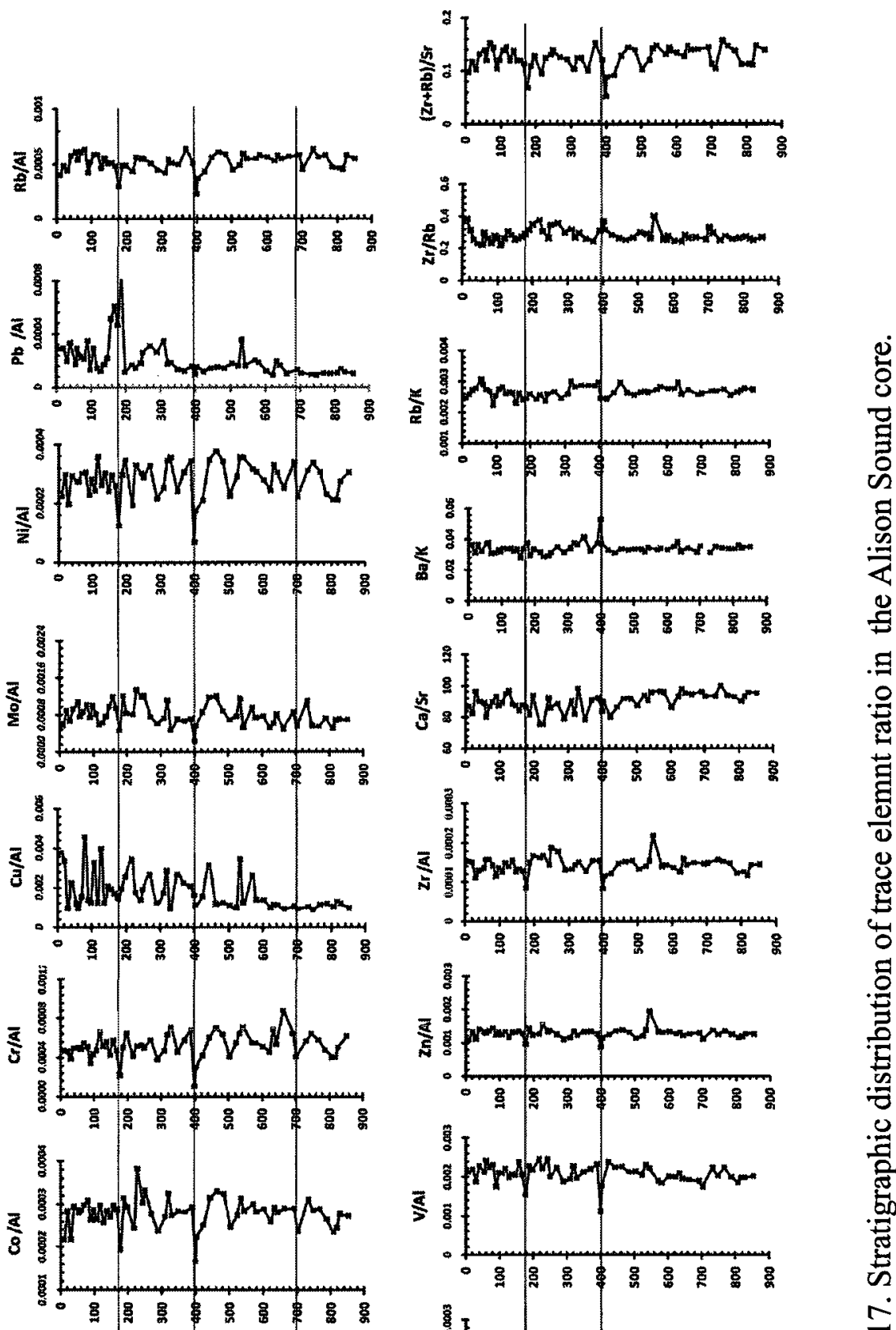

Oే
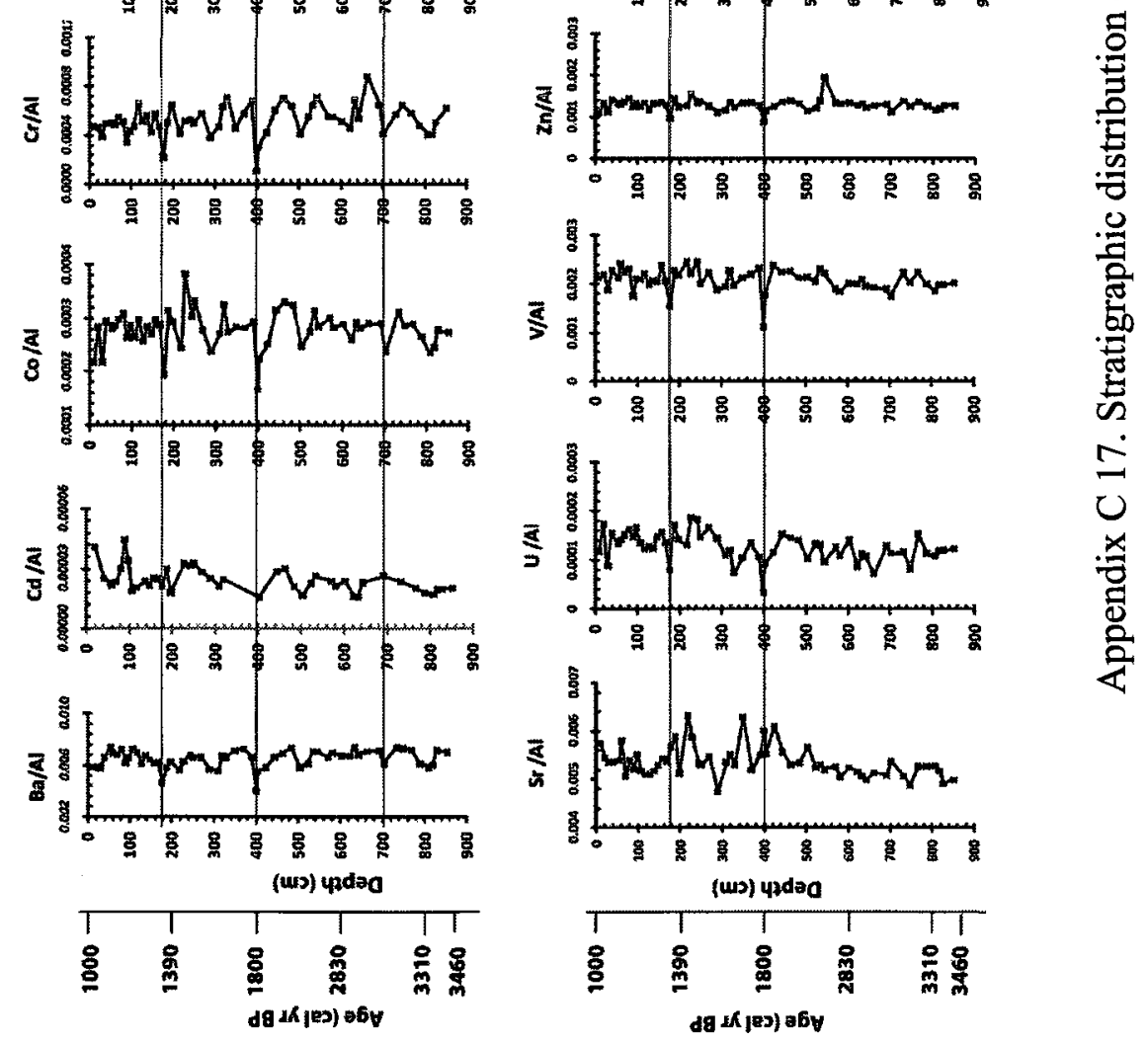
Appendix C 18. Chemical conversion factors (Geoscience Laboratories, Mannual, 2003)

\begin{tabular}{|c|c|c|c|c|}
\hline Element (\%) & Element to Oxide & Oxide (\%) & Oxide to element & Element (\%) \\
\hline $\mathrm{Al}$ & 1.8899 & $\mathrm{Al}_{2} \mathrm{O}_{3}$ & 0.5291 & $\mathrm{~A} 1$ \\
\hline $\mathrm{Ba}$ & 1.1165 & $\mathrm{BaO}$ & 0.8957 & $\mathrm{Ba}$ \\
\hline $\mathrm{C}$ & 3.6633 & $\mathrm{CO}_{2}$ & 0.273 & $\mathrm{C}$ \\
\hline $\mathrm{Ca}$ & 1.3992 & $\mathrm{CaO}$ & 0.7147 & $\mathrm{Ca}$ \\
\hline Co & 1.2715 & $\mathrm{CoO}$ & 0.7864 & Co \\
\hline $\mathrm{Cr}$ & 1.4615 & $\mathrm{Cr}_{2} \mathrm{O}_{3}$ & 0.6842 & $\mathrm{Cr}$ \\
\hline $\mathrm{Cu}$ & 1.2513 & $\mathrm{CuO}$ & 0.7988 & $\mathrm{Cu}$ \\
\hline $\mathrm{Fe}$ & 1.2865 & $\mathrm{FeO}$ & 0.7773 & $\mathrm{Fe}$ \\
\hline $\mathrm{Fe}$ & 1.4297 & $\mathrm{Fe}_{2} \mathrm{O}_{3}$ & 0.6994 & $\mathrm{Fe}$ \\
\hline K & 1.2046 & $\mathrm{~K} 2 \mathrm{O}$ & 0.8302 & K \\
\hline $\mathrm{Mg}$ & 1.6579 & $\mathrm{MgO}$ & 0.6032 & $\mathrm{Mg}$ \\
\hline $\mathrm{Mn}$ & 1.2913 & $\mathrm{MnO}$ & 0.7744 & $\mathrm{Mn}$ \\
\hline $\mathrm{Na}$ & 1.348 & $\mathrm{Na}_{2} \mathrm{O}$ & 0.7919 & $\mathrm{Na}$ \\
\hline$P$ & 2.2912 & $\mathrm{P}_{2} \mathrm{O}_{5}$ & 0.4365 & $\mathbf{P}$ \\
\hline$S$ & 2.4953 & $\mathrm{SO}_{3}$ & 0.4008 & $S$ \\
\hline $\mathrm{Si}$ & 2.1392 & $\mathrm{SiO}_{2}$ & 0.4675 & $\mathrm{Si}$ \\
\hline \multicolumn{5}{|c|}{ Carbonate } \\
\hline $\mathrm{CaO}$ & 1.7848 & $\mathrm{CaCO}_{3}$ & 0.5603 & $\mathrm{CaO}$ \\
\hline $\mathrm{MgO}$ & 2.0915 & $\mathrm{MgCO}_{3}$ & 0.4781 & $\mathrm{MgO}$ \\
\hline
\end{tabular}

